\title{
AS EXCEÇÕES E SUAS REGRAS: \\ ESTUDANTES DAS CAMADAS POPULARES EM UMA \\ UNIVERSIDADE PÚBLICA
}

Débora Cristina Piotto

Tese apresentada ao Instituto de Psicologia da Universidade de São Paulo como parte dos requisitos para a obtenção do grau de Doutor em Psicologia.

Área de concentração: Psicologia Escolar e do Desenvolvimento Humano

Orientadora: Maria Clotilde Rossetti-Ferreira

São Paulo

2007 
Piotto, Débora Cristina.

As exceções e suas regras: estudantes das camadas populares em uma universidade pública / Débora Cristina Piotto; orientadora Maria Clotilde Rossetti-Ferreira. -- São Paulo, 2007.

$361 \mathrm{p}$.

Tese (Doutorado - Programa de Pós-Graduação em Psicologia. Área de Concentração: Psicologia Escolar e do Desenvolvimento Humano) - Instituto de Psicologia da Universidade de São Paulo.

1. Ensino superior 2. Universidades 3. Classe social 4. Nível sócio-econômico I. Título. 


\section{AS EXCEÇÕES E SUAS REGRAS: \\ ESTUDANTES DAS CAMADAS POPULARES EM UMA \\ UNIVERSIDADE PÚBLICA}

Débora Cristina Piotto

BANCA EXAMINADORA

(Nome e Assinatura)

(Nome e Assinatura)

(Nome e Assinatura)

(Nome e Assinatura)

(Nome e Assinatura)

Tese defendida e aprovada em: 
Para o Brown, com amor e esperança.

Só o um-e-outra, um em-si-juntos, o viver em ponto sem parar, coraçãomente: pensamento, pensamor.

Guimarães Rosa 


\section{Agradeço}

À querida Clotilde Rossetti-Ferreira, pela generosidade com que carinhosamente me acolheu, pela presença forte e constante em minha formação, pelas tantas oportunidades que me proporcionou, minha profunda gratidão. Pelo exemplo de dedicação à docência e de compromisso com o desenvolvimento das pessoas, minha sincera admiração.

Aos professores Marília P. Spósito e José Moura Gonçalves Filho pelas valiosas contribuições e importantes sugestões na qualificação deste trabalho.

A Écio A. Portes pela solicitude, pelos textos gentilmente enviados e pela possibilidade de conversar sobre nossos temas de pesquisa.

Às assistentes sociais Claúdia e Márcia pela disponibilidade em responder às minhas solicitações.

Às alunas Gabriela e Michele pela ajuda e intermediação no contato com os estudantes.

À Da. Alda pelo jeito atento e cuidadoso com que sempre atendeu aos meus pedidos.

Aos amigos e companheiros de trabalho na USP cujo apoio permitiu a realização desta pesquisa, sobretudo, nos decisivos momentos finais; especialmente, agradeço à Elaine e Ana Lúcia pelos constantes incentivos; à Soraya pela vibrante torcida e pelo carinho especial; ao Elmir pelas valiosas sugestões de literatura; à Mara Maravilha pela preciosa ajuda acompanhada sempre de um contagiante sorriso; à Teise pela compreensão e pela solidariedade e à Lúcia pelo companheirismo e pelo apoio logístico fundamental.

À Bianca, pela amizade e pela cumplicidade; pelas infindáveis leituras e releituras do material; pelas sugestões e correções; pela presença firme, cuidadosa e constante nos momentos finais de redação da tese, quando sua ajuda foi imprescindível.

Às amigas Eliany, Andréa, Fafá, Val pelo carinho e pelo compartilhamento das agruras do doutorado; ao Marco, Fábio e Claus pelo apoio e incentivos; à Flávia pela antiga amizade, pelas gostosas recordações e pelos projetos futuros.

À Célia pelo cuidado dos assuntos domésticos enquanto eu fazia a tese, mesmo sem entender muito bem o que eu tanto fazia.

Aos meus tios Tim, Cidinha, Nilson, Elza, pelo carinho e pela compreensão da interdição da "nossa chácara” e das ausências das festas familiares.

Aos meus queridos e zelosos irmãos, Vanê e Zerô, pelo aconchego da família e pela felicidade de compartilharmos sonhos; à minha cunhada Renata pelo interesse e atenção com o doutorado e à minha linda sobrinha Beatriz, cujo nascimento abençoou nossas vidas.

A minha querida mãe, Eunice, pela fé, pela confiança e pela alegria e desejo de viver que me ensinam e me inspiram a cada dia; e ao meu saudoso pai, Walther, que nos deixou sua doce lembrança e a vontade de seguir em frente.

E, por fim, agradeço aos estudantes que tornaram possível esta pesquisa por terem me confiado suas histórias, suas dores e suas conquistas. A eles dedico minha admiração, meu respeito e minha esperança de que um dia eles não sejam mais exceções na universidade pública. 
Só esta liberdade nos concedem

Os deuses: submetermo-nos Ao seu domínio por vontade nossa.

Mais vale assim fazermos Porque só na ilusão da liberdade A liberdade existe.

(Fernando Pessoa) 


\section{RESUMO}

PIOTTO, Débora Cristina. As exceções e suas regras: estudantes das camadas populares em uma universidade pública. São Paulo, 2007. 361p. Tese (Doutorado). Instituto de Psicologia, Universidade de São Paulo.

Pesquisas que tratam do acesso e da permanência de estudantes provenientes das camadas populares na Educação Superior têm surgido, no Brasil, principalmente a partir da década de 1990. Tais estudos investigam os processos que permitem a esses estudantes o ingresso no ensino superior, através, sobretudo, da discussão sobre as práticas familiares de escolarização. Partindo das contribuições desses trabalhos, o objetivo da presente pesquisa é analisar a trajetória escolar e a experiência universitária de estudantes de cursos superiores de alta seletividade provenientes das camadas populares, bem como discutir os sentidos, atribuídos por eles próprios, do ingresso e da permanência no Ensino Superior público. Para isso, foram realizadas entrevistas em profundidade, que versaram sobre a vida escolar dos estudantes, com cinco alunos dos cursos mais concorridos de um dos campi da Universidade de São Paulo localizado no interior do Estado. Os relatos dos estudantes permitem compreender que, se por um lado, suas trajetórias são marcadas por esforço, solidão e situações de desenraizamento e humilhação, por outro, a entrada na universidade pública traz possibilidades que transformam inteiramente suas perspectivas de vida, não sendo o sofrimento a tônica de seus discursos. Além disso, destaca-se a forte presença do trabalho em suas trajetórias de vida, bem como suas percepções sobre a contribuição da escola para seus percursos. 


\begin{abstract}
PIOTTO, Débora Cristina. Exceptions and their rules: students from low-income classes in a Public University. São Paulo, 2007. 361p. Thesis (Doctoral). Instituto de Psicologia, Universidade de São Paulo.

Studies looking at ingress and completion of college courses by students from lowincome classes in Brazil have emerged, mainly from the 1990s on. Such studies have investigated the processes that allow those students enter a higher education institution largely by discussing familiar schooling practices. Based on contributions by those studies, this research aimed to assess the educational paths and experiences of students from low-income classes enrolled in highly selective schools as well as discuss the significance attributed by themselves to their ingress and completion of higher education in Public Universities. In order to reach the study's goal, in depth interviews that focused school convivial life were carried out with five students in the most wanted careers of one of the campi of the University of São Paulo. The student's reports show that their pathways have been marked by hard work, loneliness, and uprooting events and humiliation. On the other hand, entering a public university led to opportunities that completely changed their lifer's prospects, with suffering not as part of their discourse. Furthermore, hard work outstood in their life's pathways as well as their perceptions on school's contribution to their trajectories.
\end{abstract}




\section{SUMÁRIO}

1. INTRODUÇÃ

1.1 Trajetórias escolares prolongadas nas camadas populares........................... 4

$1.2 \mathrm{O}$ estudante pobre no Ensino Superior........................................................ 7

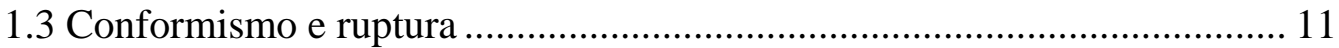

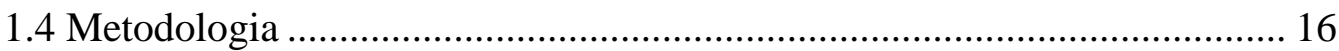

2. OS CURSOS DE ALTA SELETIVIDADE E SUAS CARACTERÍSTICAS ...... 21

3. PERCURSOS E PERCALÇOS NA CONSTRUÇÃO DE NOVOS

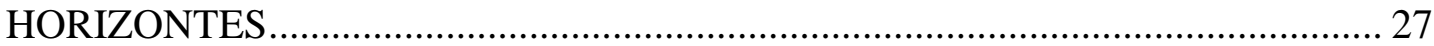

3.1 Felipe e a experiência de desenraizamento .............................................. 30

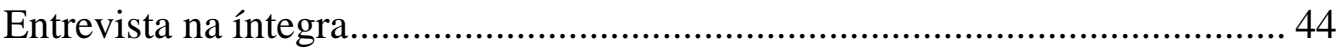

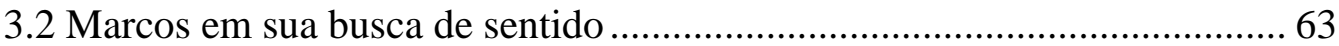

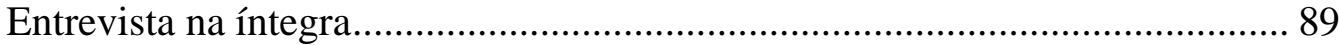

3.3 Um empreendimento coletivo na trajetória escolar de Pedro ................... 130

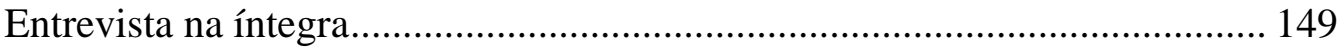

3.4 Antônio e o desejo de aprender................................................................ 173

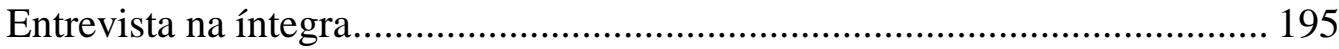

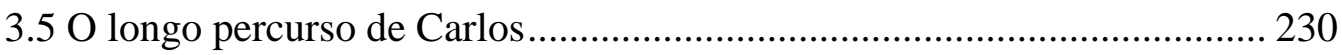

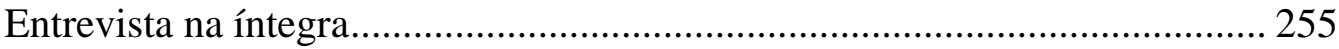

4. A CONQUISTA DE UMA ESCOLARIZAÇÃO PROLONGADA .................... 281

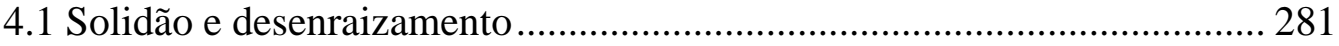

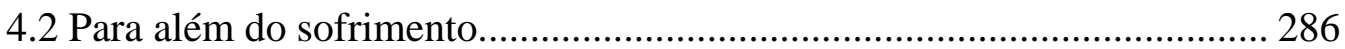

4.3 A presença do trabalho e da escola nas trajetórias dos estudantes............ 298 


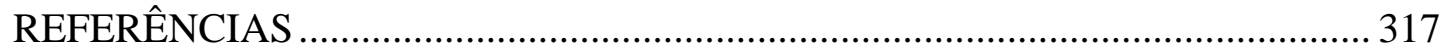

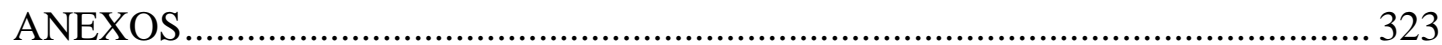

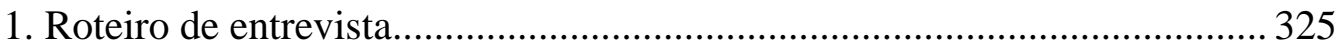

2. Informações socioeconômicas dos cursos selecionados ............................. 327 


\section{INTRODUÇÃO}

A Educação Superior no Brasil é caracterizada pela restrição. Em 2001, dos quase 23 milhões de jovens com idades entre 18 e 24 anos, apenas cerca de três milhões cursavam o Ensino Superior, um percentual de 13\% (Oliveira et al., 2006) ${ }^{1}$. A posição ocupada pelo País, em relação à taxa de escolarização na Educação Superior, é inferior a quase todos os seus vizinhos da América Latina, estando o Brasil abaixo da Argentina, cujo percentual de atendimento nesse nível de ensino é de $48 \%$, do Chile, com taxa de 38\%, da Bolívia, com 33\%, do Uruguai, com 34\% dos jovens no Ensino Superior e da Colômbia, com 22\% (Pinto, 2004).

Não obstante a taxa de escolarização na Educação Superior ser baixa, ela é fruto de uma recente expansão que aumentou em $129 \%$ o número de estudantes no Ensino Superior atendidos entre 1989 e 2002 (Oliveira et al., 2006). Essa ampliação, todavia, localizou-se predominantemente no setor privado que, em 2002, detinha $70 \%$ de todas as matrículas na Educação Superior, fazendo com que o Brasil se tornasse um dos países com mais alto grau de privatização nesse nível de ensino (Pinto, 2004).

Assim, se o acesso à Educação Superior é restrito, ele o é ainda mais quando se trata de instituições públicas. Isso não significa dizer que o Ensino Superior público seja mais restritivo que o privado, como reiteradamente se afirma no senso comum. Essa é uma das conclusões de um estudo conduzido por Sampaio, Limongi e Torres (2000) que, apoiado nos dados da PNAD (Pesquisa Nacional de Amostra de Domicílios) de 1997 e no Exame Nacional de Cursos - o antigo "Provão” - de $1999^{2}$, traz uma importante discussão sobre essa questão, ao comparar setor público e privado na Educação Superior.

\footnotetext{
${ }^{1}$ Os autores basearam-se nas informações do IBGE (Instituto Brasileiro de Geografia e Estatística) e INEP (Instituto Nacional de Pesquisas e Estudos Educacionais Anísio Teixeira), podendo esse dado ter pequenas variações em função da fonte consultada. Pinto (2004), por exemplo, baseado nas informações da Unesco (Organização das Nações Unidas para a Educação, a Ciência e a Cultura), apresenta uma taxa de escolarização bruta na Educação Superior no ano 2000 de 15\%.

${ }^{2}$ Foram avaliados os seguintes cursos: Administração, Direito, Economia, Engenharia Civil, Engenharia Mecânica, Engenharia Elétrica, Engenharia Química, Jornalismo, Letras, Matemática, Medicina, Medicina Veterinária e Odontologia.
} 
Considerando o rendimento familiar, os autores afirmam, por exemplo, que estudantes provenientes de lares com renda baixa estão proporcionalmente em maior número nas instituições públicas do que nas privadas. Do total de alunos que cursavam o Ensino Superior em 1999, 32\% estavam matriculados no setor público e, desses, 50\% possuíam renda familiar de até três salários mínimos, enquanto 24\% possuíam renda de 50 salários mínimos ou mais. No setor privado, dos 68\% dos alunos que o freqüentavam, também 50\% possuíam renda de, no máximo, três salários; no entanto, na faixa superior de renda, o quadro se inverte: os alunos que possuíam renda superior a 50 salários mínimos eram 76\% nas instituições particulares de Ensino Superior (Sampaio; Limongi; Torres, 2000). Assim, enquanto nas universidades públicas há, proporcionalmente, maior número de estudantes pobres, nas instituições particulares de Ensino Superior ocorre o contrário, existindo maior porcentagem de alunos provenientes de lares com renda elevada. Em que pesem os variados perfis socioeconômicos existentes entre os diferentes cursos ${ }^{3}$, a diferença entre a proporção de alunos com menor e maior renda mantém-se independentemente do curso. Assim, naquelas carreiras consideradas elitizadas, como Medicina e Odontologia, de fato, há maior percentual de alunos provenientes de famílias com rendas altas, tanto no setor público quanto no privado. Todavia, afirmam Sampaio, Limongi e Torres (2000), a despeito do grau de “elitização” de uma carreira, a possibilidade de um aluno das camadas populares ingressar em Medicina, por exemplo, só se realiza se esse curso for oferecido por uma instituição pública $^{4}$. Os autores discutem, ainda, que o ingresso de jovens provenientes de famílias de baixa renda ou filhos de pais com pouca escolaridade é pequeno na Educação Superior, mas, para aqueles que o fazem, os estabelecimentos públicos são uma alternativa para a realização de um curso superior. Esse conjunto de dados permite aos pesquisadores afirmarem que as instituições públicas de Ensino Superior, comparativamente às particulares, são mais permeáveis aos estudantes de origem

\footnotetext{
${ }^{3}$ Sobre a existência de diferenciação e hierarquia entre as carreiras universitárias ver Setton (1999) e Braga; Peixoto; Bogutchi (2001).

${ }^{4}$ Nessa mesma direção, comparando dados sobre renda, cor e tipo de escola onde cursou o Ensino Médio dos alunos dos cursos de Medicina e Pedagogia, Pinto (2004) afirma que o primeiro é mais elitizado do que o segundo. Contudo, apesar de as diferenças entre esses dois cursos serem observadas tanto nas instituições públicas quanto nas privadas, nessas últimas a “elitização” é ainda maior, já que nelas estudam mais alunos provenientes de famílias com rendimento elevado e que estudaram em escolas particulares e, por outro lado, menor número de alunos negros.
} 
mais pobre. Além disso, é nas universidades públicas que se formam mais estudantes negros ou pardos.

O estudo de Sampaio, Limongi e Torres (2000) também faz comparações em relação ao desempenho dos estudantes do setor público e privado, na Prova Geral do Exame Nacional de Cursos, concluindo que os alunos com renda familiar mais baixa (inferior a dez salários mínimos) de universidades públicas têm notas mais altas do que alunos com renda familiar mais elevada (superior a vinte salários) das universidade particulares, em quase todos os cursos analisados. Por outro lado, os autores perceberam também grande associação entre escolaridade dos pais e desempenho no Exame, tendo os estudantes com pais mais escolarizados obtido notas mais elevadas, independentemente da renda familiar; alunos cujos pais tinham maior escolaridade (nível médio ou superior), em todas as faixas de renda, obtiveram notas mais altas do que alunos com pais menos escolarizados, mas com renda familiar mais elevada. Esse dado foi observado em todos os cursos tanto em instituições públicas quanto em privadas. Todavia, em oito dos treze cursos avaliados, estudantes de instituições públicas, com renda familiar de até dez salários mínimos e filhos de pais com baixa escolaridade, obtiveram notas mais altas do que alunos de instituições privadas na faixa de renda mais elevada (acima de vinte salários) e filhos de pais mais escolarizados (nível médio ou superior). Nesse sentido, se a influência da escolaridade dos pais no desempenho acadêmico dos filhos é grande, a diferença que instituições públicas de Ensino Superior podem fazer parece ser ainda maior.

Sampaio, Limongi e Torres (2000) concluem o estudo afirmando que, se o acesso à Educação Superior é restrito, o sistema público de Ensino Superior não reforça a desigualdade. Ao contrário, esse sistema, segundo os autores, acaba funcionando como meio de superar ou, ao menos, de diminuir a desigualdade do sistema escolar.

Se a restrição que caracteriza o acesso à Educação Superior no Brasil aumenta quando se trata de instituições públicas e se torna ainda maior no caso de estudantes mais pobres e filhos de pais com baixa escolaridade, esses estudantes estão, proporcionalmente, em maior número no setor público do que no privado. Além disso, dada a elitização de alguns cursos, tanto nas instituições públicas quanto nas particulares, a presença de alunos das camadas populares neles constitui exceção; porém, também as exceções estão mais presentes nas universidades públicas. 
Se o jovem que conclui o Ensino Superior no Brasil é branco, morador de regiões metropolitanas do Sudeste, proveniente de famílias com renda média de R\$ 3.400,00 e filho de pais com dez anos ou mais de escolaridade (Sampaio; Limongi; Torres, 2000), quem são as exceções?

\subsection{Trajetórias Escolares prolongadas nas camadas populares ${ }^{5}$}

A partir principalmente da década de 1990, começam a surgir, no Brasil, principalmente na área da Sociologia da Educação, estudos que investigam tanto os processos que permitiram a jovens provenientes das camadas populares o ingresso no Ensino Superior, através, sobretudo, da pesquisa sobre as práticas familiares de escolarização, quanto a experiência do estudante pobre na universidade, investigando, além do acesso, também a questão da permanência nesse nível de ensino. Como exemplo dessas pesquisas podemos citar as realizadas por Viana (1998), Silva (1999), Portes (2001) e Barbosa (2004).

Alguns desses estudos valem-se de contribuições teórico-metodológicas de trabalhos produzidos no exterior ${ }^{6}$, onde a produção de conhecimento sobre o tema é menos recente, trazendo importantes contribuições ao chamar a atenção para aspectos ainda pouco explorados.

Uma dessas pesquisas é a realizada por Lahire (1997) - sociólogo francês na qual ele investigou as relações entre as posições escolares de 26 crianças provenientes de camadas populares que freqüentam a $2^{\mathrm{a}}$ série do correspondente ao Ensino Fundamental na França e suas configurações familiares. Nos perfis descritos, há casos que vão desde “fracassos” previsíveis - isto é, realidades escolares difíceis vividas por alunos cujos pais possuem baixa escolaridade, profissões nãoqualificadas, o que caracterizaria uma situação de baixo capital cultural ${ }^{7}$-, passando por histórias de “fracassos” improváveis - ou seja, crianças que, apesar de viverem em condições mais favoráveis à escolarização (pais com maior nível de instrução, por exemplo), têm desempenho acadêmico bastante ruim -, até os casos de

\footnotetext{
${ }^{5}$ Por trajetórias escolares prolongadas entendemos a permanência no sistema escolar até o Ensino Superior.

${ }^{6}$ Principalmente na literatura científica de língua francesa.

${ }^{7} \mathrm{O}$ conceito de capital cultural - proveniente dos trabalhos de Pierre Bourdieu (ver, por exemplo, Bourdieu, 1996) - é definido por Lahire (1997) como princípio socializador mais adequado ou próximo ao mundo escolar.
} 
"sucessos" brilhantes de alunos que, embora sujeitos a condições extremamente difíceis no tocante ao trabalho acadêmico, possuem um desempenho escolar exemplar. A despeito da semelhança de origem social e condições de vida, os caminhos percorridos pelas trajetórias escolares destas crianças são heterogêneos e múltiplos. E é sobre as razões das improbabilidades que se debruça Lahire.

Para este autor, não se pode entender as posições escolares dos alunos como reprodução necessária e direta das condições sociais, econômicas e culturais de suas famílias. Nem tampouco as situações estudadas encontram explicação via transmissão da herança cultural familiar. A lógica reprodutivista e a noção de “transmissão” não refletem o trabalho ativo e complexo de apropriação e construção, pelos indivíduos, de grande variedade de fatores e que redunda na diversidade dos perfis apresentados. Entre estes fatores, destacamos aqui os aspectos psicológicos de tais apropriações.

Apesar de Lahire nem sempre nomear como psíquica a dimensão de muitas das questões por ele discutidas, é disto que se trata quando este autor aborda, por exemplo, os medos e os sofrimentos das experiências escolares paternas influindo na relação que o filho estabelece com a escola. A importância assumida pelo aspecto psicológico o faz afirmar que, entre um baixo ou inexistente capital cultural e um maior nível de escolaridade dos pais, porém, marcado por experiências infelizes, é preferível a primeira situação: “... é sem dúvida preferível ter pais sem capital escolar a ter pais que tenham sofrido na escola e que dela conservem angústias, vergonhas, complexos, remorsos, traumas ou bloqueios” (Lahire, 1997: 345).

É essa herança psíquica que explica algumas das histórias de “sucessos” escolares improváveis ${ }^{8}$. É o caso, por exemplo, de Salima. Filha de pais imigrantes (provenientes da Argélia) - mãe faxineira, analfabeta, e pai operário em eletricidade, apenas lê em árabe e um pouco (com dificuldade) em francês -, Salima, a despeito de reunir condições objetivas que provavelmente gerariam fracasso escolar, obteve 7,2 na avaliação nacional e é considerada boa aluna por seu professor. Ainda neste caso, segundo Lahire, é a combinação de características da configuração familiar que possibilitará a explicação deste êxito imprevisto.

\footnotetext{
${ }^{8}$ Apesar da dimensão relativa que Lahire (1997) atribui às noções de “sucesso” e "fracasso" escolar tendo sempre o cuidado de colocar tais termos entre aspas -, para a definição dos perfis, o parâmetro adotado foram as notas obtidas pelas crianças na avaliação nacional do sistema de ensino francês. Os alunos considerados em situação de “sucesso” escolar obtiveram notas acima de 6,0.
} 
Se as razões para tal sucesso não podem ser encontradas nas práticas de leitura, escrita, ou de organização das atividades domésticas da família, o autor procura-as na relação que o pai estabelece com os filhos, principalmente no tocante às atividades escolares. Apesar de o pai de Salima não saber precisar a classe em que os filhos estão (ela tem mais dois irmãos), nem tampouco poder ajudá-los nas tarefas escolares, ele valoriza a escolarização, cuida para que façam suas lições e incentivaos a realizarem atividades acadêmicas, levando-os à biblioteca ou comprando livros. Estimula-os, ainda, a escreverem um diário de férias, expressando “... seu ressentimento em relação a essas práticas que gostaria de poder ter feito...” (Lahire, 1997: 169). Nesse sentido, os laços entre pai e filhos passam também pela escrita, não sendo obra do acaso, portanto, o desejo de Salima de ser "escrivinhadora”: "Os filhos sabem que dão prazer ao pai quando se saem bem na escola e escrevem para ele” (Lahire, 1997: 169).

Este é um dos casos descritos por Lahire no qual são as características da organização familiar que explicam trajetórias escolares bem-sucedidas, na inexistência - total ou parcial - de capital cultural. Para este autor, histórias como as de Salima evidenciam a importância da economia das relações de poder no interior das famílias.

Mesmo nos casos em que os pais dispõem de certo capital cultural, transmitese algo a mais do que este capital. Nesse sentido, algumas das histórias de “fracassos” improváveis podem ser compreendidas à luz das relações dos pais com suas próprias experiências escolares. Os adultos podem experimentar sentimentos de inferioridade ou de incompetência cultural diante da instituição escolar e transmitilos às crianças. O inverso também pode ocorrer e produzir histórias de "sucessos" inesperados como a de Salima. Neste caso, transmitem-se às crianças sentimentos de orgulho e alegria diante da experiência escolar. Mas, em ambas as situações, trata-se de uma herança de sentimentos:

A 'herança' familiar é, pois, também uma questão de sentimentos (...), e a influência, na escolaridade das crianças, da 'transmissão de sentimentos' é importante, uma vez que sabemos que as relações sociais, pelas múltiplas injunções preditivas que engendram, são produtoras de efeitos de crenças individuais bem reais (Lahire, 1997: 173). 
Além disso, para que a "transmissão" do capital cultural ocorra, são necessárias interações efetivas e afetivas. Isto é, não basta a escolarização do pai ou da mãe, é preciso que o detentor desse capital escolar esteja disponível, tanto objetiva quanto subjetivamente, de forma a possibilitar as adequadas condições para que o capital possa ser herdado. Na ausência de capital cultural, o que as histórias relatadas mostram, é que se cria, no interior dessas famílias, um lugar simbólico de grande importância ao mundo escolar ou à criança letrada. Interesse e valor demonstrados através de pequenas ações do dia-a-dia.

Vamos, então, às pesquisas que se apóiam nas questões discutidas por Lahire e que tratam de trajetórias escolares prolongadas em nossa realidade.

\subsection{O estudante pobre no Ensino Superior}

Partindo das contribuições teórico-metodológicas de Lahire (1997), entre outras, Viana (1998) e Portes (2001) discutem o acesso e a permanência do estudante das camadas populares na Educação Superior.

Viana (2000) fez entrevistas com sete estudantes (cinco mulheres e dois homens) que tinham em comum o fato de terem ingressado no Ensino Superior (alunos de graduação e pós-graduação em universidades de Minas Gerais ${ }^{9}$ ) e serem provenientes de famílias com dificuldades econômicas, baixo nível de escolaridade, pais exercendo (ou tendo exercido) trabalhos predominantemente manuais.

Analisando essas biografias escolares, Viana traz reflexões importantes para se pensar a relação entre longevidade escolar e camadas populares ${ }^{10}$. Uma delas corresponde à presença, nas histórias analisadas, de “êxitos escolares parciais” definidos como bom rendimento acadêmico e inexistência de reprovações -, sobretudo no período referente às quatro primeiras séries do Ensino Fundamental. Esses “sucessos” iniciais, e também os intermediários, contribuíram para a construção de sentidos, disposições e práticas que tenderam a reforçá-los, tornandose uma importante base para a continuidade dos estudos nas trajetórias analisadas.

\footnotetext{
${ }^{9}$ Universidade Federal de Minas Gerais (UFMG), Universidade Estadual de Minas Gerais (UEMG), Pontifícia Universidade Católica (PUC-MG) e Fundação de Ensino Superior de São João Del-Rei (FUNREI).

${ }^{10}$ Por longevidade escolar, a autora entende a permanência no sistema de ensino até a Educação Superior.
} 
Outro aspecto recorrente foi uma autodeterminação decisiva para os rumos tomados pelos percursos escolares dos entrevistados. Viana (2000) reconhece a existência de um componente aleatório em tais percursos, através do surgimento casual de oportunidades centrais para a definição dos caminhos percorridos. Apesar disso, ela atribui aos indivíduos um papel ativo na construção de sua trajetória escolar: “... essas trajetórias supõem um querer e uma autodeterminação imbatíveis, sobretudo dos filhos, condição sine qua non de produção de sobrevida escolar em meios populares” (Viana, 2000: 52). Todavia, ressalta a autora, não se trata de localizar tal autodeterminação na essência subjetiva dos entrevistados, pois ela fora construída no decorrer do processo de escolarização.

Viana discute, também, o conceito de mobilização escolar familiar, entendida como atitudes e práticas familiares voltadas sistemática e intencionalmente para a garantia do bom rendimento escolar dos filhos. Semelhante ao encontrado por Lahire (1997), a autora observou ser possível a longevidade escolar nas camadas populares sem a necessária ocorrência dessa mobilização. Nas sete histórias analisadas, ela não identificou investimentos específicos e deliberados por parte das famílias na trajetória escolar dos filhos que permitissem explicar as situações de longevidade escolar. Defende a idéia de que a presença das famílias das camadas populares nas trajetórias escolares prolongadas dos filhos assume formas específicas, bastante diferentes das comumente identificadas como propiciadoras de "sucesso”, típicas das camadas médias.

É fato que os pais contribuem para as trajetórias de longevidade escolar. Mas não através de um “acompanhamento minucioso da escolaridade dos filhos” ou de “contatos freqüentes com os professores”, nem ainda da "assiduidade às reuniões convocadas pela escola”. A participação das famílias nas trajetórias escolares dos filhos revela-se, por exemplo, na história de Catarina (pedagoga cursando especialização em psicopedagogia na Universidade Estadual de Minas Gerais), cujo pai, já com idade avançada e problemas de saúde, fazia horas-extra no colégio onde trabalhava como faxineiro para garantir isenção da taxa de mensalidade escolar dos filhos.

A autora trata, ainda, do papel das diferentes esferas presentes na configuração das trajetórias analisadas: a família, o filho-aluno e a escola, entendidas como âmbitos interdependentes. Reafirma as posições discutidas em relação à 
família e ao filho e aborda a participação da escola na questão da longevidade escolar. Embora reconheça que aspectos ligados à instituição escolar e seu funcionamento estejam relacionados com a trajetória pesquisada, e apesar de conceber “... a escola (...) como fator dinâmico do processo de construção dessas situações de sobrevida escolar...”, a autora esclarece que, em seu estudo, a escola aparece apenas de maneira indireta como "figura importante de bastidores”.

Outra pesquisa que investiga o acesso e a permanência do estudante pobre no Ensino Superior, é o de Portes (2001). Este pesquisador entrevistou seis jovens (três homens e três mulheres) provenientes de famílias das camadas populares e alunos das carreiras mais concorridas da UFMG (Medicina, Fisioterapia, Direito, Comunicação Social, Engenharia Elétrica e Ciência da Computação). Tais estudantes, apesar das trajetórias escolares brilhantes, marcadas sempre por sucessos, constituem uma "improbabilidade estatística”, já que é uma parcela reduzidíssima de alunos das camadas populares que tem acesso aos cursos citados (Portes, 2001).

Um dos objetivos da pesquisa foi entender o trabalho escolar realizado pelas famílias das camadas populares que, de alguma forma, contribuiu para o acesso dos filhos à universidade pública em cursos bastante valorizados socialmente ${ }^{11}$. Portes (2000) define trabalho escolar como qualquer ação familiar ocasional ou precariamente organizada visando ao ingresso e à permanência dos filhos no sistema de ensino, procurando influenciar sua trajetória escolar, de modo a alcançar níveis mais altos de escolaridade. Esse tipo de trabalho é algo complexo, de difícil compreensão e visibilidade, e realizado, na maior parte das vezes, na ausência de capital escolar.

Exemplo da variedade de formas que o trabalho escolar pode assumir nos meios populares, é a história de Maurício (estudante de Engenharia Elétrica). Diante da grande dificuldade de corresponder às necessidades econômicas que o curso do filho demanda, seu pai - que abandonara o emprego num hospital para tornar-se raspador de tacos e aumentar o rendimento familiar - fala ao pesquisador: “ 'Olha, tem dia que dá um desespero, rapaz... Olha só, pra você vê...' Levanta as barras rotas das calças e mostra os joelhos esfolados e calejados pelo ato de trabalhar ajoelhado

\footnotetext{
${ }^{11}$ Esse foi um dos aspectos tratados na pesquisa realizada por Portes (2001) em sua tese de doutorado.
} 
(...), como se necessitasse demonstrar o esforço que ele faz para manter a casa, como ele diz” (Portes, 2000: 66).

Esse trabalho escolar torna-se visível e ganha sentido e legitimidade através de uma série de ações que compõem o que o autor chama de "conjunto de circunstâncias atuantes”. Ele trata de seis circunstâncias: 1) a presença da ordem moral doméstica; 2) a atenção para com o trabalho escolar do filho; 3) o esforço para compreender e apoiar o filho; 4) a presença do outro na vida do estudante; 5) a busca de ajuda material, e 6) a existência e a importância de um duradouro grupo de apoio construído no interior do estabelecimento escolar.

Apesar de essa discussão de Portes (2000) estar voltada para a atuação da família no percurso escolar dos filhos, pelo menos uma das circunstâncias discutidas refere-se à escola. Em relação ao quarto item abordado - a presença do outro na vida do estudante -, este outro é, nas histórias descritas, sempre um professor ${ }^{12}$. É assim, por exemplo, que a trajetória de Alice (estudante de Fisioterapia) tomará rumo decisivo quando sua professora da $3^{\mathrm{a}}$ série pede que sua mãe a transfira para outra escola pública de melhor qualidade. A percepção por parte de determinados professores do bom desempenho escolar parece ser determinante na vida dos estudantes entrevistados, possuindo importante papel na construção de uma "lógica do sucesso" (Accardo, 1997). Portes (2000) afirma que intervenções de professores como essa são aceitas e operacionalizadas pelas famílias e modificam as possibilidades escolares dos estudantes. Estes, por sua vez, desenvolvem-se cada vez mais, confirmando prognósticos anteriores, recebendo novos elogios e caminhando em direção a níveis mais altos de escolaridade.

A “eterna aproximação dos professores” (Portes, 2000) é outro aspecto importante nas trajetórias escolares analisadas. Através do reconhecimento e do incentivo à dedicação, ao esforço e ao desempenho acadêmico, o professor contribui para a construção da autonomia, segurança e auto-estima desses estudantes.

A busca de proximidade com os professores ou de reconhecimento no interior da escola é estimulada pelas famílias como forma de delegação de cuidados que elas não podem mais exercer em relação aos filhos, segundo Portes. Tal reconhecimento,

\footnotetext{
${ }^{12}$ Com exceção do caso de Esdras (estudante de Ciência da Computação) em que este “outro” é representado pela prima, que é pedagoga, sócia de uma escola onde ele vai estudar, exercendo monitoria em troca da mensalidade.
} 
no entanto, só pode ser obtido através de um desempenho exemplar, não só em termos acadêmicos, mas também comportamentais, bem como da aceitação das determinações institucionais. A essa postura dos estudantes Portes (2000) denomina de “conformismo estratégico”.

O conformismo é uma característica comumente mencionada quando se trata de discutir casos de alunos pobres com bom desempenho escolar.

\subsection{Conformismo e ruptura}

Alunos pobres com bom rendimento acadêmico são, muitas vezes, considerados “conformistas", no sentido de serem aqueles que se conformam aos valores da escola e se submetem docilmente aos professores, adaptando-se perfeitamente às normas institucionais.

Observando uma classe considerada “fraca”, Patto (1990) refere-se às crianças tidas como "bons alunos” como aquelas que fazem exemplarmente o que a professora lhes ordena, abrindo mão de seus desejos e de sua individualidade. Na turma onde os "bons alunos” são em maior número - na classe tida como "forte” -, essa autora destaca a docilidade, afirmando que as crianças valem pela submissão e eficiência na execução do que lhes é solicitado. Chamando atenção para o custo psíquico de tal submetimento à ordem escolar, Patto (1990) fala sobre o sofrimento e o empobrecimento da personalidade que podem resultar da tentativa de a criança agradar ao professor através da adequação às suas expectativas e ao ideal de "bom aluno".

Nicolaci-da-Costa (1987) também considera a possível existência de problemas subjetivos para os membros das camadas populares com bom desempenho na escola. Entendendo tais problemas como resultados de um “choque cultural” entre escola e família, a autora afirma que o "sucesso" escolar do aluno dos meios populares tem o poder de roubar-lhe a identidade cultural ${ }^{13}$.

Hammersley e Turner (1984), por outro lado, afirmam que, ao se observar mais atentamente os comportamentos dos "bons alunos", constata-se que a classificação “conformistas” é uma simplificação. Os autores questionam essa caracterização, partindo de uma questão bastante simples, mas quase sempre

\footnotetext{
${ }^{13}$ Para uma discussão crítica sobre essa afirmação, sugerimos a consulta a Bosi (2005), Bosi (2004), Sader; Paoli (1997) e Chauí (1993).
} 
ignorada: conformidade a quê? Vários dos trabalhos que atestam tal conformidade baseiam-se em uma noção homogeneizante de supostos valores de "classe média” entre os professores, ao que Hammersley e Turner (1984) contra-argumentam atentando para o fato de que existiriam vários segmentos de camadas médias entre os professores.

Além disso, de acordo com os autores, mesmo um aluno, que se poderia chamar "conformista”, apresenta diferenças em seu comportamento: ele não se “conforma” o tempo todo. É preciso que se compreenda o comportamento dos estudantes a partir do momento e da situação em que ele ocorre, devendo esse entendimento ser priorizado em detrimento da procura do nível de adaptação geral à escola. Eles discutem ainda que a adaptação do aluno dependerá do modelo proposto pelo professor, podendo, portanto, variar. E que ela não deve ser entendida como total submissão, na medida em que sempre envolve uma participação ativa do aluno. Nesse sentido, afirmam que muito do que se entende como conformidade às exigências escolares é motivado por preocupações instrumentais, como, por exemplo, tirar boas notas. Assim, um bom trabalho pode ser muito mais uma estratégia calculada do que simplesmente resultado de uma socialização perfeitamente adaptada às normas escolares.

Tal afirmação aproxima-se da expressão utilizada por Portes (2000) conformismo estratégico - ao descrever o comportamento dos estudantes (exemplar tanto em relação ao aspecto acadêmico quanto ao comportamental), o qual visava ao reconhecimento dos professores. Esse reconhecimento mostrou ter importante papel na construção de trajetórias escolares que levaram tais alunos aos cursos superiores mais concorridos da UFMG. Parece-nos que é a isso que Hammersley e Turner se referem, quando falam em "estratégia calculada”.

Uma pesquisa que oferece outra possibilidade de significado para o conformismo, indo na direção de entendê-lo como “conformismo estratégico” é a de Silva (1999). Esse pesquisador entrevistou onze estudantes pobres que tinham em comum o fato de residirem em uma favela do Rio de Janeiro e terem realizado um curso superior.

Em suas conclusões a respeito da dinâmica do campo escolar, Silva (1999), utilizando-se de conceitos de Bourdieu (1983, 1989), afirma que um dos fatores explicativos para a permanência na escola e o alcance de níveis superiores de 
escolarização, é a posição ocupada pelos entrevistados, tanto no campo familiar, quanto no escolar. Em relação a este último, o autor atribui a posição conquistada pelos estudantes a uma "inteligência institucional”, mais do que a competências cognitivas. Esse tipo de inteligência é definido como a capacidade de compreender e saber jogar as regras do campo escolar. Construída socialmente, tal inteligência revela, mais do que conformismo, aguda sensibilidade para o jogo institucional. Exemplos dessa inteligência aparecem em várias das histórias relatadas. A "boa vontade cultural”, que é a assimilação com pouca compreensão de vários conteúdos transmitidos pela escola, por se acreditar em sua importância no futuro, é um deles. Outro exemplo é o esforço em tirar boas notas, relatado por alguns entrevistados, mesmo quando questionavam a relevância de certos conteúdos escolares para suas vidas. E, por fim, a opção por não enfrentar ou "bater de frente” com os professores.

Outra característica, também marcante nos estudos que tratam de trajetórias escolares prolongadas em camadas populares, é o fato de estas, em geral, serem entendidas a partir de uma visão que enfoca predominantemente a ruptura ou o choque cultural decorrente da diferença entre o mundo escolar e o familiar e o sofrimento, a humilhação e os prejuízos psíquicos daí provenientes.

Entre as pesquisas já mencionadas aqui, a de Viana (2000) atenta para a longevidade escolar vivida como ruptura e sofrimento nas camadas populares. A autora discute, em artigo que resume sua tese de doutorado, uma ordem de questões que se pode denominar de psíquicas. Dificuldades psicológicas, advindas do distanciamento cultural e social do mundo familiar à medida que se trilham caminhos escolares mais longos, são apresentadas em várias das biografias analisadas. O sofrimento pode ser vivido tanto no contexto da experiência escolar como no das relações familiares.

Entretanto, no próprio trabalho de Viana (1998) deparamo-nos com alguns sentidos diferentes que, embora não presentes nas conclusões apresentadas pela pesquisadora, julgamos oferecer outra possibilidade de entendimento acerca do tema em questão. Das sete biografias analisadas, em pelo menos quatro, a autora afirma que a emancipação cultural proporcionada pelo ingresso na universidade não é vivida pelos estudantes como uma ruptura com o grupo familiar. Exemplo disto é a história de Helena - estudante de Medicina na UFMG - cujo pai trabalhara como açougueiro e possuía apenas a $3^{\mathrm{a}}$ série primária, e a mãe, dona de casa, possuía o primário 
completo. Segundo Viana (1998), esta estudante autoriza-se a se distanciar dos pais sem ter sentimento de transgressão por reconhecer a legitimidade da história deles, tendo sua origem sempre como um importante ponto de apoio. Caso semelhante é o de Luís - estudante de filosofia na Fundação de Ensino Superior de São João DelRei, filho de pai semi-analfabeto, trabalhador braçal, e cuja mãe trabalhara como empregada doméstica e lavadeira. De acordo com Viana (1998), este estudante teve como fonte de energias subjetivas para sua trajetória escolar a compreensão da especificidade do universo escolar e de sua diferença em relação à família. A pesquisadora afirma que não percebera, em nenhum momento do contato com Luís, que aprender e emancipar-se culturalmente de sua família possa ter significado transgressão para ele. Olga - aluna do mestrado em educação da UFMG, que perdera o pai (mecânico) aos sete anos, e cuja mãe trabalhara como servente de escola e concluíra o primeiro grau através de supletivo - é outro exemplo de emancipação cultural não vivida com sofrimento. A mãe, cujo sonho era ver as filhas formadas como professoras, “consentia” simbolicamente que elas fossem o mais longe possível nos estudos. Assim, conforme Viana (1998), Olga autorizou-se a aproveitar ao máximo as oportunidades oferecidas pela universidade sem viver isto como transgressão, o que pode ser ilustrado em seu relato sobre a experiência na UFMG, onde, segundo sua expressão, “nadou de braçada”. E a história de Catarina pedagoga, cursando especialização em psicopedagogia na Universidade Estadual de Minas Gerais, filha mais velha de uma família de onze irmãos, mãe analfabeta, dona de casa e pai trabalhador rural com primário incompleto - é outro exemplo de emancipação não vivida como ruptura. Segundo Viana (1998), a luta de Catarina pela escolarização (alfabetizou-se no Mobral, concluindo a $4^{\text {a }}$ série com 17 anos) foi facilitada pelas relações intersubjetivas familiares, e seu processo escolar não foi vivido como transgressão.

Um trabalho que também aponta outro sentido para trajetórias escolares prolongadas em camadas populares é o de Barbosa (2004). Esta pesquisadora interessada em compreender como estudantes pobres vivem esta condição em uma universidade pública - discute duas possibilidades de significação: tal experiência pode ser vivida como situação de humilhação ou como encontro e revelação.

Barbosa entrevistou três ex-alunos da Universidade de São Paulo, que tinham em comum o fato de serem originários das camadas populares. Inicialmente 
esperando obter lembranças de humilhação vividas durante a graduação, não foi isto, entretanto, o que a pesquisadora predominantemente ouviu nos relatos.

Foi a partir da fala de uma das entrevistadas - Regina, ex-aluna do curso de psicologia, profissional estabelecida com mestrado e doutorado na área - que a autora pôde ampliar seu olhar e vislumbrar que não há apenas sofrimento e humilhação na condição de estudante pobre em uma universidade pública. Ao falar sobre seu cotidiano na universidade, Regina - proveniente de um bairro periférico de São Paulo - é enfática ao afirmar que este não era constituído apenas de sofrimento. De fato, isso existia, sobretudo, em relação ao sentimento de incapacidade para algumas tarefas acadêmicas e na convivência com colegas de turma. Mas, apesar disso, a ex-estudante afirma que se divertia e aproveitava muito o que o campus e a vida universitária ofereciam. Ela recusa-se a ver o pobre como coitado ou alguém de quem se deveria ter pena; a pobreza aparece em sua fala como um obstáculo a se vencer, mas também como possibilidade de crescimento. Regina, inclusive, afirma ter se valido desta condição como modo de se diferenciar na Universidade durante a graduação. Questionada a respeito do que mais mudara em sua vida com o ingresso na USP, ela responde que foi o acesso a uma outra vida cultural, vivenciada como enriquecimento e não como substituição à sua experiência familiar. Barbosa (2004) aponta que talvez a entrada na universidade tenha colaborado para que esta ex-aluna assumisse sua condição econômica e cultural com mais calma, sem negação ou renúncia de seu desejo de aprender e crescer mais. Acrescentamos, também, que o acesso a algumas situações e práticas que o mundo universitário proporciona, como discussões teóricas, participação no movimento estudantil e em eventos artísticos, contato com pessoas diferentes, parece ter contribuído para uma melhor elaboração de sua origem social. Assim, a experiência universitária de Regina mostra que, apesar das situações de humilhação, existe a possibilidade de "reagir a esse tipo de golpe, retirando valor, poder e saber daquilo que, na humilhação, aparece apenas como desvantagem, fraqueza e ignorância...” (Barbosa, 2004: 259).

Assim, apesar da ênfase, dada por alguns estudos, para o conformismo e a ruptura, bem como para o sofrimento daí oriundo, outras pesquisas indicam a possibilidade de existirem outros sentidos para a presença do estudante das camadas populares na Educação Superior. Nesse sentido, consideramos importante refletir sobre algumas questões como, por exemplo: Quais os custos e os benefícios 
psíquicos de uma trajetória escolar prolongada? Trajetórias de escolarização prolongada seriam sempre fonte de sofrimento? Quais dificuldades e quais possibilidades o acesso e a permanência numa universidade pública traz a um estudante pobre?

Partindo dessas questões e das contribuições dos trabalhos apresentados, o objetivo da presente pesquisa é analisar a trajetória escolar e a experiência universitária de estudantes de cursos superiores de alta seletividade provenientes das camadas populares e discutir os sentidos, atribuídos por eles próprios, do ingresso e da permanência no Ensino Superior público.

Com isso, pretendemos discutir o que significa, da perspectiva dos estudantes, construir uma trajetória rumo a uma universidade pública e dentro dela, investigando como se deu a trajetória escolar, o ingresso na Educação Superior, bem como a experiência no interior da universidade ${ }^{14}$.

\subsection{Metodologia}

Para alcançar o objetivo proposto, realizamos entrevistas com cinco estudantes considerados “super-selecionados” (Bourdieu, 1998a). Isto é, jovens que, provenientes de camadas populares, tenham tido acesso aos cursos superiores de mais alta seletividade da Universidade de São Paulo de um de seus campi (localizado no interior do Estado). A opção por se estudar trajetórias escolares que constituam exceções repousa no fato de que tais “casos-limites” podem ser “uma boa maneira de se captar a lógica dos casos normais que comumente se furta ao olhar” (Lahire, 2002: 12).

Foram escolhidos os cinco cursos mais concorridos entre os anos de 2001 e 2005 entre os existentes no campus. Os critérios utilizados para esta escolha, bem como dados sobre a relação candidato/vaga, nota de corte e informações socioeconômicas serão apresentados no próximo capítulo.

Selecionados os cursos, fomos à procura de alunos que se encaixassem no perfil desejado. Por serem poucos os estudantes das camadas populares realizando cursos de alta seletividade, esse não foi um processo fácil.

\footnotetext{
${ }^{14}$ Apesar de, evidentemente, a universidade também compor a trajetória escolar dos estudantes, ao usarmos esse termo estaremos nos referindo, prioritariamente, aos períodos do Ensino Fundamental e Médio. Já o termo experiência universitária estará reservado ao Ensino Superior.
} 
Os estudantes a serem entrevistados deveriam reunir duas condições: serem provenientes das camadas populares e terem realizado, pelo menos, metade do curso. Este último critério foi necessário tendo em vista que a pesquisa objetivava também investigar a experiência universitária dos estudantes. Assim, primeiramente recorremos a indicações das assistentes sociais da Coordenadoria de Assistência Social da USP (COSEAS) de alunos dos cinco cursos selecionados que usufruíssem algum tipo de auxílio ou benefício social, como bolsa-moradia ${ }^{15}$, bolsa-trabalho ${ }^{16}$ ou bolsa-alimentação ${ }^{17}$. Qualquer benefício é concedido a partir de seleção socioeconômica realizada pela COSEAS. Além disso, recorremos também a indicações e intermediação de alunos moradores na residência estudantil e de funcionários de uma das faculdades. A mediação entre a pesquisadora e os estudantes, a serem entrevistados, foi, em geral, realizada por alunos, com quem tinha contato, amigos ou conhecidos dos estudantes. Inicialmente, esse aluno apresentava a pesquisa para os estudantes, convidando-os a participar dela. Aceito o convite, eu os procurava e marcávamos um primeiro encontro, quando explicava mais detalhadamente do que tratava a pesquisa, como seriam as entrevistas e falava sobre minha trajetória.

As entrevistas versaram sobre a vida escolar dos estudantes, que relataram suas trajetórias desde a entrada na escola até o ingresso na Universidade, bem como sua experiência no interior dela, tendo sido realizadas em dois momentos. Num primeiro momento, procurou-se conhecer a trajetória escolar e a experiência universitária de cada estudante e, num segundo, o encontro - que foi realizado em outra data - visava ao aprofundamento ou esclarecimento de algumas questões surgidas na primeira entrevista. Assim, foram feitas duas entrevistas com cinco estudantes (um aluno de cada curso selecionado) com duração de aproximadamente duas horas cada uma. Todas as entrevistas foram realizadas nas residências dos estudantes.

Para a realização das entrevistas nos apoiamos na discussão de Bosi (1979) sobre a questão da memória, cujo trabalho com lembranças de velhos, situado na área da Psicologia Social, segundo Queiroz (1988), foi o pioneiro na retomada do uso de

\footnotetext{
${ }^{15}$ Moradia estudantil gratuita localizada no campus.

${ }^{16}$ Benefício pago pela realização de atividades em projeto previamente selecionado pela COSEAS, com valor equivalente a um salário mínimo.

${ }^{17}$ Isenção do pagamento das refeições oferecidas pelo restaurante universitário.
} 
histórias de vida como técnica de pesquisa no Brasil. Entendendo a memória como atributo humano estreitamente dependente da vida social e por esta alimentada (Queiroz, 1988), Bosi não a concebe como algo exclusivamente individual, na medida em que a família ou o grupo exerce função de testemunha das experiências relatadas, e o “conjunto das lembranças é também uma construção do grupo em que a pessoa vive...” (1993: 281). Também para a realização das entrevistas, baseamos-nos em contribuições teórico-metodológicas de Gonçalves Filho (2003) que afirma ser necessária calma no olhar e no ouvir da entrevista, permitindo que o outro seja realmente outro e não uma idéia apressada que dele temos; essa, segundo o autor, é a única garantia de que, na redação de uma pesquisa, estaremos falando de alguém e não de nós mesmos ou do que projetamos no outro.

As entrevistas foram gravadas e posteriormente transcritas de forma literal. Após a realização de cada uma delas, registrei em diário de campo fatos e outras observações que, porventura, pudessem contribuir para a interpretação de seu conteúdo.

Depois de completada a transcrição de cada entrevista, entreguei uma cópia para os estudantes visando não só ao reconhecimento de sua narrativa na forma escrita, mas também permitir ao entrevistado realizar mudanças em seu relato, caso desejasse. Solicitei autorização para a utilização das entrevistas em suas formas finais, garantindo o sigilo e o anonimato dos entrevistados.

Os estudantes demonstraram, de forma geral, grande disponibilidade em contar suas trajetórias de vida e suas experiências escolares, tendo a entrevista funcionado, em alguns casos, como momentos de auto-reflexão. O procedimento da segunda entrevista se mostrou importante e produtivo; através dele pude rever algumas interpretações, bem como ouvir o que o próprio estudante tinha a dizer sobre isso. Também a devolução do relato no formato escrito foi importante na medida em que permitiu, a alguns estudantes, rever, por exemplo, a ênfase dada a determinado evento e modificá-la.

Durante as entrevistas, procurei respeitar os caminhos escolhidos para a recordação e narrativa das trajetórias escolares, na medida em que são o "mapa afetivo e intelectual da sua experiência e da experiência de seu grupo” (Bosi, 1993) e já trazem em si informações relevantes à pesquisa. Ou seja, o que e como se relatou, constituíram informações importantes. Ao longo do depoimento, todavia, busquei 
garantir que alguns pontos fossem abordados, como, por exemplo, relação com professores, expectativa da família em relação à escolarização, desempenho escolar, entre outros (ver Roteiro de entrevista no Anexo 1).

Em que pese o respeito aos caminhos escolhidos pelos entrevistados para a narrativa de suas trajetórias, há limites para uma postura que se poderia denominar “não-diretiva”. Thiollent (1987) afirma que, se levada ao pé da letra, a nãodiretividade impossibilitaria qualquer tipo de investigação. Daí a introdução de questões no roteiro, que foram feitas quando os estudantes não as mencionaram ou quando desejei aprofundá-las.

A análise das entrevistas se realizou, primeiramente, através de um processo de “imersão" no material, por meio de leituras e releituras sucessivas das transcrições. Conforme Michelat, as repetidas leituras permitem uma espécie de impregnação, suscitando interpretações pelo relacionamento de elementos diversos. Apoiando-se na compreensão psicanalítica, este autor define o que entende por interpretação: “... significa que, além da literalidade da frase, tenta-se reconstituir sua tradução interpretativa incluindo seqüências de significação mais ou menos longas” (1987: 205). E propõe que:

... a atenção particular dedicada à singularidade de cada entrevista é concomitante a um relacionamento das diversas entrevistas entre si. Isto conduz a alternar as leituras verticais das entrevistas (guardando a lógica própria a cada uma) e as leituras horizontais, para estabelecer a relação com as outras entrevistas (Michelat, 1987: 206).

Cada entrevista foi, portanto, considerada e analisada em sua singularidade e totalidade, procurando conservar todos os detalhes que permitiram reconstituir sua lógica própria, constituindo uma análise vertical. Esta análise, por sua vez, contribuiu para a construção de categorias a serem desenvolvidas na análise horizontal. Tais categorias foram levantadas a partir do próprio material disponível através do agrupamento de temas recorrentes nas várias entrevistas ou que estavam, de alguma forma, relacionados.

Uma preocupação que guiou constantemente o trabalho de análise das entrevistas foi o respeito pelos estudantes entrevistados. A esse respeito, diz Gonçalves Filho: 
Uma pessoa não é matéria de conhecimento. (...) Alguém não é quem dissecamos, mas é com quem conversamos: não encontramos alguém como um alvo de análise, mas como um parceiro na interpretação e na interrogação do mundo. (...) Pensamos a ação ou o discurso de alguém, mas a pessoa, ela mesma, não se dá ao pensamento. Uma pessoa excede a coisa feita ou a coisa dita que nos deu a pensar. E pensamos melhor quando o agente ou o falante é nosso interlocutor, e não a coisa pensada (2003: 199).

O planejamento inicial era realizar uma entrevista-piloto que serviria como base para a reflexão sobre os procedimentos metodológicos, aprimorando-os ou modificando-os para, posteriormente, serem realizadas as demais entrevistas. No entanto, a primeira entrevista enfrentou algumas dificuldades, diante do que optei por realizar uma segunda entrevista, de modo a dispor de duas experiências para, assim, dispor de mais elementos a auxiliar na reflexão metodológica. Com essas duas entrevistas, que serão as primeiras a serem apresentadas, foi realizado o exame de qualificação e, a partir das sugestões que aí tiveram lugar, o foco da pesquisa foi novamente configurado, implicando algumas pequenas modificações no Roteiro de entrevista.

As entrevistas com os estudantes serão apresentadas na ordem em que foram realizadas e da seguinte maneira: primeiro, faremos uma análise de seus principais aspectos e, em seguida, apresentaremos a entrevista na íntegra. Essa forma de apresentação foi escolhida por avaliarmos que ela é a que melhor assegura algo que consideramos fundamental nesse tipo de pesquisa - o respeito pela fala dos entrevistados.

Antes, porém, de conhecer os estudantes e o que eles nos disseram sobre as questões que movem esta pesquisa, é necessário saber quais foram os cursos selecionados para compor este estudo. 


\section{OS CURSOS DE ALTA SELETIVIDADE E SUAS CARACTERÍSTICAS}

A seleção dos cursos de um dos campi da USP, que fariam parte da presente pesquisa, foi feita com base nos critérios relação candidato/vaga e nota de corte. Foram selecionados os cinco cursos com as taxas de seletividade mais altas nos dois critérios, entre os anos 2001 e 2005. A definição do número de cursos que comporia a pesquisa, considerou o número total de cursos existentes no ano de 2001 - a saber, onze. Assim, ao selecionar os cinco cursos, abrangemos aproximadamente a metade dos cursos existentes desde o ano de 2001. Essa restrição buscou encontrar cursos cuja história no câmpus onde a pesquisa seria desenvolvida não fosse recente e tivesse certa continuidade no tempo. Isso porque tem ocorrido grande aumento na oferta de cursos, sobretudo a partir dos anos de 2002 e 2003, sendo que, no ano de 2005, o total de cursos oferecidos é o dobro do existente em 2001, ou seja, 22.

A relação candidato/vaga corresponde ao número total de inscritos dividido pelo número total de vagas em cada curso. Segue a Tabela 1 com a relação candidato/vaga para os cursos existentes no campus onde a pesquisa foi desenvolvida entre 2001 e 2005. 
Tabela 1. Número de candidatos inscritos por vaga em cada opção de curso.

\begin{tabular}{|c|c|c|c|c|c|}
\hline Curso & 2001 & 2002 & 2003 & 2004 & 2005 \\
\hline - Ciências Médicas & 23,6 & 27,4 & 31 & 30,8 & 31 \\
\hline - $\quad$ Ciências Biológicas & 22 & 21,8 & 24,1 & 21,3 & 21,8 \\
\hline - Psicologia & 30,1 & 27 & 28,8 & 29,2 & 25,2 \\
\hline - Administração & 17,4 & 18,6 & 21 & 18,1 & 19,3 \\
\hline - Farmácia-Bioquímica (integral) & 15,8 & 18,5 & 22 & 20,2 & 15,4 \\
\hline - Farmácia-Bioquímica (noturno) & - & 6,6 & 8,5 & 7 & 7,6 \\
\hline - Economia & 9,1 & 9,2 & 9,8 & 10 & 8,3 \\
\hline - Física Médica & 8,2 & 7,5 & 8 & 7,7 & 8,5 \\
\hline - Odontologia & 14 & 8,3 & 10,4 & 8,2 & 8,6 \\
\hline - Ciências Contábeis & 9,25 & 6,2 & 6 & 6,4 & 8,4 \\
\hline - Enfermagem & 8,7 & 10,3 & 10,6 & 10,9 & 10,7 \\
\hline - Q Química (Bacharelado - a partir de 2003) & 11,7 & 6,3 & 7,1 & 7,7 & 7,6 \\
\hline - Pedagogia & - & 6,6 & 7,6 & 8,3 & 8,4 \\
\hline - Música & - & 1,5 & 1 & 1,4 & 8,4 \\
\hline - Fisioterapia & - & 19,3 & 19,8 & 18,8 & 18,5 \\
\hline - Terapia Ocupacional & - & 14,1 & 15,9 & 12,7 & 17,3 \\
\hline - Nutrição e Metabolismo & - & - & 10,4 & 17,3 & 14,6 \\
\hline - Informática Biomédica & - & - & 6,8 & 12,1 & 7,9 \\
\hline - Fonoaudiologia & - & - & 3,3 & 16,4 & 5,6 \\
\hline - Ciência da Informação e da Docum. & - & - & 3,3 & 6,8 & 5,7 \\
\hline - Química (Licenciatura) & - & - & 2,4 & 4,4 & 6,7 \\
\hline - Matemática Aplicada & - & - & 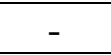 & 3,6 & 6,6 \\
\hline
\end{tabular}

Fonte: Fuvest

Com base na Tabela 1, temos que, no ano de 2001, os cinco cursos mais concorridos foram: Psicologia, Ciências Médicas, Ciências Biológicas, Administração e Farmácia-Bioquímica. Nos demais anos, estes cursos repetem-se, com exceção de 2005, em que o curso de Farmácia deixa de estar entre os mais concorridos, sendo substituído pelo curso de Fisioterapia.

A nota de corte corresponde ao total de pontos obtidos na primeira fase do vestibular da Fuvest ${ }^{18}$ do último candidato que foi convocado para a segunda fase. Nesta fase, são chamados quatro candidatos para cada vaga existente. A Tabela 2 mostra as notas de corte para os cursos entre os anos de 2001 e 2005.

\footnotetext{
${ }^{18}$ Fundação para o vestibular.
} 
Tabela 2. Notas de corte por curso entre 2001 e 2005.

\begin{tabular}{|c|c|c|c|c|c|}
\hline Curso & $\begin{array}{c}2001 \\
(n=160)\end{array}$ & $\begin{array}{c}2002 \\
(n=160)\end{array}$ & $\begin{array}{c}2003 \\
(n=100)\end{array}$ & $\begin{array}{c}2004 \\
(n=100)\end{array}$ & $\begin{array}{c}2005 \\
(\mathrm{n}= \\
99 * *)\end{array}$ \\
\hline - $\quad$ Medicina e Ciências Médicas* & 118 & 119 & 75 & 78 & 81 \\
\hline - $\quad$ Ciências Biológicas & 97 & 95 & 63 & 66 & 68 \\
\hline - $\quad$ Psicologia & 95 & 91 & 58 & 64 & 67 \\
\hline - $\quad$ Administração & 92 & 89 & 58 & 62 & 67 \\
\hline - $\quad$ Farmácia-Bioquímica & 96 & 89 & 59 & 61 & 65 \\
\hline - Economia & 84 & 85 & 54 & 57 & 59 \\
\hline - $\quad$ Física Médica & 88 & 84 & 53 & 54 & 60 \\
\hline - $\quad$ Odontologia & 86 & 79 & 50 & 51 & 56 \\
\hline - Ciências Contábeis & 75 & 73 & 43 & 44 & 54 \\
\hline - $\quad$ Enfermagem & 72 & 73 & 47 & 51 & 55 \\
\hline - $\quad$ Química (Bacharelado - a partir de 2004) & 80 & 76 & 41 & 51 & 55 \\
\hline - Fisioterapia* & - & 91 & 60 & 63 & 65 \\
\hline - $\quad$ Terapia Ocupacional* & - & 80 & 54 & 56 & 59 \\
\hline - $\quad$ Pedagogia & - & 60 & 39 & 46 & 46 \\
\hline - Música & - & 40 & 25 & 25 & 25 \\
\hline - $\quad$ Nutrição e Metabolismo & - & - & 50 & 57 & 59 \\
\hline - $\quad$ Informática Biomédica & - & - & 45 & 56 & 59 \\
\hline - $\quad$ Fonoaudiologia & - & - & 31 & 51 & 45 \\
\hline - $\quad$ Ciência da Informação e da Docum. & - & - & 31 & 43 & 45 \\
\hline - $\quad$ Química (Licenciatura) & - & - & - & 39 & 48 \\
\hline - $\quad$ Matemática Aplicada & - & - & - & 34 & 50 \\
\hline
\end{tabular}

* Notas de corte computadas juntamente com cursos da USP/São Paulo.

** Uma questão foi anulada.

Tendo como base a Tabela 2, as cinco carreiras com as maiores notas de corte entre 2001 e 2005 são Psicologia, Medicina e Ciências Médicas, Ciências Biológicas, Administração e Farmácia-Bioquímica. As notas de corte do curso de Fisioterapia, nos anos de 2002, 2003 e 2004, foram maiores do que as do curso de Farmácia; em 2005, as notas de corte foram iguais. No entanto, como o curso de Fisioterapia foi criado em 2002 e as notas de corte são computadas juntamente o curso da USP de São Paulo, optamos por manter o curso de Farmácia entre as maiores notas de corte dos cursos existentes desde 2001.

Considerando-se os critérios utilizados - a relação candidato/vaga e a norte de corte -, os cursos de mais alta seletividade do campus da USP considerado, entre 2001 e 2005, são: Administração, Ciências Biológicas, Ciências Médicas, FarmáciaBioquímica e Psicologia. 
Cabem, ainda, algumas considerações sobre o perfil socioeconômico de cada um destes cursos. Todas as informações a esse respeito baseiam-se no levantamento realizado pela Fuvest através de questionários socioeconômicos que são respondidos por todos os candidatos e entregues na inscrição para o exame do vestibular. No Anexo 2, estão disponíveis 17 questões socioeconômicas respondidas pelos alunos matriculados na primeira chamada, nos cinco cursos selecionados nos anos de 2001 a 2005.

O perfil socioeconômico traçado aqui se baseia nas seguintes informações: tipo de escola onde o aluno fez o Ensino Fundamental e o Ensino Médio, grau de instrução do pai e da mãe, renda familiar mensal e o número de pessoas que contribuem e são sustentadas com esta renda. Outros dados socioeconômicos, bem como as porcentagens completas dos aspectos citados, podem ser consultados no Anexo 2.

A Tabela 3 faz um resumo das informações, considerando-se o predominante entre os anos de 2001 e 2005 para cada curso.

Tabela 3. Tipo de escola onde foram realizados os Ensinos Fundamental e Médio, grau de instrução do pai e da mãe, renda familiar mensal e o número de pessoas que contribuem e são sustentadas com esta renda para cada curso, nos últimos cinco anos.

\begin{tabular}{|c|c|c|c|c|c|}
\hline $\begin{array}{c}\text { Cursos } \rightarrow \\
\text { Dados } \downarrow\end{array}$ & Psicologia & $\begin{array}{c}\text { Medicina e } \\
\text { Ciências } \\
\text { Médicas }\end{array}$ & $\begin{array}{c}\text { Ciências } \\
\text { Biológicas }\end{array}$ & Administração & $\begin{array}{c}\text { Farmácia- } \\
\text { Bioquímica }\end{array}$ \\
\hline $\begin{array}{c}\text { Ensino } \\
\text { Fundamental }\end{array}$ & $\begin{array}{c}\text { escola } \\
\text { particular }\end{array}$ & $\begin{array}{c}\text { escola } \\
\text { particular }\end{array}$ & $\begin{array}{c}\text { escola } \\
\text { particular }\end{array}$ & $\begin{array}{c}\text { escola } \\
\text { particular }\end{array}$ & $\begin{array}{c}\text { escola } \\
\text { particular }\end{array}$ \\
\hline $\begin{array}{c}\text { Ensino Médio } \\
\text { escola } \\
\text { particular }\end{array}$ & $\begin{array}{c}\text { escola } \\
\text { particular }\end{array}$ & $\begin{array}{c}\text { escola } \\
\text { particular } \\
\text { particular }\end{array}$ & $\begin{array}{c}\text { escola } \\
\text { particular }\end{array}$ \\
\hline $\begin{array}{c}\text { Grau instrução } \\
\text { pai }\end{array}$ & $\begin{array}{c}\text { Universitário } \\
\text { completo }\end{array}$ & $\begin{array}{c}\text { Universitário } \\
\text { completo }\end{array}$ & $\begin{array}{c}\text { Universitário } \\
\text { completo }\end{array}$ & $\begin{array}{c}\text { Universitário } \\
\text { completo }\end{array}$ & $\begin{array}{c}\text { Universitário } \\
\text { completo }\end{array}$ \\
\hline $\begin{array}{c}\text { Grau instrução } \\
\text { mãe }\end{array}$ & $\begin{array}{c}\text { Universitário } \\
\text { completo }\end{array}$ & $\begin{array}{c}\text { Universitário } \\
\text { completo }\end{array}$ & $\begin{array}{c}\text { Universitário } \\
\text { completo }\end{array}$ & $\begin{array}{c}\text { Universitário } \\
\text { completo }\end{array}$ & $\begin{array}{c}\text { Universitário } \\
\text { completo }\end{array}$ \\
\hline Renda familiar & $1500-3000$ & $3000-5000$ & $1500-3000$ & $3000-5000$ & $1500-3000$ \\
\hline $\begin{array}{c}\mathrm{N}^{\circ} \text { pessoas } \\
\text { contribuem }\end{array}$ & Duas & Duas & Duas & Duas & Duas \\
\hline $\begin{array}{c}\mathrm{N}^{\circ} \text { pessoas } \\
\text { sustentadas }\end{array}$ & Quatro & Quatro & Quatro & Quatro & Quatro \\
\hline
\end{tabular}

De maneira geral, o perfil socioeconômico dos cursos é bastante parecido, sobretudo no que se refere à escolarização. Considerando-se aproximadamente a metade dos alunos ingressantes em cada um dos cinco cursos de 2001 a 2005, pode- 
se afirmar que a maioria realizou os Ensinos Fundamental e Médio em escolas particulares, e os pais possuem Ensino Superior completo. Em relação à renda familiar, entretanto, há certa variação entre os cursos. Enquanto em Medicina e Administração a maior parte dos alunos possui renda familiar entre R \$3.000,00 e R\$ 5.000,00, nos cursos de Psicologia, Ciências Biológicas e Farmácia, a renda é de R\$ $1.500,00$ a $\mathrm{R} \$ 3.000,00$.

Dentre as informações socioeconômicas que estão sendo consideradas, a renda familiar foi a que, além de diferir entre os cursos, teve a maior variação para um mesmo curso em cada um dos anos analisados. A título de ilustração, iremos comparar os dados em relação ao tipo de escola onde o Ensino Médio foi realizado e a renda familiar para o ano de 2005 através das Tabelas 4 e 5.

Tabela 4: Tipo de escola em que realizou estudos de Ensino Médio em 2005 (em \%).

\begin{tabular}{|l|c|c|c|c|c|}
\hline & $\begin{array}{c}\text { Psicologia } \\
(\mathrm{n}=40)\end{array}$ & $\begin{array}{c}\text { Medicina e } \\
\text { Ciências } \\
\text { Médicas } \\
(\mathrm{n}=374)\end{array}$ & $\begin{array}{c}\text { Ciências } \\
\text { Biológicas } \\
(\mathrm{n}=40)\end{array}$ & $\begin{array}{c}\text { Administra } \\
\text { ção } \\
(\mathrm{n}=45)\end{array}$ & $\begin{array}{c}\text { Farmácia- } \\
\text { bioquímica } \\
(\mathrm{n}=80)\end{array}$ \\
\hline Só em escola pública & 2,5 & 2,9 & 10 & 6,7 & 7,5 \\
\hline Só em escola pública federal & - & 3,5 & - & - & - \\
\hline Só em escola particular & 97,5 & 91,7 & 82,5 & 86,7 & 90 \\
\hline Maior parte em escola pública & - & 1,1 & 2,5 & 2,2 & 1,3 \\
\hline Maior parte em escola particular & - & 0,8 & 5 & 2,2 & 1,3 \\
\hline Metade em cada tipo de escola & - & - & - & 2,2 & - \\
\hline Em supletivo ou madureza & - & - & - & - & - \\
\hline $\begin{array}{l}\text { No exterior (qualquer tipo de } \\
\text { escola) }\end{array}$ & - & - & - & - & - \\
\hline
\end{tabular}

Tabela 5. Renda familiar mensal (em reais) em 2005 (em \%).

\begin{tabular}{|l|c|l|l|l|c|}
\hline & $\begin{array}{l}\text { Psicologia } \\
(\mathrm{n}=40)\end{array}$ & $\begin{array}{l}\text { Medicina } \\
\text { Ciências } \\
\text { Médicas } \\
(\mathrm{n}=374)\end{array}$ & $\begin{array}{l}\text { Ciências } \\
\text { Biológicas } \\
(\mathrm{n}=40)\end{array}$ & $\begin{array}{l}\text { Administraçã } \\
\mathrm{o} \\
(\mathrm{n}=45)\end{array}$ & $\begin{array}{l}\text { Farmácia- } \\
\text { Bioquímica } \\
(\mathrm{n}=80)\end{array}$ \\
\hline Inferior a 500 & - & 0,5 & - & - & 1,3 \\
\hline Entre 500 e 1500 & 5 & 6,5 & 10 & 4,4 & 16,3 \\
\hline Entre 1500 e 3000 & 35 & 18,4 & 40 & 22,2 & 28,8 \\
\hline Entre 3000 e 5000 & 20 & 24,1 & 20 & 24,4 & 25 \\
\hline Entre 5000 e 7000 & 17,5 & 19,2 & 22,5 & 22,2 & 17,5 \\
\hline Entre 7000 e 10000 & 12,5 & 16,5 & 2,5 & 13,3 & 2,5 \\
\hline Superior a 10000 & 10 & 14,9 & 5 & 13,3 & 8,8 \\
\hline
\end{tabular}


Observando-se as duas tabelas, percebemos que, enquanto a renda familiar se distribui entre os diferentes níveis de rendimento, a variação para o tipo de escola onde foi realizado o Ensino Médio, é muito menor ${ }^{19}$. Com esta comparação, pretendemos mostrar apenas que, se para o dado escolaridade há certa homogeneidade entre e dentro dos cursos, a mesma afirmação não pode ser feita em relação ao rendimento.

Um último aspecto a ser considerado refere-se à cor dos alunos matriculados nos cursos selecionados. Quase todos os alunos ingressantes nos cinco cursos, entre 2001 e 2005, declararam-se como brancos (o índice mais baixo foi 75\% no curso de Ciências Biológicas, em 2004, e em Medicina, em 2005 - ver Anexo 2).

Por fim, resta apenas informar que os cursos selecionados são integrais, com exceção de Administração que é noturno.

Vamos, então, conhecer as histórias de cinco estudantes dos cursos de mais alta seletividade de um dos campi da Universidade de São Paulo provenientes das camadas populares.

\footnotetext{
${ }^{19}$ Há que se considerar também que as possibilidades variação de escola são menores.
} 


\section{PERCURSOS E PERCALÇOS NA CONSTRUÇÃO DE NOVOS HORIZONTES}

Para discutir a trajetória escolar e a experiência universitária de estudantes das camadas populares que ingressaram em cursos de alta seletividade da Universidade de São Paulo fomos conhecer as histórias de Felipe, Marcos, Pedro, Antônio e $\operatorname{Carlos}^{20}$, alunos dos cursos de Administração, Psicologia, Biologia, Farmácia e Medicina, respectivamente.

Procuramos entrevistar estudantes provenientes de estratos sociais das camadas populares que divergissem do perfil socioeconômico predominante em cada um dos cursos selecionados.

A definição e a delimitação das “classes sociais” é tema bastante complexo. Em minha dissertação de Mestrado deparei-me com essa questão ao estudar a presença da “classe média” na escola pública (Piotto, 2002). Nesse trabalho, baseada em autores como Quadros (1991) e Mills (1979), discuti a difícil e tênue delimitação entre “classe média” e "classe trabalhadora” e tendo em vista os problemas conceituais, a dificuldade de definição, bem como críticas em relação ao conceito “classe média”, optei por utilizar o termo camadas médias - sempre no plural por abranger vários estratos sociais - e trabalhar com indicadores de estratificação social. Da mesma forma, considerando a dificuldade de se definir o operariado (Bottomore, 1988) e a existência de diferenças em seu interior, estamos nos valendo, no presente trabalho, assim como o fizemos naquele (Piotto, 2002), do termo camadas populares.

Romanelli (2003) afirma que a noção de camadas populares aproxima-se da teoria de estratificação social que pressupõe que as camadas sociais podem se sobrepor e ser delimitadas, principalmente, através do fator renda. O autor adverte, entretanto, que o estilo de vida das famílias, inclusive das camadas populares, não depende apenas do rendimento mas inclui também a mediação de elementos simbólicos. Assim, se essa noção tem sido utilizada para caracterizar a população pobre de centros urbanos (Romanelli, 1997) e se as famílias que as compõem

\footnotetext{
${ }^{20}$ Todos os nomes próprios utilizados neste trabalho são fictícios.
} 
possuem vários aspectos comunas, como serviços de saúde, educação e transportes precários, não se pode agrupar todas elas sob uma homogeneizante denominação. De acordo com Romanelli (2003), a situação de escassez pode aproximá-las, mas a forma de viver tal situação diferencia-as. Nesse sentido, as condições de existência das camadas populares, assim como das demais camadas sociais, não constituem uma realidade homogênea.

Além disso, Romanelli (2003) aborda também a existência de uma “nova pobreza”, que dificulta ainda mais a delimitação entre camadas médias e populares. Essa pobreza, segundo o autor, é social e culturalmente diversificada e inclui trabalhadores com Ensino Fundamental e Médio e com ocupações não-manuais, critério habitualmente usado para caracterizar o pertencimento às camadas médias.

Portes (2001), falando a respeito de alunos pobres que freqüentavam faculdades no século XIX, caracteriza a condição desses estudantes como "pobreza particular” já que a situação socioeconômica deles, embora destoasse da maioria dos estudantes dessas instituições nesse período, não era a mesma “pobreza geral” que caracterizava a população mais pobre.

Assim, considerando as diferenças existentes no interior das camadas populares, temos claro que os estudantes entrevistados pertencem a um segmento social específico dessas camadas.

Ao longo das análises das entrevistas apresentaremos algumas características socioeconômicas dos estudantes e de suas famílias. Para facilitar o acompanhamento das diferentes histórias, entretanto, apresentamos a seguir um quadro com o resumo de algumas informações sobre cada um dos estudantes: 
Quadro resumo das características socioeconômicas dos estudantes entrevistados.

\begin{tabular}{|c|c|c|c|c|c|}
\hline Estudante & Felipe & Marcos & Pedro & Antônio & Carlos \\
\hline Curso & $\begin{array}{l}\text { Administraç } \\
\text { ão }\end{array}$ & Psicologia & Biologia & Farmácia & Medicina \\
\hline Idade & 22 anos & 27 anos & 22 anos & 23 anos & 33 anos \\
\hline Período curso & $5^{\circ} \mathrm{sem}$ & $7^{\circ}$ sem & $8^{\circ}$ sem & $8^{\circ}$ sem & $10^{\circ} \mathrm{sem}$ \\
\hline $\begin{array}{l}\text { Tipo de escola em } \\
\text { que realizou } \\
\text { Ensino } \\
\text { Fundamental }\end{array}$ & $\begin{array}{l}\text { escola } \\
\text { pública }\end{array}$ & $\begin{array}{l}\text { escola } \\
\text { pública }\end{array}$ & $\begin{array}{l}\text { escola } \\
\text { pública }\end{array}$ & $\begin{array}{l}\text { escola } \\
\text { pública }\end{array}$ & $\begin{array}{l}\text { escola } \\
\text { pública }\end{array}$ \\
\hline $\begin{array}{l}\text { Tipo de escola em } \\
\text { que realizou } \\
\text { Ensino médio }\end{array}$ & $\begin{array}{l}\text { escola } \\
\text { pública }\end{array}$ & $\begin{array}{l}\text { escola } \\
\text { pública }\end{array}$ & $\begin{array}{l}\text { escola } \\
\text { particular } \\
\text { (bolsa) }\end{array}$ & $\begin{array}{l}\text { escola } \\
\text { particular } \\
\text { (bolsa) }\end{array}$ & $\begin{array}{l}\text { escola } \\
\text { pública/ } \\
\text { escola } \\
\text { particular }\end{array}$ \\
\hline $\begin{array}{l}\text { Período em que } \\
\text { cursou Ensino } \\
\text { Médio }\end{array}$ & Noturno & Diurno & Diurno & Diurno & Diurno \\
\hline Escolaridade pai & $\begin{array}{l}\text { Ensino } \\
\text { Médio }\end{array}$ & $4^{\mathrm{a}}$ série & $\begin{array}{c}\text { Ensino } \\
\text { fundamental }\end{array}$ & $3^{\mathrm{a}}$ série & $4^{\mathrm{a}}$ série \\
\hline Escolaridade mãe & $\begin{array}{l}\text { Ensino } \\
\text { Médio }\end{array}$ & $4^{\mathrm{a}}$ série & $\begin{array}{l}\text { Ensino } \\
\text { Médio }\end{array}$ & $4^{\mathrm{a}}$ série & $4^{\mathrm{a}}$ série \\
\hline $\begin{array}{l}\text { Profissão/ocupação } \\
\text { pai }\end{array}$ & Motorista & Vigia & Pedreiro & Fundidor & Motorista \\
\hline $\begin{array}{l}\text { Profissão/ } \\
\text { ocupação mãe }\end{array}$ & $\begin{array}{l}\text { Funcionária } \\
\text { Pública } \\
\text { municipal }\end{array}$ & $\begin{array}{l}\text { Dona de } \\
\text { casa }\end{array}$ & $\begin{array}{l}\text { Dona de } \\
\text { casa }\end{array}$ & Costureira & $\begin{array}{c}\text { Dona de } \\
\text { casa }\end{array}$ \\
\hline
\end{tabular}

È importante informar que todos os estudantes entrevistados residiam na moradia estudantil e são brancos.

Conheçamos, então, as trajetórias de vida e as experiências escolares de Felipe, Marcos, Pedro, Antônio e Carlos. 


\subsection{Felipe e a experiência de desenraizamento}

Felipe, 22 anos, é estudante do quinto semestre do curso de Administração ${ }^{21}$. Sua família mora em um pequeno município do interior paulista e desde o início da graduação, há quatro anos, Felipe residiu na moradia estudantil ${ }^{22}$. Na data da primeira entrevista, porém, tinha se mudado para um apartamento no centro da cidade havia uma semana, onde foram realizadas as duas entrevistas ${ }^{23}$.

Proveniente do que ele denomina de "classe média baixa”, Felipe é filho de uma funcionária pública aposentada pela Secretaria Municipal de Administração e de um motorista do Serviço de Água e Esgoto de sua cidade natal - tendo ambos realizado curso técnico em contabilidade. Tem dois irmãos: uma irmã mais velha (25 anos), que cursou Geografia em uma faculdade particular através de bolsa e trabalha no Ministério do Trabalho e um irmão mais novo - 20 anos -, que trabalha em uma loja de confecções e concluiu o Ensino Médio; ambos residem com os pais. A renda familiar total é de aproximadamente R $2.000,00$. Sobre os avós paternos, Felipe não tem informações sobre o avô, pois não o conheceu, e a avó trabalha na Polícia de Trânsito. Do lado materno, seu avô, aposentado, trabalhou como caminhoneiro, e sua avó é dona de casa.

Felipe realizou a Pré-Escola, o Ensino Fundamental e o Ensino Médio na mesma escola - pertencente à rede pública estadual de ensino e localizada em um bairro central próximo à sua casa. Considerada uma boa escola, bem “conceituada”, como ele descreve, esse jovem relata que era difícil conseguir vaga para estudar lá e que "pegou todas as épocas que deu certo”, considerando o ensino oferecido por essa escola de boa qualidade até aproximadamente o período em que cursou a $5^{\mathrm{a}}$ e a $6^{\mathrm{a}}$ séries. Conta que se lembra de gostar de ir à escola, que sempre foi bom aluno, que seu desempenho escolar era muito bom - apesar de gostar mais das matérias de exatas (com exceção de química), ia bem em todas as disciplinas -, estando suas notas entre as maiores da turma e ele sempre entre os melhores alunos. Felipe também afirma que tem facilidade de “assimilação” e "raciocínio” e que não costuma ficar nervoso em provas ou avaliações.

\footnotetext{
${ }^{21}$ A graduação em Administração no período noturno é composta de dez semestres.

${ }^{22}$ Como veremos adiante, Felipe cursou Economia durante um ano e, posteriormente, transferiu-se para o curso de Administração que cursa há três anos.

${ }^{23}$ Felipe conta que saiu da moradia porque estava muito cansado de morar lá e por ter encontrado um apartamento com aluguel barato que dividiria com um colega.
} 
Uma lembrança escolar ruim à qual Felipe se refere diz respeito à sua professora da $1^{\text {a }}$ série, que era muito "brava” e que uma vez lhe deu uma "livrada” na cabeça por ter errado um exercício e que, além disso, costumava puxar o cabelo de outros alunos.

Esse, no entanto, parece ter sido um episódio isolado na história escolar de Felipe, já que sua relação com os professores, segundo ele, sempre foi muito boa. Ele relata que os professores o elogiavam muito, gostavam bastante dele e costumavam perguntar por ele quando não mais lhe davam aula, comentando com sua mãe que ele era bom aluno e que iria "se dar bem”. Essa valorização do desempenho acadêmico de Felipe pode ser ilustrada através de um fato ocorrido por ocasião de sua transferência, durante o Ensino Médio, para o período noturno, quando uma professora de inglês - brava, rígida, de quem os alunos não gostavam -, lamentou sua saída dizendo para seus colegas de classe que eles "perderam um aluno muito bom...”. Felipe, ao contrário dos colegas, contudo, gostava dessa professora e de sua aula: “Todo mundo ficava tenso na aula assim. Mas eu gostava dela. Eu gosto de um pouco de tensão”. O reconhecimento de seu bom rendimento acadêmico e a crença em sua capacidade, por parte dos professores, foram mencionados várias vezes por esse jovem durante as entrevistas, parecendo terem tido importante papel em sua trajetória.

Diferente era a postura de seus pais em relação à escolarização: por Felipe sempre ter sido bom aluno, eles não participavam ativamente de sua vida escolar quase não iam a reuniões nem tampouco acompanhavam ou cobravam a realização de tarefas. Ao contrário do que ocorria com seu irmão que, em virtude de um desempenho escolar ruim, demandava a presença constante da mãe às reuniões, além de outras ações, como, por exemplo, o recurso a aulas particulares. Em vários momentos nos quais Felipe trata de sua experiência escolar, ele a compara com a de seu irmão, cujo rendimento acadêmico sempre fora mais sofrível. Apesar de Felipe dizer que não havia necessidade de se "fazer muita festa" pelo seu ótimo desempenho escolar, o qual era encarado pelos pais com "naturalidade, nem com desprezo, nem com excesso de orgulho”, esse estudante ressente-se da nãovalorização de sua escolarização por parte dos pais.

Essa postura paterna refletia-se também, de modo mais geral, na relação dos pais com a sua dedicação aos estudos. Embora Felipe desejasse muito ingressar em 
uma universidade pública, seus pais, segundo sua avaliação, não o estimulavam nesse sentido. Exemplo disso foi a atitude deles durante o período em que Felipe se preparou para o exame do vestibular, realizando curso preparatório e estudando longos períodos todos os dias da semana. Felipe reproduz os comentários que seus pais costumavam fazer nessa época: “ 'Nossa, mas você está estudando muito!' Sabe? Sempre, sempre foram do contra. Tipo: 'não precisa se matar, estudar muito, tal' ". Segundo seu entendimento, esse tipo de comportamento estava relacionado com o fato de seus pais não considerarem relevante ou necessário cursar uma universidade pública, bastando, para eles, a realização de um Curso Superior em uma faculdade particular, como fez a irmã de Felipe ou, ainda, o encaminhamento para o trabalho, sem cursar Ensino Superior, como ocorria com seu irmão.

Também sua irmã não contou com o apoio dos pais para realizar o Curso Superior que desejava. Felipe conta que ela queria cursar Medicina veterinária, mas que, por ter conseguido bolsa de estudos no curso de Geografia, em uma faculdade particular existente na cidade, seus pais praticamente obrigaram-na a fazer esse curso, não permitindo que ela prestasse vestibular para o curso desejado.

A não-valorização da dedicação aos estudos parecia ocorrer em contraponto à valorização do trabalho, expressando-se, por exemplo, no estímulo dos pais para que os filhos começassem a trabalhar cedo. Ilustração da importância que o trabalho possuía em sua família foi a postura da mãe de Felipe quando ele iniciou o Ensino Médio e surgiu oportunidade de trabalhar em um banco. Esse jovem relata que ela insistiu para que ele aceitasse essa oferta de emprego, argumentando que ele não poderia "perder uma oportunidade dessa”, mesmo isso implicando que ele estudasse à noite - fato que o desagradava. Felipe resolveu aceitar o emprego e trabalhou no banco durante os três anos do Ensino Médio, que cursou no período noturno, para conciliar o estudo com o horário do trabalho.

Pelo relato de Felipe, a dedicação aos estudos parece não ter sido um valor cultivado como central em sua família. Interessante notar que esses pais, como poderemos verificar ao longo deste trabalho, são aqueles com maior grau de instrução dentre os demais pais dos estudantes entrevistados, sendo o único casal em que ambos possuem Ensino Médio completo.

Há, todavia, que se refletir acerca da falta de estímulo dos pais para o ingresso em uma universidade pública, mencionada por Felipe. A realização do curso 
preparatório para o exame do vestibular, por exemplo, foi possível porque esse jovem teve a ajuda do avô, que trabalhava para o dono de um cursinho e conseguiu desconto de $50 \%$ no valor da mensalidade, e da mãe que dividia com ele (que guardara dinheiro do trabalho no banco) o pagamento do restante do valor. Assim, podemos afirmar que Felipe contou com certo apoio familiar na busca pelo ingresso em uma universidade pública. Apesar das queixas em relação à postura dos pais, o próprio Felipe reconhece a importância do suporte familiar na sua trajetória, afirmando que "tudo" o que conseguiu teve a colaboração deles e que sua família é um importante "alicerce" em sua vida.

Não obstante tal reconhecimento, esse jovem ressalva “erros” cometidos pelos pais que se constituíram, na sua percepção, na não-valorização do estudo e no não-estímulo à aprovação no vestibular. Assim, embora Felipe tenha recebido ajuda familiar e a postura assumida por seus pais, interpretada por ele como desestímulo à sua dedicação, possa ser compreendida de outra forma, como, por exemplo, o desejo de não ver o filho sofrer estudando tanto, importa aqui a maneira como ele viveu todo esse processo: sentindo-se só e sem ter seu empenho e sua dedicação valorizados ou reconhecidos ${ }^{24}$.

A trajetória desse estudante até a faculdade foi marcada pelo esforço, pela determinação e, sobretudo, pela solidão. Durante seu relato, Felipe foi enfático ao afirmar que não contou com estímulo, incentivo ou ajuda de ninguém na busca de seu objetivo de ingressar numa universidade pública, trilhando um caminho bastante solitário: “... em termos de uma pessoa que me incentivou ou que falou: ‘Olha, vai lá, você consegue’, sabe? Ninguém. Nem vó, nem vô, nem tio, nem tia, nem ninguém. (...) pelo contrário eu só tive pessoas que me desestimularam, só”. Como vimos, seus pais não consideravam estudar em uma instituição de Ensino Superior pública como algo necessário ou, talvez, como algo possível. A falta de apoio estendia-se para além de seu núcleo familiar, transformando-se em desestímulo: seu empenho em estudar para passar no vestibular era desvalorizado por comentários, feitos por outros familiares, como tios e avós, de que de nada adiantaria estudar tanto se depois não haveria emprego. A escola, na avaliação de Felipe, além de não contribuir para o

\footnotetext{
24 “Qual a versão de um fato é a verdadeira? Nós estávamos e sempre estaremos ausentes dele. Não temos, pois, o direito de refutar um fato contado pelo memorialista, como se ele estivesse no banco dos réus para dizer a verdade, somente a verdade. Ele, como todos nós, conta a sua verdade” (Bosi, 2003: 65).
} 
alcance de seu objetivo, por oferecer ensino de má qualidade, ainda o desencorajou. Um episódio ocorrido com uma professora de Física do Ensino Médio, relatado na primeira entrevista e retomado na segunda, resume esse sentimento. Felipe perguntou a essa professora se teria chances de ingressar em uma universidade pública, ao que ela prontamente respondeu que não. Ele conta que ficou muito chateado e caracteriza esse como um dos momentos mais tristes de sua trajetória escolar:

E eu lembro que eu saí chorando, sabe? Tipo, a hora que acabou a aula, eu fiquei muito mal, fiquei mal mesmo. E fui para casa. Aí meus pais falaram: "Não, mas não precisa, não precisa passar na USP, não precisa passar na faculdade. Se não deu, faz uma outra particular". Eu falei: "Se for para fazer uma particular eu não vou fazer porque não quero”. E foi essa briga assim depois. Tanto é que no cursinho eu consegui bolsa tal, mas se eu não conseguisse, eu falei: "Se eu não fizer cursinho, eu não vou fazer faculdade que paga". Eu falei: "Eu não vou porque a gente não pode e outra porque não tem qualidade”.

A perspectiva de não passar no vestibular abalou Felipe, pois realizar Curso Superior em uma universidade pública era um "sonho" para esse estudante. No entanto, ao cursar o Ensino Médio no período noturno, ele afirma que sentia estar distanciando-se disso, o que fora confirmado pela professora. Conforme sua percepção, a educação de baixa qualidade do Ensino Médio noturno, a perspectiva dos colegas de apenas obterem o diploma, a falta de compromisso dos professores, tornavam esse contexto um meio adverso para a concretização de seu sonho. Dessa forma, o Ensino Médio no período noturno foi, para Felipe, um "período crítico de escola”, pois era “quase impossível estudar” em virtude da grande troca de professores e do desinteresse dos alunos, que eram provenientes de uma camada social diferente da sua, ou, como ele classifica, de uma "classe social bem mais baixa". Sobre esse período, Felipe lembra-se de uma "batida” policial ocorrida na frente da escola e que muito o marcou:

O que mais me chocou é estar presente naquele local, eu pensei: "Por que quê eu tô aqui né? O que quê eu tô fazendo aqui? Eu nunca, nunca passei por isso”. Eu não estava na batida, eu só estava vendo. Mas como eu nunca tinha visto aquilo, para mim era coisa de outro mundo. Eu falei: "Eu não tenho... eu não tenho nada a ver com esse lugar aqui, não, com essas pessoas aqui, não tem nada...”. O que mais me chocou foi isso assim.

Felipe sentiu estar no lugar errado. Essa é a primeira referência a um sentimento que, como veremos, parece lhe acompanhar - o de não-pertencimento. 
Esse estudante começou a vislumbrar a possibilidade de ingressar em uma universidade quando, a partir da $8^{\mathrm{a}}$ série, alguns de seus colegas de turma mudaramse para escolas particulares para realizar o Ensino Médio tendo em vista a busca por melhor preparação para prestar o exame do vestibular: "Foi quando eu comecei a pensar, sabe? 'Não, eu preciso também fazer alguma coisa!' ”. O desejo de compartilhar destinos com seus colegas de ginásio parece ter sido um forte motivador para que Felipe almejasse cursar o Ensino Superior em uma instituição pública: “... então, o pessoal começa a se mobilizar para estudar e todo mundo comentando, então, isso acaba, acho que também a te levar a querer estudar também para continuar meio parte do grupo". O "sonho" de estudar em uma universidade pública revela também o desejo de fazer parte de um grupo, de participar, enfim, um desejo de se enraizar, ou ainda de permanecer como participante de um grupo e manter o enraizamento. Entendemos enraizamento com Weil (1996) que o define como um sentimento de pertença, isto é, de pertencer ou participar ativamente de um certo “lugar” ou grupo, ou ainda, como um “sentir-se em casa”. Também relacionado com esse desejo de continuar parte de um grupo estava o objetivo de Felipe ingressar em uma universidade pública, recusando-se veementemente a cursar uma faculdade privada.

Como dissemos, Felipe fez o Ensino Médio no período noturno para conciliar os estudos com o emprego em um banco, onde iniciou trabalhando como office-boy e, posteriormente, passou para uma função de atendimento ao público. Terminado o Ensino Médio, Felipe prestou vestibular para o curso de Administração, mas não foi aprovado. No ano seguinte, tendo parado de trabalhar, realizou um curso prévestibular, pois, segundo seu relato, não aprendeu praticamente nada em termos de conteúdos escolares que o subsidiassem a ser aprovado no vestibular ${ }^{25}$.

Ingressar numa universidade pública era algo fora da realidade de Felipe naquele momento. Por isso, ele sentia-se nadando contra a correnteza. Porém, determinado em concretizar seu sonho, esse estudante empenhou-se o máximo que pôde, aproveitou a oportunidade de fazer cursinho e estudava doze horas todos os dias da semana. Ser aprovado no vestibular requereu de Felipe grande dispêndio de

\footnotetext{
${ }^{25}$ Felipe argumenta que a escola pouco contribuiu em relação ao conhecimento instrumental necessário para a aprovação no vestibular. No entanto, ressalva acreditar que, de alguma forma, a escola tenha contribuído em termos de desenvolvimento de raciocínio ou inteligência, para sua trajetória.
} 
energia. O sentimento de nadar contra a correnteza, que demanda grande esforço, explica o cansaço relatado por ele. Para ser aprovado no exame do vestibular, Felipe teve de se esforçar e de se dedicar muito.

A motivação para isso encontrava-se na vontade de mostrar que alcançou o que almejava, mesmo não tendo nada, nem ninguém a seu favor. Apesar de ter trabalhado durante o Ensino Médio, que foi muito fraco, apesar de seus pais não o estimularem a passar no vestibular, apesar de a escola o desencorajar a ingressar numa universidade pública, Felipe ingressou na USP. Seu esforço foi recompensado e tudo o que fez, conforme sua avaliação, não foi em vão. Ao desejo de se enraizar, acrescentou-se, assim, o desejo de que seu grande esforço fosse reconhecido e recompensado: “... saiu de um lugar que você não tinha condição (...) e passou numa faculdade boa. Então essa é uma recompensa, sabe? (...) Pelo esforço, (...) tipo: 'Olha, eu tava aqui, agora eu tô aqui. Eu lutei para que isso acontecesse e consegui' ”. Felipe parecia pessoalmente empenhado em mostrar a todos que era capaz.

Como a Unicamp (Universidade Estadual de Campinas) não oferecia o curso de Administração e na Unesp (Universidade Estadual Paulista “Júlio de Mesquita Filho”) só havia o curso de Administração Pública, Felipe resolveu mudar sua opção profissional e prestou vestibular para o curso de Economia nas três universidades públicas paulistas. Tendo sido aprovado na Fuvest e na Vunesp (Fundação para o Vestibular da Universidade Estadual Paulista), matriculou-se no curso de Economia da $\mathrm{USP}^{26}$.

No decorrer do curso, no entanto, Felipe conta que, embora fosse bem nas disciplinas, não estava gostando do conteúdo ministrado por ser muito voltado para a discussão de políticas públicas, sendo que seu desejo era trabalhar com empresas, e que, por isso, “não tinha muito estímulo para ir na faculdade”. Afirma ainda que um erro, cometido por muitos vestibulandos, foi não ter consultado o elenco de disciplinas que compõem a grade curricular do curso antes de fazer a opção por Economia. Mas, ao final do primeiro ano de graduação, após ter procurado um serviço de orientação psicopedagógica existente no campus, Felipe conseguiu transferência interna para o curso de Administração, tendo obtido sucesso em virtude de sua alta média ponderada, já que esse processo é concorrido, tendo grande número de alunos interessados.

\footnotetext{
${ }^{26}$ Vale lembrar que o curso de Economia é menos disputado do que o de Administração.
} 
Desde o primeiro ano da faculdade, foi Felipe quem custeou sua estada na cidade. Nos primeiros dois anos, trabalhou na biblioteca central do câmpus; posteriormente, desenvolveu atividades em um estágio remunerado e no momento da entrevista era bolsista de iniciação científica. Por ocasião das entrevistas, sua bolsa estava prestes a terminar, mas Felipe não pretendia envolver-se com pesquisa novamente porque não gostou da experiência. Considera esse um trabalho muito solitário e afirma gostar de estar perto das pessoas; além disso, comenta também que aprecia um pouco de tensão e competição.

Não obstante Felipe ter ingressado na USP e estar realizando o curso de Administração, o sentimento de "estar fora do lugar” que ele descreveu a respeito de sua convivência com os colegas no Ensino Médio, acompanhou-o na faculdade, embora por razões diversas. Se no colegial seus colegas eram muito mais pobres do que ele, falavam sobre brigas familiares e não tinham a realização de Curso Superior como meta, na faculdade, seus colegas são muito mais ricos, conversam sobre viagens ao exterior e possuem hábitos e estilos de vida que ele não compartilha. É essa diferença que faz Felipe afirmar que ainda não encontrou seu grupo. O sentimento de não-pertencimento parece acompanhá-lo. Se compreendemos o enraizamento, conforme afirmado anteriormente, como um sentimento de pertença (Weil, 1996), por oposição, desenraizamento significa um sentimento de nãopertencimento. Assim, a trajetória desse jovem parece marcada pela experiência de desenraizamento:

Quando eu estava no colegial eu me sentia deslocado porque não era meu meio, e na faculdade eu também me sinto deslocado porque está muito discrepante do... Parece que eu não encontrei ainda aquela, seu, seu grupo, sabe? Então, eu vejo assim. Tanto é que eu não tenho uma relação assim com o pessoal [da faculdade], apesar deles serem legais. O pessoal é gente boa assim, mas eu não consigo ter um entrosamento, sabe? Não consigo porque as conversas, também o meio desse pessoal que eu estou agora, também é diferente do meu, sabe? As conversas são outras então acaba ficando meio deslocado assim...

A discrepância entre as realidades sociais vividas por Felipe e pelos demais colegas de curso e a falta de coisas a compartilhar dificultam o relacionamento deles. Esse estudante explica que os colegas e, de maneira geral, os alunos da faculdade onde estuda partilham um conjunto de valores, hábitos e costumes aos quais é muito difícil ele se adaptar em virtude de sua condição social: 
... por mais que você tente se adequar àqueles valores, assim, ainda para mim é muito complicado. Para mim é muito difícil porque... não os valores, é, seria até valores. Mais do jeito de vestir, sabe? Os lugares que você freqüenta, os esportes que você pratica, as viagens que você faz, entendeu? Isso define o grupo, e aí eu fico meio deslocado porque eu não tenho esses pontos em comum com o pessoal.

Embora procure, de certa forma e sem muito sucesso, se ajustar a esse estilo de vida, Felipe, ao mesmo tempo, critica determinadas posturas e formas de pensar, que também compõem o “grupo de valores da F. [faculdade]”, compartilhadas por professores e alunos e que podem ser, segundo ele, estendidas a outras faculdades de negócios. A relação que ele parece ter com esse "grupo de valores” assemelha-se, a nosso ver, a um "nó ideológico feito de rebeldia e veneração, altivez e sacrifício, ainda à espera de decifração” (Bosi, 2005: 386) ${ }^{27}$.

Além disso, Felipe se opõe e luta contra o uso da universidade pública como um fator de distinção, valorizando, ao contrário, o conhecimento proporcionado por ela. Ele discorda da atitude dos alunos, estimulada por professores, de vangloriaremse pelo fato de estarem na melhor universidade do País, o que justificaria uma postura de arrogância e desprezo em relação a outros cursos e a outras faculdades:

[professores da faculdade ficam] Estimulando essa mentalidade, sabe: "Não, você pode ser nojento porque você tá no melhor". É muito divulgado isso lá [faculdade]. Mas eu não gosto disso, eu acho que não tem nada a ver. Acho que você teve a oportunidade e você tem que usar acho o seu conhecimento; acho que através disso você vai conseguir se sobressair, mas não porque, o fato de você estar lá não significa que você vai ser um bom profissional...

Felipe também critica e se irrita com a ostentação e a valorização que dinheiro e status assumem entre os colegas, compondo parte daquele "grupo de valores”. Ele afirma que ganhar bem, ter status, ser bem-sucedido profissionalmente e acumular dinheiro possuem grande importância e centralidade nesse meio em que ele está. Mas, quando perguntado sobre a relevância disso para ele, Felipe responde que “já foi antigamente”, pois no início do curso, ele também pensava que deveria trabalhar desvairadamente para ganhar muito dinheiro. Comenta, todavia, que hoje não pensa mais assim e considera existirem outras coisas importantes na vida além

\footnotetext{
${ }^{27}$ Essa relação remete-nos também à noção de consciência cindida, da qual trata Frederico (1978), que afirma a coexistência na consciência dos operários de uma "inquietação própria de uma situação de classe marcada pelas agruras de uma carência econômica constante" e de um "otimismo individualista e a esperança de dias melhores que caracterizam uma mentalidade enformada por uma visão linear e progressiva da história” (Frederico, 1978: 134).
} 
do trabalho, como, por exemplo, a amizade. Essa mudança o fez decidir, por exemplo, que, quando formado, procurará emprego no interior do Estado e não na cidade de São Paulo, onde, apesar de as oportunidades profissionais serem maiores, a qualidade de vida, na sua opinião, seria menor. Parece-nos que a Felipe o alcance de prestígio, baseado em dinheiro e status, seria uma forma de enfrentar a dor do desenraizamento. No entanto, ele parece ter mudado de idéia.

Felipe considera ter três amigos em sua turma que, apesar de possuírem condições socioeconômicas melhores do que as dele - cita como exemplo o fato de um deles ser filho de um professor de universidade pública e estar sempre viajando, inclusive para o exterior - e compartilharem alguns dos valores que ele critica, são "humildes".

Para enfrentar a situação contraditória que Felipe parece experimentar, já que ele critica o "grupo de valores da F. [faculdade]” e, ao mesmo tempo, tenta adequarse a alguns deles, ele apóia-se na realização do Curso que diz "adorar”. Esse estudante afirma ainda que quando se transferiu da Economia para a Administração, descobriu que era aquilo que ele queria fazer para o resto de sua vida, tendo plena certeza de querer trabalhar com administração quando se formar. Felipe dedica-se bastante ao Curso e tem bom desempenho acadêmico, nunca tendo tirado nota baixa em provas ou trabalhos.

A respeito da realidade social brasileira, esse estudante revela uma visão que contempla a dimensão da desigualdade social e comenta a respeito da grande disparidade existente entre o "mundo USP” - um "meio elitizado”, que não reflete a realidade social do País - e a vida da maior parte das pessoas:

Assim, é agora que eu estou num meio elitizado, então parece que é normal, sabe? Parece que todo mundo é assim: "Nossa! Todo mundo estuda em escolas boas, todo mundo...” E não é, na verdade. As pessoas que estão lá [faculdade] também não têm essa noção da diferença que existe, que é muita. Que são poucas as pessoas que quando a gente está no meio, a gente não consegue acho que identificar muito bem, sabe? Não consegue enxergar o lado de fora que é muito maior do que o nosso próprio, nosso próprio meio.

(...)

E eu acho que, assim, ah, o mundo que eu estou vivendo agora ele é muito pequeno, parece que não, parece que porque você só vive aquilo, aquele mundo, o mundo USP, então você acha que aquilo lá é uma coisa normal, mas não, assim, é uma minoria mesmo. 
Talvez o fato de Felipe, num determinado momento de sua história escolar, ter convivido com estudantes para quem o Ensino Superior não fazia parte de suas expectativas de vida, colaborou para que ele tivesse consciência da excepcionalidade que é cursar uma universidade pública na realidade em que vive a maior parte dos jovens brasileiros. Seu contexto de origem também parece contribuir para essa percepção da desigualdade social. Esse estudante comenta, por exemplo, a respeito de um dia em que saiu de um churrasco em uma "casa gigante” de um colega da faculdade e no caminho para sua cidade natal passou por uma cidadezinha “paupérrima” e pensou: “ ‘Nossa, gente, olha que diferença!' Uma hora eu estou num lugar, daí quarenta minutos eu estou num lugar completamente diferente”.

Esse estudante também possui clareza da dificuldade de ingressar em cursos superiores públicos quando se é proveniente das camadas populares. Dificuldade advinda, na sua opinião, tanto do raro acesso à "boa" educação quanto da menor possibilidade de se ter o avanço na escolarização como meta em contextos sociais mais empobrecidos. Por isso, Felipe considera muito difícil para pessoas pobres ingressarem em cursos de alta seletividade da Universidade de São Paulo. Para explicar os casos nos quais isso ocorre, Felipe utiliza sua própria história como exemplo, dizendo ser preciso força de vontade, dedicação e “vontade mesmo de fazer acontecer”.

Nesses casos, ele afirma ainda que o esforço e o empenho necessários para que se ingresse em uma universidade pública, mesmo "tendo todas as condições para que isso não acontecesse”, pode gerar um distanciamento do meio social de origem:

E essas pessoas acabam é se distanciando do meio, se distanciando não fisicamente, mas assim da mentalidade daquele grupo que ela está. E querendo alcançar objetivos que a outra classe social mais alta está alcançando. Então, nesse ponto existe uma convergência, assim, de objetivos, de valores e ela se afasta daquele meio que teoricamente não vê o estudo como algo fundamental, que não tem oportunidade, que não luta para que aquilo aconteça e ela vai lutar para que aquilo aconteça...

A Felipe parece ser difícil compreender que a valorização ou a desvalorização da educação está relacionada com a realidade objetiva vivida pelas famílias e pelos indivíduos, a partir da qual criam-se expectativas e elaboram-se, ou não, projetos de escolarização. 
De toda forma, ao falar sobre distanciamento, Felipe aborda uma importante questão na discussão sobre o acesso e a permanência de estudantes de camadas populares na universidade pública, tratada por alguns trabalhos como distanciamento cultural, como, por exemplo, na pesquisa realizada por Viana (1998) e aqui compreendida como desenraizamento.

Para Weil (1996), o enraizamento é uma das necessidades mais importantes e, ao mesmo tempo, mais desconhecidas do ser humano que tem uma raiz pela participação ativa e real na existência de uma coletividade. Mas, a autora afirma também que o ser humano necessita ter múltiplas raízes, destacando a importância de contatos ou trocas de influências entre meios diferentes e a relação disso com o enraizamento: "O enraizamento e a multiplicação de contatos são complementares" (Weil, 1996: 419).

Uma das condições para o enraizamento é, portanto, a troca de influências. Trocar influências significa alterar-se a si próprio e, ao mesmo tempo, afirmar-se; significa crescer sem humilhação. Representa ainda a comunicação com o mundo e a participação nele (Barbosa, 2004). Participar, por sua vez, quer dizer ter raízes, fazer daquele “outro mundo” também seu mundo.

As trocas de influências entre meios muito diferentes não são menos indispensáveis que o enraizamento no ambiente natural. Mas um determinado meio deve receber uma influência exterior, não como uma importação, mas como um estimulante que torne sua própria vida mais intensa. As importações exteriores só devem alimentar depois de serem digeridas. $\mathrm{E}$ os indivíduos que formam o meio, só através dele as devem receber (Weil, 1996: 411).

Por ter usado sua própria experiência para exemplificar como uma pessoa consegue alcançar um lugar cujo acesso é socialmente improvável, parece que Felipe, ao falar sobre distanciamento, aborda sua própria experiência de desenraizamento. Esse jovem, que se afastou dos amigos do ginásio ao ir realizar o Ensino Médio no período noturno, onde sentia-se deslocado pela diferença de condições sociais e de perspectivas de vida dos colegas, sensação que se mantém após o ingresso na universidade, tem sua trajetória de vida marcada por um sentimento de não-pertencimento decorrente das situações de desenraizamento vividas por ele.

Parece existir aí uma pista que talvez nos auxilie a compreender o sentimento de solidão que tem acompanhando esse estudante durante toda sua trajetória. Felipe 
parece não ter encontrado condições favoráveis para que uma "troca de influências" (Weil, 1996) ocorresse entre a sua realidade e as situações vivenciadas em diferentes contextos. Parece-nos que a Felipe tem sido difícil trocar influências.

Em que pese essa dificuldade, Felipe afirma que vive, no presente, um dos momentos mais felizes de sua história. Tendo se descrito como bem quieto, retraído, tímido, como uma criança sozinha, muito séria e que, segundo sua mãe, não gostava de brincar, e considerando que "tinha problema de relacionamento", ele conta que na faculdade passou a ser mais extrovertido e a conversar mais com as pessoas ${ }^{28}$. Tal mudança é atribuída ao ambiente universitário - que é “diferente”, na sua opinião -, bem como ao "amadurecimento pessoal”, fatores esses que colaboram para que, atualmente, esse jovem sinta-se melhor consigo mesmo: “... é um momento que eu estou gostando bem mais, sabe? Eu estou mais feliz, assim”.

A satisfação com a experiência universitária contrasta com a experiência escolar anterior de Felipe. Quando perguntado sobre momentos alegres de sua trajetória escolar, ele responde que durante o Ensino Fundamental e o Médio não houve ocasiões felizes das quais se lembrasse. A alegria iniciou-se com a entrada no cursinho e teve seu auge com a aprovação no exame do vestibular. Ter conseguido ingressar numa universidade pública como ele tanto queria, lhe mostrou, segundo sua percepção, que “tudo o que fez", e acrescentamos toda a solidão e isolamento vividos, “valeu a pena”. Seu sofrimento não foi em vão.

Felipe comenta também a respeito de outras mudanças tanto em relação a ele próprio quanto à sua família após a entrada na Universidade.

De sua parte, além das mudanças já mencionadas como, por exemplo, em relação às perspectivas profissionais tendo Felipe abandonado a idéia de trabalhar desvairadamente e "ganhar uma grana”, esse jovem relata maior compreensão acerca de atitudes e características familiares que antes ele reprovava. Dessa forma, a falta de incentivo para ser aprovado no vestibular e o estímulo para trabalhar - que Felipe considerava erro dos pais - não o deixam mais “chateado”.

Outrossim, a atitude dos pais em relação aos estudos também fora modificada, pelo menos em parte, após o ingresso de Felipe na USP. Ele relata que

\footnotetext{
${ }^{28}$ A esse comportamento tímido, Felipe contrapõe o do irmão: "Meu irmão era muito rueiro, nossa! Não saía da rua, estava sempre na rua, minha mãe ficava louca com ele, ele era bem diferente, ele era bem... É o oposto, é o meu oposto...”.
} 
depois disso, seus pais passaram a valorizar mais o estudo. $\mathrm{O}$ fato de residir em outra cidade trouxe igualmente possibilidades de mudanças de hábitos e atitudes desse estudante, que acabaram influenciando sua família. Felipe refere-se a uma ampliação de costumes e maior aceitação de diferentes estilos de vida, por parte de sua família, proporcionadas pelo fato de ele morar e estudar em uma cidade bem maior do que o município do qual é proveniente. Esse jovem exemplifica tais mudanças através do impacto, por exemplo, que diferentes tipos de vestuários provocavam em seus familiares e a posterior aceitação dessas novidades. O fato de residir em outra cidade contribuiu para a mudança de hábitos e posturas familiares: “... depois que eu entrei, aí, muitas coisas mudaram em casa porque aí você sai de casa, vai para uma cidade maior e volta com outras experiências, então você acaba mudando um pouco a mentalidade das pessoas, da família”. Contudo, a despeito das mudanças em termos mais gerais de comportamento, a mudança de postura em relação aos estudos parece ser a mais importante:

E, aí, eles começaram a abrir mais um pouco a cabeça, sabe? Para algumas coisas e pensar, é, diferente, assim, de que é importante, por exemplo, estudar. E assim eles se sentem orgulhosos porque eu estudo, sabe? Dos três lá eu sou o único, né? Minha irmã estudou, mas não exerce a profissão tal. Mas hoje eu sei que eles são diferentes do que eles já foram um dia assim.

O relato de Felipe nos mostra que a entrada na universidade pública pode trazer mudanças positivas tanto para o estudante das camadas populares quanto para sua família, ampliando não apenas o universo individual mas também o familiar. Para além do orgulho e da alegria dos pais, a experiência universitária do filho, bem como a experiência de residir em outra cidade maior do que a cidade de origem, parecem representar também para o grupo familiar possibilidade de crescimento. 


\section{Entrevista na íntegra}

\section{$1^{a}$ entrevista}

Débora: E daí gostaria que você me contasse a tua experiência, desde que você entrou na escola, até você ter entrado na Universidade.

Felipe: Bom, sempre estudei em escola pública, desde o Jardim. Fiz jardim, pré, sempre estudei na mesma escola, até o $3^{\circ}$ colegial, jardim, pré. Aí, depois, teve uma reestruturação do ensino público, então começou a dividir, mas eu sempre fiquei na mesma escola. Eu peguei todas as épocas que deu certo, e aí eu estudei nos três períodos, manhã, tarde e noite, durante essa fase de escola, assim, de colegial, primário, tal. É, eu comecei a trabalhar, eu fiz até a $8^{a}$ série, depois comecei trabalhar, no colegial eu mudei para o período noturno.

Assim, meu desempenho na escola sempre foi muito bom, sabe. Estava entre os melhores alunos e tal. A escola era uma escola boa, sabe? Hoje, já, o ensino público está meio sucateado mas naquela época tinha a escola padrão, sabe essas coisas, e a escola era uma escola padrão, era uma escola boa assim. Bom, aí eu mudei para noite, fiz um colegial, um colegial fraco, o colegial já estava bem destruído, já foi bem fraco. Depois eu fiz um ano de cursinho, quando entrei na faculdade, porque eu tinha prestado no $3^{\circ}$ colegial e não passei, óbvio.

D: Você prestou o quê?

F: Eu prestei administração só. Aí depois eu fiz cursinho e prestei economia na Unicamp [Universidade Estadual de Campinas], na Unesp [Universidade Estadual Paulista] e na USP [Universidade de São Paulo]. E passei na Unesp, na USP. Na Unicamp eu passei para $2^{\mathrm{a}}$ fase mas aí na $2^{\mathrm{a}}$ fase eu não passei. Aí entrei na faculdade, fiz um ano de economia, mudei para administração, porque eu não gostei do curso, tal, mudei para administração.

D: Você falou que você sempre foi bom aluno? Como era?

F: É, eu sempre me destacava em todas as disciplinas, assim, eu sempre tirei as melhores notas e tal. Eu e um outro pessoal, mas eu estava sempre no meio, sempre ia bem em relação ao restante. (silêncio)

D: Como é que foi entrar na escola? Você se lembra?

F: Ah, eu não lembro muito bem... Mas eu gostava (rindo). Eu gostava de ir para escola, eu lembro que eu tive professores, que depois eu via, sabe. Ah, eu via até há pouco tempo assim. E elas gostavam de mim essas professoras...!!! Mas, mas eu gostava... (silêncio)

\section{(...)}

D: E da primeira série você lembra alguma coisa?

F: Na primeira série só lembro de uma professora que ela puxava os cabelos dos alunos! (risadas) Aí tinha época que eu não queria ir mais na escola. Ela estava para se aposentar, era nervosa, sabe? Uma vez eu acho que eu tinha errado um exercício assim, ela pegou e me deu uma livrada na cabeça. Aí, eu falei para minha mãe que eu não queria mais voltar para escola. Aí minha mãe foi lá conversar com ela. Aí ela conversou com a minha mãe. Falou que "Não! Imagina! Não sei o quê..." Aí ela virou pros alunos: “Gente eu bati no Felipe? ” Todo mundo com medo, aí, ficou por 
isso mesmo, eu fiquei com aquela cara. Mas ela puxava, puxava, "vixe”! De uma amiga minha, sabe?

D: E que outras coisas que você lembra, que te marcaram na escola?

F: Ah! A noite, assim, foi um período crítico de escola, sabe, porque eu sempre, eu sempre pensei em fazer faculdade e eu percebi a noite, quando eu estava fazendo o colegial, que era quase impossível estudar, porque o pessoal quase não ia na aula, sabe, os professores trocavam muito, e era um pessoal bem, assim, bem classe baixa mesmo, sabe? Tipo classe social bem mais baixa, que ninguém pensava em estudar, é fazer faculdade, tal. E uma coisa que me marcou muito foi uma vez que a gente estava assim na sala e teve uma batida policial na frente da escola, teve algum, não sei se caso de droga ou roubo, não sei. Então, sempre tinha esses acontecimentos à noite. Até então, quando estudava de manhã ou à tarde, a gente não presenciava isto, era bem diferente, sabe? E os próprios alunos tanto da manhã quanto da noite, sabia que existia essa diferença entre os períodos. Então, foi um momento muito difícil para mim lá.

D: Você teve que trabalhar para ajudar a família, para se autosustentar?

F: Não. Então, foi uma coisa meio implícita da minha família, sabe? Eles não queriam assumir que queriam que eu trabalhasse, mas como sempre eles foram criados desta forma, começaram a trabalhar cedo tal, não fizeram faculdade, então foi o que eles aprenderam; hoje eu penso assim, na época eu ficava chateado. E eles acabaram passando isso para a gente. Sempre estimulando que a gente começasse a trabalhar cedo, então quando surgiu a oportunidade eu fiquei meio assim, sabe: "Ah, mãe, sabe, mas eu vou estudar à noite, tal” Ela: "Não, mas não vai, não pode perder uma oportunidade dessa e tal, trabalhar!” Foi aí quando eu acabei indo. Aí, não ajudava financeiramente em casa, não me lembro de ajudar assim, se dava era pouco, ajudava em alguma conta, mas nada muito, mesmo porque eu não ganhava muito. Mas eles sempre, sempre estimulavam assim a gente a trabalhar cedo.

D: E seus irmãos, eles estudam?

F: Minha irmã é formada, mas, assim, fez uma faculdade que ela não gostou, sabe, porque ganhou bolsa e minha mãe achava que ela tinha que fazer aquela faculdade, minha mãe e meu pai, porque ganhou bolsa. Mas, coitada, é frustrada e não exerce a profissão.

D: O que ela fez?

F: Geografia. Meu irmão não quis estudar, não quis fazer faculdade, ele trabalha só. Ele trabalha na [loja] Pernambucanas lá, nem sei o cargo, como atendente acho... Mas nunca gostou de estudar e... Não quis... (silêncio)

D: E a tua irmã, como que era na escola?

F: Minha irmã ela ia bem, assim até que eu me lembro, até que ela falava, até a oitava série. E aí no colegial é que ela sentia mais dificuldade, assim sentia bastante dificuldade, sabe? Aí ela queria prestar veterinária só que na época, naquela época não, você, não se falava de cursinho, era uma coisa muito cara, né, e para gente não era inacessível, então ela acabou não tendo a oportunidade sabe, tudo que eu tive, por exemplo, poder está fazendo cursinho, tal, sabe? Minha mãe nem deixou ela prestar na época: “Não, porque você não vai passar.” E hoje, até hoje ela joga na cara da 
minha mãe, sabe, assim... Ah, erros que pais cometem... Mas todo mundo comete, né? (pausa)

\section{D: E, como é que é ou foi na sua família o fato de você ter ingressado na USP?}

F: Então, no começo quando eu falava que se não fosse para fazer uma faculdade boa, eu não faria nada, sabe? Eles relutaram, achavam que não: "pode fazer outra, faz uma particular mesmo.” E eu falei que não. Então, eles não me incentivavam, sabe? Desta forma, não achavam que isto era importante, mas depois que eu entrei, aí, muitas coisas mudaram em casa porque aí você sai de casa, vai para uma cidade maior e volta com outras experiências, então você acaba mudando um pouco a mentalidade das pessoas, da família e hoje eles são orgulhosos com o estudo. Acho que é isso mais ou menos.

D: E na época quando você estava na escola no primeiro grau, segundo grau, como que era a tua família, teus pais em relação à escola, como era a atitude deles?

F: Eles nunca foram de cobrar nada, sabe? Assim, meu irmão, ele ia mal na escola sempre. Então, eles pagavam, às vezes, professor particular para ajudar e tal, mas nunca foram de cobrar: "Você tem que ser isso, você tem que tirar nota". Eu, como ia bem na escola, então eles nem se preocupavam muito, nem nas reuniões, às vezes, eles iam, porque eu pegava boletim, levava para casa e assinava. A do meu irmão as professoras queriam falar com a minha mãe para explicar a situação. Ele estava sempre de recuperação, então, (risada) então ela tinha que ir na escola, mas eles nunca foram de cobrar nada. O cursinho, por exemplo, que foi a época que eu estudei muito, eles ficavam: "Nossa, mas você está estudando muito!" Sabe? Sempre, sempre foram do contra (risada). Tipo: “não precisa se matar, estudar muito, tal”. E durante essa fase de colegial, de primário, assim de ginasial, também era assim, eles não pegavam no pé, tipo, para ficar estudando não.

D: Mas você sentia um estímulo?

F: O estímulo que eu tinha era mais pessoal do que por parte da família, sabe? Claro, você ia bem, assim, eles ficavam felizes. Ah, mas não era aquela, aquele fervor assim. Não era uma coisa muito divulgada em casa assim, difundida.

\section{(...)}

D: Felipe, assim, se você fosse lembrar dos momentos mais alegres dessa tua trajetória, que momentos você lembraria?

F: Ai.... Ah! Durante o ginásio, o colegial, assim acho que eu não tenho momentos muito gritantes assim que eu: "Nossa, que alegria!”. Mas o momento que eu fiquei mais contente foi quando eu comecei a fazer o cursinho e quando passei na faculdade, sabe? Porque aí eu comecei a ver que tudo o que eu fiz valeu a pena. No final deu certo, sabe, mesmo quando eu achava que tinha alguma coisa errada, que não ia dar certo, depois acabou dando certo. Mesmo o fato de eu ter trabalhado desde cedo, que achava "pô eu não vou conseguir, sabe, estudar, eu não vou conseguir...!”. No final deu certo, foi uma experiência que valeu para outras coisas depois.

\section{D: Que coisas?}

F: Ah! Estágios. “Ah, você tem experiência?” “Tá, tenho, já trabalhei”. Coisas que são importantes, sabe? 


\section{(...)}

\section{D: E momentos tristes?}

F: Momentos tristes? Bom, uma foi quando eu tive que mudar para noite, que eu comecei a trabalhar, tive que... Assim, teve uma vez que eu cheguei na professora e falei: "Professora eu queria prestar uma faculdade, a senhora acha que eu tenho chance?" Ela falou assim: "Sinceramente, não, não tem chance. Não por você, mas pelo que a escola oferece, saindo daqui você não vai ter, você não vai conseguir". Sabe, aí, foi um momento que eu fiquei muito mal, sabe? Eu falei "Nossa, eu não vou conseguir!”(risada).

\section{(...)}

D: E na faculdade? Como que é? Como é que tem sido?

F: Ah! Então quando entrei na faculdade fiz um ano de Economia que eu não gostei, eu percebi que eu não gostava, aí eu não tinha muito estímulo para ir na faculdade, eu não gostava muito. Aí, depois que mudei o curso, eu me dei super bem assim, estou gostando, descobri que é isso que eu quero, sabe! O que eu quero fazer. É, vou bem na faculdade, sabe, não tenho dificuldade, assim, nunca tirei vermelha na faculdade, sabe. É, as pessoas, eu consigo me relacionar bem com elas. Coisa que na escola assim eu não conseguia muito me relacionar com amigos de escola assim. Eu, ah... é um momento que eu estou gostando bem mais, sabe? Eu estou mais feliz, assim.

D: Da tua trajetória toda, este é o seu melhor momento?

F: Isto.

D: E a que você atribui essa diferença?

(silêncio)

F: Ai... Ah, eu não sei te falar agora (risada). Eu preciso pensar mais porque que... Parece pelas pessoas, sabe, pelo meio universitário que é diferente. Acho que o amadurecimento pessoal, sabe, de lidar com as coisas de forma diferente...

D: E, como é que você era no ginásio, no primário, no colegial?

F: Ah, eu era tímido... (risada) e não era de brincar muito, era bem quieto mesmo. Bem retraído. E, aí, depois eu entrei na faculdade eu acabei mudando. Agora eu sou mais extrovertido, converso tal. Então acho que eu estou melhor comigo mesmo. Acho que também isso seria um fator, por exemplo, que eu gosto mais desse período do que do passado. Sabe? Acho que eu tinha um problema de relacionamento com as pessoas (risadas).

(silêncio)

D: E o que você não gostou na economia?

F: Eu não gostei porque o curso começou a ser voltado muito para política, políticas públicas e, aí... eu, assim, minha vontade mesmo era mexer com empresas, sabe, administração de empresas, assim. E eu achava que economia tinha a ver e tal. Na época que a gente vai prestar vestibular a gente não tem a malícia de olhar as disciplinas que tem no curso, né, que é um erro da gente. Aí, eu vi que realmente não era minha vontade, né, de mexer com a política, essas coisas, foi quando eu mudei para Administração. 


\section{D: E como é que foi?}

F: Então, eu procurei um psicólogo na época - o Evandro - porque mudar de curso, tal, tem, sabe, aquela, né, aquele medo...

D: O Evandro do C. [Centro de Orientação Psicopedagógica] do campus?

F: É, isso. Aí, eu fui, aí expliquei para ele toda a situação tal, e é uma pessoa que ouve muito e fala pouco né... Um psicólogo que, às vezes, fica mudo, sabe, esperando que o aluno, que o paciente falasse... Mas, aí, ele chegou à conclusão também que eu estava meio certo do que eu queria, tal. Apesar de ter algumas desvantagens: que nem eu tive que voltar um ano, sabe, fazer o $1^{\circ}$ ano de novo, porque seria cursos diferentes. Mas, aí, foi assim: o processo de transferência você dá entrada e aí geralmente tem poucas vagas e bastante gente querendo entrar para administração enquanto que outros cursos são diferentes, às vezes, sobra vagas e tem pouca gente que quer entrar nos outros cursos da transferência. Aí, pela média ponderada eles avaliam quem entra, quem passa nesse processo. Aí eu entrei. Apesar de eu ir bem em economia, assim era, era um curso que eu não gostei.

D: Mas antes você tinha prestado administração no vestibular?

F: É, no terceiro colegial eu tinha prestado administração.

D: E aí você optou por prestar economia.

F: Isso.

D: Por que você mudou?

F: Não, porque eu ia prestar economia na Unicamp e não tinha administração, então eu prestei economia na UNESP, só tinha administração pública, que então também não quis. Aí, então, eu falei: "Vou prestar economia que deve ter mais a ver, né, com a parte empresarial”. Aí na USP eu acabei prestando, porque nas outras eu também prestei, né. Falei: "Vou prestar tudo igual.” Mas não foi por outros motivos...

D: E você falou um pouquinho como era a relação com os colegas da escola. E com os professores, como que era a sua relação?

F: Ah! Sempre foi muito boa assim, nunca tive problema nenhum com professor, a não ser com aquela que puxou meu cabelo lá e que me deu a livrada. Mas é, depois assim, eu ia na casa dela porque o marido dela era médico, então eu ia pegar atestado lá para piscina. Eu ia lá para tirar atestado. Mas eu, de forma geral, nunca tive problema sério com nenhum professor. Pelo contrário assim, eles, às vezes, eles viam minha mãe, assim: “e, aí, o Felipe como é que tá?” "Ele era bom aluno”. Sabe essas coisas assim... (silêncio)

\section{(...)}

D: E tinha alguma matéria que você se interessava mais no colegial?

F: Ah! Eu sempre gostei muito de matemática. De português eu não gostava. Eu gostava de matemática, exatas menos química, física eu gostava, mas eu ia bem em todas assim, não tinha uma matéria que eu ia mal, sabe?

D: E dos professores tinha algum que você...? 
F: Então, aí quando a gente vai ficando mais adulto que a gente começa perceber algumas coisas. Então, no colegial eu percebi, assim, os professores que queriam trabalhar e os professores que não queriam trabalhar. Eu nunca entrei em conflito, tentei fazer, brigar com o cara: “Não, porque você não quer dar aula, tal!”. Mas alguns professores eu gostava, outros não, eu percebia que não tinha vontade de fazer as coisas, ficava ali por obrigação.

\section{(...)}

D: Tem algum professor que você se lembre mais?

F: Um professor que eu me lembre? Tem essa da primeira série! Agora dos outros, não. Dos outros eu gostava. Gostava da maioria, assim. Ah! Tinha uma professora de inglês que eu gostava, eu gostava dela. Ninguém gostava dela porque ela era bem rígida, sabe? Mas eu gostava dela. Tanto é que quando eu mudei do período da manhã para noite, aí eu fiquei sabendo que ela falou para sala: "Ai, vocês perderam um aluno muito bom aqui”. Eu gostava dela. Ela era uma professora de inglês. Ela era bem brava. Todo mundo ficava tenso na aula assim. Mas eu gostava dela. Eu gosto de um pouco de tensão. (risadas)

(pausa)

D: Você se lembra quando você pensou em fazer um curso superior? Em que momento você se decidiu?

F: Antigamente, eu me lembro, quando estava assim na quarta, quinta série, antigamente, nem se ouvia falar em faculdade, sabe? Em fazer faculdade. É, não era uma coisa muito comum, pelo menos no meio que eu estava sabe? Aí, depois na oitava série o pessoal já começou, algumas pessoas começaram a mudar para colégios particulares para fazer um colegial, colegial melhor para prestar faculdade. Foi quando eu comecei a pensar, sabe? "Não, eu preciso também fazer alguma coisa!” É, então, nesta época mais ou menos, na oitava série que eu comecei a pensar nisto, em fazer faculdade.

D: Você falou que seus pais não tinham isto muito como coisa central? Como que era isso assim?

F: Então, ah, eu acho que na cabeça deles a vida tinha que ser assim: você estudava, aí arrumava emprego, montava sua família, tinha aquele empreguinho na cidade lá, era mais ou menos isto. Então, era meio fora do padrão você fazer faculdade fora, sair da cidade. É minha mãe, ela tem uma característica, que ela era muito medrosa sabe? Ela melhorou um pouco mas ela ainda é bem medrosa. Só o fato de sair fora da cidade tal... Mas, assim, a parte central realmente não era, pelo menos não era fazer uma faculdade tal.

(...)

D: E essas coisas de lição de casa, acompanhar, fazer tarefa, como que era?

F: Não tinha. Eles trabalhavam o dia inteiro, não tinha isso. Assim eles é, comigo pelo menos não tinha problema, porque eu fazia. Agora, com meu irmão, como ele tinha dificuldade, às vezes, meus pais não eram capaz de ajudar, mesmo porque nem lembravam mais das coisas, porque trabalhava o dia inteiro, então quando ele ia mal, às vezes, eles contratavam professor particular para ajudar. 
D: E essa escola [onde estudou] como é localizada?

F: Era perto de casa no centro da cidade. Era uma escola, assim, eu lembro que era conceituada, sabe? Todo mundo que fazia escola pública queria estudar naquela escola, queria estudar e, às vezes, era difícil conseguir vaga. Era uma escola bem conceituada. Tinha um diretor da escola também que era bem rígido, conseguia manter a ordem da escola, já faleceu já. Mas, agora como o ensino público já está sucateado, não é mais uma boa escola.

Eu já percebi isso quando já estava saindo. Que estava assim no momento de auge da qualidade de ensino pegou acho que do jardim até a $5^{\text {a }}$ e $6^{\text {a }}$ série; a gente percebia que era uma escola muito boa. Mas depois, aí com as mudanças que teve, reestruturação, é a qualidade caiu bastante...

(silêncio)

\section{(...)}

D: Felipe, eu estou chamando essas trajetórias de trajetórias bem sucedidas, o fato de ter ingressado em cursos concorridos e tal. E na sua opinião, a que você atribuiria isto?

F: Olha, é, eu acredito mais que foram alguns traços pessoais, sabe? Tipo determinação, esforço, sabe. Às vezes, eu penso, eu falo assim, às vezes, é difícil conseguir alguma coisa, e eu percebo que, às vezes, eu consigo mas empreende muita energia, sabe, às vezes, você fica fatigado, cansado no final. Você consegue, mas está cansado. Entrar na faculdade foi uma coisa assim, entendeu? Foi uma coisa assim que exigiu muito, muito esforço e determinação. Tive que estudar muito durante o cursinho. Ah, o fato de eu ingressar, eu acho que assim, em termos de conhecimento técnico, para prestar vestibular, a escola pouco contribuiu onde eu estudei. O cursinho contribuiu bastante, sabe, e as características pessoais, determinação. Às vezes, eu estudava doze horas por dia, sabe, sem sábado, sem domingo, eu estudava segunda a segunda, durante um ano eu fiz isso.

D: E essas características de dedicação, esforço, você também generaliza para sua história inteira?

F: Isso, é acho que sim. Sempre quando quero alguma coisa, e por mais difícil que seja, às vezes, não vem na hora, mas e, às vezes, me exige muito, mas eu topo. Se é uma coisa que eu realmente quero, eu dispenso bastante energia para conseguir, mesmo que eu fique cansado no final.

D: É, foi bem cansativo essa trajetória da chegada nesse seu objetivo, é isso que você está falando?

F: Foi, foi. Porque era uma coisa que estava meio fora da, assim... eu estava nadando contra a correnteza. Era uma coisa meio fora da minha realidade no momento. Eu tive que mudar alguns parâmetros e mudar o meio que eu estava, sabe? Eu estava à noite, fazendo o colegial, de repente, eu parei de trabalhar para fazer cursinho. É um outro meio, são outras pessoas com outro tipo de vida, outras características. É uma mudança que a gente faz... (pausa) 
D: Você teve colegas no ginásio, no colegial que entraram numa universidade pública?

F: Tive uma amiga que ela fez até a oitava série comigo, aí, depois eu mudei para noite, ela continuou de manhã, nesse colégio público, aí no terceiro colegial ela foi fazer num colégio particular, depois fez cursinho comigo também. Aí, hoje, ela faz medicina na Unicamp, mas ela basicamente estudou também no colégio público a vida inteira, só no terceiro colegial que ela mudou. E outro também que está fazendo psicologia, tem uma outra fazendo psicologia. Mas essas pessoas que entraram, é, no colegial elas foram fazer um colégio particular. Estudavam primeiro até a oitava, no colegial, ou no primeiro colegial ou no terceiro, foram procurar um colégio particular. Agora que estudaram comigo, por exemplo, à noite, não tem nenhum.

D: É isso que você está chamando de meio adverso, entre aspas?

F: É. Ah, todos os que estudaram comigo à noite, a maioria já está casado, com filho, trabalhando, e moram, não é querendo discriminar, mas moram na parte mais periférica da cidade, sabe. É outro meio e outras características.

D: E esse meio também que não é muito favorável, você também via na sua casa?

F: Não, não. Assim, a instituição família, você percebia que era bem diferente, sabe, da minha casa dos meus amigos, assim dos meus colegas. Claro tinha exceções, mas era diferente.

D: Diferente como assim?

F: Economicamente é, renda, essas coisas. [fim da fita]

Muitos [colegas do colegial] hoje, então, estão trabalhando, estão na cidade, casaram, enfim, não tem ninguém, acho que teve alguns que fizeram alguma faculdade particular na cidade. Então, mas estão lá mesmo. E muitos nem pensavam em fazer faculdade. É, assim, a gente conversava, só queriam terminar o colegial (risada). Só para pegar o diploma.

D: E a família, a diferença familiar, você vê em relação ao nível sócio-econômico, tinha outra diferença que você reparava assim?

F: Ah, talvez, assim, como é que a família funciona, como é que resolve os problemas, esse tipo de coisa, assim, como é dentro de casa. Aí eu via que, às vezes, tinha diferenças de alguns colegas para mim. É tipo briga em casa. É, algumas coisas que aconteciam assim, neste sentido, que não aconteciam na minha casa. As brigas entre os pais, é, ou família desestruturada, pai para um lado, mãe para o outro. Aquela coisa meio largada, sabe...

D: Você definiria sua família como?

F: Olha, eu acho que minha família é bem estruturada. É eu vejo como um alicerce muito importante, na minha vida foi muito importante. Sabe, apesar de algumas coisas que aconteceram, de erros que meus pais cometem, que é normal, que a gente também, como filho, comete. Mas, é acho que tudo o que eu consegui teve o apoio deles. Sabe, todos eles.

D: E que erros você está vendo assim?

F: Ah, é, antes eu via como erro, assim, eles não estimularem muito estudo, sabe? Então, eu ficava meio chateado com isto, não acharem que era importante, e é 
geralmente, assim... O que eu ficava mais magoado com eles era nesse sentido: não valorizaram muito isso. Até antes de entrar não era muito valorizado, depois que eu entrei eles perceberam que: "pô, legal, né, que...!" Aí é que mudou um pouco. (silêncio)

\section{(...)}

D: Como é que você vê o futuro Felipe?

F: Bom, agora, alguns planos que eu quero para o futuro, e que vai consumir muita energia, eu quero fazer intercâmbio. Então, eu vou precisar trabalhar muito para conseguir guardar uma grana. Ah, eu me vejo bem sucedido profissionalmente no futuro. Acho que o esforço não vai ser em vão. E, assim, a profissão é uma coisa que eu sempre coloco em primeiro lugar, sabe? Antes de constituir família, de coisas que para mim não têm muita relevância, sabe? Como o emprego e a profissão têm para mim.

(...)

D: Certo. Tem mais alguma coisa que você acha da tua história que você não falou?

F: Acho, acho que já falei bastante coisa. (risadas)

(...)

D: Obrigada.

\section{$2^{a}$ entrevista}

D: Retomando um pouquinho o que você tinha comentado no nosso outro encontro. Vou fazer um resumo, daí você fala se é isso mesmo o que você disse sobre sua vida escolar. Você me disse que você sempre estudou em escola pública, fez colegial noturno, colegial bem fraco. Seus pais não incentivavam muito a questão de você entrar numa universidade de qualidade, pública. Não valorizavam tanto essa coisa do estudo. Daí você fez cursinho, você se empenhou muito para conseguir entrar na universidade e você comentou um pouco isso, pelo fato de você ter feito um colegial noturno, que isso não fazia parte daquela realidade, entrar numa universidade pública...

F: Justamente. É os objetivos das pessoas daquele meio eram outros. Eu acho que pouquíssimas pessoas daquele colegial foram fazer faculdades. Assim que foi fazer faculdade pública, só eu lá daquela turma, mas é eu percebi que era característica do meio, entendeu? Todos, a condição deles era muito diferente, a vida deles era muito diferente da minha. Assim: apesar de eu estar lá, era muito diferente, sabe? Desde a estrutura familiar e socio-econômica, era tudo diferente. Claro que os objetivos acabam sendo outros. Eles queriam pegar o diploma, trabalhar, construir família essas coisas.

D: Então, daí você comentou que isso era nadar contra a correnteza, para entrar na universidade. Aí eu queria perguntar: o que que te levou a nadar contra a correnteza?

F: Foi assim: eu não sei se já comentei, teve uma...

D: Não tem problema quando você quiser retomar. 
F: Ah, tá. [teve uma] vez na escola que eu cheguei numa professora minha, à noite isso, no colegial noturno, falei: "Professora eu queria prestar uma faculdade assim, assim.” Ela falou assim: “Ó, você não vai passar.” E eu lembro que eu saí chorando, sabe? Tipo, a hora que acabou a aula eu fiquei muito mal, fiquei mal mesmo. E fui para casa. Aí meus pais falaram: "Não, mas não precisa, não precisa passar na USP, não precisa passar na faculdade. Se não deu, faz uma outra particular”. Eu falei: "Se for para fazer uma particular eu não vou fazer porque não quero". E foi essa briga assim depois. Tanto é que no cursinho eu consegui bolsa tal, mas se eu não conseguisse, eu falei: "Se eu não fizer cursinho, eu não vou fazer faculdade que paga”. Eu falei: "Eu não vou porque a gente não pode e outra porque não tem qualidade”. E foi isso. Eu falei: "Ou é isso, ou vai ser assim ou não vai ser nada”. E foi quando deu certo de eu fazer cursinho, entendeu? Que eu me esforcei, eu sabia que aquela era a única chance que eu tinha, entendeu? E eu me dediquei...

D: Se sentiu meio desafiado pela professora?

F: Isso. Não, não pela professora, pela condição. Porque ela foi sincera, tanto que eu saí do terceiro colegial, prestei e não passei e era nítido isso, que não tinha nenhuma estrutura para passar. Ela só foi sincera e, às vezes, a sinceridade dói. Tipo eu fiquei mal, eu falei: "Nossa, tanta gente que vai..." Que meus amigos que estudavam comigo até a oitava estavam estudando em colégios particulares, estavam se preparando, sabe? E eu sentia, assim, é como se estivesse distante de uma coisa que eu queria realizar. Como se eu estivesse nadando na direção oposta assim...

(...)

D: Você consegue lembrar por que você queria entrar na universidade?

F: Nossa, ai... (risada) Então, eu lembro que eu comecei trabalhar e aí eu me identifiquei com uma área que era a de administração e eu queria prestar faculdade, eu queria é... Não tem... Eu não lembro um motivo porque eu queria entrar na universidade; eu tinha vontade de entrar na faculdade e tinha que ser boa. Era um sonho. Eu não sei a partir de que série eu comecei a pensar em faculdade. Acho que quando a gente estava meio que na oitava série, assim, seus amigos começam a comentar: "acho que eu vou..." sabe? Alguns amigos nessa época mudaram para fazer um colegial numa escola particular, então, o pessoal começa a se mobilizar para estudar e todo mundo comentando, então, isso acaba, acho que também a te levar a querer estudar também para continuar meio parte do grupo. Todos seus amigos estão lá estudando. Então, e aí quando mudei de turno, fui para noite era diferente, as pessoas tinham outras intenções, então dá esse contraste, esse conflito de interesse... (risadas)

D: Eu já te falei que meu interesse nessa pesquisa é entender como é que esses alunos que têm pouca chance de entrar na faculdade, como é que isso acontece. E pensando nisso, por exemplo, no curso de administração, ou mesmo na economia que você prestou, alunos que fizeram escola pública, que estudaram a noite são pouquíssimos...

F: Na minha sala não teve acho ninguém que estudou em colégio público. Ou se estudou foi assim até alguma quinta série, mas da minha turma não tem ninguém, todos estudaram em colégios particulares tanto na turma de economia como na turma de administração. 
D: E então como é que você vê isso? Por exemplo, o seu destino natural, entre aspas, pela sua origem social não seria esse. Como é que você vê isso: essa relação entre o que seria esperado e algo diferente que aconteceu?

F: É então... Primeiro assim... Eu queria, esse negócio de, é, você está... Como é que eu vou explicar? Essa relação que você quer, entendeu? Ah, saiu de uma origem e... né? Assim, é eu não tenho muitas condições se comparado ao pessoal que está na faculdade. Tipo eu tenho condições diferentes assim, tive origens diferentes só que se comparar com pessoal que eu estudei, por exemplo, no colégio, no colegial eu tinha muito mais condições que eles, entendeu, porque quando iam pensar em parar de trabalhar... porque tinham que sustentar família ou tinham uma série de coisas assim. Então, acho que o fato assim de eu ter feito cursinho, sabe, então ninguém teve essa oportunidade que estudou comigo no colegial. Não podiam parar de trabalhar ou então tinham que fazer o cursinho à noite ou então não podiam pagar o cursinho ou várias razões. Mas, assim, como é que eu encaro hoje é estando num lugar assim. Quando eu estava no colegial eu me sentia deslocado porque não era meu meio, e na faculdade eu também me sinto deslocado porque está muito discrepante do... Parece que eu não encontrei ainda aquela, seu, seu grupo, sabe? Então, eu vejo assim. Tanto é que eu não tenho uma relação assim com o pessoal, apesar deles serem legais. $\mathrm{O}$ pessoal é gente boa assim, mas eu não consigo ter um entrosamento, sabe? Não consigo porque as conversas, também o meio desse pessoal que eu estou agora, também é diferente do meu, sabe? As conversas são outras então acaba ficando meio deslocado assim...

D: No colegial não era muito seu lugar e agora também...

F: É, isso. Uma porque é no colegial assim o pessoal era muito, muito mais pobres, muito. E aqui eles são muito mais ricos entendeu? (risadas) É diferente.

D: É difícil encontrar ponto em comum com eles, com o pessoal que agora você convive?

F: É. Então, lá, é, eles conversavam sobre brigas em casa, sabe, que estava distante da minha realidade. Aqui eles conversam sobre jogar tênis e viagens para a Europa, então, está longe da minha realidade...

D: Você está num curso bem elitizado, Felipe?

F: É, muito.

D: Como é que você vê isso? Ou vive isso?

F: Não, assim, é que eu dou muito valor ao que eu estou fazendo, ao curso em si. Que, assim, é uma coisa que eu adoro. Assim quando eu entrei... Tanto é que quando eu saí da economia para ir para administração eu falei: "Nossa! É isso que eu quero fazer pro resto da minha vida!” Porque eu gosto mesmo. E eles têm assim, o pessoal da faculdade, eles têm, geralmente, eles têm um grupo, um conjunto de valores, assim, sabe, que define essa galera da F. [faculdade]. Como as outras universidades. Um conjunto de valores, assim, e por mais que você tente se adequar àqueles valores, assim, ainda para mim é muito complicado. Para mim é muito difícil porque... não os valores, é seria até valores. Mais do jeito de vestir, sabe? Os lugares que você 
freqüenta, os esportes que você pratica, as viagens que você faz, entendeu? Isso define o grupo, e aí eu fico meio deslocado porque eu não tenho esses pontos em comum com o pessoal. Mas, assim, o curso eu adoro, eu sei que a faculdade é a melhor do país e tal e eles ainda tentam fazer lavagem cerebral no aluno para se orgulhar disso e querer se sentir melhor por causa disso é... Eu luto contra isso, eu não gosto.

\section{D: Você fala os professores lá na F. [faculdade]?}

F: Isso, é. Estimulando essa mentalidade, sabe: "Não, você pode ser nojento porque você tá no melhor”. É muito divulgado isso lá. Mas eu não gosto disso, eu acho que não tem nada a ver. Acho que você teve a oportunidade e você tem que usar acho o seu conhecimento; acho que através disso você vai conseguir se sobressair, mas não porque, o fato de você estar lá não significa que você vai ser um bom profissional...

D: Você tem pessoas que você considera amigas no seu curso?

F: Assim, tem um pessoal que assim, é muito amigo meu, da minha sala. Eles são de São Carlos. Aí é tem um que o pai é professor acho que da USP ou da UFSCar em São Carlos. Ele já até foi em casa já e eu estou sempre lá na república dele e tal. Assim, acho que é o meu melhor amigo mesmo da sala. E tem os outros que moram com ele também são meus amigos, sabe? O pessoal que eu sempre faço trabalho, a gente está sempre conversando, eles são assim bem gente boa, sabe? São humildes, são é... eu gosto de conversar com eles...

D: Você acha que eles não compartilham daqueles valores que você comentou?

F: Até, até sim, mas é quando a gente está junto assim parece que o assunto é em comum. Que nem eles já tiveram, teve um desses, são em três na verdade, três amigos meus, teve um que já teve experiência de viajar para fora, está sempre viajando, agora, hoje ele está indo para Argentina fazer intercâmbio e tal. Mas, assim, ele procura, sabe, tipo se adequar aos assuntos que a gente está conversando, sabe, ele comenta tal, mas não é aquela coisa assim. E eu peguei carona esses dias, até vou fazer o comentário, você falou para comentar coisas interessantes, eu peguei carona com o pessoal da sala esses dias e eles estavam discutindo quanto ganhava o pai de um amigo nosso: "Não, porque eu acho que ele ganha quarenta mil reais por mês!”, “Ai, não, gente ele não ganha quarenta mil, não!” - o outro, né? “Acho que ele ganha uns vinte." "Não, porque o cara é o manda chuva da empresa, ele tem uma fazenda de quinze milhões de reais.” Umas coisas assim, sabe? Você fala assim: "Ai, meu Deus!”. É que nem você vai num posto de mola, por exemplo, que a pessoa só sabe falar daquilo entendeu? Isso já começou a me irritar, sabe? Porque é uma coisa muito, um assunto muito superficial, sabe? Ficar discutindo tanto que o pai... Entendeu? E com esses meus amigos não rola esse tipo de conversa, não tem... Não tem assim, acho que é por isso que eu me dou bem também com eles.

D: E esse tipo de papo, por exemplo, te incomoda porque está muito fora da sua realidade ou porque você acha que não tem...

F: Ah, não sei... Acho que é tipo futilidade, não sei. Eu não... sabe? Não, ah, porque não tenho, porque não... Não é isso sabe? Mas é porque acho que... Não sei, um papo que não curto.

D: O pessoal da F. [faculdade] é meio fútil assim (risadas), não se preocupa com coisas maiores? 
F: Então, porque não sei se porque é característica do curso, o pessoal é muito voltado para o dinheiro, então dinheiro tem muita importância, sabe? Você ganhar bem tem muita importância, você ter status tem muita importância, ter grana, sabe? Então para, assim, o objetivo, se você perguntar, que nem você vai na GV [Faculdade Getúlio Vargas], sabe? Assim o sonho é construir o primeiro milhão próprio: "como eu vou fazer o meu primeiro milhão". O pessoal da GV, e faculdade de negócio, você acaba tendo essa visão assim, voltado para essas áreas de grana, assim, de dinheiro. Mas, assim, não é que são fúteis, ai é que uma hora ou outra pinta a conversa, de comentários meio que comparando, sabe? Comparando não, mas um vai falar que fulano ganha isso e fulano ganha aquilo, aí você está exaltando, acho que é exaltando quanto ganha.

D: E isso não é uma coisa que te preocupa, você acha relevante?

F: Ó, hã... já foi antigamente. Eu era assim, há um tempo atrás, quando eu entrei, eu achava que eu tinha que me sacrificar e trabalhar quinze horas por dia e me tornar um executivo bem sucedido e ganhar uma grana, sabe? Hoje já não é mais assim que eu penso, acho que eu não vou ser feliz, não é só isso que vai me deixar feliz, entendeu? Não adianta eu trabalhar quinze horas por dia e chegar no final da vida e falar: "Puts, o que eu fiz só? Eu só trabalhei, só...!”. E estar lá acabado, né? E hoje eu procuro equilibrar, sabe? Eu quero ter uma profissão legal sim, mas também quero ter uma qualidade de vida legal, sabe? Tem outras coisas que quero viver, não é só trabalhar, não...

\section{D: Que coisas?}

F: Ah, é amizade sabe? Sair, poder sair, poder viajar, sabe? É passear, essas coisas, coisas que se eu tiver trabalhando, dependendo da empresa que vou trabalhar é sete vezes por semana, quinze horas por dia. Porque vai ter que viver em função da empresa. É aquela história que eu estava conversando [referindo-se a uma conversa que tivemos antes do início da entrevista], às vezes, eu prefiro ficar numa cidade menor e trabalhar numa empresa aqui na região, sei lá, em outra cidade, mas fugir também de São Paulo, não ficar naquela loucura.

\section{(...)}

D: Felipe, como é que você vê o Brasil? Pensando, assim, de uma maneira mais global, em termos sociais, como é que você vê a estrutura social do país?

F: Estrutura social? Uma pergunta tão complexa.

D: Assim, eu estou querendo saber sua opinião da relação entre os destinos pessoais, de cada um, a vida que cada um segue e essa estrutura social marcada por uma desigualdade social.

F: Assim, é agora que eu estou num meio elitizado, então parece que é normal, sabe? Parece que todo mundo é assim: "Nossa! Todo mundo estuda em escolas boas, todo mundo...” E não é, na verdade. As pessoas que estão lá também não têm essa noção da diferença que existe, que é muita. Que são poucas as pessoas que quando a gente está no meio, a gente não consegue acho que identificar muito bem, sabe? Não consegue enxergar o lado de fora que é muito maior do que o nosso próprio, nosso próprio meio. Âs vezes, eu saio de P.[cidade onde se localiza o campus] que acabei de ter um churrasco numa casa gigante de um amigo meu e vou para J. [cidade natal] e passa numa cidade paupérrima que é B., eu falo: "Nossa, gente, olha que 
diferença!” Uma hora eu estou num lugar, daí quarenta minutos eu estou num lugar completamente diferente. E essas pessoas, sabe, não vão ter condição de talvez estar mudando seu, como que se diz? Mobilidade social. Aquela, justamente o estudo no capitalismo, acho que é uma forma de você ter mobilidade social, entre os padrões e... Mas a chance de você ter essa mobilidade social ela é muito pequena, entendeu? A probabilidade de sucesso ela é muito pequena porque é difícil, é difícil as pessoas terem acesso a estudo, é difícil para essas pessoas de baixa renda. Que já está arraigado até os valores também que, às vezes, nem faz parte do objetivo dessas pessoas e das que fazem parte ainda é muito difícil conseguir. Então, vai peneirando. E eu acho que, assim, ah, o mundo que eu estou vivendo agora ele é muito pequeno, parece que não, parece que porque você só vive aquilo, aquele mundo, o mundo USP, então você acha que aquilo lá é uma coisa normal, mas não, assim, é uma minoria mesmo. E que em termos de Brasil tem muito... “Em termos de Brasil”, não! Fica feio! (risadas).

Mas falando do nosso país eu acho que é muito complicado, assim, é muito difícil para alguém que sai de uma classe talvez muito baixa, talvez de classe média não seja tão difícil, sabe? E mais média baixa que nem é meu caso, mas se a pessoa tem uma classe muito baixa é muito mais difícil. Você vai ver caso, assim, muito raros de pessoas que se deram bem ou que mudaram, tiveram uma mobilidade social por causa do estudo. Você vai lá na assistente social, você vê pessoas que saíram, às vezes, da periferia de São Paulo e da, sabe, da favela e que entraram em curso não tão concorrido. É difícil ter alguém que sai da periferia e passa na medicina, passa na biologia, mas você vê ainda pessoas que conseguem passar na USP em algum outro curso e que tiveram assim todas as condições para que isso não acontecesse.

D: O que você acha que faz com que com algumas pessoas isso aconteça?

F: Olha, eu não sei... Eu acredito muito na dedicação, sabe? Acho que quando eu vou... Não sei... Eu vejo pela minha história, porque eu falei: “Ou é isso ou é nada”. Entendeu? Então você luta para que aquilo se realize porque senão não é nada. Eu acredito que seja, assim, acho que muita força de vontade, dedicação e vontade mesmo de fazer acontecer. E essas pessoas acabam é se distanciando do meio, se distanciando não fisicamente, mas assim da mentalidade daquele grupo que ela está. E querendo alcançar objetivos que a outra classe social mais alta está alcançando. Então, nesse ponto existe uma convergência, assim, de objetivos, de valores e ela se afasta daquele meio que teoricamente não vê o estudo como algo fundamental, que não tem oportunidade, que não luta para que aquilo aconteça e ela vai lutar para que aquilo aconteça...

D: E para você o estudo foi uma possibilidade de ascender, de mobilidade social?

F: Sim.

D: No caso essa possibilidade era a única?

F: Ah, não era... Não era assim... Não era a única, quando eu falo: "Ou era essa chance ou não era”, eu não estava pensando em mobilidade social, eu estava pensando sim em fazer faculdade: “Ou eu vou fazer a pública ou eu não vou fazer nenhuma”, entendeu? Mas eu não estava vendo uma possibilidade de mobilidade social, estava vendo sim a faculdade de qualidade, que não paga nada e pelo status da faculdade, da faculdade pública mas não pela mobilidade social. Acho que é conseqüência. Só é um meio de se conseguir, acho que na sociedade capitalista, um 
dos meios é você estudar e ter uma profissão de destaque assim. Mas você pode ganhar na Mega-Sena também e ter mobilidade social.

(...)

D: Quando você estava querendo entrar na USP, a sua motivação era assim "eu quero fazer o melhor" é isso? "Eu quero fazer a melhor faculdade”?

F: É a melhor justamente, eu pensava "eu não quero, eu não vou fazer uma outra que seja meia boca, eu não vou fazer, tem que ser aquela".

D: E por que você se colocava o objetivo de fazer o melhor?

F: Ah, por que?

D: Talvez você nunca tenha pensado nisso?

F: É... Não... Eu sabia que era aquela que eu queria, mas nunca parei para pensar porque que era aquela que eu queria. Eu acho que envolve aqueles três motivos: é uma faculdade que não paga, é uma faculdade de qualidade e é uma faculdade que te dá status, tem status da USP, da UNICAMP. Então acho que são os três motivos assim plausíveis para que eu escolha esse tipo de universidade.

D: Mas por que você queria status?

F: Ah, não era o meu objetivo principal, mas, é, talvez você mostrar que saiu de um lugar que você não tinha condição, entendeu, e passou numa faculdade boa. Então essa é uma recompensa, sabe? De que um dia você chegou lá, mesmo não tendo a favor, sabe, algumas coisas...

D: Recompensa a quê?

F: Pelo esforço, eu acho, pelo esforço, pela, tipo: "Olha, eu tava aqui, agora eu tô aqui. Eu lutei para que isso acontecesse e consegui”. Acho que é isso...

D: Felipe, você tinha comentado que o cursinho tinha te ajudado muito em termos de conhecimento técnico para você entrar na universidade, e o outro fator é a sua dedicação, e que a escola tinha pouco contribuído para isso...

F: É, a escola pouco me contribuiu no sentido técnico, assim como você falou. Mas acho que no desenvolvimento pessoal, sabe? É porque era uma boa escola, até a quinta série era uma boa escola, entendeu, e pessoas que estudaram nessa escola e depois fizeram cursinho, também passaram em faculdades públicas, em boas faculdades públicas.

(...)

É então... É, assim, se eu falar que eu fui lá na prova e que consegui fazer a prova do vestibular baseado no conhecimento que eu tive no colegial é mentira. A gente saiu de lá sabendo nada. Mas eu acho que, não sei, talvez a escola tenha contribuído para o desenvolvimento, é desenvolvimento de raciocínio, talvez inteligência, não sei, eu não li a respeito, não sei como que é isso.

D: O que você pensa da tua experiência?

F: É, mas como eu sempre fui bom aluno na escola, eu acho que ela tenha contribuído, eu acho, sabe, para que, de alguma forma, eu tivesse um desempenho melhor, assim, acima da média. 


\section{(...)}

Mas é... durante acho que a fase escolar, eu acho que a escola ajudou no desenvolvimento, no desenvolvimento, da criança assim (...) raciocínio, inteligência. Eu não consigo identificar, assim, porque que um consegue e outros não, devem ter características pessoais, psicológicas, essas aí, que faz com que alguns é tenham um desempenho maior e outros não. Mas eu acho que a escola teve influência, assim, nesse sentido aí anos atrás, né? Não no colegial, por exemplo.

\section{(...)}

[Os professores do colegial] não tinham vontade. Também era aquele grupo de professores da noite. Tinha aquela fama, assim: "Ah, estuda a noite, os professores da noite...”. Quem dava aula de manhã, não dava aula à noite, não gostavam sabe? Os professores, assim, tinha aquele negócio também do status lá dentro: quem dava aula de manhã, não dava aula à noite porque os professores da noite já tinham aquela fama - "ah, professores que não gostam...” Tudo contribuía, os alunos também não gostam, então, não precisam de professores que gostam porque não vai adiantar nada e era, tudo conspirava...

D: Você comentou agora que talvez, que por você ter sido bom aluno, a escola tenha ajudado mais nesse sentido e no nosso outro encontro também você disse que sempre foi bom aluno, sempre se destacava, você e outros alunos da sua classe, se destacavam em termos de nota e tal. Como que era isso, como que você vivia isso de ser sempre bom aluno, ter sido sempre bom aluno?

F: Então, era uma coisa que eu não precisava me esforçar muito, sabe? Eu nunca fui de estudar muito no colegial, mas eu tinha facilidade. Tinha facilidade de fazer prova, é não fico nervoso, sabe? Não sei, algumas coisas de auto-confiança e facilidade de assimilar, é, raciocínio, enfim. Mas você fala como eu me via assim perante a turma?

D: É.

F: Os outros alunos? Ah, não sei como eu vivia, mas eu procurava ajudar pessoas assim que tinham dificuldades. Eu lembro que tinha gente que me procurava para fazer trabalho, fazer alguma coisa. Você ia bem, também, tinha sempre aquele sanguessuga, mas eu não tenho nenhuma percepção disso, de como eu vivia assim...

D: Você se via como bom aluno já na época da escola, ginásio assim?

F: Hã hã.

D: Isso era bom, era ruim?

F: Eu acho que incomodava algumas pessoas assim, não sei, mas eu acho que incomodava porque as professoras, às vezes, comentavam... Ah, ser humano é assim quando você está bem, tem pessoas que não gostam de saber que você está bem e que você é isso, é aquilo. Não sei, talvez acho que tenha incomodado algumas pessoas, algum colega de turma assim, não sei, eu tenho essa impressão assim.

D: O que quê as professoras comentavam?

F: Ah é... Então, geralmente elas comentavam com minha mãe “Ah, o Felipe é bom aluno, é ele vai se dar bem!“ Esse tipo de comentário. Uma vez, é, tinha feito uma 
redação e a professora pediu para vários alunos lerem. Aí eu ia ler e ela fez um [monte de elogios - fim da fita]

Eu lembro que quando eu saí da oitava série eu tinha uma professora, e ela era muito boa, e ninguém gostava dela porque ela era muito brava, era muito brava, mas eu gostava dela e aí quando eu mudei para noite eu sei, eu fiquei sabendo daí um tempo que ela comentou com o pessoal: "Olha vocês perderam um ótimo aluno". E ela ficou toda chateada porque, sabe, porque eu tinha saído da manhã para ir para noite, ela ficou muito chateada, é uma lembrança assim que eu tenho quanto a isso.

\section{(...)}

D: E na tua casa, como que isso era visto?

F: Ah, minha mãe, às vezes, ela comentava, minha mãe nunca foi de ir nas minhas reuniões porque ela sabia que eu ia bem e para ela faltar do serviço para ir lá olhar o boletim e falar que está tudo bem, então, ela quase não ia. Ela tinha que ir na do meu irmão que ele ia mal para caramba (risada). E, mas assim não foi uma, ela falava, comentava: “Ai que bom que você vai bem, parabéns, não sei o quê...” Mas não era aquela coisa, sabe? Não era, não se fazia muita festa para isso, nem precisava. Mas eles encaravam com naturalidade, nem com desprezo nem com excesso de orgulho.

\section{$(\ldots)$}

D: Felipe, dessas lembranças, dos momentos mais marcantes falando em termos de pessoas, que pessoa seria mais significativa na sua trajetória toda assim?

\section{(...)}

F: Então, é claro, a família é sempre importante. Meus pais, assim, querendo ou não, não dando tanto valor, eles sempre me ajudaram, mesmo quando eu passei, sempre quando eu precisava, eles estavam dispostos, assim. Mas, em termos de uma pessoa que me incentivou ou que falou: “Olha, vai lá, você consegue”, sabe? Ninguém. Nem vó, nem vô, nem tio, nem tia, nem ninguém.

\section{(...)}

D: Um caminho bastante solitário, então, até aqui esse?

F: Ah, sim porque era desejo meu, né? E eu tinha que lutar por mim. Mas alguém que tenha me incentivado, que tenha, não tem, pelo contrário eu só tive pessoas que me desestimularam, só. Mas eu não deixei que as pessoas falassem mais alto. Reunião de família, quando tinha churrasco, essas coisas, sabe? Tipo: "Ai, não precisa disso!", "Pra que estudar tanto, pra que?” Sabe? "Depois você vai se formar e ai não vai ganhar nada, não sei o quê.” Sabe? "Não vai ter retorno". Era sempre assim as conversas, só que no começo me incomodava, mas depois eu comecei a procurar entender porque que elas achavam isso e eu via porque eles foram criados assim, sabe? Tanto meus pais quanto meus avós e eles não iam pensar diferente porque eles foram criados dessa forma. Então, no começo eu ficava chateado, mas agora eu não chateio mais não...

D: Como que você acha que era ou é, não sei se mudou, a visão que a família tem de você ou tinha, se mudou, depois que você entrou na USP? 
F: Não, eu acho que eu mudei, mudei parâmetros assim pelo fato também de eu estar na faculdade mas também pelo fato de você viver com pessoas diferentes, sabe? Ai você acaba assimilando algumas características diferentes também geralmente do meio que você está, é que agora eu não vou saber te lembrar uma específica assim, mas você, o fato de você morar numa cidade maior e então você volta assim para uma cidade menor, para sua família você volta diferente, depois de um certo tempo. E, aí, eles começaram a abrir mais um pouco a cabeça, sabe? Para algumas coisas e pensar é diferente, assim, de que é importante, por exemplo, estudar. E assim eles se sentem orgulhosos porque eu estudo, sabe? Dos três lá eu sou o único, né? Minha irmã estudou, mas não exerce a profissão tal. Mas hoje eu sei que eles são diferentes do que eles já foram um dia assim.

D: Um pouco em função da sua experiência, do que você está vivendo aqui?

F: É, hã hã, em termos escolares e relacionamento com outras pessoas e pelo fato do tamanho da cidade você acaba ficando diferente do que você era, você muda, aí quando, eu lembro que quando eu voltava, às vezes, para lá, às vezes, uma roupa meio diferente já causava um impacto: “Nossa! Mas...?”, “Não, mãe, é que todo mundo tá usando, todo pessoal usa essa roupa lá, é normal lá, é modismo.” Ia para lá era: “E esse corte de cabelo?” Sabe? Umas coisas assim que você acaba ficando...

\section{(...)}

D: Você tinha comentado no outro encontro, Felipe, que uma coisa que tinha te marcado muito foi uma batida policial que teve no colegial. Eu queria te perguntar o que mais te chocou?

F: O que mais me chocou é estar presente naquele local, eu pensei: "Por que quê eu tô aqui né? O que quê eu tô fazendo aqui? Eu nunca, nunca passei por isso”. Eu não estava na batida, eu só estava vendo. Mas como eu nunca tinha visto aquilo, para mim era coisa de outro mundo. Eu falei: "Eu não tenho... eu não tenho nada a ver com esse lugar aqui, não, com essas pessoas aqui, não tem nada...”. O que mais me chocou foi isso assim.

(...)

D: Felipe, na infância, adolescência, seus amigos eram da escola, eram da rua, da vizinhança?

F: Não, eu quase não tinha amigo na escola...

Então, eu quase não brincava, minha mãe sempre conta isso, que eu não era de brincar muito, assim. Mas eu tinha alguns amigos, assim a gente brincava ou ia no clube, sabe, assim.

\section{(...)}

Até eu terminar o meu colegial eu não tenho alguém assim que marcou, algum amigo mesmo, amigo, amigo não. Mesmo porque depois quando eu mudei para noite aí... Ah! Eu tive uma amiga, assim, essa amiga que está fazendo medicina na Unicamp agora. É uma amiga assim que a gente conversava e tal, mas também quando eu mudei para noite a gente acabou se distanciando porque eu comecei a trabalhar. Também à noite eu tive grandes, grandes colegas assim. Hoje eu não tenho muito contato com eles porque eu estou aqui, fica difícil, eu agora vou para lá só de vez em quando. Mas, também não fiz grandes amizades porque o pessoal era muito 
diferente, acabava não rolando aquela, aquela afinidade. Mas eu tenho... assim eu fiz dois grandes amigos assim... no colegial à noite mas que infelizmente não tem mais contatos com essas pessoas.

\section{(...)}

D: E da infância, o que sua mãe comenta?

F: Minha mãe fala que eu era um menino muito sério, que eu não brincava, que eu não gostava muito de brincar, que eu era quieto.

D: E seu irmão, como era?

F: Meu irmão era muito rueiro, nossa! Não saía da rua, estava sempre na rua, minha mãe ficava louca com ele, ele era bem diferente, ele era bem... É o oposto, é o meu oposto, mas a gente se dá bem sim.

D: E a tua irmã?

F: Ah, minha irmã, eu não lembro muito da infância dela porque quando eu era mais novo ela que cuidava, né, da gente não lembro muito da infância dela. (pausa)

D: Tem alguma coisa que você se lembra assim... enquanto eu fui falando que você pensou?

F: Acho que eu falei tudo (risadas), tudo de mais importante acho que eu falei.

D: Então, está bom, Felipe. Obrigada de novo. 


\section{2 Marcos em sua busca de sentido}

Marcos, 27 anos, é estudante do oitavo semestre do curso de Psicologia ${ }^{29}$. Proveniente de uma cidade mineira de médio porte, reside na moradia estudantil há quatro anos. Foi lá que ocorreram as duas entrevistas.

Filho de um vigia aposentado pela Fepasa (Ferrovia Paulista S/A), que completou a $4^{\mathrm{a}}$ série primária através de supletivo por exigências do trabalho, e de uma dona de casa, que trabalhou como costureira e também cursou até a $4^{\mathrm{a}}$ série do Ensino Fundamental, ele é o mais velho entre quatro irmãos: um com 24 anos, outro com 23, e uma irmã de oito anos. De seus avós, Marcos não sabe a escolaridade. Recorda-se apenas que a avó paterna era uma "pessoa muito simples” e que o avô paterno trabalhava em um Sindicato Rural. Do lado materno, o avô trabalhara como torneiro mecânico e como vigia, e a avó era dona de casa. Atualmente, com seus dois irmãos trabalhando e com a obtenção da aposentadoria do pai, a renda familiar gira em torno de R\$3.000,00. Marcos ressalta, porém, que, quando entrou na faculdade, a situação financeira de sua família era bem mais difícil.

Marcos realizou o Ensino Fundamental em uma escola pública estadual localizada na "periferia” de sua cidade, cuja qualidade de ensino, segundo ele, era “mediana” - e o Ensino Médio em uma escola da Polícia Militar, que atendia também a filhos de civis. Para ingressar nessa escola Marcos teve de se submeter a um exame de seleção. Segundo ele, estudar em tal escola era "o melhor” que ele poderia ter naquele momento.

Conta que sempre fora um aluno com rendimento acadêmico médio, com bom desempenho em disciplinas da área de humanas e com desempenho regular ou ruim nas da área de exatas. Entre os irmãos, era quem melhor se saía na escola e, hoje, é o único que está cursando Ensino Superior. Um deles trabalha na Polícia Militar e o outro trabalha como garçom, ambos com Ensino Médio completo. Sua irmã cursa a segunda série do Ensino Fundamental.

Sobre a relação de seus pais com a escola, Marcos afirma que eles valorizavam muito o estudo. Sua mãe sempre atenta, cuidadosa em relação a tarefas e muito presente na escola, era "figurinha" conhecida por todos os professores, chegando a ser, por vezes, na visão de Marcos, “super protetora”. De fato, sua

\footnotetext{
${ }^{29}$ A graduação em Psicologia é composta de dez semestres.
} 
dedicação à escolarização dos filhos parece ter sido grande: do acompanhamento próximo, a broncas e cobranças, chegando a “cascudos” quando os filhos não faziam as lições, passando pelo recurso a aulas particulares quando havia o risco de reprovação - necessário para os irmãos de Marcos, mas nunca para ele, já que foi o filho que "menos deu preocupações” - a mãe de Marcos sempre esteve muito presente no processo de escolarização dos três filhos e repete o mesmo comportamento com a filha caçula. Quando eles ficaram mais velhos, o monitoramento dava-se mais à distância, não deixando, todavia, de acontecer. Fica claro, pelo relato de Marcos, que era à mãe a quem cabia toda a responsabilidade pelo acompanhamento da educação escolar dos filhos.

O pai de Marcos, embora valorizasse a escola, fazendo questão de garantir a subsistência da família enquanto os filhos estudassem, atribuía também grande valor ao trabalho. Originário do meio rural, passou a trabalhar na "linha” construindo o trilho do trem, quando se mudou para a cidade - "trabalho pesado", como classifica Marcos; mas, em decorrência de problemas na coluna vertebral oriundos dessa atividade, foi realocado na função de vigia e posteriormente na de segurança, quando foi obrigado a completar a $4^{\mathrm{a}}$ série através de supletivo. A grande valorização de seu trabalho e de seu papel de "provedor” da família fez com que ele não permitisse que os filhos trabalhassem enquanto estivessem estudando. Porém, essa proibição estava muito mais relacionada, na visão de Marcos, à importância que seu pai atribuía ao seu próprio trabalho do que com a valorização do estudo. Evidência da importância que o trabalho tinha para seu pai foi o fato de ele ter ficado "tão ou mais feliz" pelo irmão de Marcos ter passado no concurso da Polícia Militar do que por esse estudante ter sido aprovado no vestibular da Fuvest.

Quando terminou o Ensino Médio, Marcos prestou vestibular para Artes Cênicas na Unicamp, obtendo aprovação para a segunda fase, mas sendo reprovado nessa última etapa. A aprovação na primeira fase de um vestibular considerado difícil, para uma carreira cuja relação candidato/vaga era relativamente alta, sem ter se preparado, empolgou Marcos. No ano seguinte, já tendo mudado sua opção profissional, Marcos prestou vestibular para Psicologia em uma universidade federal e foi reprovado na primeira fase. Essa foi a primeira de uma série de reprovações que marcou o início de um período bastante difícil na vida desse estudante: foram, ao todo, onze vestibulares, em cinco anos, durante os quais ele tentou ingressar em uma 
universidade pública, no curso de Psicologia, até conseguir aprovação no exame de seleção para a Universidade de São Paulo.

Como dissemos, o pai de Marcos não permitiu que seus filhos trabalhassem durante os estudos. Para ele, no entanto, esse período de estudos se encerrava com a conclusão do Ensino Médio ${ }^{30}$. Além disso, se ele ajudasse Marcos a custear as despesas com cursos preparatórios para o vestibular, teria de fazer o mesmo para seus dois irmãos - o que, segundo esse estudante, era impossível. Assim, para pagar o cursinho, Marcos trabalhou em uma loja de produtos de R\$1,99, como supervisor no Censo do IBGE (Instituto Brasileiro de Geografia e Estatística) e, na maior parte do tempo, trabalhou como garçom em um restaurante e choperia.

Marcos enfrentou grandes dificuldades para conciliar estudo, visando à preparação para o exame do vestibular, com a necessidade de trabalhar. Para viabilizar tal conciliação, várias estratégias foram tentadas. No primeiro ano em que fez cursinho, Marcos trabalhava meio período na loja de produtos de 1,99 e estudava à noite. Nessa primeira experiência, defrontou-se com a defasagem em termos de conhecimentos escolares: "eu ficava um pouco desesperado porque enquanto eu percebia que as pessoas estavam revisando a matéria, eu estava aprendendo...: ‘nossa! Eu tenho que saber isso?’ ”. Tendo sido reprovado no vestibular naquele ano, Marcos resolveu mudar de emprego: passou a trabalhar como garçom e a fazer cursinho pela manhã. Essa estratégia, porém, não logrou grande efeito pois, segundo Marcos, como trabalhava à noite, na manhã seguinte estava cansado e com sono, não conseguindo aproveitar as aulas, nem tampouco estudar no período da tarde, pois várias vezes dormia, ou quando não, o cansaço não lhe permitia grande aproveitamento. Novamente Marcos é reprovado nos vestibulares que prestou. No ano seguinte, ele tentou outra estratégia: trabalhar durante os seis primeiros meses e, no período restante, dedicar-se exclusivamente aos estudos, fazendo um cursinho semi-extensivo. Segundo ele, tal estratégia lhe permitiu melhorar um pouco seu desempenho, mas, mesmo assim, mais uma vez não foi aprovado nos exames de vestibular. No ano subseqüente, Marcos trabalhou como supervisor no Censo do IBGE durante o dia e fez cursinho à noite. Nesse meio tempo, iniciou um "cursinho popular” onde obteve descontos na mensalidade pelo bom desempenho, mas achou

\footnotetext{
${ }^{30}$ Durante esse período Marcos conta que fez "bicos" como office-boy no escritório de um tio e trabalhou numa casa de frangos de outro tio.
} 
que havia “algo errado” por ir bem nas provas do cursinho, sabendo que no vestibular a concorrência era muito maior. Voltou, então, para o antigo cursinho que, apesar de mais caro, era mais “puxado”. Porém, novamente foi reprovado. No ano a seguir, Marcos voltou a trabalhar como garçom, mas só aos finais de semana e, eventualmente, durante alguns dias da semana; nesse período estudou sozinho no primeiro semestre e fez um curso semi-extensivo no segundo. Finalmente, ele foi aprovado no exame da Fuvest para o curso de Psicologia.

Nesse percurso, as dificuldades enfrentadas foram tantas e o esforço e o cansaço tamanhos que seu sentimento, quando da aprovação no vestibular, foi de alívio e não de alegria:

Tive que me desdobrar, foi um, para mim, nossa foi um período muito difícil, sabe? Uns dois anos antes de entrar, aí, principalmente um ano antes de entrar aqui [USP], no último ano, é, eu trabalhava durante a noite e eu fazia o bendito cursinho pela manhã, né, cansava muito, me desgastava e eu trabalhava no final de semana e nessa época terminei com a namorada, é, não tinha tempo para sair, minha vida social acabou e eu estava cansado, estava cansado, cansaço crônico. Já, tanto que é, era a última vez que eu estava tentando, sabe? Porque senão eu ia tentar me arranjar da forma que fosse, por ali mesmo, fazer uma faculdade por ter faculdade, não necessariamente ter grandes, grandes expectativas. Ter Ensino Superior para tentar um emprego melhor, depois tentar me virar. Tanto que quando eu passei aqui foi muito engraçado é... Eu não me senti feliz, me senti aliviado, minha sensação que eu tinha era de alívio, sabe? Foi muito, muito engraçado, eu achei que eu ia, sei lá, ficar eufórico, eu, eu... "Ufa!" - a única coisa que eu senti foi descansado um pouco, sabe? Uma sensação de alívio muito grande...

A única forma possível para esse estudante ter acesso a uma universidade pública foi “desdobrando-se”, assumindo ao mesmo tempo o papel de trabalhador e de estudante e tendo de renunciar a aspectos de sua juventude, como namorar, sair aos finais de semana, ter uma vida social. As dificuldades enfrentadas na tarefa de conciliar a preparação para o exame do vestibular com a necessidade de trabalhar expressam-se, também, no relato de Marcos; em alguns momentos ele próprio confunde-se em sua narrativa e, procurando lembrar-se da ordem dos acontecimentos, pergunta-se “como que era?” ou “como foi?”. Tantas foram as adversidades que a recordação delas também fica dificultada. Foi difícil para a pesquisadora acompanhar a “epopéia” em que se constituiu o período durante o qual Marcos tentou ingressar em uma universidade. Essa dificuldade foi, de alguma 
forma, expressa no momento da entrevista, já que Marcos me perguntou se sua fala estava confusa, ao que eu, numa vã tentativa de aliviar a angústia que aquelas recordações lhe traziam, respondi equivocadamente que não. Mas, mesmo relendo várias vezes o relato desse estudante, certa confusão mantém-se: as estratégias tentadas a cada ano, os empregos assumidos e os tipos de cursinho realizados são em maior número do que a quantidade de anos que separa a conclusão do Ensino Médio da entrada na USP. Possivelmente, alguns deles ocorreram concomitantemente num mesmo ano. O que importa assinalar, entretanto, é a dificuldade de Marcos em relatar essa experiência, o que nos parece ser mais um sinal do sofrimento experimentado por ele durante esse período.

Marcos afirma que cursar o Ensino Superior sempre foi algo pretendido por ele, assim como também por seus irmãos. Um dos motivos ao qual esse estudante atribui o fato de ser o único, em sua família, a estar cursando faculdade é a educação de pior qualidade que os irmãos receberam. Por serem mais novos e também por terem reprovações em suas trajetórias escolares, eles estudaram em outro momento da educação - cuja qualidade de ensino, na visão de Marcos, era mais precária do que quando ele próprio estudou. Além disso, seus irmãos realizaram o Ensino Médio na mesma escola onde os três cursaram o Ensino Fundamental, por essa escola já atender a esse nível de ensino, e não na escola da Polícia Militar como o fez Marcos, vista por ele como oferecendo educação de melhor qualidade.

Mas, não obstante essas questões, Marcos também vê outras diferenças em relação a seus irmãos. Conta, por exemplo, que algo que lhe marcou muito foi o fato de ele e seu irmão caçula começarem a trabalhar juntos como garçom e, ao final de três anos, Marcos ter sido aprovado no vestibular e seu irmão ter comprado um carro, o que ele atribui a uma “questão de prioridades”. Além disso, Marcos comenta sobre a diferença entre suas amizades e as de seus irmãos: enquanto entre as deles a maioria dos amigos era da vizinhança ou da escola, Marcos relacionava-se muito mais com amigos de um grupo de jovens católicos do qual participou durante muito tempo. Ele relata que nesse grupo convivia com pessoas mais velhas, com diferentes experiências, algumas já cursando o Ensino Superior, tendo, inclusive, ido a algumas formaturas de amigos. A participação no grupo de jovens influenciou bastante os rumos da trajetória pessoal de Marcos e contribuiu para o acesso a outros universos culturais - foi aí, por exemplo, que ele começou a fazer teatro -, para a concepção e 
a valorização do estudo de forma mais ampla e para assunção de diferentes responsabilidades. O convívio com esse grupo, cujo perfil sócio-econômico parece diferir-se do predominante entre os amigos do bairro e da escola, colaborou para Marcos colocar-se diferentes projetos de vida. Nesse sentido, ele afirma que se identifica "muito mais" com os amigos provenientes do grupo de jovens do que com os da escola, sobretudo do período do Ensino Fundamental. Marcos relata, ainda, que muitos dos amigos desse grupo encontram-se atualmente em posições sociais melhores ("nível superior, emprego estável” ou "garantia maior de emprego") do que seus amigos da escola ou mesmo do cursinho.

Em que pesem as diferenças mencionadas por Marcos, o seu ingresso na Universidade influenciou e motivou seus irmãos. Por ocasião de sua aprovação no vestibular, um deles começou a fazer um curso preparatório e o mais velho se estimulou a estudar para um concurso da Polícia Militar, em que foi aprovado; o outro irmão, porém, acabou desistindo do cursinho. Marcos considera que se eles fossem visitá-lo no campus universitário, o que nunca ocorreu e do que ele parece ressentir-se, poderiam se interessar mais e procurar fazer Ensino Superior.

Apesar de Marcos apresentar explicações de diferentes ordens para o fato de seus irmãos não estarem cursando faculdade, em pelo menos dois momentos das entrevistas ele pergunta-se por que nem eles nem seus amigos estão em uma universidade pública ou em posição social equivalente, parecendo sofrer com isso.

Essa pergunta aproxima-se da angústia, relatada por Gonçalves Filho (1995) em pesquisa que realizou em um bairro pobre e periférico de São Paulo (Vila Joanisa), que atingia mulheres daí provenientes quando tinham acesso a lugares da cidade interditos socialmente aos pobres, como cinema, restaurante, teatro ambientes urbanos que sinalizavam claramente a exclusão; elas sofriam por não poderem compartilhar a alegria e o prazer desfrutados com parentes e amigos, com seus “irmãos de classe”. Segundo o autor, para quem conhece a vida comunitária, como a que existia na Vila Joanisa, tomar parte em um "bem privatizante”, isto é, realizado às custas da exploração ou da exclusão de muitos, é fonte de dor e melancolia. Entretanto, embora isso prejudique a satisfação pessoal, não resulta em sua rejeição. Ainda assim, para a plena fruição de situações como as citadas, por parte de quem sofre ao desfrutá-las, "seria preciso estarmos certos de que nossa satisfação pessoal não se fundamenta na insatisfação dos outros, na exclusão e no 
servilismo do outro: nada mais difícil numa sociedade de classes” (Gonçalves Filho, 1995: 133).

O depoimento de Natil - moradora da Vila Joanisa -, a respeito da ida a um shopping center e de uma viagem a outra cidade, retrata o sofrimento experimentado: “...você está naquele lugar mas você não dá o direito de estar naquele lugar, sente que não pode estar ali. (...) por que não tem essas pessoas, será que eles tem essa oportunidade de experimentar isso? Eu vivo muito isso: por que o outro não está lá?” (p. 131).

Marcos questiona-se por que, apesar das condições de vida semelhantes, seus irmãos e amigos não estão em uma universidade pública. Explica a trajetória que o levou até o curso de Psicologia da USP como fruto de empenho pessoal e "boa dose de sorte”. Mas, sente o peso dessa realização: “...eu valorizo muito o fato de estar numa universidade pública, tá, eu não sou $\boldsymbol{o}$ ativista, $\boldsymbol{o}$ militante, mas eu sei o que significa uma USP dentro da perspectiva de Brasil, quantos podem estar aqui: quantos amigos meus lá fora não estão aqui?’.

Esse estudante tem consciência da ínfima parcela de alunos que, tendo completado o Ensino Médio, consegue ingressar em uma universidade pública. Entre os milhões de jovens que estão fora do Ensino Superior, estão também seus irmãos e amigos. Assim como para Natil e as mulheres da Vila Joanisa, fazer parte de algo do qual muitos estão excluídos, embora não signifique recusa em participar, é fonte de angústia.

Para driblar a exclusão e ocupar o lugar em que, hoje, Marcos está, esse estudante teve de enfrentar esse sentimento e perseverar muito.

Além das dificuldades de conciliação entre trabalho e estudo e do despreparo em termos de conteúdos específicos para ser aprovado no exame do vestibular, Marcos fala a respeito de um despreparo mais geral: ele não sabia o que significava concorrer a uma vaga em uma universidade pública, o que era um vestibular, como deveria preparar-se para uma prova desse tipo, o que era estudar para tal exame, nem como deveria fazê-lo. Comenta também sobre certa dificuldade para escolher uma carreira e da preocupação com o mercado de trabalho.

Marcos trata ainda de outra ordem de dificuldades. Além das já mencionadas, esse estudante considera que lhe faltava “objetividade” para definir o que queria e, por conseguinte, organizar-se para, de fato, alcançar seu objetivo. Por não ter clareza 
acerca dessa questão, Marcos considera que acabou “postergando" sua entrada na universidade pública, não atribuindo tal demora apenas às dificuldades materiais que enfrentou:

\begin{abstract}
Mas como fazer? Como estar lá? Como? E se, e se eu queria mesmo esse curso ou outro curso. Então eu acabei, eu percebo que acabei é, eu posso dizer, enrolando, mas no sentido de postergando, postergando até, até o limite. Postergando não sei exatamente, por não ter muita certeza que era aquilo que eu queria, postergando por eu achar que de repente era um passo muito grande, né, postergando por eu não me achar preparado, por eu achar que não tenho formação para aquilo. Em diversos momentos eu achei "Eu não vou passar! Que eu tô...? Na verdade, tô perdendo meu tempo aqui!" "Os cursinhos tão, tão me sacaneando." Como um dia vários amigos falaram: "Marcos desencana, presta uma particular e depois se vira!”. E eu fiz outra escolha, né! E aí eu estava, estava achando que estava apostando muito, num lugar que acho que não, não poderia... Estava sonhando um pouquinho alto! (...) Então eu acho que me, me confundi um pouco nesse sentido tentando conseguir entrar...! Não era uma coisa clara para mim, nem a possibilidade de estar aqui, nem a oportunidade de estar aqui, era, saber se era possível ou não, se estava fantasiando ou não...
\end{abstract}

Assim, além das dificuldades objetivas, que não foram poucas, Marcos enfrentou também dificuldades subjetivas no trajeto percorrido rumo ao Ensino Superior público. Em que pese todo seu empenho para ser aprovado no exame do vestibular, Marcos tinha dúvidas se aquele "não era um passo muito grande”, se estava fantasiando ou sonhando alto demais; sentia-se também despreparado e não tendo formação adequada para realizar um curso superior em uma instituição pública de ensino. Enfim, Marcos teve de lidar com uma dúvida crucial que também acometeu, como veremos, outros estudantes aqui entrevistados: a universidade pública é para mim? Eu mereço estar nela? Eu posso fazer parte dela? Eu tenho esse direito?

A postergação e a confusão às quais refere-se Marcos parecem-nos relacionadas a um sentimento de inferioridade e de rebaixamento oriundos da experiência de humilhação social.

Entendemos humilhação social conforme Gonçalves Filho (1995) que a define como um tipo de angústia disparada a partir do enigma da desigualdade de classes e como o sentimento mais radical de todo sofrimento proletário. A idéia de enigma proposta pelo autor, apoiado no filósofo Claude Lefort e no psicanalista Jean 
Laplanche, remete à dificuldade subjetiva em decifrar uma mensagem misteriosa a que pessoas mais pobres estão continuamente sujeitas em diferentes contextos sociais: "vocês são inferiores".

Quem se dirige ao pobre como a um inferior saberia dizer o que lhe autoriza rebaixar com tanta naturalidade? Saberia dizer onde começou o rebaixamento? Onde começou todo esse desequilíbrio político, onde foi que começou a imaginária superioridade destes senhores impunes e a imaginária inferioridade destes servos compulsivos? (Gonçalves Filho, 1995: 141).

A humilhação social é um sofrimento provocado pelo impacto psicológico daquela mensagem enigmática e um fenômeno ao mesmo tempo político e psicológico, econômico e inconsciente. Enfim, a humilhação representa a impossibilidade de ser reconhecido como um igual (Gonçalves Filho, 1998).

O sentimento de não ser digno de algo está atrelado a uma situação real e concreta de rebaixamento, ligada à humilhação social. Sobre o sentimento de não ter direitos, afirma Gonçalves Filho (1995):

O sentimento de dignidade parece desfeito. Deixa de ser espontâneo. É preciso um esforço de atenção para conservá-lo. Um esforço nem sempre eficaz para o humilhado - o proletário não é humilhado porque sente ou imagina sê-lo: o sentimento e a imaginação estão fincados numa situação real de rebaixamento. A situação imediata é sempre a situação mediada pela longa história de rebaixamento que atravessa sua família e ainda atravessa sua classe (p. 136).

O encontro com a humilhação social ocorreu cedo na trajetória escolar de Marcos. Esse estudante afirma que sempre possuiu uma recordação negativa das primeiras séries escolares por acreditar que não conseguia acompanhar "muito bem” o desenvolvimento das atividades nesse período, tendo sido essa a primeira lembrança da escola relatada por ele. Tal crença refere-se, sobretudo, à primeira série, quando Marcos teve uma professora muito rígida, que fazia várias cobranças e tecia críticas, inclusive, ao seu cabelo, que segundo ela, por ser comprido, o estaria atrapalhando a ler. Refere-se também às constantes visitas de sua mãe à escola, o que, aliado ao comportamento da professora, era interpretado por Marcos como evidência de alguma dificuldade sua em aprender a ler e a escrever.

No momento da primeira entrevista, no entanto, Marcos parece procurar dar um sentido diferente para essas lembranças escolares iniciais. É assim que, ao contar de um episódio em que a professora da primeira série havia levado os alunos à 
biblioteca e chamado-o a ler para outra professora - o que ele interpretava como uma demonstração de suas dificuldades -, Marcos tenta olhar tal acontecimento por outro ângulo, desta vez, positivo: ao contrário de ver como um sinal de dificuldade, ele passa a enxergar o episódio como amostra de que, apesar de estar na primeira série, já estava alfabetizado dado que conseguia ler. Mas, como ele afirma: “...não é bem como eu imaginava, só que só caiu a ficha um pouco agora”.

Não nos parece ao acaso o fato de ser no presente momento que Marcos procure atribuir diferentes sentidos a tais recordações. Interessante observar que isso tenha acontecido quando ele também tenta re-significar sua experiência universitária, como veremos adiante. Por ora, importa salientar que, a despeito do que de "fato" ocorrera, ou seja, se ele enfrentou, ou não, dificuldades no processo de aquisição da leitura e da escrita, a experiência afetiva vivida por Marcos foi de rebaixamento: ele sentia-se inferior, em desvantagem, enfim, parece-nos que Marcos viveu, no início de sua trajetória escolar, uma situação de humilhação que o marcou.

Mas, não foi só no contexto escolar que esse estudante deparou-se com a humilhação. No seu trabalho como garçom, Marcos também viveu situações concretas de rebaixamento. Todavia, pelo que se pode depreender de seu relato, seu esforço para responder a elas sempre foi grande.

Marcos comenta que há, no imaginário social, uma idéia bastante difundida sobre a natureza do trabalho do garçom. Pela sua narrativa e pelos exemplos que utiliza, entendemos que ele esteja se referindo à concepção da principal atividade exercida por esse profissional - o servir - com um sentido de subserviência, servilismo. Nessa direção, o garçom, muitas vezes, é tratado como um servo ou um criado que está ali para atender a todos os desejos do cliente, bastando para isso que ele estale os dedos, chamando pelo genérico garçon - rapaz em francês. Marcos relata que era possível distinguir pessoas que iam até o restaurante apenas pelo serviço, ou seja, pelo desejo de serem servidas, ficando em segundo plano a comida ou a bebida oferecidas pelo estabelecimento e que, portanto, reproduziam o referido imaginário, e pessoas que conseguiam romper com isso, relacionando-se com os atendentes como seres humanos. Marcos conta que nunca foi um garçom exemplar, no sentido de estar sempre pronto a servir, correr, vender muito, reservar mesas e que as gorjetas que recebia eram sempre motivadas pela maneira como havia se relacionado com as pessoas atendidas, fazendo uma piada, uma brincadeira ou tendo 
outro comportamento qualquer que fugia ao procedimento mais usual de um garçom. Segundo Marcos, essa atitude visava a dar "sentido" para a sua noite, para que o trabalho não fosse “tão sofrível”. Com isso, parece-nos que Marcos procurava resgatar a dimensão humana da relação garçom-cliente, buscando sentir-se Homem nessa atividade. Marcos servia, mas não se curvava; ele mantinha a dignidade e colocava-se como um igual a quem atendia. Ele resistia a submeter-se à servidão:

Então, eu acho que eu fugia um pouco desse estereótipo do garçom para servir, de servir e servir bem, de sempre estar com isqueiro no bolso para acender o... Eu fazia questão de não ter isqueiro! Ah! Eu não tenho que acender cigarro de ninguém, cara! Pô! Quer fumar? Traz pelo menos seu isqueiro! Nossa, era pedir para morrer a hora que o cara estendia o cigarro assim para mim e eu... ?! [imita gesto e expressão de não entender].

Assim, se o trabalho alienava ou embrutecia, por comportar uma dimensão de rebaixamento, Marcos procurava dar outro sentido para essa experiência, buscando resgatar a dimensão humana daquela relação. A experiência de Marcos com o mundo do trabalho faz com que ele considere a possibilidade de conciliar desejo e necessidade em uma atividade remunerada um "sonho":

É complicado, para mim ainda é complicado. Mesmo porque eu já tive uma relação de trabalho, eu já tive que trabalhar para ter grana, eu estou, ainda, vamos ver, talvez eu consiga conciliar o que gosto muito, muito, algo que eu pagaria para fazer e estar recebendo para fazer. Esse é o meu sonho!

Falando a respeito da contradição, uma das dimensões atenção na obra de Weil, Bosi (1988) afirma a importância que tem para esta autora o trabalhador poder refletir sobre os meios e os fins de sua atividade cotidiana:

Quem trabalha com as mãos e ao mesmo tempo reflete sobre a sua obra, do primeiro gesto à última demão, aprende que está lutando com forças em tensão, desafiando resistências no trato com a matéria. É a práxis conjugada de corpo e consciência que produz a percepção do contraditório (Bosi, 1988: 86).

Em seu trabalho como garçom, Marcos não abdicou da iniciativa, o que significaria para Arendt (1993) deixar de ser humano. A ação é entendida, por essa autora, como a característica distintiva da condição humana e definida como a única atividade exercida diretamente entre os homens sem a mediação das coisas.

Dessa forma, quando Marcos recusava-se a acender cigarro ou quando brincava com quem estava atendendo, ele posicionava-se como um igual, agindo 
numa relação entre homens e afirmando a condição de igualdade do humano. Em seu trabalho como garçom, Marcos parece ter lutado cotidianamente contra o rebaixamento da condição humana.

Exemplo desse rebaixamento era a forma como as pessoas, atendidas por Marcos, reagiam ao saber que ele estava prestando vestibular para o curso de Psicologia numa universidade pública: consideravam-no um "pára-quedista”, o que, segundo sua definição, significava alguém perdido, que não sabia onde estava caindo. Como ele, garçom, aquele que serve, pretendia ocupar um lugar social de tamanha distinção que não era a ele destinado?

Marcos relata dois episódios, ocorridos quando de sua aprovação no exame da Fuvest, que ilustram tal estranhamento. A divulgação do resultado desse vestibular é simultânea à de dois outros vestibulares de sua cidade natal. No dia em que soube de sua aprovação, Marcos estava trabalhando e havia outros jovens no bar comemorando a aprovação nos vestibulares locais. A copeira do restaurante, então, cumprimentou um dos rapazes que havia passado no vestibular e comentou que Marcos também havia sido aprovado, mas na Fuvest: “Aí ele achou muito engraçado e riu dela, porque ele tinha certeza que ela estava enganada, porque como que o garçom do bar ia passar na Fuvest, né? E ela ficou toda desconcertada a ponto dela chegar para mim, achando que ela estava errada”.

Outro evento que, ao lado desse, foi marcante para Marcos também ocorreu no restaurante-choperia. Marcos foi fazer o pedido de um grupo que costumava atender quando a gerente do estabelecimento lhe parabenizou pela aprovação no vestibular sendo observada por um dos rapazes desse grupo que também lhe cumprimentou. Quando Marcos retornou levando o pedido, o rapaz contou para todos na mesa que ele havia sido aprovado no vestibular: “ 'Ah! O Marcos passou no vestibular em Psicologia!’ Aí um dos caras: ‘Ah! Parabéns’. E ele: ‘Na USP!’ Aí o cara ficou em pé, estendeu a mão: ‘Meus parabéns!' ”. Falando a respeito daquele imaginário existente em relação ao trabalho do garçom, Marcos comenta esse episódio:

E ali naquele momento o cara rompeu isso, o cara fez o pedido: “ah, beleza”. E, nossa! A USP rompe coisas! Ter passado na USP rompeu isso, rompeu de uma forma instantânea! Era o garçom servindo: "ah, parabéns, me dá chope”. "Ah, que bom, um chope claro, sem colarinho”. Não! Aí, redimensionou, aí eu: "Ah é? Ah, 
é assim que funciona? Ah, que bom, tô começando a gostar!” (risadas)

(...) E, aí, o sentido disso tudo (...) é que quebrou isso [imaginário], o cara quebrou isso lá na fala e na postura dele: "hum, passei na universidade, então, faz diferença! Ah, F.D.P. (rindo)! Sou o mesmo cara, mas agora não sou mais!”.

Ao levantar-se, colocando-se na mesma altura de Marcos, o cliente o coloca em uma posição de igualdade, já que era algo absolutamente inesperado que o garçom, "humilde", inferior, fosse aprovado em um dos exames vestibulares mais concorridos do País, como é o da Fuvest. A aprovação nesse vestibular, por um lado, confirmou a condição de inferioridade em que Marcos era colocado no seu trabalho como garçom e, por outro, permitiu que ele fosse retirado dessa posição subalterna. A entrada na Universidade possibilitou a esse jovem romper barreiras sociais. Exemplo disso foi o encontro de Marcos com um cliente do restaurante-choperia, tempos depois, quando ele já estava cursando Psicologia, em um bar de sua cidade natal. Esse cliente foi atendido por Marcos algumas vezes e era "metódico", sentando-se sempre na mesma mesa, no mesmo dia da semana, além de possuir um "ritual” que se repetia todas as vezes: junto com ele chegavam à mesa um chope e uma água (que o garçom que o atenderia já deveria pedir assim que ele entrasse no restaurante) e depois havia uma seqüência de um chope, uma água, dois chopes e uma água, alternando-se entre chope claro e chope escuro. Porém, nas ocasiões em que Marcos o atendeu, o fez sempre conversando, exercendo a sua rotineira busca por igualdade na situação de trabalho. Quando Marcos encontrou essa pessoa no bar, ela o chamou para se sentar em sua mesa e eles conversaram sobre a universidade, o curso de Psicologia e outras questões. Segundo Marcos, a maneira de ele se relacionar com esse cliente "fez a diferença”, e ele pôde, mais uma vez, ser colocado em uma posição de igualdade.

Contudo, a crença de que estudar em uma universidade pública não configurava um direito para Marcos não era exclusividade dos freqüentadores do restaurante-choperia. Como vimos, também ele tinha dúvidas em relação a poder ou não estar nesse lugar. Um amigo de condição socioeconômica semelhante à sua, mas que realizou o Ensino Médio em escola particular, através de bolsa, e que cursava Engenharia Elétrica na USP, teve papel fundamental para Marcos acreditar na possibilidade de ingressar no Ensino Superior público. Apesar de sentir-se "nadando contra a correnteza”, ao pensar que seu concorrente estava dormindo, comendo e 
estudando melhor do que ele, Marcos estimulava-se quando esse amigo enfatizava a perspectiva e o direito de realizar um Curso Superior em uma instituição de ensino pública:

E era um cara que sempre me dava força, apesar dos pesares (...) ele falava assim: "Cara! Faculdade pública é para pobre e quem pode pagar que pague, tem alguém lá, é, tem uma vaga lá para você, tem alguém lá na tua vaga, então vai pegar ela!” Nesse sentido, a forma como ele falava, é, a implicação que ele colocava naquilo me motivava muito.

Esse amigo parece ter desempenhado um importante papel na trajetória de Marcos ao dizer e ao mostrar, com sua própria experiência, que a universidade pública era lugar para jovens das camadas populares como eles.

Encontrar outras pessoas que compartilhassem do mesmo projeto de ingresso numa faculdade pública também foi importante para Marcos acreditar nessa possibilidade. Foi o caso, por exemplo, dos jovens que ele conheceu quando trabalhou no Censo do IBGE. Como ele, outros também estavam naquele emprego para poder pagar um curso preparatório para o exame do vestibular: "Então, você vai achando pontos de convergência, você não se sente solto na maré: 'nossa, não, existe um caminho possível, dá para ir por aqui...’”. Conhecer outras pessoas, com perfil sócio-econômico semelhante ao seu, que partilhavam daquele projeto foi importante para Marcos acreditar que era possível realizar seu desejo de ingressar numa universidade pública, não sendo isso "fantasia” ou mero devaneio. A possibilidade de esse desejo concretizar-se parece, de certa forma, precisar ser reconhecida e assegurada pelo outro.

Também a crença na própria competência parece nutrir-se do reconhecimento alheio. Ilustração disso foi o encontro de Marcos com uma ex-professora do Ensino Médio, aproximadamente dois anos após sua conclusão. Essa professora estranhou muito o fato de Marcos ainda não ter passado no vestibular, ao que ele pergunta: “Por que? Eu devia ter passado?”. E ela responde que é “lógico” já que ele tinha capacidade e era bom aluno: “'Puts, ó, legal!’. Fiquei me sentindo bem, numa fase ruim, porque quando você não passa recorridas vezes, tua auto-estima cai muito, daí isso já deu um up para mim...”.

Mas, apesar da dúvida em relação à possibilidade e ao direito de cursar Ensino Superior público, Marcos, como ele afirmou, “fez outra escolha” e 
perseverou em sua opção. Após um longo e cansativo percurso, marcado por grande desgaste físico e psíquico, Marcos conseguiu ingressar em uma universidade pública.

Ao chegar no campus da USP, esse estudante deparou-se com um mundo bastante diverso do que fora a sua realidade até então. Já no dia da matrícula, foi apelidado de "calouro independente”, pois chegou de outra cidade sozinho, enquanto os demais ingressantes, sobretudo os de fora do município, vinham sempre acompanhados dos pais. Nesse mesmo dia, durante o almoço, um dos veteranos perguntou-lhe se ele trabalhava, porque tinha "cara” de quem o fazia. Sobre esse episódio, Marcos fala:

E, eu não achei ruim, não, eu achei bem bacana, mesmo porque, realmente esse sou eu: "ah, que bom, fui reconhecido, prazer!" (rindo) Fui visto como eu sou, não tem nenhum problema. Começou a ser um problema quando começou o curso e você começa a perceber que você não está tão no perfil, isso que chamou a diferença num primeiro momento, continua chamando e, aí, você percebe ela...

É na convivência com os colegas que a diferença entre eles e Marcos fica evidente e torna-se um "problema”. Quando perguntado a respeito dessa convivência, Marcos considera necessário falar antes a respeito do público a quem ele atendia no restaurante. Conta de seu enorme estranhamento ao ver pessoas gastarem em uma noite o que ele ganhava em um mês. Fala também sobre sua indignação ao conhecer estudantes que cursavam faculdades públicas tendo condições financeiras para pagar por um curso superior enquanto ele, que não tinha essa possibilidade, não conseguia aprovação no vestibular. Foi também nesse momento que Marcos relatou os dois episódios, anteriormente descritos, ocorridos quando de sua aprovação no vestibular e que muito o marcaram. Esses fatos remetem à questão da desigualdade social com a qual Marcos convivia, em especial no seu trabalho como garçom, e que é recolocada, agora, na sua relação com os colegas de curso.

O contraste entre a realidade vivida por esse estudante e o mundo que encontrou na USP ficou evidente na primeira festa realizada para os calouros: seu sentimento de não-pertencimento àquele lugar foi tão grande que ele desejou ter uma bandeja nas mãos para saber como agir.

Era muito complicado para mim, é, num primeiro momento estar estudando com um pessoal que eu servia no bar. Foi muito engraçado, no primeiro dia (...) teve uma mega festa, né, a calourada, estava todo mundo lá e esse último ano tinha sido 
muito cansativo para mim, muito estressante, eu praticamente não tive vida social, tudo o que eu queria naquele momento, Débora, era uma bandeja na mão, para mim saber o que fazer! (risadas) Na festa eu percebi como eu estava, sei lá, um pouco deslocado, como eu não estava ainda, não sei exatamente te dizer, dentro daquele universo ainda, ainda não era o meu, eu queria a bandeja e, e eu via um amigo meu, hoje amigo meu, né, muito amigo meu, reclamando, indignado, porque estava sem telefone para ligar Internet, sendo que a minha preocupação naquele momento era: "O que eu vou comer? Como é que eu vou me manter aqui?" Sabe, eu achava, assim, era muito diferente, o pessoal me chamar para sair e eu estar pensando: "Onde é que eles vão? Será que eu tenho essa grana pra gastar ou não?”

Sentindo-se desenraizado (Weil, 1996), Marcos procurou apoio em suas antigas raízes. No encontro com um mundo que não era o seu, Marcos desejou ter uma bandeja para retomar o lugar social anterior, afinal era como garçom que ele costumava encontrar pessoas das camadas sociais com as quais passaria a conviver, mas agora na condição de colegas universitários. A imensa desigualdade social com a qual Marcos deparava-se no seu trabalho passou a fazer parte de seu cotidiano e tornou-se evidente no contato com novos colegas, trazendo à tona situações díspares como a por ele relatada: enquanto preocupava-se com o que iria comer, seu colega indignava-se por estar sem acesso à Internet.

Um fato narrado e definido por Marcos como “coisinhas que vão te pegando” reforça a existência dessa distância social: numa brincadeira em que alguns colegas de turma ofereciam o trabalho dos pais como presente de aniversário para outra colega - uma consulta médica ou psicológica -, Marcos perguntava-se se pediria a seu pai que vigiasse algo para ela. Esse estudante fala a respeito do choque de mundos que a grande desigualdade social provoca:

...eu estava estudando para entrar aqui ou para entrar numa pública, não era aqui, eu não tinha idéia de entrar na USP, mas eu sentia que eu estava nadando contra a maré porque meu concorrente estava dormindo melhor que eu, estava comendo melhor que eu (ri), tendo mais tempo do que eu, então é uma briga muito injusta, e quando eu entrei aqui eu topei com eles, eles eram meus concorrentes. E, também, da parte deles acho que era muito gritante esta questão do se impor nesse sentido, né, (...) de marcar quem era, como eu queria minha bandeja para marcar quem eu era ou quando eu era o calouro independente ou calouro que trabalha para marcar quem eu era, eles queriam dizer que estudaram no C. [escola particular] para dizer quem eles eram, (...) porque eles queriam ir no barzinho badalado da cidade, baladas e baladas agora sem pai e mãe, baladas caras, torrar o dinheiro do papai e da mamãe, nesse sentido, então, tinha esse choque, de eles afirmarem 
quem eles eram e esse ser o público que eu atendia, de repente, quando eu trabalhava, eram eles que estavam na mesa e gastavam na noite o que eu ganhava no mês, então, chocou...

Fruto também da desigualdade social, a convivência com os colegas é dificultada por não haver o que compartilhar, já que a única coisa que possuem em comum é o curso de Psicologia. Esse não-compartilhamento, por vezes, produz em Marcos um desejo de silenciar: "De comentar aonde foi, quem encontrou, quem conhece, você, às vezes, quer ficar calado, são lugares que você não conhece, lugares que você nunca foi, lugares que fogem da realidade universitária da gente, eu fico meio assim, meio perdidão”.

O emudecimento também é desencadeado pela humilhação social. Segundo Gonçalves Filho (1998), a humilhação social age tanto interna quanto externamente; no aspecto interno, a mensagem enigmática que ela emite produz angústia e no âmbito externo, impede seu enfrentamento através do impedimento do reconhecimento do outro como um igual. Os fatores internos e externos ligados à humilhação desencadeiam "afetos vertiginosos” cuja manifestação pode se dar de várias formas, entre as quais o emudecimento.

Mas, assim como Marcos não abre mão da ação, não abdicando de lutar pela igualdade da condição humana (Arendt, 1993), também não o faz em relação à palavra e reage, mais uma vez, a uma situação de humilhação. Em sua turma, Marcos possui um papel de destaque, sendo considerado, como ele denomina, "perguntador", cabendo a ele sempre a função de fazer a primeira questão nos debates em sala de aula. Segundo Arendt (1993: 12), “... os homens que vivem e agem neste mundo, só podem experimentar o significado das coisas por poderem falar e ser inteligíveis entre si e consigo mesmos”. Essa participação ativa, muito mais do que notas em provas ou trabalhos acadêmicos, faz com que Marcos seja bem visto pelos professores (“...eu consigo até uma impressão legal do professor, muito por esses momentos...”).

Além disso, para lidar com o choque de realidades tão díspares, esse estudante procurou, principalmente no início do curso, reafirmar sua história e apoiou-se no que ele denomina de “discurso do proletário injustiçado”. Esse discurso consistia, por exemplo, na afirmação de Marcos de que, no Ensino Superior público, deveria haver cotas para "ricos", pois esses sim eram "minorias”. Também envolvia uma postura de orgulho por ele manter-se, financeiramente, com recursos próprios - 
provenientes de economias, seguro-desemprego e FGTS -, durante o primeiro ano da faculdade. Assim, Marcos relata que pagar, ele mesmo, pela cerveja que bebia, ao contrário de seus colegas que dependiam do dinheiro dos pais, era algo simbolicamente muito importante para ele, sendo isso "marcante” e "positivo”31.

Apoiar-se na sua história de vida foi um recurso muito importante para auxiliar Marcos na tarefa de encontrar um lugar no novo mundo que se lhe apresentava. Todavia, segundo sua avaliação, dificultou ainda mais a convivência com os colegas, pois ele acabava, em suas palavras, "proletarizando" tudo e relacionando-se com representações e não com as pessoas concretas que se tornaram seus novos companheiros no Ensino Superior. Se por um lado, afirmar-se como estudante-trabalhador foi bom, pois o ajudou a enfrentar a nova situação, por outro foi ruim, em sua opinião, já que impedia a real convivência com o outro. Ao repetir e enfatizar que tinha “toda essa história”, Marcos afirma que resistia a conhecer a história do outro. Com o “discurso do proletário injustiçado”, ele considera que

[você] acaba perdendo a dimensão geral das coisas, o que quê é estar ali no curso, o que quê é estar com as pessoas ali, possibilidade de você se relacionar com essas pessoas, porque já que você quebrou esse vínculo, esse, esse vínculo, não, essa representação: "ah, tô lá dentro, estamos pau a pau todo mundo, estamos igual todo mundo", eu ficava sempre retomando ele: "não, porque eu sou diferente, não porque eu tenho toda essa história” sem querer saber qual é a história do outro, sem querer saber, né, foi bem dicotômico para mim, ao mesmo tempo que eu quebrava, que eu estava aqui dentro, eu sempre recorria a ela para dizer quem eu era, e isso foi, nossa! Difícil! Primeiro ano foi difícil. Porque eu acabava fazendo muitas coisas mais para me auto-afirmar, para mim mesmo, às vezes, até para os outros, do que realmente fazer sentido, e eu acho que você acaba se ferrando sempre nessa.

Marcos entende que se a aprovação no vestibular o colocou em posição de igualdade ("estamos igual todo mundo") com os colegas, sua insistência em constantemente recorrer e reafirmar sua história não mais se justificaria e ainda o estaria impedindo de, de fato, conhecer e se relacionar com os colegas.

\footnotetext{
${ }^{31}$ No segundo ano da faculdade, seu pai mandou-lhe dinheiro para o pagamento das despesas; depois Marcos conseguiu uma bolsa de Iniciação Científica do CNPq (Conselho Nacional de Desenvolvimento Científico e Tecnológico), que, no momento da primeira entrevista, havia recém terminado. Também nessa ocasião, Marcos acabara de enviar um projeto de iniciação científica para a Fundação de Amparo à Pesquisa do Estado de São Paulo (Fapesp) pleiteando uma bolsa. Além disso, existia ainda a possibilidade de que um estágio que estava realizando na área de recursos humanos se tornasse uma bolsa-trabalho.
} 
Todavia, há que se pontuar que a diferença e a injustiça que marcam a história desse estudante não são “discurso”. De fato, Marcos é “diferente” de seus colegas porque tem "toda essa história": sua origem social, sua condição econômica, sua experiência de trabalhador, o distinguem da maioria dos estudantes da Psicologia. Ele é vítima de um sistema sócio-econômico injusto e calcado na desigualdade social, pelo qual os colegas de curso não são direta nem pessoalmente responsáveis, mas do qual todos fazemos parte.

Mas, quando Marcos chama de “discurso do proletário injustiçado” a recorrência e a re-afirmação de sua história de estudante-trabalhador, cujo percurso entre a saída da escola pública e a entrada na Universidade foi permeado por muito cansaço e grandes dificuldades, ele consegue adaptar-se mais ao mundo dos colegas, mudando a visão que possuía deles, relacionando-se melhor com eles e encontrando um ponto de equilíbrio entre dois extremos.

Para enfrentar a "dificílima” convivência com eles e o embate cotidiano com a desigualdade, parece-nos que Marcos tem feito um grande esforço para contemporizar, conciliar e integrar visões, por vezes, contraditórias, procurando, mais uma vez, superar as marcas da humilhação social.

Nesse sentido, assim como esse estudante tem buscado re-significar lembranças ruins das primeiras séries escolares que envolveram, como vimos, situação de humilhação, ele também tem procurado dar novos sentidos para sua experiência universitária.

Marcos relata ter mudado bastante sua postura perante várias coisas no decorrer do curso, inclusive, em relação aos colegas de turma. Ele realizou, segundo suas palavras, o “efeito vareta”. Conta que, no começo da graduação, foi a muitas festas, tomou muita cerveja - hábito que não possuía antes do ingresso na universidade -, telefonou menos para a casa dos pais, foi displicente com o curso, experimentando o que ele chama de "o outro lado" e deixando um pouco de ser o "bom moço”, o "bom filho”, o "bom aluno”. Com essa postura, Marcos parece ter tentado deixar um pouco de lado o peso da responsabilidade que assumiu em sua vida, procurando minimizar a pressão exercida pela grande expectativa existente a seu respeito, tanto no âmbito familiar (“...todo mundo tinha muito perspectiva em cima de mim, sabe, de 'ah, você vai!’, sei lá, para onde, mas de alguma forma vai!”), quanto entre os amigos por quem sempre fora considerado muito responsável, 
austero, correto. Enfim, Marcos tentou diminuir um pouco o peso da vida: “...eu queria ter isso, eu queria, né, não ser tão sério, tudo, tão denso, tudo. Nos últimos anos tinha sido tudo muito sério, tudo muito denso... Não ser tão... [ser] mais fluido, ser mais leve, um pouco nesse sentido...”. Marcos afirma que, hoje, já não vê muita coisa como via antes. Diz, por exemplo, compreender que, se alguns detalhes de uma festa de formatura são para ele absolutamente dispensáveis, para algumas pessoas podem ser extremamente importantes.

No entanto, considerar discurso algo que esse estudante experimentou de fato, ou seja, todas as dificuldades enfrentadas em sua perseverante tentativa de entrar em uma universidade pública, gera confusão e não se faz sem perdas.

Assim, embora considere tal contemporização como algo bom, isso faz com que ele, em vários momentos, perca o sentido de estar na Universidade: “... acho que é, de uma forma geral, isso é positivo, apesar de, às vezes, eu perder algumas coisas, que, às vezes, eu tenho que buscar [estala os dedos], né: 'Que nossa! Qual o sentido de eu estar aqui?' ”. A tentativa de procurar acomodar-se mais às novas circunstâncias, de procurar adaptar-se ao “outro mundo” deixa-o confuso a ponto de ele esquecer-se do significado que tem, para ele, estar cursando Psicologia numa universidade pública:

Acho que eu queria participar um pouco desse outro mundo, sabe, de ir muito em balada, de, de não ser tão preocupado com as coisas, né, não ser, eu sempre tive muita estima do, do bom moço, o filho mais velho, o neto mais velho, o sobrinho mais velho, nã, nã, nã, nã, nã [fala rapidamente], mesmo de, de aluno comportado, mesmo de, e era uma coisa alguém pisar na bola, pisar no tomate, era outra coisa o Marcos pisar na bola ou no tomate. Então eu dei uma, uma aliviada nisso, vamos dizer assim... As minhas notas caíram, eu não me envolvia muito com o curso, fazia o que, ãh, não sei, o que me convinha, vamos dizer assim, o que eu gostava... e isso é que fica um pouco vazio, né, fica um pouco, meio sem sentido do porquê você está fazendo isso, mesmo que seja, nem que seja para você dizer: "eu tô fazendo para experimentar um pouco uma coisa diferente, experimentar um pouco do outro lado, para desencanar”, que já é um sentido, né. Mas quando você faz meio aleatoriamente, você está meio perdido na verdade e... é complicado...

Para Marcos, que, em função de suas condições socioeconômicas e do desejo de realizar Curso Superior, sempre teve de levar “tudo tão a sério”, não mais agir assim o deixa confuso e perdido. Sua vida nunca pôde ser mais leve e quando ele procura experimentar certa fluidez "perde o sentido" ou o sentido que se lhe 
apresenta parece pequeno ou insuficiente para dar significado às suas ações. Para esse estudante perder a necessidade é fonte de sofrimento.

A busca de sentido, de uma razão de ser, parece uma constante na vida de Marcos. Na participação do grupo de jovens, no seu trabalho como garçom, no papel de aluno numa universidade pública, Marcos está sempre em busca de um sentido. Ele procura compreender e como afirma Lafer:

A compreensão é criadora de sentido, de um sentido que, aponta Hannah Arendt, "se enraíza no próprio processo da vida na medida em que tentamos, através da compreensão, conciliar-nos com nossas ações e nossas paixões” (1993: 347).

Ao comentar sobre sua postura em sala de aula, por exemplo, ele afirma sempre procurar um sentido nas aulas e faz críticas às atitudes dos colegas:

Eu sempre procuro um sentido, eu sempre procuro fazer minha aula valer a pena. E dá para achar! Engraçado que dá achar. Você faz um exercício assim: "do que quê essa coisa tem a ver comigo?”. (...) Dá para achar! Alguma coisa você acha. Se não achar também, levanta e vai embora! Acho, não sei, chateação minha. A galera da sala, às vezes, tem uma galerinha no fundo que fica conversando, fica passando bilhetinho, sabe? Levanta e sai, pede para alguém assinar, sabe, não faz sentido, sabe, não se autojustifica estar ali, me incomoda...

Importante lembrar que Marcos tem 27 anos, enquanto a maioria de seus colegas de turma tem por volta de 22 anos. Talvez a maturidade, proporcionada em seu caso não só pela idade, mas também pelas experiências de vida acumuladas, contribuam para essa diferença de postura.

A busca de sentido de Marcos esteve presente, inclusive, na sua participação nesta pesquisa, que, segundo sua avaliação, fez “sentido” para ele. De fato, por estar vivendo um momento confuso, poder retomar a sua trajetória de vida e pensar sobre ela parece ter sido significativo para Marcos. Estando no penúltimo ano do curso, esse estudante pergunta-se sobre o que fazer depois de formado; a reflexão sobre sua história parece, de alguma forma, ajudá-lo na procura por essa resposta:

Tipo, tudo o que estou te contando agora, isso tem um peso para mim, um peso muito grande, um pouco também me diz como eu sou... (...) Se eu, se eu repasso isso, eu não sei, eu encontro alguma coisa aí, mesmo para mim continuar, não que seja uma coisa específica, não que isso que eu te disse agora me diz para fazer uma pós, você vai entrar no mercado de trabalho, isso eu não sei te explicar muito bem, mas dão uma consistência no meu curso, dão uma consistência à minha formação. 
Todavia, se a atitude conciliatória e contemporizadora de Marcos é fonte de perdas e confusão, por outro lado, parece ter sido também essa postura que permitiu a Marcos abrir-se aos colegas, "largar um pouco os estereótipos” e fazer novas amizades. Foi esse processo que possibilitou a Marcos ter, hoje, como um de seus melhores amigos o colega que reclamava da Internet enquanto ele se preocupava com o quê comer.

Uma das possibilidades de enfrentamento da humilhação é a amizade, conforme proposto por Gonçalves Filho (1995) e discutido por Barbosa (2004) em pesquisa já abordada neste trabalho, que trata da humilhação social no âmbito da universidade pública. A autora parte da idéia de que a experiência universitária dos estudantes pobres pode ser vivida sob condições de humilhação resultando em desenraizamento ou sob condições de amizade resultando em desenvolvimento e crescimento pessoais.

Assim, também na universidade Marcos deparou-se com situações de humilhação social, esforçando-se para não se sentir rebaixado; porém, ao poder contar com a amizade, parece-nos que ele tem conseguido enfrentá-la. Esse estudante parece estar sendo capaz de conhecer o outro no novo mundo que se lhe apresentou. Resta agora lidar com a difícil tarefa de encontrar um lugar para si nesse universo que permita desfrutá-lo, sem que isso signifique o esquecimento ou a negação de sua história. Enfim, Marcos parece encontrar-se diante do desafio da "troca de influências” de que fala Weil (1996).

Como vimos, essa troca é de grande importância para o enraizamento e significa alterar-se e afirmar-se ao mesmo tempo, podendo crescer sem humilhação. Representa também a participação no mundo, ao fazer daquele "outro mundo" também seu. Ao que nos parece, Marcos tem conseguido, não sem dificuldades, enfrentar tal desafio.

O ingresso no Curso de Psicologia da Universidade de São Paulo representou para esse estudante uma completa transformação em sua vida - um giro de $180^{\circ}$, como ele descreve. Representou, por exemplo, a possibilidade de resgate de saberes seus, como a filosofia e o teatro, desvalorizados no cursinho e dispensados no seu trabalho como garçom. Os aprendizados que Marcos valorizava, nesses espaços não fazia diferença, tendo isso um profundo impacto sobre ele, resultando em desgaste físico e emocional. Porém, na Universidade tal conhecimento "voltou a fazer 
sentido”, sendo aproveitado e permitindo a Marcos a entrada em um grupo de pesquisa sobre História da Psicologia e a participação no grupo de teatro da USP, o que ele relata de forma bastante entusiasmada.

O ingresso na universidade pública significou a viabilidade de outra perspectiva de vida para esse estudante. Como vimos, sem o acesso ao Ensino Superior gratuito, Marcos vislumbrava uma trajetória pessoal pouco atraente: realizar um curso qualquer numa faculdade particular com muito sacrifício para pagá-lo, conseguir um emprego um pouco melhor e constituir família. A entrada na USP representou a possibilidade de uma trajetória de vida bastante diferente de um destino mais provável tendo em vista sua origem e condição sociais.

Além disso, a experiência na Universidade significou também a “possibilidade de sonhar um monte de coisas” antes completamente inviáveis ou inimagináveis, como, por exemplo, a possibilidade de fazer pós-graduação no exterior. Sua atual orientadora está vinculada a um programa de intercâmbio com França e Itália, havendo a possibilidade de que, se ele fizer o mestrado na mesma área de pesquisa, possa realizar o doutorado em algum desses países. Ainda que isso não se concretize, tendo em vista dificuldades com as políticas de financiamento a pesquisas (principalmente nas ciências humanas), com testes de proficiência em língua estrangeira, entre outras, consideramos importante evidenciar que a entrada na universidade pública significou, para esse estudante, a possibilidade de sonhar. Como diz o título do livro de Spósito (1993), mesmo que ilusão ela não deixa de ser fecunda. Trata-se de ilusões que movem para a luta, para a ação.

A diferença que a Universidade tem feito na vida de Marcos fica evidente quando ele afirma que, antes, por mais que trabalhasse e se esforçasse, as coisas pareciam não acontecer, enquanto na USP, com um pequeno esforço, “o mundo gira”:

...então acaba girando, acontecendo, as coisas acontecem aqui [USP], enquanto que antes não estavam acontecendo, eu tinha que labutar, labutar, e, às vezes, não conseguia nada, e aqui com um esforço mínimo parece que o mundo gira, não mínimo, né, vai, estou exagerando um pouquinho, mas só para frisar bem o que eu sinto a diferença de antes e depois. 
Essa diferença pode ser ilustrada pelo modo como esse estudante chegou ao campus universitário: “com um ânimo preparado para a guerra” e com grande disposição para lutar. Entretanto, isso não foi necessário, já que desde o início da graduação Marcos pôde contar com alguns benefícios da assistência estudantil, como moradia e bolsa-alimentação, que muito o têm auxiliado, contribuindo, inclusive, para minimizar os efeitos da desigualdade social existente entre ele e os demais colegas de curso. De toda forma, o sentimento de que se foi possível enfrentar tantas dificuldades para ingressar na faculdade, permanecer nela não poderia ser mais difícil, de que não haveria nada a temer, de que o pior já teria passado, parece ter sido importante para Marcos enfrentar também outros tipos de adversidades. A discrepância entre o antes e o depois da entrada na Universidade foi tão grande, que Marcos, em sua visão, arrefeceu, ficou “largado”, “acomodado”: “...porque eu acho as coisas aqui [USP] fáceis, não sei se é porque eu tive um nível de dificuldade grande num momento, mas eu acho tudo aqui muito fácil, muito tranqüilo...”. Mais do que uma crítica ao mundo acadêmico, essa fala de Marcos parece enfatizar as enormes dificuldades enfrentadas por ele para conseguir estar na universidade pública: diante delas, as enfrentadas no cotidiano universitário lhe parecem menores.

Marcos tem consciência do lugar social que a Universidade de São Paulo ocupa numa sociedade como a brasileira e, como vimos, de sua responsabilidade por usufruir de algo a que poucos têm acesso. Ademais, esse estudante possui também uma visão bastante crítica em relação à universidade pública e à USP em especial. Critica a alta seletividade, a elitização dos cursos da Universidade de São Paulo, bem como a concorrência do exame do vestibular, que julga profundamente “desleal” ao exigir um tipo de investimento financeiro e pessoal que aqueles que trabalham não conseguem realizar. Fala ainda sobre o curso de Psicologia, cuja nota de corte aumenta a cada ano e que considera “extremamente elitista”. Dessa forma, embora Marcos defenda para amigos ou conhecidos que é possível estar na universidade pública, sendo necessário, para isso, que haja “mobilização" da parte deles, ele afirma também que tal possibilidade tem se tornado cada vez mais difícil. Critica, ainda, a expansão da Universidade através da criação de cursos como os que compõem a EACH (Escola de Artes, Ciências e Humanidades) - "USP/Zona leste” , que se constituem, na sua visão, como cursos técnicos ou especializações. 
No entanto, apesar das críticas, Marcos concebe a universidade como um “catalisador” de possibilidades. Sem o ingresso nela, as chances de poder desfrutar de muitas oportunidades que ele tem tido seriam nulas ou bastante reduzidas. Considera que nesses quatro anos de graduação "tirou a limpo" os cinco em que tentou ingressar no Ensino Superior público.

Também a escola - correspondendo aqui ao período do Ensino Fundamental e Médio - representou para Marcos um “primeiro catalisador” em outro momento e em outro patamar. Foi lá, por exemplo, que ele conheceu os amigos do grupo de jovens com quem manteve fortes vínculos e cuja influência em sua trajetória foi grande.

Quando perguntado a respeito de momentos marcantes de sua trajetória escolar até a universidade, Marcos recorda-se prontamente de alguns bons professores e que também eram "grandes figuras humanas". Lembra-se, especialmente, de professores que, para além do conhecimento específico de área ou da competência didática, eram profissionais comprometidos com o aprendizado dos alunos. Segundo ele, seu gosto e facilidade com disciplinas da área de humanas estão relacionados com a admiração por professores dessas mesmas disciplinas.

Além disso, Marcos possui um profundo respeito e valoriza grandemente o trabalho do professor. Ao falar a respeito de sua experiência acadêmica, ele tece comentários em relação a alguns professores cuja docência é objeto de polêmica no curso, demonstrando grande generosidade e tolerância em relação a eles e criticando a postura dos colegas de turma que ele considera "intolerante”. Marcos afirma que procura se colocar no lugar do docente porque também tem "vontade" de ser professor universitário, desejo esse que ele parece começar a buscar realizar: mais de um ano após a realização das entrevistas, às vésperas de sua formatura, ele nos contou que iria se preparar para prestar a próxima seleção da pós-graduação em Psicologia.

Se Marcos valoriza grandemente a figura do professor, todavia, tem dificuldade de falar a respeito da contribuição da escola para sua trajetória, pois, apesar de reconhecê-la também como um catalisador, sentiu-se “lesado” pela qualidade da educação que lhe foi oferecida e que tanto dificultou seu acesso à universidade. Mas, por outro lado, considera que essa mesma escola lhe forneceu “instrumentos” ou "mecanismos” para que ele pudesse “correr atrás”, indo em busca do que lhe faltava. 
Marcos parece, de fato ter feito do “outro mundo”, representado pela universidade, também seu mundo. Ele modificou-se sem ter renunciado a sua história; ele afirmou-se sem mais sentir necessidade de ter uma "bandeja na mão”. Para crescer sem humilhação, Marcos pôde contar, entre outros fatores, com a amizade.

Conheçamos, no próximo tópico, a história de Pedro - um de seus grandes amigos. 


\section{Entrevista na íntegra}

\section{$1^{\text {a }}$ Entrevista}

Débora: Bom, Marcos eu estava te falando que meu interesse é conhecer sua história e daí eu queria que você me contasse como é que foi a sua vida escolar, assim, suas lembranças, o que você lembra da época da escola, fatos, momentos mais marcantes, pessoas mais marcantes, queria conhecer sua história, ouvir suas lembranças.

Marcos: É, da primeira à oitava série eu estudei no mesmo colégio, eu e os meus outros dois irmãos, somos em quatro irmãos, eu sou o mais velho, a minha irmã caçula está com oito anos na segunda série agora. O que eu me lembro é, assim, é eu acho que sempre fui um aluno mediano, sabe? Eu nunca tive grandes complicações na escola, mas também nunca ganhei honra ao mérito por estar com nota máxima em todos os semestres. É a recordação que eu tenho. A primeira série, por exemplo - que eu estava pensando nisso outro dia -, que eu achei que eu tinha muita dificuldade porque minha mãe ia muito na escola, minha mãe era muito, assim, corujona e ela era muito presente, sempre brigava por causa do filhinho com as professoras (risadas)! E eu tinha uma professora que ela era muito rígida. Então, afetivamente, assim, eu lembro que eu tinha uma lembrança muito negativa da minha primeira série, mas, aí depois, eu estava conversando com a minha mãe, aí eu lembrei de um fato que eu achei bacana que foi da professora me chamar para ler um trechinho para uma outra professora e agradeceu e eu fiquei super encanado com isso, me sentindo super mal, minha mãe foi até na escola no outro dia por causa disso e depois não virou nada. Mas, eu achei assim que eu estava me sentindo mal por não estar acompanhando os outros, a professora estar mostrando "nossa ele não tá indo bem, tô preocupada com ele”. Mas, daí eu me lembrei que eu estava conseguindo ler e aí eu achei muito bacana porque a professora, apesar das pendências lá com a minha mãe, o que a professora dizia era que, é, aliás o que ela estava mostrando para outra era que eu estava lendo legal. Mas assim eu tive uma idéia muito negativa da minha primeira, segunda série. Eu achava que eu não acompanhava muito bem, mas acho que é mais uma impressão minha do que uma coisa que realmente acontecia... Então...

D: E essa impressão você acha que vem, você falou que sua mãe ia muito na escola e também de você na sala de aula é isso?

M: Um pouco é da minha mãe ir muito à escola e eu tinha uma professora... ela era muito rígida, então ela era... ela sempre cobrava muito, ela falava até do meu cabelo, eu gostava de usar cabelo grande, ela falava que tinha que cortar franja, que estava caindo no meu olho e, por isso, que eu não estava lendo direito, é coisa assim, então: "você não tá lendo direito..." coisas... pequenas pendências assim desse tipo...

D: E que na verdade ela estava pedindo para você ler mas era para, depois você pensando nisso, era para assinalar que você estava progredindo?

M: É. E eu estava, assim, eu estava marcando isso de um jeito meio negativo. Então, e por isso, procurei, um pouco tentando entender que era uma coisa positiva. Pensando hoje "eu estava na primeira série, eu já lia com certa facilidade”. Que a gente era, a situação é que a gente tinha ido na biblioteca da escola e tinham distribuído livros para as crianças, ela me chamou lá para mostrar para outra professora e me chamou e eu li. Hoje que eu: "nossa tava na primeira série eu tava 
lendo, já tava alfabetizado!” Então, não é bem como eu imaginava, só que só caiu a ficha um pouco agora. Então, é isso. É, eu sempre tive uma certa facilidade com disciplinas da área de humanas. E tive um pouquinho de dificuldade em matemática, física, química. Peguei umas recuperações em Matemática, sobretudo. O resto, minhas notas eram boas, meio desencontradas: altas em história, português e recuperações em matemática, mas em geral foi bem tranqüilo assim, o Ensino Fundamental. A partir do Ensino Médio eu tive que mudar de escola porque o colégio onde eu estava não oferecia Ensino Médio e aí eu entrei numa escola que era da Polícia Militar, era uma escola pública, só que, é, $x$ vagas eram para dependentes de militar e $x$ vagas para civis. Então, você tinha que fazer tipo um, uma prova de seleção para entrar ali e, no caso, quando eu prestei, eu passei. Não era nada assim muito concorrido, mas era efetivamente concorrido porque a escola tinha, assim, uma fama de ter um bom ensino. E lá eu fiz o Ensino Médio.

Aí eu conclui em 97 o Ensino Médio, e aí eu prestei Artes Cênicas na Unicamp [Universidade Estadual de Campinas], aí eu passei na primeira fase. Estava dando 12 por vaga, então, uma colocação até legal e eu fiquei muito empolgado por ter passado na Unicamp na primeira fase sem ter estudado muito pro teste do vestibular, fui com a bagagem que eu estava trazendo do meu Ensino Médio. E não estudei também muito para segunda fase... (risadas) E aí eu não consegui passar. Mas aí, é, eu não sei, eu não olhei nem em que foi que eu fiquei, não olhei quantos pontos, não olhei, é, se eu fiquei na lista de espera, estava muito, muito cru sabe? Muito. Não sabia muito como que era lidar com o vestibular. Pra mim era passar ou não passar e eu não tinha muito essa idéia do que quê era um vestibular, do que quê tem num vestibular. Aí eu já mudei para Psicologia, não quis fazer mais Artes Cênicas e eu prestei no meio desse mesmo ano uma federal em Uberlândia, a UFU [Universidade Federal de Uberlândia]. E “imagina passei na primeira fase da Unicamp!”, nem passar na UFU na primeira fase, eu passei...! (risada) E, aí, é, eu estava fazendo o tiro de guerra nesse ano. Então eu acabei só fazendo tiro de guerra, não estudei mais, nem estava trabalhando... É, aí no ano seguinte, eu comecei a trabalhar. É...

D: Daí você não prestou vestibular, você prestou no meio do ano e só?

\section{M: Isso.}

\section{D: No fim do ano você não prestou?}

M: Não. Aí no ano seguinte eu comecei trabalhar. Trabalhava numa loja de 1,99, uma coisa assim, uma loja bem grande que tinha na minha cidade e eu trabalhava meio período. Então, o dinheiro que eu ganhava lá praticamente acabava tudo pro cursinho que tinha que trabalhar para custear. Meu pai dizia, assim, que não gostaria que a gente trabalhasse enquanto não terminasse os estudos; estudos para ele compreendia basicamente até o Ensino Médio. E aquela coisa de "o que eu posso dar para um, eu tenho que dar para todos”. Então, se ele podia pagar cursinho para mim, ele teria que pagar para meus irmãos também senão, senão não seria justo. E, aí, eu comecei a trabalhar, trabalhava meio período e fazia cursinho à noite. Só que já pensava na Federal de Uberlândia então, assistia praticamente só as aulas que tinham a ver com o vestibular da Universidade. Então, por exemplo, algumas aulas como filosofia, algumas matérias específicas de história, que eu sabia que não caia, eu não estudava, eu não ia na aula ou matava a aula. Primeira vez que eu estudava à noite, achei isso interessantíssimo, tinha um shopping perto ali do cursinho, às vezes, eu ia lá e aí eu prestei, passei na primeira fase no final do ano, mas não passei na 
segunda... É, aí, como foi? Aí no ano seguinte... Aí, eu ia... Eu só prestei no final do ano, não prestei no meio, fiz um integral, integral que eles tinham lá. Mas para mim era muito, assim, eu ficava um pouco desesperado porque enquanto eu percebia que as pessoas estavam revisando a matéria, eu estava aprendendo, então eu via o professor dando aula e: "nossa! Eu tenho que saber isso?”. "Nossa eu tenho que saber aquilo?!” Então, eu me sentia assim num déficit muito grande e aí que eu fui um pouco dimensionar o que quê era o vestibular, como que era tentar passar numa pública, tem uma competição muito grande, e eu dentro do possível tentava, é, entrar no ritmo e nesse primeiro ano eu tive muita dificuldade. No ano seguinte eu mudei de emprego: fui trabalhar como garçom. Então, o que quê acontecia? É eu trabalhava à noite e fazia cursinho de manhã, só que estava muito comprometido porque, geralmente, de manhã eu estava com sono, aí na parte da tarde que era a parte que eu tinha para estudar, eu ia dormir ou eu ia fazer algumas coisas, não conseguia ficar com a cabeça para estudar e aí...

D: Onde você trabalhava de garçom?

M: Trabalhava numa choperia na minha cidade em U. Então, era uma choperia e um restaurante. Era uma casa grande e, geralmente, eu trabalhava finais de semana e, se eu não me engano, três dias na semana, tinha dois dias de folga durante a semana, que era quando eu pegava para estudar mais. Mas, é... não sei... não rendia muito nessa época. Aí que que eu...? Daí eu prestei novamente em Uberlândia, passei na primeira fase, prestei em Uberlândia, prestei Unesp [Universidade Estadual Paulista] também, aí, é, passei na primeira fase de Uberlândia e não me lembro como é que foi na Unesp, também não passei na Unesp. E aí tentei mudar um pouco o esquema, eu pensei: “eu trabalho seis meses, aí junto grana e seis meses seguintes eu só estudo". Tentei fazer esse esquema, foi onde eu me dei um pouco melhor aí. Mas assim, mesmo assim, eu não passei, acho que nesse ano eu acabei prestando a UFU [Universidade Federal de Uberlândia], a Unesp e se não me engano já Fuvest [Fundação para o Vestibular]. Acho que Fuvest ainda não, é, e a Ufscar [Universidade Federal de São Carlos] também. É que estava muito próximo mas eu sempre quis prestar psicologia, geralmente as notas de corte eram muito altas, então psicologia geralmente estava entre as três mais concorridas. A minha nota dava para ter passado em outras áreas, outros cursos. Mas faltava um pouco para psicologia.

D: Você continuou trabalhando, você trabalhou seis meses no mesmo emprego aí você parou e começou a estudar?

M: Comecei a estudar, mas faltava um pouco de objetividade, entendeu, no estudo, sabe? Me organizar porque eu nunca tive é, como, não sei... Eu penso que sempre estava estudando em escola pública, eu não tinha esse ritmo de "eu vou me preparar para um vestibular, eu vou me preparar para uma grande prova, eu vou...”, eu não sabia nem me organizar para isso e no cursinho não te ensinavam isso. E fui pegando um pouco disso com algumas pessoas com quem eu estudava. Você pegar um método, você pegar um cronograma e ver também como, qual que é o ritmo de estudo, como é que você estuda. Então isso demorou para caramba para mim pegar esse tipo de coisa. Aí, 2000 eu prestei um concurso do IBGE para trabalhar no Censo, passei como supervisor e aí, é, eu trabalhava durante o dia no ano de 2000, acho que foi 2000, 2001, 2000 acho que foi no censo de 2000, e aí eu trabalhava o dia todo no horário comercial e depois eu ia pro cursinho. É, antes disso, eu fiz um cursinho popular, cheguei a ganhar bolsa algumas vezes com notas de prova, minha 
nota era razoavelmente boa, na época foi melhor mas eu vi que tinha alguma coisa errada! (risadas) Porque eu estava indo muito bem e eu sabia que no vestibular a coisa era mais competitiva. Consegui bolsa dois meses vamos dizer assim, tinha uma prova bimestral assim tipo mensal, eu não sei, que quem tirasse as maiores notas ganhava a mensalidade do mês seguinte. Mas eu achava que não era tão competitivo assim, pela noção que eu tinha do cursinho anterior que eu fazia, eu pagava mais e... mas também era mais puxado. E eu fiz esse concurso do IBGE voltei pro meu último cursinho que eu fazia e aí... Minha fala está confusa?

D: Não, não.

M: E aí nessa época do IBGE, eu trabalhava no IBGE o dia todo e fazia cursinho à noite. Aí eu prestei Fuvest, acho que foi a primeira vez que eu prestei Fuvest, prestei Fuvest, prestei Unesp, prestei UFSCAR. E, aí, não passei de novo. É, aí no ano seguinte eu voltei a trabalhar como garçom, só que eu trabalhava só finais de semana, só mais como um extra eles me chamavam lá, e aí eu voltei a fazer... como que era? Voltei a fazer cursinho, mas aí acho que eu só fiz do segundo semestre em diante, eu estudei o primeiro semestre por conta e no segundo semestre eu fiz um semi. Porque estava assim cansado de fazer cursinho, eu já estava, assim, sem graça de fazer cursinho, fazer o mesmo cursinho... Foram acho que, ao todo, somando os vestibulares, onze vestibulares então, foi assim, a minha última tentativa de entrar numa pública e eu ia tentar, tentar arrumar um outro emprego, que pudesse ganhar um pouco mais e ia fazer uma particular na minha cidade, provavelmente na área de administração, que é um curso bom e razoavelmente barato.

D: E psicologia tinha mas...

M: Tinha, só que era caro e era, tinha o problema de ser integral, então não poderia trabalhar e pagar a faculdade e meu pai na época não tinha condições para isso. Aí, é, eu resolvi prestar de novo no final do ano. Eu prestei UFSCAR, prestei Fuvest, prestei UFMG [Universidade Federal de Minas Gerais]. Eu estava realmente pretendendo UFMG. Talvez em segundo a UFSCAR. E Fuvest eu prestei assim: eu fiz a inscrição no último dia e era numa cidade vizinha à minha cidade. Eu peguei um ônibus correndo e fui fazer na cidade ao lado. E, mas não era minha intenção, não era minha primeira opção a Fuvest mesmo porque eu achei que não daria para passar, aí acabou que eu passei na primeira fase da Fuvest, passei relativamente bem; a nota de corte era acho 93 ou 96, era alguma coisa assim, passei no 103, então era uma margem legal assim: "Nossa! Talvez eu consiga tirar essa diferença na segunda fase, né?” E tinha também a UFMG que eu tinha passado bem, fui bem e na UFSCAR não consegui passar. E aí eu prestei a segunda fase da Fuvest e saiu o resultado da segunda fase antes de sair a segunda fase da UFMG. Então, eu nem cheguei a prestar UFMG, como eu já tinha passado na Fuvest eu... E aí, cá estou! Acho que basicamente é isso...

D: E dessa tua experiência assim, o que quê mais te marcou? Momentos que foram mais marcantes? Pessoas que foram mais marcantes?

M: (silêncio) É, não sei, acho que eu tive, é, alguns bons professores que meio que me ensinaram a gostar de algumas coisas. É, eu penso, por exemplo, a minha dificuldade com matemática e eu acho que eu só tive um bom professor de matemática no Ensino Médio, quer dizer... Mas matérias que eu gosto, como história ou português ou geografia e mesmo área de ciência, biologia, eu tive bons professores e, assim, grandes figuras humanas, que eu me identificava muito, eu 
gostava muito e que faziam, assim, questão que os alunos aprendessem também, sabe? Que tinha um sentido a aula. Isso eu valorizava, eu tentava dar o feedback, é eu até hoje tenho um pouco de problema com professor que dá a aula por dar, eu não consigo me empenhar, para mim, você percebe que é indiferente ele estar ali ou não... Mesmo agora na faculdade, minhas notas são menores - até estava discutindo com um amigo meu sobre isso: "ah eu gosto da matéria da qual eu gosto do professor também”. Isso, eu não posso ter essa atitude, acho que na Universidade, e tem um pouco disso, eu me antipatizo com a disciplina e com o professor também é...

D: E essas pessoas que você, como você diz "professores que foram grandes figuras humanas”, você pode falar um pouquinho mais sobre eles, quem eram? Que disciplina? O que quê você lembra?

M: Tá, o que eu me lembro, eu tinha uma professora de, ela dava aula na parte de ciências e biologia, introdução a ciências naturais, o nome dela era Marília, e ela tinha sido super ativista na década de 60, então, ela era muito idealista e ao mesmo tempo, é, ela dava sentido para o que ela ensinava. E as aulas dela tinham uma qualidade muito boa, ela se atualizava bastante, ela tinha esforço lá, tinha empenho, para você entender o que ela queria passar, para absorver a matéria e para aquilo fazer um sentido para você e ter de alguma forma aplicação para aquilo, você entendeu? Pra que você estudaria aquilo ou não. Eu tive aula com ela na minha quinta, sexta, sétima, oitava série. Eu tive também, no fundamental, alguns professores muito bons em geografia, por exemplo, uma área que eu também gosto, que também se empenhavam para caramba e organizavam a aula, procuravam coisas extras, é valorizavam quando você procurava algumas coisas extras também. Então, eu acho isso bem bacana é... (silêncio)

Tive uma professora de português na oitava série, que era assim bem rígida também, mas explicava muito bem e tinha uma preocupação se você estava aprendendo ou não, nem que fosse para te dar uma bronca, nem que fosse para te tirar ponto... (risada) Mas, é, era importante para ela que, de alguma forma, você aprendesse, nem que fosse para depois quando tinham aquelas avaliações de Ensino Médio que o governo faz?

\section{D: O ENEM ?}

M: Não, não o ENEM, é, eles fazem umas avaliações, pelo menos no Estado de Minas, sobre, ah, o ensino nas escolas de, de fundamental.

D: Todo, todo sistema?

M: Isso, é. E geralmente, por exemplo, na minha escola, a disciplina de português, tinha uma cotação muito alta, os alunos geralmente tinham muito medo. Então ela ficava um pouco vaidosa por causa disso, acabava fazendo questão um pouco de manter isso, acredito, mas era uma professora muito boa. Tive bons professores, falando da escola, também no Ensino Médio, é, tinha uma dinâmica um pouco diferente, não sei, talvez pelo colégio ter uma disciplina maior, por ser um colégio da Polícia Militar, pecavam por alguns excessos. Questão de uniforme, questão de comportamento, tinham uns excessos que não faziam sentido, mas no geral a grade horária era bem organizada, os professores não faltavam tanto, era cobrado dos professores a disciplina dada, então, você acabava tendo, não sei, um certo feedback nesse sentido. (silêncio) 


\section{D: Os professores eram da rede? Era uma escola pública?}

M: Era uma escola pública só que ela tinha, ela, não sei exatamente... eu sei que era vinculada à Secretaria de Educação, ela respondia à Secretaria de Educação, mas eu não sei exatamente como que funcionava. Tanto que a gente tinha um diretor administrativo, que era o chefe da, que era o chefe da Companhia, que era um militar. Era o Comandante Geral da PM da minha cidade. E a gente tinha um diretor pedagógico, que era, no caso, uma professora que exercia um cargo mais de organização mesmo, pedagógica, da escola e, às vezes, administrativa. Seria, no caso, essa diretora ela, ela tinha basicamente a função que tem um diretor de uma escola pública, só que para responder certas coisas, certos encargos, tinha que se remeter ao comandante, é, mandar um cronograma ou alguma coisa desse tipo. Mas, geralmente a última palavra era da diretora pedagógica, mesmo tendo que submeter ao comandante .

\section{D: Por que você foi para essa escola? Era perto da sua casa?}

M: Era perto da minha casa, muito perto e, é, era uma escola que era considerada de um ensino bom, de qualidade dentre as públicas; é, não se cobrava mensalidade, eles tinham uma taxa de manutenção, mas era meio simbólica, muito por causa disso, porque naquele momento era o melhor que eu podia ter, nesse sentido.

\section{D: Foi uma escolha sua?}

M: Se foi uma escolha minha? Era um pouco assim... é, era um pouco de praxe o pessoal sair da minha antiga escola e ir para essa escola, era um movimento meio que... Ou senão para essa ou para uma do bairro próximo. Mas o primeiro movimento era tentar ir para lá... nesse sentido... (silêncio)

D: E na tua outra escola? Na primeira escola? O que quê você lembra, como é que era a escola?

M: Eu sei que gostava muito. O que eu mais me lembro eram os relacionamentos que eu tinha, né, com amigos, mesmo com professores, tanto que quando eu saí de lá foi bem complicado, mas eu ainda ia para visitar, eu ficava lá na porta para ver as pessoas. Como meus irmãos ainda estudavam lá, de vez em quando eu ia lá, é, conversava muito com a orientadora - uma pessoa assim que me acompanhou sempre lá dentro -, pessoas bem bacanas.

D: E era uma escola tida como boa, uma escola mediana, você consegue visualizar dentro do sistema?

M: Era uma escola é... acho que considerada mediana, entre mediana e boa. É eu acho que caiu bastante desde que eu estudei lá e o momento de agora. Eu fico vendo, mesmo eu estagiando agora, em algumas escolas de periferia de P.[cidade onde se localiza o campus], não sei, talvez eu fazendo uma comparação, é muito diferente, eu acho que lá era bem mais estruturado, as coisas eram bem mais organizadas, é, não se tinha problema como violência, não tão gritante, tinha um caso indisciplinar ou outro, eu já, eu ganhei uma advertência uma vez porque eu estava rindo de alguém 
que fez um desenho da professora, quer dizer, as advertências eram nesse nível, o aluno que não fica quieto, né, não, nada, nada tão, como um quadro de violência assim, como o aluno levar canivete para escola ou mesmo tráfico de droga, era uma realidade bem mais pacata nesse sentido. E eu acho que era bem mais organizada. É, mas eu acho que a qualidade de ensino lá, também, era bom. De repente eu depreciei um pouco isso tudo quando eu entrei a primeira vez no cursinho, quando eu percebi quantas coisas eu deveria saber e não sabia. Enquanto os outros estavam relembrando, eu estava aprendendo. Nesse sentido, eu me senti um pouco perdido, né, pensando "nossa que escola que eu fiz, que ensino eu tive, que educação eu tive?” Aí que caiu um pouquinho a ficha e eu... Mas, assim, no geral, hoje eu penso um pouco em escola pública, eu vejo... meus irmãos também hoje estudam em escola pública, acho que a minha escola era relativamente boa. Na época, eu acho que existia uma outra melhor, mais estruturada, pelo menos o pessoal falava mais, que tinha muita aprovação direta do pessoal nos vestibulares, mesmo porque a escola que eu estudava não tinha Ensino Médio então não dava para fazer essa comparação meio superficial assim, mas tinha um pouquinho disso.

D: Você notou que a educação lá na escola piorou também, assim, acompanhando o seu desenvolvimento?

M: É, porque meus irmãos, é, eles tinham uma diferença de duas ou três séries, três séries abaixo de mim, eles tiveram acho que reprovação e eles entraram um pouquinho mais velhos na escola por questão da data [de aniversário], mesmo que eles faziam... [fim da fita]

Não sei mas a qualidade de ensino mudou é... mesmo a cobrança, né? Aquele programa do “Acertando o Passo” da escola pública.

D: Eu não conheço porque é de Minas.

M: É, é de Minas, seria aquele programa, vocês tem aqui...

D: Progressão continuada?

M: É seria, então, o que, que acontece fica difícil assim você não pode mais reprovar o aluno, então é o que era também um, um motivo de coerção, né: "se eu não estudar eu não passo de ano", também eu acho que tinha um aspecto positivo porque "porque eu tenho que estudar, porque eu tenho que passar de ano", mas, por conseguinte, querendo ou não, eu acabo aprendendo alguma coisa, sabe? Nesse sentido então ficava muito, muito, ah, não sei, de repente largado, muito, muito solto... a tua forma de aprender, isso desestimulava, desestimulava acho que tanto o aluno, como o professor mas, não sei.

\section{D: Você não pegou esse sistema?}

M: Não, não peguei. Tinha algo parecido pras primeiras séries. Primeira e segunda séries chamavam de “Ciclo Básico de Alfabetização Contínua”. Então, você tinha níveis para atingir, você tinha, você tinha dois anos para atingir esses níveis. Mas assim não era reprovado da primeira para a segunda série mas daí em diante sim, é... e mesmo assim é... pelo o que o nível de conhecimento que eu tive quando eu saí do 
colégio, o nível de conhecimento que os meus irmãos tiveram eu acho que foi bem diferente e eu não acredito que foi tanto mais por um empenho da minha parte não, porque não sei é... eu acho que coisas muito básicas, às vezes, faltava para eles. Tanto que é... nenhum dos dois tá fazendo faculdade hoje. Já pensaram a respeito, já chegaram a tentar um vestibular ou outro mas não se tornou um ideal para eles. E eles têm uma dificuldade muito grande nisso (silêncio).

D: Você acha que você foi beneficiado de uma educação que tinha um pouco mais de qualidade? É isso?

M: Eu acho que sim. Nesse sentido sim, tanto por eu ter estudado nessa mesma escola que eles estudaram, em outro momento, por menor que seja, um pouco, são três anos, três séries de diferença que meus irmãos têm, três a quatro. Um tem três e o outro quatro séries de diferença né? Acho que fizeram, tiveram algum peso, ou seja por eu ter feito o Ensino Médio, nessa outra escola, meus irmãos já... já se mantiveram nessa primeira estadual porque aí ela ampliou e começou a ter Ensino Médio lá. É, não sei, é, meus pais sempre valorizavam muito assim a educação, eles sempre fizeram muita questão. Meu pai morou na zona rural até os 30 anos. Então ele trabalhava no sítio da família e tal e não chegou a completar a quarta série do fundamental. Eles chamavam de primário né?

\section{D: Primário é.}

M: Minha mãe completou o primário...

D: Até que série seu pai fez, você sabe?

M: Meu pai, eu não sei dizer, mas eu sei que depois, no emprego dele, ele teve que fazer uma espécie de supletivozinho para ele poder mudar de cargo e aí ele completou essa quarta série mas eu não sei dizer e minha mãe, como eu já disse também fez o antigo primário. E sempre assim, é, valorizavam muito assim: a escola era prioridade. Meu pai dizia "ah, eu não quero que vocês trabalhem enquanto vocês não terminarem os estudos”. Mas terminar os estudos para ele compreendia o Ensino Médio, é óbvio que ele queria um filho doutor, mas era uma coisa que ele nunca pensou muito a respeito e eu achei muito engraçado porque eu me lembro que na época que eu passei no vestibular na Fuvest, meu irmão também passou num concurso para Polícia Militar, era um concurso público, e ele ficou tão ou mais feliz pelo meu irmão ter passado, num concurso público, do que eu na FUVEST. Parece, parece questão acho que de valorizar o trabalho. Era um emprego, já era um bom emprego, né, tinha uma certa estabilidade, que era o funcionalismo público. Enquanto eu estava estudando ainda, estaria ainda postergando a possibilidade de estar entrando no mercado de trabalho. Então, meu pai tem essa coisa bem, bem concreta do trabalho, ele é, também a questão de o provedor, mesmo quando ele diz que a gente não trabalhe, não é porque ele não valorize o trabalho, acho que ele valorizava muito o dele então "eu trabalho, com o meu trabalho eu sustento a minha família”. Então tem muito disso no discurso dele. É, meus irmãos tem um que está sendo, está trabalhando como polícia militar e o outro está trabalhando como garçom ainda. E aí, eu não sei, aí eu acho que é um pouco de opção pessoal também, de prioridades. Porque na época que eu comecei a trabalhar como garçom, a gente 
começou junto. E no final de dois ou três anos eu entrei na faculdade e meu irmão, o caçula no caso, ele comprou um carro. Isso foi, foi bem marcante, questão de prioridades. Mas é, ainda ele diz que pensa em vestibular e tal, diz que queria fazer enfermagem mas não se mobiliza muito para isso. Na verdade, fica muito mais na idealização do que tentar entender o que é o vestibular, se articular para passar em um mesmo, também porque tem a questão econômica, né: ele teria que arrumar um emprego que ele conseguisse trabalhar e estudar. Meu pai não teria condições de arcar com ele nesse sentido.

\section{D: E tua mãe?}

M: Minha mãe é, ela trabalhava como costureira, uma época, depois, quando a gente era pequeno não, já era maior, né, a gente cresceu um pouco, ela sentiu um pouco mais de autonomia e trabalhava em casa costurando; aí minha irmãzinha nasceu, aí ela parou. Mas assim, a questão de escola, trabalho, ela valoriza o trabalho e escola é importantíssimo. "Se você quer ser alguém na vida", nos dizeres dela, "você tem que estudar!” Mesmo, mesmo para é, não sei, é ascender socialmente - é o estudo. Aí a escola, posteriormente viria o trabalho, o trabalho como meu pai via mais concreto e... Minha irmã já tem uma educação um pouco diferente. Ela começou a estudar mais cedo que a gente com quatro, quatro anos foi pro pré, escola já particular. É, minha mãe tenta investir no que pode no sentido de educação para minha irmã. Ela está estudando agora numa escola pública, um pouco que a contragosto da minha mãe, ela queria que ela estivesse numa particular, é, mas uma série de questões, conflitos com meu pai, foi resolvido que ela ficaria agora numa escola pública mas assim quando tiver condições, com certeza, minha mãe vai fazer o possível para ela passar para uma particular.

\section{D: E ela estuda na mesma escola que vocês estudaram?}

M: Não ela está em outro colégio, outra escola, uma bem profissional e o ensino que eu considero de qualidade, das públicas da minha cidade; não é muito fácil conseguir vaga lá, é uma escola mais central do que a escola de periferia que eu estudei. É isso.

D: Você comentou um pouquinho quando você estava falando da primeira série, sua mãe ia sempre na escola, ela era corujona, ela era assim com vocês três?

M: Minha mãe era figurinha conhecida na escola (risadas). Acho que nas escolas. Ela vai sempre na escola da minha irmãzinha, sempre acompanhando. Nesse sentido ela é bem, bem protetora, às vezes, até “super” protetora. É, ela cobrava muito da gente também. Mas por outro lado, ela sempre brigava pela gente. Se eu tirava uma..., se eu ia muito mal numa matéria, ou por isso ou por aquilo, e ela percebia que de alguma forma eu não estava me esforçando, ela pelo menos ia ver o que estava acontecendo. Mas, vários cascudos por não fazer tarefa! (risos)

\section{D: Ela batia?}

M: Ah, às vezes, ela dava uns tapinhas sim. Minha irmãzinha não. Já... só colhe as benesses de três irmãos mais velhos. 


\section{(...)}

D: E a sua mãe, acompanhava bem de perto assim lição, prova, boletim, nota, as reuniões?

M: Sim, sim. Coisa de sentar na mesa para fazer tarefa com a gente. Se a gente estava muito, muito mal em alguma coisa, eu até que não tive esse problema não, mas meus irmãos, às vezes, ela pagava professor particular, em alguns momentos, para dar uma ajuda, principalmente se está com vermelho e pirigando ser reprovado, aí professora particular. Meus irmãos tiveram um bom tempo de aula particular no Ensino Fundamental.

\section{D: E você, nunca precisou?}

M: Não. Eu era razoavelmente tranqüilo. Minha mãe mesmo diz que é eu fui que menos deu preocupações para ela, nesse sentido. Aí, é, estava comentando que "você cobrava!” aí ela fala "sim eu cobrava!” Não era cobrança, aliás era cobrança, mas eu não acho uma coisa negativa não, porque ela queria que eu fizesse e eu era... fazia corpo mole. Eu vejo muito isso na minha irmãzinha: não querer fazer tarefa, preferir brincar ou preferir assistir tv, aí a minha mãe insistia "vai fazer tarefa e vai fazer tarefa agora!”. Eu vejo como minha irmã fica toda reclamando, vai, mas toda... reclamando, um pouco acho que por... aí... que... questão de pegar... (silêncio)

D: E na escola ela ia falar com os professores sobre vocês, é isso?

M: Sim, sim, sim ela sempre estava lá. Todos os meus professores conheciam minha mãe, né? Então isso mais, isso mais presente eram nas séries iniciais. Depois ela acompanhava mas era mais no boletim no final do bimestre, e "Não, olha, estuda aí" ou não deixava de perguntar "Como é que você tá indo?” Ou: “Ah, vai sair? Tem aula amanhã?” Mais monitoramento. Mas não era uma coisa tão, tão mais próxima assim, já era mais por conta da gente nesse sentido.

\section{D: E seu pai, como que era em relação à escolarização?}

M: Meu pai era mais distante. Ele não era muito próximo assim de saber quanto tirou, como que está indo. “Tá estudando?” - está estudando bem genericamente (risadas). “Tá estudando, tá, então tá valendo, tem que ir bem!” (risadas). Essa cobrança de, mas nada muito de ver o que quê eu estou fazendo, de ver como que eu estou indo, essa proximidade maior, não. Um pouco mais distante. Principalmente é, teve uma época que meu pai trabalhava fora então, às vezes, eu via ele, quando eu era menor, primeira série assim, então eu via ele mais de final de semana e aí quando eu era, estava maior, não, às vezes, acontecia de ele viajar esporadicamente tal mas sempre nesse sentido, com a escolarização um pouco distante. Mas não podia tomar bomba, não podia ser reprovado mas o resto a gente ia, a gente acaba fazendo assim como desse.

(silêncio)

D: Ele trabalhava em quê? 
M: Meu pai trabalhou a vida toda, depois que ele saiu do sítio dos pais dele, ele foi para FEPASA. Ele, inicialmente, ele trabalhava é, eles chamam de trabalhar na linha, trabalhar no trecho, ele, a função que ele faz, hoje, eu acho, que nem existe mais que era realmente, efetivamente, construir trilho. Era bem trabalho pesado mesmo e quando caía uma, eles chamavam barreira, quando os lugares que o trem passa e tem os seus barrancos assim, quando caía a barreira eram eles que iam lá, tinham que abrir; hoje, tem máquina para fazer isso. Inclusive meu pai ele está aposentado como, não sei, tem um problema de coluna que veio daí. Naquele momento o que quê aconteceu, como foi a vida profissional do meu pai, ele entrou na FEPASA desse jeito, nessa função. Aí ele começou apresentar problemas na coluna. Como ele estava na FEPASA e a FEPASA é uma empresa estatal e como ele estava com problema de saúde, ele não podia ser dispensado, que quê fizeram? Aí mudaram ele de função. Ele passou para vigia e ele ficou um bom tempo nessa função de vigia. Só que dentro da FEPASA extinguiu-se o cargo de vigia e ele não poderia ser mandado embora. O que quê fizeram? Fizeram um treinamento com ele, no caso foi nessa época que ele fez uma espécie de supletivo pelo menos do primário, séries básicas para ele passar para posição de segurança. Aí dentro tinha tipo um planozinho de carreira: segurança um, dois, três dependendo do que era que você fazia segurança - se era de carga, se era de passageiro ou era de instalações e aí teria uns adicionais por periculosidade, insalubridade porque geralmente eles ficavam no pátio da estação ferroviária. Ou fazendo segurança de passageiros, ou fazendo a segurança dos carregamentos que vinham. E aí é, em 98, se não me engano, a FEPASA foi vendida, foi privatizada. Quem comprou, foi a FERROBAM. E aí, é, meu pai foi mandado embora. Ele, ele teve um acerto. Eles trocaram, fizeram uma negociação com o sindicato, trocaram a cláusula contratual dele de não ser mandado embora então, não sei como que aconteceu exatamente isso da cláusula do sindicato com a estatal, e aí isso foi pago para ele em remuneração e aí ele foi dispensado. Mas antes ele, nessa época, entre a dispensa e a aposentadoria dele, ele conseguiu um afastamento por causa do problema da coluna, aí ele manteve nesse afastamento acho que uns dois anos, acho que sempre fazendo perícia periodicamente e eles não podiam, é, dispensar ele, tirar o benefício porque ele realmente tinha um problema. Mas também não dava uma aposentadoria efetivamente. Que depois de dois anos deram efetivamente a aposentadoria para ele. E hoje ele está aposentado. (silêncio)

D: E na época da escola era seu pai só que trabalhava, quando você estava na escola?

M: Sim no início é, sim. Minha mãe, teve uma época que minha mãe trabalhava mais como costureira, mas era uma coisa assim, o rendimento era muito baixo, era mais para cobrir coisas dela, pessoais ou nossos, uma coisa ou outra, mas o rendimento familiar era sempre meu pai quem custeava. Então é, a gente morava, inicialmente numa casa que era cedida pelo meu avô paterno. E então a gente não pagava aluguel, que já tranqüilizava bastante. Quando meu avô veio a falecer e aí teve que dividir a herança, que era essa casa e mais uma e, aí, meu pai acho que pegou o fundo de garantia dele se ajeitou desse jeito e a gente continuou com a casa. (silêncio)

Eu acho que é isso. (pausa) É, eu, na minha adolescência, nos meus 16, 17 anos, eu fiz alguns bicos, né? Como office boy, essas coisas assim em escritório de contabilidade de um tio meu. Ou então trabalhava ajudando um outro tio numa casa 
de frangos que ele tinha. Isso tudo era, era uma coisa para mim mesmo, não ajudava na renda familiar com esses meus empregozinhos.

D: Uma rendinha para você?

M: É.

D: Seu primeiro emprego foi aquele na loja de 1,99 ?

M: Isso, estava com 17 para 18 ou 18, 18 anos mas que também era para me custear nos estudos né, mas não entrava na renda familiar.

D: E que que você fazia nessa loja?

M: Eu trabalhava como repositor. Isso variava um pouquinho do horário que eu entrava. De vez em quando eu invertia o horário, eu, por exemplo, eu trabalhava meio período, trabalhava das oito da manhã às duas da tarde que era justamente para mim ter tempo de estudar, então quando eu pegava o horário das duas às seis, que é quando a loja fechava, ela vai até as seis, a gente fazia reposição, ou durante o expediente, a gente fazia reposição. Eu ficava no guarda-volumes, que era uma loja muito grande, tinha todo um, tinha um sistema de câmeras, então quem ficava no guarda-volumes também tinha que ficar olhando o monitoramento. Eu ficava, às vezes, na segurança, eu fazia de tudo lá, segurança é você simplesmente tem que, tem que circular pela loja e mesmo, é, pelo cliente no sentido de "onde estava cada mercadoria" ou tinha um balcão na frente onde ficavam as peças menores e tinha que ficar alguém lá dentro para fazer a venda, às vezes, eu ficava. Fazia um pouco de tudo é, de tudo, eu só não ficava no caixa. Quem ficava no caixa, geralmente, ou era o gerente, quando precisava, ou alguém de, de confiança mais próximo ao gerente, se eu não me engano, eram duas só para fazer serviço de caixa.

D: E daí você tinha comentado, né, Marcos, que seu pai dizia que vocês tinham que não trabalhar até estudar mas que estudar era até o Ensino Médio. E como foi que você colocou essa, esse objetivo de entrar na Universidade? Como que foi que isso surgiu para você?

M: Então é... (silêncio) Uma boa pergunta. Não sei. Eu tinha isso como, um pouco, um objetivo. Já estava meio que, meio que claro assim: “Ah, o que você vai?” "Ah, eu vou ser isso, eu vou ser aquilo” mas geralmente eu pensava ensino, num ensino superior. Agora, como chegar lá ou como estruturar para isso a chance que eu ia ter ou não, eu não pensava tanto a respeito, mas mesmo na sétima série eu me lembro de comentar com outros amigos "Ah, o que que você vai fazer?" "Ah, eu quero fazer isso" e "Quero fazer psicologia”. Ou "Eu quero fazer aquilo". Mas eu tinha essa perspectiva de fazer uma faculdade. Mesmo meus irmãos tinham também, tinham essa perspectiva, mas na hora de efetivar isso é, aí mudou um pouco. Tive que me desdobrar, foi um, para mim, nossa foi um período muito difícil, sabe? Uns dois anos antes de entrar, aí, principalmente um ano antes de entrar aqui, no último ano, é, eu trabalhava durante a noite e eu fazia o bendito cursinho pela manhã, né, cansava muito, me desgastava e eu trabalhava no final de semana e nessa época terminei com a namorada, é, não tinha tempo para sair, minha vida social acabou e eu estava 
cansado, estava cansado, cansaço crônico. Já, tanto que é, era a última vez que eu estava tentando, sabe? Porque senão eu ia tentar me arranjar da forma que fosse, por ali mesmo, fazer uma faculdade por ter faculdade, não necessariamente ter grandes, grandes expectativas. Ter ensino superior para tentar um emprego melhor, depois tentar me virar. Tanto que quando eu passei aqui foi muito engraçado é... Eu não me senti feliz, me senti aliviado, minha sensação que eu tinha era de alívio, sabe? Foi muito, muito engraçado, eu achei que eu ia sei lá, ficar eufórico, eu, eu... "Ufa!” - a única coisa que eu senti foi descansado um pouco, sabe? Uma sensação de alívio muito grande mas, nossa, foi e... tanto que...

\section{D: Foi bem cansativo a trajetória até aqui?}

M: Muito cansativo, muito, muito, eu tive que me desdobrar muito, abrir mão de muita coisa, sabe? Tanto que quando eu cheguei aqui, quando eu vim para cá, eu vim meio às cegas, não sabia se tinha ou não assistência estudantil, tinha ouvido falar é, mas eu não sabia, é, como ia ser o curso efetivamente. Estava lá "integral”, mas eu não sabia se era um integral realmente integral, se tem aulas aos sábados, se tem janelas, não sabia como eram organizados os cursos, não sabia bem, bem as regras. Tanto que eu vim assim, é, eu vim meio que com um ânimo preparado para guerra: "Eu vou me virar!” Eu estava pensando: "Vou trabalhar como garçom, me virar, faço a faculdade”. Pensei: “Se eu entrei aqui desse jeito, vou sair daqui desse jeito”. Aí já fiz uns contatos, antes de vir para cá, com o pessoal da choperia do restaurante tal e...

\section{D: Você fala desse jeito é trabalhando?}

M: É isso, trabalhando como garçom, trabalhando à noite, tentando me sacrificar um pouquinho, acho que não seria nada medonho o que eu ia achar, achei, achei que eu não ia encontrar nada mais complicado, ou que não pudesse lidar, com toda dificuldade, sabe, ou coisa parecida, antes. Eu vim com um sentimento de que "Eu vou conseguir", sabe, aquela auto-suficiência de: "acho que não tem nada a temer aqui”, o pior já passou, vamos dizer assim. E quando eu cheguei aqui tinha toda uma assistência estudantil, toda uma forma de me virar, de me manter. Eu até acho que eu fiquei muito assim largado. Às vezes, até me pego "Nossa! Lutei tanto para ficar aqui ou me esforcei tanto", às vezes me pego tão displicente com o curso, tão displicente com a faculdade, com uma disciplina ou outra, vou levando assim meio que "eu sei que vou tirar nota” e tal então. Ầs vezes, me pergunto: “Nossa que discrepância?”. Estranho...

\section{D: E aqui como é que foi? Você chegou, primeiro teve que arrumar moradia?}

M: É, primeiro eu cheguei aqui já conheci já uma pessoa, que hoje mora inclusive no apartamento de cima. Perguntei como funcionava a moradia, aliás, é, no dia da matrícula eu já procurei saber, eu perguntei para algumas pessoas, como que era, como seria. E achei, achei engraçado, né, que eu cheguei, cheguei de moto-táxi, que eu vim da minha cidade. É cheguei na faculdade de moto táxi. E os veteranos sempre encarnavam nos calouros por qualquer detalhe que saltasse aos olhos ou fisionomia, ou um trejeito, aí eu fui, foi engraçado, que eu fui é: “calouro independente”. Isso marcou para caramba. Aí que, eu, não sabia, que todo mundo o pai e a mãe trouxe, aí eu fiquei me sentindo assim: "meu pai e minha mãe tinham que ter vindo?” 


\section{D: Não estava escrito no manual, né? (risadas)}

M: Não estava escrito no manual (risadas)! Fiquei tão assim, né...? Mas foi bem tranqüilo. E aí, aí que eu fui na hora do almoço, cheguei, estava na hora do almoço, não sei lá quando e o pessoal perguntava: "Você já trabalha, né?” Eu falava assim: “Trabalho. Como é que você sabe??” “Ah, tem cara!” Aí, sei lá, achei que tinha um perfil diferente, né, nesse sentido.

\section{D: Quem te perguntou isso?}

M: Um dos veteranos, acho que está no $5^{\circ}$ ano ou já se formou. E aí chegando aqui é, encontrei alguém no meio do caminho estava vindo para cá, estava na Filô, estava vindo para moradia, aí me indicaram onde que era e perguntei onde era, e conversei com o cara, ele disse "olha a gente costuma pegar, é, calouro no começo do ano para ficar como excedente, né? É, se você quiser você fica lá, você procura fulano de tal, fala que conversou comigo e você pode ficar no meu quarto”. Foi tudo muito assim. "Meu Deus!” Tava esperando assim coisa dificílima! E aí cheguei, procurei contato aqui e já fiquei, aí eu já voltei na semana seguinte meio com as minhas coisas. Porque os calouros tavam marcados para vim na, a gente é, a gente deveria vir no domingo e eu cheguei na quinta. Eu já me alojei e fiquei. Aí o primeiro ano, é, eu me mantive com dinheiro meu, seja das economias que eu tinha, seja uma rescisão contratual do bar onde eu trabalhava, do restaurante onde eu trabalhava tinha sido meu último emprego. Aí, a partir do segundo ano meu pai começou a dar uma ajuda e aí eu consegui uma bolsa de iniciação e venho me mantendo assim.

\section{$(\ldots)$}

(silêncio)

D: E a tua família, como que é visto? Ou foi visto você ter entrado na Universidade?

M: Acho que foi uma coisa bem positiva, o pessoal achou legal, bacana ter um filho e um irmão na USP. Falei que ia fazer uma propaganda para arrecadar renda "mantenha seu familiar na USP" (risadas): "Pra ter a honra de dizer que 'eu tenho um parente na USP' contribua com o fundo de...!” (risadas)

\section{D: Quer fazer uma arrecadação na própria família?}

M: Na família, lógico, tem que fazer lá dentro (risos). Mas é bem bacana, sabe? É, meu pai não entendia muito do que se tratava, sabe? Mas pelos outros dizerem para ele, sabe? Ele falava "meu filho tá na USP” e tal. Geralmente no início. Agora já acostumou, não é mais novidade. Meus irmãos achei bem bacana. Na época meu irmão começou a fazer cursinho, achei super bacana mas desanimou e desencanou. Começou a trabalhar e parou de estudar, e meu irmão, por eu ter prestado, passei, começou a estudar mais e acabou passando no concurso também, achei bacana no primeiro momento, acho que motivou também a querer e... Minha mãe ficou meio assim do filho sair de casa... Sou o filho mais velho, então sair de casa, nossa! Era para ela acho que assim... Ela não não cobrou nada não, só falou que chorou e tal... (silêncio) 
D: Você acha que para sua família é uma coisa positiva?

M: É bem positiva, é positiva sim. Vem e me perguntam como... Mas, um detalhe: nunca ninguém da família veio aqui. [fim da fita]

Mesmo meus irmãos e tal, acho que eles se interessariam mais, seria... Já chegaram a marcar, mas não deu certo. E espero que na formatura eles venham! (risadas)

D: Mas o que você acha? Por que não está ao alcance?

M: Então, não sei, algumas coisas, é a desculpa é: é longe, fica caro! Tem que fazer um stop na vida deles e vir para cá, fica todo mundo vítima. Meus irmãos estão trabalhando agora, minha irmãzinha, então, fica complicado, né. Difícil até é. Tem que ter tempo para; se mobilizar e vir mesmo; a minha família é muito assim, vamos dizer caseira, é muito caseira, eles não costumam sair muito de casa, é um custo visitar parentes mais distantes, que moram em outras cidades... [fala "enrolada"]

D: Você acha que os motivos financeiros não explicam isso?

M: Não, não porque hoje na minha casa, é, é a situação econômica é bem melhor de que quando eu comecei o curso, mesmo porque os meus dois irmãos estão trabalhando agora né, tem coisas que não justificariam.

\section{(...) [gravador desligado]}

D: Vou te perguntar assim... Eu quero saber assim, na tua opinião a que você atribuiria tua, essa tua trajetória que você me contou?

M: Eu acho que... Uma boa dose de sorte e de empenho pessoal, acho que... Não sei!

D: Sorte em relação a que?

M: Ah! Bom... sorte é todo resto vago que não depende de mim! (risadas) Mas é, é, eu não sei, é talvez um monte de coisa que eu, eu não consiga, é, pontuar agora, sabe talvez porque eu nem tenha consciência, porque eu fico pensando, pessoas que tiveram, é, situações parecidas com a minha, tipo colegas meus e mesmo meus irmãos, muitos e muitos amigos não estão aqui, sabe? E nem em lugar equivalente, né. Então, é, é, nisso coloco a minha, minha implicação pessoal nisso, mas, por exemplo, algumas coisas é, é, que minha mãe mesmo disse, né, que uma vez eu estava cobrando de um dos meus irmãos: “Ah, por que quê você não se move, por que não vai fazer faculdade e tal!" E ela falou assim: “Sabe, os seus amigos são totalmente diferentes dos amigos dele, os lugares que você freqüentava são totalmente diferentes dos lugares que ele freqüentava, então são coisas diferentes”. Depois eu parei para pensar, realmente meus amigos, é, eram, geralmente, eram mais velhos do que eu, teve uma época, que eu tenho formação católica, que eu participava do grupo de jovens, né, e muitos dos meus amigos vieram de lá e geralmente eram pessoas um pouco mais velhas do que eu, dois, três, quatro anos, às vezes, ou um pouco mais e eram pessoas que na vida tavam ingressando na universidade, então eu sempre tinha essa notícia da universidade, da faculdade, do 
ensino superior, né, fui na formatura de alguns e, né, mesmo antes de terminar o colegial, então eu tinha esse mundo um pouco mais próximo de certa forma, né, isso também, eu acho que teve um pouco de peso. É, é, eu acho que... (pausa) tudo isso, talvez encontrar as pessoas certas nos momentos certos, quanto a amigos, os professores ou, sabe, eu não consigo pontuar muito, tem esse parecer meio amplo aí...

D: Chama tudo isso de... sorte!

M: Sorte! É coisa que eu não consigo definir nesse momento!!

D: Os amigos desse irmão que que você questionou, que sua mãe disse que vocês são diferentes. Quem eram os amigos dele?

M: Geralmente pessoas que estudavam com ele, mesma faixa etária ou pessoal da rua que a gente morava, que eram pessoas que ele brincava, com quem ele saía por aí, que eram um outro perfil, era o pessoal do bairro...

D: E você não tinha amigos, assim, da vizinhança?

M: Tinha, tinha, mas bem menos! Durante minha adolescência, principalmente a maioria dos meus amigos estava nesse círculo de grupo de jovens, né? Eram as pessoas com quem eu estava junto mais tempo. Pelo menos semanalmente. Uma vez na semana, nos encontros que eles promoviam eu estava lá e isso expandia para o resto da semana, né? A gente marcava uma coisa ou outra, saía, nesse sentido. Os contatos, as redes de relação, saíram daí... Aí acabei me envolvendo lá, teve uma época que eu cheguei a participar da catequese, ser catequista, então aí, vai lá, tem um curso de formação, aí você vai participar, aí você acaba tendo contato com outro universo, que é um universo adulto, né, um universo mais, mais... as dificuldades, é um pouco diferente, te cobram coisas diferentes, um outro tipo de responsabilidade e dificuldades, inclusive, para com outras pessoas, então aos pouquinhos eu fui me articulando nesse meio.

D: E seus irmãos não circulavam por esses espaços?

M: Não, não. E foi uma coisa bem marcante para mim. Porque eu comecei a fazer teatro nesse espaço e que eu ainda faço teatro hoje pela faculdade, mas foi aí que eu comecei, foi aí que eu tive vários, é, foi um espaço que me proporcionou vários outros espaços, sabe, mesmo música, aprender a gostar de música, daquela música ou estar mais próximo de pessoas, de uma realidade diferente. Então, dá uma visão acho mais ampla das coisas.

\section{D: Diferente como assim?}

M: Diferente no sentido de você ver outras perspectivas, de outras pessoas, seja aquele que está fazendo a faculdade, já mais velho do que você, seja aquele mais novo do que você, que não passou por um monte de coisas pelas quais você já passou você, sabe, que tem desenvolvimento a partir daí, seja pessoas com o poder 
aquisitivo mais alto que o teu, seja pessoas com o poder aquisitivo bem mais baixo que o teu. É isso, toda essa gama.

D: Teve uma importância grande na tua história aí a participação no grupo de jovens?

M: Teve, teve sim, é isso, acho que foi formação pessoal, né? Metas assim! Muitas é, muitas dessas pessoas hoje estão, é, em lugares vamos dizer assim sociais, ah, não sei, melhores no sentido de com nível superior, emprego estável, ou sabe uma garantia maior, garantia maior de emprego, de...

D: Essas pessoas do grupo que você conviveu estão melhores do que elas estavam antes?

M: Melhores do que elas estavam antes e melhores do que pessoas com quem eu convivi, por exemplo, no cursinho ou na escola... né? De repente, tinha um pouco, esse, é, esse... falando agora que eu estou pensando está um pouco confuso que eu já falo e estou...

D: Não, é que você está pensando e está falando!

M: Estou elaborando aqui é!

D: Talvez você não tenha pensado nessas coisas, né, e eu vim aqui te dar trabalho!

M: (risadas) Pô, mas estão limpando a casa! (risadas) Mas é de, de ter metas, de procurar coisas de... Eu, eu me sinto muito mais, é, é, me identifico muito mais nesse sentido com essas pessoas do que com as pessoas com quem eu estudei, por exemplo, no Ensino Médio ou mais no fundamental principalmente, também no Ensino Médio, no cursinho não. (pausa) Mas, de procurar coisas, de tentar, mesmo fundamento intelectual, isso eram coisas valorizadas naquele grupo. A questão do estudo numa forma mais, mais ampla talvez, eu fiz essa ponte agora, não sei se é bem isso...

D: E esse grupo que você participava era da Igreja?

M: Comunidade era, era um grupo ali que tinha 25 anos de formação, era, é um grupo super bem citado e tinha "n" atividades. E estava muito ligado com a área social, foi uma coisa que deu para curtir bastante, então tinha lá as atribuições paroquiais da gente, né, enquanto grupo, então toda, toda formação católica condizente, mas tinha toda uma área de prática também que era estar ali tentando de alguma forma, mesmo que fosse uma forma - hoje eu vejo - assistencialista: uma campanha disso, uma campanha daquilo, mas todo mundo se mobilizava, faziam você se mobilizar para alguma coisa, muito área cultural, área artística, sempre tinha, sempre uma amostra que estava ali tentando promover, uma amostra disso, uma amostra daquilo, é teatro, tinha um teatro que era, que era da semana santa, né, as respectivas comemorações que era um público bem grande, que a gente apresentava 
ao ar livre, inclusive aí entrava a Prefeitura Municipal, entrava a fundação cultural da cidade, a gente conseguia verba, conseguia doação, uma coisa praticamente grande, os jovens da comunidade tal. Mas sempre se articulava nesse sentido, né, sempre tentando melhorar, sempre tentando organizar melhor as coisas. Isso era muito empenho, era muita dedicação...

D: E você falou que, pensa nos seus irmãos, que vocês tiveram uma vida bastante parecida ou mesmo colegas, né, aqueles que estudaram junto e que não estão numa posição, não estão aqui, nem numa posição equivalente. Tem, você se lembra, você conhece colegas que estudaram com você e que estão nas universidades?

M: Sim! Alguns, não a maioria, agora eu não sei, é, é, nem que seja na, na particular, universidade, que para mim, já é uma questão de poder aquisitivo que capacidade pessoal de cada um, porque é relativamente tranqüilo entrar no vestibular lá né? Mais complicado é você se manter né? Pelo custo da, da mensalidade, mas tem, tem alguns amigos meus que estão na pública.

\section{D: Que estudaram com você no Ensino Médio?}

M: Estudaram comigo no Ensino Médio e alguns que não estudaram comigo, mas que fizeram mais ou menos o mesmo percurso que eu fiz com alguns inclusive desse grupo, outros não! Mais ou menos isso. (pausa)

D: Tem alguma coisa que você se lembra aí, agora que você está retomando, porque a gente vai mexendo e a memória vai ativando.

M: Vai, vai! Não, tem, tem um monte coisas, mas não sei o que seria interessante para você, sabe? Várias, várias combinações aqui, vários flashizinhos, mas não sei que quê...

D: É, da tua história o que você se lembrar me interessa da tua trajetória, aí da história escolar, principalmente, ou não diretamente voltado à escola, mas que você fez uma relação...

\section{(silêncio)}

M: Não sei, é, eu fico, é que, às vezes, eu fico, eu fico me cobrando, né, me cobrando, acho que não contei isso antes, de ter entrado tão mais velho na faculdade, entrei com 23 anos, seria a idade para mim estar saindo dela teoricamente falando, uma agregação de quatro, cinco anos enquanto tinha 17, 18. Eu, às vezes, eu fico me perguntando: "Nossa! Mas que, o que faltou né?" "Foi só a questão econômica, né?" Eu acho que não, foi um pouco a questão... a, eu chamaria de objetividade - saber o que eu quero, quando eu quero e como fazer principalmente. Eu pensei nisso agora, que, é, eu queria fazer a faculdade mas eu não sabia o que era vestibular, sabia vagamente, senso comum, que ia prestar, que existia essas faculdades, existia uma USP, existia uma UFMG, existia UNESP. Mas como fazer? Como estar lá? Como? E se, e se eu queria mesmo esse curso ou outro curso. Então eu acabei, eu percebo que acabei é, eu posso dizer, enrolando, mas no sentido de postergando, postergando até, até o limite. Postergando não sei exatamente, por não ter muita certeza que era aquilo 
que eu queria, postergando por eu achar que de repente era um passo muito grande, né, postergando por eu não me achar preparado, por eu achar que não tenho formação para aquilo. Em diversos momentos eu achei "Eu não vou passar! Que eu tô...? Na verdade, tô perdendo meu tempo aqui!" "Os cursinhos tão, tão me sacaneando." Como um dia vários amigos falaram: "Marcos desencana, presta uma particular e depois se vira!”. E eu fiz outra escolha, né! E aí eu estava, tava achando que estava apostando muito, num lugar que acho que não, não poderia... Estava sonhando um pouquinho alto! (pausa) Tem um amigo meu que ele, que ele fez Engenharia Elétrica na USP de São Carlos e tem uma história um pouco parecida e tal. Só que ele conseguiu fazer, conseguiu uma bolsa para fazer o Ensino Médio num colégio lá de U. [cidade natal] que... muito bom. E, e ele entrou, um cara extremamente aplicado, mais que eu (risadas) e entrou logo no começo. E era um cara que sempre me dava força, apesar dos pesares, apesar das falas, eram desencontros que, que eu te falei, ele falava assim: "Cara! Faculdade pública é para pobre e quem pode pagar que pague, tem alguém lá, é, tem uma vaga lá para você, tem alguém lá na tua vaga, então vai pegar ela!” Nesse sentido, a forma como ele falava, é a implicação que ele colocava naquilo me motivava muito. Só que eu tinha a impressão de que eu estava nadando contra a correnteza, porque: “Ah, nossa, meu concorrente está dormindo melhor do que eu, está comendo melhor do que eu, está estudando melhor do que eu, sabe como estudar”. E eu tentando me debater, tentando chegar sei lá aonde, sabe? Então eu acho que me, me confundi um pouco nesse sentido tentando conseguir entrar...! Não era uma coisa clara para mim, nem a possibilidade de estar aqui, nem a oportunidade de estar aqui, era, saber se era possível ou não, se estava fantasiando ou não, se estava sendo... um pouco isso assim... (fala “enrolado"/ difícil compreensão) (silêncio)

\section{D: Mas você continuou ouvindo seu amigo?}

M: Continuei ouvindo (risadas). Tô aqui, eu já falei na cabeça de vários outros amigos que existe a possibilidade $d e$. Tem que se mobilizar e ir atrás né!

(pausa)

É que é engraçado, antes o discurso de... “Nossa!” quando alguém dizia para mim: "Nossa entrar na USP é tão difícil! Você está lá, você está, nossa nem me imagino lá!” No primeiro momento isso me fez muito bem. Porque de alguma forma era um reconhecimento por um esforço que eu tinha tido! Hoje, às vezes, isso me faz mal, porque é, é o outro se colocando numa posição incapaz, sabe? De, não dá para ser “Nossa você teve que estudar muito, hein, para ir lá!” . “Tive! É só estudar, é só, sei lá ter um pouco de perseverança e, é afundar a cara lá e mandar ver!”. Então, tinha muito isso, esse discurso. Agora, esse final de semana, tive oportunidade de ir para casa de um amigo meu, que mora aqui em P.[cidade onde se localiza o campus]. E, e ele tem alguns amigos que ainda não entraram, tem alguns parentes que estão querendo entrar na faculdade né? Então tem todo esse discurso, né, que é uma coisa um pouco distante. "Nossa a USP! Nossa!” O que, que é primeiro né: "Como que é? Você paga?”(risadas). E até você criar essa perspectiva do “Que, que é, que que é esse universo?” E de que ele pode ser acessível, aí vai, vai muita saliva. Pessoal não tem muita, muita idéia. Eu fico brincando: "Aí, tô desencanado porque moro em Minas, né, pago imposto lá, tô usufruindo do imposto dos paulistas!” (risadas) Mas, eu fico pensando né: “Quanta gente, né, que paga lá seu impostozinho, está 
financiando a USP e não faz idéia do que quê ela é, né, não faz idéia de que ele ou alguém que ele conhece de repente pode tentar." Tentar viu? Eu acho muito complicado estar aqui dentro e cada vez mais!

\section{D: Como assim?}

M: A questão da concorrência, questão do, da universidade ter se tornado elitista. Mesmo com esse esforço, você vê de repente, esses cursos novos que a gente estava comentando antes. Parece estar bem aqui, e, não sei, pareceu uma perspectiva de acesso eu acho que é, não sei como fica a perspectiva de emprego. Você pega uma, uma USP Leste. Fui em São Paulo num congresso que teve de estudantes da USP, estávamos discutindo isso. Os cursos que abrem aqui e que abrem lá, não é, não é questão do curso ser ruim ou não, tem que estar estruturado para fazer o que ele se propõe, mas são áreas que são especializações, para ser serem desenvolvidas no nível técnico, não precisa ser uma, uma universidade, criar esse título. Cria esse título e, não sei, não sei não, vejo mesmo a psicologia. O nível de corte cada vez sobe mais. Que, que acontece? Somos elitistas, porque o tipo de competição que o vestibular coloca é uma coisa muito desleal, porque, é, exige um preparo que eu acho, só com algumas exceções, tem quem pode investir, financeiramente mesmo, financeiramente e, não sei, e pessoalmente também, porque tem um tempo, quem trabalha não pode dedicar tanto, quem tem, porque depois, é, como é que é, que meu amigo me disse: "Paga-se antes para não precisar pagar depois”. Você paga sua mensalidade da USP anteriormente, lá pela sua quarta ou quinta série quando começa a se preparar lá já pro vestibular, um bom colégio. É tudo uma máquina para isso né! Você vai gastar com seu inglês, você vai gastar com seu curso particular, para depois entrar numa faculdade que tem status e realmente tem uma, que te possibilite uma boa formação, né, mas não está pagando mensalidade, um pouco tranqüilo. E não sei, o curso você falou que: “ah, o curso psico talvez não seja tão elitista” [refere-se a conversa anterior à entrevista em que eu me referia ao perfil sócio-econômico do curso de psicologia em relação aos demais cursos selecionados para minha pesquisa, como administração, por exemplo]. Eu acho que ele é elitista. Extremamente elitista. É, os calouros que entraram sem ser esse, no anterior, ano passado, 2004, que está lá no jornalzinho da USP - é a maior renda per capta da, da faculdade. São mesmo a maior renda per capta. E mesmo a minha sala, sabe, é, tem pouquíssimas pessoas que moram aqui no CREU. Da época em que eu entrei, mesmo porque quando eu entrei no CREU era bem mais tranqüilo né, basicamente quase todo mundo que se inscrevia conseguia vaga, no início, agora não, de 2004 e 2005 ninguém conseguiu, e mesmo antes de 2004 e 2005 são dois da minha turma do quarto ano e dois do quinto ano, se eu não me engano. Se eu não me engano tinha uma menina acho que do terceiro ano, uma menina só. Mas, é difícil se for ver o percentual dos cursos, é, no ano passado eu fui é RD [representante discente] na comissão aqui da moradia, que faz a seleção. Então eu tive acesso a alguns dados, majoritariamente quem ocupa as vagas do CREU é a Enfermagem, depois vem a Filosofia, a Filô com todos os cursos dela, e depois por último a Odonto, mas mesmo dentro desse leque se você for comparar, né, fazendo uma analogia aí, é muito baixa a porcentagem de alunos do curso de psicologia.

D: E como é que você vive isso lá no curso? A convivência com os colegas... 
M: Num primeiro momento, Débora, no primeiro ano foi complicadíssimo eu tive que redefinir um monte de coisas, muito difícil, desde que... Bom, deixa eu contar um pouquinho, então, da, do momento em que eu passei no vestibular e eu ainda estava trabalhando lá em U. como garçom de cabeça raspada, tal, antes disso, é, uma coisa que me pegava muito é ver, tipo, as pessoas gastando numa mesa de bar o que eu ganhava no mês. Isso em uma noite, isso para mim era assim: "O que tá acontecendo? Tem alguma coisa errada!” (risadas) E também, é algumas pessoas que eu sabia que estavam fazendo faculdade ou porque eu conhecia ou porque amigos meus conheciam que tinham condições de pagar uma faculdade, eu achava extremamente injusto eu não fazer uma faculdade, querendo fazer uma faculdade porque... É, e foi muito engraçado, ah um dia que eu estava trabalhando, né, são dois eventos muitos marcantes para mim. Um foi a copeira comentou com alguém porque sai junto o resultado da FUVEST com o vestibular local lá, dois vestibulares locais; então tinha um pessoal dando trote tal e eu estava trabalhando e aí uma das copeiras com um jeito muito, muito simples que era o dela virou e falou para um rapaz: “Ah! Você passou?” “Ah, passei." "Passou em que? Passei nisso e nisso.” "Ah, que legal! O Marcos garçom daqui também passou, passou lá na USP acho que é FUVEST, né?” Aí ele achou muito engraçado e riu dela, porque ele tinha certeza que ela estava enganada, porque como que o garçom do bar ia passar na FUVEST, né? E ela ficou toda desconcertada a ponto dela chegar para mim, achando que ela estava errada. (risadas) E eu achei bem bacana. E uma outra situação de um pessoal que eu sempre atendia e aí eu saí para fazer o pedido deles e a gerente estava me dando os parabéns, e aí um dos rapazes que estava na mesa, né, que eu estava atendendo, que eu sempre atendia, ele ouviu a conversa né e disse: "Ah! Você passou! Parabéns, né, passou na USP, nossa! Que legal!” Aí eu voltei para mesa para levar o pedido e ele falou pro resto do pessoal: "Ah! O Marcos passou no vestibular em psicologia!” Aí um dos caras: “Ah! Parabéns”. E ele: "Na USP!” Aí o cara ficou em pé, estendeu a mão: “Meus parabéns!” Enfim, né, bem bacana. Naquele momento pelo menos fez muito sentido para mim...

\section{D: Era algo assim absolutamente inesperado, é isso?}

M: É, bem inesperado, é. O garçom, o humilde, (?) está fazendo, ter passado na USP. O pessoal já me olhava assim, quando eu dizia que ia prestar FUVEST, né.

\section{D: Olhava como?}

M: Tipo, é, vôo de pára-quedista, né. A gente chamava de pára-quedista, a gente falava no cursinho que, é, você concorria com $60 \%$ dos inscritos, os outros $40 \%$ eram pára-quedistas, ah, ah, não sabiam aonde estavam caindo, neste sentido...

D: Você lembrou, você estava falando do curso, quando você chegou aqui, da convivência.

M: Ah, tá, ok. Era muito complicado para mim, é, num primeiro momento estar estudando com um pessoal que eu servia no bar. Foi muito engraçado, no primeiro dia de bar da Filô [Faculdade de Filosofia] teve uma mega festa, né, a calourada, estava todo mundo lá e esse último ano tinha sido muito cansativo para mim, muito estressante, eu praticamente não tive vida social, tudo o que eu queria naquele 
momento, Débora, era uma bandeja na mão, para mim saber o que fazer! (risadas) Na festa e eu percebi como eu estava, sei lá, um pouco deslocado, como eu não estava ainda, não sei exatamente te dizer, dentro daquele universo ainda, ainda não era o meu, eu queria a bandeja e, e eu via um amigo meu, hoje amigo meu, né, muito amigo meu, reclamando, indignado, porque estava sem telefone para ligar Internet, sendo que a minha preocupação naquele momento era: "O que eu vou comer? Como é que eu vou me manter aqui?” Sabe, eu achava, assim, era muito diferente, o pessoal me chamar para sair e eu estar pensando: “Onde é que eles vão? Será que eu tenho essa grana para gastar ou não?” Foi muito assim... Eu tinha um discurso... que acho que em certo momento me ajudou muito, a dar um gás de estar aqui, mas depois quando eu entrei me atrapalhou bastante, um discurso meio, meio do proletário injustiçado, sabe, de essa vaga é minha, ah, não tinha que ter vaga nem para negro nem para pobre, tinha que ter cota para rico, na verdade. A discussão tinha que ser nesse nível, cota para rico, a universidade pública, não para essas minorias, maiorias esmagadoras, né, e eu não conseguia muito lidar com isso, eu não conseguia muito lidar com as pessoas, acabava lidando com o que elas representavam para mim e até que consegui desvincular isso, é complicado.

\section{D: A relação com as pessoas da sua turma, por exemplo, foi difícil?}

M: Dificílima. Foi complicado eu me aproximar, deixar elas fazerem parte do meu mundo e eu fazer parte do mundo delas, criar esse, porque o que a gente tinha em comum basicamente era o curso, só. Era uma outra realidade. Isso passava coisas, bobagem hoje em dia, minúcias, lembro de uma vez que era aniversário de alguém e aí a mãe de uma era, era médica, a mãe de outra era psicóloga e alguém falou assim: "Ah! Eu vou pedir para minha mãe para dar de presente, para dar uma consulta para ela!” Tudo uma brincadeira, aí a outra falou: “Ah! eu vou dar...” - eu não me lembro exatamente o que era, era a posição dos pais, no sentido de que os pais dariam o presente, aí eu disse: "Puxa eu vou pedir pro meu pai vigiar alguma coisa?!" (risadas). Mas são coisinhas que vão te pegando, por bobagens assim. Desde da discussão sobre como vai ser o baile de formatura, um monte de coisas que eu acho bobagem, tipo, a decoração da mesa como é que vai ser, se vai ter violino na entrada ou não, são alguns detalhes que eu simplesmente abro mão, não é importante para mim, essa roupagem da festa não é importante para mim, ou se é importante, não tem tanto peso, algumas pessoas se pegam numas minúcias que para mim são tão, não fazem sentido. Mas eu sei que para elas faz. Sabe, então tinha bastante diferença. [fim da fita]

De comentar aonde foi, quem encontrou , quem conhece, você, às vezes, quer ficar calado, são lugares que você não conhece, lugares que você nunca foi, lugares que fogem da realidade universitária da gente, eu fico meio assim, meio perdidão.(pausa)

\section{D: É, você está na formatura?}

M: Tô, estou sim, eu quero estar, é importante para mim, simbolicamente, não sei, eu tenho muito de valorizar algumas coisas, algumas coisas simbólicas, sabe, alguns atos simbólicos, assim, para mim é importante a formatura, mesmo que eu ache, às vezes, banal, às vezes, nossa eu poderia estar aproveitando esse dinheiro de uma outra forma, mesmo a, a questão da, da solenidade em si, eu acho, às vezes, meio 
banal, meio bobo, mas é a única coisa que tem efetivamente para marcar, sabe, então eu quero estar ali, eu quero participar de tudo, eu quero que algumas pessoas participem disso comigo, sabe, pessoas que de alguma forma me incentivaram, me ajudaram.

D: Às vezes você fala de um jeito assim, eu pensava assim, eu via assim, né, você mudou a maneira como, é, você, vê, por exemplo, os colegas de turma?

M: Hum, hum. Bastante. Eu acho assim, é, acho que eu mudei muito, no decorrer do curso todo, para caramba, sabe, acho que eu fiquei um pouquinho - o famoso efeito vareta, né - a vareta vira de um lado, você solta ela tem que ir para o outro lado, para vertente contrária até parar no meio, né. Então acho que muita coisa eu não vejo mais como, como eu via antes, né, acho que, é, de uma forma geral isso é positivo, apesar de, às vezes, eu perder algumas coisas, que, às vezes eu tenho que buscar [estala os dedos], né: “Que nossa! Qual o sentido de eu estar aqui?”. Tipo, tudo o que estou te contando agora, isso tem um peso para mim, um peso muito grande, um pouco também me diz como eu sou, sabe, que, às vezes, fica tão maquinal, eu vou fazendo o curso, fazendo as coisas, inclusive não tenho perspectiva, não sei o que fazer. "Ah! O que você vai fazer quando se formar?" "Não sei muito bem." “Ah! Mas pelo menos que norte você tem?” “Ah! Não sei...” Se eu, se eu repasso isso, eu não sei, eu encontro alguma coisa aí, mesmo para mim continuar, não que seja uma coisa específica, não que isso que eu te disse agora me diz para fazer uma pós, você vai entrar no mercado de trabalho, isso eu não sei te explicar muito bem, mas dão uma consistência no meu curso, dão uma consistência à minha formação.

\section{D: Pensar sobre isso?}

\section{M: Pensar sobre isso.}

D: E a vara, a vara foi para onde? Porque no momento atual ela está no meio do caminho, mas ela estava onde antes?

M: É... onde ela estava? Acho eu queria participar um pouco desse outro mundo, sabe, de ir muito em balada, de, de não ser tão preocupado com as coisas, né, não ser, eu sempre tive muita estima do, do bom moço, o filho mais velho, o neto mais velho, o sobrinho mais velho, nã, nã, nã, nã, nã [fala rapidamente], mesmo de, de aluno comportado, mesmo de, e era uma coisa alguém pisar na bola, pisar no tomate, era outra coisa o Marcos pisar na bola ou no tomate. Então eu dei uma, uma aliviada nisso, vamos dizer assim... As minhas notas caíram, eu não me envolvia muito com o curso, fazia o que, ãh, não sei, o que me convinha, vamos dizer assim, o que eu gostava... e isso é que fica um pouco vazio, né, fica um pouco, meio sem sentido do porquê você está fazendo isso, mesmo que seja, nem que seja para você dizer: "eu tô fazendo para experimentar um pouco uma coisa diferente, experimentar um pouco do outro lado, para desencanar”, que já é um sentido, né. Mas quando você faz meio aleatoriamente, você está meio perdido na verdade e... é complicado, é isso.

D: Tem alguma coisa mais que você queira citar, que você lembrou enquanto você falava? 
M: Não acho que o mais marcante, acho que o mais, acho que o mais interessante, não sei, acho, são essas referências, é isso.

D: Obrigada!

\section{$2^{\text {a }}$ Entrevista}

D: Marcos você tinha falado um pouco no nosso outro encontro a que você atribui a sua trajetória e você tinha falado que era a uma boa dose de sorte e empenho pessoal. E nessa questão da sorte você tinha falado, você falou em alguns momentos de encontrar pessoas certas nos momentos certos, amigos, professores, e você já falou um pouco dos amigos, do grupo de jovens e dos professores também, de alguns professores que te marcaram, tinha aquela professora da $1^{\text {a }}$ série, que te marcou de um jeito negativo. Mas eu queria saber se você se lembra de alguém ou de algumas pessoas em especial, dessa coisa de você encontrar pessoas certas nos momentos certos?

M: Olha, eu acho que até cheguei a comentar na outra entrevista, uma pessoa que me deu muita perspectiva de hoje estar aqui dentro foi um amigo meu que ele fez Engenharia Elétrica na USP de São Carlos. Então, também foi um cara que ralou muito para estar lá: dificuldade financeira, e aí por sorte ele conseguiu uma bolsa porque a mãe dele trabalhava com professoras nas primeiras séries do Ensino Fundamental que conheciam alguém da Secretaria de Educação que conhecia alguém que era diretor de uma escola particular e ele conseguiu bolsa nessa escola. E, mas assim, ele era um cara que se empenhava muito e ele falava para mim: “Oh, dá para ir, oh acontece, tem como, o lugar é teu”. Então, nesse sentido de dar força, de dar uma perspectiva de "nossa, dá para chegar lá!”, muito por parte dele, principalmente num primeiro momento que eu não tinha muito noção, como eu já comentei, do que seria um vestibular, do que era entrar na faculdade, da concorrência que era, do processo como ele ocorria, de repente da falta de estrutura que eu não tinha e que eu não percebia que eu não tinha, nesse sentido. (pausa)

Mesmo quando eu comecei a fazer cursinho, as amizades que eu fazia no cursinho, as pessoas que eu encontrei lá, também tinham um projeto, tinham um projeto de vida (?) e isso era interessante, eu me identificava com isso, e aí a gente estudava junto, mesmo quando eu trabalhei no IBGE, tinha pessoas que estavam lá também que estavam fazendo cursinho também, então estava tudo junto um pouco, todo mundo, mesma faixa etária, mesma realidade, então muita gente, por exemplo, prestou o concurso pelo mesmo motivo que eu: procurando um emprego que desse uma renda legal, por um curto período de tempo, até poder se mobilizar para outras coisas. Então, tinha muita gente que fazia cursinho, várias pessoas. Então, você vai achando pontos de convergência, você não se sente solto na maré: "nossa, não, existe um caminho possível, dá para ir por aqui...”, algo assim. (pausa)

Em linhas gerais, acho que é isso. (pausa)

D: E, esse seu amigo, você conheceu onde? 
M: Eu conheci ele no judô, a gente fazia judô, no, se eu não me engano, no quartel da Polícia Militar, através de um outro amigo da escola, que tinha uns 11 ou 12 anos, a gente foi fazer judô e lá eu conheci ele e a gente ficou muito amigo, ele era um ou dois anos mais velho do que eu e a gente sempre se encontrava, saía, trocava umas idéias, teve um outro momento que ele também entrou para aquele grupo de jovens. Hoje eu até não tenho tanto contato mais com ele; ele se formou, fez o mestrado dele, está em Campinas, trabalhando numa empresa lá. A última vez que eu vi ele acho que faz uns seis meses ou mais talvez. Acho que é isso... (pausa) Tem, ah, tá! Tem o irmão dele, que também era uma pessoa bem próxima, que também ficou comigo nessa pendência, da gente prestar vestibular, de um dar apoio pro outro, e eu passei aqui e ele acabou passando em educação física na Federal de São Carlos, e, era alguém também que, não muitas vezes, mas a gente estudava junto de vez em quando, quando a gente se via ele ia mostrar o programa de estudo dele, mesmo um pouco de método eu peguei um pouco com ele, mas eu percebi que não funcionava muito o planejamento dele, não (rindo)! Era mais planejamento mesmo, e faltava por em prática! (risadas) Mas, é isso, e hoje ele está lá, um pouco isso...

D: E de professores? Você falou de amigos, e de professores? Você já tinha falado de alguns...

M: Bom, professores acho que eu comentei um pouquinho de alguns professores do Ensino Fundamental, é, no Ensino Médio, eu gostava muito dos meus professores, de determinadas áreas que eu já gostava (rindo), eu tinha uma afinidade maior. Mas eu me lembro muito de uma professora no cursinho, porque eu acabei fazendo, acho que uns três anos de cursinho, eu brinco que a gente estava ficando sócio deles lá (rindo). E ela era professora de português e redação, e era assim uma professora muito próxima dos alunos, figura humana assim muito legal. E, ela tinha o mesmo sobrenome que eu e talvez isso chamou um pouco a atenção dela, perguntou de onde eu era, do parentesco, mas a gente não achou nada muito em comum, não! (rindo) Mas, assim, é, sempre muito atenciosa, sempre me ajudou: “Ah, Marcos você tem que ver onde está pegando. Você é muito bom nisso e nisso, você tem facilidade nisso, você talvez está falhando nisso e nisso, você escreve bem, mas, olha, você está com dificuldade de expressar isso e isso.” Então esse feedback fez diferença no cursinho, porque é uma coisa meio maquinal o cursinho, meio frio: "vamos nos preparar para o combate!”, processo fabril, vai passando as matérias e você vai pegando o que você consegue de cada uma! (rindo) Mas, eu acho que é isso... (pausa)

Tem também uma professora de história no meu segundo grau, no Ensino Médio, que daí me encontrei com ela, depois, um ou dois anos que eu tinha concluído e ela estava ajudando a organizar um curso de redação e ela assim: "mas, eu não entendo, como assim você ainda não passou?!”. "Por que? Eu devia ter passado?” E ela falou: “É lógico!”. Que eu tinha capacidade para isso, que eu era bom aluno. "Puts, ó, legal!”. Fiquei me sentindo bem, numa fase ruim, porque quando você não passa recorridas vezes, tua auto-estima cai muito, daí isso já deu um up para mim, né. Mais nesse sentido... (pausa)

É, geralmente, o que me chamava muito atenção nos professores não era nem tanto a capacidade que ele tinha didática, para passar as coisas, mas era mais assim o empenho que ele tinha. Como eu já comentei, até hoje, na faculdade, quando o professor não leva a sério a disciplina, eu não consigo levar a sério nem ele, nem a 
disciplina. Tive uma professora de geografia que sempre estava trazendo coisa nova e à medida que trazia coisa nova eu também trazia, e ela valorizava isso, levava para sala de alguma forma, e, aí, era legal porque aí eu me sentia tendo que dar um feedback, eu senti um investimento em mim: "Pô, legal, vamos dar retorno!” É... e, aí, foi um pouco ruim, não sei, estou pensando agora, não sei, quando eu saí do Ensino Médio, desse nível de relação, fui cair de repente, no cursinho, nesse modelo mais impessoal e trabalhando também. E, aí, nossa! Eu percebi que muito do que eu gostava, do que eu fazia, do que eu achava que era potencialidade minha, não fazia diferença, tanto para mim trabalhar como garçom à noite ou no cursinho. Eu sempre gostei muito de teatro, sempre gostei muito de escrever, sempre gostei, fazia diferença, às vezes, um pouquinho na redação..., mas eu me senti um pouco perdido: "nossa! Tudo o que eu já fiz na minha vida! Nossa! Tudo o que eu tentei fazer...”. Mesmo a... Não sei... é... não fazia sentido para esse mundo do mercado de trabalho e mesmo de cursinho pré-vestibular e o que eu tinha que saber não era o que eu sabia, era uma outra coisa. Ou aprender de uma forma muito assim, ou saber vender, ou saber pegar uma matéria e devolver de uma certa maneira. E, nossa! Isso foi muito ruim para mim! No último ano, antes de eu entrar na faculdade, em 2001, foi um ano pesadíssimo, pesadíssimo para mim! Um desagaste emocional, mesmo físico que, acho que eu já cheguei a comentar, quando eu passei eu não me senti nem feliz, eu me senti aliviado! (riso) E foi muito bacana que quando eu entrei aqui, de novo, deu para resgatar tudo aquilo! Muito da minha formação, muito do que eu era, aqui tinha um respaldo, fazia diferença, então, tanto que, a M. [orientadora de iniciação científica] me convidou para ir no grupo de pesquisa dela porque ela percebeu que eu gostava de ler, eu sabia alguma coisa de filosofia, tinha uma base de história muito legal e gostava de falar sobre isso e fazia questão de me relacionar com as pessoas, e, de por um sentido naquilo que eu estava fazendo. Que, pro cursinho, não é isso! (rindo) Não é isso que eles querem num vestibular! Não é isso que eles querem numa prova! E, nossa, me senti muito valorizado nesse sentido! Mesmo com outras disciplinas de outras áreas, voltei a fazer teatro aqui, tem o Pândegos lá da Filô [evento artístico anual organizado pelos alunos], a primeira vez que eu apresentei, nossa, foi muito legal! É... mesmo questão de movimento estudantil, eu fui representante discente daqui da moradia uns anos anteriores aí, na comissão de moradia. Então, tudo isso meu não caiu num vazio, tudo foi aproveitado! Mesmo dentro do meu curso, não sei, eu acho que, isso de uma perspectiva minha, eu acho que para fazer psicologia você tem que ter uma certa abertura pro outro, e eu acho que um pouco a minha formação, seja pela questão do teatro, seja por se relacionar com outras pessoas, professores, alunos, seja pela questão da minha formação religiosa, não sei, acho que proporcionava isso um pouco, e eu sentia que aqui eu tinha eco, então, eu achei bacana... Não sei se eu me perdi um pouco nas idéias... (risos)

D: Não, você se deixou levar pelas idéias. Sobre os professores, Marcos, você falou um pouco de novo, e no nosso outro encontro você tinha comentado que você se dedicava às matérias cujos professores você também percebia que eram dedicados. $\mathrm{E}$ na universidade você percebia que também era assim, embora você achasse que não devesse ser. E eu queria te perguntar: por que você acha que não deveria ser assim?

M: Porque eu acho que você está num momento de formação e mesmo que o professor não esteja a fim de ensinar, é um espaço que está aberto para isso, é um 
espaço para o ensino-aprendizagem, acho que se ele não valoriza isso, acho que é um pouco responsabilidade tua valorizar isso, então não sei, eu valorizo muito o fato de estar numa universidade pública, tá, eu não sou $\boldsymbol{o}$ ativista, $\boldsymbol{o}$ militante, mas eu sei o que significa uma USP dentro da perspectiva de Brasil, quantos podem estar aqui: quantos amigos meus lá fora não estão aqui? Eu estou sendo sustentado por esta universidade, quem paga a luz que a gente está usando agora, quem paga o espaço que a gente está ocupando agora, a comida do bandejão, então mesmo que eu não tenha aquele discurso de "nossa! Vou me formar e vou para a sociedade fazer mudanças estruturais!”, eu não sei, eu sou um pouco descrente disso, mas eu estando aqui eu sei que eu tenho a necessidade de dar esse feedback também, não estou aqui por acaso, eu sei o peso que isso tem, então se o professor não quer dar aula, de duas, uma: ou eu quero ter aula e, dentro do possível, eu me esforço para isso, ou eu brigo pro F.D.P. dar aula! E cobro dele! Teve um caso que semestre passado foi complicado, que a professora, professora já bem antiga da faculdade, e ela tem cargo administrativo, quer dizer ela tem uma certa influência aqui, mas a impressão que eu tenho é que ela relega a graduação para segundo plano, algo que ela tem que fazer para se manter na faculdade, ela não estrutura a aula, ela fala muito da experiência dela! O que é bacana, que dá para aproveitar também, só que é uma coisa tão solta, tão jogada, que você não consegue fazer sentido para você, faz sentido para ela, aí você tenta ver do que faz sentido para ela o que faz sentido para você, mas aí você tem que fazer todo esse percurso e eu acho que isso não é função tua como aluno, isso é função do professor como educador: "eu tô aqui, eu tô ouvindo, então me fala! Porque eu não vou fazer esse caminho todo, esse percurso todo! Porque eu não tenho esse aparato para chegar aí onde você está, não nesse momento, não na sua experiência!” E, aí, as aulas eram todas muito repetitivas, dentro do mesmo tema, o que ela dava não se propunha a, não encaixava muito na própria proposta da disciplina, a disciplina tinha um nome, tinha uma indicação no Júpiter [sistema informatizado da graduação] e o que ela dava em aula não correspondia, ela deu uma avaliação que no final alguém teve a coragem de perguntar: "mas o que isso tem a ver com a disciplina? E por que quê você tá querendo que a gente faça isso?”. Até chegar ao ponto de ela dizer: "Ah, eu queria que vocês conhecessem mais a família de vocês”, porque ela trabalha com resgate da história da família... Então, aí o pessoal ficou meio assim: "ah, eu quero conhecer minha família num almoço de domingo, aí sento com a minha bisavó: ‘e, aí, vó, como que foi...?’” Tanto que eu inventei a minha entrevista, fiz questão de pegar um monte de texto de um outro professor, de uma disciplina da qual eu gostei e subsidiei todo o trabalho (risos)! Inventei assim: o que eu me lembrava da história da minha família eu coloquei ali, mas as lacunas eu preenchi todas! (risos) Opiniões, foi muito de senso-comum, que eu fiquei pensando: “o que quê a minha mãe falaria aqui?”, fiz assim, né. E coloquei coisas de outra matéria que era "Análise social da família”. E tinha outro texto que era a análise de um filme: baixei da Internet, sabe, copiei e colei, sabe? Não tive nem o trabalho de colocar em primeira pessoa, colei, deu duas páginas. Tinha gente fazendo trabalho de 20 páginas, teve um cara que fez o trabalho da família dele deu 47 páginas, meu trabalho total deu seis páginas de um e duas páginas do outro. Pensei: recuperação na certa! Fechei com 8! Que quê eu podia fazer? Rir. Como é que eu levo a sério uma disciplina dessas, um professor desse?? Eu não consigo!! (rindo) Eu só consigo rir e..., às vezes, sentir pena porque, sinceramente, é alguém que vai sair da faculdade, muito do que construiu, ela construiu para ela, quando ela sair, e está para sair, quando ela sair, tudo o que ela fez, vão destruir, vão refazer 
tudo em cima, quer dizer, não fica nada, não fica nem a recordação do professor que fez aquilo. Porque eu estou te falando aqui de professor do Ensino Fundamental com quem eu me relacionei há 10 anos, 15 anos atrás, né, professora do primário, quase 20 anos atrás (rindo)! Quer dizer professores que de alguma forma acabam te acompanhando, que marcam de uma maneira positiva, mesmo colocando a crítica aí. Mas, não sei, fico pensando, é um profissional que eu não quero, sabe, é um antiexemplo para mim, sabe? Dá para aprender com ela: como não se faz! Acho que é por aí...

D: Você disse que ou você deveria brigar ou se empenhar para aprender independente do professor. Você acha que você não faz isso?

M: Geralmente, eu faço. Geralmente, quando uma aula está muito chata, ou quando eu percebo que o palestrante não está falando a língua da sala, ou que o que ele está tocando não é interessante, eu faço uma pergunta que direcione para isso. Tanto é que a galera me considera o perguntador, tanto que professor já chegou a falar: "é sempre o Marcos que faz a primeira pergunta?” (ri) Porque me incomoda, me incomoda. A não ser, aconteceu, por exemplo, é, de um, de duas semanas anteriores, um professor trazer um palestrante, que é ex-aluna daqui, mesmo dele, e hoje é professora em uma universidade de Minas. E, nossa, estava uma sensação tão ruim na sala, ela gerou uma certa antipatia na sala, da forma dela se colocar, mesmo o que ela estava trazendo e gerou em mim também. E era um tema que me interessava, todo mundo sabia que me interessava, até um amigo meu me deu uma olhadinha, tipo: “você não vai falar nada?”. E eu fiz questão de ficar calado, eu falei: “não, eu não vou me manifestar!” Vocês que se virem aí. Eu sempre procuro um sentido, eu sempre procuro fazer minha aula valer a pena. E dá para achar! Engraçado que dá achar. Você faz um exercício assim: “do que quê essa coisa tem a ver comigo?”. "Por que quê colocaram isso aqui, por que quê eu tô aqui ouvindo isso?” Dá para achar! Alguma coisa você acha. Se não achar também, levanta e vai embora! Acho, não sei, chateação minha. A galera da sala, às vezes, tem uma galerinha no fundo que fica conversando, fica passando bilhetinho, sabe? Levanta e sai, pede para alguém assinar, sabe, não faz sentido, sabe, não se auto-justifica estar ali, me incomoda, e também fica me incomodando pelo outro, tipo: "nossa, cara, você tá perdendo pelo menos duas horas do seu dia aqui!”. Sabe, assim, eu não sou $\boldsymbol{o}$ estudioso, eu não sou o empenhado, mas, basicamente, esses momentos é onde eu me prendo, onde eu sou todo ouvidos, então, às vezes, eu consigo até uma impressão legal do professor, muito por esses momentos do que de um feedback que eu dou na prova. Porque eu também acho uma questão ética séria, eu tenho vontade de ser professor, eu tenho vontade de fazer uma pós e estar na academia, e eu me coloco na posição do cara, pô, o cara se preparou, ele tem uma bagagem, às vezes, ele não tem didática, não tem jogo de cintura, mas eu valorizo, se o cara fez, pô, eu acredito naquilo que ele fez e, às vezes, o pessoal é um pouco intolerante. Professor que é um pouco assim... o D., você chegou a ter aula com ele?

D: Sim.

M: O tom de voz dele é cansado, o jeito que ele explica, a forma como ele dá, ele não tem didática, ele não é uma pessoa dinâmica, mas o conteúdo que ele traz eu acho assim muito importante, mesmo sendo em PGE [Psicologia Geral e Experimental]. 
Quando ele fala em percepção, é que ele não consegue fazer os links com outras coisas, com outras disciplinas, com outras áreas, mas a questão da percepção se você fechar com a questão da filosofia, ou mesmo com uma coisa mais estrita, que o que a gente percebe é segundo o que a gente age, e o que a gente percebe não é necessariamente o real, não vamos dizer o que quê é real - não vamos entrar nesse mérito -, mas isso dá margem para $n$ coisas. Mas, pela própria dinâmica do professor, iam quatro pessoas na aula, cinco pessoas na aula, no final da aula, nas últimas aulas dele tinham quatro pessoas na sala, de 44, cadê as outras 40? Bom, nessas últimas de quatro, eu também não era uma das quatro! (risadas) Mas, antes, assim, dá para perceber que o cara tem empenho, mas o cara tem perfil de pesquisador, ele está na universidade para pesquisar! Mas, ele ainda tem esse lance de: “deixa eu passar o que eu pesquiso, deixa eu passar o que eu sei." E é do jeito dele, aí também você tem que fazer o..., não é tão fácil também entender, compreender também que não é má vontade, dentro da possibilidade dele é o que ele consegue fazer, é o que ele faz, o cara não se formou tanto para isso, ele não tem didática, ele é um pesquisador, e é um excelente pesquisador, é um cara que se interessa pela área dele. (pausa)

Mas, assim, é, voltando um pouco para sua pergunta, se esse empenho tem de partir de mim, se eu tenho ele. Eu tento ter. Eu peco muito, muito em outras áreas. Mesmo a pesquisa, a M. [orientadora] é uma mãe para mim! (rindo) Ela tem uma paciência de Jó, porque eu sou horrível com prazos, eu tenho que estar a fim de estudar, mesmo porque, de novo, a pesquisa dela é uma coisa que tem que se envolver, então se você está cansado, se você está desanimado, está com outra coisa na cabeça, está com problema, então é uma coisa meio, eu tenho que ter meus tempos e, às vezes, não dá para você ter esses tempos! O outro lado também de que dentro da universidade você não pode se dar esse luxo: eu gosto disso, eu gosto daquilo, tem um tempo, tem cronograma, tem um dado objetivo a ser atendido, você tem que saber aquilo, você tem que saber metodologia, se o professor é bom ou ruim, paciência, se o professor é bom ou não, se você gosta ou não, você tem que saber metodologia (rindo)! Então não tem muito dessa, do teu querer, teu querer é muito em função da realidade, muito em função das outras coisas, não é princípio do prazer, né, é princípio da realidade! (risos) Então, mais também nesse aspecto.

D: Marcos, você falou que naquela ocasião que um professor trouxe uma ex-aluna, você fez questão de ficar quieto. Por que você fez questão de ficar quieto?

M: Por que eu fiz questão? Ó, ah... (pausa)

\section{D: Porque você falou bem enfaticamente assim.}

M: É, é, foi uma coisa nesse sentido mesmo. Porque pegou geral na turma e eu senti que pegou em mim também da maneira como ela estava colocando, não sei se ela estava insegura, não sei se, a impressão que eu tive foi de uma arrogância e de uma agressividade muito grande com o pessoal da sala. Sabe: "Ah, vocês não sabem? Ah, vocês não estudaram isso?” Não entendi muito o que ela quis colocar. Ela estava falando sobre fenomenologia, é uma coisa que eu gosto, mas não é todo mundo que gosta, e é uma coisa que você não tem na faculdade. Então, eu acho que ela estava um pouco descontextualizada: um - a gente não tem uma formação clara dessa área, e a fenomenologia que interessa para gente é a fenomenologia aplicada à psicologia 
que é uma apropriação que a psicologia vai fazer da fenomenologia, que não fenomenologia em si, a fenomenologia ela parte da filosofia, ela é uma epistemologia, é um método, então, de novo, ela tinha que ter tentado transpor isso, fazer essa elaboração da experiência que, como eu disse, que a própria G. [professora citada anteriormente] não faz, entende? Fica você falando para você mesmo e cobrando que o outro te entenda! E eu particularmente gosto dessa parte de filosofia, então eu até estava entendendo o que ela estava falando, mas como ela estava cobrando de uma forma muito: "nossa, vocês não falam! Nossa vocês estão no quarto ano de psicologia e não estudaram isso?” Teve umas frases, mas nem é o conteúdo delas, é a maneira, o tom geral. Tanto é que tem intervalo na aula e tem duas chamadas, justamente, para manter o pessoal e o pessoal preferiu tomar falta do que continuar. E, acho que um pouco disso, porque talvez eu tenha sido enfático mesmo pela carga afetiva que me passou de rejeição, né, que foi do grupo.

D: Porque você comentou que você sempre pergunta, e esse era um tema que te interessava, então parece que você quis marcar uma posição.

M: É, quis marcar essa posição de, mesmo de protesto, talvez pessoal minha e para quem me conhece, sabe que eu gosto, eu estou assinalando: “ah, gente, foi mal, mas não gostei.” Não acho que seja isso, acho que fenomenologia é muito mais do que isso, acho que ela estava talvez até desprestigiando a área perante o pessoal. Porque já é uma coisa que o pessoal já não tem muito contato, se você começa a intelectualizar muito, se você solta frases do tipo: "ah, isso aqui é muito complexo, vocês não vão entender mesmo”, tipo, nossa! Já é uma área que tem tão pouco espaço aqui e você traz alguém que gera uma antipatia pelo próprio colocar, mas também pela área, porque quando o pessoal se lembrar não vai se lembrar dela, vai se lembrar dela falando de fenomenologia, então, tipo: "galera, tô assinalando, fenomenologia não é só isso, vai além!” Também para dar oportunidade da galera se interessar, ir atrás, eu acho uma opção legal também, porque, às vezes, a gente aqui se sente obrigado a ver outros cenários que não comportamental, e aquele comportamental de laboratório... [fim da fita]

A formação básica da gente acaba sendo muito psicodinâmica, psicodinâmica já entenda-se psicanálise, e isso é, é ruim, uma porque você não tem opção, e você acaba dogmatizando isso e acho que influencia muito a tua postura como psicólogo, porque se você fecha aquilo, se você dogmatiza aquilo, né, eu acho que você fica um profissional limitado.

D: Marcos, aproveitando que você está falando da psicologia, eu queria saber, porque no teu primeiro vestibular você prestou artes cênicas, né, daí eu queria saber o que te fez mudar e daí por que você escolheu psicologia?

M: Tá. Primeiro porque eu prestei. Eu prestei artes cênicas muito... Bom, primeiro porque que eu fui fazer artes cênicas. Eu comecei fazer artes cênicas porque uma amiga minha queria fazer um curso de cênicas e ela não tinha com quem ir e era longe, aí eu me comprometi a ir com ela nas primeiras semanas até ela fazer amizade, não tinha com quem voltar para casa e daí eu desencanaria; só que eu fui e gostei! (ri) Isso eu tinha 14, 15 anos. E daí comecei a fazer o curso, comecei a fazer outras coisas e gostava. E tinha... E engraçado que essas coisas importantes na minha 
vida sempre acontecem com relacionamento com outras pessoas, se eu não tivesse me relacionado com essa menina, com essa amiga minha eu não teria tido acesso a fazer um curso de artes cênicas, de iniciação a artes cênicas. E lá no curso eu conheci um diretor que, inclusive hoje é meu amigo, que lá dentro ele me incentivou muito: "você tem muito jeito para coisa!" e um pouco disso que ele dizia e das pessoas que estavam em volta diziam, aí eu acabei prestando: "ah, vou prestar artes cênicas”. Que era uma coisa que eu gostava muito, que me fazia bem. Só que aí eu fiquei pensando um pouco na falta de diferenciação do que era gostar de uma coisa e trabalhar com ela. Eu lembro que na outra entrevista eu estava falando que eu não sabia o que era o vestibular, eu não sabia a perspectiva que era fazer o vestibular, e nem a faculdade. Então, não tinha tanto esta questão: "ah, eu gosto de teatro, eu vou fazer artes cênicas.” Não tinha muita crítica disso. Aí, fazendo depois o processo eu fui pensar, bom, duas coisas. Uma - questão de remuneração. É um campo de trabalho muito difícil, para você arrumar um emprego, para você ter uma certa rotina, mesmo para você, que é uma coisa que talvez me fizesse muito bem pessoalmente, enquanto formação, enquanto pessoa, mas daí para eu me estabelecer no mercado de trabalho, ser um profissional da área, isso, eu me senti absolutamente inseguro nisso. Tanto que eu conhecia muitas pessoas do teatro que eram pessoas muito boas e nem por isso eram reconhecidas ou mesmo estavam empregadas. Isso já me: “Opa!”. E outra coisa que também é complicado que é a questão de vender a arte, era uma coisa minha, que eu fazia para mim, que eu queria dividir dentro do possível com os outros, mas daí você por um preço nisso e comercializar isso, para mim isso tinha um problema, era complicado. É, esse eu até não resolvi tanto, porque se você for pensar, psicologia é uma relação de ajuda, você vai comercializar uma relação de ajuda. Então se pensar muito bem, eu não ainda não pensei muito profundamente nisso, como é que é, se eu resolver ser um psicólogo clínico, chega alguém angustiadíssimo no meu consultório e não pode pagar, eu não vou atender? Vou. Uma, duas, três, cinqüenta, qual que é minha função? Quem sou eu ali? Qual é o meu papel? Sou um psicólogo, eu sou um profissional, eu sou uma ilha de caridade? É complicado, para mim ainda é complicado. Mesmo porque eu já tive uma relação de trabalho, eu já tive que trabalhar para ter grana, eu estou ainda vamos ver talvez eu consiga conciliar o que gosto muito, muito, algo que eu pagaria para fazer e estar recebendo para fazer. Esse é o meu sonho! (rindo) Espero realizar via psicologia aí. Mas eu me afastei um pouco por isso, abri mão das artes cênicas. Então, um pouco com a idéia de sair de U. [cidade natal em Minas Gerais], ir para Campinas, um universo totalmente novo, eu tinha 17, 18 anos, eu ainda era muito ligado à minha família, aos meus amigos, ao meu mundinho, na época eu estava namorando, um relacionamento super bacana, um dos meus medos era também esse relacionamento, que nesse momento estava tendo até, não sei, uma certa prioridade, de repente até em relação à própria universidade, mas eu não passei, eu não sei como seria se eu tivesse passado, talvez, talvez não, com certeza eu ia, e lá dentro eu ia me virar, me assustou também um pouco isso. Mesmo as pessoas que eu encontrei ali, eu via um certo perfil ali de artes cênicas na Unicamp, as pessoas que faziam, não achei que elas batiam com meu jeito de ser, com minha perspectiva: "nossa, eu vou ficar tão deslocado aqui!”. E aí juntou tudo isso, aí eu: “ah, quer saber? Vamos fazer psicologia.” Um porque, eu me lembro de uma conversa com uma amiga minha: "Eu vou fazer psicologia." "Ah, de repente eu também faço!”. E, aí, toda aquela visão, de o que é psicologia, muito essa visão de senso comum e talvez até essa visão de senso comum que me fez entrar aqui, de psicólogo clínico, de psicólogo que sabe da vida das pessoas, aquela coisa mágica 
que é muito engraçada! (risadas) Mas eu acho que não era nem tão, tão, tão, não sei, acho que não era nem tão pueril a minha imagem. Porque eu me lembro de uma professora de filosofia dizendo, um exemplo que ela deu em sala, eu não me lembro nem o tema da conversa que a gente estava tendo: "que profissional que se a gente colocar dentro da sala e ele ficar ali observando, vai exercer a função dele e vai saber das pessoas?”. Sabe, deu a maior deixa que era psicologia e eu não conseguia descobrir que profissional que era! E ela falou: “psicólogo”. Eu falei: "não acredito, psicólogo não faz isso tudo!” (rindo) Então, eu não idealiza tanto assim. Mas eu sabia que trabalhava com gente e eu queria trabalhar com gente que, é, uma coisa que ficou marcado para mim, estou me lembrando agora, na época que eu fazia teatro lá em U. [cidade natal], e a gente estava montando um espetáculo lá e a gente estava fazendo um aquecimento e tinha sido bem bacana, porque o grupo tinha se ligado muito e aí alguém falou assim: "gente é uma coisa muito legal, né, gente é bom!”. Aí, eu falei: "Puts, ô, gente é bom, gente é legal!” E, aí, isso acabou virando um parâmetro para mim que fez eu deixar de escolher artes cênicas e me fez escolher psicologia. “Tá, eu quero mexer com gente, eu quero estar no meio de gente”. Eu não me imagino fechado numa sala com papéis, eu não me imagino numa rotina fixa, eu quero mexer com gente. E, sei lá, vamos fazer orientação profissional, motivos inconscientes (rindo) - psicologia! Fechei por aí. Mas tanto que eu disse numa aula de orientação profissional que eu escolhi a carreira certa pelos motivos errados. Tem uma frase que um professor soltou uma vez que é, que ele estava falando sobre relacionamento: “Todo relacionamento começa de um grande engano”. Porque você idealiza a pessoa, você idealiza a relação, depois o que é, depois que você está dentro é que você vai ver o que é aquilo, mas num primeiro momento, você fantasia, é sempre um engano, uma coisa que... batata! Nunca vai corresponder a essa sua primeira idealização. Então, muito do que eu idealizei do que era a psicologia, do que eu pensava que era a psicologia, hoje não, acho que não é mais isso. Mas, eu me sinto muito satisfeito na área, mesmo tendo várias angústias em saber o que é psicologia, que é o psicólogo, qual o papel dele, que é um área que está se afirmando, e nem sei se vai se afirmar pelo próprio objeto de estudo dela, né, o homem estudando o homem, é muito, é uma questão epistemológica complicada, mas eu me sinto muito satisfeito. Mesmo eu estava conversando ontem com um professora depois da supervisão, que eu não sabia o que escolher em psicologia porque eu me sinto satisfeito em várias áreas, eu me sinto, talvez eu escolha aquela que corresponda mais e que esteja dentro da possibilidade de mercado, possibilidade de eu seguir uma carreira, de eu me estruturar dentro do campo. Mas, um pouco isso, por isso não artes cênicas e sim psicologia.

\section{D: Marcos, o que quê significou para você ter entrado em psicologia na USP?}

M: (silêncio) $180^{\circ}$ na minha vida, eu acho. Eu acho que fez toda a diferença. Tanto, primeiro, aquela coisa que eu falei num primeiro momento aqui, nesta entrevista, de retomar muita coisa que era minha e eu poder usar aqui e sentir que isso tinha algum respaldo. Voltou a fazer sentido muita coisa para mim que tinha deixado de ter. A minha angústia não era mais a falta de possibilidade, porque lá em U. [cidade natal] trabalhando como garçom, à noite, na choperia, ah, não sei, talvez seja até menosprezar o outro, mas eu olhava um cara, um dos garçons mais velhos lá, e eu pensava: "puts, o cara está há 15 anos aqui, 15 anos atrás ele estava aqui, daqui há 10 anos ou 15 anos ele vai estar aqui”. E era um cara que se envolvia, ele era chefe dos 
garçons, se envolvia com o trabalho dele, mas não tinha perspectiva profissional mais porque o serviço não oferecia isso, o cara estava mais velho, então já tinha se acomodado a um monte de coisa, o cara já não tinha mais a família dele, também se descuidou dela e... [faz gesto de ser chutado]: "puts, eu não quero isso para minha vida!”. Eu olhava mesmo os meus amigos, mais ou menos da mesma idade, que estudaram comigo, alguns, quem podia pagar, estava fazendo faculdade, quem não podia estava num escritório de alguma coisa ganhando no máximo seus dois salários mínimos, ah, aí, sei lá, aí eu já fazia minha trajetória até... sei lá: “ah, eu vou arrumar um emprego que eu ganhe meus dois salários mínimos, vou lutar igual um louco para conseguir pagar uma faculdade particular, só para ter o curso, que eu nem vou exercer, só para tentar arrumar um emprego um pouquinho melhor, vou achar uma doida aí, vou ter meus filhos e...”, sabe? Sem perspectiva. Quando eu entrei aqui eu tinha um leque tão grande de opções que eu me sentia angustiado, era tanta coisa para fazer, era tanta possibilidade, tanta novidade, né, que, nossa, eu fiquei atordoado, num primeiro momento, perdido, num primeiro momento. E eu estava conversando também com uma amiga minha outro dia, como a USP proporciona coisas para gente. Mesmo uma questão básica, tá? Viagens, encontros de estudantes, quanta gente eu conheci porque eu estou na USP, quantos lugares eu visitei porque eu estou na USP, porque eu estou fazendo esse relato da minha vida nesse momento? Porque eu estou na USP. É... a visão que as pessoas têm de mim hoje - porque eu estou na USP. Muito do eu estou sendo aqui hoje - porque eu estou na USP. Então, a USP é meio mãezona. Claro que ela tem muitos problemas, e eu meto o pau, falo mal para caramba, mas, ah, ela foi um catalisador de possibilidades para mim, acho que isso definiria a USP hoje para mim, ela catalisou um monte de possibilidades para mim na minha vida, que eu sinto que eu tirei a limpo esses cinco anos que eu fiquei de fora, que eu não consegui entrar, que eu ralei, eu senti, nossa! Que quê eu fiz nesses cinco anos? Que foram cinco anos que eu me senti muito perdido, que foram dos meus 18 aos meus 23, que foi a época que chamo de parar de estudar, porque eu não acho que cursinho é estudar, é uma coisa super técnica. Eu acho que nesses quatro anos eu tirei isso a limpo. Basicamente e amplamente é isso.

D: Você acha que se você não estivesse aqui você não teria ou teria pouca chance de ter várias dessas coisas que você tem aqui?

M: Não teria ou teria pouca chance. A não ser que eu achasse um outro catalisador aí, ou tivesse entrado em outra universidade pública, ou tivesse, por sorte, de novo, encontrado algum emprego que tivesse me proporcionado isso, o que eu acho mais difícil, ou ter encontrado um alguém que, de alguma forma, me direcionasse... Eu digo um alguém porque é engraçado, a minha vida sempre foi pautada por pessoas. Pensando agora que eu estou te falando: "ah, porque eu conversei isso com fulano." "ah, porque fulano disse isso..." “ah, porque...” Eu acho que eu gosto de pessoas sim. Ás vezes, apesar de hoje eu dizer: "Não, não, eu odeio gente, gente é muito problemático!” (rindo) Eu mal me agüento, tem dia que eu não posso ver gente na minha frente, mas eu moro com oito, estudo com 40, então... Mas eu acho que eu não teria todas essas possibilidades. Possibilidade de sonhar um monte de coisas, né, fazer uma pós fora, viajar pela Europa e ir estudando, nossa, para mim isso há cinco anos atrás era totalmente inviável. Hoje eu estou fazendo doce! A hora que você me perguntou da minha pós: "vai na mesma linha da sua pesquisa?” [referindo-se a uma conversa antes do início da entrevista]. Ah, eu acho que sim. E, se sim, se eu fizer 
mestrado, provavelmente o doutorado vai ser na França ou na Itália, que a $\mathrm{M}$. [orientadora] está com esse programa aí que rola, que tem como, que é extremamente viável, ontem na orientação ela já jogou um verde: “Ó, tá difícil Marcos, só com esses livros não vai dar, você vai ter que aprender uma outra língua, tem muita coisa em francês, ó, francês é fácil de aprender.” Fácil o caramba (rindo), né, mas quer dizer tem essa possibilidade, ela já está querendo construir também. Que não depende nem tanto de mim, as coisas vão acontecendo aqui, então o puta gás que eu tive que dar lá atrás, de correr atrás, de fazer, aqui eu me acho, às vezes, até muito acomodado, eu penso: "nossa! Como eu ralei antes! Nossa, quanta coisa eu fiz!" Agora, às vezes, eu me vejo e eu fico pensando: "nossa, cara, você tá muito acomodado!". Você deixa as coisas passarem, tipo, deixa: "ah, vamos ver como as coisas se resolvem"; acho que muito desse meu perfil eu perdi ou eu guardei em algum lugar, de ir atrás, mesmo porque eu acho as coisas aqui fáceis, não sei se é porque eu tive um nível de dificuldade grande num momento, mas eu acho tudo aqui muito fácil, muito tranqüilo, aí eu sempre dou meu jeitinho. Tem dado certo! (rindo) Mas, eu não gosto muito de ficar nesse jeitinho, porque, às vezes, falha. Por uma bobagem eu perdi uma renovação de bolsa do CNPq... foi eu perdi o prazo, era até as cinco horas da tarde e eu cheguei lá 5:15. Mas dava para eu ter me organizado, era possível eu ter me organizado antes para eu ter entregue, por exemplo, um dia antes, mas: "ah, eu não li esse texto, não li aquele, vamos ler na hora, vamos montar o projeto...” Mas, e, aí, o que sai disso? Bom, eu estou sem bolsa agora, encerrou agora em agosto, estou assim com o c. na mão na questão financeira. Mas, e, aí, o que quê está rolando? Ah, já tem uma proposta do estágio que eu estou fazendo em Pirassununga virar uma bolsa-trabalho, já resolveria meu problema, e aí já mandei um projeto para Fapesp, que eu acho que está legal, está bem redigido, é um tema que no momento está interessando eles e, se tudo der certo, eu vou ter um problema porque eu vou ter duas bolsas e eu só posso ter uma. Uma bolsa bem mais interessante que a do CNPq que é a bolsa Fapesp ou uma bolsa-trabalho que é um estágio que eu estou fazendo na área de recursos humanos, na prefeitura do câmpus de Pirassununga, que eu estou curtindo muito, que está sendo super útil para mim, estou me achando muito ali. E vou receber por isso! É algo que eu estou fazendo de graça, né, tem até um certo sacrifício porque eu estou tendo que me deslocar, tem que... Mas eu vou receber por isso! Esse é meu ideal, eu vou chegar lá! (risadas) Mas, você entende que, de alguma forma, acaba sendo proporcionado pela faculdade, pela, esse mundo universitário que eu estou inserido nele, então acaba girando, acontecendo, as coisas acontecem aqui, enquanto que antes não estavam acontecendo, eu tinha que labutar, labutar, e às vezes, não conseguia nada, e aqui com um esforço mínimo parece que o mundo gira, não mínimo, né, vai, estou exagerando um pouquinho, mas só para frisar bem o que eu sinto a diferença de antes e depois.

D: Você comentou na outra entrevista que quando você chegou no curso que no começo, sobretudo no início do curso, você quis experimentar um pouco esse outro mundo, no sentido de curtir, de ir em badala, de experimentar um outro lado seu, que você sempre foi um garoto comportado, bom aluno. Mas que você ficava pensando que, às vezes, isso ficava um pouco vazio, que sentido isso tinha. Que poderia ser feito para experimentar esse outro lado - que era um sentido, mas que se isso era feito aleatoriamente ficava vazio. Eu queria que você falasse um pouco disso, você fez para experimentar, você fez aleatoriamente, como que foi isso? 
M: Não. Tinha sentido, era para experimentar, era para fazer o efeito vareta, mesmo. De desencanar um pouco, sabe, eu percebi, assim, não sei, de uma perspectiva bem subjetiva minha, ah, eu sou o filho mais velho, o neto mais velho, o sobrinho mais velho, todo mundo tinha muito perspectiva em cima de mim, sabe, de: "ah, você vai!” sei lá para onde, mas de alguma forma vai! (rindo) Então, coisas assim, mesmo a minha mãe: "você é o filho que menos me deu trabalho.” Daí eu ficava pensando: "nossa, uma coisa é meu irmão pisar na bola, outra coisa sou eu pisar na bola." Nossa, o bom moço, né, o, eu senti que isso estava me aprisionando, estava me impedindo de fazer minhas coisas, de ser eu e achar sentido, às vezes, de ter que corresponder muito com o outro, e aí eu falei: "ah, desencana, deixa eu me sujar um pouquinho! Sujar a ponta do tênis na lama que seja!” E uma certa displicência e acho que isto assustou muito as pessoas, principalmente, minha família, mas nada muito escandaloso. Assim, por exemplo, eu não tinha vontade de ligar para casa, eu não ligava, e, às vezes, eu não ligava porque eu tinha saído e eu me dava esse direito. A minha mãe ligava chorando, para minha mãe acho que foi muito chocante, ela ligava, me chamava de filho de chocadeira (rindo) porque eu não tinha ligado, filho de chocadeira porque não tem mãe, e, aí, eu ficava todo condoído, depois não ligava de novo (rindo)! Era uma coisa de ir distanciando um pouco, estabelecendo esse vínculo mais à distância, sem precisar ficar falando sempre, sem, eu ia para casa todo final de semana, agora eu fico um mês, um mês e meio, dois meses sem ir para casa; eu ligo, geralmente, todo final de semana eu ligo. Mas, não me preocupar tanto com o que os outros pensam, ou corresponder à necessidade do outro, pensar um pouco em mim, mesmo a galera lá da Igreja, do grupo de jovens. Primeiro que dissolveu um pouco, perdeu o sentido para mim, mas perdeu prum monte de gente também, então, ateu na raiz. E eu ia e descia a lenha, mesmo pras pessoas: "nossa, mas, e, aí, cadê o sentido disso?" Descia a lenha nesse sentido de questionar, mostrar como era muitas vezes vazio o que a gente estava colocando, a gente não achava sentido ali. E todo mundo ficou assim: "pô, Marcos, caramba, o cara que era o coordenador do grupo" - uma época eu fui - “o bom moço, puts, tá vendo é a psicologia!” (risadas) "Ô, Deus queira!” (risadas). E, aí, foi engraçado que eu percebi que continuava sendo referência com a minha postura, mais do que eles porque, às vezes, a galera tinha um discurso e uma prática diferente, ainda mais adolescente, jovem, que a gente não tem essa profundidade toda de o que quê é isso, o que é aquilo. Mas, quando eu passei, foi uma coisa que eu fiquei muito chateado, quando eu passei a ser mais displicente, eu comecei a ter acesso a coisas do mundo deles, coisas banais que aconteciam, que eu não ficava sabendo pela imagem que eles tinham de mim. Como eu não estava sendo mais o bom moço, como para mim estava sendo muito mais de boa, aí, aparecia isso: “puts, por que quê eu não sabia antes?”. E eram coisas que para mim eram importantes eu saber antes. Aí, eu fui pensar um pouco, puts, era a imagem que a galera tinha de mim.

\section{D: Que tipo de coisas, assim, por exemplo?}

M: Desde coisas básicas: fulano ficou com ciclano: “ah, sabe aquela situação assim que fulano saiu assim, porque fulano estava transando com menina em tal lugar ou fulana traiu ciclano" ou porque "ah, ó essa grana, essa grana sumiu por causa daquilo, daquilo e daquilo outro", ou, "ah, sabe fulano, fulano fuma maconha”. Sabe, e daí? Eu também já fumei maconha. Sabe, assim...? Uma coisa assim que... gente! E eu achava que estava numa atitude de relação com as pessoas, de me aproximar das 
pessoas e eu estava era... Foi legal isso também, de beber até chapar, de vomitar depois, de passar muito mal no dia seguinte, e dois dias depois beber de novo: "mal sabe você que dois dias atrás eu bebi e passei mal e estou bebendo de novo!" (risadas) Mas, pelo menos tem isso. Para mim foi por esse motivo, eu queria ter isso, eu queria, né, não ser tão sério, tudo, tão denso, tudo. Nos últimos anos tinha sido tudo muito sério, tudo muito denso, né, mesmo eu terminei um relacionamento de quatro anos porque eu estava achando que estava superficial, ai, a gente estava acomodado, mesmo por tudo o que eu estava passando e tal, isso também acho que fez diferença, que hoje eu não sei, eu acho que eu não teria terminado, teria mantido, teria abaixado o nível de exigência, teria mantido e visto pelo menos o que quê dava, se não tivesse dado nada, tudo bem, terminava. Não ser tão... mais fluido, ser mais leve, um pouco nesse sentido...

D: Marcos, algumas coisas que você comentou no nosso outro encontro eu gostaria que você comentasse um pouco mais. A primeira delas é quando você passou no vestibular, você contou sobre um episódio que você estava trabalhando, aí a gerente te cumprimentou, daí um cliente viu e também te cumprimentou e quando você voltou para levar o pedido para aquela mesa, ele contou, e uma outra pessoa também te cumprimentou: “ah, parabéns”. Mas quando ele disse que você tinha passado na USP, essa pessoa levantou e te cumprimentou em pé. Você comentou que isso fez bastante sentido para você. Daí eu queria te perguntar que sentido isso fez, o que isso significou para você?

M: (pausa) Acho que foi um reconhecimento, acho que foi um reconhecimento que eu ainda não tinha me dado muito conta disso. Lembra que eu te falei que eu não me senti feliz, eu me senti, eu me senti, não sei, aliviado, e nesse momento talvez tenha caído a ficha, aí eu me senti feliz de ter passado, porque foi o outro que me deu a dimensão da coisa, pelo menos pro meu mundo ali. Pra mim: "Ufa, passei, ô, ainda bem, foi! Outra etapa!” E eu estava deixando passar batido, e, aí, essa situação redimensionou a coisa, ou dimensionou a coisa para mim, porque eu lá garçom, a galera tem toda uma idéia do que quê é o trabalho de um garçom, a idéia de servir, tem toda uma idéia no imaginário das pessoas. Dava para pegar muito isso no serviço, assim, pessoas que conseguiam romper com isso e pessoas que não conseguiam romper com isso. Pessoas que se relacionavam com você enquanto pessoa e pessoas que se relacionavam com você enquanto prestador de serviço, enquanto garçom, enquanto moço, né, em francês [estrala os dedos, imitando gesto de chamar]. E ali naquele momento o cara rompeu isso, o cara fez o pedido, ah, beleza, e, nossa, a USP rompe coisas! Ter passado na USP rompeu isso, rompeu de uma forma instantânea! Era o garçom servindo: “ah, parabéns, me dá chope”. “Ah, que bom, um chope claro, sem colarinho.” Não! Aí, redimensionou, aí eu: “Ah é? Ah, é assim que funciona? Ah, que bom, tô começando a gostar!” (risadas) Nesse sentido, eu acho, Débora, que foi a coisa, ajudou a cair a ficha.

D: Você falou desse imaginário que se tem sobre o garçom? Isso é o que? É aquele que serve...

M: É aquele que serve, aquele que, que, ah, a princípio, não sei, algumas pessoas iam lá para serem atendidas, para terem o serviço, muitas vezes independente do que queriam, ele não ia pelo chope, ele não ia pela comida, ele ia para ser atendido, 
principal objetivo de estar ali de algumas pessoas, tanto algumas que tinham um poder aquisitivo maior como outras que não. Algumas valorizavam muito o atendimento, você via isso como? Ou um comentário dele, ou o relacionamento que ele tinha com você, ou da próxima vez ele queria que você atendesse ele, por dois motivos ou porque você atendeu bem a ele, foi solícito a ele, ou porque você se relacionou bem com ele, e todas as gorjetas que eu conseguia, geralmente, não era pelo meu atendimento em si, até porque eu não era muito bom (risadas)! Vai ver que é por isso que eu estou aqui! Vai ver que o cara que está lá há 15 anos era bom naquilo! Eu...! (risadas) Eu fazia um trabalho regular, nunca era o que mais vendia na noite, mesmo porque eu não consegui ser tão produtivo, assim, de vamos correr, vamos vender, vamos jogar chope no cara sem o cara pedir, mas todas as gorjetas que eu conseguia era porque eu tinha feito uma piada, porque eu tinha brincado... [fim da fita]

Então, como eu estava falando, era muito mais da maneira como eu me relacionava com as pessoas do que fazer o bom atendimento do que levar... às vezes, eu esquecia pedido! Mas, era muito mais para minha noite fazer sentido, para não ser sofrível o trabalho, do que a perspectiva de ganhar grana, ganhar gorjeta, tanto que a técnica para ganhar gorjeta nem era essa, era reservar mesa, era justamente servir, o garçom tinha que reservar mesa. Tinha um cliente que era metódico, ele tinha a mesa dele, era aquela mesa, naquele dia, ele apontava lá, o garçom que estava atendendo ele já pedia um chope e uma água mineral que chegava na mesa junto com ele, o chope e a água mineral. Chegava junto com ele na mesa. E tinha também a seqüência, eu atendi ele algumas vezes: era sempre um chope, uma água, depois dois chope, outro chope, depois servia geralmente dois chope e uma água - um chope claro, um chope escuro, chope claro, chope escuro, enfim, tinha exatamente um ritual, cara! E, aí, eu atendi esse cara algumas vezes, né, mas sempre conversando, e óbvio ganhava caixinha como todo mundo ganhava, só que uma vez eu estava, eu já tinha passado, eu estava no segundo ou terceiro ano da faculdade, eu fui num bar em U. [cidade natal], a C. [nome do bar], que tem aqui, tem lá também, e aí eu fui e aí ele com os amigos estavam em uma outra mesa, e aí ele se levantou e me chamou para ir para mesa para gente conversar, e fez a diferença, o relacionamento, e aí a gente conversou, ele perguntou se eu estava gostando de psicologia, como era psicologia, falamos de coisas dele, conversa de bêbado (ri). Mas teve esse espaço para rolar isso depois. Então, eu acho que eu fugia um pouco desse estereótipo do garçom para servir, de servir e servir bem, de sempre estar com isqueiro no bolso para acender o..., eu fazia questão de não ter isqueiro! Ah! Eu não tenho que acender cigarro de ninguém, cara! Pô! Quer fumar? Traz pelo menos seu isqueiro! Nossa, era pedir para morrer a hora que o cara estendia o cigarro assim para mim e eu... ?! [imita gesto e expressão de não entender]. E, aí, o sentido disso tudo, é que como eu falei lá no começo da fala, é que quebrou isso, o cara quebrou isso lá na fala e na postura dele: "hum, passei na universidade, então, faz diferença! Ah, F.D.P. (rindo)! Sou o mesmo cara, mas agora não sou mais!” Nesse sentido.

D: E, aí, uma outra coisa que você contou é que você chegou aqui para fazer matrícula e te apelidaram de "calouro independente" porque você chegou aqui sozinho e você percebeu que você ficou um pouco perdido, teve até no primeiro dia, você foi almoçar e teve um veterano que te perguntou se você já trabalhava, você 
disse que sim e aí você percebeu que você tinha um perfil diferente. O que você achou disso, dessa situação?

M: Eu achei legal e eu achei que vai um pouco na direção do lance do bar que eu acabei de te contar. É um pouco o outro dimensionando, pontuando para você, te devolvendo o que, pelo menos, você representa pros outros ou para ele naquele momento. Então, era simbólico, naquele momento, o calouro não chegar com os pais porque absolutamente todos os calouros chegaram com os pais e eu vou lá e chego de moto-táxi sozinho, de outra cidade, não era nem de P.[cidade onde se localiza o campus], é, eu acho que um pouco isso, não sei... E, eu não achei ruim, não, eu achei bem bacana, mesmo porque, realmente esse sou eu: "ah, que bom, fui reconhecido, prazer!” (rindo) Fui visto como eu sou, não tem nenhum problema. Começou a ser um problema quando começou o curso e você começa a perceber que você não está tão no perfil, isso que chamou a diferença num primeiro momento, continua chamando e, aí, você percebe ela, como te falei a primeira balada que eu fui, que foi uma balada monstro com todos os calouros da faculdade, eu fiquei totalmente perdido! Fazia muito, muito tempo que eu não ia numa balada assim. Mesmo porque nos finais de semana, meus sábados estavam todos comprometidos, e eu economizava grana, e eu falei: "tudo o que eu queria agora era uma bandeja na mão porque eu sabia exatamente o que fazer”, mas, aí, eu fui trabalhando isso, não era uma coisa que me pegava mas também não dava (?) para fazer de conta que eu não via (?). Era muito bom para mim, no meu primeiro ano de faculdade, a cerveja que eu estava tomando era com a minha grana, um dinheiro que eu tinha guardado, Fundo de garantia, seguro-desemprego, então fazia toda a diferença para mim: "eu tô tomando a minha cerveja com o meu dinheiro!” E, olha, que eu comecei beber aqui na faculdade, hein, antes eu não bebia. E era, para mim era marcante isso e eu me orgulhava disso, era um ponto positivo para mim: "É, eu tô pagando a cerveja que eu bebo, a cerveja que ele bebe o pai dele paga para ele”. E, isso era ruim, depois de um certo tempo, eu vi que isso era ruim, porque acabava, eu acabava, não sei, proletarizando tudo, não sei, aquele discurso de proletário injustiçado, acaba perdendo a dimensão geral das coisas, o que quê é estar ali no curso, o que quê é estar com as pessoas ali, possibilidade de você se relacionar com essas pessoas, porque já que você quebrou esse vínculo, esse, esse vínculo, não, essa representação: "ah, tô lá dentro, estamos pau a pau todo mundo, estamos igual todo mundo", eu ficava sempre retomando ele: "não, porque eu sou diferente, não porque eu tenho toda essa história” sem querer saber qual é a história do outro, sem querer saber, né, foi bem dicotômico para mim, ao mesmo tempo que eu quebrava, que eu estava aqui dentro, eu sempre recorria a ela para dizer quem eu era, e isso foi, nossa! Difícil! Primeiro ano foi difícil. Porque eu acabava fazendo muitas coisas mais para me autoafirmar, para mim mesmo, às vezes, até para os outros, do que realmente fazer sentido, e eu acho que você acaba se ferrando sempre nessa. Não sei... acho que é um pouco por aí...

D: No nosso outro encontro você disse que se relacionava com as pessoas do curso não com o que elas de fato eram mas com o que elas representavam para você, um pouco isso que você estava falando agora, que você não conseguia a história delas...

M: Ah, é, acho que eu comentei na última entrevista, que eu estava estudando para entrar aqui ou para entrar numa pública, não era aqui, eu não tinha idéia de entrar na 
USP, mas eu sentia que eu estava nadando contra a maré porque meu concorrente estava dormindo melhor que eu, estava comendo melhor que eu (ri), tendo mais tempo do que eu, então é uma briga muito injusta, e quando eu entrei aqui eu topei com eles, eles eram meus concorrentes. E, também, da parte deles acho que era muito gritante esta questão do se impor nesse sentido, né, não de, ah, por exemplo, de... de marcar quem era, como eu queria minha bandeja para marcar quem eu era ou quando eu era o calouro independente ou calouro que trabalha para marcar quem eu era, eles queriam dizer que estudaram no Capital [escola particular] para dizer quem eles eram, que eles estavam putíssimos com a Telefônica porque eles iam ficar a semana inteira sem internet, porque eles queriam ir no barzinho badalado da cidade, baladas e baladas agora sem pai e mãe, baladas caras, torrar o dinheiro do papai e da mamãe, nesse sentido, então, tinha esse choque, de eles afirmarem quem eles eram e esse ser o público que eu atendia, de repente, quando eu trabalhava, eram eles que estavam na mesa e gastavam na noite o que eu ganhava no mês ou, então, chocou e, por isso, que chocava e vai indo você larga um pouco os teus estereótipos e eles também, cada um larga o seu, e aí a gente vai pro embate pessoa a pessoa, não precisa mais tanto daquilo para afirmar, é o seu relacionamento com os outros, então, eles eram esse estereótipo, mesmo porque eles me traziam muito isso, do que eles, de dizer quem eles eram, que marcavam deles, do que eles pontuavam, de quem eles diziam que eles eram, e eu quem era. Um pouco por aí... (pausa)

D: Marcos, eu queria saber o que você acha sobre o papel da escola na construção dessa sua trajetória. O você pensa sobre isso?

M: Tá. Se a escola..., não sei, estou pensando agora, pode ser que eu mude, se a escola tem um papel ímpar nisso tudo, eu acho que não, diferente de tudo, eu acho que não. Mas ela tem uma presença muito forte que esteve presente no contexto. Por que? Porque você fala escola, aí a gente tem que definir o que a gente está entendendo por escola. Porque quando você me pergunta da minha escola, que quê eu me lembro muito? Dos relacionamentos. Da escola também como um catalisador disso tudo, um primeiro catalisador, lembra que eu te falei, pensando agora na minha fala, que eu tive esse intervalo de sair da escola e entrar na faculdade, nesses cinco anos, aí, então, se foi intervalo é porque está tendo continuidade, né, que foi depois e o que vem antes, senão não seria intervalo, eu acho. Então, muito do que eu falei da universidade, de uma forma diferente, pro meu contexto, na época, serve para escola, então a escola era o catalisador dessa experiência, muitas das pessoas que eu citei estavam lá, os amigos, mesmo o pessoal do grupo de jovens estava lá, mesmo os professores que eu encontrei, teve o, o círculo de amigos, de comunidade, então, movimentava tudo, né, esse sistema escola tinha vários subsistemas ali agregando nele, então, era um espaço primordial porque propiciava tudo isso. Agora, diretamente na questão ensino-aprendizagem, não sei se eu consigo dimensionar isso, não sei como dimensionar isso, não sei se eu tenho critério para isso. Eu acredito que bastante. Mas, de que maneira, eu estou vivenciando isso ainda, então não sei dizer, diretamente, assim. Algo teve, mas o que... em que ponto, em que papel, eu não sei... Mesmo porque em algum momento eu me senti muito lesado pela escola que eu tive, pela educação que eu tive quando eu não conseguia passar, né... Mas de alguma forma essa mesma escola me forneceu instrumentos, mecanismos para eu correr atrás! Pelo menos bom de história eu sempre fui, bom de geografia eu sempre fui, estou dizendo em termos mais técnicos, não estou dizendo nem de estrutura pessoal, 
né. É... é, professores marcaram, me deram incentivo para ir, eu via que eles correspondiam com a aula que eles estavam dando, eu queria corresponder também, eu citei lá o exemplo ?modelar: "nossa, eu vou querer encarar meu trabalho como ela encara o dela!" Eu quero me relacionar com as pessoas como as pessoas se relacionam com outras pessoas. Agora, não sei, eu acho muito difícil, precisa de um pesquisador para isso! (risadas) Pra isso que precisa de pesquisa, para pontuar muito claramente em que, em quais pontos e o que quê ocorre. (pausa) Acho que é isso.

D: Da outra vez, você também tinha comentado que você gostava muito de sua escola de Ensino Fundamental e o que você mais se lembrava eram dos relacionamentos. É um pouco isso que você está dizendo? Quer dizer o que importa mais não é o prédio, o que se faz, mas, assim, as possibilidades de conhecer pessoas, de se relacionar?

M: É, também, tudo assim, é porque, eu vou pegar de novo esse exemplozinho do catalisador. Era ali naquele espaço físico que as coisas de fato aconteciam, então tinha essa coisa da afetividade. Então, por exemplo, quando colocaram um muro num lugar lá dentro da escola, separando o pátio da quadra, eu fiquei chateado: "nossa, tava tão bem sem muro!”. Nossa, me senti tão fechado, era a minha escola, era o meu espaço também, ninguém me perguntou (ri), “ah, muraram a escola” , “ah, legal”, "nossa, vão reformar a quadra, vão fazer uma outra quadra”, "pô, essa quadra não sai”, "ah, vai ter festa junina para reformar a quadra”, "eu quero a quadra”, "também quero a festa, por isso eu vou na festa!” É, professor me dar uma coisa numa aula que eu consigo usar isso mais tarde depois para uma outra coisa - certeza, isso vai ficar! Primavera de Praga, os cinco principais pontos da Primavera de Praga que foi usado por Stalin para fazer o plano de metas dele, quem liderou a Primavera de Praga foi Alexander Dubcek, isso tudo eu resgatei quando eu vi no noticiário que o Alexander Dubcek tinha morrido num acidente de carro. "Nossa, eu já ouvi esse nome!". Ruuuu, recuperei, porque eu sabia quem era o cara muito mais do que algumas pessoas que estavam assistindo comigo o noticiário: "ah, quem era o Alexander Dubcek?”, “ah, quem...?” Alguma coisa nesse sentido... Por aí... Não sei, é difícil para mim, tudo meio misturado, tudo muito complexo, o que quê é escola? O problema é que a gente reduz o que é escola, né, não é só a relação de ensinoaprendizagem, não é só relações de poder, hierarquias, nesse sentido, o que quê se aprende, por que quê se aprende, é a busca de sentido, qual o sentido da escola, qual o sentido da escola para uma comunidade, isso também é muito solto isso, eu vou aprender, o que quê eu vou aprender, por que quê eu vou aprender, por que quê eu quero aprender. Eu acho isso...

D: Tem mais alguma coisa que você gostaria de falar, que você pensou enquanto você falava e gostaria de falar?

M: Só retomando um pouco o que eu já te disse, né, que eu parei para pensar um pouco que quê representa a escola. De forma objetiva, não sei se eu consigo ver isso, porque eu ainda estou vivendo as conseqüências disso. É, precisaria pensar um pouco mais, rever algumas coisas, pontualmente, assim, eu não sei dizer. Mas, de uma forma geral, é o que eu já te falei, foi um lugar que pôde juntar um monte de possibilidades para mim, um espaço que, um dia, eu acabei retomando, porque quando eu me lembro da minha vida de dos meus 7 aos meus 18 anos, uma coisa que 
vem ali é a escola, sempre paralela a alguma coisa, sempre a escola perpassa alguma coisa ali, nesse sentido, assim. Mas, esse componente de ensino-aprendizagem, eu não sei se eu saberia fazer isso.

D: Mas, nem é por aí que eu estou esperando, até porque é uma história muito longa... E, quando você fala paralelamente a escola sempre estava presente, paralelamente a quê, por exemplo?

M: Paralelamente a tudo o que eu vivenciei. Vai, minha adolescência, os relacionamentos que eu tive, os conflitos que eu tive, enquanto criança, enquanto adolescente, com a família, é, tudo o que você passa no seu desenvolvimento normal, paralelo a isso estava sempre, de alguma forma, a escola ali, como um espaço destas coisas acontecerem também, seja uma advertência que eu tomei quanto a comportamento, e a minha mãe entender isso porque eu estava na adolescência, e era muito brincalhão e ela conhecia as pessoas que fizeram isso comigo, eram meus amigos, ela conhecia eles. De uma forma muito incipiente, muito básica, mas faz sentido, assim, vai alinhavando assim. Grandes amigos foram na escola, meu gosto por ler - a escola, sem dúvida, mesmo porque meu pai não tinha esse hábito, eu via meu avô lendo, é, raras vezes, minha mãe lia uma historinha ou outra, mas não era um hábito, não era mesmo, com a minha irmã, já é, com a minha irmã caçula, é bem diferente a educação que ela está tendo hoje da que a gente teve. Mas, isso... (silêncio)

D: Queria agradecer mais uma vez! 


\subsection{Um empreendimento coletivo na trajetória escolar de Pedro}

Pedro, 22 anos, é aluno do oitavo semestre do curso de Biologia ${ }^{32}$. Originário de $\operatorname{Jardim}^{33}$ - uma pequena cidade mineira de cinco mil habitantes -, reside na moradia estudantil, onde foram realizadas as duas entrevistas, desde o ingresso na Universidade e divide quarto com Marcos, que é seu amigo e através de quem se deu nosso contato.

Esse jovem é filho único de um casal de aposentados que, para ele, são "bem mais velhos”, pois sua faixa etária está acima dos 60 anos. Seu pai, que, quando criança, cursou até a $4^{\mathrm{a}}$ série e concluiu já adulto o Ensino Fundamental através de supletivo, trabalhava como pedreiro e aposentou-se por invalidez devido a um problema na coluna vertebral; sua mãe realizou curso técnico em contabilidade e trabalhou, antes de Pedro nascer, como costureira, caixa em loja de confecções e secretária. Cada um deles recebe um salário mínimo de aposentadoria, renda, por vezes, complementada com a venda de produtos cosméticos pela mãe e com eventuais trabalhos do pai, mas, como explica Pedro, tais complementos são raros e “quase sempre passa sem ter nada”.

Sobre o avô materno, esse estudante dispõe de poucas informações já que ele faleceu quando sua mãe ainda era bebê, sabendo apenas que ele trabalhava como pedreiro. A avó materna, tornando-se viúva com quatro filhos pequenos, trabalhou como lavadeira em um colégio interno para sustentar a família; Pedro conta que ela sabia ler e escrever e que lia muito a Bíblia por ser bastante religiosa. A avó paterna faleceu quando o pai era criança, por isso a única informação que Pedro tem a seu respeito é que ela sabia apenas assinar o nome. O avô paterno sabia ler, escrever, fazer operações matemáticas e foi juiz de paz em Jardim; todavia, esclarece Pedro, o cargo fora ocupado pelo avô por uma questão política.

Em virtude do baixo rendimento familiar, o prolongamento da escolarização desse jovem só pôde viabilizar-se por meio de um empreendimento coletivo ao contar com a colaboração financeira dos tios. Foi através da ajuda de alguns deles, principalmente do lado materno, que a freqüência a um colégio particular e a permanência na Universidade foram possíveis.

\footnotetext{
${ }^{32}$ A graduação em Biologia tem duração total de oito semestres.

33 Os nomes das cidades são fictícios.
} 
Pedro realizou a Pré-Escola e o Ensino Fundamental em uma escola pública estadual de Jardim. Conta que era um bom aluno - estando seu desempenho acadêmico sempre entre os melhores da classe - e também que era tímido. Do início de sua experiência escolar, possui uma lembrança ruim em virtude das várias trocas de professores ocorridas na $1^{\mathrm{a}}$ série, o que lhe dava a impressão de descaso, além de ser fonte de sofrimento: "Eu aprendi, não sei muito bem como, mas eu acho que poderia ter sofrido menos...”.

O Ensino Médio em Jardim só era oferecido no período noturno sendo, de acordo com Pedro, de baixa qualidade. Por isso, ele submeteu-se a um processo seletivo de bolsa de estudos de um colégio particular em uma cidade vizinha Pedreiras -, obtendo aproximadamente 50\% de desconto no valor da mensalidade. Seu tio materno, morador dessa cidade e ligado a duas escolas particulares por ser membro da maçonaria - à qual os colégios estavam vinculados - conseguiu transformar o desconto obtido em bolsa integral de estudos. Além disso, custeou todo o material didático de Pedro durante os três anos de colegial. Uma tia materna arcou com as despesas do deslocamento diário até Pedreiras. E um tio paterno pagou um curso de inglês, para Pedro, na última série do Ensino Médio, visando a um melhor preparo para o exame do vestibular.

Assim, quando esse estudante afirma que "a gente deu um jeito de eu estudar fora”, não se trata de uma figura de linguagem: cursar o Ensino Médio em uma escola particular e em outra cidade foi, de fato, um empreendimento coletivo de sua família. A ajuda, no entanto, não se encerrou com o ingresso na Universidade: a mesma tia lhe envia mensalmente $\mathrm{R} \$ 100,00$ para ajudar a custear sua estada em Ribeirão Preto. Pedro reconhece e enfatiza que se não fosse a ajuda dos tios ele não estaria, hoje, cursando Biologia na USP.

Mas, o cuidado da família para com Pedro foi além do investimento financeiro em sua escolarização. Ele prestou a prova para a obtenção de bolsa de estudos em uma escola, mas realizou o Ensino Médio em outra. Isso se deveu, segundo Pedro, a uma preocupação por parte dos tios e da mãe com a prevenção da humilhação, pois:

...eles achavam que assim o C. [escola onde obteve desconto inicialmente] era um pessoal mais esnobe, parece, eles falavam, eu não cheguei a conhecer esse pessoal para ver como era isso daí, mas então eles achavam que ia ter muito problema nessa parte, 
que era um povo muito orgulhoso, um povo muito arrogante, um povo que talvez iria me humilhar muito. E eles achavam que no A. [escola onde estudou] eu teria uma convivência mais legal. E eu não senti esse problema no A., há uma diferença, mas, assim, não era um preconceito, era uma constatação, existia realmente uma diferença, mas não que aquilo fosse agressivo, que aquilo me violentasse, e no C., na cabeça deles, era o que iria acontecer.

O conhecimento do funcionamento das duas escolas particulares, por parte do tio, e a preocupação dos parentes em procurar um ambiente acolhedor para Pedro estudar levaram à mudança de escola que teve como único objetivo evitar a experiência da humilhação social, possibilidade real e concreta quando do encontro de camadas sociais distintas.

Proveniente de uma família de baixa renda e de uma cidade muito pequena, estudar em uma escola particular parece ter significado para Pedro o encontro e a convivência com a desigualdade social. No entanto, ele afirma que não se sentia discriminado por sua condição social e que isso não era fonte de sofrimento na relação com os colegas:

Lá em Pedreiras era um colégio de... Bem elitizado lá, o lugar, né, então... Eu não senti uma situação de preconceito assim forte, mas eu sentia que era diferente ali, não era um lugar muito, muito... Eu não estava acostumado com aquela realidade, o pessoal estava..., ia em festas, não sei o quê, compravam coisas, foram a tais lugares, coisas que não passava na [minha] cabeça. Mas era um pessoal que não me destratava não, nunca tive problemas...

Ao contrário da humilhação, esse estudante experimentou um bom acolhimento na nova escola, fato que o surpreendeu tendo em vista sua experiência anterior na escola pública. Pedro conta que, no final do Ensino Fundamental, um aluno de outra cidade foi transferido para sua escola e que ele e seus colegas tratavam-no muito mal, chegando a agredi-lo fisicamente. Quando, na escola particular, vê-se, ele próprio, na condição de estrangeiro, estranha a boa recepção:

... Tanto foi até que eu estranhei muito quando eu fui para Pedreiras, o pessoal era super cordial, era mais tranqüilo, eu era super agressivo (...) Eu lembro, inclusive, que tinha entrado um cara que a família dele tinha vindo de São Paulo, até hoje não entendo direito porque eles foram para Jardim... (...) A gente recebeu super mal o cara! Não conversava com ele, juntava, batia nele, umas coisas bestas, assim. E em Pedreiras depois que eu fiquei..., que eu me vi como uma pessoa vindo de outra escola, eu me coloquei assim no lugar dele e... Nossa! Nem se compara a recepção que eu tive, foi muito mais tranqüilo e eu fiquei 
pensando muito nisso... na forma como eu tinha sido recebido que era super diferente... ${ }^{34}$

Mas, se a experiência com os novos colegas não fez Pedro sofrer, o afastamento dos antigos amigos e a trilha por um caminho diferente do que eles seguiram, foram bastante difíceis. Estudar numa escola particular e em outra cidade significou seguir por uma trajetória inviável para seus amigos, dadas as condições financeiras deles - e o seria também para Pedro não fosse a ajuda de seus familiares. Seus amigos de Jardim, findo o Ensino Fundamental, encaminharam-se para o trabalho, atuando na agricultura, na olaria ou no comércio. Diferentemente deles, Pedro não realizou nenhum tipo de atividade remunerada juntamente com a escola. E como poderemos observar ao longo deste trabalho, ele foi o único estudante entrevistado que nunca trabalhou. Esse fato reflete a grande valorização da escola por parte de seus pais que buscam, de várias formas, garantir a continuidade dos estudos do filho. Essa valorização concretizar-se-á, como veremos, em outras ações ao longo de sua história escolar.

Além da limitação de tempo que a nova rotina de estudos impunha, seguir por caminhos tão distintos parece ter contribuído para o afastamento dos amigos de Jardim. Sobre os novos colegas, apesar de relacionar-se bem com eles, Pedro afirma que a convivência restringia-se ao período em que permanecia na escola. Estando longe dos antigos e dos novos amigos, os anos do Ensino Médio foram marcados pela solidão. Pedro, que tem um jeito bastante sereno de falar, faz um relato desse período de modo mais enfático:

Por manter esse ritmo [de estudo] eu me afastei muito dos meus antigos amigos, e nessa época, todos, ou praticamente todos, já estavam trabalhando... (...) E aí eu não tinha mais contato com esse pessoal porque praticamente as horas livres que eu tinha, esse pessoal já trabalhava, né, então aí... Nossa! Foram anos tristes assim...! Sei lá, eu tinha três amigos assim... (...) Aí, eu conversava bastante com o pessoal de Pedreiras, durante a aula, me dava super bem com eles, mas batia o sinal eu voltava para casa e acabava, né, não tinha ir lá no fim de semana, depois eu vi, né, os outros lá de Jardim, que iam estudar lá em Pedreiras, que conciliavam muito melhor isso daí, eles iam para Pedreiras, iam visitar esses amigos, eles faziam coisas, levavam esse pessoal para conhecer, para passear em Jardim, coisas que não tinham me passado pela cabeça, que era possível, foi falta de... de jeito

\footnotetext{
${ }^{34}$ Para tamanha diferença, talvez tenha colaborado, além da faixa etária dos envolvidos, o fato de o tio de Pedro ser ligado à escola, tendo, posteriormente, quando esse jovem estava no segundo colegial, se tornado diretor desse colégio.
} 
mesmo... E então no terceiro ano, nossa! Eu fiquei muito infeliz, credo! Se eu não tivesse passado, acho que se eu não tivesse passado eu acho que não teria mais nenhum amigo...

Iniciado o afastamento de seus amigos de Jardim com o estudo em Pedreiras, afastamento esse que pode ser entendido também, de forma mais geral, como distanciamento de um mundo cultural em direção a outra realidade representada pelo projeto de ingresso na universidade pública, a fala de Pedro traz também outro sentido: se esse projeto não tivesse se concretizado com a aprovação no vestibular e a entrada na faculdade, a solidão seria completa, pois ele não se sentiria pertencente a nenhum dos dois mundos, configurando uma situação de desenraizamento.

Pedro ressalta que a solidão experimentada durante o Ensino Médio era fruto do grande esforço e da dedicação aos estudos, sobretudo na terceira série, em virtude da proximidade do exame do vestibular. No entanto, embora reafirme que a relação com os amigos do colegial fosse boa, reconhece que o fato de ter se sentido solitário durante esse período foi também conseqüência de uma dificuldade sua em conciliar as novas amizades com a residência em outra cidade. Pelo seu relato, os obstáculos para que isso acontecesse parecem ser muito mais de ordem subjetiva do que material, quando ele diz, por exemplo, que encontrar os novos amigos em outros momentos fora da escola “era possível”, mas que não ocorria por “falta de jeito mesmo".

Importante atentar para o momento do ciclo vital que Pedro vivia durante o Ensino Médio - a adolescência. Assim, as dificuldades enfrentadas por esse jovem nesse período, bem como os sentimentos relatados de solidão e tristeza podem estar também relacionados às intensas mudanças que ocorrem durante essa fase.

Pedro enfatiza também que a solidão e a tristeza estavam localizadas em um lugar - Jardim. Lá esse jovem sentia mais os efeitos que o afastamento de um destino já socialmente traçado parecia produzir; foi em sua cidade natal que Pedro passou a sofrer a experiência de desenraizamento quando se dedicou ao projeto de ingresso em uma universidade pública. Ele relata que as pessoas estranhavam muito o fato de ele ter ido realizar o Ensino Médio em outra cidade, insinuando que sua família dissimulava sua condição financeira "escondendo dinheiro”. De seu relato, pode-se depreender que estudar em Pedreiras era um fator de distinção, já que, como Pedro descreve, era reservado, sobretudo, aos filhos dos professores do Ensino Médio da própria Jardim. Por não terem a mesma oportunidade, esse estudante avalia que 
algumas pessoas tinham inveja ao pensar: "ele está num lugar onde eu não posso ir”. É por isso que ele afirma não se sentir acolhido na cidade, além de ter como firme decisão não voltar para lá depois de formado: “sob hipótese alguma eu voltaria para Jardim”. Falando a respeito do estranhamento dos moradores de Jardim, Pedro faz uma reflexão bastante pessoal de sua oposição à cidade: “... eu não sei até onde parte disso é verdadeiro e até onde é minha perseguição. Assim: eu não quero ter muito vínculo com esse pessoal, então eu digo: ‘eles me desprezam’ ou alguma coisa do tipo”. Pedro parece perguntar-se se sua relação com Jardim é resultado de um mecanismo psíquico de defesa ou marcas de real afastamento das pessoas, da cidade, dos costumes, dos valores, enfim, de um mundo cultural.

Essa oposição de Pedro em relação a Jardim parece-nos também estar relacionada, de certa forma, com a opção de seu pai de morar lá. Originário dessa cidade, o pai de Pedro morou em vários Estados, para onde se mudava a trabalho, e quando retornou a Minas Gerais, passou a residir em Pedreiras, onde conheceu a esposa; com o nascimento de Pedro, no entanto, ele mudou-se novamente para Jardim com a família. Esse estudante mostra-se bastante crítico em relação à escolha do pai, afirmando que, ao fazê-la, ele pôde desfrutar de uma "vida mais agradável”, contudo, abriu mão de oportunidades, conforto e melhores condições socioeconômicas: “ele optou por uma vida simplezinha e é o que ele tem hoje...”. Conta que a família da mãe foi contra a mudança de cidade na época e compara a situação socioeconômica de sua família com a de vários tios, concluindo que todos estão em condições financeiras melhores, alguns por terem "ousado” mais; afirma ainda que sua família é o "lado menos abastado" tanto da parte materna quanto paterna. A escassez de recursos financeiros vivida pela família de Pedro está, de algum modo, relacionada à opção do pai de "voltar para as raízes”. Isso, evidentemente, repercutiu na vida de Pedro, tornando necessária a ajuda dos tios para viabilizar a continuidade de seus estudos.

Se para o pai de Pedro residir em Jardim significa estar em contato com suas raízes, para ele essa cidade parece ter passado a representar uma experiência de desenraizamento.

Esse jovem prestou o exame do vestibular em quatro universidades públicas: USP, Unesp, Unicamp e Universidade Federal de Alfenas, tendo sido aprovado na primeira e na última. A escolha de onde estudar deu-se mais em virtude da 
assistência social existente em cada campus do que em decorrência de critérios acadêmicos. Tendo Pedro sido aprovado no vestibular, a preocupação de seus pais passou a ser como mantê-lo durante os estudos universitários. Apesar de Alfenas ser bem mais próxima a Jardim, computando todas as despesas, a escolha foi pela Universidade de São Paulo, por oferecer benefícios como refeitório, moradia estudantil e bolsa-trabalho, inexistentes na outra universidade. Assim, o suporte fornecido pela assistência estudantil foi fundamental para que esse estudante pudesse permanecer na universidade. Ademais, a gratuidade do ensino foi a única condição que tornou possível a esse jovem realizar um Curso Superior. Em suas palavras:

Eu acredito que se eu não tivesse passado, eu acho que a gente ia fazer loucuras para tentar pagar um cursinho de qualquer jeito para passar numa pública, porque eles [pais] tinham muito claro na cabeça que, por melhor ou equivalente que seja um ensino de uma particular, é inviável, não teria como a gente fazer isso daí.

Ao chegar à universidade, a primeira dificuldade com a qual Pedro se deparou foi a adaptação à nova cidade. Provir de um município de cinco mil habitantes e passar a morar em uma cidade de médio porte lhe exigiu várias mudanças, pelo fato “de tudo ser tão impressionante, de tudo ser tão diferente”. Nessa tarefa, todavia, ele pôde contar com a ajuda dos novos amigos da faculdade que, por vezes, o tratavam “meio como café com leite”. Pedro relata esse fato de maneira bastante tranqüila, sem parecer ofendido ou agredido; ele não recusa sua dependência (Gonçalves Filho, 1995), antes parece aceitar a ajuda do outro sem, com isso, sentir-se humilhado ou aviltado.

Já a adaptação à Universidade foi marcada por “choques” e "trancos”. O primeiro desafio foi residir na moradia estudantil. Pedro - filho único e sempre, segundo ele, muito "mimado" - passa a ter de dividir um quarto com mais duas pessoas desconhecidas e um apartamento com mais nove, o que ele afirma ter sido uma “experiência muito forte”35. Até então, esse jovem não tivera a experiência de compartilhar, dividir coisas, tendo o que ele denomina de "síndrome de filho único" com comportamentos “egoístas” ou “individualistas”. Quatro anos depois, ele afirma que “deu certo”, mas reforça que “de cara não foi bom”. O “choque violentíssimo”

\footnotetext{
${ }^{35}$ A moradia estudantil é composta por prédios de quatro apartamentos. Cada apartamento, por sua vez, possui uma cozinha, quatro quartos e dois banheiros. Em cada quarto residem dois estudantes, mas, às vezes, moram mais pessoas como hóspedes, cenário bastante comum principalmente no início do ano quando chegam os novos alunos.
} 
só parece não ter sido maior por ele ter contado com a colaboração dos companheiros de apartamento que deram "uma ajuda boa” no processo de adaptação à moradia. O fato de quase todos os doze moradores estarem vivendo a mesma experiência de chegada na Universidade parece ter contribuído para um melhor entendimento entre eles, pois, segundo esse jovem, não ocorreram brigas ou confusões, por vezes, comuns em alguns apartamentos.

Também o ingresso na faculdade, em termos acadêmicos, foi "outro tranco" para Pedro. Ele estranhou desde a diversidade didática dos professores até a realização de trabalhos em grupo, sendo essa "a grande novidade”. Relata que nunca tivera experiência de fazer trabalhos coletivos: no Ensino Fundamental eram raríssimas as atividades que envolviam duas pessoas ou mais e no Ensino Médio isso simplesmente não existia. Pedro assustou-se com o grande número de trabalhos em grupo e teve de se adaptar também a isso. Ele considera esse tipo de trabalho mais complexo por envolver, além de conteúdos acadêmicos, também o conhecimento das pessoas, pois entende que trabalhar em grupo implica trabalhar em conjunto com quem se tem mais afinidade. Ao longo da graduação, esse estudante pôde ir conhecendo melhor as pessoas de sua turma e hoje tem um grupo de trabalho definido. Além disso, Pedro sofreu com a grande diversidade de padrões de trabalho acadêmico existentes na universidade, tendo dificuldade de se adaptar a esse diferente estilo de funcionamento por não ter se habituado a estudar no Ensino Fundamental e por ter sido “tão treinado" no Ensino Médio:

aqui [universidade] já não, já foi tudo muito aberto, você vai pegar um livro, você vai ler, é um ritmo muito diferente... (...) até hoje eu tenho alguma dificuldade nisso daí. Muito por conta também da diferença com que cada professor dá matéria, da maneira como trabalha, então é uma loucura! Até hoje eu ainda não estou acostumado! Mas até o segundo ano era um negócio super difícil de eu me virar com isso daí; tinha professor que queria que você lesse antes, tinha outros que nem davam aula. E... Nossa! Era chocante o negócio!

Estando a menos de dois meses da sua formatura e pela ênfase do relato, parece que essa foi uma das adaptações mais complicadas com as quais Pedro teve de lidar.

Outra dificuldade enfrentada por esse estudante é a grande exigência do domínio da língua inglesa nas atividades acadêmicas. Ele afirma conseguir realizar as tarefas com a ajuda de um dicionário, contudo leva muito mais tempo do que a 
maioria dos colegas. Ao falar sobre isso, Pedro localiza a diferença existente entre ele e os colegas na questão da formação anterior, dos conhecimentos acumulados anteriormente e trazidos para a Universidade. Ele exemplifica isso contando a respeito de um amigo que, no início do curso, possuía um conhecimento prévio de Biologia “assustador”, o que levava Pedro a se perguntar onde ele teria aprendido tantas coisas. Mas, apesar de perceber tais diferenças, Pedro não se sente lesado:

...isso nunca me prejudicou muito, mas eu sempre sentia diferença disso daí, assim, dessa bagagem que o pessoal traz, porque era muita coisa! Ele sabia muito mais! Mas, dentro do que eu tenho, eu tenho conseguido estudar e tudo... Até que eu tenho bastante livro em relação assim ao pessoal da turma...

Tendo em vista seu desempenho acadêmico, de fato, parece não haver prejuízos. A trajetória universitária de Pedro é a de um "bom aluno”, não tendo em seu histórico escolar recuperações ou reprovações e estando seu rendimento escolar dentro da média da turma. Sua média ponderada é 7.5, uma boa nota para o curso e “na pior das hipóteses está razoável”, considera Pedro.

Além disso, Pedro não lamenta o fato de possuir uma "bagagem" de conhecimentos escolares aquém dos colegas. Percebe isso, mas não vive esse fato como algo prejudicial ou inferiorizante; antes procura apoiar-se naquilo que tem. Nesse processo, ele relata a sua busca por referências, representadas pelos livros. Se lhe faltam conhecimentos prévios, por outro lado ele tem a capacidade de estudar e para isso só lhe são necessários livros, aos quais esse estudante recorreu desesperadamente, principalmente no início do curso. Ele conta que, sobretudo no início da graduação, sentia necessidade de ter os livros para poder estudar, em parte porque a biblioteca não oferecia quantidade e variedade adequadas para atender a todos os alunos e em parte também por conta da experiência do colegial, quando tinha todo o material à sua disposição, podendo consultá-lo sempre que quisesse ou necessitasse. Para atender a essa necessidade, Pedro contou com o esforço, a compreensão e o apoio dos pais:

Então [pais falavam]: "se você acha que te é útil, se você acha que te é importante, a gente dá um jeito”. E aí era muito disso daí... E aí eu ficava desesperado: "ai, meu Deus, e agora? Eu preciso estudar tal coisa, tem um livro...”. Aí eles falavam: "olha, Pedro, se você acha que vai te ser útil, que é importante para você ter esse livro, você compra”. 
Sobre a possibilidade financeira de adquirir livros, Pedro relata que, até dois anos atrás, seu pai possuía um pequeno bar localizado na casa onde residiam cuja renda contribuía para o aumento do orçamento familiar; porém, como a residência era do avô paterno, essa atividade teve de ser interrompida com a venda da casa para a divisão da herança entre os tios. De toda forma, seus pais sempre se esforçaram muito para atender a essa demanda: "Eles nunca mediram esforços: 'se é para estudar, vamos dar um jeito, a gente se vira' ”. Eles acreditavam, baseados em suas experiências pessoais, que a cada função corresponde uma dada ferramenta e só com ela pode-se desempenhar adequadamente essa função. Se o trabalho a ser exercido pelo filho era o estudo, logo sua ferramenta eram os livros:

Uma coisa que minha mãe sempre falava assim: "Uma tarefa, um serviço, uma coisa, ela só é bem feita com a ferramenta certa”. E o meu pai sempre falava isso, ele é pedreiro, então ele falava isso: “como eu vou fazer um negócio se o serrote não está bom, se eu tenho um martelo pequeno sendo que eu vou pregar tora, não sei o quê”. Então era uma coisa da vivência deles: se preparar para função que você vai exercer.

É a "sabedora empírica” da qual nos fala Bosi (2005). Tratando do "materialismo animista" que caracteriza, segundo esse autor, a cultura popular e discorrendo sobre a matéria e a alma na vida cotidiana do homem pobre, ele afirma:

Materialismo, enquanto o homem pobre conhece, por força de suas obrigações diárias, o uso da matéria, lida com a terra ou com instrumentos mecânicos, que são o seu meio único de sobrevivência. Daí lhe vem um realismo, uma praticidade, um senso vivo dos limites e das possibilidades da sua ação, que convergem para uma sabedoria empírica muito arraigada, e que é a sua principal defesa numa economia adversa. (Bosi, 2005, p. 325)

Mas, com o tempo, Pedro pôde perceber que não precisaria ter todos os livros, que alguns temas ele nunca mais estudaria no decorrer no curso e que também poderia utilizar melhor os recursos oferecidos pela biblioteca. À medida que ele vai se adaptando mais ao novo mundo universitário, parece que sua necessidade de apoiar-se em referências concretas, como os livros, vai diminuindo: "Então nisso daí eu estou mais tranqüilo”.

O custeio da compra dos livros requisitados por Pedro é mais uma das ações que demonstram o grande valor que o estudo tem para seus pais. Como já dissemos, Pedro, ao contrário de seus amigos de Jardim e dos demais estudantes desta pesquisa, 
nunca trabalhou. Ele próprio reconhece que o fato de ter sido poupado do trabalho reflete a valorização do estudo pelos pais, que sempre frisavam sua condição privilegiada em relação a todos seus amigos que estavam trabalhando. Além disso, seus pais procuravam marcar as diferenças de perspectivas futuras de vida proporcionadas pelo trabalho e pela continuidade da escolarização; com um projeto mais a longo prazo para o filho, eles argumentavam que se o trabalho poderia trazer algum retorno financeiro imediato, o estudo representaria uma possibilidade de rendimento muito maior no futuro. Os pais de Pedro vêem a escolarização, em geral, como possibilidade de ascensão social e a escolarização prolongada do filho como um grande investimento. Ressentido, ao que nos parece, da impossibilidade de continuar a estudar, o pai de Pedro costuma dizer que se tivesse tido as oportunidades que o filho tem, hoje ele seria médico ou outro profissional de igual status. Seus pais gostariam que Pedro realizasse um curso tradicional de grande prestígio social e econômico, como, na visão deles, são os cursos de Medicina, Direito ou Engenharia. Eles não entendiam a opção do filho em cursar Biologia “pois nunca souberam muito bem o que era”; seu pai possuía uma visão estereotipada de que ser biólogo era algo para aventureiros e não uma profissão que pudesse proporcionar emprego e rendimento. Mas, apesar de não compreenderem e não aprovarem a escolha do filho, sempre respeitaram-na por acreditar em “vocação”. Esse respeito provém também da experiência pessoal do pai de Pedro cuja relação com o próprio pai era muito ruim por esse ser "muito bruto" e o obrigar a fazer as coisas: "acho que por conta da vivência dele, ele sempre viu que é o pior modo possível de se fazer as coisas”. Assim, os pais respeitam o desejo e a “vocação” do filho:

Eles não entendiam, não aceitavam muito bem, mas era uma escolha, então eles falavam assim: "não tem muito o quê se fazer...”. (...) então eles mais meio que aceitaram, mas nunca entendiam, nunca compreenderam bem isso daí. Acho que agora está melhorando isso daí.

No início do ano em que foram realizadas as entrevistas, Pedro sofreu um grave acidente, que deixou sérias seqüelas e exigiu a presença e a companhia de seus pais durante a hospitalização e algum tempo depois. Nesta estada, seu pai pôde conhecer a faculdade, os laboratórios e compreender melhor o que é ser biólogo e as possibilidades que a profissão oferece. Tal experiência é o que faz Pedro afirmar: “...acho que agora deu uma melhorada...”. 
A dificuldade de os pais de Pedro entenderem sua opção pela Biologia pode ser considerada conseqüência da distância cultural que separa seus cotidianos da universidade. O que eles conheciam como profissões de nível superior e achavam “muito bonito", mas mesmo assim vendo apenas "do lado de fora”, eram as carreiras mais tradicionais como Medicina ou Direito. A partir de seu universo cultural não lhes era possível conceber a Biologia como uma profissão, muito menos como a “ciência do século XXI” como se propaga hoje no meio acadêmico-científico, estando entre as carreiras mais concorridas. Todavia, a própria experiência universitária do filho pôde ajudar a mudar essa visão, permitindo uma ampliação de horizontes não só a Pedro mas também a seus pais. Além disso, quando esse jovem narra as diferenças de percepção dos pais, o faz de modo bastante tranqüilo, contando que seu pai, por exemplo, brinca que não consegue vê-lo laçando um jacaré ou pegando uma onça. A distância cultural entre pais e filho, que se acentua com a experiência universitária, não nos parece ser vivida como sofrimento e sim como oportunidade de crescimento para os três.

Se a dificuldade em compreender a escolha profissional do filho deriva da distância cultural, o respeito pela sua opção ou “vocação” é herança da formação católica dos pais de Pedro. Eles são muito religiosos e participam ativamente da Igreja: sua mãe foi catequista durante muito tempo e seu pai freqüentou um seminário, foi ministro de eucaristia e, atualmente, é coordenador, na Igreja de Jardim, da Pastoral dos enfermos ${ }^{36}$.

A despeito do grande engajamento dos pais com a Igreja, Pedro acabou se “desvirtuando”, já que ele não é católico praticante - “desgosto” para eles, que desejavam, inclusive, que o filho fosse padre. Tal desejo, entretanto, estava vinculado também à garantia de emprego e rendimento que essa atividade proporciona, na visão dos pais de Pedro que costumavam afirmar: "um negócio que sempre tem emprego, tem sempre vaga, é para ser padre; (...) não tem padre desempregado, ou coisa do tipo, né. (...) é um emprego muito bom, porque tem casa, não tem custo, só tem ganho...”. Esse jovem relata que quando residia em Jardim freqüentava a Igreja para assistir missas, mas nunca participou de outras atividades,

\footnotetext{
${ }^{36}$ A frequiência do pai de Pedro ao seminário, na visão do filho, foi a forma encontrada por ele de estudar, pois depois que fez supletivo completando o Ensino Fundamental, Pedro acha que ele acabou gostando do "troço".
} 
apesar do empenho e do estímulo dos pais, não chegando nem mesmo a fazer a crisma. Apesar da decepção com a atitude do filho, seus pais, numa postura semelhante ao respeito pela escolha profissional, também não o pressionam em relação a isso e conformam-se com a sua não-vocação religiosa.

A entrada na universidade acentuou o afastamento da religião ou, nas palavras de Pedro, “esse distanciamento ficou mais evidente”. O curso de Biologia, em especial, tornou ainda mais difícil a relação desse jovem com a religião:

...sempre que eu volto para Jardim eu vou na missa, aqui, por exemplo, eu não tenho como manter uma vida religiosa, não tem jeito, e nisso daí tem um afastamento, pelo próprio curso de Biologia, tem diversos questionamentos, assim, que faz, que dá uma abalada, né, que dá uma mexida, né, no final do primeiro ano mesmo eu fiquei... Nossa! Em choque! Eu fiquei perdido, sem rumo, nessa parte...

Embora o próprio Pedro classifique como um afastamento dos pais o fato de não ser católico praticante, ele é incisivo em afirmar que isso não é fonte de problema. Ele concebe o grande envolvimento dos pais com a Igreja como um reflexo de suas idades; considera que esse engajamento é característica mais predominante em pessoas mais velhas e não em jovens como ele e coloca em questão a devoção do pai na juventude:

Não sei se na minha idade meu pai era tão envolvido com a Igreja do jeito que ele é hoje, então nem me preocupo, é possível que ele tenha sido mais do que eu certamente... Mas eu não vejo isso como um problema.

Ademais, Pedro vê a religião como algo a ser cultivado, demandando tempo, dedicação, compromisso e devoção. Por isso, afirma ser muito difícil conciliar esse cultivo com a grande demanda acadêmica da universidade. Mas, além da disponibilidade de tempo, essa combinação é difícil, segundo ele, porque na faculdade, ao longo do Curso, a “cabeça vai mudando” e a conciliação da vida acadêmico-científica com o comportamento religioso torna-se cada vez mais complicada. Pedro afirma que tentou conciliar esses dois aspectos, mas é enfático ao dizer que não conseguiu e que não entende como algumas pessoas o fazem. Essa é uma questão de equacionamento delicado para Pedro, sendo fonte de angústia e confusão:

Essa é uma coisa que, nesse ponto, eu sinto uma certa necessidade de resolver. O que fazer? Mas, quando der tempo eu faço isso, ou 
seja, eu não sei quando... Estou adiando muito, mas é um negócio que me incomoda: ficar nesse meio termo, assim. Queria falar assim: ou é isso ou é aquilo, definir uma coisa. (...) Mas também não está dando certo... Continua uma névoa aí...

Pedro tentou freqüentar ou se inserir em alguns grupos religiosos que existem no campus universitário. Mas, decepcionou-se com a dinâmica dos encontros ou com o tipo de atividade desenvolvida. Ele queixa-se de não perceber "um crescimento" com o que era feito, não sendo um “culto declarado” nem tampouco proporcionando um “aprendizado efetivo”.

Essa última crítica remete-nos ao desejo de aprender e crescer de Pedro muito presente em sua relação com o conhecimento. Ele relata que quando fora cursar o Ensino Médio em Pedreiras tinha claro a sua vontade de continuar estudando; ao descobrir a possibilidade de realizar um Curso Superior isso se tornou a chance de dar continuidade à sua escolarização, estudando algo que lhe interessava e agradava muito - Biologia. A escolha desse curso nunca foi motivada por perspectivas de trabalho, emprego ou rendimento que a profissão pudesse lhe oferecer. O que Pedro desejava era entender, aprender e estudar mais. Sua vontade de aprender vai além de necessidades econômicas.

Pedro atribui a opção pela Biologia ao contato com a natureza propiciado por sua cidade natal e à relação com a sua família, contando, por exemplo, que seu pai gostava e o levava muito para passear no "mato". Falando a respeito de sua experiência com horta, pomar, criação de galinhas, Pedro reflete:

Acho que era por isso que eu não prestei agronomia, porque eu acho que é uma coisa muito técnica, eu queria entender mais, eu queria uma coisa mais teórica, não sei, mais ampla, esses cursos muito técnicos, muito aplicados, eu não via a faculdade dessa maneira, aprender a..., um treinamento mais sofisticado, né, mas mais de estudar coisas e entender do que ficar... Uma coisa mais de investigação, uma coisa mais desse tipo...

Pelo mesmo motivo, Pedro, apesar de ter cogitado prestar vestibular para o curso de Farmácia, também acabou desistindo dessa possibilidade. Em ambos os casos considera que fez a opção certa: "Mas eu não me arrependo, acho que o curso de Biologia foi uma escolha muito acertada, dentro do que eu tinha foi a melhor coisa que eu poderia fazer e eu gosto muito!” 
O desejo de Pedro de crescer e aprender mais através do acesso ao conhecimento pôde ser realizado, na sua trajetória, com o ingresso no Ensino Superior público.

Sobre o significado da entrada no curso de Biologia da Universidade de São Paulo, esse jovem afirma que foi uma "grande vitória”, um "grande prêmio” que ele conquistou como resultado de seus esforços, através de méritos próprios. A aprovação no vestibular parece ter significado também a chancela para que ele pudesse desfrutar do ensino oferecido pela Universidade: “a partir do momento que eu consegui, eu me vi como alguém bom o suficiente para poder usufruir disso daí”. Essa fala de Pedro traz à tona questões importantes para se pensar a presença do estudante de camadas populares na universidade pública.

Ter passado por uma grande “provação” - o vestibular -, e ter sido bem sucedido, isto é, conseguir ingressar em um curso de elevada seletividade na mais importante universidade do País, parece ser condição subjetiva necessária para que Pedro se sinta autorizado a aproveitar o que o ensino superior público tem a lhe oferecer. Sua fala nos faz pensar o quão difícil, sofrido e penoso é, para estudantes de camadas populares, sentirem-se merecedores da oportunidade de estudar em uma universidade pública. Embora Pedro não tenha se referido mais explicitamente sobre isso, seu relato remete-nos à dúvida crucial que, como vimos, também acometeu Marcos: eu tenho direito de estar na universidade pública? A resposta a essa pergunta parece ser: somente depois de vencida a árdua e quase intransponível barreira da seletividade do exame do vestibular; apenas assim Pedro pôde sentir-se tendo o direito de usufruir uma educação superior de qualidade ${ }^{37}$. Estando o sentimento de não ter direitos atrelado a uma situação de rebaixamento (Gonçalves Filho, 1995), a fala de Pedro também parece indicar que, após ser aprovado no vestibular, esse jovem sente-se em condições de igualdade em relação aos demais estudantes universitários que se tornam seus colegas. Tal igualdade, porém, é muito mais formal do que real, o que vários trabalhos sobre o tema (como, por exemplo, os de Portes, 1999 e de Almeida, 2006) já mostraram e que a própria experiência universitária desse estudante também demonstra. Contudo, essa igualdade, ainda que formal e muitas vezes encobridora de dificuldades, parece ser importante do ponto de vista

\footnotetext{
${ }^{37}$ Para uma discussão crítica acerca do exame do vestibular ver, por exemplo, Franco (1987) e Brandão (1987); para uma discussão histórica ver também Bonfim (2003).
} 
subjetivo: ao sentirem-se como iguais os estudantes de camadas populares fortalecem-se emocionalmente para enfrentar as desigualdades que são repostas no convívio social universitário e na vida acadêmico-científica.

Pedro fala ainda a respeito de uma grande “valorização” de sua imagem proporcionada pela aprovação no exame do vestibular e de um certo “deslumbramento", no sentido de uma idealização muito positiva, pelo curso de Biologia da USP. Esse fascínio inicial realimentava a sua boa auto-imagem: se o curso era bom, "então eu era muito bom”, diz Pedro. Todavia, com o passar do tempo e o contato com a realidade universitária, essa idealização se desfaz e esse jovem passa a perceber, por exemplo, falhas no curso e professores não comprometidos com o ensino. Assim, ao final de quatro anos de graduação, Pedro diz considerar a qualidade do curso que realizou como "razoável”, não o situando entre os melhores cursos de Biologia existentes no País - diferentemente do que pensava quando entrou na faculdade. Sua percepção, na verdade, parece ter oscilado para o lado oposto: se ao ingressar na Universidade ele tinha uma ótima visão do curso e de si mesmo, agora, ao sair, Pedro, não considerando ter feito um bom curso, diz se sentir despreparado seja para enfrentar o mercado de trabalho seja para fazer pós-graduação, tendo uma "sensação de inferioridade”: “Então, é bem essa sensação que eu sinto, agora fim de curso, fazendo um balanço das coisas, é uma certa frustração desse tempo todo...”

Vale lembrar, como já dissemos, que esse estudante está na iminência de formar-se, sendo que a segunda e última entrevista, em que ele falou sobre isso, foi realizada a menos de um mês da colação de grau. A sensação de despreparo e de desamparo é comum entre formandos. É importante informar também que, nessa mesma ocasião, Pedro estava finalizando um projeto de pesquisa a ser enviado para a Fapesp (Fundação de Amparo à Pesquisa do Estado de São Paulo) solicitando bolsa de auxílio à pesquisa. A realização desse projeto, que segundo Pedro estava apontando uma "possibilidade de trabalho muito boa”, redundará numa monografia, cuja defesa é requisito para a obtenção do grau de Bacharel em Biologia, que Pedro pretendia concluir no ano seguinte ${ }^{38}$.

\footnotetext{
${ }^{38}$ Esse é um recurso bastante utilizado pelos alunos do curso de Biologia: terminam as disciplinas, colam grau como Licenciados em Biologia e dedicam um ano para finalizar o trabalho de pesquisa, defender a monografia e formarem-se no Bacharelado.
} 
Mas, Pedro pode estar falando também a respeito de dificuldades que continuam acompanhando o aluno de camadas populares recém-egressos de universidades. Essa é uma importante questão e que merece maior atenção, exigindo a realização de pesquisas que acompanhem a saída desses alunos da universidade e sua trajetória profissional (a esse respeito, ver, por exemplo, trabalho coordenado por Spósito, 1995).

Se a sensação de Pedro no final do curso é de despreparo, durante o curso, no entanto, como vimos seu desempenho acadêmico foi bom. Para esse desempenho Pedro considera importante a ajuda dos trabalhos realizados em grupo. Aliás, como apontamos anteriormente, uma característica marcante na trajetória desse jovem é a possibilidade de sempre poder contar com a ajuda do outro: seus tios o ajudaram nas despesas escolares, os amigos da moradia ajudaram na adaptação à nova residência e os da faculdade na inserção na nova cidade. Pedro reconhece e valoriza essas contribuições em diferentes momentos de sua trajetória, sempre mencionando-as. Tal valorização não significa, entretanto, a renúncia ao seu compromisso e implicação pessoal: ele reconhece a ajuda do outro, mas não deixa de fazer sua parte. Isto é, Pedro aceita a colaboração do outro, sem com isso deixar de responsabilizar-se pela sua ação. Prova disso foi que, tendo lido a transcrição da primeira entrevista, esse jovem fez questão de frisar que a importância dos trabalhos em grupo deveu-se não a uma acomodação ou dependência em relação ao trabalho alheio para um bom desempenho acadêmico, mas sim à possibilidade de aprender com o outro ou, como ele denomina, de “aprender junto".

Além disso, Pedro considera que sua experiência escolar anterior contribuiu, em vários sentidos, para sua experiência universitária, fornecendo-lhe recursos para enfrentar diferentes desafios. Esse estudante afirma com bastante segurança que sua experiência tanto na escola pública quanto na particular, bem como a transição de uma para outra, o ajudaram na faculdade. Considera que o Ensino Médio lhe ajudou a ter mais disciplina, o que foi importante durante a graduação. Mas, é em sua experiência na escola pública, que esse jovem localiza vários aprendizados que foram essenciais e fizeram diferença para sua experiência universitária. Conta, por exemplo, que a "maneira de levar a coisa mais flexível” característica de sua experiência escolar até a $8^{\text {a }}$ série contribuiu para que ele não se desesperasse tanto quanto alguns colegas diante de tarefas acadêmicas ou de acúmulo de trabalho. Fala 
a respeito de colegas de turma que sempre estudaram em escola particular mas que, embora sejam ótimos alunos, tirando boas notas, perdem muito no tocante ao relacionamento e ao envolvimento com as pessoas. Segundo Pedro, esses estudantes são pessoas muito “devotadas” à faculdade em sentido acadêmico, como se a vida se resumisse a isso. Ele explica que tal afirmação não implica ser displicente com as atividades escolares, mas sim expandir a experiência universitária, abrindo-se para aprender com ela num sentido mais amplo: “As pessoas nesse esforço, né, de ‘faculdade é o mundo’ continua a mesma de lá atrás...”. Essa abertura, que Pedro considera influência de sua experiência na escola pública contribui, por sua vez, para que ele possa vivenciar mais intensamente o mundo universitário, deixando-se modificar por ele, ou seja, permitindo que ele altere seu modo de ser, sua visão de mundo. Esse estudante também fala a respeito da possibilidade de aproveitar outras coisas que a Universidade proporciona mas que não estão na sala de aula, como atividades extracurriculares e resume as contribuições de sua experiência escolar pregressa para a atual:

O colegial ele foi um bom disciplinador, mas em cima de uma coisa que o outro já tinha antes, do ensino fundamental, e eu acho que tudo isso daí me ajudou bastante aqui na universidade. Então, além da vida acadêmica, vamos aproveitar as outras coisas da universidade.

Esse estudante acrescenta outro aprendizado que a experiência na escola pública lhe proporcionou e que julgamos de extrema importância na sua trajetória e fundamental para sua experiência universitária; assim como Marcos, Pedro considera que sua experiência na escola pública o ajudou a aprender a responsabilizar-se pela sua formação: “a escola por si só não oferece tudo, tem que correr atrás...”. Lembrase também de outra situação em que essa experiência o ajudou muito: as greves na universidade. Pedro relata que para muitos colegas de sua turma, passar pelas greves foi “chocante”, impressionante, enquanto para ele, por já ter se deparado com isso outras vezes, foi uma oportunidade de reflexão acerca, por exemplo, dos motivos que levam a esse tipo de mobilização: “...como não era algo tão, não é que era comum também, mas já tinha acontecido antes, deu para elaborar, para parar para pensar, e aí: 'Por que isso acontece?’ ”. 
Assim, se o Ensino Médio particular ajudou Pedro a entrar na universidade pública por melhor subsidiá-lo com os conhecimentos exigidos no vestibular, a experiência na escola pública o ajudou a melhor entendê-la e desfrutá-la.

Em sua trajetória escolar, Pedro tem contado com a ajuda de muitas pessoas, tornando-a um empreendimento coletivo. Mas, ao mesmo tempo em que ele reconhece e valoriza tal auxílio, esse jovem assume a responsabilidade de sua ação, não recusando sua dependência e tampouco abdicando da iniciativa. 


\section{Entrevista na íntegra}

\section{$1^{\text {a }}$ Entrevista}

Débora: Então, você estava falando que você fez pré-escola, né, lá em...

Pedro: É, toda a parte de ensino fundamental eu fiz lá em Jardim [cidade natal], a cidade é bem pequenininha, daí fiz o pré, até a $8^{\text {a }}$ eu fiz lá e o ensino médio eu fiz em Pedreiras [cidade vizinha] porque lá na cidade mesmo tinha o ensino médio, mas era noturno e tal, e aí, era um ensino muito fraco, não tinha muitas condições, daí a gente deu um jeito de eu estudar fora. Bem, nesse comecinho eu acho que eu estudava sempre de manhã, é, era sempre de manhã e foi relativamente tranqüilo, era um aluno, era dos melhores lá, pelo padrão que tinha assim do pessoal, eu conseguia um destaque razoável e... Eu não lembro direito como, assim, que era, mas eu acho que era relativamente tranqüilo... Sempre em escola pública. E, aí, acho que foi em 99, é foi em 99 que eu entrei no colegial, aí eu tinha prestado o vestibulinho para entrar no Capital [escola particular] em Pedreiras, aí eu tinha conseguido uma bolsa lá, tal, só que aí meu tio, ele tinha alguma influência na escola, nessa escola de ensino médio...

\section{D: Esse seu tio ele é o que?}

P: É que essas escolas acho que é da maçonaria e o irmão da minha mãe é muito envolvido nisso daí, tanto que um ano depois, quando eu estava no $2^{\circ}$ colegial ele assumiu a diretoria de uma das escolas. Daí ele deu um jeito, ele passou a minha bolsa do Capital [escola particular] para o A. [outra escola particular] e aí eu estudei lá e, aí... é a minha mãe tem três irmãos, esse irmão e duas irmãs - uma em Pedreiras e uma em São Paulo. Esse tio, ele me ajudava com o custo do material e da mensalidade - a mensalidade em si eu não pagava -, eu pagava só o custo do material que era da escola, e essa minha tia de São Paulo, ela me pagava minha viagem de Jardim a Pedreiras todo dia... Lá em Pedreiras a aula ia das sete da manhã até uma da tarde. Eu acordava cedo pegava o ônibus, depois voltava e almoçava às duas horas da tarde em casa. E aí foram eles que viabilizaram tudo isso daí, me ajudaram bastante... Mais pro finalzinho, aí já era $3^{\circ}$ ano, do lado do meu pai, um tio me ajudou com um curso de inglês que eu ia precisar muito para prestar vestibular naquele ano e foi bem estratégico. Lá em Pedreiras era um colégio de... Bem elitizado lá, o lugar, né, então... Eu não senti uma situação de preconceito assim forte, mas eu sentia que era diferente ali, não era um lugar muito, muito... Eu não estava acostumado com aquela realidade, o pessoal estava... Ia em festas, não sei o quê, compravam coisas, foram a tais lugares, coisas que não passava na [minha] cabeça. Mas era um pessoal que não me destratava não, nunca tive problemas... (pausa)

D: E o vestibulinho, você teve uma boa colocação e por isso você conseguiu a bolsa?

P: Eu tive, eu saí como o terceiro melhor da minha cidade, assim, mas não foram muitos os que prestaram, acho que foram nove ao todo, não eram tantos até, mas daí eu tinha conseguido talvez menos da metade da bolsa, menos de $50 \%$ de bolsa, e aí em cima disso ele [tio] conseguiu fazer mais alguma coisa. Quem estava na minha frente, eu não lembro se... Eu não lembro se era por desistência, ou se era realmente por pontuação, se quem estava em primeiro lugar e daí corria, eu não lembro, mas aí eu lembro que quem era, quem estava nas melhores posições que eu, né, não tinha condições financeiras disso, de fazer, naquele ano eu acho que eu fui o único a estudar em Pedreiras Tinha mais uns... Todo ano acho que entrava mais ou menos 
dois ou três em Pedreiras, ficava fazendo essa viagem, mas no ano seguinte entrou bastante, acho que foi uns cinco, eu acho, mas a maior parte talvez eram filhos de professores lá da cidade mesmo, da escola do ensino médio, então o pessoal se esforçava bastante para tentar que os filhos estudassem fora, né, porque ali não tinha... ia para particular... [porque ali] não tinha muito embasamento.

D: Era nessa escola que você estudou, que você fez o Ensino fundamental, que tinha o ensino médio à noite?

P: Foi, foi, como a escola é muito pequena, só tinha essa escola na época, aí, pequena, desde o pré até acho que já tinha o ensino médio, aí recentemente que fracionaram, até mais ou menos a $4^{\mathrm{a}}$ série estuda na escola municipal e o resto foi para estadual, mas ainda, é praticamente uma escola ainda... não tem escola particular na minha cidade. Até o pessoal estranha: “nossa, estudou em Pedreiras!”, não sei o quê...[fala "enrolada”]

D: Como? Não entendi.

P: Assim: pelas minhas condições nunca foi possível [estudar em outra cidade], mas a gente estava dando um jeito, o pessoal dificilmente pensava assim, o pessoal pensava que a gente estava escondendo dinheiro que a gente tem, alguma coisa desse tipo...

D: Pessoal na cidade estranhava...; cidade pequena, todo mundo sabia...

P: É, estranhava bastante: “Nossa, está estudando em Pedreiras!”. Não sei o quê... Então, era... Muito por conta disso... Era, acho que muito por conta disso, era desagradável, você vai conversar assim, fala que você está na USP, o pessoal dá até uma... [faz gesto e expressão de admiração], num primeiro momento admira, não sei o quê, mas também tem, tem muito essa coisa de, certa inveja, de... Então, não me sinto muito acolhido lá, não... (pausa)

D: Tem outras pessoas na cidade que entraram na universidade, na universidade pública?

P: Não, acho que eu fui o primeiro, eu fui o primeiro, já tinha, já tinha, já tem o pessoal que já há algum tempo ingressa, mas, por exemplo, em Pedreiras tem a PUC, e tem algumas outras particulares ali na região, em S. e B. [cidades], e aí já tem um pessoal que faz faculdade, mas em pública eu acho que até então não tinha, não tinha, aí depois no ano seguinte que eu entrei... Não, calma... No ano que eu entrei, entrou mais um rapaz na farmácia numa federal lá de Minas e dali depois de dois anos entrou uma menina inclusive aqui, faz fisioterapia...

D: Então, está bem representada a população da sua cidade aqui! (risadas)

P: (rindo) É, no dia, até no ano em que ela entrou, a gente até brincava que dobrou a população de Jardim no campus! Mas aí a gente não conseguiu manter mais o ritmo, porque se mantivesse assim, ia esvaziar a cidade, o pessoal ficava brincado! (rindo) Porque é pequenininha, acho que não tem cinco mil habitantes lá... É bem pequena... (pausa) Aí, eram muito poucas pessoas, aí agora deve ter umas cinco ou seis pessoas que estão fazendo pública hoje, contando comigo, mas na particular o pessoal já tem um tempo fazendo, não muito... Geralmente as pessoas fazem curso noturno... (pausa)

D: E das primeiras séries, o que quê você lembra, da $1^{\mathrm{a}}$ série, da entrada na escola? 
P: Ih... Por essa eu não esperava... O que mais me marcou, não sei, foi na primeira série ou na segunda? (pausa) Não sei... Acho que foi... Era que trocava, trocou muito de professor, trocou acho que umas três, não, trocou acho que umas quatro vezes de professor, foi uma professora por bimestre, tinha trocado muito... Mas, no resto, era relativamente tranqüilo... Nossa! Não lembro! Ah, lembrei de uma coisa agora, no pré eu tinha começado a fazer ele de manhã, que era, o ensino era praticamente o mesmo, né, e aí, mas na metade do ano, mais ou menos, eu passei para turma da tarde, minha mãe ficava muito preocupada que eu ficava levantando muito cedo, eu sempre tive uns problemas respiratórios, eu estava passando mal, e aí tinha conseguido trocar. E aí era bastante simples as coisas da escola, eu resolvia bem assim (?). No primeiro ano trocou bastante, no segundo eu acho que foi um ano legal até... (pausa) Na terceira série eu lembro que era uma turma boa e foi... O que mais me marca, foi muito marcante na $3^{\mathrm{a}}$ série: tinha duas turmas, duas salas de manhã, acho que ainda deveria ter turma à tarde, eu acho, acho que a $3^{\text {a }}$ série era uma das primeiras séries do ensino fundamental que já tinha aula durante a manhã, $1^{\mathrm{a}}$ e $2^{\mathrm{a}}$ era à tarde, e aí $3^{\mathrm{a}}$ já tinha de manhã, era isso, e de manhã tinha duas turmas, e, aí, eu lembro que era, nossa! Era evidente! Fizeram duas turmas: uma com os alunos melhores e uma com os alunos piores, (?) eles acabavam não admitindo muito isso daí, mas, assim, as próprias atividades que a gente fazia, a gente sentia que era uma turma mais, melhor de serviço, né, o professor exigia muito mais da gente, porque a gente via a outra sala que era do lado, né, a professora ficava a maior parte do tempo pedindo disciplina por conta de bagunça, não sei o quê e tudo o mais, e aí acho que chegou em outubro, eu acho, ela já não dava mais conta da turma, e aí tinha ficado muito, aquela lá, aquela turma era uma turma mais para conseguir segurar o ano, a nossa já era para estudar mais. Aí no $4^{\circ}$ já tinha dado uma homogeneizada, aí já... Não lembro... Foi na $5^{\mathrm{a}}$ série? Na $5^{\mathrm{a}}$ série que começou a ser dividido: um professor para cada disciplina, até a $4^{\text {a }}$ série era uma professora só... da sexta série eu lembro mais de... bagunça, assim, no recreio...

D: Você fazia bagunça?

P: Na aula nem tanto. Nossa, mas brigava demais no recreio! Brigava, brigava muito, foi até, na sexta, na sexta série era pior, mas na oitava ainda tinha alguma coisa, mas era estupidez de moleque, ficar batendo nos outros, não sei o quê... Era bem complicado isso daí até. Tanto foi até que eu estranhei muito quando eu fui para Pedreiras, o pessoal era super cordial, era mais tranqüilo, eu era super agressivo, né, e tal... (?) Não tinha que arrumar encrenca, né, não precisava...

Eu lembro, inclusive, que tinha entrado um cara que a família dele tinha vindo de São Paulo, até hoje não entendo direito porque eles foram para Jardim, estava fugindo da violência, não sei o quê... A gente recebeu super mal o cara! Não conversava com ele, juntava, batia nele, umas coisas bestas, assim. E em Pedreiras depois que eu fiquei... Que eu me vi como uma pessoa vindo de outra escola, eu me coloquei assim no lugar dele e... Nossa! Nem se compara a recepção que eu tive, foi muito mais tranqüilo e eu fiquei pensando muito nisso... na forma como eu tinha sido recebido que era super diferente... (pausa)

D: E, como era a relação com os colegas, você já está falando um pouquinho, e como é que era no ensino fundamental, depois no ensino médio, na classe você tinha amigos? 
P: (pausa) Eu era, não sei, não era de grandes convivências, não lembro direito, eu lembro mais dessa relação assim por conta de recreio, na aula mesmo eu sempre fui muito sossegado, sempre fui... Era muito tímido também, também não conversava tanto com o pessoal, mas era... Lá dificilmente tinha alguma atividade em grupo, (?) às vezes, algumas tarefinhas por semana que tinha que fazer, de atividade lá não era muito... Tinha muito, uma professora de geografia, a partir da $6^{a}$ série, ela passava os filmes e aí tinha que fazer relato em grupo, assim, mas era a única coisa que tinha... E... Era difícil mesmo estudar fora do horário que estava na escola, não é uma coisa que me marca assim, de estar fazendo tarefa em casa, alguma pesquisa por bimestre, talvez...

D: Lição de casa também não tinha?

P: Muito pouquinho, muito pouco, ou eram coisas muito simplezinhas, sei lá, em meia hora dava conta, eu lembro mais de ficar à toa do que de estudar mesmo...

(...)

Mas eu lembro pouquíssimo de estudar fora do horário, muitas coisas... A gente tinha todos os livros porque o estado fornecia o livro didático, não sei o quê, mas a leitura, geralmente, a gente fazia em sala de aula, não é como a gente está acostumado, hoje em dia, o professor dá aula e fala para ler tal capítulo de livro ou então uma leitura prévia, lá, não tinha... Difícil... (pausa) Eu lia mais era durante a aula...

D: E no colegial?

P: No colegial já mudou bastante, pelo próprio sistema de ensino lá, né, eles davam uma aula, expõe, não sei o quê, a aula era num formato muito rígido, tinha que obedecer sempre o mesmo protocolo: era uma exposição, intercalava com alguma atividade, dava uma melhorada na, assim, durante o exercício, para trabalhar de novo o conceito, e para casa todo dia: leitura, bastante leitura e exercício para fixação, né, era, geralmente, eu tinha seis disciplinas, seis matérias por dia, e a cada dia era, sei lá, a leitura, não era, a leitura até que não era muita, mas eu lembro que tinha uns 20 exercícios por aula, então aí, era toda uma mudança brusca no ensino... No próprio período de estudo, que eu fazia acho que era uma hora a mais do que estava acostumado de manhã, e ainda, por conta do deslocamento, eu acordava muito cedo, chegava no comecinho da tarde, já almoçava, dava uma enrolada, aí ficou um negócio habitual, né: duas, três horas de estudo por dia, aí até pegar mais ou menos o jeito, aí a partir do segundo ano, aí já ficava quatro, cinco horas estudando. Aí no ensino médio que eu comecei a estudar, chegava em casa, almoçava, fazia uma meia horinha, e estudava até a hora da janta, e, depois, geralmente, assistia televisão, não tinha... A qualidade do lazer não era muito boa...

D: Não tinha o que fazer?

P: É, porque tanto não tinha o que fazer por conta de... Por manter esse ritmo eu me afastei muito dos meus antigos amigos, e nessa época, todos, ou praticamente todos, já estavam trabalhando, e aí, ou era alguma coisa na agricultura porque lá tem muita lavoura de café ou mesmo olaria, o pessoal trabalhava, cerâmica, a cidade lá tem bastante argila, o pessoal desenvolve bastante essa atividade lá, ou então, algum trabalhinho no comércio na cidade mesmo, alguma coisa do tipo. E aí eu não tinha mais contato com esse pessoal porque praticamente as horas livres que eu tinha, esse pessoal já trabalhava, né, então aí, nossa! Foram anos tristes assim...! Sei lá, eu tinha três amigos assim... Então... 


\section{D: Você ficou mais sozinho assim?}

P: Fiquei, fiquei muito focado no estudo pelo tempo, né, aí, eu conversava bastante com o pessoal de Pedreiras, durante a aula, me dava super bem com eles, mas batia o sinal eu voltava para casa e acabava, né, não tinha, ir lá no fim de semana, depois eu vi, né, os outros lá de Jardim, que iam estudar lá em Pedreiras, que conciliavam muito melhor isso daí, eles iam para Pedreiras, iam visitar esses amigos, eles faziam coisas, levavam esse pessoal para conhecer, para passear em Jardim, coisas que não tinham me passado pela cabeça, que era possível, foi falta de..., de jeito mesmo... E então no terceiro ano, nossa! Eu fiquei muito infeliz, credo! Se eu não tivesse passado, acho que se eu não tivesse passado eu acho que não teria mais nenhum amigo... [difícil compreensão]

(pausa)

\section{D: E você passou no terceiro ano?}

P: É, eu passei direto, eu passei direto. Eu prestei, eu fiz quatro vestibulares, prestei USP, Unicamp e Unesp e na UFOA que é a federal de Alfenas que tinha biologia lá também. Na UFOA eu tinha prestado mais, assim, para garantir uma vaga, porque pela prova que eu via, né, eu pensava: “Essa aqui eu passo, tranqüilo!”. Aí a Unesp eu prestei Rio Claro porque eu achava que era mais perto, eu acho, também achava muito boa, aí eu prestei, tinha prestado Fuvest, aí tinha ficado em dúvida... teria aqui, em São Paulo e Piracicaba, é isso. Aí Piracicaba não tinha me agradado por conta de ser tradição da Esalq, curso de agronomia, tradição em outras coisas, curso era novo, aí pensei: "não deve ser um curso muito bom”, aí fiquei entre SP e P. [cidade onde se localiza o campus], SP eu estava pensando muito porque a irmã da minha mãe mora lá, talvez ficar na casa dela, mas ao mesmo tempo morrendo de medo de uma cidade daquele tamanho...

\section{D: Sair de Jardim e ir para São Paulo! (rindo)}

P: É...! Sair de casa já vai ser um choque, mas não precisa ser tão grande (sorrindo). Daí ficou naquela, né, P.[cidade onde se localiza o campus] tem uma coisa muito de ser uma cidade de saúde, mas assim, eu queria estudar mais essa coisa de pesquisa básica, fisiologia, mais essa parte assim, e P. parecia que dava, pelo próprio perfil do campus que é muito voltado para essa parte da saúde, mesmo, eu sempre gostei muito, não sei porque eu não cheguei a fazer... quer dizer eu sei porque não fiz isso, mas, assim, eu sempre achei muito interessante o curso de farmácia, então eu pensava talvez em estudar alguma coisa, não sei...

D: E por que você não prestou [farmácia]?

P: Então, eu lembrei, muito por conta de química, a química, química orgânica, química analítica, não sei o quê, é um curso de biológicas, mas a parte de exata é muito forte, né, e é um negócio que eu acho que eu não daria muito certo, eu acho que no colegial eu até... Se eu tivesse visto, assim, conhecido o curso de farmácia como eu conheço hoje, né, talvez até tivesse prestado, acho que no último ano eu gostava muito dessa coisa de cálculo, de exatas, não sei o quê. Mas eu não me arrependo, acho que o curso de biologia foi uma escolha muito acertada, dentro do que eu tinha foi a melhor coisa que eu poderia fazer e eu gosto muito! Nossa, eu não faria, hoje, eu não faria farmácia! Eu acho que não, seria até uma frustração. Bom, aí, bom... Daí eu decidi isso daí... Foi até um amigo meu que decidiu para mim no cara ou coroa - São Paulo ou P.[cidade onde se localiza o campus]. Foi porque a Fuvest 
eu tinha prestado mais assim como, porque "Fuvest é um vestibular super difícil!". Eu vou prestar mais para ser mais um das estatísticas que presta, quero ver como é que é a prova, eu não tinha... Eu tinha mais esperança de passar no vestibular da Unicamp, Unesp eu acho que tinha até uma certa garantia. Bom, aí eu passei em Alfenas, nem fui para segunda fase do vestibular da Unicamp e da Unesp eu fui para alguma lista de chamada, não sei, não lembro o número, acho que foi centésimo e alguma coisa, $5^{\text {a }}$ lista, alguma coisa do tipo. Aqui eu já passei direto. (pausa)

D: Aqui que você não tinha expectativa?

P: É. Aqui que eu menos imaginava que foi que deu certo. Ah, eu tinha passado aqui e em Alfenas. Alfenas é bem mais perto da minha cidade, mas a assistência que teria ia ficar mais caro do que estudar aqui, porque lá não tinha o refeitório, lá teria que ficar em alguma pensão ou alguma coisa do tipo e aqui: "vamos ver o que dá para fazer”... Aí já não era nem tanto pelo status de "nossa, vamos fazer USP”, não. Era: "o que quê dá para fazer”. Aí, foi ver: “ah, tem moradia estudantil, tem alimentação”. Na época eu tinha visto: "talvez tem como arrumar uma bolsa-trabalho, tem como ganhar algum dinheiro”. Coisa que em Alfenas não tinha, Alfenas, você colocava na ponta do lápis, só via gasto, e a faculdade também, em comparação com aqui, não era muito boa e... Vim para P.[cidade onde se localiza o campus], aí deu certo, P. tem um custo de vida alto e tudo, mas o custo que eu tenho aqui é mínimo, né, deu para me manter muito bem esses anos de curso aí...

D: E como é que você teve acesso a essas informações? Como é que você sabia que aqui tinha isso e lá em Alfenas não tinha?

P: Daqui eu vi tudo naquele manual, guia de profissões que vem junto com o material da Fuvest, que fala de cada profissão, antes disso ele fala do campus e da assistência em cada campus, e aí falava, né, por exemplo, não sei se é em Bauru que não tinha, por exemplo, alojamento, aí eu via que tinha, mas, assim, foi coisa que eu vi assim na hora, não imaginava passar aqui realmente, eu estava pensando mais nos outros. Meus pais buscavam sempre isso daí: eu ia prum lugar onde vai ter uma ajuda, onde vai ter um suporte, vai ter como estudar... Porque era realmente complicado arrumar dinheiro porque meus pais são bem mais velhos, eles têm hoje 60 anos e minha mãe aposentou já faz uns dez anos talvez, trabalhou de (?), trabalhou de caixa, fez um monte de trabalhos aí, e ela conseguiu aposentar. E meu pai, ele sempre foi pedreiro e ele teve um problema de coluna há alguns anos atrás e ele não agüenta mais trabalhar e por invalidez ele ganhou a aposentadoria.

Aí tem essa aposentaria da mãe e meu pai, ele demorou muito para conseguir e praticamente só dois salários mínimos, às vezes, meu pai faz um trabalhinho ou outro e tal, e... Então se não tivesse ajuda da família, que nem meus tios me ajudaram, aqui na faculdade também, essa minha tia de São Paulo me dá uma mesada de R\$100,00 por mês, e se não fosse por conta disso aí eu realmente não teria como, a renda é muito pequena, então era a grande preocupação deles, né: "como a gente vai conseguir estudar o Pedro Como a gente vai conseguir fazer isso daí?”. E aqui tinha uma espécie de assistência estudantil. Eu acredito que se eu não tivesse passado, eu acho que a gente ia fazer loucuras para tentar pagar um cursinho de qualquer jeito para passar numa pública porque eles tinham muito claro na cabeça que, por melhor ou equivalente que seja um ensino de uma particular, é inviável, não teria como a gente fazer isso daí.

D: E eles estudaram até que série? 
P: É, minha mãe ela fez, dos irmãos dela, ela foi a que mais estudou durante a juventude. Ela fez até o médio? Acho que ela fez o médio, ela fez técnico em contabilidade, alguma coisa do tipo. Meu pai, ele tinha estudado até a quarta série durante a juventude, e depois logo que ele tinha saído da cidade, ele estava trabalhando de pedreiro já, aí ele fez supletivo do ensino fundamental. Acho que o médio ele não chegou a concluir... Ele chegou a estudar uns tempos em seminário, (?) porque eu acho que não era lance de vocação, mas realmente era opção de estudo, né, para quem não tinha condições de se manter, é, então eu acho que ele fez mais por conta disso daí, tanto é que no penúltimo, no último ano ele parou, eu não tenho muito bem certeza porque, ele diz que fechou o seminário, tal, mas era a opção de estudo que ele tinha.

\section{D: Aí que ele fez o supletivo?}

P: Não, ele já tinha feito, eu acho, ele fez, aí ele... Pelo o que ele fala, ele teve uma experiência muito ruim das primeiras séries, da professora, ele comentava... Porque pelo o que ele fala, o ensino era muito dirigido para casa, era feito em casa, ela dava as tarefas e o pessoal da família mesmo que alfabetizava, não sei o quê, e... Não tinha isso na família dele, porque minha vó morreu quando ele tinha sete anos e meu avô era muito bruto, muito difícil, ele tinha até uma boa formação, ele era juiz de paz na cidade e tal, mas ele era super bravo, meu pai conta que a lembrança que ele tem dele é mais que ele apanhava dele do que essa coisa de ensinar. E aí, quando ele estava trabalhando, ... (?) e convenceu ele a voltar a estudar e aí ele pegou e fez supletivo, foi indo e acho que ele gostou do troço e acho que foi nisso daí que ele entrou no seminário, uma coisa assim.

\section{D: E ele era da sua cidade?}

P: Ele nasceu lá e aí aos 15 anos, aí ele já foi trabalhar, foi para outro lugar, esse seminário ele fez em, fez em Guaxupé, até a época que ele fez supletivo ele morava aqui em P.[cidade onde se localiza o campus], ele trabalhou aqui uns tempos. Mas ele, nossa! Meu pai viajou muito, não sei em que época, se antes ou depois dessa formação escolar, ele trabalhou no Paraná, Mato Grosso do Sul, ele viajou bastante, mas ele... E, aí, acho que há uns 30 anos, hoje ele está com 62, isso, há uns 30 anos, ele está lá em Minas, procurou se estabelecer por lá, aí ou morava em Pedreiras ou ali nas cidades da região, ficou um tempo viajando, depois... Minha mãe é de Pedreiras, os pais dela vieram de São Paulo, e aí moravam em Pedreiras, tinha um pouco da família lá, e praticamente passou a vida dela toda lá, e desde que eles se casaram, eles passavam um tempo em Jardim, um tempo em Pedreiras, e até que quando eu nasci eles ficaram de vez em Jardim Meu pai foi super criticado pela família da minha mãe, porque Jardim não tinha recurso, que era uma cidadezinha pequena, tanto que a escolarização teve que fazer tudo em Pedreiras porque a cidade mesmo não oferece muito suporte.

D: E a família da sua mãe continua lá em Pedreiras?

P: Continua, continua em Pedreiras. Os irmãos mesmo do meu pai moram em Pedreiras. Mas ele preferiu morar lá porque era "terra natal", que não sei o quê, que era muito apegado... Não sei, deu certo, mas eu não sei se eu arriscaria o que ele fez...

D: E os pais da sua mãe, o que eles faziam? 
P: Meu avô, ele, não me lembro se ele era (?) ou alguma coisa do tipo porque... eu não sei muito bem porque ele morreu quando ela era muito novinha, ela devia ter um ano ou alguma coisa assim, então... E aí minha vó, viúva, né, ela precisava sustentar os quatro, e ela trabalhava de lavadeira num colégio interno lá que tinha lá em Pedreiras, e ela lavava roupa. Nossa! Ela trabalhava demais e aí eles já muito cedo já começaram a trabalhar, os irmãos da minha mãe, ela foi acho que a que, ela era a caçula, ela começou a trabalhar mais tarde, tanto que, os mais velhos geralmente segurando as pontas para tentar que os mais jovens assim desse um jeito, não precisassem trabalhar tanto como eles tinham feito. Meu tio mesmo ele começou a trabalhar com dez anos, arrumava um serviço aqui, outro ali, ele conseguiu depois, retomando os estudos, ele conseguiu formar advogado, trabalhando numa empresa lá de Pedreiras, ele aposentou bem. Essa minha tia de São Paulo, ela conheceu o marido lá em Pedreiras mesmo e, aí, assim que eles casaram, eles foram para São Paulo. Ela não fez o que meu pai fez, eles foram bem mais ousados, foram para São Paulo, meu pai já quis voltar para as raízes... Esse meu tio montou uma gráfica, uma empresa pequenininha. E esse marido da irmã da minha mãe, ele era mecânico, essa que mora em Pedreiras e.... Do lado da minha mãe, a gente é o lado menos abastado que tem, do lado do meu pai acho que talvez... não tem ninguém rico do lado da minha mãe, mas eles têm uma vida razoável, uma vida legal... (pausa)

D: E daí Pedro, você passou no vestibular e como que foi chegar aqui?

P: Aí... Eu vim para moradia, né, aí foi uma experiência muito forte, né, porque eu sempre fui, sou filho único, sempre tive meu canto, sempre fui muito mimado, daí cheguei aqui, na época a gente estava em 12 até! Três por quarto, três em cada quarto, então era muita gente e aí... Foi.... Nossa! Foi um choque violentíssimo, né. Foi, não digo um trauma na minha vida, mas pela própria adequação mesmo. Até eu estava num apartamento muito bom assim, pessoal deu uma ajuda boa, quando eu entrei era, mais da metade do apartamento, era de calouro, então estava todo mundo ali no mesmo barco, então foi, eles deram uma boa ajuda também, porque tem muitos aí se (?) metem muito, dá pau, não sei o quê, eu não tive nada desses problemas aqui não. Na Faculdade foi duro, outro tranco, né, na parte acadêmica porque no ensino fundamental não estava habituado a estudar, no ensino médio eu estudava dentro daquele roteirozinho e aqui já não, já foi tudo muito aberto, você vai pegar um livro, você vai ler, é um ritmo muito diferente, então eu acho que até hoje, por conta de eu ter sido tão treinado no colegial, até hoje eu tenho alguma dificuldade nisso daí. Muito por conta também da diferença com que cada professor dá matéria, da maneira como trabalha, então é uma loucura! Até hoje eu ainda não estou acostumado! Mas até o segundo ano era um negócio super difícil de eu me virar com isso daí; tinha professor que queria que você lesse antes, tinha outros que nem davam aula. E nossa! Era chocante o negócio! Tinha a própria questão de trabalho em grupo, coisa que eu não estava acostumado muito, muito trabalho em grupo, toda disciplina tinha um trabalho em grupo para fazer ou que você entrega no fim do semestre ou mesmo para fazer uma atividade, e isso daí... Eu lembro que foi a grande novidade: no colegial nunca teve nada, e no ensino fundamental o que tinha era alguma atividade em dupla, mas bem pouquinho. Agora, aqui, não, muita coisa! Foi, foi bem diferente.

D: É difícil assim?

P: Não é difícil, mas é um, é uma forma, que ela envolve muito mais variáveis, então, não é simplesmente sair com um tema bom de trabalho, tem que montar um grupo 
certo e nisso daí, nesses quatro anos, você vai conhecendo as pessoas, vai vendo com quem tem melhores afinidades e tal... Eu estava brincando esses dias, estava relembrando o grupo de seminário do primeiro semestre, olhando hoje, nossa! É coisa que é impossível como que, em algum momento, nesse percurso, juntou aquelas pessoas para um trabalho em comum; são ritmos bem diferentes, né, eu estava pensando, tinha um cara que, ele é super inteligente tal, e tudo, mas um cara que não é muito, vamos dizer, empenhado, é um cara mais tranqüilo, faz o negócio de última hora e tinha uma menina que hoje a gente sempre fala da excelência dos trabalhos dela, faz pesquisa e não sei o quê, e ela gosta sempre de entregar as coisas com uns 15 dias de antecedência. (...) E aí eles estavam no mesmo grupo que eu, no primeiro semestre, e aí o trabalho saiu, e na época a gente mesmo não sabia, quer dizer, se não era com aquelas pessoas, com que outras poderiam ser? Então era uma coisa meio sorteio, quem estava ali do lado quando falou que tinha que fazer um trabalho grupo. Hoje já não, tem os grupos bem definidos, e eu falo assim muito da minha turma que tem panelinhas, no sentido de que as mesmas pessoas que fazem trabalho juntas, porque tem uma afinidade, porque esses trabalhos despendem muito tempo; uma coisa que a gente comentava, assim, você escolhe o grupo, você escolhe os amigos com quem você vai falar nos próximos seis meses, porque o resto do pessoal não tem muito como você manter muito contato. Mas a minha turma é super unida, o pessoal se dá super bem, tem as maiores afinidades com um ou outro, isso é normal, mas é um bom ambiente, eu acho... (pausa)

\section{D: E a convivência no dia a dia como é que é?}

P: Ah, eu acho que foi sempre muito boa, eu acho não teve, assim, grandes problemas... O pessoal, muito pela condição de eu vir de uma cidade muito pequena, de tudo ser tão impressionante, de tudo ser tão diferente, nossa! O pessoal me ajudou muito: horário de ônibus, onde procurar as coisas, onde fica no centro. O pessoal sempre me ajudou muito nessa parte, pessoal muito legal, pessoal até, muitas vezes, me tratava assim meio como “café com leite”... Sempre estava ali, dando ajuda, um apoio, assim, sempre quebrando um galho.

D: E a questão do rendimento na faculdade assim?

P: Meu desempenho acadêmico assim ele é bom, tem sido bom. Não é dos dez melhores da turma, mas está longe de ser dos piores. Mas eu não me vejo me esforçando tanto como, por exemplo, eu me esforçava no colegial, talvez um esforço um pouco menor, ou, é equivalente, mas talvez não seja tão direcionado, não sei. Mas tenho conseguido manter um nível bom tanto por conta dessas atividades em grupo e, aí, sempre eu tenho turmas muito boas, o pessoal de grupo, né, de trabalho, mas eu acho que eu tenho conseguido acompanhar. Eu tive muito problema por conta de... Porque eles exigem muita coisa em inglês e eu não tive essa formação, então é um negócio que até hoje eu peno bastante, eu preciso fazer alguma coisa é o dicionário ali do lado, né, já o pessoal da minha turma já chega, já passa o olho e já, isso daí que eu sinto diferença, né, da formação que eles trazem, né. Eu lembro que um amigo nosso que ele tinha um conhecimento prévio em biologia que era assustador, né: “mas aonde que ele estudou tudo isso, né?!” Era uma coisa assim... isso nunca me prejudicou muito, mas eu sempre sentia diferença disso daí, assim, dessa bagagem que o pessoal traz, porque era muita coisa! Ele sabia muito mais! Mas, dentro do que eu tenho, eu tenho conseguido estudar e tudo... Até que eu tenho bastante livro em relação assim ao pessoal da turma, agora nem tanto nos últimos 
tempos eu não tenho comprado muito, nos últimos dois anos, mas nos primeiros era desesperador, eu xerocava, eu comprava, eu precisava ter alguma referência ou alguma coisa assim, a biblioteca aqui na parte de biologia não é muito boa... E aí eu fui levando e fui passando esses anos aí de curso...

D: Você teve alguma reprovação?

P: Não, reprovação, nunca. Eu tirei notas baixas, cinco, mas pouco também, não chegaria a cinco notas menores do que 6,0. Minha média é sete. Sete e quanto? 7.5, eu acho. Nos outros semestres ela estava um pouco mais baixa 7.2, 7.3, esse ano que ela foi para 7.5. Mas não tive reprovação, recuperação, nada. Na pior das hipóteses, está razoável.

D: É uma média boa pro curso, né?

P: Eu considero que sim porque tem o programa de pós-graduação da biologia, tem dois programas - o de entomologia que é bem mais tradicional e tem o de biologia comparada que é novo - e eles exigem ter uma média superior a 7.0 para ingressar direto, nem precisa fazer a prova, aí tem uma prova de inglês, não sei se tem alguma coisa de gramática, mas a prova específica de biologia, tendo uma média acima de 7.0, você não precisa fazer. Então, eu considero uma nota boa, é uma nota, uma média, acho que a maior parte da turma tem nível, sei lá, não chegaria a $20 \%$ quem tem uma média maior do que isso hoje, eu acho, tudo entre 7,8 , e também acho que não chega a $20 \%$ quem tem nota abaixo de $7,6.5$, por exemplo. É normal...

D: E a relação com os professores, como é que é?

P: Acho que... uma relação boa, os professores, uns mais outros menos, tem professores que realmente não faz diferença: "é só um a mais que está passando na minha mão, é só uma turma a mais que eu tenho que aplicar prova”. Mas tem outros que tem uma interação legal, mais abertura, especialmente esse ano, né, acho que muito em função do acidente, nossa tenho conversado, nossa! Professores muito bacanas, marcam almoço, vai na casa de um, de outro. Mas, de modo geral, acho que tem uma boa abertura e talvez metade, metade não quer nem saber, aí já acho que é uma coisa meio inerente, assim, não está nem aí, para saber da vida do outro, mesmo para saber do andamento da disciplina, chega lá, faz a parte dele, como ele acha e fica por isso mesmo, professores assim para conversar são realmente muito poucos, a gente encontra no CV [centro de vivência], toma um café juntos, brinca, mas de maneira geral eu acho que é um relacionamento bom. Na parte de trabalhos eu nunca tive grandes problemas, mudança de prazos, quando buscava também ajuda para algum trabalho... Professores são até maleáveis, eu acho, em comparação com outros cursos que a gente ouve falar, por exemplo, eu moro com um cara da química e ele fala que os professores são super intransigentes; na biologia eu tive problema só com um professor: eu precisei mudar uma data da prova e ele me exigiu, ele colocou a coisa como sendo um certo privilégio, fazer em outro horário: “então você vai ser mais exigido”. Mas é um caso bem pontual. De resto acho que tem abertura....

D: Você chegou a fazer iniciação na biologia ou não?

P: Não, formalmente, não. Eu faço estágio em laboratório desde o segundo ano. Aí eu tinha entrado num laboratório aqui da química, entrei em fevereiro e saí acho que em outubro. Eu nunca tive muita disciplina para fazer essa parte, essa coisa de laboratório, então eu sempre via como algo que, se desse uma folga da graduação, né, tendo um tempinho eu vou lá, eu faço alguma coisa, mas nunca encarei com 
muita seriedade isso daí E, aí, nesse laboratório de química eu estava fazendo, mas não era aquilo, não deu muito certo, aí eu fiquei esse resto de ano... O que culminou para eu sair desse laboratório foram umas matérias muito difíceis, umas matérias muito complicadas, não estava dando conta, daí eu pedi as contas já lá. Daí, no ano seguinte, eu tentei ver alguma coisa na biologia, de certa forma eu sempre busquei alguma coisa a ver com planta; aqui na química era com enzimas, (?) cinética, bioquímica, não sei o quê, mas era de vegetais. E aí, no ano seguinte, teve alguma coisa de anatomia lá na biologia mesmo e aí não deu muito certo, e, aí, nesse meio tempo, uma amiga minha começou a desenvolver um trabalho lá na genética, aí ia ver as flores que as abelhas visitam, alguma coisa muito grande, era um trabalho muito grande, era complicado, e eu já ia dar uma ajuda para ela e, aí, como eu tinha saído lá da biologia, daí me interessei e, daí, eu fui muito pro trabalho com abelha, aí foi esse resto do terceiro ano, estava lá, mexia com botânica, mas o que tinha que fazer era mais com abelha, e aí, no ano passado mesmo, já vi que não estava dando certo, o professor era super enrolado, não tinha perspectiva de desenvolver o negócio e eu saí. Aí, eu fui aqui para farmácia, conversei com a professora, ela gostou que fosse um aluno da biologia, ela é bióloga, só que ela sempre trabalhou ali com o pessoal da farmácia, a própria formação dela, o próprio trabalho, o laboratório dela é de biologia, mas aconteceu que ela está na farmácia, e aí, só que, aí, ela só teria tempo, ela deu algumas orientações para estudar, só que ela falou que ela estava meio cheia e era para eu ir dali um tempo, só que teve o acidente e aí agora só em agosto que eu consegui retomar isso daí. E, aí, ela tinha me pedido o projeto, dei mais uma enrolada nela, pedi mais um prazo (sorrindo), mas acho que dá para fazer, está indicando assim uma possibilidade de trabalho muito boa, acho que agora vai! (rindo)

D: Pedro, e quando você começou a pensar a entrar na universidade, a fazer biologia? Como é que foi isso? De onde veio isso?

P: A biologia, acho que foi a partir do segundo ano, porque eu vi assim, a formação do colegial nessa escola era muito para fazer vestibular, era voltado pro vestibular, o produto final, vamos dizer assim, era aprovar o aluno no vestibular, daí eu comecei a pensar nesse negócio de vestibular e tal e eu sempre gostei muito de biologia.

D: Deixa eu só te perguntar uma coisa: você foi para essa escola sabendo disso, por isso, quando você saiu da sua cidade você já pensava em fazer uma faculdade...?

P: Fazer, acho que não, não, eu pensava... [toca telefone celular]

Eu sempre via, assim, que a grande expectativa, né, eu tinha essa idéia, mas não era muito clara, de estudar, ir estudando, estudando, mas não sabia muito bem como. Aí, no colegial que a coisa definiu um pouco melhor, né: "fazer uma, estudar numa faculdade, fazer alguma coisa assim”. E, aí, mais pro segundo ano que eu pensei: “ah, biologia, né”. Eu gostava muito da disciplina e aí não vi muito por, por trabalho, por trabalho, por oportunidade de emprego, alguma coisa assim, quando eu prestei, eu via mais assim: dar continuidade no estudo naquilo que eu gostava mesmo, até hoje...

[fim fita]

E aí, era muito disso daí, dar continuidade ao que me interessava, não muito... que nem eu via alguns assim: "ah, eu vou fazer tal coisa para trabalhar em...” - já estava ?projetando daqui uns 30 anos, né, “quero ser assim daqui...”, e aí, na cabeça deles já 
tinha esse perfil, eu num tinha muito... Até porque essas perspectivas elas foram mudando muito, né, antes de entrar na faculdade, você não tem muito bem como saber o que é isso daqui, né, por mais que você já (?) tenha visto, que você pense assim mil coisas, vai ser diferente, né, é muito complicado... E, aí, ao longo desses anos foi mudando: "nossa, o que fazer, agora, e não sei o quê...?” Ainda bem que não entra com uma meta bem definida como sair da faculdade porque certamente tende a frustrar muito, alguma coisa do tipo, então eu acho que é muito disso daí... Agora o curso de biologia, eu acho que é uma opção que tem a ver com os meus pais, não sei, meu pai sempre gostou de fazer caminhada no mato, não sei o quê, sempre me levou bastante... Minha vó mesmo sempre gostou muito de bicho e o próprio lugar lá, né, é um lugar super pequenininho, né, então, eu sempre tive um contato maior com a natureza, digamos assim. E em casa sempre... A gente morava numa outra casa antigamente que era um pouco maior, então tinha um quintal super grande, então tinha pomar, tinha horta, criava galinha, acho que essa coisa de mexer com horta, de mexer com planta, começou daí, né, meu pai fazia muito disso daí, aí manteve... Acho que era por isso que eu não prestei agronomia, porque eu acho que é uma coisa muito técnica, eu queria entender mais, eu queria uma coisa mais teórica, não sei, mais ampla, esses cursos muito técnicos, muito aplicados, eu não via a faculdade dessa maneira, aprender a..., um treinamento mais sofisticado, né, mas mais de estudar coisas e entender do que ficar... Uma coisa mais de investigação, uma coisa mais desse tipo...

\section{D: E como era a relação de seus pais com o estudo assim?}

P: Ah, eles sempre valorizaram muito, né, eles, eles sentiram, assim, muita falta de não terem feito isso, né, então eles ...(?) todo mundo, então eles falavam assim: "se eu tivesse a formação que você tem hoje, eu seria um médico ou alguma coisa do tipo, né”. E era algo que eles sempre, sempre quiseram, eles teriam muito gosto se eu fosse um médico, um engenheiro, né, porque é o mais “top de linha” que eles conhecem, né, tanto de status social, como econômico, e eles sempre viram o estudo, né, como veículo para isso daí, né, para permitir isso daí, né, então eles valorizavam demais o estudo, tanto que nunca precisei trabalhar, eles falavam assim “não...”, eles sempre falavam muito isso daí: "muitos de seus colegas estão aí trabalhando na roça, que não sei o quê e tudo mais..., por conta de necessidade ou mesmo só para não ficar desocupado...”. [toca telefone] Aí, e aí, sempre valorizaram muito isso daí... Ah, sim, e eles sempre falavam "pessoal está trabalhando, não sei o quê...” Mas, eles tinham muito claro que, por exemplo, começa a trabalhar e tal, vai, a pessoa (?)ganha seu poder aquisitivo mas dificilmente ela vai conseguir sair muito além disso. Então, eles sempre pensaram alguma coisa mais a longo prazo: "se o filho hoje pode ganhar um salário, ele estudando daqui para frente ele pode ganhar uns 10 salários que seja...” (...) Eles sempre deixaram essa idéia, sempre, eles sempre pensaram dessa maneira, sempre passaram isso, nessa questão de estudo... Tanto que valorizam para caramba, meu pai, muitas vezes, ficava falando por quê que eu não sou médico, não sei o quê, e tal... Aí agora ele veio para cá, né, e ele viu, mais ou menos, ele conheceu os laboratórios, aí ele viu, mais ou menos, que o trabalho de biólogo é um trabalho, que tem como ter estabilidade financeira, que tem como... (?) Sei lá, alguma coisa, assim, então acho que agora deu uma melhorada...

Ele falava muito assim, ele costumava brincar, falava assim: "não sei quê que você vai fazer...”, porque ele tinha uma impressão muito, por exemplo, aquelas coisas do “Globo repórter”, então vai lá um fulano lá no Pantanal e laça um jacaré, vai não sei 
o quê e pega uma onça, aí ele falava assim: "Pedro, eu não vejo você dando conta desse tipo de coisa, indo pro mato...!”. Ele via mais como um aventureiro, um cara que vai pro mato, vai..., né, não está muito nem aí com nada, né, e agora acho que eu consegui mostrar para eles que não: é um trabalho, é uma profissão, agora acho que... Porque foi sempre o que eles..., eles nunca tiveram muito, souberam muito bem o que era, por exemplo, formava médico, alguma coisa assim, mas eles sempre viam aquilo do lado de fora e achava aquilo muito bonito, então eles queriam que eu tivesse essa posição, acho que hoje eles vêem que não precisa ser necessariamente um médico, um engenheiro ou um advogado, tem mais coisa no mundo para se fazer, para se estudar, e tal...

D: Quando você resolveu prestar biologia eles foram contra, como é que foi?

P: Eles achavam muito estranho, não sei, mas... Eles sempre acharam muito estranho, mas, assim, eles sempre acreditaram muito na coisa de vocação: "se fulano tem vocação para isso, se ele tem vocação para isso, ele não vai ser outra coisa ou se ele vai ser, ele não vai desempenhar bem”. Meu pai falava isso muito dessa questão pelo próprio seminário, eu acredito: "fulano tem vocação para ser padre; por mais que ele vai fazer um trabalho, ele vai se formar para ter emprego...” Ele sempre falava assim: "um negócio que sempre tem emprego, tem sempre vaga é para ser padre”. Eles falavam, né: "não tem padre desempregado, ou coisa do tipo, né”. Então, eles falavam: "não, porque é um emprego muito bom, porque tem casa, não tem custo, só tem ganho...” Mas, era algo que eles tinham muito claro, assim, que eles faziam muita questão que eu fosse padre também, mas, eles falavam assim: “mas, já que não tem vocação para quê que vai forçar, vai obrigar, né? Contrariando, não tem como fazer isso...”. Na cabeça do meu pai isso sempre foi muito claro, nas coisinhas mais mínimas... muitas coisas que o pai dele sempre obrigou ele a fazer, quase tudo ele era obrigado a fazer, do trabalho, o modo como fazer tudo isso aí e eu acho que por conta da vivência dele, ele sempre viu que é o pior modo possível de se fazer as coisas. Então, eu falava assim: "eu quero ser biólogo". Eles não entendiam, não aceitavam muito bem, mas era uma escolha, então eles falavam assim: "não tem muito o quê se fazer...”. Teria como talvez mudar, fazer a pessoa mudar de opinião, ver que não está fazendo uma escolha muito legal, ou coisa do tipo, mas como eles não viram muito isso daí, então eles mais meio que aceitaram, mas nunca entendiam, nunca compreenderam bem isso daí. Acho que agora está melhorando isso daí.

D: E eles são religiosos?

P: Bastante, bastante. Meu pai fez o seminário, né, e acho que até uns cinco anos atrás, eu acho, ele foi ministro de eucaristia, e minha mãe, acho que até mais ou menos quando eu nasci, não, acho que até um pouco mais, acho que até uns 10, 15 anos atrás ela era catequista. Eles se conheceram num grupo da igreja, não sei o quê tem, então tem todo um contexto aí... Então, eles têm uma formação católica, assim, forte. Eu... acabei desvirtuando, né...

D: Você não é praticante?

P: Não, assim, sempre que eu volto para Jardim eu vou na missa, aqui, por exemplo, eu não tenho como manter uma vida religiosa, não tem jeito, e nisso daí tem um afastamento, pelo próprio curso de biologia, tem diversos questionamentos, assim, que faz, que dá uma abalada, né, que dá uma mexida, né, no final do primeiro ano mesmo eu fiquei... Nossa! Em choque! Eu fiquei perdido, sem rumo, nessa parte.... 
Agora está resolvido, está sossegado, né. Mas, aí, tem essa formação muito forte... até que eu não tenho praticado muito não... É desgosto para eles, né... Mas... (silêncio)

D: Conciliar teoria da evolução com Deus é difícil, né, Pedro?

P: É complicado, é muito complicado, nem sei se vai ser possível um dia, mas... ou se é mesmo necessário...

[Interrupção e encerramento da entrevista]

\section{$2^{\text {a }}$ Entrevista}

P: [falando a respeito do relato transcrito do primeiro encontro] Um negócio que eu fiquei pensando, eu li, eu não fiquei com essa impressão, mas eu lembro que do jeito que eu comentei muito, aquela coisa que eu tinha falado de muito trabalho em grupo, não sei o quê, aí talvez tenha passado a impressão, não sei, de que eu tenha acomodado muito, tenha dependido muito do trabalho dos outros. Mas não era bem nesse sentido, mais era questão de aprender junto, e tudo mais, mas a avaliação é uma coisa mais individual, porque não sei, eu fiquei pensando que deu a impressão de que eu fui bem esses anos porque eu tinha dependido dos outros...

D: Não, eu não fiquei com essa impressão, não. Quando você leu você ficou?

P: É, eu fiquei um pouco...

D: Então, é importante que você está comentando porque daí fica registrado. O que eu entendi do que você comentou foi a respeito da diferença de trabalhar em grupo porque antes você tinha dito que não tinha muito isso e da ajuda dos amigos.

P: É, é isso. Ah, é.

D: E, além disso, tem mais alguma coisa que você se lembrou, que você pensou, desde que a gente se encontrou?

P: (pausa) Ah, acho que não, não lembrei de nada não...

D: Então, tem algumas coisas que eu gostaria que você falasse um pouquinho mais e outras que você esclarecesse alguma coisa. Sobre a escola, você comentou de muita troca de professores, isso foi na $1^{\mathrm{a}}$ ou na $2^{\text {a }}$ ?

$\mathrm{P}$ : Acho que foi na $1^{\mathrm{a}}$ mesmo.

D: E o que quê te marcou disso, por que quê você se lembra disso? Como é que foi isso?

P: Eu estava lembrando que tanto na $1^{\mathrm{a}}$ quanto na $2^{\mathrm{a}}$ teve algumas trocas, mas na $1^{\mathrm{a}}$ acho que foi mais, achei que eu comentei, acho que foi praticamente uma professora por bimestre. Na $2^{\mathrm{a}}$ acho que trocou era meados de agosto ou setembro, a professora teve um problema e teve que se afastar. Eu não sei, que dava muito uma impressão de descaso, uma coisa nesse sentido, porque, naquela época, no pré chamava a professora de tia, né, então a professora tinha toda uma atenção, cuidado, ela demonstrava... (?). Aí na $1^{\mathrm{a}}$ série a hora que você está acostumando como é que trabalha, porque era muito diferente assim o jeito de trabalhar de uma professora para 
outra, era um tempo complicado porque estava alfabetizando, né, eu lembro que uma riscava o quadro assim como as linhas do caderno, e aí ia riscando aquelas letras enormes, a gente copiava, daí a outra já tinha um jeito mais ágil, daí trocou, a gente tinha que acostumar, e a matéria ficou tudo bagunçado, eu acho, né. Eu aprendi, não sei muito bem como, mas eu acho que poderia ter sofrido menos, nesse sentido.

D: E você lembra de ter se alfabetizado, ter aprendido a ler nessa $1^{\text {a }}$ série?

P: É aprender a ler, a formar sílabas foi nessa $1^{\text {a }}$ série... Aí, eu lembro que tinha uma professora que fazia uns cartõezinhos com o nome, já outra eu não conseguia aprender nem o nome dela para escrever no caderno, para fazer aquele cabeçalho. Foi bagunçado aquele ano...

D: Você não conseguia aprender o nome da professora?

P: É, porque essa outra $1^{\text {a }}$ professora ela dava uma cartolina, aí tinha o meu nome, o nome dela e o nome da escola, aí eu sabia como é que fazia o cabeçalho, dia tal, para assinar os trabalhinhos, não sei o quê. A outra, que pegou lá para outubro, novembro, acho que era Luciana, mas eu não lembrava do sobrenome, aí eu ficava tentando lembrar como é que faz, aí ela não arrumava nada, aí já em ritmo quase de férias... (pausa)

D: E você tinha comentado também que na $3^{\text {a }}$ série que tinha duas classes: uma boa e uma ruim e que isso era muito explícito. O que quê te chamava atenção, e o que você se lembra disso? Ou por que quê você se lembra disso de uma maneira tão forte?

P: Eu não sei se nas outras séries também teve isso daí, mas na $3^{\mathrm{a}}$ série era muito declarado... Na $3^{\mathrm{a}}$ série acho que marcou muito por causa daquela novidade que eu já falei porque era a primeira vez que eu estava voltando a estudar de manhã, o pré, a $1^{\text {a }}$ e a $2^{\mathrm{a}}$ eu estudei à tarde, e na $3^{\mathrm{a}}$ eu acho que já teve uma certa disciplina, eu era um dos mais novos da turma, não era tanto de aprontar, de fazer bagunça essas coisas, isso eram os mais velhos, e o que me marca mais era mais essa parte da aula, da escola mesmo, aí das outras eu já me lembro mais de bagunça, tal. Mas, eu acho que era muito por conta disso: que era uma coisa muito declarada pelos professores - um negócio que nos outros anos não teve, $6^{\mathrm{a}}$, $7^{\mathrm{a}}$, eu lembro que era uma coisa bem mais homogênea. Mas na $3^{\mathrm{a}}$, era escrachado: a turma A e a turma B - a preferência que dava, as atividades complementares, coisa extra-classe, a outra não tinha nada! Acho que era uma postura da diretoria na época.

D: E o que você pensa, o que quê te chamava atenção?

P: (pausa) É, é que é uma situação de preconceito na escola... Ainda mais vindo assim dos próprios professores... Sempre tem, mas é um negócio que é evitado ao máximo, nesse caso, eu não sei porque não tinha pudor nenhum em admitir um negócio desse. Então é uma situação super chata. Tinha um rendimento melhor da minha turma, eu concordo, mas pagar o preço por não homogeneizar isso daí acho que não vale a pena, por fazer essa distinção porque uns vão se dar muito bem e outros que vão continuar não se dando bem! Uma coisa meio desagradável... (pausa)

D: Você chegou a conhecer alguém dessa $3^{\mathrm{a}}$ série; você conhecia alguém?

P: (pausa) Conhecia, conhecia... Eu fui me entender mais com esse pessoal acho que foi na..., esses que são meus amigos mesmo, acho que fui conhecer melhor acho que foi na $6^{a}$ série, porque na época ainda tinha reprovação, então uma boa parte desse pessoal já era mais velho, e na classe que eu estava estavam os vizinhos, assim, tal, 
então eu conversava mais com eles, mas depois eu conversei com os outros, tal, o pessoal era mais fraquinho realmente, eles sempre falam que a $3^{\text {a }}$ série foi um ano meio complicado.

D: Eles sentiram isso?

P: É, eles sentiram bastante, né, porque a professora se afastou por causa do desgaste com a turma, não era nada, um problema de saúde, externo ou algo assim, não, o problema era por conta deles, isso ficou bem marcado... Então é isso daí.

D: E depois tem algum momento que vocês estudaram juntos?

P: Tem um amigo meu que estudou comigo acho que na $5^{\text {a }}$ série só... Um tinha caído de turma e um outro, o outro sempre conversou comigo mas... Uma das coisas que ele sempre lamentou é que a gente nunca tinha conseguido estudar junto, a gente caía sempre em sala separada. Mas pouquíssimos, pouquíssimos... Não estudei com muitos deles não, os que eu estudei com os que era das turmas separadas, mas com meus amigos dessa $3^{\text {a }} \mathrm{B}$ eu nunca estudei, não. (pausa)

D: Agora falando de um passado mais recente: você comentou que o fato de você ter estudado fora e depois ter entrado na faculdade era uma coisa que as pessoas estranhavam. Como é que era isso?

P: Era, eu não sei até onde parte disso é verdadeiro e até onde é minha perseguição. Assim: eu não quero ter muito vínculo com esse pessoal, então eu digo: "eles me desprezam" ou alguma coisa do tipo. Mas, sempre partiu de uma coisa de tios, não sei o quê, que ficam orgulhos porque eu estou estudando, "vai ser alguém na vida", alguma coisa do tipo. E aí sempre tinha um pessoal em Jardim que nunca ia ter essas condições, não iam ter essa oportunidade. Então, o pessoal ficava assim com uma inveja. E aí o pessoal ficava perguntando, mas tentava ver algum ponto para desmerecer: “ah, como você está fazendo?” não sei o quê, e aí via alguma coisinha para criticar em cima... Não era uma valorização, não era um elogio, queria ficar sabendo só para falar mal, alguma coisa do tipo, isso teve bastante, mas mais no começo, na faculdade não teve tanto, acho que teve mais quando eu fui estudar em outra cidade, e aí eles ficavam muito nessa, né: "fulano tem as oportunidades que eu não tenho", isso aí tinha bastante, um ou outro amigo que: "meu amigo está estudando, que bom, está fazendo uma coisa que ele gosta...”. Ficar feliz pelo outro. Geralmente é: “ele está num lugar que eu não posso ir.” (pausa)

D: E quando você estava fazendo o colegial, você falou que o $3^{\circ}$ colegial foi um ano triste. E o que quê você acha que aconteceu que foi um ano tão triste?

P: Não foi assim um ano tão triste, foi o ano que eu tive a melhor convivência da sala, até os amigos que eu eventualmente visito em Pedreiras são dessa época, não são nem do $1^{\circ}$, nem do $2^{\circ}$, mas esse pessoal do $3^{\circ}$. Então, na sala eu tinha uma convivência boa. Mas, é que era realmente muito exigido, o volume de coisas para estudar tinha praticamente dobrado do segundo para o terceiro, e tinha muito aquela cobrança: "no fim do ano tem vestibular”, então é um esforço que depende de cada um. Então, era se entregar ao estudo de qualquer jeito, estava ali para isso, então, era abraçar a causa e ir embora! Não tinha muito o quê se fazer... E realmente era coisa demais, demais! Porque lá era um esquema que tinha o primeiro, o segundo e aí no terceiro, tinha o terceiro e a revisão dos outros anos. Então, era o número de coisa para estudar era muito grande... Então, a gente ficava meio desesperado com isso... Não tinha como não ser... Se fosse pegar para valer para se preparar tinha que ter 
uma certa disciplina, um engajamento, que comprometia outras coisas, né. Em Jardim sim! Foi um ano triste! (ri)

D: E que coisas que teve que comprometer, assim?

P: Então, era um negócio que eu me via tão envolvido com aquilo, assim que eu não vejo nem o que eu deixei de fazer. Então, o que eu fiz? Eu estudei. Agora o resto que eu deixei de fazer, Ixe! Coloca tudo o que imaginar, coloca aí! Deixa aí, porque eu realmente eu nem lembro do que eu deixei de fazer. Pode até: eu não viajei, eu não... [interrupção para acertar o gravador]. No terceiro ano eu estudei. O resto eu não... (?) (silêncio)

D: Você comentou a respeito da inserção de seus pais na igreja. Você contou que sua mãe era catequista, mas já parou há algum tempo e seu pai foi ministro de eucaristia...

P: É, minha mãe acho que ela está realmente parada, não está mexendo com nada não. Meu pai, agora, ele assumiu uma pastoral - a Pastoral da Saúde - visita doente, não sei o quê, ele é coordenador desse grupo, é o que ele está fazendo no momento. Eu não sei se ele tem tido problema de novo com a paróquia, com o padre lá, mas ele está envolvido com isso daí.

É que lá é uma cidade pequenininha e lá não tinha padre, e daí, não sei como trouxeram um padre da Bélgica, faz muito tempo, meu pai recebeu ele, ajudou bastante e ele foi embora há uns quatro ou cinco anos, e o padre se envolveu muito com política, então ele arrumou confusão, e nisso daí ele estava meio se desentendendo com o meu pai e quem ele colocava nos cargos ali na paróquia era por conta de outros interesses, e meu pai foi ficando meio de lado, daí trocou o padre, meu pai começou a trabalhar mais, mas o padre acho que tem uma outra filosofia de trabalho, não sei como é que funciona o negócio lá, começou a descentralizar, meu pai fazia bastante coisa, era ministro, fazia catequese de crisma, não sei o quê, aí padre foi deixando ele de lado para trazer outras pessoas para paróquia, e aí o padre trouxe a idéia das pastorais e meu pai pegou uma. Mas aí está (...?) vai vir um outro padre lá, daí vamos ver como é que vai ficar.

(...) Há uns tempos atrás quando ele era ministro ele trazia para si muitas funções, e agora com essa postura nova do padre: "vamos fazer com que o máximo de pessoas trabalhem, quer dizer sobrepor funções o mínimo possível”, aí ele arrumou só essa lá, mas está indo bem.

(pausa)

D: E isso eles faziam desde antes de você nascer e também depois, né? E como é que era, você acompanhava, você ia junto?

P: Então, nessa parte eles têm muito desgosto, mas eu nunca tive muita vocação para coisa. É... Eles falavam em acompanhar, não sei o quê, eu nunca me importei não... E é um negócio que, de certa maneira, eles não gostam, mas também eles não pressionam muito. Eu não cheguei a fazer crisma, porque o curso, porque o bispo acho que ia uma vez por ano, alguma coisa do tipo, então o curso era uma vez só. Então daí eu lembro que estava tendo um monte de problema, que era época do terceiro ano, terceiro colegial, daí eu tinha prova no sábado, era uma loucura, e não dava tempo de ir no curso, eu acho que eu nem cheguei a ir no curso, e aí estava falando com o padre e ele falou: "olha a turma está muito adiantada, não tem como o 
Pedro entrar agora”. E deixou. Aí eu não fiz crisma em 2002, aí em 2003 eu entrei aqui, aí depois não teve jeito, e, aí, ele ficou, né... Apesar de toda a vocação dele, ele tem um filho que até hoje não fez crisma... E aí eles falavam muito para mim ir no grupo de jovens, retiro espiritual, não sei o quê, ele lembro que eu fui uma vez só e não... Aquele especificamente não tinha sido bem organizado, e aí... Mas eu falei: "olha, eu fui, conheci, não gostei muito...!" Mas eles incentivavam muito; parece que eles na juventude, eles foram muito nisso daí, participaram muito... Mas eu nunca tive muita vocação para Igreja, apesar da vontade deles, e é uma coisa que eles, de certa maneira, eles não gostam, mas até que eles respeitam de algum modo. Fala, reclama, mas... Deixa. Acaba ficando mais tranqüilo. (pausa)

D: Você tinha comentado sobre isso que "nisso daí tem um afastamento". Como é que você vê isso?

P: Ai... (pausa) Eu não vejo assim como um grande problema porque eu penso nos meus pais assim, até pela própria idade deles, eu vejo assim mais, não sei, eu tenho um pouco essa impressão assim: gente idosa se envolve mais com religião, uma coisa mais beata. Mas, eu sempre achei uma coisa muito descontextualizada, e aí eles sempre faziam um esforço para mostrar que não é bem assim - grupo de jovens, não sei o quê - mas eu não conseguia ver isso, então para mim ficou uma coisa muito, assim essa coisa de religião ficou muito em comparação a eles, e não, sei lá, ao pessoal da minha idade, então eu vejo até com uma certa naturalidade, esse comprometimento todo, esse engajamento, acho que é muito do tempo, não sei se na minha idade meu pai era tão envolvido com a Igreja do jeito que ele é hoje, então nem me preocupo, é possível que ele tenha sido mais do que eu certamente... Mas eu não vejo isso como um problema. (pausa)

D: Quando você diz "nisso daí” tem um afastamento, você quer dizer que em relação a outras coisas poderia ter também, mas você não sente isso?

P: Em relação a outras coisas? (pausa) Talvez, não sei... Não sei... Como assim?

D: Por exemplo, você está estudando, no nosso outro encontro você comentou um pouco sobre, por exemplo, essa questão e o fato de você estar fazendo biologia, por exemplo.

P: Ah! Sim. Ah, aí depois que eu entrei na faculdade o negócio ficou mais crítico ainda. Esse distanciamento ficou mais evidente... Ainda tento alguma coisa, mas eu assim não... Desde então, praticamente, eu não vou mais... Quando eu volto para Jardim, eu ainda vou à missa, mas é muito mais uma questão de respeito a eles, do que devoção propriamente dita, então é uma coisa de seguir a cultura da cidade, então é uma coisa de: respeitar os costumes. Agora envolvimento com isso, de devoção, já deixou de..., já perdeu sentido, já é outra coisa agora.

D: Aqui no campus você também nunca se envolveu com nenhuma comunidade?

P: Não, não. No primeiro ano aqui eu ainda ia na missa de domingo, fazia um certo esforço.

[fim lado A]

Aí no primeiro ano eu ia na missa, tinha um certo envolvimento, e aí eu cheguei a conhecer algumas das comunidades, da Aliança Bíblica, alguma coisa, eu fui num encontro deles uma vez, num almoço, não gostei do negócio. Eu fui convidado para ir numa missa de um grupo da renovação carismática, daí eu não achei que seria 
interessante, que renovação carismática meu pai mesmo não gostava muito, então eu nem (?)falei disso daí... (sorrindo) Daí esses outros grupos, tem a Aliança Bíblica, tem um outro ainda, já me abordaram, conversaram comigo. Uma vez eu cheguei a ir só para ver como é que era e não virou nada... Mas também só no primeiro ano, depois... (...) Eles liam um trecho da bíblia, faziam uma discussão, tentavam uma vivência, mas era um negócio muito, era subjetivo demais, aquilo era muito pessoal, partiam muito do conhecimento da própria pessoa, não tinha um crescimento com aquilo, não era uma coisa mais sistemática, não era um culto declarado, mas também não era um aprendizado efetivo, não deu certo. E aí o envolvimento com a Igreja é um negócio complicado, né, porque é um negócio que exige uma disciplina, você tem que ficar cultivando essa coisa da espiritualidade, e aqui eu não... E aí tanto por uma posição mais cômoda, pela própria correria não dá tempo de ir atrás dessas coisas, quanto também a cabeça vai mudando, e aí (?)necessidade de comprometimento ser... Então é mais complicado... Agora, por exemplo, estamos chegando na época do Natal. Eu lembro quando eu estava lá em Minas ainda o Natal ele tinha toda uma, o Natal ele fazia sentido quando existia uma preparação para o Natal: quatro domingos antes (?). Agora que nem vou chegar lá em Jardim semana que vem, já é Natal e eu ainda estou aqui trabalhando com projeto, ainda estou, quer dizer a cabeça está... E nisso daí não... Aí chega lá já está naquele clímax religioso. Eu não estou nesse pique! Então isso daí só piora a situação. É um negócio que você tem que trabalhar ao longo do ano todo, é um negócio que você cultiva, não tem como: “não, agora eu vou ser religioso!" Você é ao longo do tempo, e aí como eu não tenho conseguido fazer isso, aí vai se perdendo.

D: É difícil conciliar vida acadêmica com vida religiosa?

P: Ah... Não consegui, não consegui. Eu vi pouquíssimos casos que realmente conseguiram. Eu não entendo como, mas conseguiram... Manter o ritmo e ter uma espiritualidade, uma religiosidade, (?) realmente devotado para aquilo. Eu não consegui, não consegui.

D: Tem a própria questão da biologia também acho que mexe com isso, né?

P: Também mexeu um pouco, mexeu um pouco. Essa é uma coisa que, nesse ponto, eu sinto uma certa necessidade de resolver. O que fazer? Mas, quando der tempo eu faço isso, ou seja, eu não sei quando... Estou adiando muito, mas é um negócio que me incomoda: ficar nesse meio termo, assim. Queria falar assim: ou é isso ou é aquilo, definir uma coisa. Só para falar... (?) uma vontade... Mas também não está dando certo... Continua uma névoa aí... (sorrindo)

D: Agora falando da experiência aqui dentro, eu queria saber o que significou para você entrar na Universidade, na USP, no curso de biologia?

P: (breve pausa) Eu acredito que foi uma vitória muito grande, uma sensação de conquista... (?). Era algo que eu idealizei como um grande prêmio, uma grande vitória, e a partir do momento que eu consegui, eu me vi como alguém bom o suficiente para poder usufruir disso daí. Foi um cara que conseguiu pelos seus próprios méritos, fez por onde conseguir isso daí. Então era uma valorização da minha imagem muito boa. Isso daí mais no começo do curso. $E$ aí um deslumbramento do negócio, do curso... Mas com o tempo isso foi meio que passando, não sei... Eu acho que é um curso bom, e tal, mas eu não vejo como um dos melhores, no sentido de que essa imagem que tinha no começo do curso, então eu era muito bom. Eu estipulei (?). Agora olhando assim dentro da biologia, qualquer 
desafio que eu proponho eu fico vendo falhas em conseguir alcançar; hoje eu não me orgulho muito de ter feito biologia em P. [cidade onde se localiza o campus]. Eu fico vendo aquela coisa meio patriota, mais bairrista assim: "Na F. [faculdade] é um curso muito bom”. Pra mim não é um curso bom. Vira e mexe eu fico pensando nas defasagens do curso, é um curso razoável. Aí pessoal sempre fala: "não, mas se você olhar para fora é muito pior.” Realmente é. Só que não tem como comparar. Mas se for comparar com outras biologias também, essa daqui fica dos últimos. Então dá muito uma sensação de inferioridade.

D: Por exemplo, que outros cursos?

P: Por exemplo, biologia da Unicamp, de SP, da Esalq; de São Carlos é bom também. Outros eu não sei dizer, UFMG, UNB, deve ser mais ou menos isso também, não deve fugir muito disso, não. Mas, que nem, o da Unicamp, o da Esalq, é, eu não sei até onde o curso é realmente bom, mas tem um empenho, um certo comprometimento do departamento, do Instituto, sei lá, o quadro de professores é muito bom lá, e aqui é, tem um grupo que... Além de ser muito menor, acho que deve ser o menor departamento da Filô... Porque, por exemplo, o da Psico já está com bastante curso, né. Que nem tem licenciatura em química, em biologia. Que nem na Química, agora eles vão formar 100 químicos; é um departamento que já está virando um Instituto. Agora a Biologia tem lá seus 40 alunos e não contrata mais professores e não faz mais nada. Então nesse sentido. Daí eu fico pensando... Eu estava conversando com a minha orientadora e ela estava me falando que ela teve 14 disciplinas de botânica, eu tive cinco, seis no máximo!

D: Onde ela fez?

P: Ela fez na Unicamp. Ela estava falando, né, que na licenciatura dela... Eu fiz Psicologia da Educação. Ela disse que ela teve umas três, quatro psicologias, eu tive uma. Quer dizer... Da maneira como eu me preparei no colegial para enfrentar o desafio da etapa posterior, eu não me sinto nem um pouco preparado para enfrentar o desafio de ir para um mercado de trabalho ou uma pós-graduação. Eu fico pensando: "eu vou ter que tirar um tempo para me preparar". Vou ter que fazer algo semelhante a um cursinho, uma analogia: "ensino médio não foi bom, então eu vou batalhar num cursinho para dar certo”. Eu não precisei fazer para entrar na USP, mas acho que para sair daqui eu vou precisar de alguma coisa desse tipo. Então, é bem essa sensação que eu sinto, agora fim de curso, fazendo um balanço das coisas, é uma certa frustração desse tempo todo... (pausa)

D: E da sua trajetória tanto pessoal quanto escolar, você acha que essa tua história te ajudou a estar aqui na Universidade, enfrentar as coisas que foram aparecendo aqui?

P: Eu acredito que ajudou bastante. Também por outro lado complicou muito; que nem eu sou filho único, né, nunca tive, não sei o que é conviver com irmão, e aqui na moradia já foi uma experiência diferente, no começo teve: "mas como que é isso?" (?) Isso pintava muito. Síndrome de filho único, coisas muito egoístas, coisas muito individualistas, coisa da própria (?) pressão, você não está acostumado a dividir um quarto, por exemplo, coisa que foi... Aí deu certo, né, mas de cara não foi bom. Mas, muita coisa me ajudou muito. Eu acho que a disciplina que eu desenvolvi ao longo do Ensino Médio ajudou muito a me manter aqui... Eu acho que, de um modo mais, a maneira de levar a coisa mais flexível que eu tive até a $8^{a}$ série também fez com que eu não me desesperasse tanto, eu vejo pessoas que a vida toda estudaram em escola particular que tinha metas muito definidas, era uma pessoa praticamente 
condicionada, eu acho que tendo essa... E hoje na faculdade tiram notas boas e não sei o quê, mas perde muito na questão de relacionamento, de envolvimento com as pessoas; são pessoas muito devotadas à faculdade, do jeito que eu falei como se isso aqui fosse algo extremamente importante, como se fosse a melhor coisa do mundo e não é. Não que tenha que ser displicente, mas não é só isso daqui. As pessoas nesse esforço, né, de “faculdade é o mundo" continua a mesma de lá atrás, né. Eu acho que mesmo a transição de uma escola para outra, contribuiu bastante para isso daí, o próprio ensino fundamental: não se apegar tanto à escola no sentido acadêmico, é ver que a escola tem outras possibilidades, tem coisa a mais a oferecer, eu acho que isso ajuda bastante. O colegial ele foi um bom disciplinador, mas em cima de uma coisa que o outro já tinha antes, do ensino fundamental, e eu acho que tudo isso daí me ajudou bastante aqui na universidade. Então, além da vida acadêmica, vamos aproveitar as outras coisas da universidade.

D: Que coisas, você fala a escola tinha outras coisas a oferecer...?

P: Mais na questão de... Não é tanto uma coisa extra-classe, de outras atividades, culturais, coisa e tal, mas mais na questão da convivência mesmo, de ver que a escola por si só não oferece tudo, tem que correr atrás disso daí... Então, aqui tem bastante coisa além do currículo, bastante coisa, né, é aí é mais nesse sentido, aí entra atividades culturais, exposições, não sei o quê... O... Uma coisa que eu lembrei... Chegar aqui na Universidade e ver a quantidade de greves que teve, para muita gente isso foi chocante, e eu já, não que eu tivesse me envolvido, mas eu já tinha passado por algumas greves no ensino fundamental, então era algo que também já ajudou a lidar com uma certa naturalidade, de não ser um choque, de não ficar tão impressionado, seguir tranqüilo, pensar "por que tem greve, por que se faz isso".

D: Você percebia que alguns colegas tinham mais dificuldade de...?

P: Muita, muita. "Como assim greve? Eles são pagos para cumprir uma função e eles não estão fazendo! Eles querem ganhar mais e ele fazem isso?!” Quer dizer todo mundo já deve ter ouvido falar de greve, mas nunca ninguém, só assim: "ouve falar". E aí... Nisso daí, como não era algo tão, não é que era comum também, mas já tinha acontecido antes, deu para elaborar, para parar para pensar, e aí... "Por que isso acontece?”. Eu acho que foi bom, porque tinha muita gente nunca tinha visto nada. (...) A minha turma participava bastante. Essa coisa de centro estudantil, DCE, não muito, mas essa coisa de greve, eles participavam bastante. Até que ano passado, eles foram para SP, no veto do Alckmin, e eles voltaram bastante decepcionados porque teve alguns funcionários que foram para fazer arruaça, daí eles lá militando, e eles falaram: "Peraí não dá para ser assim". Daí eles pararam de ir. Mas o pessoal da minha turma até que agita bastante. (...) Tanto que em 2004 a gente obrigou os professores a entrar em greve, porque eles não queriam. Nós que fizemos. Aí depois de muita conversação eles paralisaram, com a greve, e aí teve uma reposição depois e correu tranqüilamente. Mas ali é difícil...

D: Você tinha comentado que no começo do curso você tinha necessidade de referência, e que você comprou bastante livro. Daí eu queria saber duas coisas: primeiro sobre a questão financeira e segundo é por que você tinha essa necessidade?

P: Bom, na questão financeira, meus pais, eles nunca mediram esforços: "se é para estudar, vamos dar um jeito, a gente se vira”. Na época, meu pai ainda tinha um negociozinho lá na cidade, então tinha uma rendinha, agora há uns dois anos já não 
tem mais, então a renda que tem é a aposentadoria de cada um e a mesada que minha tia manda de SPedreiras

D: O que era, o que ele fazia?

P: Era um barzinho. Na casinha antiga da família que a gente morava - a gente não tinha casa própria, era uma casa de herança, era a casa do meu avô, aí a casa começou a, estava com um monte de problema, aí meu pai falou: "eu arrumo a casa, eu cuido dela mas eu moro nela.” O aluguel seria a manutenção da casa, alguma coisa assim. Aí os irmãos meio que aceitaram, mas não gostaram muito, e aí foi levando. E aí há uns dois anos, a casa sempre esteve à venda, fechou o negócio, eles tinham mais um terreninho em Pedreiras, juntou mais um dinheirinho e comprou a casa onde a gente está hoje. A casa é pequena, mas é bem legal, a casinha... (?) E aí lá meu avô tinha venda, né, na época, há uns 50 anos atrás... E agora desmanchou toda a casa... (?) Mas eles sempre davam um jeito. Uma coisa que minha mãe sempre falava assim: "Uma tarefa, um serviço, uma coisa, ela só é bem feita com a ferramenta certa”. E o meu pai sempre falava isso, ele é pedreiro, então ele falava isso: "como eu vou fazer um negócio se o serrote não está bom, se eu tenho um martelo pequeno sendo que eu vou pregar tora, não sei o quê”. Então era uma coisa da vivência deles: se preparar para função que você vai exercer. Então, quer dizer, se eu preciso estudar, quais são as ferramentas que eu preciso? Eu preciso de livros para estudar. Então: "se você acha que te é útil, se você acha que te é importante, a gente dá um jeito”. E aí era muito disso daí... E aí eu ficava desesperado: “ai, meu Deus, e agora? Eu preciso estudar tal coisa, tem um livro...”. Aí eles falavam: “olha, Pedro, se você acha que vai te ser útil, que é importante para você ter esse livro, você compra”. Aí eu fui vendo que eu não precisaria ter todos os livros, não precisava sair correndo e ir lá comprar. É bom ter o livro, mas não é crucial, não é uma coisa emergencial, se tiver... (?). Então, eu comprei bastante livro no primeiro semestre, eu comprei acho que três livros, xeroquei uns cinco, aí foi bastante. Aí depois, aí no outro ano eu comprei um livro, no ano passado eu acho que eu nem comprei... E aí deu uma amenizada. Mas era muito nesse sentido, meus pais, nesse ponto, eles eram bastante práticos: "você precisa de uma coisa, ué, você tem que desempenhar essa função.”

\section{D: Mas esse desespero te deu mais no começo?}

P: É, mais no começo, eu comprei livros aí que eu vou até jogar fora. No primeiro semestre tinha uma disciplina que chamava "Complementos de matemática" e eu estava indo super mal na disciplina, daí eu falei: "eu vou comprar o livro". Hoje eu penso: "Por que eu comprei um livro de matemática?” Teve outros que já foram melhores, eu comprei um livro de botânica mais geral, e deu para usar em todas as disciplinas de biologia vegetal, eu usei. Biologia celular, eu xeroquei dois livros, foram importantes. Aí depois, eu fui vendo que não precisava ter ele para você... Porque, como no colegial aquelas apostilas e, às vezes, quando eu estava me preparando para prestar vestibular, então tinha muito essa coisa, essa necessidade de revisar o material: "ai, eu estudei um negócio no primeiro bimestre, eu não estou lembrando direito" então eu ia lá e consultava. Então eu tinha muito essa preocupação: "vai que uma hora eu preciso, já está aqui, né”. Só que aí, não necessariamente, porque tem coisa que você estuda naquela vez e é só aquela vez, você não vai precisar ficar recorrendo àquilo. E se precisar também, tem a biblioteca, aprender a usar melhor esse recurso. Então, coisas que eu acho que são mais 
abrangentes, que eu gosto de, vira e mexe, de dar uma olhadinha, então eu compro, xeroco, mas com o tempo eu vi que não tem necessidade, levou um tempo para ver isso... (rindo)

(pausa)

D: Você tinha comentado que seu pai quis voltar para a cidade onde ele nasceu, que deu certo, mas que você não faria o que ele fez. E por que quê você não faria?

P: Por conta das opções de vida, porque é um certo retrocesso, porque se acostumou a viver com mais recurso, vamos dizer assim. Por exemplo, qualquer problema de saúde tem que ir para Pedreiras

[fim da fita]

Como eu estava falando, não tem uma assistência médica adequada. A cidade também lá não oferece um lazer de qualidade, não tem nada lá. Então, é nesse monte de coisa. Apesar de ser um lugar pequeno, de relativamente fácil acesso, você vai para qualquer lugar a pé, mas também esse tudo é pouca coisa. Então vira e mexe, alguma coisa que precisa, tem ir para Pedreiras, alguma coisa nesse sentido. Então, é se submeter a condições quase mais precárias de vida. Está sempre dependendo de alguma coisa, Pedreiras também não é auto-suficiente, agora tem coisa que... Mas é fazer uma opção por uma vida extremamente simples, não precisa ser tão... Não é nem humildade lá, sei lá... Coisa de, de regredir mesmo, uma opção por uma condição menos confortável de vida. Então, eu acho muito nesse ponto... Eu não vejo nenhuma vantagem nisso, está certo que hoje eu moro em P. [cidade onde se localiza o campus], mas eu penso em morar, por exemplo, em Pedreiras, que não me oferece tudo o que P. oferece, mas ainda assim eu acho que seria uma vantagem. Fazendo um paralelo, por exemplo, Pedreiras tem quase, sei lá, 200 mil habitantes, P. tem seu meio milhão, sei lá, três vezes mais. Jardim não! Cinco mil! Quer dizer, proporcionalmente, o progresso em uma e outra é muito, é uma discrepância muito grande... P. não me agrada tanto, mas sob hipótese alguma eu voltaria para Jardim (pausa)

D: E para o seu pai você acha também que de certa forma foi uma regressão? Por que ele morava em Pedreiras?

P: É, foi. Ele levou uma vida mais agradável, mas na questão de conforto, com certeza ele teria muito mais condições... É muito da opção que ele fez, ele optou por ter uma vida mais simplezinha e é o que ele tem hoje, não tem muita coisa... Esse fim de semana eu voltei para lá para ir numa formatura de uma prima e eu encontrei um amigo que formou lá. A gente era amigo, né, até mais ou menos os dez anos e daí ele mudou para Pedreiras E a família está bem, os irmãos dele, ele estava formando no curso técnico, está todo mundo empregado, está todo mundo levando uma vida boa, está todo mundo meio estabilizado lá em Pedreiras Eu vejo mais uma questão de... É se permitir ter boas oportunidades, coisa que ele abriu mão a partir do momento em que ele resolveu ir para Jardim Ele limitou muito as chances dele, pois em Jardim é muito mais difícil ser bem sucedido, e foi isso o que aconteceu... Acho que é mais por aí. 
D: Uma última coisa que eu me lembrei agora: você conseguiu bolsa numa escola e depois você mudou para outra. Por que você mudou de uma escola para outra?

P: Então, foi, minha mãe foi lá e falou com esses meus dois tios - com esse meu tio de Pedreiras que estava envolvido com a escola e com essa tia de SP que ajudou a custear. E eles acharam melhor [mudar do Capital para o A.] pelo próprio, pelo perfil da outra escola que era um público um pouco mais elitizado, eu acho, um pessoal mais arrogante mesmo... (rindo) E questão de preço, eu acho que era mesma coisa, eu acho que era muito por conta do perfil e também o sistema de ensino, meus tios acreditavam mais no A., no Capital [escolas particulares] eles não sentiam... Meu tio ele estava muito mais envolvido com a direção da outra escola. Era o Capital e o A., os dois eles são vinculados à maçonaria, mas ele sempre teve um trânsito, uma ligação bem maior com o "Pelicano", com o A. E eu acho que foi muito por conta disso, foi uma decisão deles. A questão de preço eu acho que não faria diferença, acho que ia ficar mesma coisa. Era bem a questão do público.

D: Eles queriam que você estudasse, convivesse mais com essas pessoas?

P: É, eles achavam que assim o Capital [escola particular] era um pessoal mais esnobe, parece, eles falavam, eu não cheguei a conhecer esse pessoal para ver como era isso daí, mas então eles achavam que ia ter muito problema nessa parte, que era um povo muito orgulhoso, um povo muito arrogante, um povo que talvez iria me humilhar muito. E eles achavam que no A. [escola particular] eu teria uma convivência mais legal. E eu não senti esse problema no A., há uma diferença, mas, assim, não era um preconceito, era uma constatação, existia realmente uma diferença, mas não que aquilo fosse agressivo, que aquilo me violentasse, e no Capital, na cabeça deles, era o que iria acontecer. E aí tinha o lance do sistema de ensino, mas eu acho que isso não foi... Teve um peso secundário, deve ter contado mas nem tanto. (pausa)

D: Tem alguma coisa que você gostaria de acrescentar, de falar?

P: (silêncio) Acho que não... Você vai falando, vai lembrando de um monte de coisa, hoje eu lembrei de coisa, nossa, do fundo do baú! Eu nem lembrava que tinha passado por uma greve... Acho que não, Débora. Mas acho que é isso... Espero ter ajudado em alguma coisa.

D: Com certeza! Então, eu quero agradecer Pedro. 


\subsection{Antônio e o desejo de aprender}

Antônio, 23 anos, é aluno do décimo semestre do curso de Farmácia ${ }^{39}$. Proveniente de uma pequena cidade mineira é residente da moradia estudantil desde seu ingresso na USP, onde ocorreram nossos encontros. Quando nos conhecemos, Antônio acabara de ser aprovado na seleção do Mestrado em Farmácia e, na ocasião da primeira entrevista, sua colação de grau havia ocorrido há poucos dias.

Seu pai, atualmente aposentado, cursou até a $3^{\mathrm{a}}$ série e trabalhou como fundidor em uma empresa de cerâmica. Sua mãe estudou até a $4^{\mathrm{a}}$ série e trabalhou em casa como costureira prestando serviços para uma fábrica de confecções até recentemente, quando seu irmão, de 22 anos, que possui Ensino Médio, passou a trabalhar na mesma empresa em que o pai trabalhou, dispensado, assim, a necessidade do trabalho remunerado materno. Antônio tem ainda uma irmã de 17 anos que cursa o segundo ano do Ensino Médio na mesma escola pública onde estudou o irmão. A renda familiar é de aproximadamente R\$1.500,00, excluído o rendimento de seu irmão. Antônio explica que, por vezes, quando a mãe costurava, esse valor poderia aumentar dependendo do volume de costuras realizadas no mês.

Sobre o avô paterno, Antônio afirma que ele, embora nunca tenha freqüentado a escola, aprendeu a ler sozinho e lia muito, tendo, inclusive, lido toda a Bíblia; da avó paterna esse jovem afirma apenas que ela sabia ler. Do lado materno, seu avô não sabe ler e escrever e sua avó aprendeu a ler antes de freqüentar a escola, tendo completado a $4^{\mathrm{a}}$ série do Ensino Fundamental já adulta no Mobral (Movimento Brasileiro de Alfabetização); ele conta ainda que a avó materna sempre teve vontade de estudar, não tendo, porém, oportunidades de fazê-lo.

Antônio realizou a Pré-escola e o Ensino Fundamental em uma escola pública estadual, considerada uma ótima escola. Sua experiência na Educação Infantil, no entanto, não foi muito satisfatória, pois ele não gostava de realizar algumas das atividades mais comuns nessa etapa da Educação - desenhar e pintar. Isso por um motivo que marca a sua história escolar e de vida: um desejo imenso de aprender. Esse jovem conta que tinha muita vontade de entrar na escola, porém sentia-se "meio deslocado" no pré porque o que ele queria era aprender a ler, a escrever e a fazer contas e não realizar atividades artísticas. Tais atividades eram feitas de modo muito

\footnotetext{
${ }^{39}$ A duração desse Curso é de dez semestres.
} 
rápido e sem nenhum esmero por Antônio, que procurava findar logo o que via como obrigação para poder ocupar-se do que realmente lhe interessava:

...assim, eu pintava um pouquinho e aí ia lá e ia conversar com ela [professora] sobre outra coisa: “como é que escreve isso? Como é que acontece isso? Por que quê o céu é azul? Como é que faz uma conta de multiplicação? Como é que escreve caixa?” Sabe? Eu queria saber essas coisas e a professora acabava dando atenção. Mas, pintura, desenho, eu fazia o mais porco possível, assim, não estava nem aí e entregava assim para professora e mudava o assunto. Quando na Pré-escola era aula de escrita, a gente tinha escrita também, [aula] de conta, de matemática, aí eu gostava mais. Mas quando era esse ambiente de pintura, assim, dia festivo - Dia da Árvore, Dia do índio - eu odiava, eu não gostava, ficar pintando, assim, ixe! Eu sou canhoto ainda... Com a mão boba... Nossa! Pintar era, era muito ruim! A minha letra é feia, eu sempre tive problema com professor por causa da minha letra.

Todavia, Antônio diz que seu desgosto por esse tipo de atividade nunca foi motivo de repreensão por parte da professora de Educação Infantil, que entendia seu apreço pela leitura e escrita e lhe dava atenção, como seu próprio relato nos mostra. Sua letra, feia até hoje segundo ele, por vezes tornava-se motivo de desespero para os professores, como no caso da professora da $1^{\mathrm{a}}$ série que dizia que ele era relaxado e a da $3^{\text {a }}$ que ameaçava colocá-lo de castigo por conta disso. Ainda assim, Antônio afirma não se lembrar de que isso o tenha atrapalhado ou mesmo tenha sido fonte de algum “estresse”: “pelo menos não que eu me lembre...”, reforça ele.

Foi a partir da $1^{\text {a }}$ série que seu desejo pôde, finalmente, ser realizado quando ele aprendeu a ler, a escrever e a fazer operações matemáticas básicas. Seu relato parece falar a respeito de um novo mundo que se abriu com o domínio da leitura e da escrita e das muitas possibilidades que isso lhe trouxe: “Aí não parou mais!”. Esse estudante afirma que a partir desse momento adaptou-se bem à escola; acrescenta que durante toda sua experiência escolar sempre gostou muito de ler, principalmente a respeito de História e Geografia.

Esse jovem fala ainda a respeito da contribuição da mídia televisiva para seu desejo de aprender e como forma de acesso ao conhecimento. Ele conta que, quando criança, assistia muito a programas educativos na tv, querendo fazer, imitar ou ter como profissão quase tudo o que via, desejando, por exemplo, ser astronauta e cientista, profissões essas só conhecidas através da televisão. Seu relato nos remete ao trabalho de Setton (2005) que discute a importância da mídia como forma de acesso ao conhecimento e complemento à escola para os estudantes de camadas 
populares. A autora defende a idéia de que a mídia seria uma nova fonte de recursos, potencializando disposições de alunos pobres e contribuindo para o seu "sucesso escolar”, ao constituir um "novo capital cultural”.

Antônio afirma que não conhecia ninguém que já fosse à escola ou algo semelhante que explicasse seu desejo de ingressar na escola para aprender a ler, escrever e contar; nos oferece, no entanto, algumas pistas para entender um pouco mais sobre essa vontade enorme de aprender. Conta que a mãe lhe dava jogos, cadernos, lápis (ele montou um quebra-cabeça com três anos de idade) e que o ensinou a escrever seu nome e de alguns familiares; contudo, esse jovem não vê isso como "ensino" da leitura e da escrita, caracterizando o que aprendera como "coisinha leve". Embora essa postura da mãe não atendesse plenamente à sua "vontade absurda” de aprender a ler e a escrever, parece-nos ter contribuído para, pelo menos, aumentar seu desejo de acesso ao conhecimento escolar. Antônio conta-nos ainda outro fato que reforça essa idéia: sua mãe, quando jovem, gostava de estudar e queria ser professora, mas como residia na zona rural e era a filha mais velha - não se beneficiando da mudança posterior para a cidade como os tios de Antônio - não pôde dar continuidade à sua escolarização. Quando passou a residir na cidade aprendeu o ofício de costureira, ocupação que a avó materna de Antônio desejava exercer, mas que não lhe foi possível. Esse estudante considera tal fato interessante já que, hoje, sua mãe, por sua vez, quer que sua irmã seja professora. Ele esquece-se, nessa comparação, que ele próprio, como veremos, também deseja ser professor.

Mas, apesar do apreço da mãe pelo estudo, ela nunca acompanhou mais proximamente a escolarização de Antônio. Isso porque ele ia muito bem na escola, fato comentado por muitos professores que, por exemplo, dispensavam a presença da mãe nas reuniões. O contrário ocorria com seu irmão, um ano e meio mais novo, que não gostava de estudar, ficava sempre de recuperação, foi reprovado em uma série e, por isso, demandava muito mais a atenção e o acompanhamento maternos.

A trajetória escolar de Antônio até a $4^{\mathrm{a}}$ série foi exemplar: seu desempenho acadêmico era muito bom, sempre tirando boas notas e, além da dedicação à escola, esse estudante procurava também estudar conteúdos extras às matérias escolares. Esse percurso, entretanto, sofreu uma ruptura na $5^{\mathrm{a}}$ série quando ele se tornou, em suas palavras, um “picareta”, perdendo o interesse pela escola: não estudava, não 
fazia os deveres de casa, ficava de castigo na escola e suas notas pioraram ${ }^{40}$. Ele atribui seu desvirtuamento à influência de amizades feitas nessa série com alunos que não gostavam de estudar. Sua mãe, que parece ter estado sempre muito atenta ao comportamento dos filhos, ao primeiro sinal de desvio, providenciou uma rápida correção de rota. Juntamente com a avó materna de Antônio, ela lhe deu um sermão no final daquele ano e o encaminhou para o trabalho: na $6^{\mathrm{a}}$ série Antônio continuou a estudar de manhã e passou a trabalhar como ajudante de tapeceiro numa fábrica de estofados no período da tarde. A intenção de sua mãe ao fazê-lo trabalhar era discipliná-lo e ocupá-lo para que ele não tivesse tempo ocioso, permanecendo na rua: “...porque ela tinha certeza que algum colega meu ia passar lá em casa e ia me chamar para soltar pipa, para pescar, para ir jogar bola, ela sabia que eu não ia estudar”41. Essa atitude materna assemelha-se à encontrada por Paparelli (2001) em pesquisa que investigou a relação entre a inserção precoce de adolescentes no mercado de trabalho e a escolarização. Nela, muitas mães referem como motivos para encaminhamento dos filhos para o trabalho a proteção contra o mundo da marginalidade e o desvio do "bom caminho", além de aludirem ao caráter disciplinador do trabalho, visto como complementação à educação. Diz a autora:

para protegê-los dos descaminhos a que a existência de tempo ocioso fora do período escolar pode conduzir, como a excessiva permanência na "rua", os "amigos" inadequados etc., o ingresso no trabalho, principalmente em seu componente disciplinar, é praticamente a única possibilidade, tendo em vista a falta de alternativas imposta à classe social a que pertencem (Paparelli, 2001, p. 161).

O trabalho é visto como uma atividade que ocupa o tempo e disciplina o adolescente, além de exigir responsabilidade, conduzindo-o à trilha da "boa conduta” .

Na 6 a série Antônio melhorou novamente seu rendimento escolar, voltando ao "normal”, como ele descreve. Mas, na sua avaliação, a retomada do "prumo” não se deu em virtude do "sermão” da mãe, mas sim pela mudança de ambiente: nesse ano ele não teve mais como colegas de turma os antigos amigos "bagunceiros”. Esse jovem também atribui a melhoria no desempenho acadêmico ao fato de estar

\footnotetext{
${ }^{40}$ Importante mencionar que da $1^{\mathrm{a}}$ à $4^{\mathrm{a}}$ série Antônio teve aulas com a mesma professora.

${ }^{41}$ Também seu irmão mais novo foi encaminhado para o trabalho, mas diferentemente de Antônio, desde os 14 anos ele trabalha ininterruptamente: “...sempre trabalhou, não consegue ficar sem trabalhar".
} 
trabalhando, o que era visto por ele como um estímulo à escola. Embora se sentisse cansado, Antônio é incisivo em afirmar que gostava de trabalhar, não vendo prejuízo na conciliação entre trabalho e estudo; ao contrário, diz ele, além de aprender uma “profissão nova”, suas notas aumentaram, ele estudava mais e estava mais disciplinado. Na $7^{\mathrm{a}}$ série, após ter permanecido um período apenas estudando, voltou a trabalhar, desta vez, numa fábrica de vassouras e rodos.

Por serem ambientes descontraídos, de "fundo de quintal”, Antônio afirma que era divertido trabalhar, não obstante também mencione o cansaço de ter de estudar e fazer as tarefas escolares à noite, aos 13 anos de idade. Esse jovem assume uma ética do trabalho ou o trabalho como um “código moral” (Romanelli, 1997), nos quais sua mãe também parecia se apoiar, e concebe a relação entre trabalho e estudo como complementar e não como antagônica.

Todavia, tal assunção não se fez sem resistência ao controle e vigilância acirrados da mãe. Além de dar-lhe um sermão e arrumar-lhe um emprego, a mãe de Antônio sugeriu também que ele realizasse o curso de Guarda Mirim que havia iniciado na cidade. Mas ele se recusou a ir, só resolvendo participar na $8^{\text {a }}$ série, dois anos depois da sugestão da mãe: “Aí eu fui por espontânea vontade, as outras duas vezes minha mãe me pediu e eu não fui, eu não quis, na terceira vez minha mãe já estava indiferente, já tinha desistido e eu fui por conta, porque eu quis ir”. Conta que, naquele ano, decidiu freqüentar o curso por ver outros adolescentes arranjando bons empregos e por estar preocupado em conseguir trabalho após terminar o Ensino Fundamental: “... a gente via as pessoas entrando lá e saindo bem, sabe, a gente via que era um local bom para quem é pobre assim ter um início, sabe, porque vários colegas meus hoje tem profissões normais”. Para Antônio, a Guarda Mirim seria uma forma mais fácil e rápida de conseguir emprego, sobretudo pelos contatos que o curso proporcionaria - uma boa alternativa para quem não dispunha de "capital social” (Bourdieu, 1998b). Esse jovem fala a respeito das possibilidades de trabalho que poderiam surgir a partir da realização desse curso:

Porque lá [Guarda Mirim], por ter esse curso de sete meses, os orientadores lá tinham contato com os alunos, então eles eram as referências dos alunos para as empresas, então, é bem mais fácil você ter uma referência do que ir sozinho, sem referência nenhuma, então era aí que muitos conseguiam emprego e ficavam, né. (...) e bem mais simples, sem ter vínculo nenhum com o 
empregador, sem ter nenhuma referência, só dos orientadores, né, não é parente, nada, sabe, é bem mais fácil.

A experiência na Guarda Mirim foi, nas palavras de Antônio, um “divisor de águas” em sua vida, transformando por completo a sua trajetória. Entendamos porquê.

Segundo Antônio, o curso era regido por uma disciplina semelhante à militar, sendo ministrado por dois professores e um sargento reformado, e aos adolescentes eram ensinadas noções de leis, direitos, educação civil, "bons modos” e oferecidos cursos de datilografia, informática, primeiro socorros, tendo como principal objetivo ensiná-los a comportarem-se no ambiente de trabalho. Também eram dadas aulas complementares e instrumentais de português e matemática. Para a maioria dos que estavam na Guarda Mirim, por serem “bem mais pobres” e por estudarem em escolas ruins localizadas na parte mais pobre da cidade, segundo explicação de Antônio, muitos desses conhecimentos eram novidade, tendo alguns adolescentes dificuldades bastante sérias em relação a leitura, escrita e matemática; para ele, no entanto, que era bom aluno, estudava em uma boa escola e gostava de ler, não eram. Informações sobre postura no ambiente de trabalho também não eram algo novo para esse jovem já que, como ele mesmo afirma, seu pai, apesar da baixa escolaridade, sempre teve emprego fixo em uma empresa tradicional da cidade, o que fazia com que ele conhecesse, de certa forma, esse tipo de ambiente, ao contrário de seus colegas, na maioria, filhos de trabalhadores rurais ou de pais com outras ocupações pior remuneradas e pouco valorizadas na área urbana. Ademais, ele próprio já tinha tido a experiência de trabalhar em dois locais diferentes.

O que então esse estudante aprendeu na Guarda Mirim que foi tão decisivo para sua trajetória de vida? O que parece ter marcado e se tornado um aprendizado fundamental para Antônio foi que essa experiência o fez descobrir a possibilidade da igualdade e do esforço e dedicação ao estudo como forma de ascensão social. Vejamos suas palavras:

Na Guarda Mirim eles pregavam que a gente tem capacidade de evolução, de aprender mais, de ter uma profissão, de ser alguém na vida, sabe, de sempre evoluir, que todo mundo era igual, sabe, lá eu vi que você trabalhando, com seu esforço você teria capacidade de evoluir, eles pregavam uma filosofia assim, sabe. (...) Esse, eu considero, quando eu estava na Guarda Mirim, um divisor de águas, porque eu aprendi muita coisa lá, aprendi muita 
coisa, de geral da vida assim, principalmente como se comportar num local assim, como se esforçar para conseguir uma coisa...

Antônio conheceu na Guarda Mirim a perspectiva de “evoluir” através de seu esforço e, seguindo o ensinamento de que "se você gosta de trabalhar, trabalha bem, se você gosta de estudar, estuda bastante...”, esse jovem começou a dedicar-se intensamente aos estudos.

Na metade da $8^{\mathrm{a}}$ série, nas férias escolares e da Guarda Mirim, ele resolveu preparar-se para um concurso de bolsas de estudo de uma escola particular. Ele estudou durante 15 dias e acabou prestando a prova em três colégios particulares concorrendo com alunos da rede pública e da rede privada de toda a cidade: obteve primeiro lugar em dois deles e segundo no outro ${ }^{42}$. O diretor de um dos colégios chamou a ele e à sua mãe para uma reunião quando apresentou toda a estrutura da escola e ofereceu bolsa integral de estudos a esse estudante. Foi aí que Antônio realizou todo o Ensino Médio sem ter de pagar nenhuma taxa ${ }^{43}$.

Estudar para o concurso de bolsas exigiu desse estudante certa organização. Ele conta que foi a primeira vez que se preparou para uma prova, procurando dedicar-se mais às disciplinas nas quais tinha dificuldade, estudando com antecedência, reunindo-se com amigos para esclarecer dúvidas, enfim, desenvolvendo uma estratégia de estudo que foi por ele aperfeiçoada ao longo de toda sua trajetória escolar, incluindo-se aqui o período universitário.

Importante mencionar também que, para o ingresso no curso de Guarda Mirim, era necessário submeter-se a uma prova de conhecimentos gerais e Antônio, juntamente com outro adolescente, foi o primeiro colocado obtendo nota 10,0 na prova. Essa foi a primeira de uma série de excelentes colocações que marcaram o final do Ensino Fundamental e o Ensino Médio desse estudante.

Foi a partir do ensinamento da Guarda Mirim de que para evoluir era necessário estudar, que Antônio afirma ter desenvolvido um “sentimento de disputa”. Quando surgiu a oportunidade de prestar o "vestibulinho" nas escolas particulares, ele diz que quis realizá-lo para saber até onde conseguiria chegar, ao contrário de

\footnotetext{
${ }^{42}$ No primeiro "vestibulinho" que Antônio prestou, os alunos que ficaram em terceiro, quarto, quinto e sétimo lugares estudavam na mesma escola que ele.

${ }^{43}$ No primeiro ano ele teve isenção também da taxa de material e nos outros dois, além de manter a isenção da mensalidade por sempre ficar em primeiro lugar nos exames gerais da escola, também teve isenção daquela taxa por exercer monitoria.
} 
seus amigos de escola que tiveram receio de serem avaliados, mesmo aqueles que, assim como Antônio, possuíam bom rendimento escolar:

...muitos [amigos] não fizeram a prova, não quiseram fazer, não quiseram medir a capacidade, não quiseram, simplesmente falaram: "isso não é para mim, eu não vou! Eu não quero me testar, me estressar, eu não vou a lugar nenhum com isso”. Eu falei: "eu vou, vou ver o que vai acontecer. Eu vou estudar, vou me preparar, para ver até onde eu chego”.

Antônio conta que ao resolver prestar a prova não tinha em mente obter a bolsa de estudos, já que ele não entendia exatamente a diferença entre uma escola pública e uma particular, não sabia muito bem o que era vestibular, nem que aqueles colégios particulares visavam à preparação para esse exame, enfim, ele não tinha a dimensão da diferença que poderia ter, para sua trajetória, o fato de estudar em uma escola particular. Ele foi movido muito mais por um sentimento de competição e vaidade e por um desejo de auto-afirmação: “...a gente foi mais para, vamos dizer assim, para ter um resultado, assim, um resultado bonito, um status assim: 'ah, passei, fui bem no vestibulinho, sou inteligente!" ”.

A determinação e a segurança demonstradas por Antônio nessa ocasião parece-nos não só relacionada à sua história escolar de “bom aluno” e ao aprendizado do valor do estudo na Guarda Mirim, mas também ao lugar destacado que esse jovem deveria ocupar lá, pois, além de ter sido o primeiro colocado na seleção, ele também se destacava nas atividades do dia-a-dia na medida em que conhecia e dominava quase todos os conteúdos ministrados no curso. Assim, a diferença maior entre Antônio e seus amigos de escola com "igual capacidade” parece residir mais no sentimento de que se é capaz, fornecido pelo outro do que em diferenças de competências. Foi munido desse sentimento que Antônio não temeu ser avaliado; antes ele preparou-se o máximo possível, para um adolescente de 14 anos, visando medir toda a sua capacidade.

Esse estudante é incisivo ao afirmar que resolveu fazer a prova do “vestibulinho” a partir da experiência na Guarda Mirim e que a idéia de se preparar para esse exame o "salvou na hora certa”. Apesar de questionado, Antônio não explicita muito claramente a que essa idéia de salvamento remete; todavia, parecenos que ele está falando a respeito de ter se desviado de um destino social mais provável tendo em vista sua condição socioeconômica. Após ser aprovado em 
primeiro lugar no "vestibulinho" e obter bolsa integral de estudos para cursar o Ensino Médio em uma escola particular, Antônio continuou trabalhando na gráfica, onde fora empregado depois de terminar o curso da Guarda Mirim, até a véspera do início das aulas no ano seguinte e explica o porquê: "Para mim a vida era aquilo lá: trabalhar"44. Foi desse destino que a obtenção da bolsa de estudos o desviou. O prolongamento da escolarização através da aprovação no exame do vestibular e do ingresso no Ensino Superior público era algo absolutamente fora do horizonte da vida desse jovem naquele momento:

Se eu não fizesse essa prova, eu não teria entrado em escola particular e eu não chegaria onde eu estou hoje; estar onde eu estou hoje, quando eu estava no Guarda Mirim era inimaginável, eu nem sabia que tinha essa possibilidade, eu nem pensava nisso! (...) Por mim eu ia estar trabalhando hoje, se eu continuasse lá, se eu não fizesse essa prova, eu trabalharia numa gráfica, (...) e nem teria sentimento de perda nenhuma que eu não conhecia fazer Curso Superior, ter profissão, sabe, ter nível superior, nem passava pela cabeça, para mim era coisa de gente rica, sabe, de quem tem dinheiro e não era para o meu bico. Aí eu passei na prova, fiz o Capital [escola particular], fiquei estudando no Capital [escola particular] (...) Então, isso aí foi tipo uma ponte que fez com que eu entrasse em outro mundo, assim, que facilitou, me ajudou, fez com que eu chegasse até hoje, assim, conseguisse esses objetivos que eu não tinha antigamente...

Se Antônio não tivesse se preparado, prestado e passado no concurso de bolsas de estudo, ele vislumbra que hoje, provavelmente, seria um técnico de artes gráficas tendo profissão e remuneração razoáveis para os padrões de vida de sua cidade natal e não se sentiria perdendo nada. Para esse jovem, a realização do Ensino Superior era reservada a outra camada social, não sendo vislumbrada como objetivo possível a pessoas com origem semelhante à dele. Para Antônio, seu destino “natural” era o mundo do trabalho, assim, nenhuma outra possibilidade seria sequer aventada, não fosse o acesso a “outro mundo”.

A travessia para esse mundo foi feita em parte através da realização do Ensino Médio no colégio particular. Assim como ocorreu com Pedro, estudar na rede privada significou o encontro e a convivência com a desigualdade social. Recém saído da Guarda Mirim onde convivia com “pessoas mais simples”, Antônio passou a estudar com o que ele chama de "elite da cidade”, o que lhe causou um “choque”. O

\footnotetext{
${ }^{44}$ Durante a realização do Ensino Médio, Antônio conta que trabalhou apenas aos finais de semana ajudando um tio a cuidar da lavoura de café, atividade que continuou realizando, até recentemente, durante as férias da faculdade.
} 
período mais difícil foi o primeiro ano do Ensino Médio marcado por solidão, demorada adaptação e grande confusão. Com a entrada na nova escola, Antônio foi pouco a pouco se afastando dos antigos amigos e, dado o estranhamento do novo ambiente, demorou a fazer outros, o que fez com que ele fosse se "isolando": “...demorou um ano para eu me adaptar, eu ficava mais na minha assim, quieto”. Ele conta também que nesse período sua vida limitou-se a ir à escola e voltar para casa, sem convívio social extra-escolar, aspecto também semelhante à história do estudante Pedro. Ademais, esse primeiro ano foi bastante confuso para Antônio, confusão que ia desde entender as novas possibilidades que se lhe apresentavam naquele momento, como prestar vestibular e realizar um Curso Superior ("No primeiro ano eu ainda estava confundindo isso, eu não sabia o que era, eu não sabia como funcionava um vestibular, eu não sabia como funcionava um curso de nível superior, eu não sabia nada!”), até uma confusão de ordem mais emocional quando esse jovem parece falar a respeito dos efeitos do desenraizamento, como vimos, também sofridos por Felipe e Pedro. Ao distanciar-se de sua origem social, esse jovem ficou confuso e não soube como agir: “...o primeiro ano foi um período meio, assim, de mistura, foi meio misturado, eu não sabia ainda onde que eu estava, como eu devia me portar, pensar, sabe? Só no segundo ano o negócio melhorou...”. A partir do segundo ano na escola particular seu sentimento de pertença aumentou e Antônio iniciou a travessia da ponte: "eu entrei mais no mundo deles, assim. Comecei a pensar mais em vestibular e não mais em ter profissão operária ou técnica, em ter uma profissão de nível superior”. Para essa "troca de influências” (Weil, 1996) parece ter contribuído a monitoria que Antônio passou a exercer a partir do segundo colegial, conseguida por uma professora da escola; além de isentá-lo do valor da taxa de material, ser monitor - de todas as disciplinas, com exceção de inglês, para todas as séries - o conduziu a outro lugar, a saber, de destaque na escola, contribuindo para sua melhor adaptação.

Além do encontro com a desigualdade social, conviver com a "elite" significou para Antônio também deparar-se com o preconceito. Ele conta que, no colégio, havia pessoas com dinheiro, mas que eram “simples”, porém havia também estudantes arrogantes e com preconceitos raciais e religiosos, embora fossem minoria. Ao convívio com tais estudantes esse jovem contrapõe sua experiência na escola pública onde não via pessoas de “cabeça mais fechada” ou “com preconceito”. 
Para esse estudante, a grande diferença entre quem estudava aí e na escola pública não residia no comportamento ou nos hábitos, mas no "modo de pensar". Eram as ambições e os projetos para o futuro que distinguiam os colegas do colégio particular dos seus antigos amigos. Antônio considera a maneira como adolescentes de diferentes origens sociais comportam-se semelhante, parecendo referir-se a certa unidade criada pela cultura de massas e por hábitos próprios dessa fase da vida. Mas, se os adolescentes assemelham-se em virtude de seu comportamento, a diferença social não tarda a ser reposta: tanto os de camadas médias quanto os de camadas populares gostam, por exemplo, de festejar, todavia não vão aos mesmos locais. Retratando certa confusão em relação ao que pensar e desejar, Antônio fala a respeito dos colegas do colégio particular:

[Eles pensavam] ...Bem mais longe. Era mais uma diferença de pensamento, de objetivo do que de modo de se comportar. É claro que eles freqüentavam ambientes diferentes na cidade, tipo, a festa de um não era a festa do outro, eram ambientes diferentes, eles tinham costumes diferentes dos outros, né, e... Mas... O modo de pensar era diferente, mas o comportamento no dia-a-dia assim era parecido, por todo mundo ser da mesma idade, né, o modo de lidar com todos era bem parecido, mas o pensamento e o local que eles freqüentavam era diferente. Então, ficava nisso, né, nessas duas partes. Eu não freqüentava onde eles freqüentavam, freqüentava com os outros, mas eu já começava a pensar como eles, e não como os outros, por influência, e vi que o objetivo deles, apesar de ser mais difícil de alcançar, era possível e eu queria seguir esse caminho, já tinha esquecido do outro.

Embora por sua condição socioeconômica lhe fosse interdito socialmente estar em determinados locais - e ele continuava freqüentando os mesmos lugares que seus antigos amigos -, o estudo, o acesso a informações, a convivência com outra camada social o faz mudar o seu "modo de pensar": Antônio passa a almejar o mesmo futuro que via antes como reservado exclusivamente aos "ricos" e vislumbra tal realização através de sua grande capacidade de estudo. Esse jovem resolveu atravessar a ponte e para isso estudou “pesado”.

Antônio destacava-se no Ensino Médio pelo excelente desempenho acadêmico. Nos exames gerais realizados periodicamente na escola, que funcionam como simulados do teste do vestibular, esse estudante obtinha pontuações superiores às de alunos de séries acima da sua. No segundo colegial, quando prestou o vestibular da Fuvest como treineiro, ele tinha escore suficiente para ser aprovado, na primeira fase, em cursos de menor seletividade. 
Os professores foram grandes aliados na caminhada desse jovem rumo à universidade e ele nutre carinho, admiração e reconhecimento especiais em relação aos mestres. A contribuição deles no Ensino Médio estendeu-se desde o fornecimento de material extra de estudo, passando pela já mencionada obtenção da vaga de monitoria, até o auxílio decisivo na escolha da carreira - foi por sugestão de uma professora que Antônio decidiu prestar vestibular para o curso de Farmácia. Esse jovem relata que sempre teve uma ótima relação com professores, desde o Ensino Fundamental até o Ensino Superior, mas foi no Ensino Médio que tal relacionamento foi melhor, em virtude da maior proximidade com os docentes e de sua própria maturidade. Seu respeito para com a figura do professor parece vinculado à sua relação com o conhecimento: “...ele [professor] está ali para ensinar e o gosto dele é ver você aprender, então, se você se esforçar para isso, não tem erro”. Para o ingresso na universidade os professores do Ensino Médio foram "peça chave”; Antônio reconhece e afirma repetidas vezes que o apoio dos professores foi fundamental para que ele conseguisse aprovação no vestibular ${ }^{45}$. Quando volta à sua cidade natal, esse estudante afirma sempre ter contato com antigos professores. Evidência da manutenção dessa boa relação foi a presença de sua ex-professora de matemática na sua colação de grau do curso de Farmácia.

O ingresso no curso de Farmácia da USP representou na vida desse jovem, ao lado da experiência na Guarda Mirim, outro “divisor de águas”. Cursar o Ensino Superior era algo absolutamente inesperado para ele e, mais ainda, para sua família. Antônio fala a respeito do significado chocante da entrada na Universidade:

Ah... Era uma coisa inimaginável, eu não imaginava entrar aqui [USP], por mim eu ia estar trabalhando lá em A. [cidade natal] para ser empregado, assim, uma coisa baixa, eu já estava com isso na... Todo mundo tinha isso na cabeça lá, eu fui o primeiro da família a entrar numa faculdade! $\mathrm{E}$ ainda entrei numa faculdade pública e do estado de São Paulo ainda, que eu era de Minas! Então, foi um negócio diferente, foi um choque, assim...

Na chegada ao campus universitário esse jovem estranhou a comida do restaurante universitário, o clima da cidade, as festas da faculdade e o convívio com

\footnotetext{
45 “... os professores sabiam que se eu seguisse o básico lá [escola particular] eu não ia conseguir passar aqui [USP], então eles sempre me estimulavam a estudar, me davam material extra, sempre fazia os simulados que eles preparavam lá, sempre fui muito bem apoiado pelos professores de lá, eles tinham a noção que eu tinha uma possibilidade de passar mas que eu deveria me esforçar mais e sempre me estimularam”.
} 
pessoas com os mais diferentes comportamentos e personalidades na moradia estudantil. Era mais uma vez "outro mundo” que se apresentava a esse estudante.

Antônio teve de se adaptar à cidade, à moradia, ao campus e ao ambiente acadêmico-científico. De todas essas adaptações, parece-nos que a mais difícil foi à residência estudantil, tanto que seus amigos de moradia costumam brincar que ele levou seis meses para falar a primeira palavra lá. Para melhor inserção no novo local de residência contribuiu o fato de Antônio ir morar em um apartamento em que os estudantes, embora também gostassem de festas e de dar trote nos calouros, procuravam integrá-los. A respeito da brincadeira dos amigos sobre a desconfiança e a timidez de Antônio, esse jovem afirma que esse é seu jeito de se inserir em novos ambientes e explica seu processo de adaptação à moradia:

Só que aí eu fui descobrindo as coisas, sabendo como é que funcionava, porque eu sou assim: eu sempre fico num canto, esperando e eu analiso quando eu estou num lugar diferente, muito diferente como era o caso aqui [moradia], vou ver como se comportam, como eles são, para mim poder fazer, me enturmar, né.

Na moradia estudantil Antônio passa a conviver com pessoas que embora mais próximas no aspecto sócio-econômico, são bastante diferentes em estilo, modos de ser e de se comportar. Pelo seu relato, a experiência de residir lá parece ser um constante exercício de convivência com as diferenças.

A adaptação ao curso de Farmácia, no entanto, foi mais fácil. Esse estudante fala a respeito de uma grande semelhança entre seus companheiros na faculdade e os colegas do Ensino Médio, dizendo que ao ingressar na USP sua impressão foi de que tivesse saído de uma sala do colegial e entrado em outra, guardadas algumas diferenças como, por exemplo, em relação a número de alunos por turma. Tal similitude parece-nos decorrente do perfil mais elitizado de cursos de alta seletividade como é o caso de Farmácia. Os efeitos do encontro com a desigualdade social no Ensino Médio, no entanto, não se repetiram com a entrada na Universidade, pois, embora Antônio percebesse que seus colegas possuíam nível sócio-econômico melhor do que o seu, ele já estava habituado a se relacionar e a conviver com outra camada social: “...eu já estava acostumado, já sabia lidar com esse tipo de, com essa turma, com esse tipo de classe, de gente, então foi bem mais fácil...”. Mais do que isso, Antônio parece sentir-se pertencente ao novo contexto universitário, tendo 
conseguido realizar o que Weil (1996) considera ser, como vimos, de grande importância para o enraizamento - a "troca de influências”: “... meus colegas da Farmácia, eles têm um pensamento parecido com o meu, aliás, a influência lá é mútua...”.

Se a inserção no grupo de estudantes foi tranqüila, a adaptação de Antônio ao ambiente acadêmico científico exigiu maior esforço. Esse jovem, bastante afeito ao estudo e estando sempre entre os melhores alunos nas escolas em que estudou, deparou-se na universidade com estudantes mais bem preparados que ele e mais acostumados a estudar (segundo sua avaliação, porque estariam habituados à rotina de cursinho), passando a ter um desempenho escolar pior do que estava habituado ${ }^{46}$. Sua média ponderada no primeiro semestre foi 7,0, considerada baixa por ele. Mais uma vez esse jovem lançou mão de sua capacidade de estudo e a aperfeiçoou, o que demandou um grande e novo esforço: a partir do segundo semestre do curso, e até seu recente ingresso na pós-graduação, Antônio passou a estudar todos os dias, das 19 às 22 horas, na biblioteca do campus. Esse estudante afirma que teve de se "readaptar", pois aprendeu a estudar "mesmo" durante a faculdade; com a rotina diária de estudos o objetivo de aumentar sua média ponderada foi alcançado, já que, ao final do curso, sua média foi 8,0. Ele afirma que em sua turma há alunos com notas maiores, porém parece satisfeito com o que conseguiu: "mas para mim foi suficiente, está muito bom, para quem se esforçou com o tempo assim”.

Além da grande capacidade de estudo de Antônio, destaca-se também sua capacidade de adaptação. Em que pesem as dificuldades inerentes às mudanças que ele teve de enfrentar em sua trajetória da Guarda Mirim, do colégio particular, à moradia estudantil, passando pela faculdade, esse jovem parece ter se inserido em diferentes contextos de forma satisfatória, mantendo sempre uma boa convivência com amigos e colegas. Falando sobre a época do Ensino Médio, ele exemplifica sua capacidade adaptativa:

O incrível é que eu me adaptava tanto a essa turma da Guarda Mirim, como nos de "boyzinhos". Na minha convivência assim, eu nunca briguei com ninguém, eu sempre tive muitos amigos,

\footnotetext{
${ }^{46}$ É importante mencionar que, além da diferença entre escolas públicas e particulares, Antônio também se refere a uma hierarquia existente entre as escolas particulares, sendo que as localizadas em cidades maiores (de onde provém grande parte de seus colegas) possuiriam ensino de melhor qualidade do que as escolas situadas em cidades do interior (onde ele estudou).
} 
aqui [na universidade] também, em qualquer lugar, eu nunca tinha confusão...

Por ser avesso a brigas, gostar de inventar brincadeiras e gostar de ler, Antônio era uma espécie de referência para os amigos na infância. Esse papel manteve-se já que até hoje, freqüentemente, é procurado na moradia para dirimir dúvidas que surgem em conversas entre os estudantes sobre temáticas da área de História, pois todos sabem que ele gosta muito dessa área: “... eu gosto mais de História do que de Farmácia praticamente...”.

Ao seu comportamento conciliador, Antônio contrapõe o do irmão, de temperamento explosivo:

Na escola, na rua, ele brigava muito. (...)eu separava briga dele direto, era muito, muito comum separar briga dele, muito comum. (...) todo mundo me respeitava, ao contrário do meu irmão, que se cutucasse ele, ele já virava assim, xingava, mandava para aquele lugar. Então, eu sempre separei briga do meu irmão, mas raramente eu briguei, quando eu briguei, briguei por causa dele (ri). Ele era mais novo, menor, né, então, sempre entrava em confusão, quanto entrava em confusão, meus amigos entravam também, então virava um balaio.

O desejo imenso de aprender que fazia com que Antônio quisesse entrar na escola esteve presente também na sua experiência universitária. Ele próprio compara o grande interesse por novos aprendizados na universidade com a vontade de aprender a ler e a escrever no passado:

Mesma coisa hoje, que eu nunca tinha mexido com biologia molecular, é fazer um PCR, eu sou louco para fazer um PCR (rindo), que é amplificação de material genético, clonagem, eu era louco para fazer isso na minha graduação, só que não tinha aula para isso, aí eu entrei em contato com isso na pesquisa, fiquei deslumbrado! Mesma coisa ler e escrever no primário, eu queria muito aprender, aprender bastante, o que eu pudesse aprender estava bom...

Além do desejo de crescimento e superação, Antônio é movido também por uma meta de aprimorar-se o máximo possível dentro da área de Farmácia. Foi por esse motivo que ele não quis ter bolsa-trabalho pois, apesar de ser um valor significativo $^{47}$, não havia projetos relacionados à área na qual pretendia atuar; assim, a participação em qualquer projeto de bolsa-trabalho significaria mais dinheiro, por um lado, mas, por outro, na sua visão, implicaria desvio de tempo de estudo de sua

${ }^{47}$ O valor da bolsa é de um salário mínimo. 
área para dedicar-se a uma atividade não relacionada a ela. Podendo contar com uma ajuda financeira mensal de sua família que cobria suas despesas, esse estudante optou por não ter esse tipo de bolsa. Assim como vimos na trajetória de Pedro, também na história de Antônio o desejo de aprender é maior do que a necessidade econômica.

Ele reconhece, no entanto, que para vários de seus companheiros de moradia não há alternativa, já que eles não conseguiriam manter-se estudando sem esse auxílio. Ao falar disso, Antônio traz à tona a questão da diferenciação socioeconômica existente entre as camadas sociais que compõem as camadas populares, já mencionada por esse estudante quando abordava a diferença entre ele e seus colegas da Guarda Mirim. Na moradia, esse estudante diz que vários colegas são “obrigados” a ter bolsa-trabalho pelo fato de o nível sócio-econômico ser "muito, muito baixo”, não lhes restando alternativa a não ser dedicarem dez horas semanais para atividades que muito freqüentemente não guardam relação direta com suas áreas de formação. Reconhece ainda que, pelo fato de ter contado com o apoio financeiro dos pais, ele “aproveitou”, no sentido de dedicar-se exclusivamente ao estudo, o que foi "excelente".

Todavia, Antônio comenta também a respeito de outros colegas que, a seu ver, possuem a mesma condição socioeconômica que ele, mas que, apesar disso, tiveram bolsa-trabalho, o que considera “perda de tempo" e prejuízo ao futuro profissional, além de perigoso pela ilusão que essa renda pode criar. Ele explica que o valor da bolsa é muitas vezes maior do que a renda per capita das famílias dos estudantes que residem na moradia e que, por isso, muitas vezes, após o encerramento da bolsa, que tem um prazo máximo de dois anos por aluno, muitos estudantes procuram empregos fora de sua área de atuação para poderem manter o padrão de vida alcançado com o valor da bolsa. Antônio fala das conseqüências do que ele considera uma opção:

Bolsa-trabalho, por exemplo, muitos aqui [moradia] sofrem disso, (...) dentro de dois anos ele é obrigado a sair para dar lugar para outro aluno, então ele cria um nível de vida incompatível, nesses dois anos, (...) então ele cria um nível de vida diferente, eu percebo isso, muitos aqui passam esses dois anos e passa o maior aperto depois, e vai pedir iniciação, fazer iniciação, (...) não tem experiência nenhuma de iniciação, tem que começar do zero. Então, seria melhor ter começado do zero e ter passado mais apertado no começo, eu penso assim, e ter tido a experiência para depois, quando você estiver no fim do curso, qualquer trabalho que vier você consegue fazer com a maior facilidade. Há casos 
aqui de pessoas que fazem dois anos de bolsa-trabalho, depois não tem mais como se sustentar e estão num padrão diferente, mesmo sendo um nível social mais baixo, mas é um padrão diferente, eles apelam: tipo, quem faz curso noturno está procurando emprego fora, trabalhando de operário fora do campus aqui e diminui o tempo livre para meia hora, tempo de sair do emprego e vir aqui na aula, para poder manter o nível de vida que eles tinham antes, muito mais pelo costume.

Talvez não estritamente fiel à realidade da maioria dos estudantes que residem na moradia e que são provenientes de cursos de menor seletividade, cujo perfil sócio-econômico é mais baixo, a visão de Antônio nos fala de escolha. Em seu caso, tratou-se de uma opção firme e revestida de certo ascetismo; esse jovem visava à “evolução intelectual” e não financeira, evolução essa que, segundo sua avaliação, conseguiu alcançar. Para isso, ele desenvolveu uma estratégia para "sobreviver" no ambiente universitário: ao perceber a diferença que o separava de seus colegas da Farmácia, ele buscou se igualar a eles através de um grande e intenso esforço de estudo, do qual a atividade da bolsa-trabalho o desviaria:

Porque, senão, perigoso a gente ficar defasado porque meus colegas de sala não precisam, eles têm o tempo inteiro para estudar, quando eles trabalham, eles fazem iniciação, para mim não ficar atrás eu tenho que fazer uma coisa parecida, né, se eu for já me diferenciar desde o começo de um modo tão negativo assim, então é bom nem começar.

Ao falar sobre isso, Antônio toca em uma questão muito importante quando se trata de discutir o acesso e a permanência do estudante de camadas populares na universidade pública: a reposição da desigualdade social na experiência universitária. Como mostra, por exemplo, o trabalho de Almeida (2006), a possibilidade de usufruir do que é oferecido pela universidade não é a mesma para todos os alunos, variando em função de sua condição social. Assim, por exemplo, não são todos os alunos que têm oportunidade de realizar iniciação científica durante a graduação, experiência profundamente valorizada no ambiente acadêmico e, também, no mercado de trabalho, como ocorre em algumas carreiras como na Farmácia, onde a experiência de estágio em determinados laboratórios de pesquisa transforma-se em importante moeda de troca na competição por um emprego na indústria. A “concorrência desleal”, utilizando expressão com que o estudante Marcos avaliou o vestibular, vale também para os processos seletivos existentes no interior da 
universidade, nos quais a desigualdade social é reposta vitimando, mais uma vez, aqueles que têm de se preocupar com a sua existência material cotidiana:

Então, eles [alunos da Farmácia] têm um certo privilégio, em não ter essa obrigação... Em ter a liberdade de escolher o que quer, o que quer fazer e isso é, esse tipo de privilégio é muito bom, se todo mundo do C. [moradia estudantil] tivesse essa chance, muita gente sairia daqui bem mais qualificada, com uma carreira bem mais promissora, perderia bem menos tempo, né, perderia muito menos tempo; e esse privilégio faz com que a turma lá saia muito bem qualificada enquanto muita gente aqui [moradia] que faz Química não consegue disputar com eles porque mora aqui no C. [moradia] e tem que ter bolsa-trabalho.

Embora a aprovação no vestibular represente um momento em que todos os alunos estão em condição de igualdade, assim que iniciam o Curso, e ao longo de toda a experiência universitária, a desigualdade social vai sendo atualizada, acabando, muitas vezes, por dificultar a trajetória dos estudantes das camadas populares no Ensino Superior.

Antônio percebe isso. Mas, ele percebe também que o conhecimento é a moeda da Universidade, não estando, todavia, seu acesso plenamente desvinculado da questão econômica. Esse jovem aprende rapidamente as regras do jogo institucional e opta pelo conhecimento: “... ter conhecimento também é bem melhor do que você sair da sua área por causa de dinheiro”.

Em relação à experiência de Antônio com pesquisa durante a graduação, esse jovem relata que inicialmente ela foi decepcionante. No terceiro ano do curso, ele fez iniciação científica durante um ano em um laboratório mas, segundo ele, “não rendeu nada” não tendo bolsa nem resultando em outros desdobramentos, fazendo com que esse estudante se desiludisse com a área de pesquisa. No quarto ano, já preocupado por não ter resolvido o que faria depois de formado, ele diz que decidiu “do nada” fazer pós-graduação em outra área da Farmácia. Não obstante Antônio veja como repentina tal decisão, esse estudante teve bons motivos para isso: ele havia gostado muito da disciplina da área, a matéria “entrava na cabeça muito fácil” e seu desempenho foi exemplar, pois tirou nota máxima nas duas provas terminando a disciplina com média final 10,0. Ele justifica-se contra certo preconceito que parece existir em relação à opção pela pós-graduação na área de Farmácia: sua decisão de fazer mestrado foi tomada com bastante antecedência e não como última alternativa para quem não restaram escolhas por ocasião da formatura. Durante o quinto e 
último ano da graduação, portanto, Antônio teve outra experiência de iniciação científica, bastante diferente da anterior e, como ele afirma, foi "tudo muito rápido" já que conseguiu bolsa de iniciação científica da Fapesp e no final desse mesmo ano foi aprovado na seleção do Mestrado. Inicialmente, quando procurou a professora, que viria a ser sua orientadora, solicitando estágio em seu laboratório, Antônio pensava em fazer pós-graduação para ser docente porque gosta e tem facilidade em explicar, expor, dar aulas, habilidade reconhecida e elogiada pelos colegas de turma. Com o tempo, no entanto, esse jovem foi encantando-se com o fazer científico para o quê seu apreço pelo estudo muito parece ter contribuído:

...e o incrível é que eu gostava, que a minha orientadora fala que a maioria faz o experimento, dá errado, desiste, quer ir embora, eu gosto de fazer o experimento, se der errado, trabalhar em cima e melhorar... (...) então nessa área, a tendência é sempre dar errado, sempre dá errado, e eu gostei, acabei gostando dessa coisa de dar errado, porque quando você consegue é uma coisa incrível, para quem pesquisa é o máximo isso. E é uma coisa que eu gostei, pegar, fazer pesquisa, ficar estudando a coisa: “Ah, o que quê eu posso fazer aqui, mudo aquilo...”

A perseverança, a disciplina, a vontade de saber desenvolvidas por esse jovem ao longo de sua trajetória escolar e de vida, qualidades bastante afins com a atividade científica, sobretudo nas áreas biológicas que exigem o cumprimento de rotinas de laboratório, parecem estar sendo de grande valia para Antônio. E se ele iniciou essa experiência de pesquisa pensando em apenas ensinar, agora, como ele descreve, “está meio a meio” já que ele está gostando muito da experiência de pesquisar. A determinação e a vontade de se superar continuam as mesmas de quando prestou "vestibulinho” ao final do Ensino Fundamental: "Eu quero fazer mais coisas, mais coisas, e ver até onde eu consigo ir. Meu objetivo é ser docente. Vamos ver.”

Aos 23 anos, Antônio que no início do Ensino Médio achava que “a vida era trabalhar”, está na pós-graduação.

Contribuindo para a sua bem-sucedida experiência universitária, Antônio destaca, de sua experiência anterior, o curso da Guarda Mirim como um dos principais aprendizados:

Então, isso [Guarda Mirim] ajudou bastante aqui [Universidade], cumprir horário de trabalho, fazendo iniciação você não pode faltar, mesmo não precisando você tem que ir lá, sabe, estudar, procurar alguma coisa. Então, a gente teve disciplina de horário, 
nas aulas também, não faltar nas aulas, não chegar atrasado, foi muito bem sedimentado na gente que você tem que ter horário, cumprir seu horário, respeitar, saber conversar e saber ouvir, sabe, saber a hora de falar, e falar a coisa certa, a coisa diplomática assim, não chegar estourando, explodindo, sabe, ter um certo controle. Isso ajudou muito aqui [Universidade], essa parte mais de disciplina que eu não tinha antes de passar por aí, eu não tinha tanto essa noção, sabe, eu era mais disciplinado por medo de professor, de repetir de ano, mas a noção de que isso era bom, isso era útil, eu tive lá, foi bem aumentado lá na Guarda Mirim...

Na Guarda Mirim, Antônio aprendeu, além da importância do auto-controle, “como se esforçar para conseguir uma coisa”, no caso, como, através da dedicação aos estudos, poderia ter acesso ao Ensino Superior público, algo totalmente distante de sua realidade naquele momento:

Se não fosse lá, certamente eu não teria... Eu estaria continuando a trabalhar noutra fábrica, não ia nem estar aí com estudo, não que não ia estudar por gosto, mas eu não tinha essa noção de que se estudasse bastante eu poderia chegar a um Curso Superior, sabe? Não tinha feito essa ponte ainda, a primeira parte da ponte foi feita por essa passagem na Guarda Mirim e o resto da ponte foi feita no colegial, se eu não tivesse passado essa primeira parte da ponte eu não ia conseguir o resto. Foi essa fase aí fundamental...

A travessia para o mundo da Universidade foi possibilitada por uma ponte representada na trajetória desse estudante pela experiência na Guarda Mirim e por uma educação de melhor qualidade oferecida, em sua cidade, pelo Ensino Médio particular. Entrar no curso de Farmácia na USP significou para Antônio a viabilização de mobilidade social e uma transformação tão brusca, em relação à posição social ocupada por sua família, que ele reconhece que, atualmente, mesmo formado e já aluno de Mestrado, ainda se surpreende com as possibilidades que constantemente se lhe apresentam. Reforçando que considera a entrada na Universidade como um “divisor de águas” em sua vida, ele diz:

Para mim foi um divisor mesmo, um negócio que vai assim repercutir nos filhos, nos netos, assim, porque mudou o pensamento de toda a minha família, eu, tipo, mudei para melhor, certo, eu vou ter uma vida melhor que meu pai, bem melhor que meu pai, meu filho possivelmente vai ter uma outra educação, vai evoluir mais ainda, então foi um negócio que tirou a gente de uma posição estagnada já, posição estagnada, promoveu, me promoveu, né! Que eu estava numa posição que eu ia dar continuidade, assim, não ia me levar a nada para uma posição melhor, de evolução, o pensamento mudou com isso e graças ao contato que eu tive depois que eu entrei no colegial, e continua até hoje, essa evolução, esse sempre querer ir para frente, sabe, nunca 
parar no lugar. Então, foi uma mudança violenta assim na minha vida, eu não esperava isso, sendo sincero até hoje eu não sei onde eu posso ir, o que quê eu posso fazer porque eu nunca vi, nunca tive um exemplo, sabe, um exemplo desde criança assim desse tipo de coisa, até meus 18 anos quando eu fiquei lá [cidade natal], nunca tive um exemplo desse. Então, para mim ainda está sendo uma surpresa até hoje fazer isso! Na minha família então, bem maior!

Para além da possibilidade de ascensão social individual, entrar na universidade pública significou também uma mudança de pensamento não só de Antônio, mas de toda sua família. A experiência dele tem contribuído para que sua família, não só nuclear, mas também tios e primos, mudem a forma de pensar a escolarização: “já mudou o pensamento, antigamente, quando eu tinha a idade deles [irmã e primo de 17 anos], (...) eu não tinha esse pensamento, eles já têm, eu acho que eu até ajudei um pouco a mudar esse pensamento...”. Além disso, por ser o pioneiro no Ensino Superior público, tanto do lado paterno quanto materno, Antônio transformou-se numa espécie de exemplo que todos querem seguir ("Pelo meu exemplo todo mundo quer tentar também”). Na sua família, a trajetória de sua irmã está sendo facilitada por sua experiência, na medida em que seus pais puderam compreender melhor e conhecer mais sobre o acesso à universidade: “...eles estão estimulando, pela minha experiência eles já sabem mais como lidar com a minha irmã: onde você vai estudar, com que você vai estudar, se precisar fazer cursinho, vai fazer...”. Ao contrário do que aconteceu com ele, já que Antônio diz que se não passasse no vestibular no terceiro colegial talvez não fizesse cursinho, pois seus pais não entendiam essa aprovação como resultado de uma preparação, mas sim como tendo ou não capacidade ("eles pensavam de outro jeito: 'ah, você não conseguiu passar no terceiro ano, você não vai conseguir passar nunca’ ”). Além de sua irmã, um primo também vai prestar vestibular, o que mostra que a sua experiência tem sido fonte de modificação de pensamento em toda a família: “Aí o resto quer fazer parecido, sabe que é possível, sabe, mais ou menos, como é que funciona então é bem mais fácil do que quem nunca teve contato...”.

A experiência desse estudante nos permite afirmar que existem outros sentidos para a relação entre filho/aluno e família além do sofrimento advindos de um distanciamento cultural, como apontam alguns estudos, como, por exemplo, o de Viana (1998). 
De todas as mudanças que a entrada desse jovem na universidade pública representou para a sua família, a mais fundamental parece ser essa: a sua trajetória mostra que é possível, também aos estudantes de camadas populares, ter acesso a um ensino superior de qualidade que faça, de fato, diferença em suas vidas. 


\section{Entrevista na íntegra}

\section{$1^{a}$ Entrevista}

Antônio: Então, eu entrei no pré em 1990 e aí eu sempre gostei, eu estava ansioso para ir para a escola, me adaptei rápido, aí, e no pré, eu não me dei muito bem porque eu não gostava de fazer pintura, de desenho, nunca gostei, eu gostava mais de fazer conta, escrever, aprender a escrever, essas coisas. Então, no pré eu ficava meio deslocado, eu gostava de ir, mas não gostava tanto das atividades. Aí, eu fui para primeira série, na mesma escola, escola estadual de Minas, eu fiz os oito anos, do pré à oitava série, na mesma escola. Aí no primeiro ano eu comecei a ter mais contato com matemática, português, aí eu comecei a estudar mais, me interessar bastante, aí me adaptei, tirava notas boas, assim, no primeiro ano e tudo, e gostava muito de ler, geografia, história, professora dava lá eu me interessava, eu lia bastante. Aí, segunda série, terceira série, quarta série tudo desse jeito, nesse esquema e seguia as diretrizes da escola, a escola ensinava tal assunto e eu aprendia daquela forma, aprendia alguma coisa por fora, por minha conta porque não tinha tanto estímulo de fora, sabe, (...) da família, amigos, assim, porque escola estadual sempre foi meio relaxada, não era feita assim, não era para fazer o aluno estudar bastante, só o básico, aprender mesmo o básico. E aí até a quarta série, assim, foi bem sossegado, tirava notas boas porque não era muito exigido, sempre com a mesma professora, chamava de tia. Daí eu fui para quinta-série, ginásio, na mesma escola ainda, daí eu não sei o quê aconteceu, eu me desinteressei da escola: desinteressei, não fazia dever de casa, fiquei bem, bem relaxado, só ficava na rua, ia na escola porque minha mãe me obrigava, mas ficava enrolando, direto de castigo porque não fazia os deveres de casa, não fazia nada na aula, virei um picareta lá, ficava só, só bagunçando. Aí no fim da quinta série, minha mãe me deu um sermão lá, eu não dei muita bola, aí de repente eu falei: “Ah, eu tenho que estudar, senão não dá...” Eu via alguns colegas evoluindo bastante, assim, eu falei: "Nossa! Eu tenho que estudar.” Aí da sexta série eu comecei a estudar mais, aí minha mãe viu que estava desvirtuando, no ano anterior, me botou para trabalhar meio período, e ao invés de desestimular a escola, melhorou, eu ia de manhã na escola, à tarde trabalhava e à noite eu fazia dever de casa, estudava mais, era cansativo mas eu vi que estimulou muito mais. Aí na sexta eu voltei a me adaptar à aula, à escola, a trabalhar também, e foi melhorando, melhorando, melhorando. Na sétima série aí eu parei de trabalhar, comecei só a estudar, aí deslanchou, foi bem.

Débora: Só um parênteses: o que quê você fazia?

A: Nesse ano eu era ajudante de tapeceiro, fábrica de estofado, aí fazia de tudo lá, aprendi bastante coisa só que eu tive que sair por conta que eu estava ficando bastante cansado, ia na aula ficava com sono, porque não dava para todo dia manter esse ritmo, porque eu tinha 13,14, 13 anos, era meio pesado. Aí, minha mãe, porque não precisava, era mais para me disciplinar do que ganhar dinheiro, trazer dinheiro para casa, porque meu pai sempre trabalhou no mesmo lugar e mesmo não tendo estudo, ele conseguiu um lugar razoável, suficiente, então era mais para disciplinar mesmo; meu irmão também seguiu a mesma coisa, só que ele não gostava de estudar, ele pegou gosto mais por trabalhar. Aí na sétima série eu só estudei, evoluindo, evoluindo, só que aí o sistema de ensino começou a se corromper muito, ficou muito parecido com o que é hoje em muitas escolas, sabe, falta de disciplina, porque na 
quinta série eu ficava de castigo porque tinha disciplina na escola, eles obrigavam a fazer dever de casa, essas coisas, na sétima série, já estava ficando fraco isso, eu tive a sorte de ter os professores antigos daquele antigo sistema, então não era tão falho, mas eu via que já tinha sinais de sucateamento, já estava ficando... Aí na sétima série fui muito bem, tudo, e na oitava série eu voltei a trabalhar de novo, numa fábrica de vassouras, rodo, esses equipamentos de limpeza, e gostava de trabalhar, e estudava, mesmo esquema, só que eu já era um pouco mais velho, já estava muito bem adaptado. Aí na minha cidade apareceu o "Guarda mirim”, sabe? Aí minha mãe me sugeriu para mim entrar, que era melhor, aí eu falei: “Ah, eu vou entrar, né.” E é uma coisa muito interessante porque muitos dos meus colegas da Guarda mirim eram bem mais pobres que eu e eles não tinham noção de educação civil, noções de direitos, de leis, sabe, e lá eles ensinavam tudo isso, primeiros socorros, como se comportar no ambiente de trabalho, como se trabalha, tivemos curso de informática, de office-boy, de datilografia, então formou muito bem os guarda-mirins, era chamado de guardamirins, era tipo uma educação militar, era muito parecida com educação militar só que não tão rigorosa, tinha muita coisa que ensina escola militar, então a pessoa fica mais sintonizada, aprende a ter bons modos, sabe todo um esquema para ele se portar bem no ambiente de trabalho. Aí eu fiz a prova para entrar na Guarda Mirim, uma prova de conhecimentos gerais de sétima, sexta série, passei tudo, normal. Comecei a fazer em março, eu acho, e ia me formar em setembro, dia sete de setembro, aí eu continuava na escola, só que eu parei de trabalhar naquela fábrica de vassoura, fiquei só três meses lá, e eu fiquei fazendo curso de Guarda mirim. E, aí, eu fiquei lá na Guarda Mirim, o bom é que lá eles estimulavam também a estudar, então aumentou ainda mais o interesse por estudo, essas coisas, e um ano antes eles tinham montado três escolas particulares de colegial na minha cidade: o Capital, o Hoje e o Pontual. E o Hoje tinha começado um ano antes, quando eu estava na sétima, a fazer vestibulinho para selecionar os melhores alunos para ganhar bolsa. Aí, na oitava série apareceu de novo, o primeiro vestibulinho foi do Hoje. Aí o vestibulinho seria em agosto e eu teria as férias de julho livres na Guarda Mirim, nem ia estudar nem ia para Guarda Mirim. Aí eles iam nas escolas públicas e garimpavam os alunos, eles iam, entregavam a ficha de inscrição, entregavam o que ia cair no vestibulinho para estimular mesmo os alunos a procurá-los, para eles terem, garimpar mesmo, achar os bons alunos. E a minha escola no ano anterior tinha ido muito bem, o primeiro e o segundo lugar era tudo da escola que eu estudava. Aí eu fui nessas férias de julho eu resolvi estudar matemática, português, o que ia cair, recapitulei tudo, estudei bastante, primeira vez que eu tinha estudado assim para uma prova especifica, longo prazo, estudei uns 15 dias. Aí fiz a prova assim, sabe, meio desencanado: "tem muita gente boa aqui.” Eu fiquei na minha. Aí no fim mês de agosto saiu o resultado, aí eu tinha passado em primeiro.

\section{D: O primeiro de todas as escolas ou da sua escola?}

A: Não, o primeiro geral, da cidade. Eu fui o primeiro, uma moça de uma escola particular ficou em segundo, o terceiro, o quarto, o quinto e o sétimo foi tudo da minha escola. Aí continuei na Guarda Mirim, eu sabia que ia estudar no Hoje [escola particular] no outro ano, tinha ganhado bolsa, tudo, não ia pagar nada, na verdade, ia pagar uma taxa de material bem pequena, não era pesado. Aí eu continuei na Guarda Mirim, eu falei: "eu vou terminar o curso de Guarda Mirim e vou trabalhar esse tempo ainda que sobra para ver se eu aprendo alguma coisa”. Aí as outras duas escolas também fizeram a prova. Aliás tinham mais três, o Agora[escola particular] 
também tinha começado, era mais antigo ainda. Eu fiz essas três provas, só que aí os meus colegas de escola também queriam entrar, no mesmo esquema, como eu já tinha o lugar, a gente ia mais para mim ir assim e de alguma forma passar cola para eles, nas outras escolas. Aí eu fiz a prova do Agora[escola particular], passei em segundo, esse do Pontual eu não fiz, e fiz o do Capital [escolas particulares] que foi o último, o do Capital eu passei em primeiro. Aí o diretor do Capital foi lá, me chamou para uma reunião, eu e minha mãe, e mostrou toda a estrutura do Capital, tudo, e como o Capital tinha bem mais dinheiro, era bem mais estruturado que o Hoje, e ele ofereceu, e eu não ia pagar nada no Capital, nada, nada. Aí eu conversei com a minha mãe e a gente resolveu ficar no Capital, fiquei no Capital. Aí nesse tempo eu formei na Guarda Mirim e passou dois meses eu arranjei emprego numa gráfica. E o pessoal da gráfica não sabia que eu tinha bolsa, que eu ia ter que sair no outro ano, trabalhei lá, tudo, aprendi muita coisa de gráfica, como imprimir, como ?ripar, mexer em impressora e tudo, trabalhei de outubro até fevereiro, até começar as aulas, aí eu tive que sair, o povo me apoiou lá: “Não, a gente arranja outro Guarda Mirim aqui”. E eu fui estudar no Capital, só que era totalmente diferente de escola pública, era matéria mais pesada, os professores diferentes, mais capacitados, assim, e o pessoal diferente também, gente que eu nunca tinha visto, turma que tinha mais dinheiro, sabe? Então, eu saí de um ambiente que era de Guarda Mirim, galera mais simples, para uma turma mais, eles chamam de "boyzinhos", né. O incrível é que eu me adaptava tanto a essa turma da Guarda Mirim, como nos de "boyzinhos". Na minha convivência assim, eu nunca briguei com ninguém, eu sempre tive muitos amigos, aqui também, em qualquer lugar, eu nunca tinha confusão, eu mais separava briga do meu irmão, dos meus primos do que brigava assim, não tinha nenhum tipo de confusão. Aí no Capital, o primeiro ano lá, eu mantive um nível médio, estava me adaptando, tudo, eu fui bem, fui bem assim. Aí eu fiz o simulado e eu tive ponto de aluno do terceiro ano de lá mesmo, aí o diretor: "Nossa! Você continua estudando porque você vai bem.” Estimulando, os professores estimulavam, era bem diferente da escola pública. Aí no segundo ano começou a ter aquela pressão para escolher um curso para prestar vestibular, aí eu não sabia o que eu escolhia, não sabia, aí eu comecei a estudar um pouco mais pesado, aprender um pouco mais, aí eu queria agronomia, eu queria agronomia, eu fiquei até o fim do segundo ano querendo agronomia. E o povo: "não, vai fazer medicina, vai fazer odonto, vai fazer farmácia!”. Sabe esses cursos mais tradicionais, direito, e eu não, queria fazer agronomia. E lá na minha cidade agrônomo não tem muito boa reputação porque lá tem várias escolas, várias faculdades que formam agrônomos, particular, então lá é saturado, então aquela região ali tem muitas escolas que formam agrônomos e eles não são muito bem vistos.

\section{D: Porque eles são mal formados, é isso?}

A: É, também, há muitos e mal formados, então eles não conseguem emprego lá. Ao contrário de quem forma na Esalq, na Unesp, aí é diferente, só que eles não tem contato com esse pessoal, então tem uma má impressão. Aí no segundo ano, estudando, estudando, estudando, eu fiz o simulado, aí eu tinha nota para passar em Odonto aqui, Odonto, Química, os cursos mais leves aqui. Aí eu falei: "mas, para agronomia ainda estou no limite.” Só que eu tinha outro gosto também, que eu tinha deixado em segundo plano: eu gostava muito de coisa de laboratório, que era o que terminou comigo fazendo farmácia. Eu tinha interesse por reação química, enzima, fermentações, sempre fui muito interessado nessas coisas que têm a ver também com 
agronomia. E peguei gosto por agronomia também porque meu tio comprou terra lá e eu ia lá ajudar trabalhar, formar lavoura de café, comecei a ter gosto assim, então muita gente tem esse gosto lá e é desestimulado no fim. O pai ou um parente tem terra lá e o cara fica muito interessado por agronomia mas é desestimulado. Lá é uma região de pequenas propriedades, tem muitas propriedades pequenas, é de formação de imigrantes italianos, tem muitos imigrantes, então é uma formação parecida com o sul do Brasil, diferente do resto de Minas, é um lugar meio diferente ali. Aí eu fui para o terceiro ano, aí eu comecei a estudar pesado, comecei a estudar, estudar, até que saturou, os professores, o sistema lá não conseguia mais, me oferecer mais, sabe, aí eu comecei a estudar muito por conta, em casa, no terceiro ano eu estudei muito. Aí eu escolhi fazer farmácia por causa... Não! Mentira, minto: eu queria fazer Biomedicina porque eu era interessado em análises clínicas, essa parte de diagnóstico.

\section{D: Você já tinha essas informações?}

A: Desde muito pequeno eu queria trabalhar com tubo de ensaio, análise, analisar sangue, sabe, essas coisas, e falava para minha mãe que eu queria ser cientista, essas coisas, quando era bem criança mesmo.

D: E onde você via isso?

A: Na televisão, televisão.

D: E na escola tinha laboratório?

A: Não, tudo na televisão. Eu via as coisas na televisão, eu também era muito interessado por planetas, astronomia, sabe, eu era pequeno eu desenhava os planetas, assim. Tudo o que eu via na televisão eu queria fazer, típico de criança: pensava em ser astronauta, depois queria ser cientista. Aí, eu tinha enterrado isso, e eu fui desenterrar só no terceiro ano (rindo)! Aí eu resolvi fazer Biomedicina, só que aí uma professora minha de biologia chegou e falou: “ó, faz farmácia que é mais completo, tem a parte química, tudo, você vai estudar mais, vai aprender mais, você vai sair mais capacitado.” Falei: “Ah, tá bom. Vou fazer farmácia então.” Aí, nesse tempo, no primeiro ano não, mas no segundo e no terceiro ano, outra professora me arrumou uma vaga como monitor da escola, então os alunos que estavam com dificuldades eles iam lá, eu dava aula e aí eu não precisava pagar o material do curso, do colegial. Então, de manhã até 12:15 eu tinha aula, eu tinha aula duas vezes por semana à tarde também, isso no segundo e terceiro ano, e nas horas vagas eu dava aula de monitoria.

D: De quais disciplinas?

A: Ah, de tudo, menos de inglês, menos de inglês só que eu não tinha domínio. Mas o resto, tudo, porque eu tinha contato nas aulas, eu praticamente ajudava em tudo. Os mais pedidos eram física e química, o povo lá tinha muita dificuldade nessas duas matérias e foi o que acabou me ajudando no vestibular. Aí eu comecei a me esforçar, fiz inscrição para duas, dois vestibulares só: aqui e em Araraquara, na Unesp. Aí chegou o Enem, fui bem no Enem, e fui fazer essas provas aqui. Eu tinha feito Fuvest no segundo ano, colegial, como treineiro, eu tinha ido mesma coisa, eu tinha nota para passar em Odonto, nota de corte, passar em Odonto, Química aqui. Aí eu sabia que eu tinha que me esforçar um pouco mais para tentar Farmácia. Eu tinha certeza que eu precisava passar de 100 pontos, eu tinha conseguido 89, 90, então eu precisava de um reforço. Só que o sistema lá, por ser uma escola do interior era mais fraco, né, porque quem quer passar no vestibular lá na minha cidade vai fazer 
cursinho em Campinas, até o colegial em Campinas, ou até aqui em P.[cidade onde se localiza o campus], só que Campinas é um pouco mais perto. E aí eu fiz as provas, né, tudo, primeira vez que eu tinha feito segunda fase, e fiquei esperando, tudo e passei, nos dois, na Unesp e aqui. Daí fiquei contente, aquela festa, aí eu falei: "vou ter que sair de A. [cidade natal], agora, vou ter que escolher um lugar”. Aí, vendo revista, sabe aquelas revistas que dão notas para curso, eu escolhi P., os professores lá do Capital apoiaram, aí eu vim para cá, aí na semana da matrícula vim aqui para o C. [moradia estudantil], conheci a diretoria aqui, eles falaram que eu poderia vir, que ia ter processo seletivo, tudo, e aí uma semana depois eu vim para cá. Estranhei totalmente: era outro mundo, outro esquema, levou seis meses para eu me adaptar aqui. Sorte que eu fui morar num apartamento, não era esse, era o $\mathrm{X}$, era um povo mais, eles gostavam de bagunça, mas eles sempre foram pé no chão, nunca abusaram de trote, sempre queriam que o calouro interagisse assim, aí não é à toa que eu fiquei muito amigo deles. Aí, isso ajudou a me adaptar aqui em P.[cidade onde se localiza o campus], mas eu estranhava desde o calor à comida do Bandejão, tudo, tudo, tudo, tudo.

\section{D: E aqui na moradia, o que você estranhava?}

A: Na moradia, na moradia, no começo eu estranhava os colegas de quarto até porque eu nunca tinha visto, não conhecia, não sabia os costumes, então eu ficava muito quieto, muito na minha, não é à toa que eles brincam comigo que eu levei seis meses para falar a primeira palavra aqui (ri). Só que aí eu fui descobrindo as coisas, sabendo como é que funcionava, porque eu sou assim: eu sempre fico num canto, esperando, e eu analiso quando eu estou num lugar diferente, muito diferente como era o caso aqui, vou ver como se comportam, como eles são, para mim poder fazer, me enturmar, né. Nisso foi mais ou menos um semestre, e nesse um semestre na Farmácia é pesado as disciplinas, e na verdade eu aprendi a estudar mesmo foi aqui! Porque o ritmo que eu tinha lá em A. não seria suficiente para ir bem aqui, não é à toa que as notas foram um pouco mais baixas, não fiquei de "rec" nada, mas foram mais baixas, eu fiquei com média ponderada 7.0, que eu não estava acostumado. Aí no segundo semestre eu já estava totalmente adaptado, aí já ia em festa aqui, já conhecia muita gente aqui no C. [moradia estudantil], fora do C., como é hoje, praticamente como é hoje. Aí, só estudava, não fazia iniciação, nada, nada de bolsa trabalho, nada. Aí segundo ano, recebemos os calouros, aí eu vi que eu não era mais o calouro, demorou um pouco para eu perceber que eu não era mais calouro, até porque eu evitava zoar os calouros pensando que eu ia levar alguma coisa também, algum tipo de trote, como se eu estivesse zoando um veterano (rindo). Foram uns dois meses ainda do segundo ano para mim poder ver que eu era veterano.

D: Para você se convencer disso ou você não sabia como é que era o esquema?

A: Não, eu sabia, mas eu estava muito encanado no primeiro ano porque eu via calouros aqui levar uns trotes bárbaros (rindo), assim, por desrespeitar, fazer brincadeira com veterano, sabe, tipo, veterano caiu ali, ele zoa, o cara está bêbado, ele zoa, então eu ficava mais na minha assim, para evitar confusão. Aí no segundo ano eu resolvi que eu ia estudar bastante para aumentar a média ponderada.

D: E você estranhou essa coisa, te interrompendo um pouco, porque até então você era um ótimo aluno e quando você chegou aqui não foi bem assim, como é que foi isso? 
A: Então, aqui eu encontrei alunos bem melhores, bem mais acostumados a estudar, eu não fiz cursinho, eu vim direto do terceiro ano, mas a maioria da minha sala, veio do cursinho, então eles estavam acostumados a um ritmo de estudo, eu não, eu estava mais sossegado, eu tive que me readaptar para começar a estudar mais. Daí eu peguei o costume de ir para a biblioteca, toda noite eu estudava tipo das sete até às dez todo dia, eu fiz isso até a prova do mestrado agora. Isso foi bom porque a minha média de sete, eu consegui aumentar ela para 8.0 no fim do curso. Tem gente na minha sala que tem média 8.8, 8.7, mas para mim foi suficiente, está muito bom, para quem se esforçou com o tempo assim. Aí eu não trabalhava, assim, não procurava iniciação, no terceiro ano eu fui atrás de iniciação científica, eu trabalhei um ano, assim, mas não rendeu bolsa, não rendeu nada porque no laboratório essa área já estava morta, não tinha aluno de pós, eu era o único aluno de iniciação, e a orientadora tinha colocado os esforços na outra área, o laboratório tinha duas áreas - físico-química e outra microbiológica - eu queria microbiológica, aí eu trabalhei um ano, e vi que não ia render, aí eu larguei mão, desisti no terceiro. Aí no quarto ano na Farmácia, tem o “adeus básico”, aí o aluno ou escolhe fármaco-medicamentos, que é para trabalhar na indústria, ou escolhe análises clínicas, que é para laboratório, eu como sempre gostei de análises clínicas, escolhi análises clínicas. E ainda não sabia o que eu ia fazer depois que formar, totalmente perdido no quarto ano! Teria mais um ano: do meio do quarto ano ao meio do quinto ano, seria a especialização em análises clínicas, depois seria seis meses de estágio. Aí eu comecei a fazer o curso de análises, aí estava muito bem adaptado, estava fazendo disciplinas que eu gostava, via a parte mais biológica, aí deslanchou. Aí teve uma disciplina da minha orientadora atual, que era parasitologia clínica, eu peguei a matéria para estudar para prova, via que entrava na minha cabeça muito fácil. Nossa! Gostei muito da disciplina! Aí eu fiz as duas provas, né, tirei dois 10.0, fechei com 10.0. Eu falei: "nossa! Esse negócio é muito fácil! Eu gosto disso!” E outra coisa que eu gostava era biologia molecular. Aí, eu não sabia o que fazer, eu fui embora para casa, (...) [em um feriado] em outubro, aí eu cheguei na minha casa, de repente eu pensei: "nossa, eu gosto dessa matéria, não sei o quê, eu vou bem nessa matéria, pá! Eu acho que eu vou fazer pós-graduação!” Do nada, assim, surgiu. No quarto ano! Geralmente a pessoa que não conseguiu nada, vai e no último ano, na última hora, vai fazer pós-graduação. Eu não, eu já vi: "eu vou tentar para ver o que quê é, então eu vou trabalhar no laboratório até me formar para ver se eu vou gostar." Aí fui conversar com a minha professora, orientadora, ela aceitou tudo, assim, novembro, aí ela estava com laboratório recémfeito, ela é recém-contratada, estava com laboratório novo, eu fui o primeiro aluno dela, aí eu comecei a trabalhar lá esse ano de 2006, foi tudo muito rápido, consegui bolsa Fapesp, tudo muito rápido, coisa que lá na outra iniciação, que tinha até desistido, tinha até desiludido com pesquisa, não tinha conseguido nada, fazia muita coisa por conta. Aí nesse foi mais a orientadora que me estimulou, no outro eu que tinha que estimular a orientadora, era o contrário. Aí comecei a trabalhar, e como eu estava no quinto ano, eu conhecia muitas técnicas, eu fiquei tipo meio independente da orientadora, assim, ela não precisava ficar me ensinando, nem a técnica, me ensinaram o que eu não sabia, o mais básico que eu não sabia, e eu comecei a trabalhar meio por conta, lá, eu evolui muito rápido, e o incrível é que eu gostava, que a minha orientadora fala que a maioria faz o experimento, dá errado, desiste, quer ir embora, eu gosto de fazer o experimento, se der errado, trabalhar em cima e melhorar, como foram muitas técnicas lá que eu re-adaptei, melhorei para facilitar, diminuir o tempo, melhorar rendimento, porque a gente trabalha com parasitas e 
precisa ter um certo rendimento na produção desses parasitas porque a gente usa o material genético deles para vários experimentos, então nessa área, a tendência é sempre dar errado, sempre dá errado, e eu gostei, acabei gostando dessa coisa de dar errado, porque quando você consegue é uma coisa incrível, para quem pesquisa é o máximo isso. E é uma coisa que eu gostei, pegar, fazer pesquisa, ficar estudando a coisa: "Ah, o que quê eu posso fazer aqui, mudo aquilo..."

Se o cientista chega a uma conclusão ele tem mais dez dúvidas, quando você tem um erro, você tem mais dez sugestões para você tentar, o único fator limitante é o tempo, mas isso pode ser superado trabalhando um pouco mais. Então, foi uma coisa que eu gostei muito de trabalhar e vi que ali é um lugar para se trabalhar, fazer carreira. Só que o início, meu objetivo inicial para fazer pós-graduação não era pesquisa, e sim era dar aula, ser docente porque desde o segundo ano, do segundo semestre do curso de farmácia, quando tem apresentação de seminário, eu adorava ir lá na frente e falar, dar uma aula, expor, e os colegas também sempre me elogiavam: "ah, você tem que ser professor, tem que dar aula, porque você tem facilidade, não fica nervoso na frente da turma assim.” E aí eu sempre fiquei com isso na cabeça e aí para pedir a vaga no laboratório eu falei para minha orientadora: "eu quero ser docente, muito mais ser docente do que ser pesquisador, eu vou tentar pesquisar, né". Ela falou: “Tudo bem. Então você vai fazer pós-graduação?” Eu falei: “Vou”, tudo. Agora está meio a meio, porque primeiro faz muito tempo que eu não dou seminário, não pratico algum tipo de aula, e a pesquisa acabou me envolvendo mais, eu acabei gostando desse negócio de erra, acerta, erra, acerta, e vou continuar nisso e fiz a prova de mestrado, tudo, passei, normal, e agora eu vou me dedicar a essa parte de pesquisa, pós-graduação para no futuro ser docente. E uma coisa assim que na minha vida eu acho que é divisor de águas foi a hora que eu saí dessa empresa de rodo e fui ser Guarda mirim, porque aí que me ensinaram que eu devia estudar: "o indivíduo tem que estudar porque senão ele não vai evoluir”. Esse tipo de coisa não era colocado na nossa cabeça na escola pública até aquele momento. E quando chegou isso eu comecei a ter sentimento de disputa também, sabe, por isso que eu comecei a estudar para vestibulinho para ver até onde eu poderia ir, e num bom caso, como foi, num caso ótimo, eu acabei passando, tudo, e aí começou, os estímulos aumentaram muito mais: "você tem que estudar, você vai conseguir", depois disso, esse foi o divisor. Muitos colegas meus que não fizeram isso, que tinham capacidade muito parecida com a minha ou até melhor, mas não tiveram esse divisor, então, eles continuaram na escola pública, fizeram colegial na escola pública, e não conseguiram nem fazer vestibular, porque a escola pública, o colégio lá público é estadual, e ele é totalmente sucateado, perto da minha escola de ginásio, minha escola de ginásio é muito melhor do que a escola estadual de nível médio. Então, lá os alunos praticamente são perdidos. O ensino médio é muito ruim, muito mesmo. Porque acabou repetência tudo, todos os meus colegas, do mais dedicado ao mais relaxado, passavam com notas parecidas. Então o aluno dedicado fica desestimulado também. Primeiro que não tem esse estímulo dele estudar e passar no vestibular, muitas vezes não vem da família também porque a família que tem mais consciência coloca o filho na escola particular e... E muitos amigos meus perderam assim, não tiveram a capacidade aproveitada, eu tive a sorte de ter uma idéia que acabou me salvando na hora certa.

D: Amigos do ginásio, você diz?

A: Isso, muitos. Uns quatro ou cinco, assim todos alunos bons que acabaram não indo. 
D: Mas, eles chegaram a prestar as provas que você prestou?

A: Não, eles tinham na cabeça que não iam passar. Na verdade, os que iam comigo para mim passar cola eram os mais relaxados que viram que eu passei e também queriam mas já era tarde. E quem tinha capacidade parecida com a minha, muitos ficaram com medo de fazer a prova: "ah, eu não vou fazer, eu vou mal, não sei o quê, (?) vou sair com atestado...” Tipo o cara ia receber aquele atestado: "você não tem capacidade”. Muitos tinham medo disso, e eu fui fazer também com receio disso, mas não tinha nada a perder, também tinha estudado, tinha me preparado um pouco, e fui fazer e acabou dando tudo certo.

D: Você tem notícias deles ou de alguns deles?

A: Na minha cidade tem uma empresa lá de cerâmica grande, indústria grande, meu pai trabalhou, meu irmão está trabalhando lá agora, os meus colegas com capacidade estão todos lá, a empresa pegou todos. O cara que passou em terceiro, era amigão meu, neste vestibulinho, a gente passou, eu com 60 pontos, a moça com 59 e ele com 58, muito próximo os pontos, ele trabalha lá, está relativamente bem, mas era para ele estar aqui também, era para ele estar aqui mas ele resolveu trabalhar, falou que o negócio dele não era estudar, não quis, não aproveitou, preferência dele, acabou... E tem outros que foram embora da cidade, a maioria foi embora da cidade, eu nem sei onde foram parar. E... O que eu lembro de relevante da história é essa parte assim.

D: E essa escola que você estudou, você consegue localizar se ela era uma escola mediana, se era uma das melhores?

A: A minha escola de ensino fundamental era a melhor da cidade, no começo até a minha sexta série ela era muito boa, excelente. Não é à toa que nesse período de vestibulinhos, não sei se ainda existe lá, mas um ano antes que o meu, quando começou, e uns três depois a minha escola sempre estava entre os primeiros. Com o advento do ensino fundamental particular lá, aí os alunos acabaram perdendo, mas os donos de colégio sentiram isso, que teria uma concorrência desleal - ensino particular e ensino público - e dividiram a prova, eles continuam garimpando, só que eu creio que acabou esse tipo de garimpo, como eu chamo, por causa do sucateamento da escola, a escola acabou perdendo a qualidade, porque os melhores professores da escola, eram professores excelentes, foram absorvidos pelo sistema particular, e não tinha professores novos para colocar no lugar, traziam professores não capacitados, sem concurso, sem nada e a escola começou a perder um pouco da filosofia de disciplina, foi perdendo disciplina, perdendo disciplina, e está muito parecido hoje com escolas que a gente vê na mídia aí, que é sempre mostrado escolas com alunos violentos, professores não são respeitados, a estrutura da escola tipo caindo aos pedaços, está muito perto disso, a escola particular acabou levando a mão de obra da escola pública, a minha escola ela era muito boa. No meu vestibulinho era eu, o terceiro, o quarto, o quinto, o sexto e o sétimo! Todos eram da minha escola, todos da minha classe! E todos nesses pontos, tipo 60 pontos, o sétimo teve 50 pontos, então muito próximo, a gente tinha capacidade muito parecida, graças aos professores porque eram bons professores. Agora as outras escolas lá já eram mais... Porque essa escola ficava na parte alta da cidade, a parte alta é a parte mais antiga, mais tradicional, sabe, a parte onde o povo que tem mais dinheiro vive, então no tempo que não existia escola particular lá, foi ter escola particular em 95 que era o Ângulo, todo mundo estudava ali, e a parte de cima da cidade estudava ali, em compensação a parte de baixo, que eram pessoas mais pobres, pessoas que vinham 
para trabalhar nas lavouras de café, migrantes, tudo, do Nordeste, e tudo, pessoas mais simples, que não estão tão acostumadas à educação, a ter educação, ficaram em escolas mais, mais, piores, né, os professores não tinham gosto de dar aula lá, os professores preferiam dar aula aqui, na parte alta [faz gesto explicando], então acabou tendo essa diferença. Uma coisa interessante é quando eu fui Guarda Mirim, a grande maioria dos Guarda Mirins era da parte de baixo, eles queriam arranjar emprego, e era incrível as pessoas entravam lá, meus colegas entravam lá, sem noção nenhuma de como se portar no trabalho, tudo, e eles eram ensinados, educados para ter uma disciplina, como trabalhar, como se comportar no trabalho, não é à toa que a grande maioria acabou evoluindo nessa área, é raro ver colega meu ser despedido por motivos, sem justa causa, com justa causa também, é muito difícil ver esse tipo de coisa. Então, é uma instituição bem, bem formada... Agora ela saturou, pelo fato da cidade não ter capacidade de absorver todos os jovens que fazem Guarda Mirim, as primeiras turmas tiveram privilégio, mas agora já está saturado, então ela não tem mais aquele efeito, sabe, ainda disciplina, ensina, mas o jovem sai e não consegue emprego, é muito mais difícil.

\section{D: E você morava onde na cidade?}

A: Eu morava na parte mais alta. Porque a minha família, com exceção do meu pai, meu pai chegou lá na década de 70, ele veio de C. - uma cidadezinha perto de M. [cidades mineiras] - ele veio de lá; agora a minha parte materna é toda de lá, tipo minha parte materna, minha vó, é tudo imigrante italiano e espanhol, meu avô foi dos primeiros que colonizaram o local, dos fazendeiros de gado, meu avô, ele descende daquela gente, daquela parte da cidade e minha vó da parte dos imigrantes, então isso no século retrasado ainda, eles vieram na primeira leva de italianos e dos portugueses, portugueses, negros que trabalhavam antes lá. Então, eles se fixaram na parte alta da cidade. Meu pai, veio depois, mas casou com a minha mãe, então acabou morando lá também, porque meu vô, meu vô, minha vó, trabalhavam de meieiros de café, na zona rural, aí mudaram para cidade, trabalharam, compraram terreno lá nessa parte alta, porque a cidade ainda era pequena, então acabou fazendo casa, e a gente acabou ficando lá, na parte melhor. Para você ter idéia na minha rua, no meu bairro, a maioria das pessoas tem sobrenome de origem italiana, espanhola, pessoas de origem imigrante, europeu. Já na parte de baixo da cidade a maioria é imigrante do Norte do Brasil, nordestino, nortista, então tem uma grande diferença nas partes da cidade, a parte de cima é mais valorizada, a parte de baixo é menos valorizada. Então, tudo o que tinha lá era diferente: o posto de saúde da parte de cima é diferente do posto de saúde da parte de baixo, escola de cima é diferente da escola de baixo. E o colégio público, ele agregava os dois, as duas partes, e ele acabou tendendo à parte mais populosa que é a parte de baixo, então acabou ficando mais com pior qualidade também porque os professores não gostavam de dar aula lá. A escola que eu estudei primeiro no ensino fundamental foi onde os melhores professores ficavam, isso foi um diferencial, e tipo a escola da minha casa era dois quilômetros, no máximo, então dava para ir a pé, voltar a pé, tranqüilo. (pausa)

D: Agora voltando lá no começo, você comentou que você tinha vontade de ir para a escola. Você se lembra por que você tinha vontade, da onde que vinha essa vontade?

A: Nossa, eu tinha uma vontade absurda de aprender a ler e a escrever, eu ficava assim, olhando assim letra, ficava escrevendo as letras que eu sabia, não fazia conexão, não sabia nem ler, nem escrever. Eu queria aprender, queria aprender a 
fazer conta, sabe, fazer conta de multiplicação: “como é que faz isso, não sei o quê?” Mesma coisa hoje, que eu nunca tinha mexido com biologia molecular, é fazer um PCR, eu sou louco para fazer um PCR (rindo), que é amplificação de material genético, clonagem, eu era louco para fazer isso na minha graduação, só que não tinha aula para isso, aí eu entrei em contato com isso na pesquisa, fiquei deslumbrado! Mesma coisa ler e escrever no primário, eu queria muito aprender, aprender bastante, o que eu pudesse aprender estava bom, eu não gostava da parte de pintura, desenho, essas coisas, eu pegava pintura grande para fazer, eu fazia um risco no meio assim vermelho que era o chapéu, o casaco preto fazia outro risco, a bota outro risco, assim, um negócio bem, bem mal feito (rindo). Igual fazer relatório de coisa que eu não gosto hoje, na graduação, fazia também nas coxas. Mas eu tinha um gosto assim absurdo para aprender a ler, a escrever e matemática.

D: Você via alguém, você tinha contato com alguém que ia na escola antes de você ir?

A: Não, não tinha, minha mãe tinha me dado, sempre me dava quebra-cabeça, eu montei um quebra-cabeça com três anos de idade. Lego, me dava caderno, lápis de cor, assim, mas nunca me ensinava, me ensinou a escrever meu nome, coisinha leve, nome do meu pai, nome da minha mãe, coisas mais familiares, aí ganhava relógio, aprendi a ver a hora, assim, eu ficava deslumbrado com isso! Aí eu assistia muito televisão, programa Rá-tim-bum, esses programas educativos da Cultura, eu ficava o dia inteiro assistindo, aí via as coisas lá, queria fazer em casa também, tacar fogo na casa, esse tipo de coisa. O Rá-tim-bum eu assistia muito, assim, eu e o meu irmão. A televisão foi bem decisiva assim também, quando eu via as coisas na televisão eu queira aprender, ir para escola também, aí comecei a ter amigo na escola, aí não parou mais!

\section{D: Seu irmão é mais velho ou mais novo que você?}

A: Mais novo, um ano e meio mais novo. Ele estava um ano atrás de mim na escola. Ele não gostava, ele nunca gostou de ir na escola. Ele ia mais na escola por causa de amizade, de brincar, jogar futebol, essas coisas, do que estudar mesmo. Ele nunca gostou de estudar e até hoje ele trabalha, como a maioria dos meus amigos lá todo mundo trabalha, ninguém assim pegou gosto pela escola porque os pais, assim, é difícil eles ensinarem os filhos a estudar desde pequeno, começa a fazer pressão quando está no colegial, aí já é meio tarde, o pessoal tem que correr contra o tempo e se adaptar ao estudo mesmo, eu tive a sorte de pegar o gosto desde pequeno.

D: E seu irmão terminou o colegial e parou?

A: Fez, fez. Mas fez de um modo muito fácil, sabe? Não tem repetência, nada, então ele ia na aula, fazia uma provinha, coisa leve, acabou fazendo o colegial. Diferente dos meus tios, meus tios também não gostavam de estudar, mas eles não passaram, meus tios não conseguiram nem fazer a oitava série porque a escola era mais rigorosa, o sistema era mais rigoroso.

D: Seus tios por parte de mãe?

A: Parte de mãe. Meus tios por parte de pai fizeram $4^{\text {a }}$ série, igual meu pai e minha mãe, também. E minha mãe é a mais velha, então meus tios mais novos já foram na escola, já estavam morando na cidade, minha mãe já morava na roça, então era mais difícil. Minha mãe gostava de estudar também, mas pela distância, não tinha transporte, acabou ficando até a $4^{\text {a }}$ série. Aí, a escola, por estar mais de pior 
qualidade, diretrizes ruins, meu irmão, assim, muito fácil, não teve problema nenhum. Quando ele estava na escola antiga, que eu fiz o ensino fundamental, ele repetiu de ano a segunda série, e todo ano ele ficava de recuperação, ele e um monte de gente, vários dos meus colegas que não gostavam de estudar ficavam de recuperação, e só passavam se realmente mostravam que sabiam a matéria, isso começou a mudar quando eu estava na sétima série, que teve essa mudança de política, aí ficou mais fácil passar, aí foi a diferença, a escola começou a perder qualidade.

D: Como que era a relação de seus pais, da sua família, com a escola? Eles iam nas reuniões, acompanhavam as tarefas?

A: Minha mãe nunca me acompanhou, assim, que eu sempre fui mais independente, assim, que ela sabia que eu ia na aula, que eu prestava atenção, que eu tirava nota boa, a não ser na minha quinta série que ela pegou no meu pé, (?) isso aí em outubro (?), mas daí eu melhorei depois. Agora o meu irmão ela acompanhava muito por causa dele não gostar de escola, e ela estimulava muito mais ele do que eu, ela sabia que eu estava no caminho certo. E chegou um momento também, pelo fato dela ter feito só a $4^{\mathrm{a}}$ série, ela não conseguia mais me acompanhar, então ela ficou mais em cima do meu irmão para ele estudar. E meu pai sempre me proibiu de trabalhar, nunca gostou que eu trabalhasse, ele queria que eu ficasse estudando, mas eles não sabiam como me fazer estudar, onde estudar, com quem estudar, o que estudar, eles não tinham essa noção, eu tive que aprender sozinho, e depois lá no colegial os professores lá me deram assistência. Eles ficaram com esforço mais sobre o meu irmão que precisava mais do eu. Mas, quando precisava ir em reunião minha mãe, ela ia, mas até os professores falavam que não precisava ir, tudo, aí acabou ficando tendo maior esforço, dando maior ênfase para o meu irmão. E agora também para minha irmã também, minha irmã mais nova, ela tem mais gosto pelo estudo que o meu irmão, então eles estão estimulando, pela minha experiência eles já sabem mais como lidar com a minha irmã: onde você vai estudar, com que você vai estudar, se precisar fazer cursinho, vai fazer, no meu caso não, se eu não passasse no terceiro ano talvez eu nem fizesse cursinho porque eles pensavam de outro jeito: "ah, você não conseguiu passar no terceiro ano, você não vai conseguir passar nunca.” Já com a minha irmã é diferente, porque eles viram que o esquema era diferente, o sistema é diferente, na minha cidade, agora está mudando, mas antigamente a pessoa tinha que passar no terceiro ano, eles não tinham essa visão de cursinho: "porque cursinho não vai servir para nada, a pessoa não ia passar mesmo, se não conseguiu uma vez não consegue nunca.” Eles tinham muito essa visão, começou a mudar há pouco tempo. Antigamente lá não tinha cursinho, só colegial particular, começou depois que eu saí de lá.

D: Ela está em que série?

A: Ela está no segundo colegial. Os próprios professores dessa escola, ela está numa escola pública [onde o irmão também estudou], os professores lá estão mudando o pensamento também, os professores estão montando tipo um cursinho paralelo para, eles pegam os alunos interessados, e dão aulas mais pesadas para eles e estimulam a estudar mais para poder enfrentar um vestibular ou pelo menos estar adaptado a um cursinho porque a pessoa que sai de uma escola como aquela, eu percebia lá, ele vai fazer cursinho, ele tem que fazer dois, três anos de cursinho porque ele está muito defasado, diferença de ensino da escola pública para a particular lá, eu acho que na 
maioria dos locais, assim, é muito grande, e duma escola particular de lá, para uma escola particular de centro, como é Campinas, São Paulo, P. [cidade onde se localiza o campus] também, a diferença também é grande. Então, o povo lá que tem dinheiro manda para fora, quem não tem, tenta lá mesmo, estimula estudar, faz cursinho, mas agora todo mundo está com um pensamento melhor com relação à educação. (pausa)

D: E você tinha comentado que no Capital[escola particular] você não iria pagar nenhuma taxa...?

A: Isso, no primeiro ano. No segundo eu tive que pagar material, mas como eu era monitor, eu não precisei pagar material. E no terceiro, a mesma coisa. Todo ano eu fiz vestibulinho, e todo ano eu passei em primeiro.

D: E essa coisa do trabalho, você falou que seu pai não queria que você trabalhasse e sua mãe queria. Como é que era isso?

A: Minha mãe queria para me disciplinar, para não me deixar na rua. Porque ela tinha certeza que algum colega meu ia passar lá em casa, e ia me chamar para soltar pipa, para pescar, para ir jogar bola, ela sabia que eu não ia estudar e quando ela percebeu que eu trabalhei, quando eu estava na sexta série, e eu comecei a estudar mais, eu estudava à noite, ela percebeu, e eu percebi também, que trabalhar disciplinava melhor, estimulava mais a estudar, do que você ter meio período de aula e ficar à toa, sabe? Tipo dava uma quebrada na preguiça, com o tempo, conforme você vai tendo relação com gente mais velha, a maioria dos locais lá que eu trabalhei era fundo de quintal, então, era um negócio engraçado, o povo era zoeira, então eu gostava também, apesar de cansaço, de pesado, eu gostava muito.

D: E seu irmão trabalhou também?

A: Meu irmão trabalha desde os 14 anos, assim, sempre trabalhou e não consegue ficar sem trabalhar, e ele ficou muito mais tempo trabalhando do que eu, bem mais, eu sempre teve essas quebras, eu saía, não agüentava, junto com a escola, me esforçava na escola, depois Guarda Mirim, depois o Capital, no colegial eu não trabalhei mais, eu só trabalhava no colegial de fim de semana que eu ajudava meu tio a cuidar da lavoura de café, eu gostava também, eu ficava lá. Até hoje! Nos semestres anteriores, nas férias, eu ficava lá trabalhando, só agora que eu comecei a pesquisar de verdade que eu não voltei mais lá, mas foi assim... (pausa)

D: E na escola, na primeira escola que você estudou até a $8^{\text {a }}$ série, como que era a relação com os professores?

A: No ensino fundamental? Ah, cada professor era dum jeito mas eu tive amizades assim profundas com professor, com alguns professores, a maioria, a maioria, assim, eu fiz grandes amizades. Minha professora do terceiro ano primário, meu letra é horrível, é horrível até hoje! Cada vez pior! Ela ficava em cima de mim: "Antônio, você tem que fazer letra mais bonita, faz letra bonita senão ninguém vai entender o que você escreve...” Aí acabou rolando amizade grande, assim, ela me ameaçava botar de castigo, ela ficava desesperada, tentava fazer letra melhor, mas no fim acabou tendo amizade grande. Professores da oitava série também, sétima série, oitava série, fiz grandes amizades, assim. Nunca briguei com professor, nunca precisou brigar, era mais zoeira, brincadeira, piada, esse tipo de coisa, a relação era muito boa, assim, com professores. Já vi aluno bater em professor dentro na sala de aula na escola pública: professora queria que aluno ficasse na sala de aula, ele não queria ficar, aí rolou ameaças, ameaças, e dentro de uma semana o aluno bateu no 
professor. Eu já vi isso assim, eu acho absurdo. Mas minha relação assim com professor sempre foi muito boa... Até aqui na faculdade, tudo. Eu acho que a maioria dos professores não tem má fé, então você fazendo a sua parte, estudando, se esforçando, o professor não vai te atrapalhar, ele vai te ajudar, são raros os professores que te atrapalham, pelo menos até onde eu fiz, tanto na escola primária, tanto colegial, quanto aqui na faculdade, sempre tem apoio, ele está ali para ensinar e o gosto dele é ver você aprender, então, se você se esforçar para isso, não tem erro.

\section{D: E no colegial também era uma relação boa?}

A: Boa. Melhor do que no fundamental porque tinha um contato maior pelo fato da sala ser menor, ter menos turmas, o professor estava mais presente, tinha mais aulas também, professor estava mais presente. Pelo fato da gente estar mais velho também, tinha assuntos mais compatíveis, falava bastante de política, de religião, assuntos mais adultos assim, sabe? Então, acabava aproximando mais o aluno do professor. Aliás, até mais do que aqui, né, que as salas são maiores, o contato é menor, lá as salas eram menores, no ensino fundamental, a salas eram maiores, na escola pública, então tinha 40, 45 alunos por sala, aí já era mais difícil ter contato, mas ainda tinha.

D: E a relação com colegas aqui na Universidade, como é que isso?

A: Com colegas? Eu sempre, desde que eu tive relação com colegas, todo mundo sempre me respeitou, sabe, eu não sei porquê, depois que eu virei veterano aqui, nossa! Sempre relação boa com colegas, na escola pública também, como eu disse, eu nunca briguei, nunca precisei brigar com ninguém, eu mais separava briga dos outros do que brigava. Eu sempre fui um cara de conversa, de brincadeira, de brincadeira saudável, sempre fiz brincadeira saudável, gosto de fazer jogo de palavras, essas coisas, então, a pessoa acaba tendo amizade comigo, assim. E aqui [moradia estudantil] foi um local bom, porque tem muita gente de vários locais, de cursos diferentes, de pensamentos diferentes, muito mais que na Farmácia, porque ali todo mundo tinha mais ou menos uma área para atuar, uma área parecida, aqui não, tem relação com gente da Química, da Enfermagem, da Física, são pessoas totalmente diferentes, e eu consegui ter relação boa com todo mundo, então nunca tive problema nenhum. É claro que eu sempre tenho grande paciência, você viu a cozinha aqui está uma bagunça (sorrindo), onde eu morava então é pior, mas isso é o esquema aqui, não tem como você chegar e brigar com todo mundo. Eles me respeitam, ninguém invade meu quarto, ninguém mexe nas coisas ali, então, para mim está bom. Então, nunca tive nenhum momento de estresse assim com colega, não, muito difícil. Já discuti por causa de jogo de futebol... Eu discuti, mas nada de violência, nada, sempre muito sossegado...

\section{D: E seu irmão brigava na escola?}

A: Nossa! Muito! Na escola, na rua, ele brigava muito. Agora ele parou, né, agora ele sossegou (rindo). Tem até mais amizade que eu, né, lá na minha cidade, que eu saí de lá, ele tem muitos amigos lá. Mas eu separava briga dele direto, era muito, muito comum separar briga dele, muito comum. E pelo fato de eu estudar bastante, saber muita coisa, meus colegas sempre vinham me perguntar coisas assim perdidas. Até hoje eu gosto de estudar história e por ser um campus que não... Aqui no C. [moradia estudantil] pouca gente sabe História, então sempre quando tem discussão eles vêm conversar comigo porque eu gosto mais de História do que de Farmácia praticamente... (rindo) Eu me interesso muito por essas coisas, então eu sempre procuro assim... Então, são sempre conversas legais, saudáveis, um negócio bem 
interessante, assim. Desde pequeno era assim, eu sempre inventava as coisas, brincadeiras, coisas para fazer, sempre tive uma posição assim de ensinar, mesmo, todo mundo me respeitava, ao contrário do meu irmão, que se cutucasse ele, ele já virava assim, xingava, mandava para aquele lugar. Então, eu sempre separei briga do meu irmão, mas raramente eu briguei, quando eu briguei, briguei por causa dele (ri). Ele era mais novo, menor, né, então, sempre entrava em confusão, quanto entrava em confusão, meus amigos entravam também, então virava um balaio. Então, sempre tive boa relação assim, nunca tive nenhum problema.

D: Antônio, agora uma pergunta mais geral: eu queria saber o que quê para você significou ter entrado aqui na USP no curso de farmácia?

A: Ah... Era uma coisa inimaginável, eu não imaginava entrar aqui, por mim eu ia estar trabalhando lá em A. [cidade natal] para ser empregado, assim, uma coisa baixa, eu já estava com isso na... Todo mundo tinha isso na cabeça, lá, eu fui o primeiro da família a entrar numa faculdade! E ainda entrei numa faculdade pública e do estado de São Paulo ainda, que eu era de Minas! Então, foi um negócio diferente, foi um choque, assim... E o que eu aprendi do significado do curso de farmácia, o que é fazer um curso superior foi aqui. Então, eu sei mais ou menos o que me espera, assim. E não esperava isso quando eu estava lá em A. [cidade natal], não sabia o que ia fazer, nem sabia se ia passar no vestibular, eu estava meio que me esforçando, já pensando que ia trabalhar depois, sabe, eu estava meio assim.

D: Mesmo quando você estava no colegial?

A: Mesmo quando eu estava no colegial. Para mim foi um divisor mesmo, um negócio que vai assim repercutir nos filhos, nos netos, assim, porque mudou o pensamento de toda a minha família, eu, tipo, mudei para melhor, certo, eu vou ter uma vida melhor que meu pai, bem melhor que meu pai, meu filho possivelmente vai ter uma outra educação, vai evoluir mais ainda, então foi um negócio que tirou a gente de uma posição estagnada já, posição estagnada, promoveu, me promoveu, né! Que eu estava numa posição que eu ia dar continuidade, assim, não ia me levar a nada para uma posição melhor, de evolução, o pensamento mudou com isso e graças ao contato que eu tive depois que eu entrei no colegial, e continua até hoje, essa evolução, esse sempre querer ir para frente, sabe, nunca parar no lugar. Então, foi uma mudança violenta assim na minha vida, eu não esperava isso, sendo sincero até hoje eu não sei onde eu posso ir, o que quê eu posso fazer porque eu nunca vi, nunca tive um exemplo, sabe, um exemplo desde criança assim desse tipo de coisa, até meus 18 anos quando eu fiquei lá, nunca tive um exemplo desse. Então, para mim ainda está sendo uma surpresa até hoje fazer isso! Na minha família então, bem maior! E eu (?) quero fazer mais coisas, mais coisas, e ver até onde eu consigo ir. Meu objetivo é ser docente. Vamos ver.

D: E eles vieram na sua formatura [ocorrida dias antes]?

A: Vieram, vieram. Veio muita gente. (pausa)

D: E como foi?

A: A formatura? Ah, foi legal. Fiquei nervoso também, essas coisas de formatura, mesmo. Estava calor também, né, típico aqui né (rindo). Mas foi muito bom, uma experiência muito legal. Uma coisa é estar lá formando, outra coisa é ver de fora, né. Mas é uma coisa bem legal. Família veio tudo. Veio a professora do Capital de lá. 


\section{D: Professora do quê?}

A: Matemática. Ela me ajudou bastante, também, do colegial, sabe, todos os professores, ela, a professora de biologia, vários professores, português, me entregavam materiais extras para eu ir estudando, sabe, livros da Fuvest, sempre me ajudando, eu tive um apoio absurdo dos professores, me ajudou bastante. Na verdade, foram eles que deram, tipo, um rumo assim para eu seguir porque quando eu saí do ensino fundamental, nossa, estava totalmente perdido, quando eu fui entrar no colegial eu não sabia que vestibular tinha nota de corte, que você tinha que estudar tanto, que um curso era diferente do outro, para mim era tudo a mesma coisa, tudo era difícil, tudo... Sabe, a carreira não interessava, para mim era tudo igual. Lá no colegial é que eu comecei a ter essa noção, né, aí resultou na escolha de farmácia... (?) Por incrível que pareça (sorrindo) eu nunca gostei de medicina, nunca gostei de odonto, nunca gostei de enfermagem, mas escolhi farmácia mesmo por causa do, de ver, de trabalhar com líquido, sabe, tubo de ensaio, ver o negócio criar cor, sabe, mexer com microorganismos, eu adora microorganismo, sabe, tem alguns colegas meus que queriam essa área mais de saúde, eu não, tenho horror a sangue, ver a pessoa cortada, eu não gosto (rindo), então... É parecido com agronomia, sabe, um negócio experimental, essas coisas. Mas eu acabei tendendo para farmácia e não foi ruim, sabe, no terceiro ano eu falei: “é esse curso que eu quero fazer mesmo!” No primeiro e segundo ano é mais exatas, assim, o curso, então eu fiquei meio assim, mas no terceiro ano que começou a ser farmácia, propriamente dito, parte de microbiologia, sabe, doenças, assim, mais a parte mais experimental do que a parte clínica, aí eu me adaptei, e eu falei: “Ah, agronomia é passado! Estou no lugar certo”. Mas foi bom, eu não me arrependo de nada, foi bom...

D: Da sua história pessoal e escolar, o que você acha de dessa história te ajudou a estar aqui na Universidade?

A: O que me ajudou a estar aqui? Foi a hora que eu estava na oitava série, no começo da oitava série e os professores pediam para gente estudar para fazer vestibulinho, prevendo que algum ali ia sair e ia acabar indo para escola particular num sistema melhor, isso foi reforçado porque quando pede assim para estudar geralmente poucos ouvem, nem eu ouvia, mudou quando eu entrei na Guarda Mirim. Na Guarda Mirim eles pregavam que a gente tem capacidade de evolução, de aprender mais, de ter uma profissão, de ser alguém na vida, sabe, de sempre evoluir, que todo mundo era igual, sabe, lá eu vi que você trabalhando, com seu esforço você teria capacidade de evoluir, eles pregavam uma filosofia assim sabe. E foi aí que eu peguei o gosto e eu falei: "vou fazer essa prova, vou estudar e vou ver até onde eu chego.” Esse, eu considero, quando eu estava na Guarda Mirim, um divisor de águas, porque eu aprendi muita coisa lá, aprendi muita coisa, de geral da vida assim, principalmente como se comportar num local assim, como se esforçar para conseguir uma coisa, foi lá, um pouco dos professores, mas a grande parte de lá. Lá eram dois professores e um sargento reformado que davam aula, então, principalmente esse sargento, me ensinou muito coisa para mim, mesmo sendo militar, a disciplina mais pesada, mas nossa! Você aprende muita coisa, principalmente para quem é jovem, 14, 13, 14 anos. A pessoa está lá, nunca teve contato com trabalho, nada, nem sabe como é, nada, entra lá e é formado para trabalhar em qualquer lugar, assim já tem as características básicas passadas. Então, esse foi um local onde eles ensinam: se você gosta de trabalhar, trabalha bem, se você gosta de estudar, estuda bastante, foi aí que... Se não fosse lá, certamente eu não teria... Eu estaria continuando a trabalhar 
noutra fábrica, não ia nem estar aí com estudo, não que não ia estudar por gosto, mas eu não tinha essa noção de que se estudasse bastante eu poderia chegar ao um curso superior, sabe? Não tinha feito essa ponte ainda, a primeira parte da ponte foi feita por essa passagem na Guarda Mirim e o resto da ponte foi feita no colegial, se eu não tivesse passado essa primeira parte da ponte eu não ia conseguir o resto. Foi essa fase aí fundamental... (pausa)

D: E dessa experiência toda, você acha que alguma coisa te ajudou na tua experiência aqui na Universidade?

A: Ah, sim... Primeiro ser guarda mirim, você tem disciplina numa sala de aula, a gente não conversa, conversa paralela, sabe, a gente foi ensinado a não ter conversa paralela, você sempre ouvir uma pessoa, nunca interromper, sabe, as coisas básicas de comportamento, a gente aprendeu. Então, isso ajudou bastante aqui, cumprir horário de trabalho, fazendo iniciação você não pode faltar, mesmo não precisando você tem que ir lá, sabe, estudar, procurar alguma coisa. Então, a gente teve disciplina de horário, nas aulas também, não faltar nas aulas, não chegar atrasado, foi muito bem sedimentado na gente que você tem que ter horário, cumprir seu horário, respeitar, saber conversar e saber ouvir, sabe, saber a hora de falar, e falar a coisa certa, a coisa diplomática assim, não chegar estourando, explodindo, sabe, ter um certo controle. Isso ajudou muito aqui, essa parte mais de disciplina que eu não tinha antes de passar por aí, eu não tinha tanto essa noção, sabe, eu era mais disciplinado por medo de professor, de repetir de ano, mas a noção de que isso era bom, isso era útil, eu tive lá, foi bem (?)aumentado lá na Guarda Mirim, a gente via as pessoas entrando lá e saindo bem, sabe, a gente via que era um local bom para quem é pobre assim ter um início sabe, porque vários colegas meus hoje tem profissões normais. Eu seria um técnico de artes gráficas, então eu teria uma profissão razoável se eu continuasse lá, não seria totalmente ruim, né, eu teria um salário hoje bom para os padrões de lá, teria uma profissão boa, difícil de aparecer lá, tudo graças a esse início, sorte que teve um desvio assim e eu evolui mais. (pausa)

D: E na sua história, o que na sua opinião te possibilitou você estar aqui, ter entrado no curso de farmácia, na USP?

A: O que possibilitou? É... Foi o colegial, né, foi o ensino do colegial e o apoio que os professores deram, os professores sabiam que se eu seguisse o básico lá eu não ia conseguir passar aqui, então eles sempre me estimulavam a estudar, me davam material extra, sempre fazia os simulados que eles preparavam lá, sempre fui muito bem apoiado pelos professores de lá, eles tinham a noção que eu tinha uma possibilidade de passar mas que eu deveria me esforçar mais e sempre me estimularam. Então, primeiro, a primeira coisa que fez eu entrar aqui, uma das possíveis causas foi eu ter entrado num sistema melhor, não ter ido para escola pública e outro o apoio dos professores. Os professores foram peça-chave nesse processo. Aí que eu comecei a ter um espírito mais de estudo, um espírito mais, um estudo pesado, do que o estudo básico que eu fazia no fundamental, saber que se eu estudasse mais eu teria chances maiores, se eu estudasse o certo eu teria chances maiores, eu comecei a criar essa estratégia também de estudo, de como se preparar para uma prova, e os professores (?) me ajudaram muito nessa hora, eles me estimularam bastante. Me apóiam até hoje, quando eu vou para A. [cidade natal] sempre tenho contato com eles assim, sempre me ajudaram bastante... (silêncio)

D: Mais alguma coisa que você queira falar? 
A: Não, não. O que eu lembro é isso de importante. O principal é isso.

[explicação de como se manteve financeiramente durante o curso]

A: [falando a respeito de sua opção de não ter bolsa-trabalho durante a graduação] Não tive evolução financeira, mas tive evolução intelectual, isso foi bom, é o que a maioria aqui faz, poucos se aventuram assim a uma bolsa, assim bolsa-trabalho que não tem nada a ver com o curso, são poucos, maioria faz igual eu, assim. Iniciação, nem se for para trabalhar de graça, mas iniciação, para ter essa evolução. Porque senão perigoso a gente ficar defasado porque meus colegas de sala não precisam, eles têm o tempo inteiro para estudar, quando eles trabalham, eles fazem iniciação, para mim não ficar atrás eu tenho que fazer uma coisa parecida, né, se eu for já me diferenciar desde o começo de um modo tão negativo assim, então é bom nem começar. Então, eu tive apoio do meu pai, da minha mãe, então eu aproveitei.

D: Você quer acrescentar algo, mais alguma coisa?

A: Não, do que eu lembro eu já falei tudo, já.

D: Então, eu queria agradecer muitíssimo.

\section{$2^{\text {a }}$ Entrevista}

Débora: Primeiro eu queria saber se você se lembrou de algo depois que a gente conversou, algo que você gostaria de falar que se lembrou depois, ou acrescentar?

Antônio: Não, não. Falei tudo assim, falei tudo possível, assim, falei bastante coisa, né. É difícil lembrar quando fala muita coisa assim de uma vez, assim, acaba talvez omitindo, mas é coisa muito pequena, o principal eu falei, talvez se eu lembrar agora eu fale, ou vou repetir de novo ou falar mais...

D: Não tem problema se você repetir. Então, eu vou pedir, como eu te falei, para você falar um pouco mais sobre algumas coisas que você falou no nosso outro encontro. Primeira coisa que você comentou que você tinha uma trajetória de bom aluno até a $5^{\mathrm{a}}$ série quando você mudou, você não fazia lição de casa...

A: Eu relaxei, relaxei.

D: Relaxou, né? Você falou que você não sabe o que aconteceu. Mas, eu queria saber se você já pensou sobre isso, se você tem alguma hipótese, alguma idéia de porquê isso aconteceu?

A: É eu comecei a andar com a galera mais picareta, fiz amizade com o povo mais preguiçoso, então eu ficava andando, ficava na rua, só ficava jogando bola, soltando pipa, não queria saber de nada... É mais influência de alguns amigos assim. Depois, no outro ano eles se afastaram um pouco, afastou, assim, normal, foi praticamente espontâneo, sozinho, não fui eu que deixei de ver eles, continuei amigo, tudo, mas afastou, e eu comecei a andar com uns outros amigos que eu tinha antigamente. Aí melhorou, comecei a trabalhar também um pouco também, sabe, na $6^{a}$ série eu já trabalhava à tarde, eu ajudava meu tio, tudo, aí fiquei mais disciplinado, assim, 
mudou um pouco as amizades. Mas na $5^{\mathrm{a}}$ série foi por causa de influência. Aí na $6^{\mathrm{a}}$ deu uma mudada, mudou bastante. Eu quase não via esses amigos que eu via muito na $5^{\mathrm{a}}$, eu quase não via na $6^{\mathrm{a}}$, alguns repetiram de ano, aí, mudou a influência, aí eu voltei ao normal, melhorei de novo.

D: E você comentou também que sua mãe te deu um sermão na $5^{\mathrm{a}}$ série, você lembra o que ela falou?

A: Ah, ela e a minha vó, nossa! Eu não lembro direito, mas sermão tradicional, aquilo que...: " você está errado, isso não vai te levar a nada, você tem que voltar para um caminho normal!” Sabe, um sermão, assim, eu não lembro direito, mas foi um sermão daqueles de mãe mesmo, normal assim, aquele bem firme, pesado. Mas, não adiantou muito não, foi mais a mudança de ambiente mesmo, que ajudou mais que sermão... Sermão, para adolescente, pré-adolescente ainda, não serve de nada! Serve pouco, né, (sorrindo) a gente não tem muito ouvido quando é bem mais novo assim. Foi mais mudança de ambiente que influência da mãe, assim, da família.

D: Esses colegas que não repetiram, eles continuaram na mesma classe que você?

A: Não, não. Mudou tudo, mudou tudo. Aí, tipo, desses que não faziam nada, entraram outros que eram relaxados também, mas procuravam fazer alguma coisa, sabe, não gostava de entrar em atrito com professor, aí acabaram, eu acabei tendo muita amizade assim por eu ajudar eles a fazer lição, trabalho, fazia prova em dupla também, fazia bastante, prova em grupo, então eu ajudava bastante essa turma aí, então eles eram relaxados, não gostavam muito de escola, mas não queriam ir lá para estragar, e ficar tipo... Não quer ficar queimado com a família, a família gosta que o aluno vá lá e pelo menos faça o básico, né, e, apesar de eles não gostarem de aula, eles queriam, pelo menos, fazer o básico para não ter problema em casa. Então, era outro tipo de influência, além de ter alunos bons também. Eu sempre tive a sorte, assim, com exceção da $5^{\text {a }}$ série, nas outras séries, sempre teve bastante alunos bons perto de mim, assim. Então, mudou ambiente, ajudou bastante. Só esse ano assim que foi uma exceção, foi muito bagunçado, a sala era bem, bem indisciplinada, na $5^{\text {a }}$ série, na $6^{\mathrm{a}}, 7^{\mathrm{a}}, 8^{\mathrm{a}}$ era muito melhor.

D: Às vezes, as escolas fazem essa coisa de classe melhor, geralmente $1^{\mathrm{a}} \mathrm{A}, 2^{\mathrm{a}} \mathrm{A}, 3^{\mathrm{a}}$ A, $4^{\mathrm{a}} \mathrm{A}$. Você se lembra em qual turma você estudava, e se na $5^{\mathrm{a}}$ série isso mudou?

A: Na $5^{a}$ série era uma turma $A$, mas tinha muita gente relaxada. Tipo, a escola não... Tinha A, B e C, mas não era pelo nível dos alunos, era pelo... Tipo, pegava dez alunos bons, e o resto dos alunos médios, ruins, e fazia tudo misturado. E na 5 a série deu uma proporção meio ruim, sabe, muita gente ruim e pouca gente boa, assim, então a sala ficou bem, bem mal formada. Agora, na $6^{\mathrm{a}}$, $7^{\mathrm{a}}$, $8^{\mathrm{a}}$ série também tinha $\mathrm{A}$, B e C mas era totalmente misturado. Os professores de lá não gostavam que dividisse as salas em níveis assim, só em relação ao número, né: três salas iguais de 35, com alunos parecidos. Porque professor também não gosta de ir numa sala muito boa e ir numa sala muito ruim, né, ele nem sabe como dar essa aula - para uma sala boa e para uma sala ruim - acaba até atrapalhando. Então, a escola decidiu depois... $\mathrm{Na} 4^{\mathrm{a}}$ série ainda tinha esse tipo de divisão por níveis. Depois na $5^{\mathrm{a}}$ e na $6^{\mathrm{a}}$ começou a mudar, mudou bastante, então a minha sala era $6^{\mathrm{a}} \mathrm{B}$, era igualzinha a $\mathrm{A}$, que era igualzinha a C. $8^{\mathrm{a}}, 7^{\mathrm{a}}, 6^{\mathrm{a}}$ e $5^{\mathrm{a}}$ eram três salas, eram todas iguais. Então, todo ano mudava as amizades com os colegas. Eles misturavam, aí... Eu achava bem melhor desse jeito do que uma sala só de alunos bons e outra sala só de alunos ruins porque os bons influenciam os ruins que nem era na $6^{a}$ série, tinha muito aluno ruim assim 
que não gostava de aula, mas queria fazer alguma coisa, assim, não ficar para trás, de ver os alunos melhores, por influência.

D: E você tinha consciência disso na época, você já sabia que era misturado, que não era aquela sala melhor, na época você já sabia disso?

A: Já, já. Os professores comentaram bastante isso, essa mudança, os alunos também falavam bastante disso. Porque quando eu estava no ensino fundamental, básico, $1^{\mathrm{a}}$ a $4^{a}$, era dividido, então, eles sentiam muito essa diferença, tipo, na minha primeira série, tinha A, B e C. Eu era da B. A turma A eles terminavam a cartilha no meio do ano; a gente ia mais dois meses; a $C$ não terminava a cartilha. Então, isso é... Seria melhor que todos terminassem a cartilha no mesmo tempo que eu, do que um não terminar e o outro ficar sem, por já ter terminado. Foi isso o que aconteceu: uma turma terminou bem antes, aprendeu a ler muito rápido e a outra turma não aprendeu porque os alunos eram mais, só tinha alunos ruins e alunos indisciplinados. Isso até atrapalha o professor, o professor não vai ter o mesmo rendimento.

D: Quando você fala “eles sentiam muito isso”, quem sentiam, os professores?

A: Os professores, os professores falavam, falavam muito disso, que um professor trabalhava muito bem e o outro trabalhava muito mal, não pelo professor ser ruim, mas pela sala não ter um padrão bom. Se fosse misto, ele poderia deixar uma turma de alunos mais livres, os melhores mais livres, aprender mais sozinho, e se dedicar mais a uma turma menor de alunos ruins, né, do que uma sala inteira de alunos ruins, o professor só não dava conta; enquanto o professor da sala melhor ficava bem mais sossegado... Aí no ginásio mudou tudo isso, aí misturou, e pelo fato também de ter mais professores, né, mais aulas, mais professores, professores diferentes, eles não queriam sair de uma sala muito boa na primeira aula e ir para a segunda aula numa sala ruim e dar a mesma aula, não ia ser igual, não ia, não ia ter o mesmo desempenho, isso para qualquer profissional era ruim, né, ter desempenho num lugar e não ter em outro, e os alunos não iam aproveitar também. (pausa)

D: Interessante isso, porque o mais comum é o contrário. É uma escola é interessante assim.

A: É, essa escola, igual eu falei da outra vez, ela sempre teve um bom desempenho assim, quando os alunos saem da oitava série e prestam esses vestibulinhos, não sei se existe mais lá, mas essa minha escola é que se saía melhor, sempre. Os diretores de escolas particulares sempre iam lá garimpar alunos, e depois os professores também, levaram a grande maioria dos professores para o sistema particular...

D: Garimparam os professores também?

A: É. Ficou ruim para a escola, né, porque ficou sem professores, mas o serviço privado aproveitou bastante essa fase da escola.

D: E, aí, nessa época que você “desvirtuou”, entre aspas, assim, foi nessa época, no ano seguinte que sua mãe sugeriu que você fizesse o curso de Guarda Mirim, né?

A: É, sugeriu, mas eu não quis ir. Desde a sexta série, sétima série, também ela sugeriu, eu só fui entrar na oitava série. Quando eu estava na sexta série abriu o curso de Guarda Mirim, primeiro ano lá em A. [cidade natal], na sétima teve o segundo ano, eu não quis ir de novo. Na oitava série teve a terceira vez, aí tinha limite de idade também nessa terceira vez, tipo eu poderia entrar bem mais novo, na oitava série tinha um limite [mínimo] de 14 anos, eu estava no limite. Aí na oitava série só 
que eu pensei em entrar, já pensando em procurar emprego, né, porque eu via, primeira turma, segunda turma, todo mundo conseguia emprego assim, e aí eu pensei que seria uma boa eu fazer Guarda Mirim. Até porque eu estava trabalhando numa fábrica lá de fundo de quintal, não sei se eu contei isso: na oitava série eu trabalhava numa fábrica de fundo de quintal que eu estava lá só para passar a tarde porque...

D: Você contou que primeiro você trabalhou numa tapeçaria e depois numa fábrica de vassoura.

A: Isso, a fábrica de vassoura! Era... Tipo, era divertido, por ser descontraído o lugar lá por ser de fundo de quintal assim, mas não tinha evolução nenhuma. Aí, o Guarda Mirim, por ser mais organizado, me atraiu mais, aí eu acabei indo, já pensando: “ah, eu vou seguir esse rumo porque é mais fácil, eu vou ter mais apoio do que seguir sozinho”. Aí eu fui por espontânea vontade, as outras duas vezes minha mãe me pediu e eu não fui, eu não quis, na terceira vez minha mãe já estava indiferente, já tinha desistido e eu fui por conta, porque eu quis ir.

D: E ela sugeriu por que, assim?

A: Então, os Guarda Mirins, eles sempre participavam de campanhas, trabalhos, eles eram muito ativos na cidade, e todo Sete de Setembro, eles faziam desfile, marchavam, era a formatura, sabe, eles andavam fardados, e trabalhavam em lugares bons, assim, sabe, Prefeitura, lojas, fábricas de médio porte, que eram organizadas, sabe, que tinham sistema de ajuda para o funcionário, fábricas normais; não se via Guarda Mirim fazendo trabalho braçal, não se via Guarda Mirim saindo da escola, era obrigado a ter boas notas, então... Fora que tinha um curso antes de sete meses que preparava o adolescente, dava as noções básicas para o adolescente de comportamento numa empresa, era um curso mesmo profissionalizante, geral. E eles faziam essa propaganda e a notícia corria, a cidade era meio pequena, a notícia corre rápido, então todas as mães assim de pessoas da minha idade procuravam o Guarda Mirim. Muitos iam obrigados, muitos adolescentes iam obrigados fazer o curso, mas a grande maioria ia por vontade porque sabia que ali seria mais fácil evoluir do que sozinho, né. Porque lá, por ter esse curso de sete meses, os orientadores lá tinham contato com os alunos, então eles eram as referências dos alunos para as empresas, então, é bem mais fácil você ter uma referência do que ir sozinho, sem referência nenhuma, então era aí que muitos conseguiam emprego e ficavam, né. Eu tenho vários colegas daquele tempo que hoje tem profissão, profissão normal, assim, ganham razoavelmente bem, porque teve esse primeiro contato muito jovem, para se tornar um profissional bem mais rápido, e bem mais simples, sem ter vínculo nenhum com o empregador, sem ter nenhuma referência, só dos orientadores, né, não é parente, nada, sabe, é bem mais fácil. Isso atraía muito as pessoas da periferia, da parte mais baixa da cidade, que é a parte mais nova, Cohab, essas coisas, ia muita gente de lá, e essas pessoas são imigrantes que vão lá trabalhar na lavoura de café, de uva, então, eles não tem referência nenhuma para conseguir emprego em locais mais sofisticados, então o Guarda Mirim era essa ponte para o filho do lavrador poder entrar numa empresa, numa indústria, numa empresa de serviços, na Prefeitura serviço público empregava bastante: primeiro o Guarda Mirim ia, trabalhava tipo como estagiário, ganhava um salário na Prefeitura, já se preparava para depois prestar um concurso e continuar lá, já tinha experiência e tinha tudo para continuar no local. Muitos também seguiram essa carreira, quer dizer, quem andasse na linha 
lá, fizesse tudo correto, se dava bem sim. E, aí, as mães, os pais, assim, até a gente mesmo, se empolgava com essas oportunidades, aí eu fui. (pausa)

D: E, aí, você falou de novo isso, que seus colegas eram mais pobres...

A: Bem mais pobres...

D: Que também não tinham noção de direitos, leis...

A: Nada, nada.

D: E como você se via em relação a eles?

A: Então, o meu pai, ele já era, ele trabalhava numa empresa de lá grande, da cidade, a minha mãe sempre trabalhou em empresa maior, né, toda a minha família assim é gente que trabalhou em empresas mais estruturadas. Então, eu já ouvia, já tinha noção, eles me ensinaram mais ou menos como me portar em ambiente de trabalho, eu já tinha trabalhado em algumas coisas também, e eu já tinha essa noção. E também eu estudava Geografia, essas coisas, eu gostava bastante, eu gosto bastante, então isso dava noção também de leis, sabe, eu sempre me interessei por essas coisas, então eu tinha uma certa noção. Mas, eles lá dessa turma, geralmente pai e mãe não trabalhavam em empresas estruturadas, geralmente era empregada doméstica, lavrador, trabalhadores sazonais que trabalha em colheita, sabe, então eles não têm tanto esse ambiente de trabalho assim como é no ambiente urbano, assim, uma empresa, como a maioria trabalha. Eu via lá gente que não sabia noções de trânsito básicas, não conhecia placas de trânsito básicas, conhecia só placa "Pare", não conhecia mais nada, tinha gente que não sabia olhar o semáforo. A gente também tinha aulas de Primeiros Socorros, tinha gente que não tinha noção nenhuma, nenhuma de Primeiros Socorros. Tinha gente que não sabia Hino Nacional, não sabia nenhum tipo de hino, nem sabia que tinha hino, sabe, dificuldade para ler, escrever, fazer conta, aritmética básica, então a gente tinha tudo isso lá, tipo, a aritmética para poder trabalhar no comércio, a gente teve essa introdução, a maioria não sabia, não sabia fazer troco. Então, tinha gente que estava no básico do básico e lá teve a noção, foi preparado para poder sair de lá capacitado para poder ter um emprego básico, um emprego mínimo, com salário mínimo. E, se não fosse isso, eles não teriam essa chance, ia ser muito mais difícil. A gente teve curso - por sem em 98, ainda tinha um certo contato - a gente teve curso de datilografia, curso de Office-boy e curso de Administração, tudo no Guarda Mirim, então isso ajudou muita gente. E a maioria não tinha noção nenhuma dessas coisas, nada, nada, nada. É um negócio interessante, sabe, muito bom. Deveria continuar, agora eu acho que não existe mais, eu nunca mais ouvi falar em Guarda Mirim lá, eu acho também que saturou as ofertas de trabalho, não sei, acabou. E foi bom, para mim foi bom, eu peguei a fase boa; os meus colegas também, todo mundo que passou lá, a grande maioria que passou lá, hoje, tem emprego que ganha mais que um salário mínimo, pelo menos, que tem alguma qualificação, a grande maioria. Foi bom sim...

D: Agora, essas coisas de ler, escrever, fazer conta, isso para você não fazia diferença, isso você já sabia, né?

A: É. Era, era bem diferente, era bem diferente, assim, a turma do lado alto e a turma do lado baixo. Apesar da gente ser pobre também, ter uma renda mais baixa, mas por ser um local tradicional, a gente tinha uma noção melhor, a gente não sofria tanto com essas coisas. Eram 120 alunos, 120 adolescentes, 30 ou 40 era da parte alta ou do centro, da parte alta e do centro, o resto era tudo da parte baixa, a grande maioria 
era da parte baixa. Eu e os meus colegas era uns dez do meu bairro ali, a gente não tinha dificuldade nenhuma, a gente já estudava nessa escola melhor que é da parte de cima, escola tradicional, escola bem antiga, e eles estudavam em escola recémconstruídas, que os professores não eram concursados, sabe, um sistema bem parecido com as escolas de periferia hoje. Então, eles já vinham defasados, a gente não, a gente já vinha mais estruturado, por isso a gente já fez o curso de modo mais light, sem dificuldade, para mim foi só uma passagem assim, eu gostava, e não tive dificuldade nenhuma, e a maioria dos meus colegas da parte ali também não, e alguns da parte de baixo também não, mas a maioria teve uma certa dificuldade, mas no fim todo mundo conseguiu superar.

D: Você comentou bastante sobre essa experiência que te fez estudar mais, te estimulou a estudar mais. E você comentou também que foi a partir daí que você começou a ter um sentimento de disputa. Eu queria saber como é que é isso, queria que você falasse um pouco mais sobre isso.

A: Disputa? É... (pausa) Para entrar lá, no Guarda Mirim, tinha um processo seletivo, e todo mundo fazia as provas para os orientadores terem uma noção da capacidade de cada um.

\section{D: Matéria da escola assim?}

A: É, matemática básica, noções, tipo, noções da cidade, para saber se você conhecia a cidade, perguntava o nome do hospital da cidade e, tipo, perguntava nome de um hospital público de uma cidade grande onde você teria que ir se o hospital da cidade não te atendesse, não tivesse capacidade de te atender. Fazia esse tipo de pergunta: "diga o nome de pontos turísticos”, “diga o nome dos rios”, “diga o nome de quem fundou”, sabe, "em que ano fundou a cidade”, sabe, noções básicas do local onde a gente vivia, e Matemática, Português básicos, de ginásio. Aí, eu fiz a prova, passei, eu tirei 10.0, eu e mais um, em primeiro e aí veio o resto, e... Incrível assim prestar atenção a esta classificação, dos 20 primeiros, uns 15 era todos da parte alta da cidade, cinco era da parte de baixo, e da parte baixa da classificação, praticamente todo mundo era da parte de baixo, tinha essa diferença. Aí começou... Aí não tinha tanta disputa porque era, a gente sabia que ia ficar pouco tempo lá e cada um ia seguir um rumo, numa empresa diferente, numa profissão diferente, então aí foi uma disputa mais leve. A disputa começou de verdade quando eu entrei no colegial. Eu fiz vestibulinho, passei lá, ganhei bolsa, passei em primeiro, ganhei bolsa, aí já começou a ter mais disputa. Sempre tinha aluno na minha sala, colega que queria tirar nota maior que a minha, ficava disputando, todo ano tinha vestibulinho e era aquela bagunça, gente querendo, sabe, tinha gente que falava demais: "ah, vou passar na sua frente!”, querendo disputar. Mas sempre assim, nunca teve nenhum momento estressante, mas sempre teve disputa sim entre a gente, principalmente, no colegial. Aí no terceiro colegial diminuiu porque cada um seguiu - que nem no Guarda Mirim - cada um ia sair, ia pegar um rumo, então não tinha mais disputa. Por exemplo, prestar Farmácia aqui seria só eu e mais uma aluna da minha sala, então a concorrência já acabava, mas no primeiro e no segundo ano sempre tive alguém assim querendo disputar alguma coisa, seja, nota, classificação no vestibulinho, simulado. Mas, eu não me importava muito não, eu me preocupava mais com o resultado prático, para mim se eu passasse em segundo e ganhasse bolsa, para mim eu não me importava passar em primeiro, eu tinha um pensamento prático, mas sempre tinha gente que queria ter um status assim, superar o outro, não só eu como 
os outros alunos bons também, sempre havia disputa entre eles e comigo assim, mas eu nunca levei a sério essas coisas, sempre pensava no meu objetivo, na prática, e não no resultado, no que o resultado poderia levar, não o que o resultado era. Era mais por isso. E aqui na faculdade também, sem disputa pessoal com ninguém, é uma disputa geral, eu queria melhorar, na verdade, a vontade era aumentar a média ponderada, e eu consegui aumentar, esse objetivo eu consegui cumprir, mas sempre aparece, sai nota, sempre tem disputa, né, eu não queria ter esse pensamento de superar alguém mas sim ter meu objetivo pessoal, e eu consegui cumprir, sempre nesse esquema assim, sem disputa acirrada, assim, nada pessoal, nada, sem querer superar alguém, mas sim chegar a um fim.

D: Você estava falando do colegial, eu queria que você falasse um pouco mais como foi quando você entrou no Capital. Você comentou que era bastante diferente da sua escola anterior, eu queria que você falasse um pouco mais sobre isso.

A: É, eu que saí do Guarda Mirim, convivendo com pessoas mais simples, eu fui estudar numa escola que estudava a elite da cidade. Então, foi um choque assim! Eram outros costumes, assim... Esse primeiro ano eu fiquei na minha assim, não fazia nada, só ia em casa, ia na escola, voltava para casa, ia para a escola, fui perdendo contato com esses amigos do Guarda Mirim, da outra escola que eles estavam estudando em escola pública que era um caminho totalmente diferente do que eu pegava para ir para o Capital, então eu fui perdendo contato com eles, e nesse período eu fui me isolando, assim, tanto da turma da minha sala, do Capital, eu fui fazendo amizade aos poucos, quanto dos amigos antigos. Aí eu comecei a perceber e a me adaptar a esse novo perfil, mas demorou um ano para eu me adaptar, eu ficava mais na minha assim, quieto. Aí no segundo ano eu já estava mais acostumado com o povo do Capital, do que com os outros que eu já tinha perdido a maioria dos contatos já, então eu fiquei mais, eu entrei mais no mundo deles, assim. Comecei a pensar mais em vestibular e não mais em ter profissão operária ou técnica, em ter uma profissão de nível superior. No primeiro ano eu ainda estava confundindo isso, eu não sabia o que era, eu não sabia como funcionava um vestibular, eu não sabia como funcionava um curso de nível superior, eu não sabia nada! Passei a ter uma noção do segundo ano para frente quando eu passei a ter contato com essas pessoas que tinham um outro pensamento, até os professores tinham um outro pensamento do que os professores do nível básico público. Aí mudou a influência e com o tempo eu fui mudando o pensamento também. Antigamente eu não tinha esse pensamento de fazer curso superior quando eu estava na oitava série, só depois que eu entrei nesse colégio que eu comecei a mudar esse pensamento. Mas o primeiro ano foi um período meio, assim, de mistura, foi meio misturado, eu não sabia ainda onde que eu estava, como eu devia me portar, pensar, sabe, só no segundo ano o negócio melhorou. No segundo ano também eu passei a ser monitor da escola, aí eu comecei a ter um contato muito mais próximo com os alunos, não só da minha sala, mas de todas as classes, né, do terceiro, do segundo, do primeiro, da oitava série, de todo mundo, então, contatos com pessoas que eu não tinha contato antigamente, isso fez com que eu mudasse o pensamento.

D: E como era conviver com a elite da cidade?

A: Ah... Lá tinha de tudo, assim. Tinha gente simples, pessoa que tinha dinheiro, mas era simples, como (... ?) antes. E tinha alguns arrogantes, sabe, típico da classe, né, tinha muita gente arrogante, é... Tinha gente que tinha preconceito contra evangélico, 
contra negro, contra... Sabe? As discriminações tradicionais que as pessoas brasileiras têm, assim, tinha alguns lá que tinham esses pensamentos. Mas, no geral, eu fiz amizades com todos, assim, cada um com seu pensamento. Mas, tinha pessoas de todos os tipos lá, que eu não via quando eu estava lá [escola pública anterior], principalmente essas pessoas mais, de cabeça mais fechada, sabe, cidade do interior, tinha muita gente com preconceito lá, preconceito.

D: Você não via quando estava lá onde?

A: Na escola pública. Não tinha isso. Mas era minoria também, até nessa escola era minoria também. No básico, o comportamento era parecido, o modo de pensar é que era diferente, eles tinham ambições mais altas.

[Eles pensavam] ...Bem mais longe. Era mais uma diferença de pensamento, de objetivo do que de modo de se comportar. É claro que eles freqüentavam ambientes diferentes na cidade, tipo, a festa de um não era a festa do outro, eram ambientes diferentes, eles tinham costumes diferentes dos outros, né, e... Mas... O modo de pensar era diferente, mas o comportamento no dia-a-dia assim era parecido, por todo mundo ser da mesma idade, né, o modo de lidar com todos era bem parecido, mas o pensamento e o local que eles freqüentavam era diferente. Então, ficava nisso, né, nessas duas partes. Eu não freqüentava onde eles freqüentavam, freqüentava com os outros, mas eu já começava a pensar como eles, e não como os outros, por influência, e vi que o objetivo deles, apesar de ser mais difícil de alcançar, era possível e eu queria seguir esse caminho, já tinha esquecido do outro. (pausa)

D: E nessa época do colegial, você teve amigos lá no Capital?

A: Na verdade, eu tenho mais contato com eles do que com os antigos hoje, tenho muito mais amizade com eles do que com os antigos. Primeiro que eu não volto tanto para A. [cidade] e não tenho contato com os outros, a maioria está trabalhando, assim, então quando eu estou de férias, está todo mundo trabalhando, não tem tanto contato, freqüentam lugares diferentes também. E, pelo fato de eu usar Internet aqui, sabe, ou multimídia, eles, a parte que tem mais dinheiro lá é que tem esse contato, então eu me comunico muito mais com eles do que com a turma antiga, apesar de eu ter amizade com eles também, mas quase não os vejo, assim, a minoria, a grande minoria tem acesso à Internet, assim para ter uma comunicação mais fácil, mais acessível. E eu tenho muitos amigos do colegial, tenho bastante, eu fiz bastante amizade lá e é quem eu tenho mais contato hoje. Fiquei três anos lá, né, com a mesma turma, então... E não só da minha sala, mas das outras séries também, tive bastante contato com todo mundo. Então, hoje, é mais pelo acesso à informação, à comunicação do que pelo fato da diferença social... É por causa da diferença social, mas... Eu tenho mais contato com a turma do Capital... (pausa)

D: Agora falando sobre a escolha do curso. Você falou que a primeira coisa que você pensou em fazer foi agronomia. Eu queria que você falasse um pouco mais porque você deixou essa opção de lado?

A: Ah, porque lá na minha cidade, essas faculdades que rodeiam lá, todas têm curso de agronomia, e quem se forma lá, não tem mercado, forma em agronomia e não faz nada, então ficou meio mito que agrônomo não tem profissão, é um curso que não leva a nada, tinha esse pensamento lá. E aí os professores, nenhum professor me recomendou fazer isso, poucos falaram para mim seguir essa carreira: "ah, escolhe outra coisa, procura outras coisas, tem bastante coisa, analisa de novo!” Então eu 
acabei desanimando, mais pela influência externa. E na realidade eu via muita gente que tinha formado em agronomia e não tinha emprego, porque lá forma muita gente, e, ao contrário do farmacêutico, do médico, do enfermeiro, do dentista [que] lá é procurado. Aí, eu comecei a mudar, comecei a procurar outra carreira, aí eu tinha escolhido que eu não queria nem Odonto, nem Medicina, nem Enfermagem para não ter contato com pessoas assim, sabe, pessoas doentes, pessoas que sofrem. Mas, eu gostava dessa parte mais de conhecer a doença, a medicação, dos exames que se fazem. Aí, eu me interessei por Biomedicina. Aí uma professora disse que Farmácia era mais adequado, era mais completo. Aí eu comecei a pesquisar sobre o curso, né, aí eu acabei me identificando. Nisso eu olhei também todos os outros cursos de direito, química, administração, mas eu não me identifiquei com nenhum. O curso que eu mais me identifiquei assim pesquisando, procurando foi Biomedicinia e depois Farmácia. Não é à toa que a primeira parte do curso de farmácia, que é a parte mais química eu tive mais dificuldade que eu gosto da outra parte que é a parte biológica. Mas eu me identifiquei bastante com o curso e não via vantagem nos outros, nenhuma vantagem nos outros cursos. Eu queria fazer essa área e, como já tinha desistido também de agronomia, eu falei: “é essa área aí." Engenharia, Medicina, Odonto e Enfermagem, de jeito nenhum, eu sabia que eu não ia me adaptar, vendo assim, a situação, como era o curso, a profissão, mesmo alguns deles tendo um salário maior, e tudo assim, carreira mais bem remunerada, mas eu não me identificava nessa situação, aí eu acabei optando por Farmácia e só prestei Farmácia.

D: E você comentou também que você via semelhança entre Farmácia e Agronomia. Eu queria saber assim o que você vê como semelhante, o que é semelhante, em que sentido?

A: Agronomia se preocupa mais com o reino vegetal, assim, de plantas, mas eles têm também uma noção muito grande também de drogas, de química para as plantas, para as culturas. E o farmacêutico tem para os seres humanos, a mesma noção de farmacologia, só que um é voltado para a terra e outro é voltado para os seres humanos. Eles também... É muito, agora que eu fiz o curso, eu reparei que tem muito mais, têm muitas coisas em comum. Eles têm que ter conhecimento em química, grande, assim, igual a gente tem, só que o nosso, como sempre, é voltado para os seres humanos, e eles são voltados para a terra, para as culturas. E... É pragas, no nosso caso doenças, a pesquisa deles é muito parecida com a nossa, só que a nossa é voltado para outra área, mas é conflitante. Hoje eu trabalho com... A minha área de pesquisa é agronomia e veterinária, não é saúde, que eu trabalho em farmácia, só que a pesquisa pede todos os conhecimentos que um farmacêutico tem, conhecimento de biologia molecular, conhecimento de farmacologia, conhecimento de química, se não fosse áreas distintas, eles poderiam se interconverter facilmente, eles têm as mesmas, a mesma base eles têm, só que um é zoologia e outro é botânica, isso é o que separa os dois. Fazendo o curso de Farmácia, por isso que eu me identifiquei, eu vi que é o mesmo modo de pensar de um farmacêutico e de um agrônomo, só muda o contato, um contato com a biologia, a biologia não, a zoologia, que são os animais, os seres humanos, que pode ser aplicado em animais também, é parecido, e eles é mais a botânica, as culturas; é bem, apesar de ser oposto, é muito parecido. Por isso que eu me adaptei ao curso de Farmácia assim, é muito parecido com o de Agronomia, é o mesmo modo de pensar.

D: A base, né, você fala, a aplicação é que é diferente? 
A: Isso, a aplicação é diferente. Por incrível que pareça hoje a minha área é de agronomia e veterinária.

\section{D: A área que você está pesquisando agora no mestrado?}

A: É. Iniciação também. A minha orientadora é veterinária. A graduação foi em veterinária e a pós graduação foi em parasitologia e biologia molecular. Mesma coisa que eu estou fazendo agora, mesma área.

D: Acabou convergindo os interesses...?

A: É, andou, andou, andou, acabou chegando no mesmo lugar (rindo).

D: E agora falando aqui da faculdade, você falou que quando você entrou aqui você estranhou tudo, da comida ao calor. Agora eu queria que você falasse um pouquinho mais o que mais você estranhou além do calor e da comida. Como é que foi essa chegada aqui?

A: Ah, lá em A. [cidade] eu não tinha tanto contato, assim, com pessoas diferentes, a gente era... Tipo, eu ia na escola, voltava em casa, escola e em casa, não tinha isso de eu ter um vizinho que não tinha nada a ver comigo, um colega de quarto. É bem diferente, é bem diferente. Tive que me adaptar a tudo isso. Aqui tem muita festa, muita bagunça, se você quiser se perder, você se perde 'facinho' (rindo)!

\section{D: Você fala aqui, é na moradia?}

A: No campus, tudo, tudo, tudo. Na moradia também! O povo aqui bebe muito, bebe muito. E eu acabei, tive que me acostumar a pessoas diferentes, a pensamentos diferentes, e... Mas não foi tão difícil adaptar, mas foi, foi um choque, foi um semestre, assim, para se adaptar bem, eu só fui, eu só me desvinculei de A. [cidade natal] no segundo ano, [quando ficou] parecido com hoje, eu volto lá para ver minha família, mas eu não tenho mais contato com A., a cidade, conheço pouca coisa de lá agora, se mudou alguma coisa, eu não conheço, conheço muito mais P. [cidade onde se localiza o campus] agora do que a minha cidade. E adaptação aqui foi... A faculdade também exigia mais, um curso de graduação exige mais do que o colegial, tem diferença também, tive que aprender a estudar mais, tive que aprender a dividir horário, antigamente eu não tinha isso, eu estudava qualquer hora, a hora que eu pudesse, aqui tive que ter horário fixo de estudo, mesmo lá eu não tinha horário fixo de estudo nem para vestibular, estudava muito um dia, não estudava nada no outro, aqui, não, aqui eu tive que intercalar e fazer um horário, isso fez com que eu mudasse totalmente a minha rotina do que era lá, foi mais nesse âmbito aqui. Com as pessoas aqui foi fácil sim me adaptar, ter amizade, tudo, foi mais o contato com a minha cidade que atrapalhava um pouco, eu sempre queria voltar para casa, sabe, eu estava muito mais ligado com o lugar, com Minas, do que com aqui. Mas com o tempo esse negócio foi mudando, hoje é equilibrado e tende mais aqui porque eu tenho uma carreira aqui, lá é mais para descansar, lá é um local para descansar, aqui é um local para trabalhar, então eu tenho muito mais contato com esse lugar aqui. Eu estou muito mais acostumado aqui do que lá! Agora inverteu tudo. Agora eu passo frio lá, acho lá mais úmido, sabe (sorrindo), estranho a comida lá, eu acho a comida mais pesada. Sabe, mudou tudo. Lá eles têm uma comida muito pesada. Eu não consigo mais ter a rotina que eu tinha lá. Sabe, você muda de lugar, você passa muito mais tempo aqui, você acaba se acostumando mais aqui do que de onde você vem. Mas, aqui a adaptação foi, foi rápida, não teve nenhum tipo de contratempo, atrito, nada, sabe, só teve aquele, aquela adaptação típica da pessoa que sai de uma cidade 
pequena, vem para a cidade maior fazer faculdade, é o típico, que não se desvia, que continua no caminho, no objetivo dele, mas é aquela adaptação básica. Adaptação que a maioria daqui teve, aqui da Moradia, que todos têm assim. Aqui, o ruim aqui da Moradia é que você não pode ter personalidade muito forte, forte assim para influenciar o outro, você pode ter personalidade forte, mas tem que saber equilibrar para não entrar no habitat do outro, do colega para não ter atrito, sabe, tem que saber muito mais equilibrar isso do que quando você está em casa, aqui tem que ter um pouco mais de diplomacia, muita gente aqui tem atrito pelo fato de não ter esse, de não saber dosar a personalidade, pessoas muito diferentes convivem muito perto, isso também tem que saber, a pessoa tem que saber, acostumar com a presença do outro que é diferente, que é ao contrário da sua casa, que você vai lá é todo mundo parecido. No meu colégio mesmo, mesmo as pessoas tendo nível social maior, a gente era muito parecido, modo de pensar, modo de agir, atitudes, gostos, né; aqui já não, aqui você já não encontra tanta homogeneidade, então você tem que saber dosar a personalidade, o comportamento, até onde você pode chegar. Mas, isso com um pouco de sensatez assim, você consegue se acostumar, se adaptar, sem problema nenhum. $\mathrm{O}$ meu caso foi o típico caso de aluno que sai de cidade pequena vem para cidade maior para fazer faculdade, é normal, no fim dá certo.

D: Essa dificuldade de desvincular era o quê? Voltava sempre para casa...?

A: A cada 15 dias eu voltava para casa. Hoje só em feriado, muito mais pelas responsabilidades aqui do que por vontade, se eu pudesse eu voltava direto, mas eu tenho compromissos aqui, né, então, quando eu era calouro eu não tinha tanto, era estudar e fazer prova só, era bem mais fácil voltar para casa, se bem que atrapalhava um pouco, tinha muita prova de segunda, terça-feira, que não era legal voltar para casa; mas por um semestre, no primeiro semestre, eu voltava a cada 15 dias para casa, depois foi diminuindo as idas, e hoje é só em feriado assim quando é possível.

D: E a convivência com os colegas lá na Farmácia?

A: Na Farmácia, na Farmácia foi, ah, foi mais fácil! Foi mais fácil. Eu achei muita gente que eu me identifiquei, muita, muitas pessoas mesmo, lá foi muito fácil, eu nunca tive nenhum tipo de problema com colega, nunca. Lá o povo, apesar de ter panela, coisa normal, algumas picuinhas, mas a gente era unido, assim, muitos amigos, muitos, muitos. Ali foi um local que... Tive colegas que convidavam para sair daqui, para ir morar com eles, fazer república, pagar um terço do aluguel do que tinha que pagar, ir de graça (sorrindo)! Então eu fazia amizade muito... No início eu tinha muito amizade com eles, muito mais com o povo da Farmácia do que com o povo do C. [moradia estudantil]. Com o tempo isso foi mudando, quando começou a apertar lá, né, a aumentar o compromisso lá, cada um começou a pegar um rumo, eu comecei a ter mais contato com as pessoas daqui, mas adaptação com eles foi muito mais fácil, muito. Primeira semana já tinha com quem conversar, já passeava com a turma já, aliás com os que são mais amigos hoje. Foi bem fácil, assim, bem rápido. Ali praticamente não teve adaptação, foi muito simples, com a turma da Farmácia, com os veteranos também, depois com o tempo com os calouros também, são todos bem unidos... Raramente tem alguma confusão, pelo menos do que eu vejo... (silêncio)

D: Voltando lá na Guarda Mirim, você comentou que essa experiência te estimulou a estudar e quando teve o vestibulinho para o Hoje[escola particular] você resolveu estudar e você comentou também que essa idéia foi que te salvou. Daí eu queria que 
você falasse um pouco mais disso, como que salvou, te salvou do quê, de que situação?

A: É... Eu fui estudar, né, eu fiquei 15 dias estudando o que eu tinha mais dificuldade que era matemática, eu sabia, eu queria medir a capacidade, até onde eu poderia chegar, sabe? Eu não estava com a cabeça de passar em primeiro, ganhar bolsa e estudar em escola particular, como a maioria dos meus colegas também não, esses que tinham capacidade, capacidade parecida, eram bons alunos; muitos não fizeram a prova, não quiseram fazer, não quiseram medir a capacidade, não quiseram, simplesmente falaram: "isso não é para mim, eu não vou! Eu não quero me testar, me estressar, eu não vou a lugar nenhum com isso.” Eu falei: "eu vou, vou ver o que vai acontecer. Eu vou estudar, vou me preparar, para ver até onde eu chego.” Aliás, até depois que eu fiz a prova do Hoje[escola particular], eu saí, eu falei: "ah, eu fui bem, mas não sei... Eu vou passar bem, mas... Mas foi um experiência legal.” E vinha com esse pensamento, eu só mudei a forma de pensar, que eu acho que isso que me salvou, assim, foi que eu estudei, tive essa idéia de estudar, me preparar e depois veio o resultado que eu tinha ganhado bolsa, mas eu não tinha me situado ainda no que aconteceu, eu ganhei bolsa, mas eu não sabia: "ah, eu vou estudar em escola particular; mas que diferença isso faz?” Eu não sabia disso, que era para me preparar, para fazer vestibular, que vestibular era difícil, que tinha que estudar mais, eu não tinha essa noção, meus colegas também não tinham. Eu queria mais medir a capacidade, mais como um jogo, assim, um campeonato, do que alguma coisa com um objetivo, assim, por isso que muitos dos meus colegas desistiram, não foram fazer a prova porque a chance, assim, de passar em primeiro e ganhar a bolsa era pequena, porque era bastante gente, e eles não sabiam o que estudar numa escola particular poderia fazer para eles. Porque Guarda Mirim formava a gente para trabalhar como técnico, né, não como profissional de nível superior, não para ir mais longe, então a maioria tinha um pensamento diferente. A maioria das pessoas que prestou esse vestibulinho se tornariam meus colegas de colegial; eram todos que estudavam na mesma escola que eu assim, mas eram de um nível social maior, ou já vinham de escola particular. Então eram pensamentos diferentes, a maioria das pessoas que fez a prova comigo era desse esquema e não dos Guardas Mirins ou alunos de classe baixa. Só hoje, mais recentemente, que o pensamento do povo lá está começando a mudar: não tem mais esse abismo assim entre Ensino Superior e Ensino Básico. Hoje eles têm a noção de que para alguns cursos é possível chegar lá, e se estudar e se esforçar é possível tudo, sabe, eles mudaram um pouco esse pensamento. Mas, antigamente eles não tinham esse pensamento. E eu, por sorte, resolvi estudar para ver até onde eu chegava, aí eu acabei ganhando a bolsa, foi o que me salvou e eu só estou aqui hoje por causa dessa mudança de perfil em 15 dias, que eu me dediquei ao estudo, eu nunca tinha feito isso de ter estudado um tempo para uma prova, eu estudava dois, três dias, de véspera, em escola pública a prova era fácil, eu, do nada, eu mudei isso, minha mãe não me falou nada, minha família não falou nada, eu fui porque eu quis fazer a prova, né, eles foram fazer propaganda lá no Guarda Mirim para gente fazer a prova, eu me interessei, eu fui atrás de tudo, assim, fazer inscrição, pegar material para estudar, eu juntei com uns outros colegas para fazer uma revisão assim antes da prova, fui tudo por conta assim, e eu não sabia até onde isso chegaria, mas eu queria fazer e me preparei para não ir, para medir toda capacidade, assim, para não ir sem preparo, eu fui com um pensamento diferente dos outros do meu meio, assim, do meu meio social. 
$\mathrm{D}: \ldots(?)$

A: Eles não tinham um pensamento de estudar em escola particular, nem sabiam para que quê servia escola particular, eu também não sabia - sabia que a escola era boa e que ia ajudar a fazer faculdade no futuro, mas não sabia que tinha vestibular, que vestibular era difícil, que existia um vácuo gigante entre escola pública, entre colégio público e colégio particular, não sabia isso, para mim eles eram muito parecidos, não eram parecidos, não são parecidos, e eles também não tinham essa noção, a gente foi mais para, vamos dizer assim, para ter um resultado, assim, um resultado bonito, um status assim: “ah, passei, fui bem no vestibulinho, sou inteligente!” Sabe? Mas sem ter um objetivo, assim, final, fundamental, a escola particular é boa, escola pública é ruim, a gente sabia que tinha diferença, mas para gente era pequena porque a gente nunca conviveu em um e no outro, nunca tinha convivido. E a gente já estava meio que condicionado para começar a trabalhar já, feito a Guarda Mirim, oitava série, a gente ia concluir o Ensino Médio só para complementar, não para... É... É... Entrar no vestibular e fazer um curso superior, passar no vestibular, era diferente.

D: Antônio, mas isso te salvou do quê?

A: É... Eu falo salvou do... Se eu não fizesse essa prova, eu não teria entrado em escola particular e eu não chegaria onde eu estou hoje; estar onde eu estou hoje, quando eu estava no Guarda Mirim era inimaginável, eu nem sabia que tinha essa possibilidade, eu nem pensava nisso! Muitos dos meus colegas do Capital já tinham esse pensamento já, de onde poderia chegar, o que quê tinha que fazer. Eu não! Por mim eu ia estar trabalhando hoje, se eu continuasse lá, se eu não fizesse essa prova, eu trabalharia numa gráfica, que é onde eu trabalhava depois que eu saí do Guarda Mirim, e nem teria sentimento de perda nenhuma que eu não conhecia fazer curso superior, ter profissão, sabe, ter nível superior, nem passava pela cabeça, para mim era coisa de gente rica, sabe, de quem tem dinheiro e não era para o meu bico. Aí eu passei na prova, fiz o Capital, fiquei estudando no Capital, aí mudaram meu pensamento lá, aí eu comecei a conhecer, saber como o é que funcionava. Se não fosse isso, hoje eu estaria trabalhando numa gráfica, normal, sem nenhum sentimento de perda, mesmo se eu tivesse passado no vestibulinho, nem faria curso superior nada. Então, isso aí foi tipo uma ponte que fez com que eu entrasse em outro mundo, assim, que facilitou, me ajudou, fez com que eu chegasse até hoje, assim, conseguisse esses objetivos que eu não tinha antigamente, antes de entrar no Capital, antes de fazer vestibulinho.

D: Depois que você passou no vestibulinho, que você conseguiu a bolsa, você continuou trabalhando nessa gráfica, né, que você saiu do Guarda Mirim e entrou nessa gráfica, né...

A: Continuei até o início das aulas. A aula começaria numa segunda-feira de fevereiro e eu trabalhei até sexta-feira.

D: E por que quê você continuou trabalhando?

A: Então... Eu não... Eu continuei, eu gostava, para mim a vida era aquilo lá: trabalhar. Eu ia entrar numa escola, mas, sabe, eu não me preocupava: "eu vou estudar num colégio particular”, não: “eu vou terminar isso, daí eu começo o outro e vejo como é que funciona”. Sabe, eu terminei o trabalho mesmo por gosto, assim, queria até continuar trabalhando, mas não dava para conciliar com estudo porque o colégio ocupava mais da metade do dia, e eu acabei saindo... 
D: Mas, você que quis ficar, não foi sua mãe que falou...?

A: Não, porque nem tinha mais necessidade porque sabia que eu ia ficar três anos num colégio particular e não ia ter como continuar trabalhando. Aí eu falei: “ah, eu vou terminar isso daqui quem sabe eu aprendo alguma coisa...” E continuei, até porque eu não contei para os meus patrões que eu tinha passado no vestibulinho, eu falei: “ah, vou ficar aqui.” Eu tinha amigos também lá na gráfica, aí eu não queria sair e ficar à toa lá em casa não: "vou terminar, aí depois eu vou mudar a rotina e ver como é que fica”. Mas eu fiquei lá porque eu quis, porque eu gostava.

D: Você falou que você quando entrou na escola, você tinha muita vontade de ir para a escola, de aprender a ler, a escrever e a fazer conta. Mas, você não gostava de atividades da pré-escola de pintar, desenhar, essas coisas. Isso trazia algum problema, isso era um problema na época da pré-escola ou não?

A: Ah, na pré-escola, tipo, a professora dava coisa para pintar, assim, eu pintava um pouquinho e aí ia lá e ia conversar com ela sobre outra coisa: "como é que escreve isso? Como é que acontece isso? Por que quê o céu é azul? Como é que faz uma conta de multiplicação? Como é que escreve caixa?” Sabe? Eu queria saber essas coisas e a professora acabava dando atenção. Mas, pintura, desenho, eu fazia o mais porco possível, assim, não estava nem aí, e entregava assim para professora, e mudava o assunto. Quando na pré-escola era aula de escrita, a gente tinha escrita também, [aula] de conta, de matemática, aí eu gostava mais. Mas quando era esse ambiente de pintura, assim, dia festivo - Dia da Árvore, Dia do índio - eu odiava, eu não gostava, ficar pintando, assim, ixe! Eu sou canhoto ainda... Com a mão boba... Nossa! Pintar era, era muito ruim! A minha letra é feia, eu sempre tive problema com professor por causa da minha letra. Mas, na pré-escola eu sempre gostava mais de Português e Matemática do que coordenação motora, pintura, desenho, nunca gostei.

D: Mas, isso gerava repreensões da professora, alguma coisa?

A: Ah, ela falava que eu era relaxado, mas ela sabia que eu gostava de outras partes, então não repreendia tanto assim. Ela falava: "Capricha mais, você pode fazer mais". Mas, ela não fazia nenhum tipo de repreensão não.

Tinha alguns alunos que era o contrário, né, gostava mais dessa parte e não gostava da outra e a professora, assim, já conhecia como funcionava, então ela incentivava o aluno a melhorar a parte que ele não gostava, mas sem nenhum tipo de estresse, assim, pelo menos que eu me lembre nada, não lembro de nada que, assim, atrapalhou... Mas, eu passei a gostar mesmo da escola, a empolgar mesmo, foi na primeira série; no pré eu gostava também, mas eu sabia que tinha dia que ia ser ruim, que ia ser chato... É isso aí.

[explicação de que era uma professora por série]

D: Outra coisa que você comentou que sua mãe quis que você começasse a trabalhar para você não ficar na rua, essas coisas. E você disse também que seu pai não queria que você trabalhasse. Mas, eles divergiam, como é que era isso?

A: O meu pai, ele trabalhava o dia inteiro, então ele não ficava em casa, ele não via que eu ficava lá à toa, minha mãe via, então nisso que eles diferenciavam. Depois que eu comecei a trabalhar, meu pai percebeu que eu estudava à noite, que fazia lição à noite, primeira vez que ele me via fazendo lição que era a hora que ele estava lá, dever de casa, aí ele mudou de idéia também, no início ele não gostava, mas depois 
ele mudou porque ele viu que eu passei a cumprir horário, assim, fácil, sabe, e me esforçava o dia inteiro, depois estudava à noite, fazia lição à noite, então ele acabou gostando também da idéia, no começo não, mas depois... Porque ele nunca me via, quando eu estava na quinta série mesmo relaxado, ele não me via, ele só me via à noite, e à noite não é hora de estudar, ele pensava: “então, está tudo certo!” A minha mãe que via que eu estava perdendo o prumo, assim, e resolveu mudar um pouco a rotina. E isso foi bom para mim e ele percebeu que também foi, então eles acabaram concordando. Eu sempre fiquei, ficava um período trabalhando, depois parava um pouco de trabalhar, aí voltava a trabalhar de novo e eu gostava disso; era muito cansativo, mas eu gostava. Aí no fim todo mundo acabou... Meu irmão também começou a trabalhar, sabe, e meu irmão não gostava, não gosta tanto de escola, não gostava muito de escola, ele começou a se dedicar muito mais ao trabalho do que à escola, então no fim, nós dois estávamos trabalhando e meu pai achou bom isso no fim. Porque ele trabalhou desde os sete, oito anos de idade, ele não teve tempo para ir à escola, então para ele trabalhar era sinônimo de abandonar a escola, mas depois ele viu que não é bem como era no tempo dele que tinha que abandonar totalmente a escola para ir trabalhar, já era possível conciliar os dois e que um ajudava o outro, apesar de cansativo, um complementava o outro, né. E minhas notas aumentaram, eu estava mais disciplinado, eu estava aprendendo uma profissão nova, então não tinha nada de desvantagem nisso, era vantajoso. E meu pai e minha mãe acabaram entrando num acordo e minha mãe acabou ganhando a disputa com o meu pai, né, meu pai concordou.

[mãe trabalhava numa confecção como costureira; depois de casada ela continuou costurando para essa mesma fábrica, mas em casa, prestando serviço terceirizado; só parou “agora” porque situação estabilizou, irmão começou a trabalhar, ele (Antônio) já tem uma renda, só tem a irmã; “então, ela não precisa mais trabalhar. Pai está aposentado há dois anos.]

D: Você tinha comentado que você optou por não pegar bolsa-trabalho que não tivesse nada a ver com o seu curso, que lá na Farmácia quem trabalha faz iniciação científica. E você comentou que se fosse para você fazer isso e se diferenciar de um jeito negativo desde o começo era melhor nem começar, né.

Antônio É.

D: E como é que é isso, se diferenciar...?

A: Aqui, o povo do C. [moradia estudantil] aqui, muitos têm bolsa-trabalho, então, você faz um trabalho, se dedica um tempo a uma área que não é a sua, na grande maioria das vezes. A única área de Farmácia que tem [bolsa-trabalho] é a Assistência farmacêutica, e não é minha área, mesmo sendo farmacêutico não é minha área, a única área de bolsa-trabalho é Assistência farmacêutica. O resto eu trabalharia em USPLegal, USPRecicla, CIRP, Biblioteca, isso não tem nada a ver com a minha área, seria só para ganhar, para ter uma renda, só isso. Então quer dizer: eu vou fazer uma iniciação, nem que seja de graça para mim aprender alguma coisa da minha área, ter experiência, porque eu sabia que uma hora eu ia ter que sair daqui, eu ia me formar, e lá fora ou até aqui fazendo pós a técnica, assim, é muito mais importante, aprofundar numa técnica, do que você ter tido experiência numa outra área que vai pouco 
acrescentar. Então, o que eu fiz? Eu fazia iniciação, ou quando, o tempo que eu não fazia iniciação, eu estudava, né, estudava matéria assim normal, as áreas que eu gostava, que era Microbiologia, Parasitologia, sabe, a parte dos microorganismos, estudei bastante isso e fiz iniciação de graça nessa área - Microbiologia - e eu vi que hoje no meu trabalho de mestrado e de iniciação isso é muito útil, eu detecto problemas no meu laboratório que a minha orientadora, por não ser da área de microbiologia, ela é veterinária, não tem tanto essa base, não consegue detectar, tipo noção de contaminação, regulagem de estufa. A gente já perdeu cultura porque a estufa estava mais quente; tipo, ontem, eu estava, a gente botou uma cultura para crescer lá, para se desenvolver e a gente viu que a cultura não se desenvolvia, eu abri a estufa e, pela experiência - eu fiquei um ano trabalhando num laboratório mais antigo onde a estufa já estava há anos calibrada, e essa é nova, recém-calibrada - eu senti a diferença de quatro graus na temperatura, isso foi experiência da outra iniciação. Fazer meios, usar os meios, fazer inóculo, trabalhar toda a parte básica do laboratório, eu tive essa parte na outra iniciação, e estudando também, sabe, o tempo que eu teria perdido fazendo bolsa-trabalho eu ganhei me especializando na área que eu gosto. Então, isso foi de grande valia para mim, e é uma carreira, né, você vai trabalhar com isso talvez o resto da vida, então é sempre bom você ter uma base. Bolsa-trabalho, por exemplo, muitos aqui sofrem disso, a pessoa começa no segundo ano a bolsa-trabalho, no primeiro ano a bolsa-trabalho, dentro de dois anos, na maioria das vezes, dentro de dois anos ele é obrigado a sair para dar lugar para outro aluno, então ele cria um nível de vida incompatível, nesses dois anos, ele ganha uma bolsa que é maior do que a renda per capita da família dele aqui, então ele cria um nível de vida diferente, eu percebo isso, muitos aqui passam esses dois anos e passa o maior aperto depois, e vai pedir iniciação, fazer iniciação, porque bolsa-trabalho não pode ter mais porque já teve dois anos, não tem experiência nenhuma de iniciação, tem que começar do zero. Então, seria melhor ter começado do zero e ter passado mais apertado no começo, eu penso assim, e ter tido a experiência para depois, quando você estiver no fim do curso, qualquer trabalho que vier você consegue fazer com a maior facilidade. Há casos aqui de pessoas que fazem dois anos de bolsatrabalho, depois não tem mais como se sustentar, e estão num padrão diferente, mesmo sendo um nível social mais baixo, mas é um padrão diferente, eles apelam: tipo, quem faz curso noturno está procurando emprego fora, trabalhando de operário fora do campus aqui e diminui o tempo livre para meia hora, tempo de sair do emprego e vir aqui na aula, para poder manter o nível de vida que eles tinham antes, muito mais pelo costume. Eu, por ter planejado desse jeito, hoje eu tenho bolsa, estou sossegado e sempre segui a mesma linha. Eu achei de maior valia fazer isso do que ter uma bolsa-trabalho de uma área que certamente eu nunca mais ia ter contato; é bom no sentido financeiro. Muitos que estão aqui são obrigados a fazer isso, infelizmente eles sabem que não é certo, que eles estão perdendo tempo, mas eles são obrigados por ter nível social muito, muito baixo, não conseguir se sustentar com o que a família manda, né, tem uma renda muito baixa, aí, eles mesmo reconhecem, a maioria reconhece que é dar murro em ponta de faca, mas tem uma necessidade de... Eu que tive a oportunidade de ficar um pouco melhor e poder segurar desse modo, para mim foi excelente! Como tem gente que está na mesma situação minha e optou pela bolsa-trabalho e acabou perdendo um tempo.

D: Os seus colegas de turma lá na Farmácia, a maioria não precisa, né, de bolsatrabalho. Então você se diferenciaria deles nesse sentido? 
A: É dos meus colegas da Farmácia, eles têm um pensamento parecido com o meu, aliás, a influência lá é mútua, eles têm um pensamento parecido com o meu: eles fazem iniciação não por causa da bolsa mas por causa da experiência. Porque eles já escolhem uma área, a maioria forma para trabalhar na indústria: "eu quero área de controle de qualidade na indústria”, “controle de qualidade físico-química” - que é uma área lá. Então, eles já vão no laboratório de controle de qualidade físico-química no segundo ano, em $90 \%$ das vezes eles são aceitos como alunos de iniciação sem bolsa, e começam um trabalho lá e acabam ganhando toda a experiência em controle de qualidade, se formam, se formam não, chega a época do estágio, eles vão pedir o estágio: "eu tenho experiência de iniciação científica três anos em controle de qualidade" e eles vão ter certamente a preferência do empregador e é o que geralmente acontece. E, todos têm... Os veteranos já passam essa informação para os calouros, e a gente absorve isso assim. Então, lá é raríssimo pessoa que pega bolsatrabalho, é raríssimo, é muito fácil a gente conseguir bolsa de assistência farmacêutica, mas só vão atrás de assistência farmacêutica quem gosta de assistência farmacêutica; na minha sala três ou quatro que gostam de assistência farmacêutica, então eles fizeram toda a iniciação em assistência farmacêutica, mais com bolsatrabalho do que com bolsa de iniciação, né. Mas a grande maioria escolheu uma área específica lá e começou a trabalhar nem se for de graça e foi trabalhando pensando na experiência. Eu também fiz isso, eu comecei em controle de qualidade microbiológico, eu gostava de microbiologia, eu gosto de microbiologia, depois eu saí, fiquei um ano só estudando, aí comecei em parasitologia, mas tudo pensando que a experiência de um vale na experiência do outro porque ambiente cientifico é parecido, né, microbiologia e parasitologia as diferenças são pequenas, então é de grande valia. Todo mundo lá pensa desse jeito. Aqui no C. [moradia estudantil] eles pensam diferente, por necessidade, por opção todo mundo quer fazer isso, mas por necessidade. E eu tive sorte de escolher o mesmo pensamento deles, isso ajudou bastante, na verdade, ajuda todo mundo -o que faz a gente da USP ser diferenciado, assim, nos processos lá, eles dizem, não é falar inglês fluentemente, sabe, não é ter $n$ qualificações, é ter experiência, o mais importante é ter experiência na área, ter conhecimento na área, porque os outros é, a gente se adapta, a gente procura, essa parte já vem, você só consegue ter esse conhecimento praticando, e a gente pratica lá, isso é bem valorizado; então isso é tipo uma tradição, é passado de veterano para calouro.

D: Você fala nas seleções nas indústrias...?

A: É, fazer pós-graduação também, sabe, ter conhecimento também é bem melhor do que você sair da sua área por causa de dinheiro. Como lá a maioria não precisa, não tem esse problema, aí já vão com esse objetivo, e eu segui também, apesar de ser mais tardio, mas eu segui também.

D: Como você se vê em relação a seus colegas lá da Farmácia, em relação assim ao nível sócio-econômico?

A: Então, eles têm um certo privilégio, em não ter essa obrigação... Em ter a liberdade de escolher o que quer, o que quer fazer e isso é, esse tipo de privilégio é muito bom, se todo mundo do C. [moradia estudantil] tivesse essa chance, muita gente sairia daqui bem mais qualificada, com uma carreira bem mais promissora, perderia bem menos tempo, né, perderia muito menos tempo; e esse privilégio faz com que a turma lá saia muito bem qualificada enquanto muita gente aqui que faz 
Química não consegue disputar com eles porque mora aqui no C. [moradia estudantil] e tem que ter bolsa-trabalho. Há pessoas aqui que sempre optaram por bolsa-trabalho, monitoria em Pró-aluno, e faz Química, mas não consegue disputar vaga com um farmacêutico dali porque eles têm muito mais experiência, porque fizeram iniciação ao invés de fazer bolsa-trabalho. Mesmo o aluno que só fica, que não faz iniciação e só se dedica aos estudos acaba tendo vantagem também porque ele vai ter mais conhecimento, teórico, mesmo sendo teórico, mas ele vai ter mais conhecimento do que alguém que por obrigação, foi obrigado a dedicar oito, dez horas por semana na bolsa-trabalho. A única vantagem da bolsa-trabalho é retorno financeiro, temporário, né, dois anos, mas de resto, iniciação, ou mesmo só estudar tem vantagem muito maior.

D: E você via aqui a diferença que você percebia quando você entrou no colegial, porque você disse que via uma diferença entre você e os alunos, né, que você chamou de elite lá da sua cidade, né. Aqui você via essa diferença lá no curso de Farmácia?

A: Não porque eu já estava acostumado com o povo do Capital, né, ali é, tipo, é um reflexo, é muito parecido, pessoas muito diferentes mas, de um nível social melhor do que o meu, mas muito parecido com o do Capital, por isso que a minha adaptação na Farmácia foi bem melhor do que aqui no C. [moradia estudantil] porque eu já estava acostumado, já sabia lidar com esse tipo de, com essa turma, com esse tipo de classe, de gente, então foi bem mais fácil. Ali foi muito rápido, ali, eu, praticamente, eu saí da sala do colegial, e entrei noutra sala, é como uma sala de colegial expandida, com outras pessoas, foi bem mais fácil, adaptação mesmo foi viver aqui em P.[cidade onde se localiza o campus], mas do ponto de vista acadêmico, assim, foi, eu não senti nenhuma diferença. Há outros tipos de pessoas, né, pessoas muito extravagantes, pessoas que falam mais, pessoas que falam bem menos, muito introvertidas, há esses extremos, que é bem mais destacado ali no curso de graduação do que no colégio, mas tirando esses extremos, a turma normal, mediano [faz gesto] é muito parecido, é diferença praticamente de sotaque dependendo da região e de alguns costumes mínimos, mas são muito parecidos, então não tive problema de adaptação, não vi diferença nenhuma.

[fala a respeito da família]

A: Pelo meu exemplo todo mundo quer tentar também

\section{(...)}

Eu tenho uma irmã de 17 e um primo de 16 que vão tentar. Já mudou o pensamento, antigamente, quando eu tinha a idade deles, um pouco mais novo, antes de entrar no Capital, como eu já disse, eu não tinha esse pensamento, eles já têm, eu acho que eu até ajudei um pouco a mudar esse pensamento, dos meus tios, né...

D: Você está sendo um exemplo assim?

A: É o primeiro, né... Aí o resto quer fazer parecido, sabe que é possível, sabe, mais ou menos, como é que funciona então é bem mais fácil do que quem nunca teve contato, né, ? no meu caso/não é o caso.

D: Você quer acrescentar alguma coisa? 
A: Ah... Do que eu lembro, eu acho que eu não esqueci nada, o mais importante eu falei.

D: Então, eu quero agradecer mais uma vez. 


\subsection{O Longo percurso de Carlos}

Carlos, 33 anos, é aluno do décimo semestre do curso de Medicina ${ }^{48}$. Proveniente de um grande centro urbano, reside na moradia estudantil desde seu ingresso na Universidade e, casado há 13 anos, divide o apartamento com a esposa desde o final do primeiro ano da faculdade ${ }^{49}$.

Filho de um motorista de táxi que estudou até a $4^{\mathrm{a}}$ série e de uma dona-decasa que possui Ensino Fundamental completo, esse estudante tem mais dois irmãos: uma irmã de 30 anos que completou o Ensino Médio e trabalha como supervisora de vendas de uma imobiliária, e um irmão com 22 anos que cursa Administração na Pontifícia Universidade Católica de São Paulo (PUC/SP) através do Prouni ${ }^{50}$. Seus pais estão separados há aproximadamente dez anos. Sobre os avós, Carlos dispõe de poucas informações afirmando somente que os pais de sua mãe sabiam ler e escrever e tinham uma "bodega”, e que os avós paternos viviam das atividades desenvolvidas no sítio que possuíam e também dominavam a leitura e a escrita.

A trajetória escolar de Carlos é a mais irregular entre as aqui analisadas, sendo ele o estudante cujo ingresso na Universidade foi o mais tardio, aos 29 anos de idade.

Carlos realizou o Ensino Fundamental em uma escola pública estadual. Aluno exemplar, com apenas um conceito “C” entre notas “A” e “B” nas oito séries, destaque em matemática e física, mediano nas matérias da área de humanas, ele foi indicado pelo diretor para ser bolsista no Ensino Médio de uma escola particular de grande prestígio - Colégio Paulista ${ }^{51}$. A bolsa foi oferecida por uma Fundação a dez alunos de seis escolas públicas da cidade. Essa experiência teve grande impacto para Carlos e representou uma ruptura em sua trajetória escolar.

\footnotetext{
${ }^{48}$ A duração total desse Curso é de doze semestres.

${ }^{49}$ A moradia estudantil para os estudantes de Medicina é gerida pela Faculdade (e não pela Coseas) e localiza-se em prédio distinto da moradia destinada aos demais cursos existentes no campus. Diferentemente dessa, na moradia da Medicina os apartamentos são individuais, sendo os banheiros e a cozinha coletivos.

${ }^{50}$ Programa Universidade para Todos do Governo Federal que oferece bolsas integrais ou parciais para estudantes de baixa renda estudarem em faculdades particulares.

${ }^{51}$ Todos os nomes de escolas utilizados neste trabalho são fictícios.

O Colégio Paulista é conhecido por dispor de um corpo docente altamente selecionado e bem remunerado e pela aprovação nos exames vestibulares, notadamente em cursos muito concorridos. A título de exemplo, no vestibular de 2007, os alunos aprovados em primeiro lugar em alguns dos cursos de mais alta seletividade de prestigiadas universidades públicas estudaram nessa escola.
} 
A entrada no Colégio Paulista foi marcada por certo encantamento: Carlos impressionou-se com a limpeza, a conservação das carteiras, a sofisticação dos laboratórios e o tamanho da biblioteca. Chamou-lhe atenção também a qualidade das aulas ministradas pelos professores que "não olhavam no livro”, a liberdade de poder sair da escola durante os intervalos, bem como a quantidade de material didático, também fornecido pela Fundação e com antecedência: “Era um monte!”. Esse deslumbramento, no entanto, durou até as primeiras provas quando Carlos descobriu que não estava aprendendo conforme o esperado naquela escola.

Com um histórico escolar de "bom aluno", ele assustou-se com as notas baixas, tendo ido mal em todas as disciplinas no primeiro bimestre, com exceção de duas, que não foram, entretanto, aquelas nas quais sempre se destacou: “As que eu tinha facilidade foi que eu mais tomei na cabeça”. Carlos define como decepção e “depressão” a experiência de um fraco rendimento na escola: “[Eu] Nunca tinha tirado nota baixa na minha vida...”.

Mas, ele não estava sozinho nesse desempenho ruim, pois todos os dez alunos bolsistas foram muito mal no primeiro bimestre na nova escola. Preocupados, eles reuniram-se e foram até a Fundação, onde foram tranqüilizados em relação a isso já que como o sistema de pesos de cada bimestre no Colégio Paulista aumentava gradativamente, indo de um no primeiro bimestre a quatro no último, aquelas notas valeriam apenas $10 \%$ da média final sendo, portanto, bastante viável a recuperação. Esses estudantes, então, numa tentativa coletiva de auxílio mútuo, começaram a se reunir para estudar junto. A iniciativa, contudo, não foi duradoura nem logrou efeito satisfatório, em função, segundo Carlos, das dificuldades de deslocamentos dos estudantes, especialmente para ele que era o único que morava em uma região oposta aos dos demais colegas bolsistas, e das diferenças no andamento das disciplinas em cada classe, já que eles estavam alocados em turmas diferentes.

Como mais uma tentativa de melhorar seu desempenho, Carlos solicitou ajuda de um colega de classe que se sentava ao seu lado na sala de aula, mas que se recusou a fazê-lo. Ao relatar isso, Carlos compara tal postura com sua experiência anterior na escola pública:

Um fato que marcou bastante: eu era acostumado sempre a fazer grupo de estudos, um ajudava o outro, eu sempre me destaquei na escola, eu sempre ajudava os outros, a gente se reunia, eu ensinava, lá quando eu fui pedir ajuda um menino chegou e: "não, 
eu não vou te ajudar porque se eu te ajudar você pode ficar na frente no currículo”.

O adolescente referia-se a uma classificação existente no colégio que divulgava a nota individual dos alunos e o quanto cada um encontrava-se acima ou abaixo da média de todos para cada série.

Carlos tentou ainda estudar sozinho e melhorou um pouco o rendimento no segundo bimestre. Ele conta que a impressão que tinha era a de que "aprendia atrasado": quando estava fazendo as avaliações do segundo bimestre é que compreendia a matéria do primeiro. Não obstante esse pequeno progresso, ele abandonou a tentativa de acompanhar o ritmo da escola e foi reprovado no final do ano, perdendo a bolsa de estudos: “Aí o terceiro e o quarto [bimestres] eu desencanei de vez, aí eu desisti, eu abri mão”. Mais uma vez ele foi acompanhado por seus colegas provenientes de escolas públicas, já que entre os dez alunos bolsistas somente quatro foram aprovados.

Essa experiência escolar de Carlos remete-nos à história de três adolescentes francesas que enfrentaram a dolorosa mudança de colégios medianos para um "liceu" elitizado, discutida por Broccolichi (1997). Consideradas ótimas alunas nas escolas de origem, essas alunas passaram a enfrentar várias dificuldades na nova escola, experimentando uma queda brutal em seus valores escolares e um sentimento de fracasso por ocupar uma posição desvalorizada na hierarquia escolar (Broccolichi, 1997). Assim como para Carlos, a mudança de escola representou a: “... passagem de um universo do colégio comunitário e caloroso, fundado sobre a ausência de exclusão e a solidariedade (...), ao universo frio e anônimo do liceu fundado sobre a violência da segregação e da concorrência...” (Broccolichi, 1997: 511).

Além da experiência de fracasso escolar, o impacto da recusa do colega de classe em prestar auxílio parecer ter sido decisivo para a desistência de Carlos de acompanhar o ritmo do Colégio. Essa é não só a primeira lembrança relatada em relação à escola como também o primeiro, e talvez um dos mais marcantes, fato que Carlos nos contou a respeito de toda a sua trajetória. A respeito da negação de ajuda, ele faz uma reflexão bastante pessoal:

Aí eu desencanei, recebi o baque. Também, na verdade, eu acho que foi mais uma desculpa para mim mesmo para desistir. Não sei. Eu acho que eu não estava preparado na época para fazer a 
escola... Eu acho que a mudança foi muito brusca, eu tinha 13 anos quando isso aconteceu e não soube lidar com a situação.

Com qual situação Carlos não soube lidar e para a qual não estava preparado naquela época? Com o estudo em um colégio cujo ritmo de ensino era muito mais forte do que ele estava habituado na escola anterior em que ele "ia bem sem estudar”?

Talvez. Importante esclarecer, no entanto, que após ser escolhido pelo diretor da escola em que estudava para ser bolsista no Colégio Paulista, Carlos teve de prestar um vestibulinho cuja pontuação definiria a turma onde ele estudaria, já que nessa escola as classes eram formadas de acordo com o desempenho escolar dos alunos. Ele, e mais um aluno vindo também de escola pública, foram classificados na melhor turma da primeira série do Ensino Médio. Assim, além de ter tido um dos dois melhores desempenhos dentre os dez bolsistas, Carlos, segundo a avaliação realizada pelo próprio colégio, possuía um nível inicial de conhecimento semelhante ao dos demais alunos da turma do primeiro colegial em que fora alocado. Não se trata aqui de defender esse tipo de procedimento de formação de classes; o que pretendemos mostrar é que Carlos não entrou nessa escola particular com defasagem ou grande diferença de conhecimentos em relação aos demais estudantes que já estudavam na escola ou que estavam nela ingressando. Apesar das dificuldades pedagógicas que podem ter surgido ao longo de sua adaptação à nova escola, parecenos, com base em seu histórico escolar, que Carlos tinha condições potenciais para conseguir acompanhar sua turma. Mas, o que aconteceu para que ele não o tenha feito?

A situação mais difícil a ser enfrentada por Carlos na escola particular não foi, a nosso ver, a de ensino-aprendizagem - não se desconsiderando, todavia, as dificuldades presentes também aí - mas, antes, a experiência da humilhação social.

Assim como para Pedro e Antônio, também para Carlos estudar em uma escola particular representou o encontro e a convivência com a desigualdade social, mas, ao que nos parece, com outro desfecho, já que ele parece ter sofrido as dores da humilhação social.

Como afirmamos anteriormente neste trabalho, a humilhação consiste em um sofrimento psíquico cuja origem é o impacto traumático da desigualdade social (Gonçalves Filho, 1998). 
Carlos relaciona, de alguma forma, a sua desistência de tentar acompanhar o ritmo de estudo no Colégio Paulista com a segregação social que afetava a ele e a seus colegas provenientes de escolas públicas: “Aí logo no segundo [bimestre] foi meio assim, quando eu pedi essa ajuda e foi negado... A gente era meio separado, também, né, dos outros, né. Acho que era condição social mesmo”. Além da discriminação, Carlos fala também a respeito de algo a ela relacionado: a enorme desigualdade social que os distinguia dos demais alunos da escola.

...a gente ficou, era meio discriminado, bolsa: "Mas, como você conseguiu bolsa? O colégio não dá bolsa!” Aí eu falava: "não, a Fundação A., tal” e explicava a situação. E ficava. Era diferente! A gente era diferente. A gente se vestia pior, os meninos chegavam e diziam que foram para Nova York, viajou, não sei o quê, a gente... Até hoje eu não andei de avião, né! (sorrindo) Então, já cria um abismo socialmente entre nós e eles. E, não se juntou, simplesmente não se juntava [fazendo gesto de ligar com as mãos]!”

Tal discriminação está diretamente ligada à grande desigualdade existente na sociedade brasileira que foi, nesse caso, re-apresentada nas relações estabelecidas no interior do colégio. A separação da qual fala Carlos já estava dada socialmente, tendo sido atualizada na interação dele e dos demais alunos bolsistas com os adolescentes pertencentes à camada social que freqüentava aquela escola. Discriminar não constitui sempre um ato intencional, individual ou ostensivo por parte de quem envia a mensagem inferiorizante; ao contrário, muitas vezes, trata-se de algo bastante sutil, tornando mais difíceis e sofridos a sua compreensão e o seu enfrentamento por quem a recebe. Embora Carlos tenha usado, ele mesmo, o termo “discriminado", procurando explicar-se melhor, ele recusa o sentido de intencionalidade individual da ação presente na discriminação sofrida por ele e seus colegas na escola particular:

Então, não é bem... Não sei explicar direito. É... Éramos diferentes, não é que tinha discriminação, que o pessoal isolava; a gente, simplesmente, não conseguia conversar as mesmas coisas, os meninos, eles ouviam outras músicas, eles tinham acesso a sons diferentes, assim, a gente ficava meio naquele negócio pop, assim, FM, eles tinham outras coisas. Era como se fosse um mundo à parte. A gente não conseguia misturar! É mais complicado do que simplesmente dizer que era discriminado. Não, não era! Tipo, eles não chegavam e: "não vou falar com você". Nada disso! Era simplesmente... Não batia! A gente não conseguia conversar das mesmas coisas. A gente não tinha os mesmos conhecimentos, a gente não se divertia igual. Pô, eles ir para o Playcenter: "Ah, o 
Playcenter é porcaria!” Para a gente era: “Nossa! A gente vai no Playcenter!” (rindo)

Além do fato de estudarem na mesma escola, não havia algo em comum que unisse Carlos e seus colegas bolsistas aos demais estudantes daquele colégio. Não existindo experiências a serem compartilhadas, a diferença entre eles afigurava-se como dois mundos completamente diferentes separados por um "abismo" social que fez com que esses mundos não conseguissem se comunicar, não por rejeições individuais (embora elas também pudessem existir), mas por impedimentos sociais.

Entendendo a experiência vivida por Carlos no Colégio Paulista como uma situação de humilhação social, sua fala traz a complexidade desse fenômeno e ao mesmo tempo a dimensão do enigma nele presente. A vivência dos efeitos da desigualdade social é tão dolorosa que descrevê-la torna-se uma tentativa difícil:

Sei lá, é como... Dando um exemplo bem esdrúxulo, é como o restaurante Fasano lá em São Paulo, você simplesmente não vai porque você não tem dinheiro, então, não é que te discriminam, se você quiser pagar até que você vai... Mas não... Não discriminam, você não consegue se misturar, é diferente. É mais... Nem sei dizer (ri)! Está fugindo a palavra...

Os dois mundos à parte não conseguem conviver, comunicar-se ou "trocar influências”, como diz Weil (1986). A palavra foge e Carlos não consegue nomear ou encontrar no universo semântico um código que reflita ou decifre o sofrimento vivido por ele naquela escola. Além disso, a dificuldade em compreender e poder falar a respeito atinge também quem provoca a humilhação:

A angústia tem seu ponto de partida em mensageiros humanos e ultrapassa a aptidão tradutiva dos seus destinatários - o destinatário sofre a mensagem sem poder traduzi-la. Há mais: freqüentemente, as mensagens enigmáticas, que confundem e angustiam o destinatário, são enigmáticas para os próprios mensageiros. É este o caso da desigualdade política, geradora da humilhação social (Gonçalves Filho, 1995: 141).

Como já vimos, a amizade é uma das formas de enfrentamento de enigmas intersubjetivos como é o caso da humilhação social (Gonçalves Filho, 1998).

Foi justamente com a colaboração e a amizade dos novos colegas da escola particular que Carlos não pôde contar. Além do episódio narrado, esse estudante afirma lembrar-se de apenas mais dois alunos dessa escola, com quem, todavia, perdeu todo contato após sair de lá. Aluno tímido, anteriormente exemplar, 
experimentando pela primeira vez um mau desempenho na escola, sentindo-se rebaixado, ele procurou ajuda de um colega. Ao ter seu pedido negado, num ambiente caracterizado por ele como competitivo e individualista, Carlos, um adolescente de 13 anos, viu-se sozinho na tarefa de enfrentar essas dificuldades e desistiu.

Mas, apesar de ter sofrido o golpe da humilhação social, Carlos não sucumbiu a ele. Antes tirou proveito e aprendizado da experiência. Ele considera que a vivência no Colégio Paulista representou uma quebra em sua trajetória escolar, porém “positiva” e não “ruim”, classificando-a como uma “experiência rica”. Uma das vantagens que essa experiência lhe trouxe foi proporcionar uma bagagem de conhecimentos que lhe possibilitou cursar o primeiro colegial novamente com muita facilidade, na medida em que “já sabia muita coisa, era bem mais adiantado”, contribuindo, como veremos a seguir, para o resgate de uma posição de destaque na escola. Além disso, a experiência naquele colégio lhe permitiu conhecer a dimensão da desigualdade escolar ao mostrar-lhe a diferença existente entre o ensino da escola na qual ele estudava - uma boa escola pública - e onde era considerado "bom aluno" e uma escola particular destinada às mais altas camadas sociais. O conhecimento dessa discrepância foi importante para estimulá-lo a estudar e a se preparar quando resolveu, muito tempo depois, prestar vestibular para o curso de Medicina. De certa forma, quando Carlos estudou no Colégio Paulista, ele conheceu quem seriam seus potenciais futuros concorrentes na disputa por uma vaga para o curso de Medicina numa universidade pública:

E a experiência, né, de ver que eu estava bem, só que é meio ilusório, né. É bem para uma escola estadual, mas é bem distante do que é realmente as coisas. E isso foi um fator até que fez eu correr mais atrás, de estudar mais tarde, de estudar por conta no Exército, de ensinar o pessoal, depois para eu mesmo ficar estudando para o vestibular. Eu vi que não bastava seguir, ou sei lá, achar que aprendeu, né, precisava de algo mais. Lá [no Colégio Paulista] foi interessante para mostrar isso: ver que o mundo é maior do que eu imaginava, essas coisas, que o que é bom para uma escola estadual não chega nem, não chega aos pés deles...

Conhecer a desigualdade escolar fez com que Carlos se dedicasse mais aos estudos. Como também veremos adiante, ele permaneceu longo período trabalhando no Exército, tempo durante o qual continuou estudando sozinho além de ajudar os soldados que faziam supletivo ensinando algumas matérias e tirando dúvidas. 
Após ser reprovado no Colégio Paulista, por sugestão de uma amiga que também perdera a bolsa de estudos, Carlos fez a prova para o concurso de bolsas de outra escola particular - Colégio Santo Antônio -, obtendo 70\% de desconto na taxa de mensalidade (desconto máximo oferecido por essa escola). Nela realizou novamente a primeira série do Ensino Médio, sendo sua experiência nesse colégio, no entanto, inteiramente diversa da anterior.

Carlos passou a estudar no período noturno e a trabalhar como digitador durante o dia. Já tendo estudado as matérias do primeiro colegial, esse estudante teve muita facilidade com as disciplinas no Colégio Santo Antônio fazendo essa série lá “com os pés nas costas”. O conhecimento prévio e o bom rendimento escolar, aliados à sua facilidade nas disciplinas de exatas, que eram a grande dificuldade dos alunos, fizeram com que ele conseguisse resgatar o lugar de destaque que havia perdido no Colégio Paulista, destaque esse reconhecido não só pelos colegas de turma que solicitavam sua ajuda, mas também pela escola que lhe premiou, no final do ano, com uma medalha de melhor aluno de todas as primeiras séries do Ensino Médio: “Eu levei de boa. E daí voltou o esquema da 8 a série, juntar turminhas para estudar, essas coisas. Foi aí que foi integrando, tudo, eu fiquei bem...”. Além da integração ao grupo e do bem-estar, a experiência no Colégio Santo Antônio possibilitou a ele conhecer Renata - sua atual esposa -, que tem ocupado um lugar fundamental na sua vida desde então: Carlos ensinava-lhe matemática e física e foi assim que eles começaram a namorar. Não é coincidência o fato de ele possuir lembranças muito boas da experiência nesse colégio, que apesar de breve foi bastante significativa: “Foi legal, foi muito bom. Tenho ótimas recordações de lá, foi um ano fácil, passei bem... (...) Foi interessante, foi um ano legal”.

No ano seguinte, Carlos mudou-se com a família para Brasília. Seu pai fora sorteado com uma casa de um programa de habitação para o qual havia se inscrito havia muitos anos e, por ser mais perto do Estado de Mato Grosso, onde iniciara negócios com a comercialização de diamantes, optou por mudar-se para lá. De acordo com Carlos, essa opção foi uma “furada completa”, pois a nova atividade do pai não prosperou e a família perdeu os bens que possuía, como apartamento quase quitado, táxi e linhas telefônicas; ademais, foi depois disso que seus pais se separaram e que ele se afastou mais do pai, que passou a residir em Mato Grosso. 
Carlos não queria mudar e prometeu a sua mãe voltar para a cidade natal assim que completasse 18 anos de idade.

Em Brasília, esse estudante realizou um curso técnico em eletrônica em uma escola pública. Ele conta que desde o fim do Ensino Fundamental desejava fazer um curso técnico. Dessa experiência também possui boas recordações pela facilidade com que realizava as atividades, mantendo seu lugar de "bom aluno" que ia bem sem precisar estudar, e pela grande proximidade que a turma de 20 alunos e quatro professores proporcionava.

Ao fazer 18 anos, no entanto, Carlos não pôde voltar à cidade natal como pretendia, pois fora convocado a prestar o serviço militar obrigatório, tendo de continuar o namoro com Renata à distância. A partir daí, tem início uma importante fase de sua vida.

Como já possuía Ensino Médio completo, Carlos fez uma prova com vistas ao preenchimento de vagas no Núcleo Preparatório de Oficiais da Reserva. Segundo ele, para esse fim, o Exército preferia jovens que estivessem na faculdade, mas, diante de seu bom desempenho na avaliação, foi convocado para fazer o curso preparatório para oficial temporário.

Servindo o Exército, Carlos ingressou no curso de Física na Universidade de Brasília (UNB). Apesar de seu apreço pela disciplina, tal escolha foi motivada pela facilidade de acesso em virtude da menor concorrência para esse curso, tendo Carlos considerado a baixa relação candidato/vaga como se escolhesse um prato pelo preço: “...eu brinco que eu escolhi pelo lado direito do cardápio, né. Eu vi o que era menos concorrido ali e prestei...”. Também contribuiu para essa decisão o fato de um colega do Exército cursar Física. No final do ano, no entanto, Carlos voltou para a cidade natal, e tendo optado por continuar no Exército, conseguiu fazer lá o estágio obrigatório da formação para oficial temporário e abandonou o curso de Física na UNB.

Carlos foi residir com uma tia materna e ingressou novamente em Física, desta vez na USP; porém o curso abandonou quatro meses depois. Carlos atribui os abandonos do curso de Física ao ritmo das atividades no Exército, bem como à sua preocupação com a falta de mercado de trabalho para Físico, com exceção da função de professor, para o quê ele afirma não possuir perfil, embora sua história escolar seja marcada pela ajuda a colegas, principalmente nas disciplinas da área de exatas: 
“... eu tenho uma péssima didática, eu não sei transmitir muito o conhecimento, eu tenho muita dificuldade para achar palavras para conversar, para exemplificar, (...) e para ser um professor ruim eu não quero...”. Concomitante ao exame da Fuvest, Carlos também prestou vestibular para o curso de Engenharia Eletrônica na Unicamp, mas não foi aprovado.

No ano seguinte, Carlos e Renata, aos 20 anos de idade, resolveram se casar, tendo sido esse o principal motivo para ele ter continuado no Exército e lá permanecido por quase dez anos. O casamento foi alvo de críticas por parte de familiares, sobretudo do lado paterno, com quem Carlos rompeu relações a partir de então ${ }^{52}$.

No Exército, Carlos foi assumindo posições hierarquicamente superiores, passando, após três anos, a exercer funções administrativas nas quais permaneceu até a sua saída. Durante o período em que trabalhou no Exército, ele ingressou no curso de Processamento de Dados na Faculdade de Tecnologia de São Paulo (Fatec/SP) para o quê preparou-se, pela primeira vez, através de um curso pré-vestibular. Apesar de afeito à área de exatas e “meio fascinado por eletrônica, televisão, computadores”, Carlos afirma que, fazendo o curso, descobrira que computador para ele era um “excelente” instrumento, mas não um fim para o qual desejasse dedicar sua vida profissional. E pela terceira vez ele abandonou um Curso Superior: “... não ia com as minhas aspirações, com que eu achava que era viver, ficar na frente de um computador, não era para mim mesmo”. Próximo ao fim do prazo máximo de permanência no Exército como oficial temporário e sem saber o que fazer, Carlos pensou em cursar Administração (“Administração, tipo não tem opção, vamos fazer administração...”), em função do tipo de atividade que ele desenvolvia no Exército e visando a dar continuidade à vida que já levava.

Mas, foi também nesse período que Carlos conheceu um médico no Exército e passou a cogitar a possibilidade de fazer o curso de Medicina. Ele conta que desde criança era sempre ele quem, na família, lia bulas de remédios e primeiro socorria pessoas machucadas. Contudo, por sua origem socioeconômica, o desejo de cursar Medicina permaneceu "latente”, “lá no fundinho”, como ele caracteriza, pois considerava impossível essa opção: "Eu sempre fui inclinado para Medicina, tal, né, mas pais pobres: meu pai é motorista de táxi, minha mãe é dona de casa, meu pai tem

\footnotetext{
${ }^{52}$ Até hoje Carlos não mantém contato com o pai, de quem tem notícias através de parentes.
} 
até $4^{\mathrm{a}}$ série, minha mãe tem até a $8^{\mathrm{a}}$, então eu não via possibilidade nenhuma de fazer”. Todavia, ao conhecer as condições em que aquele médico, que se tornara seu amigo no Exército, fez a graduação, Carlos passou a considerar o antigo desejo. Esse amigo realizou o curso de Medicina em nove anos e meio na PUC, pois foi obrigado a conciliar trabalho e estudo a partir da metade do curso quando os negócios da família faliram. Esse médico, que trabalhou como garçom durante a graduação, lhe assegurou que era possível fazer Medicina, principalmente se Carlos ingressasse em uma universidade pública. Assim, a possibilidade de fazer Medicina foi dada e assegurada pela experiência do outro: “... daí eu falei que eu pensava só que não dava, que já era tarde, daí ele falou: ‘não, não é tarde, dá para fazer!’. Foi nessas conversas que me abriu para ter vontade novamente para fazer Medicina”.

Passando a acreditar na viabilidade de cursar Medicina, Carlos, no entanto, considerava impossível assumir tal desafio e continuar casado. Na época ele e Renata possuíam um apartamento - financiado, cuja prestação era alta -, um carro e um padrão de vida confortável proporcionado pelo salário de Carlos de R\$ 3.500,00 e pelo rendimento da esposa, que se formara em Psicologia numa faculdade particular e trabalhava na área de recursos humanos. Carlos escondeu sua intenção de prestar vestibular para Medicina e quase se separou de Renata por não ter coragem de lhe confessar esse intento. O apoio incondicional da esposa, entretanto, foi imprescindível para que Carlos realizasse seu desejo, fazendo com que ela assumisse um lugar de porto-seguro na jornada do marido para ingressar e permanecer no curso de Medicina: “Tipo, se eu tivesse me separado para fazer Medicina eu acho que eu também não faria Medicina, eu ficaria totalmente desestabilizado... O apoio dela foi fundamental...”.

Estudando sozinho Carlos conseguiu ser aprovado para a segunda fase dos vestibulares da Unifesp (Universidade Federal de São Paulo), Unicamp e USP, ficando, no entanto, bem distante na classificação final. Daí, ele prestou o concurso de bolsas de um curso preparatório para vestibular e, por ter obtido um bom desempenho na prova, além de ter sido aprovado para a segunda fase daqueles vestibulares, conseguiu bolsa integral de estudos. Tendo saído do Exército e recusado uma boa oferta de emprego como supervisor de segurança, Carlos passou a se dedicar integralmente à preparação para o exame de vestibular. 
Carlos conta que nesse ano estudou muito: fazia cursinho no período da manhã, permanecia lá estudando à tarde e em casa, à noite, após a esposa deitar-se, estudava até de madrugada. Esse foi um “ano bem difícil” para Carlos, mas não só pela pesada carga de estudo.

Tanto a sua família quanto a de Renata posicionaram-se contra a sua opção de estudar para prestar vestibular. Seus pais não aprovaram tal decisão, estando tal oposição relacionada à relação deles com o estudo e o trabalho. Segundo Carlos, o trabalho sempre foi muito valorizado em sua casa, tanto que ele trabalhou desde os 13 anos de idade, quando, informalmente, fazia sapatilhas e armas numa academia de Kung-Fu para pagar sua mensalidade; depois trabalhou como digitador e posteriormente, em Brasília, fazendo estágio em eletrônica. Essa valorização familiar do trabalho dava-se em detrimento da escolarização: “O que eu via em casa era, tipo: 'trabalhar é mais importante do que estudar'. Sei lá, pode ser qualquer trabalho, mas trabalho é meio que condicionado, trabalho é mais importante que tudo, estudar é: 'se der, você estuda' ”. Como ilustração disso, Carlos conta que embora ele e sua irmã sempre tenham estudado no período matutino, não se lembra de sua mãe os chamando para ir à escola; ele diz ainda que em sua família a questão do estudo era “livre” e que cada um fez seu próprio “caminho”. Outro exemplo dessa nãovalorização familiar do estudo, segundo Carlos, é o fato de sua irmã não ter continuado a estudar, tendo finalizado o Ensino Médio através de supletivo não porque estivesse em idade escolar atrasada, mas “só para ir mais rápido”. Todavia, não obstante Carlos considerar que sua família não valorizasse a escolarização, ele relata que sua mãe ficava brava quando ele e sua irmã faltavam à escola e estimulava o estudo como forma de "ser alguém na vida”. Assim, freqüentar assiduamente a instituição escolar e estudar, ainda que esse estudo carecesse de maiores qualificações e que inexistissem cobranças ou pressões, parecem-nos ser valores, em relação à escola, preconizados por sua mãe, numa atitude semelhante ao trabalho escolar realizado pelas famílias de camadas populares discutido por Portes (2000). Como vimos, esse trabalho compreende toda ação, ainda que precariamente organizada, empreendida no sentido de assegurar a entrada e a permanência do filho no sistema escolar, sendo algo complexo e de difícil visibilidade. De toda forma, parece também que, em sua família, convivia, ao lado disso, uma grande valorização do trabalho. E é essa importância que fez com que os pais de Carlos se 
surpreendessem tanto com a sua decisão de fazer cursinho para prestar Medicina: “Tanto que foi até um baque na época que eu fiquei sem trabalhar: 'como que você vai ficar sem trabalhar?!' É bem aquilo estudar não é trabalho. Ser professor não é trabalho: ‘você é só professor ou você trabalha também?’ ’”. Além disso, realizar um Curso Superior era algo fora do horizonte familiar de Carlos: “Tanto que na época de prestar vestibular, era um assunto que não se falava em casa, de estudar, de fazer faculdade, isso nunca foi falado, única coisa que ela [mãe] falava é que tinha que estudar”. Carlos é o pioneiro da família no Ensino Superior: do lado materno composto por oito tios - que é a parte da família com quem tem mais contato - ele, juntamente com o irmão e uma prima, são os únicos que estão cursando faculdade ${ }^{53}$. Ao se formar, ele será o primeiro da família a obter diploma universitário: “Eu vou ser o primeiro a me formar, eu estou com 33 anos e da família eu vou ser o primeiro ainda, né”.

Da parte de sua esposa, além de os familiares não acreditarem que ele conseguiria aprovação no vestibular para o curso de Medicina, também consideravam o fato de ele não trabalhar, enquanto Renata o fazia, sinal de ociosidade.

Além da oposição familiar e da pressão daí advinda, Carlos e Renata enfrentaram problemas de ordem econômica. Quando Carlos resolveu dedicar-se à preparação para o exame do vestibular, eles dispunham de uma reserva financeira obtida através de poupança feita ao longo dos anos e acrescida do valor recebido pela rescisão de Carlos do Exército. No entanto, a situação, já difícil, tornou-se ainda pior: Renata ficou desempregada em abril, só voltando a trabalhar em novembro. Nesse período, além de gastarem todo o dinheiro economizado, eles foram obrigados a interromper o pagamento das parcelas do financiamento do apartamento, resultando mais tarde na perda do imóvel; eles tiveram também de vender o carro para conseguir custear despesas nesse período. Carlos afirma que esse momento foi muito difícil e que só não desistiu de estudar porque Renata o apoiou. Ele pôde contar também com a ajuda de uma irmã dela que, ao contrário dos outros cinco irmãos, tinha grande crença de que Carlos seria aprovado no vestibular (“... [ela] acreditava mais do que eu que eu ia passar!”) e foi quem passou a lhe fornecer os passes de

\footnotetext{
${ }^{53}$ Da família paterna, Carlos afirma que vários primos cursaram ou estão cursando Ensino Superior, mas que por residirem longe, em diversos Estados, não mantém contato com eles.
} 
ônibus para seu deslocamento até o cursinho. Contudo, o suporte principal e fundamental veio de sua esposa, o que Carlos reconhece emocionado: "Mas, o apoio mesmo foi da Renata, acreditou no meu sonho, ficou sempre do meu lado...”.

Carlos prestou vestibular na USP, Unesp, Unicamp, Unifesp e Fanema (Faculdadde de Medicina de Marília) e foi aprovado no exame da Fuvest, na sua segunda opção, o que implicou na mudança de cidade, tendo sido, inicialmente, um “baque”, pois Renata permaneceu na sua cidade natal durante o primeiro ano da faculdade. Ela mudou-se apenas no final desse ano quando conseguiu um emprego passando, desde então, a residir com Carlos em um quarto na moradia estudantil, vivendo em condição irregular, já que é proibido a residência de pessoas que não sejam estudantes da Faculdade. Renata trabalha no departamento de recursos humanos de uma universidade privada e é através de seu salário de aproximadamente R\$ 1.000,00 que eles custeiam a estada na cidade. Além dessa fonte de renda, Carlos teve bolsa-trabalho durante o segundo e o terceiro anos da faculdade, possui bolsa alimentação, e, eventualmente, faz "bicos” como, por exemplo, ser fiscal da prova do vestibular. No início do quinto ano do curso, por ocasião da segunda entrevista, Carlos estava contente, pois conseguira uma bolsa de iniciação científica na área em que deseja se especializar - ortopedia. Com o rendimento total, Carlos afirma que dá para “viver bem”, mas enfatiza que isso só é possível porque eles residem na moradia estudantil, frisando a importância da assistência estudantil para a permanência do estudante das camadas populares na universidade.

O apoio material e emocional, bem como a compreensão de Renata, foram e têm sido “decisivos” para que Carlos ingressasse no curso de Medicina e nele permanecesse. Como condições que possibilitaram a sua aprovação no vestibular, ele menciona a realização de um bom curso preparatório e o suporte proporcionado pela companheira:

Para mim, o que me ajudou assim, primeiro, foi o apoio da Renata, isso, sem dúvida, foi fundamental para mim; na hora do desespero ali, ela estava lá, acalmava e tal, final do ano, perto do vestibular, eu estava uma pilha, ela: “calma, vai”. Ela me agüentou também, nervoso, irritado, síndrome pré-vestibular, tipo TPM das mulheres (ri). Então, primeiro lugar foi ela, sem dúvida. (...) O caminho para mim foi esse: foi o cursinho para aprender, para mostrar o caminho, e o apoio da Renata, né. (...) Fazer um bom cursinho para mim foi o caminho e o apoio em casa, Renata acreditando ali que eu ia passar, tudo, dando força, acho que foi isso que proporcionou eu ingressar aqui. 
Apesar da alegria que a aprovação no vestibular lhe proporcionou, Carlos fala a respeito de uma recepção "estranha” da notícia por parte de sua mãe. Por ser algo tão fora da realidade de sua família, e tendo sido Carlos sempre um bom aluno, ela considerou natural o filho ser aprovado no vestibular. Tal reação se, por um lado, valorizou o histórico de bom desempenho escolar de Carlos, por outro desconsiderou o enorme esforço feito por ele para conseguir a aprovação numa das carreiras tradicionalmente mais concorridas do Ensino Superior: "Eles [familiares] não têm consciência do quanto é difícil entrar, né, isso, vestibular, essas coisas, é tão distante deles que eles não têm nem consciência do quanto é, então para minha mãe foi quase que normal: 'você sempre consegue qualquer coisa que você tenta' ”.

Já a família de Renata, possuidora, nas palavras de Carlos, de uma "cultura de fazer faculdade” e de maiores condições para compreender o significado de sua aprovação no vestibular, foi mais receptiva à notícia, comemorando mais e, de alguma forma, sentindo certo alívio: "Mesmo porque senão, para Renata, eu ia ficar como o vagabundo-mor (rindo), fiquei sendo sustentado por ela durante um ano, a gente sem emprego...”.

Falando a respeito do significado da entrada no curso de Medicina da USP, Carlos traz uma importante questão quando se trata de discutir a presença do aluno das camadas populares na universidade: além do ingresso há que se pensar nas condições de permanência desse estudante no Ensino Superior até a conclusão do curso. Se para entrar na Universidade ele teve de se esforçar e abrir mão de muitas coisas, a permanência nela não é feita de lutas menores. Ele enfatiza tanto a dificuldade da decisão de prestar Medicina, quanto as dificuldades que acompanham a realização da graduação, mostrando que a batalha ainda não terminou:

[a entrada no curso de Medicina] Acho que foi, está sendo a realização de um sonho, né. Eu brinco com a Renata, inclusive, que eu plantei minha sementinha, só que vai demorar seis anos para nascer (rindo)! Eu acho bastante significante, está significando uma vida, uma decisão que vai ser, depois, uma decisão dura, foi batalhada, está sendo difícil, não está sendo fácil, a gente tinha apartamento, a gente tinha carro, se eu aceitasse o emprego que eu recusei eu provavelmente conseguiria manter o padrão de vida que eu tinha quando eu estava no Exército, e a gente deu bastante passos para trás, vamos dizer assim. (...) E está sendo significativo, está sendo, eu brinco que eu investi alto aqui, né, em busca de um sonho, e estamos indo, não sei dizer muito bem o que significa... Às vezes, termina significando mais trabalho árduo, tal, do que, de fato, realização, realização acho que 
vai vir daqui há dois anos, quando terminar realmente, acho que eu estou conquistando ainda... Eu brinco que a gente já começou a descer a ladeira, a gente estava subindo, já estamos descendo...

Embora ser médico fosse um sonho para Carlos, ele tem clareza de que o ingresso no curso de Medicina não garante a sua realização. E mesmo que a parte mais difícil já tenha passado e agora ele esteja na “descida”, ainda assim o significado atual e mais imediato de estar cursando Medicina é o do esforço e o do trabalho duro. É por isso que quando perguntado sobre como foi ter passado no vestibular, logo em seguida à menção à alegria dessa conquista, Carlos fala a respeito do "primeiro baque" representado pela dificuldade do curso aliada ao conteúdo básico - sem relação prática com a profissão - das disciplinas do primeiro e segundo anos da graduação. Carlos relata que realizou esse período aos "trancos e barrancos”, conseguindo aprovação nas recuperações. No primeiro ano, colaborou para esse mau desempenho o fato de Renata ainda estar morando em outra cidade, o que fazia com que ele viajasse todos os finais de semana, reduzindo o tempo disponível para estudo. A partir do terceiro ano, com o início das matérias clínicas, vendo maior aplicabilidade dos conhecimentos estudados, seu rendimento acadêmico melhorou, tendo sido aprovado em todas as disciplinas dos segundos semestres do terceiro e quarto anos sem recuperação.

Mas, de modo geral, Carlos não se enquadra dentro do que se costuma considerar como "bom aluno” na Universidade. Sua média ponderada é 6,4, baixa em relação à sua turma e também a mais baixa dentre os estudantes cujas trajetórias foram aqui analisadas e que mencionaram voluntariamente essa questão ${ }^{54}$. Esse baixo desempenho está relacionado ao fato de ele ter entrado no curso bem mais velho do que seus colegas, o que, na sua visão, entretanto, lhe traz mais vantagens do que desvantagens. Entre as últimas encontra-se a falta de disposição, inclusive física, de Carlos para estudar: ele não consegue mais passar noites inteiras estudando como fazem seus colegas de 22, 23 anos. Ele reconhece que estuda bem menos do que a maioria dos alunos de sua turma, menos, inclusive, do que julga ser necessário estudar. A pouca dedicação de Carlos tornou-se motivo de gozação entre os colegas que brincam que ele testa se, estudando o mínimo, é possível ser aprovado nas

\footnotetext{
${ }^{54}$ Embora essa não fosse uma pergunta constante do roteiro de entrevista, pelo menos três estudantes referiram-se ao valor da média ponderada (Pedro, Antônio e Carlos) e um deles (Felipe) explicou que conseguira transferência para o curso de Administração em função de sua alta média ponderada.
} 
diferentes disciplinas. Mas, para além da disposição física, seu comportamento acadêmico parece dever-se, principalmente, a uma postura crítica diante do mundo universitário proporcionada por sua maturidade. Nesse sentido, Carlos tece críticas à dinâmica educacional, especialmente à existente no curso de Medicina, afirmando, por exemplo, que seu objetivo na Universidade é aprender e não tirar nota; em relação à sua média ponderada ele diz, com grande segurança, que ela é baixa em relação à turma mas, para ele e para o que pretende ao cursar Medicina, é “suficiente”. Ele critica também a existência de um jogo institucional que preconiza, entre outras questões, a cobrança de detalhes em avaliações o que acaba estimulando comportamentos desonestos, por parte de alunos, como o recurso à cola escolar, jogo do qual Carlos se recusa a participar. Refletindo acerca da diferença de idade entre ele e os colegas afirma a contribuição que a maturidade lhe traz:

Eu não tenho mais o mesmo pique que o pessoal, eu vejo eles, vai para balada numa noite, no outro dia já está lá na aula inteiro, se eu passar a noite acordado, eu estou um caco no outro dia! Mesmo o pique de estudar, não tenho mais aquele pique de ficar seis horas em cima de um livro, eu estudo ali três horas, eu já estou morto, começa a não render, começo a misturar, não vai mais... Então eu paro, eu fico nessa, e eles continuam, conseguem fazer isso. Eu acho que eu não consigo e o legal é ter maturidade: "meu, eu estou fazendo o suficiente para eu passar”. Sem me matar muito, sem querer nota, meu objetivo, eu vejo que muita gente tem objetivo de tirar nota, eu não, eu tenho objetivo de aprender, aí eu termino até selecionando, não fico muito no rodapé, estudo mais o que cai, o que tem por aí... (...) então maturidade é deixar essas coisas de lado até, às vezes, não ir atrás de nota, né, não é meu objetivo, colar, eu nunca colei, eu vejo o pessoal... Eu acho que o próprio sistema pede que você faça isso ao cobrar rodapé de livro, coisinha, não que é sem importância, é que é exceção, não é regra, é exceção da exceção, um caso em um milhão, a incidência de algumas coisas que eles cobram como se estivesse presente o tempo todo.

Assim, se ter ingressado na faculdade mais velho lhe traz limitações para estudar, por exemplo, é também a maturidade que lhe permite lidar com essa diferença. Carlos é muito enfático ao afirmar que sua experiência anterior à entrada na universidade lhe ajuda na sua experiência dentro dela. A vivência no Exército, além de ter contribuído para a aprovação no vestibular, através da disciplina e da determinação lá exigidas, também lhe ajuda durante a graduação. Mesmo tendo dificuldade e resistência em estudar matérias das quais não gosta, Carlos diz que a idéia de cumprir uma missão, central no Exército, lhe ajudou a conseguir aprovação 
em algumas disciplinas na graduação, sobretudo, no início do curso: "tem que passar, então vamos lá!”. Além de importante para a experiência atual na faculdade, Carlos considera que o tempo passado no Exército será ainda mais valioso, para ele, no momento da Residência médica, ajudando, principalmente, a enfrentar as dificuldades iniciais: “a gente sabe que passa, né, por mais difícil que seja, passa...”. A maturidade também contribui para a certeza de sua opção pela Medicina, ao contrário de alguns colegas que ainda se questionam sobre o acerto dessa decisão; Carlos é bastante incisivo quanto à clareza do desejo de ser médico: “...eu entrei querendo fazer, foi por escolha, não foi porque os outros acham legal, porque meu pai acha legal, foi porque eu quis mesmo, foi lutando”. Reforçando a contribuição de sua experiência anterior para a vida acadêmica, ele afirma:

Acho que é importante sim, foi importante, vai ser mais importante ainda na Residência. Acho que aceitar, às vezes, até cobranças mais, que a gente vê, mais grossas assim, de aceitar isso e deixar passar, e continuar em frente fazendo o seu melhor aquilo que você pode fazer.

Sobre esse tipo de cobrança, ele dá, como exemplo, "broncas homéricas” que alguns docentes dão em médicos residentes na frente de pacientes, principalmente durante o primeiro ano de Residência. Carlos relata que ele mesmo já foi repreendido na frente de uma paciente, durante uma prova prática, por estar tratando-a por "você" e não por “senhora”, já que a “menina” era mais jovem do que ele. Além de lhe chamar a atenção, a professora da disciplina lhe descontou nota. Mas, isso não fez com que Carlos mudasse sua concepção a respeito e, com bastante segurança, afirma que continuará a chamar pacientes, principalmente mulheres, de "você": "Então, isso aí eu vou continuar fazendo o que eu acho que é certo, não acho que é errado fazer isso”. E sobre ter perdido nota por esse motivo, ele responde rindo: “Tudo bem”.

O fato de ser mais velho, na percepção de Carlos, também contribui para que professores e colegas tenham maior "respeito" por ele, fazendo com que a relação estabelecida com ambos seja diferente. Ele relata, por exemplo, que quando da entrada na faculdade, embora o trote seja bastante difundido, sobretudo, na residência estudantil, com Carlos isso não ocorria. Era ele quem procurava entrar no meio das "brincadeiras" visando, na sua opinião, a se integrar aos colegas. Carlos parece mesmo ocupar um lugar diferenciado na turma. Pelo fato de ser mais velho, casado há mais de dez anos, já ter trabalhado e se sustentado, ele conta que vários 
colegas, homens e mulheres, o procuram perguntando sobre essas experiências e pedindo sua opinião sobre assuntos como "briga com namorado" ou relacionamento com os pais. Carlos afirma inclusive que, às vezes, brinca com os colegas recomendando que procurem sua esposa que é psicóloga.

Esse papel de alguém mais experiente a quem os mais jovens recorrem quando querem falar a respeito de aspectos da vida ainda por eles desconhecidos, como relacionamentos, trabalho, contrasta com a auto-imagem que Carlos nos apresenta. Em diversos momentos de sua fala, ele descreve-se como alguém distante, sem paciência, que não sabe se expressar, que não se vincula às coisas ou às pessoas e, que às vezes, é até “grosso”. A respeito da relação com os colegas, por exemplo, Carlos afirma que é boa, que a turma é unida, mas que ele acaba se tornando "um pouco distante” pelas suas “características”. Também com os professores, ele diz que a relação é boa, porém ele é distante, interessando-se e envolvendo-se apenas com as disciplinas das quais gosta.

Mas, se Carlos fosse tão distante assim, como descreve, os colegas o procurariam para falar de assuntos tão pessoais? O próprio Carlos toca nessa contradição, atribuindo esse lugar de referência apenas ao fato de ser mais velho do que os colegas: “... muitas coisas eles perguntam para mim, mesmo sendo até um pouco distante deles, às vezes, eles vêm para mim, acho que é porque eu sou mais velho mesmo".

A auto-imagem de Carlos também contrasta com nossa experiência com ele. Conhecemos Carlos através de outro estudante de Medicina, também residente na moradia, que nos foi indicado por funcionários da faculdade para integrar a pesquisa, mas cujas entrevistas, no entanto, mostraram que ele não se encaixava no perfil procurado. Esse estudante, por sua vez, nos falou de Carlos dizendo que se ele aceitasse participar da pesquisa ele o diria na hora, pois era bem direto, relacionando esse comportamento ao fato de ele ter feito parte do Exército, sugerindo que ele possuiria um temperamento pouco afável. No entanto, nossa experiência com Carlos foi bastante diversa do que esperávamos a partir dessa advertência: ele mostrou-se, desde nosso primeiro contato, sempre muito disponível, aberto, empenhado em participar da pesquisa, demonstrando grande sensibilidade no decorrer das entrevistas e não se furtando a refletir sobre sua experiência de vida. 
É ao final da segunda entrevista que Carlos nos conta um episódio que ajuda a compreender essa imagem de alguém de difícil trato que ele parece ter entre os colegas e com a qual parece concordar.

Dada a sua longa permanência no Exército, Carlos conta que se habituou a ser repreendido, pois lá isso era algo bastante normal, fazendo parte do regime disciplinar. A experiência de "levar broncas" rotineiramente fez com que Carlos as encarasse como parte do trabalho, não entendendo as constantes repreensões como mostra de falhas pessoais, mas como a constatação de pequenos "deslizes" que podem ocorrer em qualquer tipo de atividade desenvolvida. É essa experiência de “levar bronca” que faz com que Carlos não se abale com as advertências públicas de professores e procure influenciar alguns colegas de turma, principalmente as garotas, para que não se abalem pessoalmente com repreensões de professores: “...algumas meninas levam bronca de professor: nossa! Elas acham que não são nada, que acabou o mundo; eu levava bronca todo dia (ri)! É uma coisa normal, não leva para o lado pessoal”. Contudo, foi essa mesma experiência que fez com que Carlos se acostumasse não só a "levar”, mas também a dar "broncas”, obrigando-o a ter de se vigiar porque pegou o "hábito". Ele relata que no primeiro ano da faculdade, durante uma reunião da Comissão de Formatura, da qual fazia parte, mas que depois abandonou, ele deu uma bronca em uma menina que se esquecera de fazer algo que lhe havia sido atribuído:

eu comecei a falar um monte, assim, ela começou a chorar, eu estranhei, enfim... Para mim seria normal, tipo, às vezes, a gente deixava de fazer as coisas porque não tinha tempo mesmo! (...) Depois eu vi que é diferente: "calma, você não está mais no Exército”. Então, isso me deixou um pouquinho distante assim da turma, porque essas coisas se espalham, e as meninas assim... Mas, foi só no momento, depois me policiei mais para não fazer essas coisas e não deu... Ficou tranqüilo. Essa menina fala comigo, é amiga, tudo, ficou sem ressentimentos depois.

Assim, se por um lado a experiência no Exército o ajudou a ingressar na Universidade e a enfrentar as dificuldades encontradas lá dentro, por outro trouxe dificuldades no tocante às relações inter-pessoais. Mas, Carlos conseguiu perceber isso, procurando se controlar para que eventos desse tipo não se repetissem, parecendo ter obtido êxito. Vale lembrar que o fato narrado aconteceu no primeiro ano da faculdade, permitindo-nos supor que a experiência universitária ao longo desses quatro anos também possa ter contribuído para sua adaptação ao mundo “fora 
do Exército”. Ainda assim, o fato narrado parece ter deixado marcas na memória coletiva e na maneira como Carlos se vê e se insere no grupo de colegas.

Outra característica pessoal mencionada várias vezes por Carlos é a sua tendência a "desencanar”, “deixar para lá” coisas vistas como impossíveis ou muito difíceis de serem alcançadas. Sobre, por exemplo, ter desistido de tentar acompanhar o ritmo do Colégio Paulista ele afirma: "Eu tenho essa mania de desencanar, quando o negócio começa a ficar muito difícil eu desencano, parto para outra, deixo para lá mesmo”. E sobre a impossibilidade de cursar Medicina, esse estudante nos diz:

Pensava [em fazer Medicina], só que... Aquela minha característica, né, de falar, tipo: “ah, não dá, desencana”. Eu tenho isso. Eu me desligo muito fácil das coisas, não crio muito vínculo, não sei explicar isso... A Renata fala que eu sou frio (ri). Aí, eu tinha desencanado totalmente: "não dá para fazer, não dá. Vamos ver o que dá”. Nesse aspecto eu sou bem prático.

Mais do que de um mecanismo psíquico de defesa, parece-nos que esse comportamento de Carlos, no tocante à escolarização, aproxima-se do que Portes (2000) denominou de “conformismo estratégico”. Nesses casos, conformar-se com aquilo que é possível fazer em determinado momento parece ser menos resignação do que uma importante estratégia para o prolongamento da escolarização, podendo resultar, como nas histórias aqui analisadas, no ingresso no Ensino Superior.

Falando ainda sobre sua percepção de que fazer Medicina era impossível para ele, Carlos reflete, mais uma vez, sobre aquela característica pessoal:

Quando criança era brincadeira mesmo, depois, logo de cara, eu desencanei: “não, não dá”. Então, já foca para outras coisas, né. Eu sou bem assim, eu digo que eu não gosto de ficar dando murro em ponta: "vamos atrás do que é possível fazer". Esse é um pensamento que eu consegui verbalizar isso depois, né, mas eu sempre fui assim, sempre correndo atrás do que eu achava que eu podia alcançar, não, nunca, eu não me lembro de querer coisas impossíveis, essas coisas, assim, grandes sonhos, não, eu sempre fui "meio pezinho no chão" assim. Eu não sei dizer porquê, eu sempre fui assim.

Fazer o que é possível e desejar o que é alcançável - esse parece ter sido o recurso estratégico utilizado por Carlos para ir aproveitando as chances que se lhe apresentaram em diferentes momentos de sua trajetória. Além disso, Carlos nos fala também de outra estratégia que nos parece bastante presente em sua história: assumir uma, dentre as alternativas possíveis em um determinado momento, realizando-a da 
melhor forma. Para quem não pode contar com outros recursos além da capacidade de trabalho, de estudo ou de dedicação, como é o caso daqueles que pertencem às camadas populares, tal estratégia pode ser uma possibilidade para trilhar um caminho diferente de um destino social mais provável. A frase de Carlos, já aqui citada, “continuar em frente fazendo o seu melhor aquilo que você pode fazer” parece-nos bastante ilustrativa nesse sentido.

Assim, se na adolescência e na juventude Carlos via como impossível a realização do curso de Medicina por não ter como se sustentar nem poder contar com a ajuda da família para isso, tendo aproveitado outras chances que se the apresentavam, quando as condições foram mais favoráveis foi em busca da realização de um sonho. Afirmar isso, no entanto, não significa dizer que esse comportamento tenha sido calculado ou ainda que seja inteiramente consciente. Quando Carlos entrou no Exército ele não cogitava fazer o curso de Medicina, aliás, como ele mesmo afirma, ele não sabe dizer se a vontade de realizar esse curso resurgiu ou, na realidade, surgiu ao conhecer o médico que se tornara seu amigo. Todavia, ao perceber como possível o ingresso e a permanência no curso de Medicina foi em busca disso e fez o "seu melhor".

A forma como foi se construindo a trajetória escolar de Carlos é bastante próxima da discussão sobre longevidade escolar nas camadas populares, realizada por alguns trabalhos. Viana (1998) e Silva (1999), por exemplo, afirmam que ingressar na universidade é um projeto que se vai construindo aos poucos. D’Ávila (1998) acrescenta ainda que, além das estratégias de investimento educacional constituírem-se paulatinamente, elas também transcendem às expectativas construídas no estrito círculo familiar.

Estudar Medicina numa universidade pública representou na trajetória de Carlos a ruptura com um destino social mais provável. Essa mudança, no entanto, não significará, na visão de Carlos, alteração em termos socioeconômicos, já que, como ele explica, seu padrão de vida modificou-se a partir de sua entrada no Exército. Quando se tornar médico, o que esse estudante pretende é poder, novamente, desfrutar daquilo que já possuiu: uma casa, um carro, ter dinheiro para sair, comer fora, enfim, poder usufruir de aspectos da vida nos quais ele afirma estar em “pause”. As perspectivas futuras de Carlos em termos financeiros são modestas: ele deseja apenas resgatar o conforto do padrão de vida que possuía antes de 
ingressar na universidade. Assim, a coragem e a ousadia de mudar o rumo de uma vida já estabilizada e todo o esforço e a dedicação para conseguir ingressar e realizar o curso de Medicina têm como objetivo a realização profissional, em sentido mais imediato, e a realização pessoal num sentido mais amplo. O desejo de realizar-se excede a ambição financeira; suas aspirações são profissionais:

Eu não pretendo, não sonho nada além daquele padrão que eu já tive. Para mim está ótimo aquilo, eu não aspiro nada além disso. O que eu aspiro agora é ter realizações profissionais mesmo, né, ser reconhecido pelos pares naquilo que você está fazendo, fazer bem feito, acho que em termos de realizações, eu acho que é isso o que eu pretendo agora. Em termos sociais, de realizações, dinheiro, essas coisas eu acho que vai ser manter o que a gente tinha antes, não acho que vai mudar mais do que isso, não...

No caso de Carlos, como de outros estudantes entrevistados neste trabalho, o desejo de aprender é maior do que a necessidade econômica. O que ele deseja é realizar-se pessoal e profissionalmente, realização cujo auge será atuar na área médica em que ele escolheu especializar-se:

Eu estou fazendo justamente aquilo que eu sonhava fazer, assim, já tinha desistido, e retomou. Então, em termos de realização profissional eu acho que vai ser plena assim. Vou fazer aquilo que eu gosto, assim, se entrar na residência da ortopedia, assim, então, eu vou trabalhar no dia-a-dia realmente com aquilo exatamente que eu quero...

Além disso, para as perspectivas socioeconômicas que Carlos possui para o futuro, as possibilidades de trabalho abertas com a conclusão do curso de Medicina serão excelentes. Como ele pretende apenas resgatar e manter o padrão de vida que possuía anteriormente, Carlos acredita que será bastante viável conciliar trabalho e dedicação à família, já que ele e Renata pretendem ter um filho daqui há três ou quatro anos:

Acho que, pelo menos para o que eu espero, está perfeito! (...) E, as perspectivas são boas. Eu não pretendo ter quatro empregos, dois está bom (ri)! (...) Mas, sem estressar muito, sem querer ganhar, sei lá, 15, 20 mil. Não é, não estou... Minha perspectiva não é essa... Só quero viver só, dentro dos padrões, assim, ganhando mais ou menos o que eu ganhava no Exército (...) para mim já está bom. Acho que mais que isso é querer se matar à toa, sabe? Trabalhar para viver e não viver para trabalhar. Eu quero trabalhar para viver, mais ou menos isso. 
O contentamento, a satisfação, a alegria, a convicção de fazer algo que gosta e vislumbrar realização profissional e pessoal através disso são evidentes na fala de Carlos.

Para esses sentimentos, parece-nos que colabora também o clima de amizade existente entre os colegas do curso de Medicina. Carlos referiu-se várias vezes à boa relação entre os estudantes, sempre comparando com o clima de competição e individualismo que seriam a marca do curso de Medicina na sua cidade natal. Ele considera os colegas de curso bastante receptivos, prestativos e o clima existente agregativo, conciliador, enfim, pela sua descrição, parece existir um ambiente acolhedor entre os estudantes. Para o clima de amizade concorre também o fato de a maioria deles ser proveniente de outras cidades:

É legal, um clima de amizade, assim, é muito bom, não é ninguém tentando ser melhor do que ninguém, está todo mundo ali junto. (...) na minha turma só tem 15 ou 20 [de um total de 100 alunos] de P. [cidade onde se localiza o campus], o resto é tudo do interior ou de S. [outras cidades], então acho que tem um fator que ajuda o pessoal ser mais amigo um do outro, um ajuda o outro, tudo isso. Sempre que precisa ir em algum lugar, assim, é só ligar para alguém, alguém vem te buscar, dá carona, isso aí, a amizade é boa aqui, não tem nada a reclamar.

Esse clima solidário também permite, segundo Carlos, que os colegas reconheçam as dificuldades que os estudantes mais pobres enfrentam para conseguir realizar o curso de Medicina. Ele dá como exemplo a realidade de outro colega com sérias dificuldades econômicas que os colegas ajudam dando materiais como estetoscópio. Colocando-se na posição de alguém que difere do perfil sócioeconômico majoritário dos estudantes de Medicina, Carlos afirma: “Ah, os colegas eu diria que eles reconhecem bastante, né, as nossas dificuldades, é como se eles tivessem estudando no Paulista a vida toda, né, então eles reconhecem bastante”.

Embora compare seus colegas de faculdade com aqueles que estudaram no Colégio Paulista, a experiência de Carlos na Universidade tem sido inteiramente diversa da que viveu nessa escola particular. Não obstante a desigualdade social estar presente também na Universidade, Carlos não experimenta nela a situação de humilhação. Quando fala a respeito da discriminação que acompanhou sua experiência naquele colégio, e do sofrimento daí advindo, ele contrapõe à atual experiência vivida na USP: 
Então, aqui [USP] eu já cheguei mais velho, né, acho que mais maduro. Não senti, e também eu tinha outras experiências vamos dizer, da minha sala eu sou o único que já trabalhou, que já fez outras coisas -, então a gente chega com uma bagagem diferente, aí não acontece, né. Então, aqui eu não senti isso. Eu conseguia me misturar mais. Justamente por ser mais maduro. Eu imagino que eu era meio bichinho do mato, também, essas coisas. Antes eu não sabia me entrosar, também. Hoje é bem mais fácil, eu consigo me misturar, consigo conversar com as pessoas, antes eu lembro que eu era tímido, essas coisas, então eu não conseguia...

Ao refletir sobre a experiência no Colégio Paulista, Carlos menciona uma importante questão que também ajuda a entender as dificuldades enfrentadas nessa escola: o momento do ciclo vital que ele vivia quando lá estudou. Aos 13 anos de idade, Carlos era um adolescente que, muito possivelmente, deveria estar às voltas com as mudanças e as crises que acompanham essa fase da vida

Importante lembrar, entretanto, como já afirmamos aqui, que a amizade, com a qual Carlos não pôde contar na época, é uma das formas de se enfrentar a humilhação social. Assim, a despeito das dificuldades próprias da adolescência, o apoio de amigos talvez pudesse ter ajudado Carlos a inserir-se na nova escola, como um ano mais tarde aconteceu no Colégio Santo Antônio. Isso porque, segundo Gonçalves Filho (1995), a humilhação não ocorre e não acaba sem os homens, pois sendo um enigma de ordem intersubjetiva, a elaboração do impacto interno da inimizade dos outros depende da amizade também dos outros:

Efeito da desigualdade política, a humilhação social é um fato psicossocial que reconduz sempre o homem ao outro homem. (...) a desigualdade não pode nunca dispensar os homens para que se mantenha. Não poderá igualmente dispensá-los para que seja neutralizada e cancelada (Gonçalves Filho, 1995: 154).

Embora Carlos, ao ingressar no curso de Medicina da Universidade de São Paulo, passe a estudar com alunos cuja origem social é semelhante à dos que estudavam no Colégio Paulista, não se sente discriminado. Sua experiência de vida e maturidade propiciaram-lhe recursos subjetivos para enfrentar a desigualdade social. Tendo acumulado diferentes experiências de vida, estando mais fortalecido emocionalmente e podendo contar com a amizade dos colegas e o amor da esposa, Carlos afirma com segurança: “aí não acontece”, evitando que a vivência da situação de humilhação social se repita em sua experiência universitária. 


\section{Entrevista na íntegra}

\section{$1^{a}$ Entrevista}

Carlos: Bem, eu estudei em escola pública praticamente quase todo o período, né, até oitava série eu fiz em uma escola pública em S., estadual, Escola M. ela ficava ali na T. [rua], B. [bairro], pessoal conhece a região ali como B.. Aí na $8^{a}$ série eu ganhei uma bolsa de estudos para o Colégio Paulista em S. [cidade natal], é famoso, um colégio bom, né, só que nesse primeiro ano eu reprovei, era acostumado com escola pública, ia bem sem estudar, não agüentei o ritmo do Paulista, tive algumas discussões lá, o pessoal lá era muito competitivo. Um fato que marcou bastante: eu era acostumado sempre a fazer grupo de estudos, um ajudava o outro, eu sempre me destaquei na escola, eu sempre ajudava os outros, a gente se reunia, eu ensinava, lá quando eu fui pedir ajuda um menino chegou e: "não, eu não vou te ajudar porque se eu te ajudar você pode ficar na frente no currículo”. Não sei se você conhece, o sistema Paulista tem um boletim todo mês que mostra a sua colocação em relação aos outros alunos, a sua nota, quanto você está acima da média, quanto você está abaixo, tem tudo isso. Média do primeiro ano inteiro, pelo menos isso era em 84, não, 88. Então, reprovei lá e aí eu fui fazer... Deixa eu ver... Aí eu repeti o $1^{\circ}$ ano, daí eu fui fazer o Colégio Santo Antônio, fiz à noite lá, tinha bolsa de $70 \%$, que era o máximo que eles davam, tinham um vestibulinho para entrar, tudo, aí o $2^{\circ}$ e o $3^{\circ}$ ano eu me mudei para Brasília, fiz o curso de Eletrônica... Depois, no ano seguinte eu entrei na UNB, sem fazer cursinho, sem nada, mas entrei em Física, né. Aí fiquei, aí fiz CPOR [Centro Preparatório de Oficiais da Reserva], entrei no Exército lá... No ano seguinte eu voltei para S., fiz vestibular no final do ano, entrei em Física novamente...

\section{Débora: Você abandonou na UNB?}

C: Abandonei na UNB, né, nem cheguei a concluir porque eu estava no Exército junto, é meio complicado. Então, eu vim para S. no ano seguinte com a intenção de continuar para ser temporário, eu já namorava minha esposa e tudo, a gente queria casar, casamos super novos e... Deixa eu ver: Física, terminei entrando em Física, abandonei, eu fiz quatro meses só, abandonei, não cheguei nem a terminar o primeiro semestre. E, aí, fui seguindo, fiquei no Exército, né, fui seguindo até 96 eu entrei em Processamento de Dados lá na Fatec, né, só que eu fiz um cursinho preparatório lá de 6 meses só, entrei em processamento, fiquei um ano, abandonei também - computador eu acho que é ferramenta, não um fim, estudar só para trabalhar com computador, eu vi que não era isso que eu queria. Aí eu fui ficando no Exército até 2002, saí do Exército, fiz um ano de cursinho no E., ganhei bolsa 100\% também através do teste de bolsa que eles tem lá, aí no ano de 2002 eu fiquei só estudando, recusei um emprego que tinha, estava tudo certo, já, como controle. E o que eu acho que fez eu entrar aqui eu acho que foi dedicação, o ano de 2002 eu não fiz outra coisa senão estudar, me dedicava de verdade. O período era de manhã no cursinho e à tarde eu ficava lá também só para ficar estudando. O sistema do E., eles têm umas apostilas só de exercícios, eu fiz todos, preenchi todas as apostilas, e acho que foi isso que possibilitou eu entrar na Fuvest. Eu fiz vestibulares para todos os de Medicina em S., só que eu só passei na Fuvest, não passei nos outros. Prestei todas públicas, né, Unesp, Fanema, Unicamp, Unifesp, todas públicas. O que eu acho que me dificultou nas outras assim: eu passava com nota bem, mas só que eu sempre fui 
um pouco fraco em redação, aí isso não deixava eu entrar, eu chegava perto, mas não chegava a passar. É isso... Aí... Apoio? Minha esposa apoiou muito. No ano anterior eu quase me separei dela por causa dessa decisão de fazer Medicina, mas fui eu que corri dela porque eu não tive coragem de contar para ela que eu queria fazer Medicina, sei que não dá para trabalhar, essas coisas... Ela ficou questionando, questionando, eu terminei falando e o apoio dela foi bastante decisivo para mim para isso.

\section{(...)}

D: E nesse período você estudava, quando você trabalhava no Exército?

C: No Exército eu terminava estudando porque lá tem, forma-se grupos para ajudar os soldados, a fazer supletivo, tem tudo isso aí. Eu sempre, terminei o tempo todo sendo monitor deles, sempre fiz isso, eu terminava estudando por tabela, sempre tive muita facilidade para as matérias de exatas, mesmo fazendo curso técnico - física, matemática, eu aprendia sozinho, só olhando o livro, vendo os exercícios, para ajudar eles, eu tinha uma missão, né, ter que ensinar, e eu gostava também; eles faziam, eu esqueci o nome, tinha um programa na televisão que era para fazer o supletivo... É tipo tele-curso, só que era um outro nome, tipo tele-curso. O quartel recebia esses vídeos de doação, passava para eles, deixava à disposição para depois do expediente eles fazerem, e era eu que tirava dúvidas, só que eu tirava dúvida em matemática, física, química eu arranhava, mas dava para tirar a maioria... Eu sempre me destaquei bem nessas duas e no cursinho eu fui aprender o resto, né, foi matéria nova nesse ano.

D: E a bolsa de estudos que você ganhou no final do Ensino Fundamental, como é que foi?

C: Foi no final do ano, não foi bem o Colégio Paulista que ofereceu, foi a Fundação A.. A A. era uma empresa importante de tecnologia militar - eu não tinha nada a ver ainda com militares na época, foi bem depois que eu entrei - e eles ofereciam essa bolsa inicialmente lá para o pessoal de S.J.dos Campos, daí eles entraram em S. também, fizeram um convênio com o Colégio Paulista, entraram pela Secretaria de Educação da nossa região, e terminou que eles pegaram dez alunos de seis escolas da região lá. Então tinha a minha escola, tinha o B. [escola], a minha escola ficava na T. [rua], B. [bairro], o B. [escola] ficava na C. [rua], teve outra escola ali pela A. [região], teve mais outras mas não lembro de onde são os outros alunos, mas essa da A. [região] teve uns três alunos de lá. Enfim, nos éramos em dez, quatro passaram de ano, seis reprovaram esse primeiro ano. A D. que era uma colega da bolsa, ela que me indicou o Santo Antônio, a mensalidade, com a bolsa lá, a gente fez o ano brincando lá no Santo Antônio, lá eu pagava o equivalente hoje a R \$ 70,00, então era barato, dava para levar bem. Fui trabalhar, eu trabalhava como digitador numa empresa na Consolação, nem lembro mais o nome da empresa... (rindo).

D: E para conseguir essa bolsa foi escolhido na escola ou você prestou uma prova?

C: Não, foi escolhido na escola. Foram os diretores, não sei como foi o processo de seleção... Na nossa escola foram selecionados dois: eu e mais um. Só que foi... Foi num período já de férias e eles conseguiram me contactar e não conseguiram contactar o M., aí terminou indo só eu. Aí fomos para o Paulista, ficamos um ano lá. Só que lá são quatro bimestres e as notas é: $1^{\circ}$ bimestre é peso um, segundo peso dois, terceiro peso três e quarto peso quatro. Eu fui muito mal no primeiro! Nunca 
tinha tirado nota baixa na minha vida... (rindo) Aí logo no segundo foi meio assim, quando eu pedi essa ajuda e foi negado... A gente era meio separado, também, né, dos outros, né. Acho que era condição social mesmo. A gente era meio que a panela dos dez, a bolsa envolvia o material também, todo material, almoço lá, porque tinha alguns laboratórios que eram à tarde. Só que no segundo semestre eu praticamente desisti... Assistia aula, uma ou outra, depois ia para o Centro Cultural Vergueiro e ficava lá, lendo livro, essas coisas, ouvindo música. Basicamente isso, eu desencanei... No segundo semestre eu desencanei. Dava para recuperar, tudo, os quatro também foram muito mal, aliás os dez foram mal no primeiro semestre, os quatro conseguiram recuperar; eu desencanei. Eu tenho essa mania de desencanar, quando o negócio começa a ficar muito difícil eu desencano, parto para outra, deixo para lá mesmo. E foi isso...

D: Pelo que você está contando você era um bom aluno, nunca tinha tirado nota baixa. Como que era antes de você entrar no Paulista? Você era um dos melhores alunos da escola?

C: Era, eu era. Não sei, era natural. Não é que eu... Eu não estudava, eu tirava... até porque eu ia mal em História, Geografia, eu sempre fui mediano ali; eu sempre me destaquei muito em exatas, sem precisar estudar, sem nada, eu ia muito bem. E história e geografia eu sempre estudei de véspera; Português mesmo, português era uma das minhas notas mais baixas, a vida inteira. Mas, o resto, lia, estudava de véspera assim, passava sem dificuldade.

D: Você fez pré-escola?

C: Fiz. Deixa eu ver... Não lembro se foi um ou dois anos... Não foi um ano só de pré-escola. Eu entrei, faço aniversário em agosto, então eu entrei com seis anos, na época minha mãe correu atrás, foi um pouquinho difícil, mas ela terminou conseguindo me colocar com seis anos, na $1^{\mathrm{a}}$ série. E um ano antes eu lembro de ter feito pré-escola, eu acho, não fiz Jardim. Era lá na Consolação, lembro da escolinha, tudo, eu lembro que eu não queria ir... (ri) É, período de adaptação, comecinho. A única coisa que eu lembro...

D: Da primeira série você lembra alguma coisa?

C: Da primeira série? Não lembro muito não... (pausa) O que eu lembro mais... Deixa eu ver... A quarta-série eu acho que marcou mais assim, uma professora que era ao mesmo tempo durona, cobrava, era um destaque lá na escola. Eu lembro que a gente tinha armário na sala de aula que ela correu atrás, tal, e a gente deixava algum material lá, ela incentivou bastante isso... É engraçado, né, hoje a gente sabe que escola pública sempre tinha turma A, B e C, eles tentavam homogeneizar as turmas, os melhores iam para A, B... E, nessa da quarta série eu lembro que foi isso que aconteceu... Essa professora, tinha até um caso de um menino que era queimado, e ela conseguiu uma cirurgia com o Ivo Pintangy para ele, então ela era bem dedicada... O nome dela acho que era Marlene. Uma que marcou bastante... Depois, deixa eu ver... Quinta, sexta, sétima, já não lembro muito bem... Na oitava foi um ano legal também porque português foi com um professor que era ex-diretor da escola, brincalhão, um que me puxava orelha para eu estudar um pouco mais, falava que eu ia bem e tal e que eu precisava só de um pouco mais de vergonha na cara... (rindo) Era legal isso. Aí o primeiro [colegial] foi no Paulista, não estudei muito, depois no Santo Antônio, foi legal também, só que foi quando eu conheci a minha 
esposa... E dos professores não tem nada de excepcional não. Segundo e terceiro foi o curso de eletrônica a gente...

D: Desculpe, só te interrompendo um pouquinho. Você resolveu fazer esse curso por quê?

C: Ah, eu sempre quis fazer curso técnico, né. Tinha um colega meu na $8^{a}$ série que eu permaneci em contato com ele, ele continuou no M. [escola], só que ele continuou no M.[escola] porque ele não tinha passado na Escola Técnica Federal, aí no ano seguinte ele passou, e foi para lá, ele fez vestibulinho, e ele sempre me falava para eu fazer. Eu sempre mantive contato, enquanto eu estive em S., eu tive contato. Ah! O curso de eletrônica eu falei que eu fiz em Brasília, eu me mudei de S. para Brasília, do primeiro para o segundo ano. Aí lá eu tive oportunidade de entrar num curso de eletrônica. Eu tinha possibilidade de escolha: eu podia fazer eletrônica, edifícios ou fazer normal que eles chamam lá, aí eu peguei e fui fazer eletrônica. Mas, foi questão de oportunidade, nem foi tanto que eu corri atrás. Apareceu as três para eu escolher e eu escolhi eletrônica... Era uma escola pública normal, aí tem os cursos técnicos, tinha processamento também, mas eu não me interessei na época... Aí eu fiz eletrônica... Aí eu fiz eletrônica... E foi muito interessante porque a gente tinha quatro professores só. Então, o primeiro ano, o segundo, né, porque eu entrei no segundo, no segundo tinha português e matemática que era dois professores e o resto era tudo de eletrônica, e eletrônica só eram dois, então cria um vínculo muito grande com os professores, a turma tinha 20 alunos, então praticamente a prova ele mal olhava, ele já sabia quem estava fazendo, quem não estava, quem era bom, quem não era. Aí também eu me destacava bastante na eletrônica digital, na analógica era mais ou menos, acho que foi por isso também que eu fui fazer processamento depois, né, na faculdade... Também lá terminou voltando o mesmo esquema de passar sem estudar; professores eram muito próximos, a gente aprendia ali, tirava dúvidas na hora da aula, então não precisava estudar, mesmo os outros também, pouca gente tinha que estudar para fazer alguma coisa, terminava sendo uma coisa bem prática... E foi isso...

D: E você terminou o $3^{\circ}$ e resolveu prestar para Física, foi isso?

C: Foi, lá em Brasília, fiz um ano e meio, fiz vestibular e eu brinco que lá eu escolhi... Eu não queria nada de humanas, dentro de exatas tinha algumas que era difícil passar, daí e tal, eu brinco que eu escolhi pelo lado direito do cardápio, né (rindo). Eu vi o que era menos concorrido ali e prestei... E foi... Eu não prestei assim que eu saí, lá tem vestibular no segundo semestre, eu prestei no segundo semestre e passei. E tinha um outro colega, na época eu já estava no CPOR, e eu tinha um colega que fazia Física também e foi mais um fator que fez eu ir, foi meio que no embalo, assim... Aí o curso de Física eu achava interessante, assim, só que voltou aquela idéia de não ver campo para trabalhar depois, aí também a gente ficou quatro meses, aí final do ano, Exército começou a puxar um pouquinho, tive que faltar à noite, tirar serviço, aí terminei abandonando. Aí em S. eu entrei querendo ver, conhecer, terminei abandonando de novo porque no Exército, se você quiser continuar você tem que fazer um curso, que era durante o dia, um curso de 4 meses, aí eu estava no diurno aqui, aí abandonei também...

D: E, quando você voltou, você voltou com a sua família para S.?

C: Não, voltei sozinho. Voltei sozinho. Eu não gostei de Brasília, eu não gostava. Eu já namorava a Renata - que é a minha esposa. 


\section{D: Quando você foi para lá você já namorava ela?}

C: Já, já. Daí a gente se encontrava a cada quatro meses, nas férias, ou se tinha um feriado prolongado eu vinha para S. ou ela ia para Brasília. E... Foi assim... Aí eu voltei para S.. E eu prestei vestibular inclusive lá em Brasília, né.

\section{D: Fuvest?}

C: Não, Unicamp. Fuvest eu voltei, eu perdi minha formatura do Exército para fazer a Fuvest, inclusive. A Unicamp eu prestei lá, não passei, porque na Unicamp eu prestei para engenharia também, engenharia eletrônica. E terminei passando em Física de novo.

\section{D: Como você se preparou? Você fez cursinho?}

C: Não, não, fui fazer cursinho depois só para entrar em Processamento, na Fatec, foi a primeira vez que eu fiz cursinho. Depois fui ensinando o pessoal lá, eu fiz o Hoje[escola particular] à noite em Alphaville, só que foi em 2000, eu estava chegando perto de sair do Exército, eu queria fazer Administração. Administração, tipo não tem opção, vamos fazer administração... (ri) Meu irmão também caiu nessa de fazer Administração, ele está fazendo. E, aí, no último ano tinha um médico lá no Quartel... Eu sempre fui inclinado para Medicina, tal, né, mas pais pobres: meu pai é motorista de táxi, minha mãe é dona de casa, meu pai tem até $4^{\mathrm{a}}$ série, minha mãe tem até a $8^{a}$, então eu não via possibilidade nenhuma de fazer.

D: Inclinado, como, você pensava nisso...?

C: Pensava, só que... Aquela minha característica, né, de falar, tipo: “ah, não dá, desencana”. Eu tenho isso. Eu me desligo muito fácil das coisas, não crio muito vínculo, não sei explicar isso... A Renata [esposa] fala que eu sou frio (ri). Aí, eu tinha desencanado totalmente: "não dá para fazer, não dá. Vamos ver o que dá." Nesse aspecto eu sou bem prático. E, então, aí, no último ano entrou um médico lá [no Exército] que ele fez inclusive a PUC - Sorocaba, e ele fez o curso em quase dez anos - ele fez o curso em nove anos e meio - porque acabava o dinheiro, no começo a família dele tinha e aí quebrou, nisso ele já estava indo para o terceiro ano, acabou o dinheiro dele, pai dele faliu, não sei dizer direito o que aconteceu, então ele ia, enquanto tinha dinheiro ele foi, aí parava de estudar, ia trabalhar como garçom porque era um emprego que dava dinheiro e ele conseguia trabalhar, inclusive, durante as aulas, só que ele ia aos trancos e barrancos, aí ele trancava porque não tinha dinheiro, juntava, pagava o semestre anterior, entrava de novo, fazia, aí tinha que trancar de novo e foi intermitente o curso. Aí ele falava, o último ano ele pagou só depois que entrou no Exército, aí ele falava: "se entrar em escola pública, o pessoal ajuda, os veteranos te emprestam material, tem tudo isso. Dá para fazer.” Aí foi o ano que eu te falei que eu quase me separei da Renata que eu falei: "é possível”. Então, eu fui atrás. Isso foi em 2001 que eu conheci ele, daí eu comecei a ver, já estava: “ah, vou fazer”. Aí prestei vestibular, ainda passei para segunda fase estudando sozinho, só que fiquei bem longe, passei praticamente na nota de corte. Daí eu brincava que eu fiz mesmo esquema: prestei todas as escolas públicas de S. e tinha a alternativa $f$, que era a prova de bolsa, do cursinho, para fazer o cursinho... E eu terminei indo para alternativa $f$. Eu tinha o material, porque, às vezes, o pessoal, chegava material de cursinho e deixava lá. Aí eu estudava, só que estudava no Quartel mesmo, nas horas vagas, sozinho, foi suficiente para isso, só para passar e eu 
fui bem na prova de bolsa do E., aí juntou isso, ainda ganhei uns pontos por ter passado para segunda fase, aí terminei ficando como bolsista integral. (pausa)

D: Você comentou que você quase se separou porque você achava que não dava para conciliar...?

C: É, conciliar casamento com o curso. Isso foi difícil para mim porque... Tipo, se eu tivesse me separado para fazer Medicina eu acho que eu também não faria Medicina, eu ficaria totalmente desestabilizado... O apoio dela foi fundamental. Da família, assim, a família foi bem contra (ri).

D: A sua ou a dela?

C: A minha já nem contava muito porque quando a gente se casou eu terminei brigando com alguns tios por parte do meu pai, né, minha família é muito grande: a família da minha mãe, eles são em nove e meu pai em treze. Então, a família do meu pai eu praticamente deixei de lado, quando a gente casou, falaram: “ah, está grávida!” E não era, sei lá, foi meio loucura nossa de querer casar mesmo... Deu certo, a gente está até hoje! (ri) E a família da minha mãe é um pouco longe, são poucos tios que estão juntos ali... E... Eu vou ser o primeiro a me formar, eu estou com 33 anos e da família eu vou ser o primeiro ainda, né. Dos primos, assim, eu sou o mais velho, mas dos primos mais novos o mais novo tem 23, 24 anos, então, quem está fazendo faculdade da família da minha mãe é eu, meu irmão, minha irmã não faz, não está, e uma prima, só. Do meu pai tem bastante, só que é meio distante, tem um pessoal lá em Brasília, um pessoal no Nordeste, é bem espalhado, a gente não tem muito contato. E... desculpa, eu perdi o que eu estava falando...

D: Você estava falando que a família foi bem contra...

C: Ah, tá! Então, eu tenho essa... Eu deixo as pessoas de lado, eu sou um pouco grosso, às vezes. Então, o pessoal não falava para mim, mal falava para ela [esposa], mas a gente sente que... $\mathrm{O}$ ano que eu decidi fazer cursinho para entrar em Medicina, primeiro que não acreditavam que eu ia passar, e segundo que eu fiquei de vagabundo, né! Fiquei só estudando às custas dela. Foi um ano bem difícil, né. Mas a gente fez um pé de meia, só que ela ficou desempregada em abril e ela só foi arrumar emprego novamente em novembro. Então, o pé de meia foi embora, nessa época. Todo o dinheiro que a gente tinha juntado, a minha rescisão do Exército, um valor até significativo, foi tudo embora, nesse período, né. Eu fiquei... A gente chegou a conversar, eu quase parei de estudar, e ela falou: "não, continua, se é isso que você quer; não adianta nada você ter uma casa, e tal, e ser um frustrado profissional”. O fato acho que de ser psicóloga [a esposa], acho que ajudou bastante (rindo) a ter tomado essa decisão de continuar! Ela é a sétima de sete irmãos, ela é a caçula. Uma irmã dela acreditava mais do que eu que eu ia passar! (ri) Ela deu bastante apoio; no final ela que me dava os passes de ônibus para ir para o cursinho... E teve uma outra irmã dela também que eu acho que foi bem neutra: não falava mal, nem bem. O resto eu acho que falava bem mal. Essas coisas a Renata também não conta porque ela sabe que eu vou ficar zangado e eu também falo que eu não quero saber. Mas, foi isso. Meus pais foram contra eu fazer isso... Mas, o apoio mesmo foi da Renata, acreditou no meu sonho, ficou sempre do meu lado... (emocionado)

D: Vai ter de dividir com ela o diploma.

C: Vai (ri). Eu diria que até mais da metade é dela. Está me agüentando até hoje, fazendo faculdade, tudo, do meu lado... (pausa) 
D: Antes da gente falar daqui, essa coisa do Exército, como é que foi? Você resolveu entrar...

C. Tá. Eu entrei, eu não queria, eu queria vir... Eu fui servir, daí me chamaram. Na época que eu fui servir eu já tinha o $2^{\circ}$ grau completo e daí tem opção de fazer o CPOR. Eu falo CPOR porque é como o pessoal conhece aqui em S., lá [Brasília] é NPOR, que é Núcleo. A diferença é que em S., é CPOR, você entra lá, você escolhe o curso que você quer fazer e é uma escola, é um quartel-escola. Em Brasília é um quartel de verdade, no caso artilharia, e lá dentro tem o curso para oficial temporário. Aí eu não queria servir, fui escalado, eu me alistei como tem que alistar, e me pegaram. Como eu tinha $2^{\circ}$ grau eu fiz a prova do NPOR, daí eu passei bem, foi pela nota, porque eles davam preferência para quem já estava na faculdade e não para quem tinha terminado o $2^{\circ}$ grau, aí eu fui bem na provinha, terminei entrando contra a vontade. E serviço militar obrigatório mesmo, não queria, eu queria vir para S., já namorava a Renata, conhecia tudo aqui em S., morei até os 15 anos, já tinha acertado com uma tia para morar com ela, inclusive o ano que eu vim eu morei com ela, aí eu casei no ano seguinte. Aí eu queria voltar, e não deu, aí eu fui até o final, né, tem que ir (ri) e aí tem a opção quando a gente termina de continuar ou não, você que escolhe, nisso queria vir para S., vim para S.. Aí em S., depois que você termina, tem o estágio obrigatório, aí você vai para Quartel mesmo, vai ser aspirante lá. Nisso eu já fiz meu estágio aqui em S. já, pedi transferência, e conversando com a Renata: “a gente podia casar”. Eu ia morar com a minha tia, esse foi um fato que a gente casou cedo, e para gente casar tinha que trabalhar, aí eu tinha a opção de continuar no Exército e eu terminei continuando, foi esse o fator que fez eu ficar no Exército esse tempo todo.

D: E como que era, você gostava?

C: Ah... Gostava (ri). Acho que se não gostasse, não tinha agüentado ficar. Lá o esquema é antiguidade, tem hierarquia e disciplina, quanto mais antigo você é, mais regalias você tem. De certa forma, então, os primeiros dois anos é um pouco difícil, só que depois você já fica antigo, então, aquelas tarefas mais difíceis, vai sempre para pessoal que está chegando, né. Lá você escolhe, quanto mais antigo, você escolhe primeiro e o que sobrar fica para quem entrou por último. Aí depois fui ficando antigo, e eu peguei uma função administrativa também, foi relativamente fácil ficar lá, acostuma também, né, com o sistema, é fácil conviver, é muita lenda o que contam aí fora, termina sendo um serviço como outro qualquer...

D: O que você fazia como função administrativa?

C: Função administrativa lá, eu, no começo, eu peguei almoxarifado, aí eu fiquei... Nos primeiros três anos eu era instrutor da bateria - ensinar o soldado recruta a ser soldado, a fazer as funções de artilheiro que é atirar com canhão - nos primeiros três anos foi isso. Depois eu fiquei dois anos como almoxarife, almoxarifado, e os últimos três já dentro da fiscalização administrativa que aí envolve almoxarifado, provisionamento - que é comida - fiscalização de material, patrimônio, essas coisas, daí no final fiquei na fiscalização.

D: E foi nesse último ano que você conheceu esse médico?

C: Foi. Lá os oficiais médicos entram como aspirantes lá. Como há hierarquia e disciplina no Exército a gente forma círculos, tem, por exemplo, os tenentes são todos amigos - os aspirantes são considerados tenentes. Então, formam círculos, aí 
tem o círculo dos capitães, aí, depois é oficiais superiores, então a gente ficava com o pessoal dos tenentes ali e os médicos quando chegam são tenentes, então, eles chegam, tem um trote no começo lá, não é nada do que falam que é... O trote lá é mais leve que o da faculdade, a gente sai para beber junto e tal e... Período de adaptação, a gente usa a disciplina levada ao extremo, né, o cara mal pode espirrar que... O trote termina sendo esse, da gente cobrar a disciplina ao máximo. E nisso faz amizade, a gente almoça junto e tal, quando tem uma tarefa lá a gente fica conversando, foi nisso que eu conheci essa parte de fazer medicina e tal, que ele falou como ele fez a dele, daí eu falei que eu pensava só que não dava, que já era tarde, daí ele falou: “não, não é tarde, dá para fazer!” Foi nessas conversas que me abriu para ter vontade novamente para fazer medicina.

D: E aí, como é que foi entrar aqui?

C: Entrar aqui (ri). Bom, primeiro alegria, depois o primeiro baque, né, é difícil (ri), né, o curso. É estranho porque logo no começo você está embalado da alegria de entrar e aí depois o "Básico” começa a ser o básico, né, a gente vê que não tem muita aplicação depois, é difícil, ainda mais para mim que eu sou meio teimoso, aí não via aplicação também não estudava, aí passava ali, passei aos trancos e barrancos o "Básico" - $1^{\circ}$ e $2^{\circ}$ ano.

D: Você não estava gostando muito?

C: Não, gostava, só que não via aplicação, então... Acho que entrar mais velho deixa a gente mais, tipo, não querendo fazer o que eles querem, o que agrada, o que os professores... Não vê utilização, então... Simplesmente muita coisa eu ignorava, estudava para passar mesmo só... Aí, sei lá, tanto é que minha média ponderada é mais ou menos baixa, é 6.4 , baixa em relação à turma - suficiente. Então o $1^{\circ}$ e o $2^{\circ}$ ano foi complicado, vim para cá, a Renata em S., ela só veio para cá no final do $1^{\circ}$ primeiro ano, eu ia embora todo final de semana, então era meio complicado até para estudar, final de semana não estudava, e durante a semana não via aplicabilidade também não estudava muito, aí melhorou no $3^{\circ}$ ano. No $3^{\circ}$ ano começam as matérias clínicas e a gente se dedica bem mais, $3^{\circ}$ ano, no segundo semestre eu passei sem recuperação, agora no $4^{\circ}$ também no segundo semestre sem; e os outros sempre passando ali na recuperação, no último momento, dando gás e passando, né. $\mathrm{O}$ pessoal fica brincando que eu fico testando se estudando o mínimo dá para passar (ri). Mas, eu acho que é por causa mais disso mesmo que eu estudo pouco mesmo em relação aos outros colegas, estudo bem menos, aquilo que eu vejo que não tem aplicabilidade ou que eu não gosto eu acabo não me dedicando como deveria, né. Aí, esse ano - o $4^{\circ}$ - eu vi tudo, escolhi o que eu quero fazer para a residência, vai ser, quer dizer, quero, é ortopedia. Aí, de novo, volta aquilo, tipo, psiquiatria eu passei com o mínimo necessário, ortopedia eu fui bem, aí termina que eu vou bem nas matérias que eu gosto, que eu estou a fim, ou que alguns professores que são muito bons que termina te incentivando, né. Aqueles professores que, sei lá, que são mais pesquisadores que professores, termino não indo muito bem; nas matérias que eu não gosto só se for um professor muito bom, senão eu termino indo na média mesmo.

D: Quando você veio para cá, como é que foi? A questão financeira...?

C: Então, no último ano foi que a gente acabou com a reserva, com o pé de meia que tinha feito tudo. Aí no primeiro ano eu vim, no dia da matrícula, tinha um colega do Exército que era aqui de P.[cidade onde se localiza o campus], aí eu fiquei na casa dele, né, e aí fiz a matrícula, e já vim para morar aqui na C. [moradia estudantil], aí 
um dia antes de começar as aulas eu já estava morando aqui. Essa casa era meio abandonada pela faculdade, então para vir morar aqui era só conversar com o presidente da casa, que era um aluno, ele arrumava um quarto para você e você entrava e ia ficando. Agora que a Faculdade retomou a casa, está mais organizada essa parte, tem seleção, tudo, e na época também a oferta era bem maior do que a procura, então acho por isso também que ficava na mão deles. Eu fiquei aqui desde o primeiro momento, fui ficando aqui na Casa, (?) a Renata estava trabalhando, aí a gente conseguia dinheiro para eu ir para S. todo final de semana, eu pagava meia, sempre comendo no Bandejão, a seleção de bolsa (alimentação) não era no final do ano que nem é agora, era em abril, maio, então eu peguei, passei, então já não me preocupava com alimentação. No final do primeiro ano, eu peguei uma bolsatrabalho do Pró-Aluno, e ia ganhando lá também, daí eu fazia um bico lá. Fazia outros bicos também de vestibular, prova, ser fiscal, Fuvest eu trabalhei primeiro, segundo e terceiro ano, só não consegui esse ano trabalhar. Fui me mantendo assim. A bolsa do Pró-Aluno foram dois anos, foi até o terceiro, esse ano que eu estou sem bolsa, eu fiz o ano sem bolsa, mas nisso a Renata já está empregada, dá para gente viver bem, morando aqui, né (ri)! É assim que eu venho me sustentando esse tempo. (pausa)

\section{D: E como é que é a convivência com os colegas?}

C: A convivência com os colegas é legal, assim, porque eu termino não me misturando muito, uma porque eu já sou casado, então, tipo, balada, eu já passei da fase, né, então, nunca fui; não bebo muito, não gosto, assim, não sei, eu costumo beber em casa com amigos, amigos mais próximos, não colegas. Então, nisso eu sou um pouquinho distante da turma, amigo, companheiro, ali de ajuda, essas coisas, eu estou sempre presente, agora para balada, eu terminei ficando um pouquinho distante, né. Essa parte é até boa, fico distante mais do pessoal que não tenho vínculo porque medicina separa muito os grupos, né, durante o ano; cada subgrupo são seis pessoas, então esses seis, a turma $\mathrm{A}$ ali são 30, divididos em três, aí termina dividindo em mais subgrupos ainda, aí fica A1 e A2, aí fica 15. Então, a turma A1, o grupo de 15 ali, tem mais amizade, e aí, às vezes, o A1 fica re-dividido, aí tem seis ali que eu chamo que é a panela ali, né, de estudar junto, de se reunir, ter mais amizade. E o pessoal da Casa [moradia], porque aqui é a sala de estudos, em véspera de prova, vem todo mundo estudar aqui, mais um pessoal de fora, a gente se reúne e termina estudando junto. É legal, um clima de amizade, assim, é muito bom, não é ninguém tentando ser melhor do que ninguém, está todo mundo ali junto. O clima aqui é diferente da Medicina de S., eu tenho uma amiga lá que eu conheci no cursinho, lá o pessoal é mais competitivo, porque em P.[cidade onde se localiza o campus] acho que o pessoal, a maioria é de fora da cidade, na minha turma só tem 15 ou 20 [de um total de 100 alunos] de P. [cidade onde se localiza o campus], o resto é tudo do interior ou de S. [outras cidades], então acho que tem um fator que ajuda o pessoal ser mais amigo um do outro, um ajuda o outro, tudo isso. Sempre que precisa ir em algum lugar, assim, é só ligar para alguém, alguém vem te buscar, dá carona, isso aí, a amizade é boa aqui, não tem nada a reclamar. Eu, pelas minhas características, que eu termino sendo um pouco distante, mas o pessoal, a gente vê que é bastante unido.

D: E a relação com os professores, como é? Você já falou um pouco, né. 
C: A relação com os professores, alguns te dão oportunidade de chegar, outros são distantes mesmo, o que eu vejo é que eles estão disponíveis ao aluno, com raras exceções, um ou outro que não é, os outros são bem disponíveis, se você tentar chegar lá, eles te auxiliam, fazem tudo, né... É boa, eu que termino sendo um pouco distante também, me aproximando mais das áreas que eu sou mais a fim, falta de interesse, né, termino dormindo na aula, tudo, aí termina se aproximando mais daqueles que vão ao encontro do que eu quero. Tranqüila, a convivência com eles é boa, não tem nada ruim, não. É uma questão mais de você ir atrás. Tem pesquisa, a maioria do pessoal tem bolsa, pesquisando, de iniciação científica. Eu fiz uma só que sem bolsa, no final do segundo ano, fiquei 6 meses lá na Farmacologia, aprendi bastante lá, com o Prof... Deu branco agora (ri), depois eu lembro. Daí fiz bastante pesquisa lá com umas drogas, foi legal. Mas eles estavam bem disponíveis, aí é questão de você ir atrás que você fazia alguma coisa com eles, essa faculdade para isso ela é boa, é uma questão de você correr atrás. (pausa)

D: Carlos, o que significou para você ter entrado no curso de Medicina aqui?

C: Ah... Acho que foi, está sendo a realização de um sonho, né. Eu brinco com a Renata, inclusive, que eu plantei minha sementinha, só que vai demorar seis anos para nascer (rindo)! Eu acho bastante significante, está significando uma vida, uma decisão que vai ser, depois, uma decisão dura, foi batalhada, está sendo difícil, não está sendo fácil, a gente tinha apartamento, a gente tinha carro, se eu aceitasse o emprego que eu recusei eu provavelmente conseguiria manter o padrão de vida que eu tinha quando eu estava no Exército, e a gente deu bastante passos para trás, vamos dizer assim. Foi um choque para o meu sogro, para meu sogro isso foi difícil ele entender que a gente estava perdendo as coisas, a gente perdeu o apartamento, para fazer, para reconquistar depois, um sonho de reconquistar depois. E está sendo significativo, está sendo, eu brinco que eu investi alto aqui, né, em busca de um sonho, e estamos indo, não sei dizer muito bem o que significa... Ás vezes, termina significando mais trabalho árduo, tal, do que, de fato, realização, realização acho que vai vir daqui há dois anos, quando terminar realmente, acho que eu estou conquistando ainda... Eu brinco que a gente já começou a descer a ladeira, a gente estava subindo, já estamos descendo, apesar que ainda tem residência, mas pelo menos eu já estou trabalhando, isso já vai desafogar bastante, a gente vai ter uma casa nossa, de novo, ter os gatinhos de volta (ri), estão com meu irmão...

$\mathrm{D}$ : E vocês tiveram que vender o apartamento?

C: O apartamento a gente perdeu mesmo, o tempo que a gente ficou sem trabalhar, ficamos sem pagar, aí depois, a prestação era alta, 700 e poucos Reais, a gente pensou bem se voltava a pagar ou não, ficou um saldo muito grande, aí a gente viu que não valia a pena, deixamos de pagar, aí a Caixa leilou e tudo. O carro a gente vendeu para se manter nesse período e é isso.

\section{(...)}

Aqui em P.[cidade onde se localiza o campus] era minha segunda opção, foi meio que um baque vir para cá, ainda tentei voltar para lá, só que ainda fiquei um pouquinho... Fiquei em terceiro na lista de espera para ir para S.. Hoje até acho melhor a gente estar aqui, o custo de vida aqui em P. é bem mais baixo do que em S., aqui a Renata arrumou um emprego melhor do que lá. Então, está sendo bom, tanto que a gente não tem mais pretensão de voltar para capital, a gente pretende morar perto só, a gente escolheu assim mais ou menos S. J. dos Campos, uma cidade 
próxima, mas não S., depois que vê a qualidade de vida do interior que é muito melhor do que lá. Já é uma decisão, né, se a gente voltar para S. vai ser meio que por acidente.

D: Carlos, como que era essa coisa de estudar na sua casa?

C: Em casa, deixa eu ver... Em casa era livre... Tipo, eu sempre estudei da $1^{\mathrm{a}}$ à $8^{\mathrm{a}}$ série de manhã, no Bandeirantres também eu estudei de manhã, e eu não lembro da minha mãe me chamando para ir para aula. Tinha um despertador lá, a gente, eu e a minha irmã, [a gente] não tem hábito de tomar café da manhã, então despertava, a gente ia lá, trocava de roupa, pegava seu material e ia para a escola. Tinha cobrança, assim, quando ela percebia que a gente não ia para aula (rindo), minha mãe acordava tipo oito e meia, nove horas, aí vinha a bronca, né. Mas, em termos de cobrar para estudar, nunca teve, eu, minha irmã, tocava despertador, a gente se trocava, não chamava ela e ia embora, não teve muita cobrança. Entrar na faculdade... Tanto que na época de prestar vestibular, era um assunto que não se falava em casa, de estudar, de fazer faculdade, isso nunca foi falado, única coisa que ela falava é que tinha que estudar. É o famoso: “se quiser ser alguém na vida, tem que estudar”. E era basicamente isso. Não teve muito... Tanto que minha irmã desencanou totalmente de fazer faculdade, ela terminou o $2^{\circ}$ grau fazendo supletivo, não que ela precisasse, ela estava lá só para ir mais rápido, ela trabalha hoje com vendas, é supervisora de vendas de uma imobiliária. Meu irmão, ele é 11 anos mais novo, tanto que ele está fazendo agora. Meu irmão, eu tive pouco contato com ele; eu fiquei com ele até quando ele tinha sete anos, depois eu vim para S., não estive junto da vida escolar dele, nem sei dizer como era. Está fazendo faculdade agora, entrou pelo Prouni, ele está fazendo Administração na PUC-S. e está gostando, ainda bem. E em casa, assim, cobrar para estudar, só assim em termos genéricos, né: "se quiser ser alguma coisa tem que estudar”. Mas não que fosse falado nisso, na família não tem exemplos disso. Tanto que foi até um baque na época que eu fiquei sem trabalhar: "como que você vai ficar sem trabalhar?!” É bem aquilo estudar não é trabalho. Ser professor não é trabalho: "você é só professor ou você trabalha também?" Foi assim, meio que cada um fez seu caminho.

D: Você fala ficar sem trabalhar é quando você fez cursinho?

C: É, esse período que foi um baque para eles de eu não trabalhar... E eu comecei a trabalhar cedo, eu comecei a trabalhar com 13 anos, trabalhava [numa academia de Kung-Fu] [fim fita]

Eu fazia as armas, fazia as roupas, as sapatilhas, terminava trabalhando lá montando sapatilhas. Eu fazia isso à tarde até à noite. Academia, eu fazia academia também, então eu chegava lá cedo lá, trabalhava, eu não pagava mensalidade, dava o equivalente a um salário hoje, e eu e trabalhava quatro horas por dia só. Aí depois eu fui trabalhar, aí eu parei de trabalhar quando eu fui para o Paulista, isso foi antes do Paulista, parei de trabalhar no Paulista. E aí no ano seguinte eu passei a trabalhar como digitador, trabalhei um ano só, que foi no tempo do Santo Antônio, em Brasília eu não trabalhei, só trabalhei no terceiro ano, lá na Telebrasilia, já fazendo estágio de eletrônica, aí isso foi no segundo semestre do $3^{\circ}$ ano. Aí depois entrei no Exército e continuei. O que eu via em casa era, tipo: "trabalhar é mais importante do que estudar”. Sei lá, pode ser qualquer trabalho, mas trabalho é meio que condicionado, trabalho é mais importante que tudo, estudar é: se der, você estuda.

D: E esses trabalhos, o dinheiro que você ganhava era para você? 
C: Era para mim. Não, isso sempre foi. O dinheiro que eu ganhava era sempre para mim. Na época eu gostava de sair, né, terminava gastando, eu ganhava pouco, na época eu achava que era muito, eu terminava tendo mais dinheiro que todo mundo, ia para balada, essas coisas, coisa de criança também, saía bastante, final de semana cinema, Mc Donald, mas o dinheiro era meu, nunca precisei ajudar em casa, meu pai dava conta disso daí, então eu nunca precisei... (pausa)

D: E como é que foi a reação da família quando você entrou?

C: Ah, foi bastante positiva, assim... É meio que... (ri) Eu brinco que se eu não passasse eu ia ser fuzilado de vez, né (rindo). Aí como eu passei, então, terminou sendo positiva, com exceção do meu pai que, por ele, eu tinha que fazer agronomia (ri), ele tem umas terras lá no Mato Grosso e então por ele, ele queria que eu fosse para esse lado, tocasse isso por ele, realizasse o sonho dele... Mas foi bastante positivo, assim, um pouco... Minha mãe falando assim: "sabia que você ia entrar, você sempre entra". Estranho isso porque... Eles não têm consciência do quanto é difícil entrar, né, isso, vestibular, essas coisas, é tão distante deles que eles não têm nem consciência do quanto é, então para minha mãe foi quase que normal: "você sempre consegue qualquer coisa que você tenta". A família da minha esposa nisso foi mais receptiva e tal, já conhece um pouco mais, os filhos são formados, já tem uma cultura de fazer faculdade, essas coisas, então, eles foram bem mais receptivos, sei lá a palavra certa para isso - comemoraram mais. Mesmo porque (rindo) senão, para Renata, eu ia ficar como o vagabundo-mor, fiquei sendo sustentado por ela durante um ano, a gente sem emprego, os dois, né... (ri) Mas foi isso. Mas foi até, até um baque, né, na época, os dois sem emprego e eu tendo a opção de continuar estudando ao invés de ir trabalhar... Mas no fim está dando certo. Deu certo, né, porque o primeiro objetivo era passar e deu certo. Agora, é terminar aqui e continuar a vida.

D: E o que você acha que da sua história pessoal e escolar te ajuda aqui na Universidade?

C: Olha, ajuda, ajuda bastante... É que eu sempre tento influenciar a turma com maturidade, né, tipo, por exemplo, agora no final do ano teve os plantões voluntários, eu estou fazendo, eu ia fazer na ginecologia/obstetrícia também, só que aí os professores começaram a exigir um monte de coisas - a gente só tem um mês de férias, né, as aulas terminaram dia 15 de dezembro e recomeçam dia 15 de janeiro - e por eles você passava as férias todas dando plantão voluntário, e isso: "não, se for assim não dá”. E termina abrindo mão do currículo, porque isso vai para currículo e algumas residências exigem que você tenha um currículo bom para entrar, vale pouco, mas vale, é o que, às vezes, sai como parâmetro de desempate. E eu acho que vale muito, a experiência, a experiência do Exército, lá você tem que, lá você tem a missão e você tem que fazer, de um jeito ou de outro, isso foi, às vezes, tem sido fundamental para mim para estudar algumas matérias que eu não gosto, desde o começo: “tem que passar, então vamos lá!” (pausa)

A maturidade de fazer medicina porque realmente quer isso, tipo, tem muita gente que eu vejo na turma que entrou em medicina mas tem dúvida se é isso que quer; eu entrei querendo fazer, foi por escolha, não foi porque os outros acham legal, porque meu pai acha legal, foi porque eu quis mesmo, foi lutando. A relação com os professores não é aquela relação... Tem um respeito por eu ser mais velho, tudo, termina sendo um pouco diferente, eu percebo isso. A própria turma, eles me respeitam, no trote aqui mesmo na Casa, que é famoso o trote, em mim não tinha! (ri) 
Assim, era meio eu que entrava que era para... Porque é um intercâmbio, né, de estar junto ali, senão você termina ficando isolado e... Era um barato isso, eu lembro, primeiro dia de aula, lá na matrícula, a D. que é uma turma na minha frente, ela chegou e: "eu não tenho coragem de dar trote, de pintar você!” E eu: "não, pode pintar!” Eu acho que é um... Foi bom essa maturidade, de já ter trabalhado, e tal, e acho que vai ser, essa parte de Exército, tudo, acho que vai ser fundamental mais na residência, que tem bastante isso de primeiro ano ser mais difícil que o segundo, que o terceiro, eu vou meio que voltar às origens lá no Exército, a gente sabe que passa, né, por mais difícil que seja, passa, o R1, depois vem o R2, vai ficando mais fácil, o 3. É uma experiência que para hora do desespero: "eu tenho um monte de coisa para fazer e tenho que fazer tudo!” Eu não tenho mais o mesmo pique que o pessoal, eu vejo eles, vai para balada numa noite, no outro dia já está lá na aula inteiro, se eu passar a noite acordado, eu estou um caco no outro dia! Mesmo o pique de estudar, não tenho mais aquele pique de ficar seis horas em cima de um livro, eu estudo ali três horas, eu já estou morto, começa a não render, começo a misturar, não vai mais... Então eu paro, eu fico nessa, e eles continuam, conseguem fazer isso. Eu acho que eu não consigo e o legal é ter maturidade: "meu, eu estou fazendo o suficiente para eu passar”. Sem me matar muito, sem querer nota, meu objetivo, eu vejo que muita gente tem objetivo de tirar nota, eu não, eu tenho objetivo de aprender, aí eu termino até selecionando, não fico muito no rodapé, estudo mais o que cai, o que tem por aí, porque uma característica dessa faculdade é que os professores são muito pesquisadores, ela produz muito na [área] científica, então tem muito especialista em uma coisinha que você nunca mais vai ver na vida, então maturidade é deixar essas coisas de lado até, às vezes, não ir atrás de nota, né, não é meu objetivo, colar, eu nunca colei, eu vejo o pessoal... Eu acho que o próprio sistema pede que você faça isso ao cobrar rodapé de livro, coisinha, não que é sem importância, é que é exceção, não é regra, é exceção da exceção, um caso em um milhão, a incidência de algumas coisas que eles cobram como se estivesse presente o tempo todo. Eles mesmos falam que na vida deles algumas coisas eles nunca viram, e, no entanto, estudam isso. Acho que é importante sim, foi importante, vai ser mais importante ainda na residência. Acho que aceitar, às vezes, até cobranças mais, que a gente vê, mais grossas assim, de aceitar isso e deixar passar, e continuar em frente fazendo o seu melhor aquilo que você pode fazer.

\section{D: Cobrança, como assim?}

C: Ah, cobrança, deixa eu ver... A gente vê muito, às vezes, o R1 tomando, em mais de uma oportunidade eu já vi isso, R1 tomando broncas homéricas de professor na frente de paciente, coisa que, às vezes, eles estão aprendendo aquilo ainda, só que como eles já são médicos, eles quase que têm obrigação de já saber. Então, eu já vi essa parte de tomar bronca na frente de paciente e tudo. Eu mesmo já tomei uma, no dia da prova, por estar chamando, a menina, a paciente era mais nova do que eu, aí eu estava chamando ela de "você", tratando mais informalmente, tomei uma bronca de uma professora, foi inclusive no dia da prova, teve desconto da nota por estar tratando a paciente de "você". Até contra-argumentei: “ela é mais nova do que eu, se fosse o contrário que ela se sentiria ofendida - se eu tratasse ela de "senhora'" Enfim... Tipo, eu continuo chamando de "você”! (ri) É uma idéia que eu tenho, principalmente mulher, se fosse homem, geralmente as mulheres não gostam que chame de "senhora". Então, isso aí eu vou continuar fazendo o que eu acho que é certo, não acho que é errado fazer isso. Era uma prova prática de gastrologia. 


\section{D: E você perdeu nota por isso?}

C: Ah, pouquinho, era uma questão, e era uma parte dessa questão, vamos dizer se a questão valia 1.0, eu perdi 0.1 por isso. Tudo bem (ri).

[explicação sobre plantão voluntário e sobre o ensino da ortopedia no curso]

C: Eu estou indo [no plantão voluntário] mais para aprender, tanto que até está dando um problema lá [no plantão de ortopedia] porque a gente não conseguiu preencher todos os dias, e o professor está falando que não vai dar certificado de plantão voluntário. Eu, hoje eu vou resolver isso aí, e eu vou tentar fazer mesmo sem certificado, o objetivo não é tanto currículo, mesmo porque para ortopedia não tem currículo, são algumas áreas que exigem currículo, outras não, eles simplesmente abandonaram currículo, só é a prova prática da residência que vale, ortopedia, por exemplo, não tem currículo. Eu estou indo mesmo para conhecer a área, ver se é isso mesmo que eu quero, já fiz um ontem, foi aquilo que te falei... [interrupção] Que essa semana eu estou bem ocupado porque ontem eu estava fazendo plantão voluntário, amanhã tem, quinta tem, na sexta eu abri mão para viajar, a Renata vai sair na hora do almoço, então não vai dar, eu viajo, a gente volta no dia 7 de janeiro, uma semana antes de começar minhas aulas, e essa semana eu vou fazer a semana praticamente inteira de plantão voluntário lá na ortopedia, independente de certificado, mais para conhecer, conhecer o pessoal, alguns dos R1 de hoje vão ser meus R3, residência é muito tutorado o curso, é um ensinando para outro, eu acho que isso é importante para se enturmar, já estar conhecendo todo mundo, conhecendo o serviço, eu acho que, para mim, isso é importante.

[falando de um preconceito que existia em relação ao ortopedista] Pessoal brinca que: “meu, tem que estudar muito para ser ortopedista!” É uma ciência grande. Só que está sempre vendo pessoas quebradas, né, e isso é um choque para maioria das pessoas. É um barato, pessoal fala que "médico não pode ter medo de sangue”. Isso não é verdade, tem gente na minha turma que não vê sangue, passa mal até hoje, tem áreas na Medicina que você não vai ver sangue nunca - radiologia, patologia, patologia até tem um pouco (ri) - mas tem áreas que é tranqüilo nesse aspecto. E é um perfil meu também, né, aquilo que eu te falei, eu sou muito prático, eu gosto de chegar e resolver, não de ficar: "ah, vamos testar tal coisa, vamos tentar tal tratamento, vamos ver, volta daqui dois meses para gente ver como você está”. Não, isso não é muito para mim, não. Tanto é que eu estou querendo ir para área bem de trauma mesmo. Tanto que o pessoal brinca: “não quero ser seu paciente nunca!” (ri) Também espero que os conhecidos não sejam! (rindo) Porque é aquele negócio: está quebrado, você vai lá, conserta e... É uma característica minha. É legal isso na Medicina, que você sempre vai ter uma área que é de acordo com o seu perfil, se você gosta mais de pesquisar, tem a área de pesquisa inteira aí para você fazer, se você gosta de um trabalho mais mental, testar tratamentos, tem a clínica para você fazer isso, se você gosta de idosos, tem paciência, porque eu acho que é fundamental, você faz geriatria, se você gosta de criança - pediatria, sempre vai ter uma área para você seguir, de acordo com o que você gosta, isso é bom, é muito bom isso.

D: Carlos, você já falou um pouco, mas vou pedir para você falar um pouco mais: o que você acha que te ajudou a entrar aqui, em Medicina? 
C: Para mim, o que me ajudou assim, primeiro, foi o apoio da Renata, isso, sem dúvida, foi fundamental para mim; na hora do desespero ali, ela estava lá, acalmava e tal, final do ano, perto do vestibular, eu estava uma pilha, ela: “calma, vai”. Ela me agüentou também (ri), nervoso, irritado, síndrome pré-vestibular, tipo TPM das mulheres (ri). Então, primeiro lugar foi ela, sem dúvida. Cursinho, para mim, foi fundamental, cursinho sozinho não faz nada, mas se você quer, ele te dá material, ele te mostra o caminho, vamos dizer, assim, você segue se você quiser, eles estão ali te mostrando o caminho para entrar, a experiência de vestibulares, para você entrar e tudo, muita coisa, para mim, muita coisa foi matéria nova que eu só vi lá: química orgânica eu nunca tinha visto, foi lá que eu aprendi. O caminho para mim foi esse: foi o cursinho para aprender, para mostrar o caminho, e o apoio da Renata, né. Acho que apoio em casa é... Ambiente para estudar, eu fazia uns horários loucos, eu chegava do cursinho por volta de seis horas, sete. A Renata estava fora ainda porque ela estava fazendo um curso acho que de Jung à noite, então ela chegava oito e meia, nove horas. Eu chegava do cursinho seis horas, sete, às vezes, um pouco mais cedo e ia dormir. Aí por volta das nove eu acordava, ficava um pouco com ela, ela ia dormir e eu ia estudar, continuar estudando, estudava até duas, três horas da manhã. Aí acordava às sete para ir para o cursinho de novo. (...) Fazer um bom cursinho para mim foi o caminho e o apoio em casa, Renata acreditando ali que eu ia passar, tudo, dando força, acho que foi isso que proporcionou eu ingressar aqui. (silêncio)

D: Você gostaria de acrescentar alguma coisa, falar alguma coisa que não tenha falado?

C: Ah, acho que não... Foi isso aí. A única coisa é que foi difícil para mim fazer tudo isso. Acho que é bem mais fácil, quando aquilo do perfil que você estava falando no começo, né, estatisticamente, pessoas que têm melhores condições, é mais fácil, já vem de uma escola boa, mesmo na minha turma muita gente, é exceção o cara entrar direto, geralmente faz cursinho para entrar.

D: E, às vezes, mais de um ano.

C: Bem mais de um ano. Na minha turma tem o C. que fez, ele não fazia cursinho, mas ele tentou nove vezes entrar em Medicina, ele entrou na nona, eu tentei duas, passei na segunda. Aqui na Casa tinha o W., ele fez seis anos de cursinho para entrar, no próprio cursinho, os professores faziam piada com isso: "ah, estou entrando na turma de biológicas, aqui eu tenho que tomar cuidado porque aquele pessoal ali que fica ticando as piadas porque já está fazendo cursinho pela $3^{\text {a }}$ ou $4^{\text {a }}$ vez”. A minha turminha de cursinho, dois entraram na Unifenas - que é uma particular -, uma não entrou, justamente a que a gente achava que ia entrar, sem dúvida, já era o $4^{\circ}$ ano de cursinho dela, só que ela amarelava na hora da prova, ficava nervosa, - isso foi uma coisa que para mim foi tranqüilo, eu não fico nervoso na hora de prova - uma outra amiga entrou na USP/S., eu entrei aqui, cinco, nós éramos em cinco mesmo. E calma, né, não adianta nada você estudar o ano inteiro e ficar nervoso na hora da prova e não conseguir fazer, acho que ter calma ali na hora é fundamental para fazer. E lutar, né, (ri) se você quer corre atrás. Eu até brinco com algumas pessoas de não fazer o que eu fiz antes - de escolher Física, que nem eu escolhi pelo lado direito; vê realmente o que você quer e vai em frente. Se você quer mesmo, lutando, às vezes, até bastante, você consegue.

D: Você acha que na sua turma, você teve que batalhar bem mais para conseguir chegar aqui? 
C: Não digo bem mais. É diferente, né, não é que eu lutei mais, é questão de oportunidade mesmo. Às vezes, algumas pessoas têm mais oportunidade de estudar, então termina sendo conseqüência de tudo o que ela teve, né. A única coisa que eu acho que eu tive que correr atrás mais do que os outros, que alguns, né. Tem um menino na minha turma que, com certeza, ele teve que batalhar muito mais do que eu. Questão dele social é bem precária mesmo, então esse realmente, foi sem apoio, eu tive alguém atrás de mim que me incentivava bastante, ele acho que nem isso ele teve, foi meio que por conta mesmo. Então, termina sendo, não é nem uma questão nem de batalhar, é uma questão de oportunidade mesmo... (pausa)
D: Mais alguma coisa?
C: Acho que era só isso mesmo.
D: Então, eu agradeço muito.

\section{$2^{\text {a }}$ Entrevista}

D: Primeiro eu queria saber se depois que a gente conversou, você se lembrou de algo que você gostaria de falar?

C: Não, não. Não lembrei de nada, não.

D: Então, uma das coisas que eu gostaria que você falasse um pouco mais foi sobre a sua experiência no Colégio Paulista. Primeiro eu queria saber como é que foi, quando você chegou, eu queria que você falasse um pouquinho mais sobre isso.

C: Bem, chegada, foi legal, né, tudo novidade, era bem diferente, escola limpinha, carteiras impecáveis, né, então primeira impressão foi muito legal, todo mundo alegre de estar lá. E, diferente, os professores, eu lembro que foi uma surpresa para mim os professores não davam aula olhando no livro, né! Eles sabiam tudo, eles iam escrevendo no quadro, dava aula, perfeitinha, tipo, eu fui ver isso novamente só no cursinho, e na faculdade, né, enfim... Na escola, lá no M.[escola], eu era acostumado, o professor dava aula com o livro aberto, olhando, copiando algumas coisas na lousa, explicando, então isso assim foi um impacto logo de cara. Depois veio os laboratórios, eu nunca tinha entrado num laboratório, né. Tinha o de Física, tinha vários experimentos, tinha um trilho que saía ar para fazer objetos moverem em movimento uniforme. O de Química tinha todas as substâncias lá nas prateleiras, a gente montava, fazia algumas reações, tudo. Isso foi o prático, tal, até a prova eu achava que eu estava aprendendo, a primeira prova que foram os primeiros baques porque a gente viu, aí que eu vi que o negócio lá é diferente. Lá não tem prova semanal, não tem nada, cada bimestre é uma semana de prova, tanto que você fica uma semana só fazendo prova. As carteiras lá são duplas, então fica alguém do seu lado do segundo ou do terceiro ano fazendo prova também, ele também está fazendo prova. E era assim. Tinha uma biblioteca grande. A gente recebia todo o material da Fundação A., logo no primeiro dia de aula. Eu sempre estava na correria para comprar livro porque na escola anterior a gente recebia a lista de livro na primeira aula, então ficava uma ou duas semanas ali correndo atrás lá. E a gente recebeu uma lista bem antes, logo no dia da matrícula, e a gente já chegou no primeiro dia, um dia 
antes, eu lembro até que foi num domingo, assim, a gente foi na casa de uma menina, a gente escolheu uma representante entre nós e ela comprou todo o material, todos os livros. Era um monte! E foi assim o Paulista, essa parte. Outra coisa era a liberdade que a gente tinha lá, no segundo grau, a gente podia sair da aula, quer dizer não durante a aula, mas, tipo, nos intervalos você podia sair para lanchar fora da escola, ia na padaria e tudo, foi nessa que eu comecei a ir no Centro Cultural depois (rindo). $\mathrm{E}$ foi isso. O que mais você queria saber?

D: E desse baque, você comentou que você sempre era um ótimo aluno, nunca tinha tirado notas ruins, essa foi sua primeira experiência. Como é que foi isso?

C: Ah, foi decepcionante (ri). Primeiro, depressão mesmo, todo mundo ali, todo mundo foi mal, os dez! Quem foi menos ruim foi um japonês daqueles bem, bem tradicionais, sabe. Ele foi mais ou menos, mas mesmo assim fechou quase tudo com vermelha. Eu lembro que eu só passei em duas matérias, não lembro em quais... Por incrível que pareça não foi matemática, não foi física (rindo), eu fui bem mal nessas! Acho que foi geografia, história, alguma coisa assim. As que eu tinha facilidade foi que eu mais tomei na cabeça. Aí a gente se reuniu: "vamos ver o que a gente pode fazer”. E, de acordo com a nota do vestibulinho, você fica numa turma diferente. Então é aquele esquema: os melhores ficam numa sala, e depois de acordo com a nota vai indo. Aí, eu e esse japonês pegamos a sala 116 - que é a top, né - aí era uma sala só de meninos, não era mista, era só de meninos, porque era assim mesmo, era separado, o pessoal mais para o final que vinha as turmas mistas, que ficava mais para trás. Eu peguei essa... Uma menina, daí tinha a melhor das meninas também, uma conseguiu ficar na melhor das meninas, aí separou, enfim, os dez ficamos pulverizados. Daí a gente conversou tudo, a gente conversou com o pessoal da Fundação, também, que tinha ido mal, mas aí o que eles conversaram é que o sistema do Paulista era esse mesmo, era normal as pessoas irem mal no começo, né, era aquele sistema de pesos, que primeiro bimestre é peso um, dois, três e quatro. Então, vale $10 \%$ só da nota no final, então era recuperável. Então, vamos lá! A gente começou a estudar junto, entre a gente, só que não se via sempre, as matérias, pessoal não andava junto, era professores diferentes nas turmas, ia um pouco mais rápido, e... Aí a gente se juntou e tudo, mas não dava para estudar junto, era complicado, todo mundo morava longe um do outro, todo mundo morava lá pela A. [região], eu morava na B. [região], eu era o único que morava para lá, então não deu certo de ficar se juntando para estudar. E, durante a aula ali, intervalo, essas coisas... Foi quando eu... Foi quando eu, um pouquinho antes do segundo bimestre ali, que eu fui pedir ajuda e o menino me falou aquilo lá, aí eu... O segundo eu ainda fiz, tentei estudar sozinho, melhorei um pouquinho em relação ao primeiro, só que melhorei muito pouco, né. Aí o terceiro e o quarto eu desencanei de vez, aí eu desisti, eu abri mão.

D: E esse menino era da sua classe?

C: Era da minha classe. Sentava do meu lado, tudo...

D: Era o que se sentava do seu lado na carteira?

C: Não, ele sentava do outro lado. O do meu lado eu nem lembro dele, na verdade. Lembro de uns dois colegas só de lá, o J. e mais um - outro menino que eu me lembro assim, que eu tenho uma vaga lembrança. Mas eu não lembro de conversar muito com o do lado, era mais amizade de escola, mesmo. Mas, para estudar assim não dava muito certo, o pessoal era bem individualista, né, diferente, bem diferente 
daqui, né, é o clima de S., mesmo, né: cada um cuida do seu, mais ou menos de morar num prédio e não conhecer seu vizinho, né. Então, não deu certo e eu terminei desistindo mesmo.

D: Mas você achava ou acha que era diferente da sua escola anterior? A relação com os colegas?

C: Ah, era totalmente diferente! Não sei... Foi aquilo que eu te falei, a gente ficou, era meio discriminado, bolsa: "Mas, como você conseguiu bolsa? O colégio não dá bolsa!” Aí eu falava: “não, a Fundação A., tal” e explicava a situação. E ficava. Era diferente! A gente era diferente. A gente se vestia pior, os meninos chegavam e diziam que foram para Nova York, viajou, não sei o quê, a gente... Até hoje eu não andei de avião, né! (sorrindo) Então, já cria um abismo socialmente entre nós e eles. E, não se juntou, simplesmente não se juntava [fazendo gesto de ligar com as mãos]! $\mathrm{O}$ único que eu, assim, ia na casa de vez em quando era esse J. O japonês era totalmente estranho, era "nerd", né, então, totalmente... A gente não conseguia conversar com ele, ele era monossilábico, assim, né.

D: Esse J. quem era?

C: J. era um colega de lá, ele morava pertinho da escola, morava três quadras do colégio, e eu lembro que, de vez em quando, eu ia na casa dele, já almocei na casa dele, essas coisas. Tanto que ele é o único que eu lembro, mas também quando eu saí de lá perdi totalmente o contato. Aí eu desencanei, recebi o baque. Também, na verdade, eu acho que foi mais uma desculpa para mim mesmo para desistir. Não sei. Eu acho que eu não estava preparado na época para fazer a escola... (sorrindo) Eu acho que a mudança foi muito brusca, eu tinha 13 anos quando isso aconteceu e não soube lidar com a situação.

D: E essa coisa da discriminação que você coloca, você sentia isso, você e os outros sentiam isso?

C: Então, não é bem... Não sei explicar direito. É... Éramos diferentes, não é que tinha discriminação, que o pessoal isolava; a gente, simplesmente, não conseguia conversar as mesmas coisas, os meninos, eles ouviam outras músicas, eles tinham acesso a sons diferentes, assim, a gente ficava meio naquele negócio pop, assim, FM, eles tinham outras coisas. Era como se fosse um mundo à parte. A gente não conseguia misturar! É mais complicado do que simplesmente dizer que era discriminado. Não, não era! Tipo, eles não chegavam e: "não vou falar com você". Nada disso! Era simplesmente... Não batia! A gente não conseguia conversar das mesmas coisas. A gente não tinha os mesmos conhecimentos, a gente não se divertia igual. Pô, eles ir para o Playcenter: “Ah, o Playcenter é porcaria!” Para a gente era: “Nossa! A gente vai no Playcenter!” (rindo)

D: Não é explícito, né, é isso o que você está dizendo?

C: É, não é explícito. Sei lá, é como... Dando um exemplo bem esdrúxulo, é como o restaurante Fasano lá em São Paulo, você simplesmente não vai porque você não tem dinheiro, então, não é que te discriminam, se você quiser pagar até que você vai... Mas não... Não discriminam, você não consegue se misturar, é diferente. É mais... Nem sei dizer (ri)! Está fugindo a palavra... (pausa)

D: Eu estou entendendo o que você está dizendo. Aqui você chegou em algum momento a sentir isso? 
C: Então, aqui eu já cheguei mais velho, né, acho que mais maduro. Não senti, e também eu tinha outras experiências - vamos dizer, da minha sala eu sou o único que já trabalhou, que já fez outras coisas -, então a gente chega com uma bagagem diferente, aí não acontece, né. Então, aqui eu não senti isso. Eu conseguia me misturar mais. Justamente por ser mais maduro (sorrindo). Eu imagino que eu era meio bichinho do mato, também, essas coisas. Antes eu não sabia me entrosar, também. Hoje é bem mais fácil, eu consigo me misturar, consigo conversar com as pessoas, antes eu lembro que eu era tímido, essas coisas, então eu não conseguia... (pausa)

D: Você acha que essa sua experiência no primeiro colegial foi uma quebra na sua trajetória, porque você vinha desde o pré, na mesma escola, era um bom aluno...?

C: Quebra em que sentido, de continuar sendo bom aluno assim?

D: De ter significado uma mudança aí na sua trajetória.

C: Foi, foi uma quebra, mas eu diria que foi até positiva, não foi ruim, não. Eu, como eu tinha falado, depois no Santo Antônio o primeiro ano foi super fácil (sorrindo) porque lá no Paulista, apesar de ter desistido, eu ia nas aulas, eu matava uma ou outra, não era, eu não reprovei por falta, eu fechei com $80 \%$, mesmo porque tinha o controle da A. [fundação], eles cobravam isso. Então, eu sentia que no Paulista eu aprendia atrasado... [toca celular] O que eu sentia lá, como eu disse, é que eu aprendia atrasado, era estranho. Matemática, um negócio lá, todas as provas são cumulativas, eu acho que eu não contei isso, né?

D: Não. Cai toda a matéria?

C: Cai sempre toda a matéria, sempre. Aí, quando eu estava fazendo a prova do segundo [bimestre] era como se estivesse aprendendo a do primeiro, né (rindo)! Eu chegava a aprender a anterior, só que sempre um bimestre atrasado, era como se fosse isso. Então, a experiência foi rica, lá no Santo Antônio eu fiz com os pés nas costas, já sabia muita coisa, era bem mais adiantado, tudo isso. Então, foi tranqüilo. $\mathrm{E}$ a experiência, né, de ver que eu estava bem, só que é meio ilusório, né. É bem para uma escola estadual, mas é bem distante do que é realmente as coisas. E isso foi um fator até que fez eu correr mais atrás, de estudar mais tarde, de estudar por conta no Exército, de ensinar o pessoal, depois para eu mesmo ficar estudando para o vestibular. Eu vi que não bastava seguir, ou sei lá, achar que aprendeu, né, precisava de algo mais. Lá foi interessante para mostrar isso: ver que o mundo é maior do que eu imaginava (sorrindo), essas coisas, que o que é bom para uma escola estadual não chega nem, não chega aos pés deles, né, ritmo, os professores, realmente é diferente, não há como questionar isso, eles estão, não sei se é porque é o Paulista, eles estão muito na frente. No Santo Antônio, era particular também, só que era, como eu estava fazendo à noite, o pessoal trabalhava, eu lembro da minha sala a maioria trabalhava, o ritmo era bem mais ameno. Era como se fosse, era mais forte que a estadual, só que era, era como se fosse uma estadual boa, né, das que se destacam.

D: Você conheceu sua esposa lá?

C: É, ela era da minha sala. Eu ficava ajudando ela, e tudo. A gente começou a namorar assim, né, eu ensinando para ela, matemática e física que era o horror lá também, é um pouquinho puxado, né, mas como eu já tinha feito, para mim era revisão, né (ri). Eu levei de boa. E daí voltou o esquema da $8^{\mathrm{a}}$ série, juntar turminhas para estudar, essas coisas. Foi aí que foi integrando, tudo, eu fiquei bem... Eu 
trabalhava seis horas só, então, duas horas eu saía, ia para casa, almoçava e, às vezes, ia para a escola mais cedo. Com a minha altura toda, eu gosto de jogar basquete! [ri, satirizando o fato de ter baixa estatura] E, o colégio Santo Antônio é um prédio e do primeiro para o segundo andar, ele é aberto, e é onde ficam as quadras, o pátio, então a gente ficava lá jogando, brincando. Eu chegava sempre uma hora antes de começar as aulas, e lá tinha piscina, tinha tudo, então a gente jogava, faltava 15 minutos, ia lá tomava uma chuveirada e ia para aula. Então, a gente tinha como hábito fazer isso. Foi legal, foi muito bom. Tenho ótimas recordações de lá, foi um ano fácil, passei bem, ganhei medalhinha de melhor aluno da sala. Eles têm esses incentivos assim. Eu nem sabia, a gente foi lá, tem a formatura do pessoal do terceiro ano, me convidaram para ir, eu nem sabia o que quê era, a gente foi, aí chegou lá tinha isso de medalhinha lá, aí chamaram os melhores do primeiro, os melhores do segundo, tinha também para os melhores do terceiro. Foi interessante, foi um ano legal.

D: Agora, voltando um pouquinho lá para o ensino fundamental, você tinha comentado sobre uma professora da $4^{\mathrm{a}}$ série. Essa $4^{\mathrm{a}}$ era a melhor $4^{\mathrm{a}}$ série da escola?

C: Era, era. No M. [escola estadual onde estudou], teve um ano que eu peguei turma B só, o resto era tudo turma A. Não foi, $4^{\mathrm{a}}$ série, foi $4^{\mathrm{a}} \mathrm{A}$. $6^{\mathrm{a}} \mathrm{B}$ só que eu peguei, que deu uma quedinha, só olhando o boletim, que apareceu um C lá, mas eu era sempre B ou A. Não lembro o que aconteceu na $5^{\text {a }}$ que deu uma quedinha... Acho que novidades, né, pelo jeito, né (ri). Falando agora eu acho que esse negócio de novidade me atrapalha um pouco, né.

D: Mudança, né?

C: Mudança. Mas isso só me veio na cabeça agora. Enfim, foi isso.

D: E na $8^{a}$ série você comentou de um professor de português que pegava no seu pé, e você disse que ele era legal. Como é que era isso?

C: Não, é que ele tinha sido diretor da escola, aí mudou, não sei como era essa mudança também. Enfim, ele era legal, ele cobrava da gente, só que ele cobrava sempre brincando, não era de dar bronca, né, era uma brincadeira. Ele me chamava: "Carles [trocando uma letra do nome]! Vamos melhorar! Só está faltando isso!" Brincando, sempre brincando. E não era só comigo, com a classe toda ele fazia isso! Então, era uma forma, ele puxava ali, mas brincando, não deixava cair o nível, era, foi interessante. É um dos exemplos de professores assim que eu tenho, foi ele. Mas, era, a bronca que ele puxava assim, era sempre brincando, uma coisa super sadia, assim, foi legal. Ele brincava mais comigo, com. o E., com o M. Eu sentava na frente, eu nunca gostei de primeira fileira, mas eu sentava na segunda, só pra... (ri) Só para não ser primeira. Ele brincava mais com a gente ali, o pessoal da frente, pessoal do fundão... Era o fundão, né, mais bagunceiro, então... Eu lembro que eu tinha um outro colega também que era um palhaço e ele aceitava as brincadeiras dele; ele era um dos poucos professores que aceitava, ele aceitava, interagia um pouquinho, mas ele sempre, ele era sempre disciplinador, então ele dava risada ali, só que em seguida já retomava aula. Ele sabia lidar com os alunos. É interessante como alguns professores conseguem fazer isso, não perder a turma e outros, mesmo tentando ser disciplinador, não conseguem. (pausa)

D: Você comentou que entrar aqui foi uma decisão difícil. Eu queria saber o que ter entrado aqui e se formar aqui vai significar para a sua vida no futuro? Depois que 
você se formar, o que isso vai significar para seu futuro, para sua vida pessoal, da sua família, você e sua esposa?

C: Ah, eu acho que vai ser positivo, né. Tipo, eu estou fazendo uma coisa que inicialmente eu achava que era impossível, né. Isso já está sendo, vai ser, está sendo uma grande realização para mim, né. Então, pelo menos eu não vou ser um profissional frustrado que fez uma coisa, mas que na verdade queria fazer outra. Eu estou fazendo justamente aquilo que eu sonhava fazer, assim, já tinha desistido, e retomou. Então, em termos de realização profissional eu acho que vai ser plena assim. Vou fazer aquilo que eu gosto assim, se entrar na residência da ortopedia, assim, então, eu vou trabalhar no dia-a-dia realmente com aquilo exatamente que eu quero, eu vou trabalhar com trauma, eu vou fazer cirurgia, enfim, mais essas coisas. Acho que as perspectivas são excelentes, né. Em termos profissionais, não falta emprego para médico, isso a gente vê. Não ganha mais como antigamente, né, que antes, era sinônimo de rico, né. Hoje, rico... Em termos de Brasil, é milionário, né (rindo)? Eu lembro que eu li uma entrevista com a Marilena Chauí e ela comentou que ela ganhava $\mathrm{R} \$ 4.000,00$, e que era pouco pelo o que ela fazia, mas que era muito se fosse pensar em relação ao Brasil. Então, as perspectivas são boas de emprego. Outra coisa é que vida de médico, tem de onde tirar dinheiro, se tiver aperto. Eu e a Renata somos meio descontrolados, e tudo, e sempre você pode fazer plantão extra. Então, isso é mais tranqüilo. Acho que, pelo menos para o que eu espero, está perfeito! Eu também não espero trabalhar, ficar trabalhando direto, de ter quatro empregos, eu vejo que tem gente que faz isso, trabalha, não tem fim de semana. Agora, eu e a Renata, como eu te falei, nós estamos planejando agora em ter um filho, que antes não dava, então eu espero me dedicar... Antes era uma opção nossa não ter, mas como a gente se afastou da família, está sozinho aqui em P.[cidade onde se localiza o campus], então a gente começou a ver que isso é importante também, né. Então, a gente pensa em ter um filho, vai ser, mais ou menos, daqui uns três ou quatro anos. E, as perspectivas são boas. Eu não pretendo ter quatro empregos, dois está bom (ri)! Mesmo porque médico são 20 horas semanais, 20, 24. Eu pretendo mesmo isso, trabalhar, segunda a sábado, mesmo, ou ter uma folga, aí. Mas, sem estressar muito, sem querer ganhar, sei lá, 15, 20 mil. Não é, não estou... Minha perspectiva não é essa... Só quero viver só, dentro dos padrões, assim, ganhando mais ou menos o que eu ganhava no Exército que era em torno de R\$3.500,00, para mim já está bom. Acho que mais que isso é querer se matar à toa, sabe? Trabalhar para viver e não viver para trabalhar. Eu quero trabalhar para viver, mais ou menos isso. Respondi?

D: Sim. Mas o fato de você se formar, você acha que vai te dar uma mudança em relação à sua origem social, à sua condição social, por exemplo?

C: Eu acho que já mudou quando eu entrei no Exercito, né, essa condição social. Você começa a participar de outras coisas, eu tinha dinheiro, a gente saía junto com um outro pessoal, acostumamos com certas coisas, a comer fora. Isso já mudou, já ficou bem diferente em relação ao resto da família. Agora, o que eu acho que vai acontecer que eu vou manter o que eu já tinha conquistado antes, né, que agora deu uma parada, eu brinco que eu estou em "pause” nisso aí, e voltar o que estava antes, o que a gente já fazia antes. Essa parte acho que mudou quando eu fiquei no Exército mesmo. Eu não pretendo, não sonho nada além daquele padrão que eu já tive. Para mim está ótimo aquilo, eu não aspiro nada além disso. O que eu aspiro agora é ter realizações profissionais mesmo, né, ser reconhecido pelos pares naquilo que você 
está fazendo, fazer bem feito, acho que em termos de realizações, eu acho que é isso o que eu pretendo agora. Em termos sociais, de realizações, dinheiro, essas coisas eu acho que vai ser manter o que a gente tinha antes, não acho que vai mudar mais do que isso, não... (pausa)

D: Você tinha comentado também sobre entrar no curso de medicina que você percebia que para alguns de seus colegas foi um pouco menos difícil - porque medicina é um curso tão concorrido que para todos é difícil, não é mesmo? Não sei se você concorda, né?

\section{C: Concordo.}

D: E para alguns isso vem como uma coisa que é reflexo das condições que eles tiveram, né? Como é que você vê isso, por exemplo, na sua convivência com os colegas?

C: Ah, os colegas eu diria que eles reconhecem bastante, né, as nossas dificuldades, é como se eles tivessem estudando no Paulista a vida toda, né, então eles reconhecem bastante. Tem o outro colega, que eu te falei que tem uma situação bem pior, e o pessoal ajuda, é um barato, dá algumas coisas, alguns materiais dá para ele, tudo, ele ganhou o estetoscópio, é bem receptiva a turma. Aqui, não sei, como é interior aqui, pessoal da sala, a maioria vem de fora, tem uns 15 de P.[cidade onde se localiza o campus] e o resto veio de fora, então é um fator agregador ali, pessoal se junta mais, é mais amigo aqui, é como eu te falei, em S. é cada um na sua, né, é bem pensamento paulistano, aquilo que eu te falei: você não conhece seu vizinho. Aqui, não, aqui, o pessoal é bem receptivo, bem conciliador, está todo mundo sempre junto, é diferente, eu acho que é melhor aqui do jeito que é... (pausa)

D: Você comentou que quando você estava fazendo Física, um dos motivos que te fez deixar o curso foi a questão do campo de trabalho. Esta era uma questão que te preocupava já, logo na primeira vez que você fez um curso superior?

C: Sim. Porque Física aqui no Brasil é: você faz Física, você é professor, né, com raríssimas exceções você se torna outra coisa, ou professor secundário, ou quando você se realiza você se torna de faculdade, acadêmico, né. E, eu nunca me vi sendo professor. Apesar de juntar o pessoal para estudar junto ali, é aquela, eu tenho uma péssima didática, eu não sei transmitir muito o conhecimento, eu tenho muita dificuldade para achar palavras para conversar, para exemplificar, então, eu nunca me vi como professor justamente por isso, e para ser um professor ruim eu não quero, né. Então, eu não vi perspectivas de trabalho para isso, né. E, como eu falei na época, eu escolhi Física porque eu gostava de Física, na época da escola, né, eu adorava. E foi pela direita, né, (ri). Eu olhava a concorrência ali que era mais fácil, era só sete para um (ri) que ainda é bastante mas em relação aos outros ainda é bem menos, né. E na época eu não escolheria nunca Medicina, uma que tinha que se sustentar, aquilo que eu te falei, e outra que para mim eu achava impossível, né. Eu acho que a disciplina do Exército me ajudou nesse aspecto também de ter um objetivo lá na frente e fazer você fazer ele, né. No Exército tem a missão, tem que fazer: "se vira negão, vai lá e faz!” O lema dos coronéis lá é: "não quero saber se o pato é macho, eu quero o ovo aqui na minha mesa!” (ri) Então, eu acho que essa parte de determinação do Exército também ajudou um pouco, né. A disciplina de parar, estudar, apesar de depois não render mais, aí você vai lá, da uma descansada e retoma, né. É isso, né. Um pouquinho de disciplina para fazer as coisas, no fim dá certo. 
D: E a idéia da Medicina, você se lembra quando você chegou a pensar e logo abandonar? Foi na época do vestibular, antes...?

C: Não. Medicina, assim, foi bem assim, eu acho que eu estava... Deixa eu ver... Eu achava que dava para fazer, só que no Paulista eu entrei com... Eu era mais criança... Medicina... Depois entrou Ciências, tal, e aí eu fui me inclinando para Exatas. Eu lembro que quando eu entrei no Paulista eu queria Engenharia, Engenharia Eletrônica, meio fascinado por eletrônica, televisão, computadores, essas coisas, então... Eu nem sabia o que era, na verdade, né! (ri) O que quê era Engenharia, essas coisas, mas pelo que via assim e tal. Medicina ficou bem esquecido para dizer a verdade, assim. Era um negócio, sempre quem lia bula de remédio era eu, eu sempre me interessava, quando alguém se machucava era eu que ia lá fazer curativo, isso aí desde criança era assim, nego machucado era eu o primeiro a ver lá o que aconteceu, então fiquei bem... Eu diria que ficou bem latente assim o negócio de Medicina, ficou lá no fundinho. E no Exército assim meio esquecido também, aí ficou aquele tempo meio perdido, sem saber o que fazer, foi que eu falei que, provavelmente, eu iria fazer Administração, trabalhava com isso, já estava acostumado com isso, com rotina administrativa, fiscalização, essas coisas, e aí... Um colega, quando entrou lá, conversando devagarinho, brincando ali: “ah, sempre quis fazer, mas não dava...” Aí foi reacendendo a chama, né, ou reacendeu, ou surgiu, nem sei dizer direito... (ri) Foi mais ou menos assim, né, não sei dizer, uma época que eu quis fazer Medicina, assim. Quando criança era brincadeira mesmo, depois, logo de cara, eu desencanei: “não, não dá.” Então, já foca para outras coisas, né. Eu sou bem assim, eu digo que eu não gosto de ficar dando murro em ponta: “vamos atrás do que é possível fazer”. Esse é um pensamento que eu consegui verbalizar isso depois, né, mas eu sempre fui assim, sempre correndo atrás do que eu achava que eu podia alcançar, não, nunca, eu não me lembro de querer coisas impossíveis, essas coisas, assim, grandes sonhos, não, eu sempre fui "meio pezinho no chão" assim. Eu não sei dizer porquê, eu sempre fui assim.

D: Você pensou em fazer Administração na época em que você entrou em Processamento de dados?

C: Foi em seguida a Processamento, né... Processamento foi uma desilusão, né. Com aquilo, né, eu pretendia fazer Engenharia, eu gostava muito de Exatas, Física, eu via muito destino de alguns Físicos era se tornar programador, né, aí eu vi o que quê é realmente ser programador: é ensinar uma máquina a pensar, fazer as perguntas de modo que ela responda sim ou não, né, na verdade, é isso o que o computador faz, né. Aí eu vi que não era isso, né, o computador para mim é uma excelente ferramenta, eu gosto dele como ferramenta, né, agora trabalhar com aquilo, ficar... Você termina sendo como se fosse um intérprete para a máquina, então, não deu. Não sei se é o curso também que era processamento, então, é bem isso mesmo, é ensinar a máquina a fazer os processos, é estabelecer rotinas, essas coisas. Talvez se eu fosse mais para a parte de Engenharia, que é ligação de máquina com outras coisas, com periférico, essas coisas, talvez eu tivesse ficado, mas dentro do processamento, realmente, esse negócio de ser intérprete da máquina, não colou para mim. E... Ficou diferente, foi diferente do que eu achava que era... Aliás, eu nem sei o que quê era... (ri) E, mas, não ia com as minhas aspirações, com que eu achava que era viver, ficar na frente de um computador, não era para mim mesmo.

D: E foi aí que você pensou em fazer Administração? 
C: Foi. Acostumado com rotina administrativa, eu já estava na administração do Quartel, né, e continuidade, e: "vamos levando", eu estava mais ou menos nessa, né. Eu pensava nisso, "vamos continuar", porque você vai subindo no Exército, você vai fazendo trabalho burocrático, né, acaba aquela parte de instrução, simulação de guerra, essas coisas, e você vira um burocrata, isso os oficiais fazem, e o que eu imaginei para mim seguir isso, né, eu recusei um emprego, né, já estava tudo certinho para continuar isso, né, então fazer administração seria o curso ideal para levar a vida nessa seqüência, né.

D: Esse emprego, que quê era?

C: Eu ia ser supervisor de segurança. Era um coronel, ele tinha se aposentado, e ele ia abrir uma empresa de segurança para carga, para acompanhar carga, faz esse papel de escolta, essas coisas, de caminhão, carga de cigarro, carga de remédio que tem grande valor agregado, principalmente remédio, tem muito roubo, né. E o que eu ia fazer lá, eu ia fazer parte de planejamento, eu ia determinar rota, determinar paradas, essas coisas, eu ia viajar bastante, e depois ia fazer essa parte de planejamento e fiscalização, ver, estudar, ver se os caras estavam realmente parando onde tinham que parar, se estavam descansando, eram essas coisas que o coronel conversou comigo que eu ia ter que fazer. Era mais ou menos a mesma rotina de Quartel, né, um pouquinho diferente, mais ou menos rotinas específicas que a gente planejava. $\mathrm{O}$ que ele queria era isso; a gente era acostumado com uma rotina de fazer todo o planejamento antes que era isso que a gente faz no Quartel, todo exercício tem todo um planejamento: tal pessoa faz tal coisa, tal pessoa faz isso, em linhas gerais e você destrincha aquilo, você recebe uma ordem geral, tem que montar um evento, aí você vai lá e planeja realmente o evento, sei lá, tem que ter tantos banheiros para tantas pessoas, tantos quilos de carne para... Então era isso o que eu iria fazer, já estava acostumado a fazer isso, já tinha trabalhado com ele, ele sabia como eu trabalhava, então ia seguir e geralmente eles fazem isso, eles pegam os profissionais R2, eles conhecem, já lidou, sabe que trabalha direitinho, então ia ser uma continuação, só isso.

\section{(...)}

D: Você comentou que você acha que te ajuda bastante aqui o fato de você ter entrado mais velho do que os colegas, que a maturidade te ajuda em vários momentos. E você comentou que você tenta influenciar a turma ou ajudar de alguma forma com a sua maturidade. Eu queria te perguntar como é que é isso, que tipo de ajuda é essa?

C: Ah, é bem experiência mesmo. A CF, por exemplo, a Comissão de Formatura lá da turma, fui eu que praticamente escrevi o estatuto e tudo. Eu entrei e saí em seguida, que eu entrei vendo coisa errada, aí eu entrei, mexi lá, e daí saí em seguida porque eu não pretendo fazer, eu acho que vai ficar muita gente de fora, aí então fica todo mundo de fora, e tudo bem. Porque formatura eu acho que é mais para a família, não sei, é a minha concepção, eu não sou muito festeiro, essas coisas, então eu não ligo. Aí, eu entrei, eu escrevi o estatuto, porque já tinha feito isso, a organização de cobrança, controle... Eu me surpreendi um dia desses que eu estava vendo o pessoal fazer, porque eles se reúnem aqui [moradia] também, é o que eu deixei ainda, eles 
não mudaram. Isso é positivo. Outra coisa é desencanar do tipo, alguns eu ainda não consegui influenciar tanto, mas algumas meninas levam bronca de professor: nossa! Elas acham que não são nada, que acabou o mundo; eu levava bronca todo dia (ri)! É uma coisa normal, não leva para o lado pessoal. Eu, tipo, essa parte da Medicina, como eu te falei, que eu já vi professor dando bronca na frente de paciente e tudo, é, acho que entrar depois, já ter tido experiência, quase nada eu enxergo como pessoal, só quando está ofendendo a mim mesmo, mas tomar bronca em grupo de estudo, para mim é normal, não é pessoal, é como se fosse de trabalho ali, é deslize, é diferente. Então acho que isso, mostrar isso para os outros que essas coisas não são pessoais, acontece, acho que é bem positivo, isso aí. Mostrar a experiência de já ter trabalhado, dizer como é, se sustentar, casamento, o pessoal brinca, pergunta como é: pô, alguns aí já estão morando junto, é isso, é a continuação disso, não muda, se a relação muda com o casamento, eu acho que tem alguma coisa errada (ri). Outros vêm chorar que não está bem, vem perguntar para mim as coisas: "o que quê você acha?” Às vezes, eu fico até: “eu acho melhor você falar com a Renata, ela que é psicóloga!” Então, eu levo muito na brincadeira, estou sempre zoando o pessoal, que eu acho que é, é um pouco distante de mim até, eles acham que se perder um show de rock, alguns, nossa! Vai acabar a vida, né! (ri) Isso é um revezinho (ri), então tem que mostrar isso que a vida... [fim da fita]

\section{D: Você estava falando que eles vem falar coisas pessoais?}

C: É, coisas pessoais, tipo briga com namorado, situação com os pais, essas coisas, relacionamento, muitas coisas eles perguntam para mim, mesmo sendo até um pouco distante deles, às vezes, eles vêm para mim, acho que é porque eu sou mais velho mesmo. (pausa)

\section{D: E você tomava muita bronca onde, lá no Exército?}

C: Não, não, isso aí, lá é normal. Você fazendo certo ou errado, você vai tomar... É nosso passatempo... (ri) Faz parte... É o sistema, a gente acostuma. Quando não toma bronca é que a gente fica preocupado porque “desencaram". Você está sempre fazendo uma coisinha errada, né. Você, a continência, que o pessoal fala, bater continência, é um cumprimento né, às vezes, você está num mau dia, você não cumprimenta ou está passando direto assim ou, às vezes, você não viu algum superior e o cara já chega dando bronca que você não prestou continência, né. Então, são coisas normais, é coisa de rotina, lá é normal isso. Tanto que eu tenho que me policiar porque eu peguei o hábito! (ri) Eu já diminuí bastante, mas no começo eu, às vezes, dava bronca nos outros, assim, brincando, era assim, né. Eu já fiz menina chorar no primeiro ano por causa disso e depois, depois que eu vi que é diferente, né, você acostuma com lá e você vê que as pessoas são mais sensíveis aqui, lá é normal.

D: Dar bronca por causa de trabalho acadêmico, assim?

C: É. Essa menina foi inclusive numa reunião da Comissão de Formatura, o que aconteceu foi que ela deixou de fazer não lembro o quê, ela não fez, nem olhou, eu comecei a falar um monte, assim, ela começou a chorar, eu estranhei, enfim... Para mim seria normal, tipo, às vezes, a gente deixava de fazer as coisas porque não tinha tempo mesmo! Tem tantas tarefas e uma ficava de lado, era normal! E você tomava bronca e depois você fazia e dava tudo certo. Ninguém chorava por isso, ninguém ficava chateado. Depois eu vi que é diferente: "calma, você não está mais no 
Exército.” Então, isso me deixou um pouquinho distante assim da turma, porque essas coisas se espalham, e as meninas assim... Mas, foi só no momento, depois me policiei mais para não fazer essas coisas e não deu... Ficou tranqüilo. Essa menina fala comigo, é amiga, tudo, ficou sem ressentimentos depois.

(...)

D: Você quer acrescentar alguma coisa do que você falou?

C: Estou à disposição. Acrescentar, não. Eu acho que é isso que eu já falei. Da monitoria [havia relatado que no final do ano anterior, depois da $1^{\mathrm{a}}$ entrevista, recebera a notícia de que conseguira bolsa de monitoria na ortopedia] foi aquilo que eu te falei, aqui na Fac. de Medicina quem corre atrás de iniciação, essas coisas, é só chegar no professor, falar que está interessado ali, mostrar algum interesse, sai, né. Isso eu tinha comentado eu acho até, né. É correr atrás que iniciação sai, escreve um projetinho, realmente a Faculdade aqui, acho que S. também, né, a USP, em geral, né... Aqui na Casa, a maioria tem bolsa, faz iniciação. É questão de correr atrás, mesmo.

D: Eu queria agradecer mais uma vez. 


\section{A CONQUISTA DE UMA ESCOLARIZAÇÃO PROLONGADA}

As trajetórias apresentadas no capítulo anterior retratam histórias bastante distintas, com particularidades que fazem de cada uma delas trajetórias únicas. Não obstante tal singularidade e muito embora o presente estudo, marcado por uma metodologia essencialmente qualitativa, não busque regularidades, algumas recorrências nas trajetórias analisadas chamam a atenção e nos ajudam a pensar sobre a presença do estudante das camadas populares no Ensino Superior público. Se cada trajetória analisada aqui é singular, no sentido de que a configuração de fatores é única, os estudantes que participaram desta pesquisa estão inseridos num determinado tempo histórico e social, numa determinada cultura e sociedade. Assim, suas trajetórias são, ao mesmo tempo, individuais e sociais e não só revelam as vicissitudes que esses estudantes enfrentaram para ingressar e permanecer na Universidade de São Paulo, mas também nos fazem refletir, principalmente, sobre o acesso e a permanência do estudante das camadas populares em universidades públicas, bem como sobre as formas de enfrentamento das dificuldades encontradas, sobre a relação com as famílias, sobre a experiência na escola pública. Nesse sentido, ao partirmos do dado particular, nesta discussão, temos em vista abrir caminhos para interpretações mais abrangentes (Fonseca, 1999).

\subsection{Solidão e desenraizamento}

Como vimos no início deste trabalho, uma característica marcante nos estudos que tratam da longevidade escolar em camadas populares é o fato de que ela, em geral, é entendida a partir de uma visão que enfoca, predominantemente, a ruptura ou o choque cultural decorrente da diferença entre o mundo escolar ou ambiente universitário e o contexto de origem ou familiar dos estudantes, e o sofrimento, a humilhação e os prejuízos psíquicos que provêem daí.

Contudo, nas trajetórias escolares e experiências universitárias aqui analisadas, o sofrimento não constitui a tônica dos relatos dos estudantes, apesar de 
haver, como pudemos observar, solidão, tristeza e situações de desenraizamento e humilhação social no caminho percorrido por eles até o Ensino Superior e em suas vivências no interior da Universidade. Senão vejamos.

Dentre os cinco estudantes entrevistados, dois - Pedro e Antônio - realizaram o Ensino Fundamental em escolas públicas e todo o Ensino Médio em escolas particulares através de bolsas de estudos; Carlos estudou parte do Ensino Médio - o primeiro colegial - em escola privada também através de bolsa e os demais - Felipe e Marcos - realizaram toda a escolarização em escolas públicas - tendo os últimos três se valido de cursos preparatórios para obterem aprovação no exame do vestibular.

Para os três estudantes que cursaram o Ensino Médio ou parte dele em escolas particulares, essa experiência significou o encontro e a convivência com a desigualdade social, tendo sido marcada por solidão e tristeza. No entanto, a intensidade e os efeitos dessa vivência, bem como as formas de reagir a esses sentimentos, foram diferentes.

Ao realizar o Ensino Médio num colégio particular em Pedreiras, vimos que Pedro enfrentou uma situação de desenraizamento. O estudo em outra cidade e o projeto de ingresso no Ensino Superior o afastaram dos antigos amigos. Ao mesmo tempo, a convivência com os novos colegas de escola, embora fosse boa, restringiase ao período em que esse jovem permanecia no colégio. Longe dos antigos e dos novos amigos, Pedro sentiu-se triste e solitário durante o Ensino Médio, sobretudo, na terceira série desse nível de ensino, solidão e tristeza que, no entanto, tinham local certo para ocorrer: Jardim - sua cidade natal. O afastamento dos amigos levou Pedro a afirmar que, se não tivesse ingressado no curso de Biologia, não teria mais nenhum amigo. Interpretamos essa afirmação como a percepção desse jovem de que, se o projeto de realização de um curso superior e a passagem para outro mundo cultural não tivessem se concretizado, ele não se sentiria pertencente a nenhum dos dois mundos; isto é, ele não mais se identificaria totalmente com seu contexto de origem nem teria tido acesso ao "outro mundo", no caso, à Universidade pública. Com a aprovação no vestibular, todavia, Pedro ingressou na Universidade de São Paulo, ambiente ao qual, pelo que pudemos depreender de seu relato, parece sentir-se pertencente. 
Antônio também viveu os efeitos de uma situação de desenraizamento. Esse jovem relata ter experimentado um isolamento no início do Ensino Médio na escola particular onde estudou, quando, longe dos antigos amigos, demorou a adaptar-se à nova realidade e a fazer novas amizades. Ele sentiu-se confuso nesse período, pois não sabia como agir e se portar, nem o quê pensar. Um sentimento de pertença pôde ser desenvolvido na medida em que Antônio passou a ter, naquela escola, uma posição de destaque em virtude de seu ótimo desempenho acadêmico e também em função da monitoria de disciplinas que passou a exercer a partir do segundo ano desse nível de ensino.

A experiência de Carlos no Colégio Paulista foi mais dolorosa, tendo esse estudante vivido, como acompanhamos, uma experiência de humilhação social. Aluno com rendimento acadêmico exemplar, tímido, ele deparou-se com hostilidade, competição e individualismo neste colégio. Não conseguindo enfrentar sozinho as dificuldades que se lhe apresentaram, nem com a colaboração dos colegas bolsistas, nem tampouco podendo contar com a ajuda dos novos colegas, esse estudante, na época com 13 anos de idade, desistiu de tentar se adaptar à nova escola e foi reprovado. Ao conviver cotidianamente com uma desigualdade social bastante acentuada, já que o colégio atendia a altas camadas sociais, Carlos viveu as dores da humilhação social. Na escola em que realizou novamente o primeiro ano do Ensino Médio, no entanto, sua experiência foi inteiramente diversa, já que nessa escola teve seu lugar de destaque e seu valor escolar resgatados, guardando dela ótimas recordações.

Importante lembrar que Pedro, Antônio e Carlos viviam, por ocasião das experiências nas escolas particulares em que estudaram, uma fase específica em seus ciclos vitais que corresponde à adolescência e ao início da juventude. Podendo ser considerado um período de transição entre a infância e a vida adulta ${ }^{55}$ repleto de transformações biológicas e psicológicas, a adolescência é caracterizada, em especial pelos trabalhos na área da Psicologia do Desenvolvimento, como uma fase de crises, rupturas e de intensas modificações, quando o adolescente procura afirmar o seu $e u$ em contraposição ao outro, no processo de construção de sua identidade. Nesse sentido, consideramos que a tristeza, o isolamento e a solidão experimentados pelos estudantes que freqüentaram escolas particulares também estão, em certa medida,

\footnotetext{
${ }^{55}$ Para uma reflexão crítica sobre a transição para a vida adulta ver Camarano (2006).
} 
relacionados ao momento específico de desenvolvimento vivido, caracterizados por uma condição peculiar.

Todavia, a vivência desses períodos do ciclo vital pode variar conforme, entre outros fatores, a condição socioeconômica. Madeira (2006), por exemplo, mostra que o prolongamento da juventude - fenômeno observado em países desenvolvidos ou emergentes - não tem sido observado de modo generalizado no Brasil, considerando-se a realidade vivida pela maior parte dos jovens. Apenas uma pequena parcela deles (provenientes de famílias com maiores rendimentos e níveis de escolaridade) apresenta comportamento semelhante ao observado naqueles países, comportamento caracterizado, principalmente, pelo prolongamento da escolaridade, através da conclusão do Ensino Médio e do acesso ao Ensino Superior. A partir desse dado, a autora afirma que a desigualdade existente no Brasil também está presente no “espaço concedido à moratória juvenil” (Madeira, 2006: 145) e que essa desigualdade vem aumentando. Nessa mesma direção, Camarano et al. (2004) destacam que o amadurecimento psicossocial é diferenciado de acordo com o estrato social em que os jovens estão inseridos.

Assim, consideramos que, às dificuldades que enfrenta um adolescente e um jovem na crise de identidade que marca esse período, com todo o sofrimento que ela pode trazer, foram acrescentadas outras relativas às condições econômicas, à origem social e à convivência com a desigualdade social.

Contudo, apesar de terem vivido situações de desenraizamento e de humilhação social, Pedro, Antônio e Carlos conseguiram responder a elas ou superálas. O estranhamento provocado pelo encontro e pela convivência com a desigualdade social, e vivido no Ensino Médio, não se repetiu quando da entrada na Universidade. Lembremo-nos, por exemplo, que Antônio afirmou, sobre seu ingresso na faculdade, já estar acostumado a lidar com aquele "tipo de classe" e que sua sensação era a de estar em uma sala de aula de sua antiga escola, tamanha semelhança do perfil sócio-econômico dos estudantes do curso de Farmácia com os alunos que freqüentavam a escola particular onde estudou. Carlos, por sua vez, embora tenha comparado o nível social de seus colegas do curso de Medicina ao dos que freqüentavam o Colégio Paulista, afirmou que na faculdade “não acontece” a humilhação social. Tendo ingressado na Universidade mais velho, ele acumulou experiências de vida, como a inserção no mercado de trabalho e o casamento, as 
quais, por seu turno, lhe permitem melhor enfrentar situações de desigualdade social; além disso, na faculdade Carlos pôde contar com a amizade dos companheiros de Curso.

Um estranhamento do mundo social da Universidade, entretanto, esteve presente nas experiências universitárias de Marcos e Felipe. Assim, se para os que realizaram o Ensino Médio em escolas particulares, a convivência com a desigualdade social e o sofrimento dos efeitos de uma situação de desenraizamento ocorreram nessa época, para aqueles que sempre estudaram na rede pública de ensino, tal experiência deu-se na universidade. Todavia, assim como para Pedro, Antônio e Carlos, a intensidade, os efeitos e as formas de reagir foram diferentes ${ }^{56}$.

A trajetória de Marcos é emblemática do choque entre dois mundos. Sua origem social e seu histórico de estudante-trabalhador destoavam do perfil sócioeconômico de seus novos colegas da Universidade, que era semelhante ao do público que ele atendia quando trabalhava como garçom em um restaurante-choperia. Essa diferença foi percebida logo por ocasião da matrícula no curso de Psicologia, momento em que foi apelidado de "calouro independente" e lhe foi dito que tinha “cara” de quem já trabalhava. O sentimento de não-pertencimento ao mundo universitário expressou-se de maneira intensa durante a primeira festa da faculdade, quando Marcos desejou ter uma bandeja nas mãos para saber como agir. Como vimos, ele enfrentou situações de humilhação social no seu trabalho como garçom; na Universidade, porém, além da humilhação, esse estudante se deparou também com o desenraizamento. Para enfrentá-lo, Marcos tem procurado apoiar-se em suas raízes, tentando encontrar um lugar no novo mundo em que está vivendo, sem esquecer ou negar sua história de vida.

A trajetória de Felipe também retrata um sentimento de não-pertencimento efeito da experiência de desenraizamento. Como sabemos, no Ensino Médio noturno, esse jovem sentia-se deslocado por não partilhar com os colegas nem a condição social, nem seus projetos para o futuro. Já na Universidade, Felipe tem a mesma sensação de estar deslocado, igualmente em função da disparidade dos níveis socioeconômicos, mas com os pólos invertidos: se no colegial seus colegas eram

\footnotetext{
${ }^{56}$ Assim como mencionamos a adolescência como podendo ter contribuído para as dificuldades enfrentadas por Pedro, Antônio e Carlos, também consideramos que, no caso de Felipe e Marcos, as adaptações que a entrada na universidade requer possam ter colaborado para as dificuldades enfrentadas por eles.
} 
muito mais pobres do que ele, no curso de Administração eles são muito mais ricos. Embora esse jovem tenha mudado o seu "meio social”, ele foi acompanhado do mesmo sentimento de estar fora do lugar. Diferentemente de Marcos, no entanto, pareceu-nos que a Felipe tem sido mais difícil conseguir encontrar formas de "trocar influências” (Weil, 1996), o que colaboraria para seu processo de enraizamento.

A convivência com a desigualdade social, quer no Ensino Médio quer no Ensino Superior, faz sofrer. Mas, em que pesem as situações de desenraizamento e de humilhação enfrentadas, bem como a solidão e a tristeza experimentadas pelos estudantes entrevistados, o sofrimento não é característica marcante em seus relatos.

\subsection{Para além do sofrimento}

Exemplo disso é a visão de Carlos sobre sua experiência no Colégio Paulista. A despeito das dificuldades encontradas, da humilhação social, do sentimento de rebaixamento e da reprovação, quando lhe perguntamos se considerava essa experiência uma ruptura em sua trajetória escolar, ele nos respondeu que sim, mas acrescentou que a concebia como uma experiência "rica”, “positiva” e não "ruim”. Como já apresentado, essa experiência permitiu a Carlos conhecer a desigualdade escolar, ajudando-o a dimensionar a dificuldade de ingressar em um curso de altíssima seletividade, como é o caso de Medicina, e estimulando-o a estudar. Também concorreu para a avaliação positiva da passagem pelo Colégio Paulista o aprendizado daí advindo, que lhe possibilitou resgatar uma posição escolar de destaque no Colégio Santo Antônio, onde conheceu sua esposa.

Felipe, apesar do sentimento de não-pertencimento que o acompanha em sua experiência universitária, afirmou, como vimos, que está vivendo um dos momentos mais felizes de toda sua trajetória, considerando-se estar mais extrovertido e conseguindo relacionar-se melhor com as pessoas. A satisfação e o bem-estar experimentados são atribuídos por ele tanto à maturidade pessoal quanto ao ambiente universitário.

Também Carlos relatou, como resultado de sua maturidade, que atualmente consegue relacionar-se melhor com os colegas, "entrosando-se" e "misturando-se" mais, algo que antes não conseguia.

Importante destacar a menção feita, tanto por Felipe quanto por Carlos, à maturidade como sendo um aspecto que os ajudou no tocante ao convívio social. A 
depender do momento do ciclo vital vivido por cada estudante, as adversidades surgidas em suas trajetórias parecem poder ser mais bem enfrentadas, fazendo com que o sofrimento diminua.

Em relação à experiência universitária dos estudantes entrevistados, embora eles relatem choques e embates, o sofrimento também não é a característica predominante em suas narrativas. Antes, a experiência na Universidade pública aparece em suas falas como representando perspectivas de vida nunca imaginadas.

Lembremo-nos de Marcos que, não obstante as dificuldades, principalmente subjetivas, enfrentadas em seu cotidiano universitário, considerava, entusiasmado, que a entrada na universidade pública representou completa transformação em sua vida. Significou a possibilidade de sonhar, de conciliar desejo e necessidade no trabalho como psicólogo, de estar em um lugar social não reservado a ele, enfim, representou a possibilidade de mudança, de fazer o mundo "girar".

Trilhar um caminho diferente do já traçado socialmente também foi o que o ingresso no Ensino Superior representou para Antônio. A realização do curso de Farmácia na USP constituiu uma marca divisória em sua vida, sendo uma "mudança violenta”, como ele descreveu. No futuro, esse jovem vislumbrava, mobilidade social para ele e também melhores condições de vida para a família que ele pretende formar um dia. Além da mudança de posição social, a entrada na Universidade representou também uma modificação de "pensamento" de toda sua família, isto é, possibilitou não só a Antônio, mas também a seu grupo familiar, entrever diferentes projetos de vida, antes não cogitados, o que o levou a afirmar que, até hoje, se surpreende com as novas possibilidades que constantemente se lhe apresentam, sendo que, para sua família, a surpresa é ainda maior.

O relato de Antônio nos fez refletir acerca dos efeitos que se produzem em uma família das camadas populares com a entrada de um filho na universidade pública. A partir da experiência desse jovem, podemos afirmar a existência de outros sentidos, além do sofrimento, para o relacionamento entre o estudante pobre, que ingressa no Ensino Superior, e sua família.

No presente estudo, mesmo quando esse distanciamento foi mencionado, como no caso de Pedro, cujo afastamento do mundo religioso foi concebido por ele como um afastamento dos pais - católicos praticantes e muito ativos na Igreja -, vimos que esse jovem foi claro ao afirmar que não enxergava nesse fato um 
problema para a sua relação familiar. Outro fator que demonstrava a distância cultural entre ele e seus pais, e que pareceu ter se acentuado com a entrada na Universidade, era a não-compreensão, por parte deles, de sua opção profissional. Contudo, pudemos observar que, ao invés de fonte de sofrimento, isso representou uma oportunidade de crescimento para os pais, na medida em que, através da convivência com o filho e do compartilhamento de sua experiência universitária, eles puderam entender melhor o que é ser Biólogo, ampliando, assim, seus horizontes, especialmente em relação ao Ensino Superior.

Felipe referiu-se a uma ampliação de hábitos por parte de sua família e maior aceitação de diferentes estilos de vida proporcionados pelo fato de ele morar e estudar em uma cidade bem maior do que o município onde sua família reside. A grande mudança no grupo familiar, entretanto, refere-se justamente à maior queixa desse estudante em relação à sua família: como vimos, Felipe relatou que, após seu ingresso na Universidade, seus pais “abriram mais um pouco a cabeça” e passaram a valorizar o estudo, o que ele caracterizou como mudança de "mentalidade”, e o fez afirmar que, atualmente, a partir de sua experiência, os pais "são diferentes do que eles já foram um dia...”.

Marcos também comentou que sua aprovação no curso de Psicologia na USP influenciou e motivou seus irmãos, fazendo com que um deles estudasse e fosse aprovado em um concurso público e o outro iniciasse um curso pré-vestibular ${ }^{57}$.

Nesse sentido, as experiências dos estudantes mostram que o ingresso e a permanência na universidade não significa necessariamente fonte de sofrimento para os filhos/alunos das camadas populares no tocante à relação com suas famílias. Pelo contrário, os relatos indicam que a entrada no Ensino Superior pode trazer mudanças positivas também para as famílias dos estudantes. Para além do orgulho e da alegria dos pais, os estudantes relatam, por exemplo, alterações de alguns hábitos familiares, estabelecimento de outro tipo de relação com a escolarização e maior aceitação de determinados comportamentos. A presença dos filhos em uma universidade pública parece representar, para as famílias, possibilidade de ampliação de horizontes, de acesso a novos conhecimentos, de formulação de diferentes projetos de vida, enfim, possibilidade de desenvolvimento, aprendizagem e crescimento.

\footnotetext{
${ }^{57}$ Mas, que, como vimos, terminou abandonando.
} 
Romanelli, ao comentar a necessidade de se considerar a dimensão temporal e o aspecto processual da vida doméstica no entendimento das trajetórias familiares, afirma que:

... a posição social dos integrantes da família muda de acordo com suas trajetórias individuais, pois estas envolvem a transição etária, a inserção no mercado de trabalho e o grau de escolaridade, que, conjuntamente, contribuem para a incorporação de capital escolar e cultural. Tais transformações no plano individual alteram a própria trajetória da família e suas estratégias de reprodução social, inclusive aquelas voltadas para a escolarização dos filhos (2003: 251).

Parece-nos que foi isso o que ocorreu na família de Antônio. A partir de sua trajetória escolar e sua experiência universitária, os pais desse jovem mudaram a forma de pensar a escolarização dos filhos e já estavam agindo de forma diferente com a caçula, de modo a proporcionar-lhe maiores condições para o ingresso no Ensino Superior público.

A partir das questões aqui expostas, podemos afirmar que, para além do sofrimento, os relatos dos estudantes têm permitido compreender não só as dificuldades enfrentadas, mas também as possibilidades que se lhes apresentam quando ingressam em uma universidade pública, significando tal experiência completa transformação em suas perspectivas de vida e possibilidade de crescimento para as famílias.

Afirmar isso não significa negar a existência de sofrimento no percurso dos estudantes até o Ensino Superior público, nem tampouco em suas experiências universitárias. Ao longo das cinco trajetórias, analisadas na presente pesquisa, pudemos verificar que eles sofrem e, em alguns casos, muito. As dificuldades enfrentadas pelos estudantes das camadas populares para ingressar e permanecer na universidade, como discutidas por várias pesquisas - ver, por exemplo, os trabalhos de Portes (1993 e 2001), Viana (1998), Silva (1999) e Zago (2006) - e que também aqui foram apresentadas, são muitas, de diversas ordens e fazem sofrer.

Ademais, impossível seria negar o sofrimento vivenciado pelos estudantes tanto pelo material apresentado, quanto pelas conversas ao final das entrevistas, pelos pedidos de interrupção da gravação para revelar algo que não se queria tornar público, por confissões de ordem afetiva e pelo contato pessoal com os estudantes que me 
mostraram que eles sofrem por questões familiares, psíquicas e por acasos infelizes da vida.

Não obstante, muito embora ao falarem a respeito de sua trajetória até a Universidade e de sua experiência nela os estudantes relatem esforço, solidão, sentimento de não-pertencimento, eles não se apresentam como sofredores em suas narrativas. Esse fato pode dever-se a grande variedade de fatores. Poderíamos, por exemplo, interpretá-lo como resultante de um mecanismo psíquico de defesa, através do qual os estudantes estariam negando o sofrimento vivido por eles como forma de enfrentar as adversidades encontradas. Poderíamos, ainda, entendê-lo como resultado da criação de uma biografia vencedora, no sentido da "ilusão biográfica” discutida por Bourdieu (1996). Neste trabalho, no entanto, procuramos compreender esse fato a partir do que o próprio estudante afirmou a respeito de si e de sua experiência de vida. Ao contarem suas trajetórias, os estudantes aparecem como pessoas que aprofundam a dimensão da ação.

Arendt (1993) diferencia três atividades que considera fundamentais no que ela chama de "vita activa”: o labor, o trabalho e a ação. O primeiro corresponde às atividades ligadas diretamente às necessidades biológicas humanas. $\mathrm{O}$ trabalho, por sua vez, diz respeito às atividades que produzem um mundo de coisas que se distinguem do mundo natural e cujo produto é “artefato humano”. Já a ação, conforme apresentado anteriormente, é definida por Arendt (1993) como a característica distintiva da condição humana e a única atividade exercida diretamente entre os homens sem a mediação das coisas, correspondendo à capacidade de iniciar algo novo, ou seja, agir, tomar iniciativa, iniciar, imprimir movimento a alguma coisa. Segundo Lafer (1993), apoiado em Bikhu Parek, se no labor o homem revela suas necessidades corporais e no trabalho a sua criatividade artesanal, na ação ele revela a si mesmo; fonte de significado da vida humana, a ação é a capacidade de começar algo novo que permite ao indivíduo revelar a sua identidade. Para Arendt (1993), o agir desvia o homem da destruição e da morte, sendo considerado por essa autora um “milagre humano”, um “impulso” para a vida.

Talvez se encontre aí uma pista que nos ajude a entender a posição dos estudantes diante de suas trajetórias escolares e experiências universitárias. Em que pese, por exemplo, em alguns momentos das entrevistas, a auto-identificação espontânea deles como pessoas “pobres”, é claro em seus relatos que eles não se 
sentem desprovidos, pelo menos não de capacidades ou habilidades. Antes, eles procuram apoiar-se naquilo que possuem para buscar o que lhes falta. Seus principais apoios internos, nas trajetórias narradas, parecem ter sido: grande capacidade de estudo, capacidade de se esforçar em busca de algo, capacidade de renúncia, de determinação, de disciplina, capacidade de perseverar, de insistir e de resistir. Externamente, vimos que os estudantes contaram com o apoio e a ajuda da família, do grupo de jovens, da esposa, dos amigos, dos professores, dos ensinamentos da Guarda Mirim. A partir desses apoios, os estudantes entrevistados iniciaram um movimento novo. Apesar de sofrerem, eles não lamentam, buscam agir. Agir novamente, re-agir.

Além da dimensão da ação, que nos parece aprofundada nos estudantes entrevistados, consideramos também haver outras questões que podem nos ajudar a compreender seus relatos.

Em pesquisa cujas discussões nortearam algumas das análises empreendidas neste trabalho, Gonçalves Filho (1995) acompanhou, através de pesquisa participante, um grupo de mulheres moradoras da Vila Joanisa que assumiu, comunitariamente, o trabalho de três Centros de Juventude da região. O relato dessa experiência inicia-se com reflexões do pesquisador, apoiado, entre outros autores, em Weil, sobre a sua "passagem" para a Vila Joanisa: filho de um professor de bioquímica que lecionou na Faculdade de Medicina da USP, o contato do pesquisador com os moradores e a realidade daquele bairro foi como abandonar seu próprio mundo e adentrar em outro. Gonçalves Filho (1995) afirma que se afastar de “um mundo próprio” significa perder a companhia de suas qualidades, das pessoas que o compõem, significa perder, enfim, "o meio de nosso enraizamento”. Porém, esse afastamento constitui também uma forma de assumir o "mundo próprio" e ir além dele, devendo ser: “... meio de nosso enraizamento e não de nosso enterro nele. A liberação do mundo próprio libera nossa humanidade, libera a humanidade que se havia insinuado por meio dele e que arrisca nele aprisionar-se” (Gonçalves Filho, 1995: 35).

Embora tais reflexões tenham sido feitas a respeito da passagem de um mundo marcado pela “cultura universitária” (Bosi, 2005) para o "mundo dos pobres” (Gonçalves Filho, 1995), consideramos que elas possam contribuir para se pensar o movimento inverso, nos ajudando a refletir também sobre a presença do estudante 
das camadas populares na universidade pública, resguardando-se, evidentemente, as diferenças entre um e outro caso.

Com efeito, a idéia de passagem, travessia, encontro com outro mundo esteve presente nos relatos dos estudantes. Lembremos, por exemplo, que Antônio descreveu a sua experiência na Guarda Mirim como a primeira parte da ponte que o conduziu à Universidade, completada posteriormente com o estudo na escola particular. Marcos também falou a respeito do choque, quando ingressou na faculdade, com um mundo que não era o seu. Felipe, por sua vez, abordou a disparidade existente entre o “mundo USP” e o mundo onde vive a maioria das pessoas. No relato do percurso em direção ao ingresso na universidade, os estudantes, sobretudo aqueles que estudaram em escolas particulares, referiram-se, ainda, ao afastamento de antigos amigos e a diminuição de afinidades com eles. Os estranhamentos e os distanciamentos aludidos pelos estudantes parecem constituir efeitos de um processo de desenraizamento. Eles vão, pouco a pouco, perdendo a companhia das pessoas que compõem seu mundo próprio.

Contudo, também paulatinamente os estudantes vão se apropriando desse outro mundo como seu próprio mundo. Fazem novos amigos, inclusive com aqueles que em determinado momento representaram a oposição daquele outro mundo, como no caso de Marcos que se tornou grande amigo do colega que se preocupava com o acesso à Internet enquanto ele não sabia o que iria comer; contam com a ajuda dessas novas amizades. Inserem-se na vida universitária; realizam o curso de forma satisfatória; são considerados bons alunos ${ }^{58}$; fazem iniciação científica; são bolsistas; passam na seleção da pós-graduação. Essas e outras ações confirmam não apenas a “passagem”, mas também a inserção dos estudantes entrevistados no mundo da Universidade, o que não se fez sem dificuldades ou conflitos, como pudemos acompanhar na descrição da trajetória de cada estudante. Ainda assim, de diversas maneiras e em diferentes graus, os estudantes têm conseguido ou buscado apropriarse desse outro mundo, fazendo dele também o seu.

A apropriação da qual estamos nos ocupando aqui é de ordem subjetiva, isto é, trata-se do sentimento de que o ambiente universitário também faz parte do mundo dos estudantes, já que, como vimos, objetivamente todos eles conquistaram esse

\footnotetext{
${ }^{58}$ Exceção é o desempenho acadêmico de Carlos que pode ser considerado regular; as razões disso foram discutidas no capítulo anterior.
} 
lugar. Além de se encaixarem no que se considera, na academia, como "bons alunos”, alguns deles já tinham se formado ou estavam prestes a fazê-lo; e mesmo para aqueles que não estavam próximos de concluírem a graduação, não havia nenhum indício de que poderiam abandonar o curso. É verdade que a inserção objetiva, representada pela conclusão do curso, mesmo se acompanhada do sentimento de pertença ao ambiente universitário, não é garantia de êxito social ou profissional. Questões atuais como restrição (ou saturação - a depender da área) do mercado de trabalho e necessidade de contínua qualificação sugerem que nem o ingresso, nem tampouco o término de um curso superior, ainda que em uma universidade de grande prestígio social como a USP, podem garantir esse êxito. O que acontecerá com os estudantes entrevistados quando eles saírem da Universidade de São Paulo?

Embora isso não tenha sido o objeto de nosso trabalho, consideramos a questão de grande importância, de sorte que estudos longitudinais de acompanhamento da trajetória de alunos com esse perfil, após a conclusão do Ensino Superior, parecem fundamentais. Todavia, é possível inferir que se o diploma de uma universidade, como a Universidade de São Paulo, não é garantia de êxito profissional, as chances de que isso ocorresse na vida dos estudantes entrevistados sem o acesso à Educação Superior pública seriam bem menores.

A respeito da tônica dos relatos dos estudantes, consideramos importante mencionar também outra questão.

De acordo com Gonçalves Filho (1995), a humilhação social pode surgir nos momentos e espaços mais insuspeitos já que, como vimos anteriormente, a situação imediata que se apresenta e provoca a dor da humilhação é sempre mediada pela história de rebaixamento que atravessa a família e a "classe” do humilhado, sendo a atualização de um sofrimento antigo e amplo. Esse sofrimento atualizado nas situações as mais imprevisíveis dificulta "manter o ânimo, a disposição adulta, gosto bom da vida pública” (Gonçalves Filho, 1995: 139). Além disso, como também já aludido aqui, a dignidade no humilhado perde espontaneidade e passa a depender de esforço. Isso porque a humilhação social age destruindo os dois extremos do psiquismo: do lado interno ataca através dos enigmas que ferem, infestam e inscrevem-se na subjetividade como fonte de angústia e, pela parte externa, suprime 
a segurança que vem dos outros, "roubando do humilhado o reconhecimento do outro, o reconhecimento de sua dignidade” (Gonçalves Filho, 1995: 140).

É a própria exclusão que, internalizada na forma de humilhação, impede seu enfrentamento. E é nessa direção que pensamos existir uma diferença importante no caso das trajetórias analisadas neste trabalho. Apesar de os estudantes terem vivenciado situações de humilhação social, eles passam a ter, ao menos provisoriamente, o reconhecimento do outro e de sua dignidade, dispondo justamente daquilo que impossibilitaria a reação à humilhação. Esse reconhecimento surge com a aprovação no exame do vestibular ${ }^{59}$ : após terem sido submetidos a uma grande provação - que no caso dos estudantes das camadas populares torna-se ainda maior, tendo em vista a precariedade da escola que, em geral, freqüentaram, bem como suas origens sociais - são alçados à condição de iguais, provam que são dignos e "obtêm” o direito de estudar em uma universidade pública. Após passar no vestibular, os estudantes provenientes das camadas populares rompem barreiras e conseguem reconhecimento social de seu mérito, de sua capacidade e do merecimento de estudar numa universidade pública. Tamanha a exclusão que caracteriza o acesso ao Ensino Superior no Brasil, maior ainda no caso de um ensino reconhecidamente de maior qualidade como o das universidades públicas, e imenso quando se trata de cursos concorridos dessas mesmas instituições por parte de alunos das camadas populares, que os estudantes entrevistados parecem só conseguir sentir que têm direito de aí estudar após passarem pelo “calvário” do vestibular. Recordemos, por exemplo, o significado do ingresso na Universidade para Pedro - "grande vitória”, "grande prêmio” conquistado por méritos próprios - e vejamos mais uma vez suas palavras: “a partir do momento que eu consegui [a aprovação no vestibular], eu me vi como alguém bom o suficiente para poder usufruir disso daí”. Conseguir passar pela seletíssima "peneira” do vestibular é, nesse caso, a chancela, a condição subjetiva que outorga o direito de estudar em uma universidade pública. Como vimos anteriormente, o sentimento de não ter direitos está ligado a uma situação de rebaixamento. A dúvida sobre merecer estar no Ensino Superior público acometeu também Marcos; esse estudante interpretou a demora em conseguir ser aprovado no

\footnotetext{
${ }^{59}$ Embora, de maneira geral, essa tenha sido a experiência de reconhecimento mais marcante relatada pelos estudantes, também outras formas de reconhecimento estiveram presentes nas trajetórias, como, por exemplo, o lugar de destaque que Antônio passou a ocupar na escola particular em que estudou a partir de seu excelente desempenho acadêmico ou o prêmio que Carlos ganhou como melhor aluno da primeira série do Ensino Médio no Colégio Santo Antônio.
} 
exame do vestibular como uma “postergação”, por não se sentir preparado para realizar um Curso superior e por ter dúvidas se seu projeto de ingresso em uma universidade pública não seria "um passo muito grande”, sonho ou fantasia de sua parte.

Para os estudantes entrevistados neste trabalho acrescente-se ainda o fato de que, além de serem provenientes das camadas populares e terem ingressado numa universidade pública, eles foram aprovados no vestibular mais concorrido do País, de uma das Universidades de maior prestígio nacional, em cursos muito concorridos. Esse caráter excepcional é fato surpreendente, inclusive, para eles próprios. Pedro, Marcos e Carlos comentaram que se preparavam para passar no vestibular, mas, não esperavam ser aprovados na Fuvest, o que foi surpresa para eles. Antônio, por sua vez, disse que nunca havia concebido entrar numa faculdade, sendo isso “inimaginável” para ele, muito menos pensava em estudar numa universidade pública. Recordemos, também, do episódio narrado por Marcos quando um cliente do restaurante-choperia, a quem ele estava atendendo, o cumprimentou ao saber que ele havia sido aprovado no vestibular para o curso de Psicologia, mas levantou-se apenas ao ter conhecimento de que tal aprovação fora na USP.

Quando ingressam na faculdade, os estudantes das camadas populares o fazem em condição de igualdade com todos os demais alunos, já que como eles também precisaram se submeter a um exame e foram aprovados. Essa condição, entretanto, não anula a desigualdade social existente que é logo atualizada em suas experiências universitárias resultando em dificuldades como: a falta de domínio de uma língua estrangeira, conforme relatou Pedro; a necessidade de envolver-se em atividades remuneradas não relacionadas à área de formação, como o fizeram Felipe que trabalhou na biblioteca e Carlos que exerceu monitoria numa sala de computação; a diferença do preparo ou da formação anterior dos colegas, como observou Antônio; o desconhecimento de lugares e pessoas alheios ao ambiente universitário, como mencionou Marcos. Não obstante, a condição de igualdade alcançada com a aprovação no teste do vestibular parece ser importante do ponto de vista subjetivo pois, ao sentirem-se iguais e com o direito de estudar numa universidade pública, os estudantes entrevistados pareceram fortalecer-se emocionalmente para lidar com as dificuldades que apareceram no seu cotidiano acadêmico e no convívio social universitário. 
Nesse sentido, a aprovação no vestibular parece trazer consigo, para o estudante das camadas populares, o reconhecimento de sua dignidade pelo outro, fazendo com que ele se sinta igual e com o direito de estudar numa universidade pública. Como vimos, é esse reconhecimento que inexiste na humilhação social e que acaba por impedir o seu enfrentamento. Dessa forma, acreditamos que, ao dispor do reconhecimento do outro, os estudantes por nós entrevistados passaram a reunir maiores condições de lidar com situações de humilhação social e de desenraizamento que surgiram em seu cotidiano universitário.

Além da dimensão da ação, que julgamos aprofundada nas trajetórias aqui analisadas, e do reconhecimento do outro obtido com a aprovação no vestibular da Fuvest, consideramos importante também levantar outros aspectos que, a nosso ver, podem ter, de alguma forma, contribuído para que a tônica dos relatos dos estudantes entrevistados tenha sido diferente do apontado em outros estudos sobre o tema.

Um desses aspectos refere-se ao período da graduação que os estudantes cursavam quando foram entrevistados. Estando, no mínimo, na metade do curso, além de já terem acumulado experiência para poder refletir sobre sua vivência universitária, eles também puderam relatar as dificuldades que marcaram, principalmente, o início dessa experiência ${ }^{60}$. Os estudantes falaram a respeito de “choques”, “embates”, “trancos”, “barrancos”, “baques” em suas adaptações à cidade, à moradia estudantil, ao modelo acadêmico-científico universitário, ao curso e aos colegas da faculdade. A entrada na universidade e as adaptações que isso requer parecem ter grande impacto sobre os estudantes, sendo o início dessa experiência bastante “chocante” - usando uma expressão de Pedro. Nesse sentido, consideramos relevante o critério aqui adotado de que os estudantes a serem entrevistados tivessem cursado, pelo menos, metade do período de duração total da graduação. Isso permitiu não só uma reflexão sobre a experiência universitária - um dos objetivos deste trabalho -, mas também certo distanciamento do período inicial de adaptação que, pelo relato dos estudantes, é marcado por muitas dificuldades. Depois de acostumados com a nova cidade (lembrando que todos os estudantes são provenientes de outros municípios), acomodados e adaptados à nova residência, bem

\footnotetext{
${ }^{60} \mathrm{Na}$ realidade, Felipe é quem está na metade da graduação, cursando o terceiro ano de Administração; todavia, por ter iniciado o curso de Economia, esse estudante já estava, na época das entrevistas, há quatro anos na USP.
} 
como após terem aprendido a nova dinâmica acadêmica, conhecido os colegas, feito novos amigos, enfim, compreendido um pouco mais o que é a universidade, os estudantes parecem conseguir tanto estar melhor dentro dela quanto refletir com mais calma sobre essa experiência.

Outro aspecto a ser destacado, e que desempenha papel fundamental na permanência dos estudantes das camadas populares no Ensino Superior público, é a assistência estudantil. Todos os estudantes que participaram desta pesquisa são atendidos com, pelo menos, um benefício da assistência social existente na Universidade de São Paulo - a bolsa moradia, que lhes garante residir gratuitamente dentro do campus universitário. Outros estudantes tiveram bolsa-trabalho e bolsaalimentação. Esses auxílios são imprescindíveis para a permanência deles na Universidade e contribuem para minorar as dificuldades enfrentadas em seus cotidianos universitários e amenizar o sofrimento aí presente. Basta nos lembrarmos de que a opção de Pedro por estudar na USP, e não na outra universidade pública em que também fora aprovado e que era mais próxima de sua cidade natal, ocorreu em função da assistência social existente na Universidade de São Paulo. É importante ressaltar, todavia, que os benefícios oferecidos têm se mostrado insuficientes para atender ao crescente número de alunos que necessitam de alguma forma de assistência social, como evidenciaram, por exemplo, recentes reivindicações estudantis que tiveram lugar na USP. Um dos problemas é a falta de vagas nas moradias estudantis, do que é testemunha os quartos sempre lotados dessas residências, especialmente quando da chegada dos calouros, como declararam os estudantes aqui entrevistados. Vale lembrar, também, que eles ingressaram na USP antes do grande aumento no número de cursos que ocorreu no campus onde esta pesquisa foi desenvolvida, conforme afirmamos no segundo capítulo, o que configurava, na época, uma menor demanda pelos benefícios sociais existentes. Marcos relatou, por exemplo, que, quando foi aprovado no curso de Psicologia e passou a residir na moradia estudantil, não era difícil conseguir vaga, situação bastante diversa da que ele observa quatro anos depois. Também Carlos, residente da moradia da Faculdade de Medicina, comentou que, por ocasião de seu ingresso na faculdade, era fácil obter uma vaga lá; esse quadro, no entanto, é muito diverso do momento atual pois, em virtude do aumento do número de cursos oferecidos, cujo perfil socioeconômico dos alunos é mais baixo do que os do curso de Medicina (que 
até pouco tempo era o único oferecido por essa faculdade), a demanda pela moradia aumentou muito.

Os alunos entrevistados, por terem ingressado em um momento de menor demanda dos serviços de assistência social existentes na USP, puderam usufruir de vários benefícios, o que, conforme pudemos constatar, parece ter feito diferença significativa em suas experiências universitárias e talvez tenha colaborado para minorar o sofrimento vivido por eles, evidenciando, mais uma vez, a importância da assistência estudantil e corroborando a necessidade de sua ampliação.

\subsection{A presença do trabalho e da escola nas trajetórias dos estudantes}

Além da tônica dos relatos dos estudantes entrevistados, chamou-nos atenção outra característica recorrente em suas trajetórias de vida: a presença do trabalho. Todos os estudantes, com exceção de Pedro, trabalharam durante algum período de seu percurso escolar, desempenhando o duplo papel de estudante-trabalhador, antes do ingresso na Universidade. Como vimos, Felipe trabalhou em um banco durante os três anos do Ensino Médio, que cursou no período noturno para poder conciliar com esse emprego. Para arcar com as despesas dos cursos preparatórios para o vestibular, Marcos trabalhou durante os cinco anos em que tentou ingressar no Ensino Superior público: em uma loja de produtos de R \$1,99, como supervisor no Censo do IBGE e, na maior parte do tempo, como garçom em um restaurante-choperia; antes, durante o Ensino Médio, fez "bicos” como office-boy e em uma casa de frangos. Antônio trabalhou, durante a adolescência, em uma fábrica de estofados, em outra de vassouras, em uma gráfica, além de ter feito o curso de Guarda Mirim tendo em vista conseguir um bom emprego; além disso, na segunda e terceira séries do Ensino Médio exerceu monitoria na escola em que estudava em troca da isenção da taxa de material escolar. No final do Ensino Fundamental, Carlos trabalhou numa academia para pagar a mensalidade do curso de Kung-fu e, no início do Ensino Médio, quando realizou novamente o primeiro ano, trabalhou como digitador e estudou à noite; posteriormente, em Brasília, realizou estágio remunerado durante a terceira série do Ensino Médio, e concluído esse nível de ensino, trabalhou como “oficial temporário” no Exército durante dez anos. Assim, vemos que o trabalho esteve presente na vida dos estudantes entrevistados, ainda que de diferentes formas e por períodos variados. Mesmo para Pedro - único estudante que não exerceu nenhuma atividade 
remunerada - também o trabalho se fez presente por meio da constante lembrança e ênfase dos pais de que ele, ao contrário de todos seus amigos, não estava trabalhando para poder dedicar-se aos estudos. O fato de Pedro ter sido poupado da necessidade de trabalhar foi fruto de um grande investimento familiar em sua escolarização; seus pais, embora sejam aqueles que, entre as famílias dos estudantes entrevistados, possuem o menor rendimento, foram os que nos pareceram ter um claro projeto de prolongamento escolar para o filho, para o quê mobilizaram não só a si próprios e os parcos recursos econômicos existentes, mas também toda a família, em especial a família materna. Além de a continuidade da escolarização de Pedro ter sido constantemente contrastada, pelos pais, com a realidade de seus amigos que, findo o Ensino Fundamental, foram trabalhar, também a forma como essa família se relaciona com o estudo parece permeada pelo mundo do trabalho. Lembremo-nos de quando Pedro falou a respeito da necessidade que sentiu, no início da graduação, de ter os livros utilizados nas diversas disciplinas do curso de Biologia. Seus pais não economizaram esforços para atender a essa necessidade, por acreditarem que a cada atividade ou "serviço" a ser realizado correspondia determinada ferramenta; assim, se o trabalho do filho era estudar, logo sua ferramenta eram os livros. Dessa forma, parece-nos que, de certo modo, na família de Pedro, a forma de se relacionar com o estudo é mediada pela experiência com o mundo do trabalho.

A influência da relação com o trabalho na escolarização também parece estar presente na trajetória de Antônio. Para esse estudante, como vimos, a vida, após o término do Ensino Médio, resumir-se-ia a trabalhar, não fosse a realização do curso da Guarda Mirim, onde ele aprendeu que se alguém gosta de trabalhar, é preciso que trabalhe bem, da mesma forma que se gosta de estudar, é necessário que estude bastante. Foi o que ele fez a partir de então: estudou para os “vestibulinhos” das escolas particulares de sua cidade e conseguiu bolsa de estudos em todas elas; teve ótimo desempenho durante o Ensino Médio, o que lhe garantiu a manutenção da bolsa de estudos; após o ingresso na faculdade passou a estudar todos os dias à noite para aumentar sua média ponderada, no que obteve êxito; e, atualmente, formado, cursa a pós-graduação em Farmácia.

O trabalho também parece ser algo central para a família de Felipe. Recordemos que esse estudante afirmou existir certa pressão implícita de seus pais para que os filhos começassem a trabalhar cedo e se ressentiu da insistência da mãe 
para que ele assumisse o emprego no banco e estudasse à noite. Também Carlos relatou que percebia em sua família a prioridade do trabalho em detrimento da escola, ficando os estudos em segundo plano. Ao contrário do que afirmamos acontecer na família de Pedro, na dele o estudo não é visto como um tipo de trabalho: “É bem aquilo, estudar não é trabalho. Ser professor não é trabalho: 'você é só professor ou você trabalha também?' ” - nos disse Carlos.

Embora de formas e em períodos variados, o trabalho esteve fortemente presente na vida dos estudantes, quer concretamente a partir de suas próprias experiências como trabalhadores, quer indiretamente, por meio da experiência de trabalho dos pais que influenciou no modo de se relacionar com o estudo.

Também Portes, ao entrevistar 37 alunos dos cursos oferecidos pela UFMG provenientes das camadas populares, encontrou uma "longa e significativa história de trabalho remunerado” (1999: 68) nas trajetórias dos estudantes, sendo que 81\% deles trabalharam durante o Ensino Médio.

A presença do trabalho nas trajetórias dos estudantes está em consonância com a realidade da maior parte da juventude brasileira. Spósito (2005), comentando os resultados da pesquisa "Perfil da juventude brasileira", atenta para o fato de que, em que pese a aumento da escolaridade entre os jovens, o trabalho continua integrando seu horizonte de vida, já que, dentre os investigados, 76\% estavam trabalhando ou desempregados, e entre os que trabalhavam, mais da metade (55\%) conciliavam trabalho e estudo. Assim, a autora afirma que, à expansão da escolaridade entre os jovens no Brasil, não correspondeu um desligamento da juventude do mundo do trabalho, sendo observado, ao contrário, a simultaneidade, para muitos deles, entre essas duas esferas (Spósito, 2005). Para aqueles que não estavam estudando, essa condição, todavia, não implica o abandono de projetos em relação à escolarização: “Assim, para os jovens brasileiros, escola e trabalho são projetos que se superpõem ou poderão sofrer ênfases diversas de acordo com o momento do ciclo de vida e as condições sociais que lhe permitam viver a condição juvenil” (Spósito, 2005: 106). Chamando a atenção para a importância que o mundo do trabalho assumiu nos dados analisados, Spósito aponta a necessidade de se considerar a mediação efetiva e simbólica do trabalho para a construção da categoria “juventude” no Brasil. 
Importante destacar, aqui, também o fato de que todos os estudantes que nos foram indicados, e que entrevistamos para esta pesquisa, foram homens, apesar de não existir, de nossa parte, nenhuma restrição no tocante à questão de gênero. Embora não caiba aqui uma discussão aprofundada sobre a essa questão, tendo em vista os objetivos do presente trabalho ${ }^{61}$, consideramos relevante mencionar a relação entre esse fato e a presença do trabalho nas trajetórias dos estudantes.

Discutindo a socialização e a construção da identidade de filhos do sexo masculino em famílias das camadas populares, Romanelli (1997) analisa o papel do trabalho nesse processo. Através do que o autor denomina de "pedagogia do trabalho”, essas famílias procuram, de maneira geral, incutir nos filhos a importância e o valor de assumirem a condição de trabalhador, a partir do que suas identidades vão sendo forjadas. Na construção da identidade masculina nas camadas populares o trabalho tem, portanto, papel central ${ }^{62}$.

A respeito do trabalho das mulheres, Romanelli (1997) afirma que as restrições existentes devem-se não tão somente à imposição do marido (no caso da esposa), mas também a uma avaliação objetiva do valor pago pela força de trabalho feminina (incluindo-se, nesse caso, o trabalho das filhas). Além disso, a atividade profissional masculina é considerada, no plano das representações, como mais importante do que aquela realizada pela mulher. Essa visão está ligada à ética do provedor: “Assim, nas classes populares - mas não só nelas -, enfatiza-se a importância do trabalho do marido e dos filhos, deixando-se em segundo plano o da esposa e das filhas” (Romanelli, 1997: 31).

A importância do trabalho para a construção da identidade masculina aparece também na discussão empreendida por Camarano, Mello e Kanso (2006) a respeito dos marcos da transição da juventude para a vida adulta. As autoras afirmam que essa transição é caracterizada, na população masculina, pela participação no mercado de trabalho e pela constituição de domicílio próprio, enquanto para a feminina é marcada também pela constituição de domicílio, mas independente da entrada no mercado de trabalho.

\footnotetext{
${ }^{61}$ Para uma discussão sobre a influência da questão de gênero na experiência escolar de meninos e meninas, ver, por exemplo, Carvalho (2003) e Silva et al. (1999).

${ }^{62}$ Importante ressaltar que se trata de um trabalho realizado na esfera pública enquanto o trabalho feminino, muitas vezes, ocorre exclusivamente na esfera privada ou doméstica.
} 
Assim, se as famílias das camadas populares adotam um código moral comum, resultando em um estilo de vida baseado, entre outros aspectos, no trabalho (Romanelli, 2003), a “pedagogia do trabalho” (Romanelli, 1997) parece incidir, principalmente, sobre os filhos do sexo masculino. A identidade de trabalhador parece fornecer aos homens dessas camadas, tanto no plano pessoal quanto social, a dignidade de se perceberem como pessoas ou cidadãos. Isso porque:

Ao assumirem essa condição [de trabalhador], os filhos incorporam simbolicamente esse novo elemento na composição de sua identidade pessoal e social, que se configura como atributo identificador positivo, separando-os contrastivamente do universo dos ociosos e desocupados (Romanelli, 1997: 32).

Ser trabalhador significa mais do que possuir uma ocupação; para além de substantivo, essa palavra parece funcionar como um importante adjetivo nas camadas populares. Ser um sujeito trabalhador é sinal de virtude, grandeza e dignidade.

O código moral baseado no trabalho (Romanelli, 2003), ou a ética do trabalho, parece estar presente, embora de formas variadas, nas famílias dos estudantes entrevistados nesta pesquisa. A presença do trabalho nas trajetórias desses estudantes, quer através de suas próprias experiências como trabalhadores, quer através da experiência de trabalho dos pais, parece-nos ter contribuído para desenvolver um modo peculiar de estar na escola e de relacionar-se com o estudo ${ }^{63}$. Lembremos de Antônio que não via como antagônica a relação entre trabalho e estudo, concebendo-a, ao contrário, como uma relação de complementaridade, ao afirmar que passou a ser mais disciplinado, a estudar mais e a ter notas melhores quando começou a trabalhar. Talvez a persistência e a disciplina observadas nas trajetórias dos estudantes estejam relacionadas com a experiência com o mundo do trabalho. A grande capacidade de estudo, por exemplo, da qual todos eles dispõem (ou dispuseram em certo momento de seus percursos escolares), parece-nos estar, de algum modo, relacionada com o lugar que o trabalho ocupa em suas famílias.

Com efeito, a posição ocupada pelos estudantes no universo escolar, nos períodos do Ensino Fundamental e Médio, foi de destaque. Seus desempenhos escolares variaram de bons alunos, como no caso de Pedro, ou medianos, indo bem em algumas disciplinas e mal em outras, como ocorreu com Marcos, a ótimos alunos,

\footnotetext{
${ }^{63}$ Lembremos que os pais dos estudantes entrevistados possuíam emprego fixo ou atividade ocupacional estável; apenas o pai de Carlos passou a exercer, a partir de determinado momento, uma atividade mais irregular.
} 
como Antônio e Felipe, ou ainda a alunos excepcionais, como no caso de Carlos. Essas trajetórias escolares bem sucedidas, no entanto, não ocorreram sem rupturas, quebras ou percalços. Basta lembrarmos de Antônio, cujo ótimo rendimento escolar foi substituído por um desempenho ruim durante o período da $5^{\mathrm{a}}$ série, ou de Carlos, cuja trajetória de excelência foi interrompida com a experiência de reprovação no Colégio Paulista. Assim, embora seus percursos escolares, no que diz respeito à Educação Básica, tenham sido, em geral, bons, isso não resulta em trajetórias lineares cujo destino previsto seria o ingresso na Universidade. Antes, suas trajetórias escolares correspondem a percursos mais ou menos “acidentados”, cujo delineamento foi se fazendo aos poucos e sujeito a acasos.

Bastante diversas são as trajetórias de estudantes universitários de camadas médias intelectualizadas, filhos de pai e mãe professores do ensino superior/pesquisadores, detentores da mais alta titulação possível, investigadas por Nogueira (2000). Nos percursos escolares de 37 alunos dos cursos oferecidos pela UFMG, a autora afirma que muito pouco espaço é deixado ao acaso, sendo a chegada à universidade uma certeza evidente do destino escolar. Além disso, o vestibular, para esses estudantes, era um momento naturalmente esperado, sendo que a maioria dos entrevistados foi aprovada na primeira tentativa de ingresso na universidade.

Mas, se a ética do trabalho pode nos ajudar a compreender a disposição e a capacidade para o estudo existente entre os estudantes entrevistados, ela não é suficiente para explicá-la. Recordemos que Marcos, Carlos, Antônio e Pedro foram os primeiros ou eram os únicos, até o momento da realização das entrevistas, de seus núcleos familiares a cursarem o Ensino Superior ${ }^{64}$. Às suas trajetórias escolares bemsucedidas, os estudantes contrapuseram, em vários momentos das entrevistas, as experiências escolares dos irmãos, sempre piores ou vividas com mais dificuldades do que as deles próprios. Felipe, Marcos e Antônio comentam que os irmãos não queriam estudar, não gostavam da escola e exigiam atenção e acompanhamento próximo e constante das mães no tocante às atividades escolares; Carlos menciona o não-apreço da irmã pelo estudo, que fez supletivo apenas para “ir mais rápido”. Os estudantes entrevistados parecem ter sido, no interior das "configurações familiares” (Lahire, 1997), os “bons” alunos, enquanto seus irmãos eram os “maus” alunos, que

\footnotetext{
${ }^{64}$ A irmã mais velha de Felipe, como vimos, cursou Geografia em uma faculdade particular através de bolsa.
} 
iam mal e davam "trabalho" na escola. Mais do que isso, no interior das dinâmicas familiares, além de ocuparem a posição de "bons” alunos, eles parecem ter sido os "bons” filhos: lembremo-nos de Marcos comentando sobre o fato de ser considerado, em sua família, o "bom moço" e por ser o filho mais velho, o sobrinho mais velho e o neto mais velho, sobre ele eram depositadas grandes expectativas que, caso frustradas, representavam decepção maior do que se o mesmo ocorresse com outro filho, sobrinho ou neto. Esse estudante também nos relatou que, na visão de sua mãe, foi o filho que "menos deu preocupações" a ela. Felipe também comentou que seu irmão mais novo ia mal na escola, o que demandava freqüentemente a presença dos pais e o acionamento de estratégias como aulas particulares para evitar reprovações; ademais, seu irmão, ao contrário dele, era “rueiro”, deixando sua mãe “louca”. Em direção semelhante, o rendimento escolar do irmão mais novo de Antônio era bastante diferente do seu, já que ele ficava sempre de recuperação na escola e foi reprovado em uma série. Além disso, Antônio contrapõe a sua forma "diplomática" de se relacionar com as pessoas ao temperamento explosivo e briguento do irmão. Destaca-se, também, o fato de seu irmão ter trabalhado "bem mais” do que ele.

Segundo Romanelli (2003), as manifestações de preferência parental podem ocorrer de acordo com a ordem de nascimento e com o gênero dos filhos, podendo os pais estimular a escolarização de alguns em detrimento de outros. A posição do filho na fratria também pode ter influência sobre seu desempenho escolar já que, em tese, os filhos mais velhos, como é o caso dos estudantes aqui entrevistados, teriam melhores condições para a escolarização ao disporem de mais tempo "exclusivo" com os pais ${ }^{65}$. Entretanto, outros fatores podem influir nesse processo, como, por exemplo, a melhoria das condições financeiras da família e a experiência dos irmãos mais velhos, que beneficiariam o caçula (Glória, 2005).

Paparelli (2001), em pesquisa já citada neste trabalho, mostra que o encaminhamento dos filhos para o trabalho passa por um minucioso processo familiar de seleção, que considera não só o rendimento escolar, mas também

\footnotetext{
${ }^{65}$ No caso, evidentemente, de esses pais deterem capital cultural e escolar que contribua para a escolarização do filho. Além disso, conforme afirmamos na INTRODUÇÃO deste trabalho, segundo Lahire (1997), para que ocorra a "transmissão" do capital cultural, são necessárias interações efetivas e afetivas, interferindo, nesse processo, entre outros aspectos, a própria experiência escolar dos pais. Por outro lado, é possível uma história de "sucesso" escolar na ausência daqueles capitais quando, por exemplo, se atribui, no interior da família, um lugar simbólico de grande importância ao mundo escolar ou à criança letrada (Lahire, 1997).
} 
aspectos do comportamento dos filhos, principalmente a existência de problemas de indisciplina ou de não-assiduidade à escola. Tais problemas constituem um critério importante na seleção familiar para o trabalho, já que a atividade laboral é vista como podendo trazer benefícios ao processo de escolarização, tornando o filho mais responsável, na medida em que o retira das "más influências da rua” e dos maus pensamentos decorrentes da ociosidade. Ponderações essas que, como vimos, parecem ter levado a mãe de Antônio a encaminhá-lo para o trabalho.

O investimento familiar na escolarização de um filho é fenômeno bastante complexo, no qual podem estar presentes, entre outros, fatores que vão desde características de personalidade de cada genitor, aspectos não-conscientes da dinâmica interna familiar, envolvendo afetos e preferências paternas, passando por seus sonhos e projetos, pelo capital cultural e escolar disponível, bem como pelo momento da trajetória de cada unidade familiar.

Nesse complexo processo há de se considerar também a participação da escola. É preciso recordar aqui que, se os estudantes entrevistados desfrutavam de um lugar de destaque no interior das famílias, lugar esse construído em contraposição ao mau desempenho escolar dos irmãos mais novos, a condição de "bons” alunos foi alcançada a partir dos "veredictos escolares" (Bourdieu, 1997). Assim, seus bons rendimentos acadêmicos eram valorizados e destacados tanto na família quanto na escola. Felipe, por exemplo, nos relatou que os professores o elogiavam muito, diziam que ele "iria longe" e dispensavam sua mãe das reuniões de pais e mestres em virtude de seu bom rendimento e bom comportamento. O ótimo desempenho escolar de Antônio e os comentários positivos dos professores em relação a ele também liberavam sua mãe da necessidade de freqüentar reuniões de pais. No caso de Carlos, o desempenho acadêmico exemplar foi reconhecido, por exemplo, através de sua indicação para receber uma bolsa de estudos e freqüentar o Colégio Paulista, bem como do prêmio de melhor aluno das primeiras séries do Ensino Médio.

Notemos também que os estudantes entrevistados referiram-se a uma característica pessoal que marcou o início de suas experiências escolares ou as suas infâncias: a timidez. Felipe, Pedro e Carlos afirmaram, sem que isso lhes tivesse sido solicitado, que eram alunos tímidos ${ }^{66}$; Felipe comentou também que era uma criança

\footnotetext{
${ }^{66}$ Talvez estejam relacionadas a essa característica pessoal lembranças negativas que os estudantes relataram sobre o início de suas experiências escolares, sobretudo, em relação às primeiras séries.
} 
muito séria e quieta. Antônio, por outro lado, pela descrição que fez a respeito de sua experiência na educação Infantil, parecia ser um aluno participativo; de toda forma, também era elogiado pelos professores. Sabemos que a escola, em geral, ao avaliar positivamente um aluno não leva em consideração apenas seu rendimento acadêmico, mas também atribui grande importância ao aspecto comportamental. Os estudantes entrevistados parecem ter reunido duas condições para uma boa avaliação escolar e para reforçar essas características: tinham bom rendimento e bom comportamento.

Nesse sentido, vai-se tecendo uma complexa rede entre as dinâmicas familiares e escolares que resultam em lugares de destaque para os filhos/alunos, quer na família, quer na escola, como os ocupados pelos estudantes entrevistados nesta pesquisa.

Sobre a instituição escolar, os estudantes, por sua vez, embora tenham afirmado a precariedade da educação que receberam na escola pública, o que, em alguns casos, dificultou sobremaneira o ingresso no Ensino Superior público, reconheceram algumas contribuições dessa mesma escola. É assim que Marcos, apesar de ter se sentido "lesado” pela educação escolar que recebeu, concebeu a escola como um catalisador, no sentido de constituir um espaço de sociabilidade que permitiu o acesso a outros espaços ou lugares sociais, papel atualmente desempenhado pela Universidade, porém em outro nível. Além disso, esse estudante considerou que se a escola falhou no oferecimento de uma educação de melhor qualidade, ela contribuiu fornecendo subsídios (“instrumentos” ou "mecanismos”) para que ele próprio pudesse conseguir os recursos necessários para o ingresso no Ensino Superior público, ou em suas palavras, para “correr atrás”. Pedro partilhou conosco uma visão semelhante acerca de sua experiência na escola pública, ao afirmar que ela colaborou para que ele aprendesse a responsabilizar-se pela sua formação, usando a mesma expressão utilizada por Marcos: “a escola por si só não oferece tudo, tem que correr atrás...”. Esse jovem relatou também que o Ensino Médio, realizado na escola particular, foi importante para a sua experiência universitária, pois lhe deu disciplina, o que o auxiliou durante os estudos da graduação. Todavia, foram a "flexibilidade" e até as adversidades vividas na escola pública no Ensino Fundamental que o ajudaram, em sua opinião, a compreender melhor e usufruir mais da universidade. Lembremos de seu comentário em relação às greves ocorridas na USP: pelo fato de já ter vivenciado esse tipo de movimento 
anteriormente na escola pública em que estudou, Pedro afirmou que pôde buscar entender os motivos daquelas mobilizações e refletir sobre elas. Esse jovem também avaliou a si próprio como mais aberto ao contato e ao relacionamento interpessoais, do que alguns colegas de turma que, por terem estudado a vida toda em escolas particulares e por serem excessivamente dedicados ao mundo acadêmico acabavam, em sua visão, perdendo oportunidades de conhecer pessoas ou de aproveitar outros recursos oferecidos pela Universidade que extrapolavam a sala de aula e as atividades curriculares ou estritamente acadêmicas. Assim, na trajetória de Pedro, pareceu-nos que, se o estudo na escola particular permitiu o ingresso na Universidade ao oferecer os conhecimentos exigidos no vestibular e o desenvolvimento de uma atitude mais disciplinada em relação aos estudos, a experiência na escola pública contribuiu para que ele pudesse melhor desfrutar do ambiente universitário. Comparando sua experiência na escola pública com a que viveu na particular, Antônio afirmou ter notado nessa última algo que não percebia na que realizou o Ensino Fundamental: preconceito. Embora a atitude preconceituosa observada fosse restrita a pequena parte dos alunos, esse jovem disse que, na escola pública, não havia conhecido pessoas de “cabeça mais fechada” como aquelas que encontrou na escola particular. Carlos, por sua vez, estranhou o individualismo e a competitividade existentes no Colégio Paulista e contrapôs essa experiência à anterior vivida na escola pública, onde, em decorrência de sua facilidade com as disciplinas, principalmente na área de exatas, sempre ajudava os colegas, reunindo-se com eles e os ensinando. Felipe considera que a escola pública, além de não tê-lo ajudado a passar no vestibular, ainda o desencorajou em relação a isso. Todavia, ele afirmou que talvez ela tenha contribuído, em sua trajetória, para o desenvolvimento de raciocínio e inteligência.

Da experiência escolar, tanto na escola pública quanto na particular, os estudantes entrevistados fazem menção especial aos professores. Como vimos, Marcos, ao ser solicitado a falar dos momentos mais marcantes de sua trajetória escolar, recordou-se imediatamente de bons professores que eram também "grandes figuras humanas”, percebidos por ele como comprometidos com o aprendizado do aluno; atribuiu ainda seu gosto e sua facilidade com disciplinas da área de humanas à admiração que tinha por professores das disciplinas dessa área. Ademais, recordemos que ele, ao falar de sua experiência atual como aluno, demonstrou valorização, 
tolerância e generosidade em relação ao trabalho docente, afirmando que procurava colocar-se no lugar do professor, pois nutria desejo de, um dia, também assumir a docência como profissão. Antônio afirmou, ainda, que sempre teve boas relações com os professores. Como se viu, elas foram de grande importância em sua trajetória, principalmente durante o Ensino Médio, tendo sido o apoio dos professores fundamental para que esse jovem conseguisse a aprovação no vestibular para o curso de Farmácia. A ajuda deles estendeu-se desde a obtenção da vaga de monitoria, passando pelo auxílio na decisão da profissão a ser seguida, até o freqüente oferecimento de conteúdos extra-curriculares - que parecem ter contribuído de forma especial para o ingresso de Antônio na USP -, além dos constantes estímulos. A trajetória desse estudante nos remete à discussão, feita por Portes (2000), sobre a presença e a proximidade dos professores, bem como sobre a importância do seu reconhecimento e estímulo nas histórias de alunos das camadas populares que ingressaram numa universidade pública. Além disso, nos faz pensar que, embora Antônio fosse um bom aluno e estivesse estudando em uma escola cujo ensino era focado no vestibular, a ajuda extra-curricular recebida dos professores foi imprescindível para que ele conseguisse ingressar numa Universidade pública ${ }^{67}$. Pelos mestres, esse jovem expressou admiração, carinho e reconhecimento especiais. Ilustração dessa boa relação foi a presença da ex-professora de matemática do Ensino Médio na sua colação de grau no Ensino Superior. O respeito demonstrado por Antônio, para com o trabalho docente, pareceu-nos ligado à sua relação com o conhecimento ou à sua relação com o saber (Charlot, 2000). Assim como Marcos, Antônio também quer ser professor, mas, já estando na pós-graduação, ele foi mais assertivo: “Meu objetivo é ser docente. Vamos ver”. Carlos também teve boas relações com os professores, destacando as ocorridas durante o curso técnico, que foram facilitadas pelo pequeno número de alunos e, conseqüentemente, por maior proximidade com os docentes. Carlos nos pareceu atribuir grande importância e responsabilidade ao trabalho do professor, quando afirmou, como uma das explicações para ter abandonado o curso de Física, que não considerava possuir as

\footnotetext{
${ }^{67}$ Isso nos leva a questionar o mito da excelência da escola particular, como faz Whitaker e Fiamengue (2001) a respeito do "efeito cursinho", ao mostrarem que a constante freqüência a cursos preparatórios por alunos, tanto de escolas públicas quanto privadas, coloca em xeque a propalada maior qualidade do Ensino Médio particular.
} 
características pessoais necessárias para ser um bom professor, concluindo: “... e para ser um professor ruim eu não quero...”.

Os professores também tiveram menção especial entre os jovens que participaram da pesquisa sobre o perfil da juventude brasileira discutida por Spósito (2005). Apesar de expressarem insatisfação em relação à escola quanto ao interesse pelos problemas dos jovens e ao entendimento deles, queixa essa que aumentava conforme a elevação da escolaridade, sendo os universitários os mais insatisfeitos nesse aspecto, a figura do professor é depositária de grande confiança. Essa confiança aumenta conforme a escolaridade, sendo os universitários os jovens que mais afirmaram confiar nos professores. Comentando a respeito da necessidade de novas investigações que pudessem melhor precisar os sentidos atribuídos ao termo “confiança”, Spósito (2005) afirma que, considerando o fato de também ter sido a população universitária a mais crítica em relação à escola, possivelmente, com a alusão à confiança, os jovens estariam indicando respeito ao desempenho, à competência e às condutas dos mestres e não uma interação pessoal forte e afetiva com os professores.

De maneira geral, também os estudantes entrevistados neste trabalho, embora teçam críticas à qualidade da educação recebida na escola pública, atribuem grande importância ao professor. Além disso, reconhecem a sua experiência nessa escola como um espaço de sociabilidade, bem como de maior solidariedade e tolerância. A escola como um espaço de múltiplas interações sociais também foi um dos aspectos positivos citados, em relação a essa instituição, por jovens estudantes de uma escola pública de Ensino Médio de São Paulo participantes de pesquisa realizada por Spósito e Galvão (2004). As adversidades enfrentadas na escola pública, principalmente no que se refere à dificultação ou à obstrução ao direito à educação ${ }^{68}$, não obstante tenham sido reconhecidas pelos estudantes, parecem não ser encaradas apenas como aspectos negativos, mas também como possibilidade de desenvolvimento de outras capacidades, como, por exemplo, a capacidade de assumir a responsabilidade pela sua formação e de melhor desfrutar do que a universidade pública tem a oferecer.

\footnotetext{
${ }^{68}$ É importante lembrar que os estudantes, de maneira geral, comentaram que as escolas em que estudaram eram consideradas boas escolas, pelo menos até determinada etapa de sua escolarização.
} 
Desnecessário dizer que não se trata de defender a precariedade que tem marcado a educação pública brasileira praticamente desde sua instituição como um sistema de ensino e já amplamente discutida por trabalhos como os de Campos e Goldenstein (1981), Patto (1990), Collares e Moysés (1996), Cruz (1997) e Sawaya (1999), entre muitos outros. O acesso à escola, a permanência nela e o aprendizado a partir da socialização dos saberes e dos bens culturais produzidos e acumulados pela humanidade é um direito - que vem sendo reiteradamente negado à população pobre deste País.

Trata-se aqui de dar relevo à experiência desses estudantes quanto a poderem aprender e se desenvolverem a partir de situações educacionais, muitas vezes, hostis ou adversas. Trata-se de ressaltar uma capacidade que não é avaliada pelo exame do vestibular, mas que parece ter se mostrado importante na trajetória dos estudantes das camadas populares, entrevistados nesta pesquisa, tanto no seu percurso até a Universidade quanto em sua experiência no interior dela - a capacidade de agir, no sentido de Arendt (1993), e de re-agir.

Consideramos relevante, ainda, destacar um último aspecto que, embora já mencionado aqui, julgamos merecer maior atenção: a relação dos estudantes com a educação, de forma mais geral, e com o conhecimento ou o saber, de maneira mais específica, parece-nos ser algo digno de nota. Para Pedro, cursar o Ensino Superior esteve relacionado a um desejo de aprender e de crescer mais, e para Antônio esse desejo representava a possibilidade de “evoluir”. Vimos também que Carlos afirmou que seu objetivo na faculdade é aprender e não tirar boas notas. Além disso, observamos que o desejo de aprender, em muitas ocasiões nas trajetórias dos estudantes, excedeu a motivação econômica. Além disso, os estudantes nutrem uma relação de respeito e admiração pelo trabalho do professor, tendo Marcos e Antônio revelado o desejo de também serem docentes. Sobre a continuidade dos estudos através de pós-graduação, observamos que, além de Antônio, que já cursa o Mestrado, também Marcos afirmou a intenção de prestar pós-graduação em Psicologia e Pedro aventou a possibilidade de prosseguir na área acadêmica após a conclusão do curso com a defesa da monografia ${ }^{69}$.

${ }^{69}$ Carlos e Felipe não mencionaram a possibilidade de fazer pós-graduação; Carlos estava empenhando em realizar residência em ortopedia, após o quê parecia decidido a atuar na área, e Felipe afirmou que não desejaria seguir carreira acadêmica porque não gostou da experiência em pesquisa. 
Uma dimensão não-utilitarista da relação com o conhecimento foi observada por Nogueira (2000) em pesquisa, citada anteriormente, com 37 alunos da UFMG, filhos de professores universitários. Se a certeza evidente do Curso Superior e a inexistência de acasos distinguem esses estudantes dos que foram por nós entrevistados, a relação desenvolvida com o conhecimento parece, de certa forma, aproximá-los. Nogueira (2000) verificou a existência de um desprezo pelo utilitarismo ou por formas utilitárias de aprendizagem escolar em contraposição à valorização e à defesa do conhecimento como fim e valor em si mesmo. Além disso, em relação à participação em projetos de pesquisa através de bolsas de iniciação científica, a autora verificou que 51\% dos estudantes entrevistados detinham ou já haviam tido bolsas desse tipo. No presente trabalho, pudemos observar que os cinco estudantes participaram ou estavam participando de projetos de pesquisas, sendo que Marcos, Felipe e Antônio já tinham tido bolsas de iniciação científica, Carlos havia recém obtido uma e Pedro estava fazendo uma solicitação.

Assim, se as origens sociais, os níveis socioeconômicos das famílias e o grau de escolaridade dos pais, bem como as trajetórias sociais e escolares distinguem os estudantes entrevistados por Nogueira (2000) dos que conhecemos nesta pesquisa, a relação com o conhecimento e a busca pelo saber parecem, em certo sentido, tornarem-nos mais semelhantes.

Os estudantes provenientes das camadas populares que ingressaram em cursos de alta seletividade da Universidade de São Paulo, entrevistados no presente trabalho, parecem-nos ter desenvolvido uma relação especial com a educação escolar, de forma geral, e com o conhecimento, mais especificamente, além de nutrirem admiração e respeito pela figura do professor. Tal relação não constitui exatamente uma surpresa; afinal, foi a partir da educação escolar e através dos professores que lhes foi possível ter acesso a "outro mundo”, representado pelo ingresso no Ensino Superior público, em cursos de alta seletividade, mundo esse que, embora lhes apresente dificuldades, abriu-lhes muitas possibilidades. 


\section{CONSIDERAÇÕES FINAIS}

As histórias dos cinco estudantes de cursos de alta seletividade da Universidade de São Paulo que pudemos conhecer, ao longo deste trabalho, nos mostram que os caminhos para a construção de trajetórias escolares prolongadas nas camadas populares, como afirma Lahire (1997), são heterogêneos e múltiplos, a despeito de semelhanças de condições de vida e de origem social.

No presente estudo buscamos responder o que significa, da perspectiva dos estudantes, construir uma trajetória rumo a uma universidade pública e dentro dela. Assim, ao analisarmos essa experiência, empenhamo-nos em mostrar como os estudantes entrevistados vivenciaram suas trajetórias escolares e como têm vivido suas experiências universitárias, atentando também para os sentimentos presentes nesse processo. Isso não implica, entretanto, que tais sentimentos sejam exclusividade desses alunos nem daqueles com origens sociais semelhantes. Assim, por exemplo, um sentimento como o de não-pertencimento presente nas trajetórias dos estudantes pode estar relacionado a outras questões, que não a socioeconômica como afirmamos acontecer no caso deles. Apenas a título de ilustração citamos o exemplo do crítico literário Edward W. Said. Nascido em Jerusalém, proveniente da elite palestina, educado em escolas coloniais inglesas, formado em Princeton e Harvard e professor de literatura comparada na Universidade de Columbia, Said viveu permanentemente a condição de estrangeiro, de não pertencimento e fez dessa experiência a oportunidade para uma discussão intelectual e política, defendendo a idéia de que o Oriente foi uma construção teórica do Ocidente (Said, 1990). O sentimento de não se sentir pertencente está presente em sua autobiografia cujo título “Fora do lugar” (Said, 2004) fala por si só.

Além disso, não obstante este trabalho ter sido realizado na área da Psicologia e lidado com casos singulares, não entendemos as trajetórias analisadas apenas como individuais. Apesar do destaque a algumas questões e características psicológicas e da consideração da importância desta dimensão no estudo do acesso e da 
permanência do estudante pobre no Ensino Superior ${ }^{70}$, não entendemos as questões observadas como resultados de uma essência intrínseca aos estudantes nem como oriundas única e exclusivamente de seus empenhos pessoais. Com efeito, esforço, determinação, perseverança, autodisciplina, dedicação estiveram presentes nas trajetórias dos estudantes entrevistados. Afirmar isso não significa, entretanto, compartilhar a crença ideológica de que quem se esforça sempre alcança. Entre os milhões de jovens que estão fora da Educação Superior, certamente muitos deles também se esforçam, mas nem por isso tiveram acesso a uma universidade pública. Assim, como já afirmado neste trabalho, entendemos as trajetórias apresentadas como, ao mesmo tempo, individuais $e$ sociais, sendo fruto de uma construção coletiva baseada em uma rede de apoio que, variando em tamanho e relevância, esteve presente nas histórias dos cinco estudantes. Nesta rede de apoio podemos incluir a família que mobilizou outros parentes buscando garantir a continuidade dos estudos do filho; as mães que desempenharam um importante papel de acompanhamento e incentivo, sobretudo, no início da vida escolar de alguns dos estudantes entrevistados; o grupo de jovens e os amigos que permitiram ampliar horizontes e vislumbrar diferentes perspectivas de vida; a experiência com o trabalho e com ensinamentos voltados para esse mundo que permitiu vislumbrar a possibilidade do esforço e dedicação como formas de se conseguir algo; o suporte material e emocional da companheira que compartilhou um "sonho" e participou ativamente da busca de sua realização; o reconhecimento de um bom desempenho escolar, o estímulo e ajuda por parte de professores na construção de uma trajetória prolongada. Vários outros aspectos também funcionaram como importantes apoios para os estudantes e poderiam ser incluídos nessa relação. O que todos mostram, no entanto, é que o acesso e a permanência de um aluno das camadas populares no Ensino Superior público é uma realização pessoal e social.

A consideração da dimensão social da presença de um estudante pobre na Educação Superior pública traz a necessidade de mencionarmos algumas ações, voltadas para essa questão, que têm tido lugar na instituição campo desta pesquisa a Universidade de São Paulo. Já mencionamos aqui a importância da assistência estudantil observada nas trajetórias dos estudantes entrevistados, bem como a necessidade de ampliação dos benefícios existentes. O Inclusp - Programa de

\footnotetext{
${ }^{70}$ Em outro lugar destacamos os aspectos psíquicos desse tipo de trajetória (Piotto, 2007).
} 
Inclusão Social da Universidade de São Paulo -, aprovado em 2006, tem entre seus objetivos ampliar o número de alunos de escolas públicas na USP, bem como apoiar a permanência desse estudante em seu interior. Como parte dessas ações, a Universidade decidiu, em 2006, em caráter experimental, acrescentar 3\% na nota final das duas fases do vestibular para os estudantes provindos de escolas públicas. Naquele programa, outra ação está voltada para o apoio a cursos preparatórios para o vestibular de caráter comunitário ${ }^{71}$. Além disso, visando contribuir para a permanência dos estudantes pobres na Universidade, foi instituído o programa “Ensinar com pesquisa” que fornece bolsas de iniciação científica a estudantes de graduação, priorizando aqueles com renda familiar de até R\$1.500,00. No presente ano, a Universidade implementou também o programa "Embaixadores da USP” que leva alunos que estudaram em escolas públicas e foram aprovados no vestibular de volta às suas escolas de Ensino Médio para compartilharem suas experiências e fornecerem informações sobre a Universidade. Esse programa, embora interessante, parece ainda não ter trazido diferenças para o número de alunos provenientes de escolas públicas que tentam ingressar na USP. Há alguns anos, a Universidade instituiu a isenção da taxa de inscrição no vestibular a alunos que passassem por um processo de seleção socioeconômica. Este ano a Fuvest dispôs um total de 65 mil isenções, das quais mais da metade não foram aproveitadas, já que apenas 32 mil alunos se inscreveram e, destes, somente 30.647 obtiveram a isenção (Folha de S. Paulo, 24/08/2007); em anos anteriores também ocorreu sobra nas isenções oferecidas. Vimos que a idéia do direito e da igualdade estiveram presentes nas trajetórias dos estudantes entrevistados, muitas vezes sob a forma de dúvida. Ao longo de seus percursos, os estudantes perguntaram-se se tinham o direito ou mereciam estudar em uma universidade pública e não se imaginavam sendo aprovados no exame da Fuvest. Para enfrentar o desafio de desejar algo que duvidavam merecer, os estudantes buscaram se colocar numa posição de igualdade e tiveram de afirmar para si mesmos o direito do acesso a uma Educação Superior de qualidade que tem feito diferença em suas vidas e nas vidas de suas famílias.

\footnotetext{
${ }^{71}$ A discussão a respeito de uma dessas experiências - o Programa Pró-Universitários realizado pela Universidade de São Paulo em parceria com a Secretaria de Estado da Educação - pode ser encontrada em Mitrulis e Penin (2006).
} 
Neste trabalho procuramos mostrar, além das dificuldades e do sofrimento que marcam as trajetórias de estudantes das camadas populares que ingressam no Ensino Superior público, também as possibilidades de vida que se abrem com a realização de um curso superior em uma universidade pública. Em um momento em que o acesso de estudantes provenientes das camadas populares a esse nível de ensino está na “ordem do dia”, enfocar as possibilidades que o ingresso e a permanência na universidade pública abrem para o aluno pobre pode ser um instrumento na luta pela ampliação, com qualidade, do número de vagas nessa instituição. 


\section{REFERÊNCIAS}

ACCARDO, A. Sina escolar. In: BOURDIEU, P. (coord.) A miséria do mundo. Petrópolis: Vozes, 1997.

ALMEIDA, Wilson A. Esforço contínuo: estudantes com desvantagens socioeconômicas e educacionais na USP. SP, 2006. Dissert. (mestr.) FFLCH.

ARENDT, Hannah. A condição humana. RJ: Forense, 1993.

BARBOSA, Maira Alves. Estudantes de classes pobres na universidade pública: um estudo de depoimentos em psicologia social. SP, Dissertação (mestrado), IPUSP, 2004.

BONFIM, Talma A. O CAPE em nossas vidas: a visão de um grupo de alunos, exalunos, colaboradores sobre um curso pré-vestibular gratuito. RP, Dissertação (mestrado), FFCLRP, 2003.

BOSI, Alfredo. Cultura brasileira e culturas brasileiras. In: Dialética da colonização. $4^{\text {a }}$ ed. 2005. das letras, 1988.

. Fenomenologia do olhar. In: Novaes, A. (coord). O olhar. SP: Cia

BOSI, Ecléa. Cultura e desenraizamento. In: BOSI, A. Cultura brasileira: temas e situações. 4. ed. São Paulo: Ática, 2004.

$277-284,1993$.

A pesquisa em memória social. Psicologia USP. SP, vol. 4, n. 1/2, p.

. Memória e sociedade: lembranças de velhos. SP: TAQueiroz, 1979.

BOTTOMORE, T. Dicionário do pensamento marxista. RJ: Jorge Zahar Editor, 1988.

BOURDIEU, Pierre. A escola conservadora: as desigualdades frente à escola e à cultura. In: NOGUEIRA, M.A.; CATANI, A. (orgs) Escritos de educação. RJ: Vozes, 1998a.

O capital social - notas provisórias. In: Nogueira, M. A. e Catani, A. Escritos de educação. $4^{\mathrm{a}}$ ed. Petrópolis: Vozes, 1998b. (coord.) A miséria do mundo. Petrópolis: Vozes, 1997.

A doxa e a vida cotidiana. In: ZIZEK, S. Um mapa da ideologia. RJ: Contraponto, 1996. 
Lisboa: Ed. Difel, 1989.

O espaço social e gênese das “classes”. In: O poder simbólico.

SP: Zahar, 1983. p.89-94.

Algumas propriedades dos campos. In: Questões de sociologia.

BRAGA, Mauro Mendes; PEIXOTO, Maria do Carmo L.; BOGUTCHI, Tânia F. Tendências da demanda pelo ensino superior: um estudo de caso da UFMG. Cadernos de Pesquisa. SP, n. 113, p. 129 - 152, julho 2001.

BRANDÃO, Zaia. O processo de seletividade social e o vestibular. In: MINISTÉRIO DA EDUCAÇÃO. Secreatrai da Educação Superior. Seminários Vestibular hoje - coletânea de textos. Brasília: 1987.

BROCCOLICHI, Sylvain. Um paraíso perdido. In: BOURDIEU, P. (coord.) A miséria do mundo. Petrópolis: Vozes, 1997.

CAMARANO, Ana Amélia (org.). Transição para a vida adulta ou vida adulta em transição? RJ: Ipea, 2006.

CAMARANO, Ana Amélia; MELLO, Juliana L.; KANSO, Solange. Do nascimento à morte: principais transições. In: Camarano, A.A. (org.). Transição para a vida adulta ou vida adulta em transição? RJ: Ipea, 2006.

CAMARANO, Ana Amélia et al. Caminhos para a vida adulta: as múltiplas trajetórias dos jovens brasileiros. Ultima Década. Valparaíso, n. 21, p. 11-50, diciembre 2004.

CAMPOS, M.M.; GOLDENSTEIN, M.S. O ensino obrigatório e as crianças fora da escola: um estudo da população de sete a catorze anos excluída da escola na cidade de São Paulo. SP: FCC/DPE, Projeto Educação e Desenvolvimento, Subprojeto 5, 1981.

CARVALHO, Marília Pinto. Sucesso e fracasso escolar: uma questão de gênero. Educação e Pesquisa. SP, vol. 29, n.1, p. 185-193, jan/jun 2003.

CHARLOT, Bernard. Da relação com o saber: elementos para uma teoria. Porto Alegre: Artmed: 2000.

CHAUÍ, Marilena. Cultura do povo e autoritarismo das elites. In: Cultura $e$ democracia: o discurso competente e outras falas. 6 ed. São Paulo: Cortez, 1993.

COLLARES, C.A.L.; MOYSÉS, M.A.A. Preconceitos no cotidiano escolar: ensino e medicalização. Campinas: Cortez/Unicamp, 1996.

CRUZ, S.H.V. Representação de escola e trajetória escolar. Psicologia USP, São Paulo, vol. 8, n. 1, p.91-111, 1997.

FOLHA DE S. PAULO. Fuvest divulga lista de isentos de taxa. 24/08/2007. 
FRANCO, Maria Aparecida Ciavatta. O acesso à universidade: uma questão política e um problema metodológico. In: MINISTÉRIO DA EDUCAÇÃO. Secretaria da Educação Superior. Seminários Vestibular hoje - coletânea de textos. Brasília: 1987.

FREDERICO, Celso. Consciência operária no Brasil. São Paulo: Ática, 1978.

GLÓRIA, Dília Maria A. Relação entre escolaridade e diferenças constitutivas das fratrias. Paidéia. Ribeirão Preto, vol. 15, n. 30, p. 31-42, 2005.

GONÇALVES FILHO, José Moura. Problemas de método em Psicologia Social: algumas notas sobre a humilhação política e o pesquisador participante. In: BOCK, A.M.B. (org). Psicologia e compromisso social. SP: Cortez, 2003.

. Humilhação social - um problema político em

psicologia. Psicologia USP. SP, vol. 9, n. 2, p. 11-67, 1998.

Dissert. (mestr.) Ipusp. . Passagem para a Vila Joanisa. São Paulo, 1995.

HAMMERSLEY, M.; TURNER, G. Conformist pupils? In: HAMMERSLEY, M.;WOODS, P. (eds) Life in school: the sociology of pupil culture. Milton Keynes, Open University Press, 1984.

LAFER, Celso. Posfácio - A política e a condição humana. In: Arendt, H. A condição humana. RJ: Forense, 1993.

LAHIRE, Bernard. O homem plural: os determinantes da ação. Petrópolis: Vozes, 2002.

SP: Ática, 1997. O sucesso escolar nos meios populares: as razões do improvável.

MADEIRA, Felícia. Educação e desigualdade no tempo de juventude. In: Camarano, A.A. (org.). Transição para a vida adulta ou vida adulta em transição? RJ: Ipea, 2006.

MICHELAT, Guy. Sobre a utilização da entrevista não-diretiva em sociologia. In: THIOLLENT, M. Crítica metodológica, investigação social e enquete operária. SP: Ed. Polis, 1987. $5^{\text {a }}$ ed.

MILLS, Charles Wright. A nova classe média (White collar). $3^{\mathrm{a}}$ ed. RJ, Zahar Editores, 1979.

MITRULIS, Eleny; PENIN, SôniaTeresinha S. Pré-vestibulares alternativos: da igualdade à eqüidade. Cadernos de Pesquisa. São Paulo, v. 36, n. 128, maio/ago. 2006.

NICOLACI-DA-COSTA, Ana .Maria. Sujeito e cotidiano: um estudo sobre a dimensão psicológica do social. RJ: Campus, 1987. 
NOGUEIRA, Maria Alice; ROMANELLI, Geraldo; ZAGO, Nadir. Introdução. In: Família e escola: trajetórias de escolarização em camadas médias e populares. Petrópolis: Vozes, 2000.

OLIVEIRA, João Ferreira et al. Políticas de acesso e expansão da Educação Superior: concepções e desafios. Brasília: MEC/INEP, 2006.

PAPARELLI, Renata. Trabalho precoce e escolarização: uma trama complexa. SP, Dissertação (Mestrado), IPUSP, 2001.

PATTO, Maria Helena S. A produção do fracasso escolar: histórias de submissão e rebeldia. SP: TAQueiroz, 1990.

PINTO, José Marcelino R. O acesso à Educação Superior no Brasil. Educação e Sociedade. Campinas, vol. 25, n. 88, p. 727-756, out. 2004.

PIOTTO, Débora Cristina. Aspectos psíquicos de trajetórias escolares prolongadas nas camadas populares. Trabalho a ser apresentado durante a $30^{\mathrm{a}}$ Reunião Anual da Anped (Associação Nacional de Pós-Graduação e Pesquisa em Educação) em Caxambu de 07 a 10 de outubro de 2007.

. Retrato de um (des)encontro: camadas médias na escola pública. SP, Dissertação (Mestrado), IPUSP, 2002.

PORTES, Écio Antônio. Trajetórias escolares e vida acadêmica do estudante pobre da UFMG: um estudo a partir de cinco casos. Belo Horizonte, 2001. Tese (dout.) FAE/UFMG.

- O trabalho escolar das famílias populares. In: NOGUEIRA, M.A.; ROMANELLI, G.; ZAGO, N. Família e escola: trajetórias de escolarização em camadas médias e populares. Petrópolis: Vozes, 2000.

O universitário de camadas populares no espaço do herdeiro. Boletim do Departamento de Didática/Unesp. Araraquara, ano XVI, n. 15, 1999.

Trajetórias e estratégias escolares do universitário das camadas populares. BH, Dissertação (Mestrado), FAE/UFMG, 1993.

QUADROS, Waldir José. O “milagre brasileiro" e a expansão da nova classe média. Campinas, Instituto de Economia, Tese (Doutorado), 1991.

QUEIROZ, M.I.P. Relatos orais: do “indizível” ao “dizível”. In: SIMSON Von, O.M. (org). Experimentos com histórias de vida. SP: Vértice, 1988.

ROMANELLI, Geraldo. Questões teóricas e metodológicas nas pesquisas sobre família e escola. In: Zago, N.; Carvalho, M.P.; Vilela, R.A.T. (orgs). Itinerários de pesquisa: perspectivas qualitativas em Sociologia da educação. RJ: DP\&A, 2003. 
Famílias de classes populares: socialização e identidade masculina. In: Cadernos de Pesquisa - NEP. Campinas, ano III, n. 1 e 2, p. 25-31, 1997.

SAMPAIO, Helena; LIMONGI, Fernando; TORRES, Haroldo. Eqüidade $e$ heterogeneidade no ensino superior brasileiro (Documento de Trabalho 1). São Paulo: NUPES, 2000.

SADER, E.; PAOLI, M.C. Sobre "classes populares" no pensamento sociológico brasileiro (Notas de leitura sobre acontecimentos recentes). 3. ed. Rio de Janeiro: Paz e Terra, 1997.

SAID, Edward W. Fora do lugar- Memórias. SP: Companhia das Letras, 2004.

Companhia das Letras, 1990.

. Orientalismo - o Oriente como invenção do Ocidente. SP:

SAWAYA, S.M. A leitura e a escrita como práticas culturais e o fracasso escolar das crianças de classes populares: uma contribuição crítica. São Paulo, 1999. Tese (dout.), Ipusp.

SETTON, Maria da Graça J. Um novo capital cultural: pré-disposições e disposições à cultura informal nos segmentos com baixa escolaridade. In: Educação e sociedade. Campinas, vol. 26, n. 90, p. 77-105, abr. 2005.

A divisão interna do campo universitário: uma tentativa de classificação. Revista Brasileira de Estudos Pedagógicos. Brasília, vol. 80, n. 196, p. 451-471, set./dez. 1999.

SILVA, Carmem A.D. et al. Meninas bem comportadas, boas alunas; meninos inteligentes, indisciplinados. Cadernos de Pesquisa. São Paulo, n. 107, p. 207-225, julho/1999.

SILVA, Jailson de Souza. "Por que uns e não outros?” - caminhada de estudantes da Maré para a universidade. Vols I e II. Rio de Janeiro, Tese (doutorado), PUC/RJ, 1999.

SPÓSITO, Marília Pontes. Algumas reflexões e muitas indagações sobre as relações entre juventude e escola no Brasil. In: Abramo, H.W.; Branco, P.P.M. (orgs) Retratos da juventude brasileira: análises de uma pesquisa nacional. SP: Instituto de Cidadania/Ed. Perseu Abramo, 2005.

.Programa de estudos do destino ocupacional dos exalunos da Universidade de São Paulo. Pro reitoria de graduação, Naeg/USP, 1995. relatório técnico.

populares. SP: Hucitec/Edusp, 1993.

A ilusão fecunda: a luta por educação nos movimentos

SPÓSITO, Marília Pontes; GALVÃO, Izabel. A experiência e as percepções de jovens na vida escolar na encruzilhada das aprendizagens: o conhecimento, a 
indisciplina,a violência. Perspectiva. Florianópolis, v. 22, n.2, p. 345-380, jul./dez.2004.

THIOLLENT, Michel. O processo de entrevista. In: Crítica metodológica, investigação social e enquete operária. SP: Ed. Polis, 1987. $5^{\mathrm{a}}$ ed.

VIANA, Maria José B. Longevidade escolar em famílias de camadas populares algumas condições de possibilidade. In: NOGUEIRA, M.A.; ROMANELLI, G.; ZAGO, N. Família e escola: trajetórias de escolarização em camadas médias e populares. Petrópolis: Vozes, 2000.

. Longevidade escolar em famílias de camadas populares:

algumas condições de possibilidades. Belo Horizonte, Tese (doutorado), FAE/UFMG, 1998.

WEIL, Simone. A condição operária e outros estudos sobre a opressão. $2^{\mathrm{a}}$ ed. RJ: Paz e Terra, 1996.

WHITAKER, Dulce Consuelo A.; FIAMENGUE, Elis Cristina. Ensino Médio: função do Estado ou da empresa? Educação e Sociedade. Campinas, ano XXII, n. 75, p. 200-232, agosto 2001.

ZAGO, N. Do acesso à permanência no ensino superior: percursos de estudantes universitários de camadas populares. Revista brasileira de educação. Campinas, v. 11, n. 32, p. 226-237, maio/ago. 2006. 
A NEXOS 


\section{A N E X O 1}

\section{ROTEIRO DE ENTREVISTA}

\section{$\underline{1^{0} \text { encontro }}$}

Gostaria de lhe contar sobre a pesquisa que estou realizando e sobre o que falaremos neste encontro. Estou interessada em histórias de estudantes que estatisticamente têm poucas chances de ingressar em uma universidade pública como a USP, sobretudo em cursos concorridos - estudantes mais pobres (tendo em vista o perfil sócioeconômico destes cursos), assim como eu que cursei psicologia, sempre estudei em escolas públicas, meu pai era caminhoneiro e ele e minha mãe estudaram até a $4^{\text {a }}$ série. Meu objetivo é entender como essas histórias foram construídas. Por isso, gostaria de conhecer sua experiência, ouvir suas lembranças e histórias marcantes da época de escola. Gostaria que você me contasse sobre momentos ou pessoas que marcaram sua vida nesta época, desde que você entrou na escola (pré ou $1^{\mathrm{a}}$ série) até seu ingresso na USP.

se necessário retomar:

- como viveu esta experiência

- momentos ou pessoas mais significativos

\section{$\underline{2^{\circ} \text { encontro }}$}

$\checkmark$ Retomada do $1^{\circ}$ encontro: esclarecimentos e aprofundamentos sobre o que foi falado

$\checkmark$ A que você atribui sua trajetória escolar bem sucedida?

$\checkmark$ O quanto a sua experiência anterior na escola ajuda na sua experiência na universidade?

Questões a serem perguntadas caso não sejam abordadas:

- Etapas da escolaridade e seus momentos decisivos (especialmente, $1^{\circ}$ s anos escolares)

- Desempenho na escola

- Relação com amigos/colegas de escola

- Relação com professores

- Pessoas significativas na trajetória escolar

- Significado da entrada na USP, no curso

- Relação com pais e irmãos

- Expectativas, projetos e postura familiar sobre escolarização 
- Escolaridade e trajetória profissional dos pais e irmãos (história escolar da família)

\section{OUTRAS INFORMAÇÕES}

- idade

- curso (semestre/ano)

- dados familiares

escolaridade pais

ocupação/profissão pais

renda familiar

irmãos (escolaridade, profissão/ocupação)

avós (escolaridade, profissão/ocupação)

- escolas nas quais estudou (pública, particular) e períodos 


\section{CURSO PSICOLOGIA}

\section{(Fonte FUVEST)}

Questão 1: Onde fez seus estudos de ensino fundamental?

em \%

\begin{tabular}{|l|c|c|c|c|c|}
\hline & $\begin{array}{c}2001 \\
(\mathrm{n}=40)\end{array}$ & $\begin{array}{c}2002 \\
(\mathrm{n}=40)\end{array}$ & $\begin{array}{c}2003 \\
(\mathrm{n}=40)\end{array}$ & $\begin{array}{c}2004 \\
(\mathrm{n}=39)\end{array}$ & $\begin{array}{c}2005 \\
(\mathrm{n}=40)\end{array}$ \\
\hline Só em escola pública & 22,5 & 25 & 20 & 2,5 & 15 \\
\hline Só em escola particular & 52,5 & 50 & 67,5 & 80 & 65 \\
\hline Maior parte em escola pública & 12,5 & 15 & 5 & 2,5 & 5 \\
\hline Maior parte em escola particular & 10 & 10 & 2,5 & 7,5 & 10 \\
\hline Metade em cada tipo de escola & 2,5 & - & 5 & 7,5 & 5 \\
\hline
\end{tabular}

Questão 2: Onde você realizou seus estudos de ensino médio?

\begin{tabular}{|l|c|c|c|c|c|}
\hline & $\begin{array}{c}2001 \\
(\mathrm{n}=40)\end{array}$ & $\begin{array}{c}2002 \\
(\mathrm{n}=40)\end{array}$ & $\begin{array}{c}2003 \\
(\mathrm{n}=40)\end{array}$ & $\begin{array}{c}2004 \\
(\mathrm{n}=39)\end{array}$ & $\begin{array}{c}2005 \\
(\mathrm{n}=40)\end{array}$ \\
\hline Só em escola pública & 5 & 10 & 12,5 & 5 & 2,5 \\
\hline Só em escola pública federal & - & 2,5 & 2,5 & - & - \\
\hline Só em escola particular & 87,5 & 77,5 & 77,5 & 87,5 & 97,5 \\
\hline Maior parte em escola pública & 5 & 5 & 2,5 & - & - \\
\hline Maior parte em escola particular & 2,5 & 2,5 & 2,5 & 7,5 & - \\
\hline Metade em cada tipo de escola & - & - & - & - & - \\
\hline No exterior (qualquer tipo de escola) & - & 2,5 & 2,5 & - & - \\
\hline
\end{tabular}

Questão 3: Em que período você realizou seus estudos de ensino médio?

\begin{tabular}{|l|c|c|c|c|c|}
\hline & $\begin{array}{c}\text { em \% } \\
(\mathrm{n}=40)\end{array}$ & $\begin{array}{c}2002 \\
(\mathrm{n}=40)\end{array}$ & $\begin{array}{c}2003 \\
(\mathrm{n}=40)\end{array}$ & $\begin{array}{c}2004 \\
(\mathrm{n}=39)\end{array}$ & $\begin{array}{c}2005 \\
(\mathrm{n}=40)\end{array}$ \\
\hline Diurno (só de manhã ou só a tarde) & 87,5 & 92,5 & 95 & 92,5 & 95 \\
\hline Diurno integral (manhã e tarde) & 7,5 & 2,5 & - & 5 & 2,5 \\
\hline Noturno & - & 5 & - & - & - \\
\hline Maior parte diurno & 5 & - & 2,5 & 2,5 & 2,5 \\
\hline Maior parte noturno & - & - & - & - & - \\
\hline Metade no diurno, metade no noturno & - & - & 2,5 & - & - \\
\hline
\end{tabular}


Questão 4: Você se preparou, por quanto tempo, ou está se preparando em algum cursinho pré-vestibular?

\begin{tabular}{|l|c|c|c|c|c|}
\hline & $\begin{array}{c}2001 \\
(\mathrm{n}=40)\end{array}$ & $\begin{array}{c}2002 \\
(\mathrm{n}=40)\end{array}$ & $\begin{array}{c}2003 \\
(\mathrm{n}=40)\end{array}$ & $\begin{array}{c}2004 \\
(\mathrm{n}=39)\end{array}$ & $\begin{array}{c}2005 \\
(\mathrm{n}=40)\end{array}$ \\
\hline Não & 40 & 37,5 & 35 & 30 & 35 \\
\hline Sim, menos de um semestre & 2,5 & 2,5 & 7,5 & 5 & 5 \\
\hline Sim, um semestre completo & 2,5 & 2,5 & 7,5 & 5 & - \\
\hline Sim, de um semestre a um ano & 37,5 & 30 & 25 & 40 & 32,5 \\
\hline Sim, de um ano a um ano e meio & - & 2,5 & 5 & 7,5 & 5 \\
\hline Sim, de um ano e meio a dois & 7,5 & 15 & 20 & 12,5 & 17,5 \\
\hline Sim, mais de dois anos & 10 & 10 & - & - & 5 \\
\hline
\end{tabular}

Questão 5: Qual o grau de instrução mais alto que seu pai obteve?

\begin{tabular}{|l|c|c|c|c|c|}
\hline & $\begin{array}{c}2001 \\
(\mathrm{n}=40)\end{array}$ & $\begin{array}{c}2002 \\
(\mathrm{n}=40)\end{array}$ & $\begin{array}{c}2003 \\
(\mathrm{n}=40)\end{array}$ & $\begin{array}{c}2004 \\
(\mathrm{n}=39)\end{array}$ & $\begin{array}{c}2005 \\
(\mathrm{n}=40)\end{array}$ \\
\hline Não freqüentou escola & - & - & - & - & - \\
\hline $\begin{array}{l}\text { Iniciou o ensino fundamental, mas } \\
\text { abandonou entre a 1a e a 4a série }\end{array}$ & 10 & 10,3 & 2,5 & 2,5 & - \\
\hline $\begin{array}{l}\text { Iniciou o ensino fundamental, mas } \\
\text { abandonou entre a 5 }{ }^{\mathrm{a}} \text { e a 8a série }\end{array}$ & 5 & - & 2,5 & - & 2,5 \\
\hline Ensino fundamental completo & - & - & 5 & 2,5 & - \\
\hline Ensino médio incompleto & 2,5 & 5,1 & 7,5 & 2,5 & 2,5 \\
\hline Ensino médio completo & 17,5 & 7,7 & 10 & 15 & - \\
\hline Universitário incompleto & 7,5 & 10,3 & 7,5 & 7,5 & 20 \\
\hline Universitário completo & 45 & 53,8 & 52,5 & 62,5 & 65 \\
\hline Mestrado ou Doutorado & 12,5 & 12,8 & 12,5 & 7,5 & 10 \\
\hline
\end{tabular}


Questão 6: Qual o grau de instrução mais alto que sua mãe obteve?

\begin{tabular}{|l|c|c|c|c|c|}
\hline & $\begin{array}{c}2001 \\
(\mathrm{n}=40)\end{array}$ & $\begin{array}{c}2002 \\
(\mathrm{n}=40)\end{array}$ & $\begin{array}{c}2003 \\
(\mathrm{n}=40)\end{array}$ & $\begin{array}{c}2004 \\
(\mathrm{n}=39)\end{array}$ & $\begin{array}{c}2005 \\
(\mathrm{n}=40)\end{array}$ \\
\hline Não freqüentou escola & - & - & - & - & - \\
\hline $\begin{array}{l}\text { Iniciou o ensino fundamental, mas } \\
\text { abandonou entre a 1a e a 4 a série }\end{array}$ & 5 & 5 & - & - & - \\
\hline $\begin{array}{l}\text { Iniciou o ensino fundamental, mas } \\
\text { abandonou entre a 5a e a 8 }\end{array}$ & 2,5 & 2,5 & 5 & - & 2,5 \\
\hline $\begin{array}{l}\text { Ensino fundamental completo } \\
\text { Ensino médio incompleto }\end{array}$ & 2,5 & 2,5 & - & - & - \\
\hline Ensino médio completo & 2,5 & 10 & 7,5 & 2,5 & 2,5 \\
\hline Universitário incompleto & 12,5 & 17,5 & 22,5 & 20 & 27,5 \\
\hline Universitário completo & 27,5 & 2,5 & 12,5 & 10 & 15 \\
\hline Mestrado ou Doutorado & 35 & 50 & 47,5 & 65 & 50 \\
\hline
\end{tabular}

Questão 7: Qual a situação profissional atual de seu pai?

em \%

\begin{tabular}{|l|c|c|c|c|c|}
\hline & $\begin{array}{c}2001 \\
(\mathrm{n}= \\
40)\end{array}$ & $\begin{array}{c}2002 \\
(\mathrm{n}= \\
40)\end{array}$ & $\begin{array}{c}2003 \\
(\mathrm{n}=40)\end{array}$ & $\begin{array}{c}2004 \\
(\mathrm{n}=39)\end{array}$ & $\begin{array}{c}2005 \\
(\mathrm{n}= \\
40)\end{array}$ \\
\hline Proprietário de empresa grande ou média & - & 2,5 & - & 2,5 & - \\
\hline Proprietário de pequena ou microempresa & 20 & 12,5 & 17,5 & 20 & 12,5 \\
\hline $\begin{array}{l}\text { Funcionário público da administração direta } \\
\text { ou autarquia }\end{array}$ & 15 & 12,5 & 10 & 7,5 & 10 \\
\hline $\begin{array}{l}\text { Profissional liberal, trabalhando por conta } \\
\text { própria }\end{array}$ & 25 & 22,5 & 25 & 30 & 35 \\
\hline $\begin{array}{l}\text { Funcionário de empresa privada ou estatal } \\
\text { Capitalista (vive de rendimento de aluguéis } \\
\text { ou de investimentos financeiros) }\end{array}$ & - & - & - & - & - \\
\hline $\begin{array}{l}\text { Aposentado ou pensionista para } \\
\text { momento, não exerce atividade }\end{array}$ & - & 5 & 7,5 & - & 27,5 \\
\hline $\begin{array}{l}\text { Nomunerada e nem recebe pensão ou } \\
\text { aposentadoria }\end{array}$ & 5 & 5 & 17,5 & 5 & 10 \\
\hline \begin{tabular}{l} 
Outra \\
\hline
\end{tabular} & & 17,5 & 12,5 & 5 & 5 \\
\hline
\end{tabular}


Questão 8: Qual a situação profissional atual de seu mãe?

em \%

\begin{tabular}{|c|c|c|c|c|c|}
\hline & $\begin{array}{l}2001 \\
(\mathrm{n}= \\
40)\end{array}$ & $\begin{array}{l}2002 \\
(\mathrm{n}= \\
40)\end{array}$ & $\begin{array}{c}2003 \\
(n=40)\end{array}$ & $\begin{array}{c}2004 \\
(n=39)\end{array}$ & $\begin{array}{l}2005 \\
(\mathrm{n}= \\
40)\end{array}$ \\
\hline Proprietária de empresa grande ou média & - & - & - & - & - \\
\hline Proprietária de pequena ou microempresa & 5 & 5 & 2,6 & 10 & 5 \\
\hline $\begin{array}{l}\text { Funcionária pública da administração direta } \\
\text { ou autarquia }\end{array}$ & 17,5 & 12,5 & 12,8 & 5 & 17,5 \\
\hline $\begin{array}{l}\text { Profissional liberal, trabalhando por conta } \\
\text { própria }\end{array}$ & 5 & 17,5 & 17,9 & 22,5 & 15 \\
\hline Funcionária de empresa privada ou estatal & 22,5 & 17,5 & 12,8 & 15 & 20 \\
\hline $\begin{array}{l}\text { Capitalista (vive de rendimento de aluguéis } \\
\text { ou de investimentos financeiros) }\end{array}$ & - & - & 2,6 & - & - \\
\hline Aposentada ou pensionista & 12,5 & 10 & 12,8 & 17,5 & 5 \\
\hline $\begin{array}{l}\text { No momento, não exerce atividade } \\
\text { remunerada e nem recebe pensão ou } \\
\text { aposentadoria }\end{array}$ & 30 & 27,5 & 33,3 & 22,5 & 27,5 \\
\hline Outra & 7,5 & 10 & 5,1 & 7,5 & 10 \\
\hline
\end{tabular}

Questão 9: Qual é a sua cor?

em \%

\begin{tabular}{|l|c|c|c|c|c|}
\hline & $\begin{array}{c}2001 \\
(\mathrm{n}=40)\end{array}$ & $\begin{array}{c}2002 \\
(\mathrm{n}=40)\end{array}$ & $\begin{array}{c}2003 \\
(\mathrm{n}=40)\end{array}$ & $\begin{array}{c}2004 \\
(\mathrm{n}=39)\end{array}$ & $\begin{array}{c}2005 \\
(\mathrm{n}=40)\end{array}$ \\
\hline Branca & 90 & 90 & 80 & 97,5 & 85 \\
\hline Preta & - & - & 2,5 & - & - \\
\hline Amarela & 5 & - & 2,5 & - & 2,5 \\
\hline Parda & 5 & 7,5 & 15 & 2,5 & 12,5 \\
\hline Indígena & - & 2,5 & - & - & - \\
\hline
\end{tabular}

Questão 10: Qual é a renda familiar mensal (em reais) de sua casa? em \%

\begin{tabular}{|l|c|c|c|c|c|}
\hline & $\begin{array}{c}2001 \\
(\mathrm{n}=40)\end{array}$ & $\begin{array}{c}2002 \\
(\mathrm{n}=40)\end{array}$ & $\begin{array}{c}2003 \\
(\mathrm{n}=40)\end{array}$ & $\begin{array}{c}2004 \\
(\mathrm{n}=39)\end{array}$ & $\begin{array}{c}2005 \\
(\mathrm{n}=40)\end{array}$ \\
\hline Inferior a 500 & 5 & 2,5 & 2,6 & - & - \\
\hline Entre 500 e 1500 & 12,5 & 22,5 & 15,4 & 10 & 5 \\
\hline Entre 1500 e 3000 & 35 & 25 & 30,8 & 35 & 35 \\
\hline Entre 3000 e 5000 & 25 & 25 & 20,5 & 20 & 20 \\
\hline Entre 5000 e 7000 & 12,5 & 7,5 & 12,8 & 10 & 17,5 \\
\hline Entre 7000 e 10000 & 2,5 & 12,5 & 5,1 & 12,5 & 12,5 \\
\hline Superior a 10000 & 7,5 & 5 & 12,8 & 12,5 & 10 \\
\hline
\end{tabular}


Questão 11: Quantas pessoas contribuem para a obtenção dessa renda familiar?

\begin{tabular}{|l|c|c|c|c|c|}
\hline & $\begin{array}{c}2001 \\
(\mathrm{n}=40)\end{array}$ & $\begin{array}{c}2002 \\
(\mathrm{n}=40)\end{array}$ & $\begin{array}{c}2003 \\
(\mathrm{n}=40)\end{array}$ & $\begin{array}{c}2004 \\
(\mathrm{n}=39)\end{array}$ & $\begin{array}{c}2005 \\
(\mathrm{n}=40)\end{array}$ \\
\hline Uma & 42,5 & 40 & 45 & 30 & 32,5 \\
\hline Duas & 55 & 55 & 42,5 & 65 & 65 \\
\hline Três & 2,5 & 2,5 & 7,5 & 2,5 & 2,5 \\
\hline Quatro & - & - & 5 & 2,5 & - \\
\hline Cinco ou mais & - & 2,5 & - & - & - \\
\hline
\end{tabular}

Questão 12: Quantas pessoas são sustentadas com a renda familiar?

\begin{tabular}{|l|c|c|c|c|c|}
\hline & $\begin{array}{c}2001 \\
(\mathrm{n}=40)\end{array}$ & $\begin{array}{c}2002 \\
(\mathrm{n}=40)\end{array}$ & $\begin{array}{c}2003 \\
(\mathrm{n}=40)\end{array}$ & $\begin{array}{c}2004 \\
(\mathrm{n}=39)\end{array}$ & $\begin{array}{c}2005 \\
(\mathrm{n}=40)\end{array}$ \\
\hline Uma & 5 & - & 2,5 & - & - \\
\hline Duas & - & 2,5 & 2,5 & 5 & 2,5 \\
\hline Três & 12,5 & 7,5 & 12,5 & 22,5 & 20 \\
\hline Quatro & 45 & 60 & 45 & 35 & 47,5 \\
\hline Cinco & 32,5 & 12,5 & 30 & 27,5 & 25 \\
\hline Seis & 2,5 & 17,5 & 5 & 10 & 5 \\
\hline Sete & 2,5 & - & 2,5 & - & - \\
\hline Oito ou mais & - & - & - & - & - \\
\hline
\end{tabular}

Questão 13: Você exerce atualmente atividade remunerada?

\begin{tabular}{|l|c|c|c|c|c|}
\hline & $\begin{array}{c}2001 \\
(\mathrm{n}=40)\end{array}$ & $\begin{array}{c}2002 \\
(\mathrm{n}=40)\end{array}$ & $\begin{array}{c}2003 \\
(\mathrm{n}=40)\end{array}$ & $\begin{array}{c}2004 \\
(\mathrm{n}=39)\end{array}$ & $\begin{array}{c}2005 \\
(\mathrm{n}=40)\end{array}$ \\
\hline Não & 92,5 & 92,5 & 85 & 90 & 90 \\
\hline Eventualmente & 5 & 5 & 12,5 & 7,5 & 5 \\
\hline Em meio-período (até 20 horas semanais) & - & - & - & 2,5 & 2,5 \\
\hline $\begin{array}{l}\text { Em período semi-integral (de 21 a 32 horas } \\
\text { semanais) }\end{array}$ & - & 2,5 & - & - & - \\
\hline $\begin{array}{l}\text { Em tempo integral (mais de 32 horas } \\
\text { semanais) }\end{array}$ & 2,5 & - & 2,5 & - & - \\
\hline
\end{tabular}


Questão 14: Como pretende se manter durante seus estudos universitários?

\begin{tabular}{|l|c|c|c|c|c|}
\hline & $\begin{array}{c}2001 \\
(\mathrm{n}= \\
40)\end{array}$ & $\begin{array}{c}2002 \\
(\mathrm{n}= \\
40)\end{array}$ & $\begin{array}{c}2003 \\
(\mathrm{n}=40)\end{array}$ & $\begin{array}{c}2004 \\
(\mathrm{n}=39)\end{array}$ & $\begin{array}{c}2005 \\
(\mathrm{n}= \\
40)\end{array}$ \\
\hline Somente com recursos dos pais & 30 & 40 & 27,5 & 45 & 41 \\
\hline $\begin{array}{l}\text { Trabalhando, mas contando, para o } \\
\text { essencial, com os recursos da família }\end{array}$ & 40 & 37,5 & 42,5 & 45 & 41 \\
\hline $\begin{array}{l}\text { Trabalhando para participar do rateio das } \\
\text { despesas da família }\end{array}$ & 5 & 5 & 2,5 & 2,5 & - \\
\hline $\begin{array}{l}\text { Por minha conta, com recursos oriundos de } \\
\text { trabalho remunerado }\end{array}$ & - & - & 7,5 & 5 & - \\
\hline $\begin{array}{l}\text { Com bolsa de estudos ou crédito educativo } \\
\text { bolsa ou crédito educativo, }\end{array}$ & 5 & 7,5 & 2,5 & - & - \\
\hline $\begin{array}{l}\text { Com apoio } \\
\text { trabalhando e contando ainda com o apoília } \\
\text { da família }\end{array}$ & 5 & - & 2,5 & 2,5 & 2,6 \\
\hline \begin{tabular}{l} 
Outros \\
\hline
\end{tabular} & & 15 & - & 15,4 \\
\hline
\end{tabular}

Questão 15: Quantos carros existem em sua casa?

\begin{tabular}{|l|c|c|c|c|c|}
\hline & $\begin{array}{c}2001 \\
(\mathrm{n}=40)\end{array}$ & $\begin{array}{c}2002 \\
(\mathrm{n}=40)\end{array}$ & $\begin{array}{c}2003 \\
(\mathrm{n}=40)\end{array}$ & $\begin{array}{c}2004 \\
(\mathrm{n}=39)\end{array}$ & $\begin{array}{c}2005 \\
(\mathrm{n}=40)\end{array}$ \\
\hline Nenhum & 5 & 10 & 7,5 & 2,5 & 2,5 \\
\hline Um & 37,5 & 37,5 & 42,5 & 40 & 42,5 \\
\hline Dois & & & & & 32,5 \\
\hline Três & 37,5 & 40 & 37,5 & 42,5 \\
\hline Quatro & 17,5 & 10 & 10 & 22,5 & 10 \\
\hline Cinco ou mais & 2,5 & 2,5 & 2,5 & 2,5 & 2,5 \\
\hline
\end{tabular}

Questão 16: Quantos microcomputadores existem em sua casa?

\begin{tabular}{|l|c|c|c|c|c|}
\hline & $\begin{array}{c}2001 \\
(\mathrm{n}=40)\end{array}$ & $\begin{array}{c}2002 \\
(\mathrm{n}=40)\end{array}$ & $\begin{array}{c}2003 \\
(\mathrm{n}=40)\end{array}$ & $\begin{array}{c}2004 \\
(\mathrm{n}=39)\end{array}$ & $\begin{array}{c}2005 \\
(\mathrm{n}=40)\end{array}$ \\
\hline Nenhum & 10 & 10 & 12,5 & 5 & 2,5 \\
\hline Um & 87,5 & 67,5 & 75 & 80 & 67,5 \\
\hline Dois & 2,5 & 20 & 12,5 & 15 & 20 \\
\hline Três & - & - & - & - & 10 \\
\hline Quatro ou mais & - & 2,5 & - & - & - \\
\hline
\end{tabular}


Questão 17: Você acessa a Internet?

\begin{tabular}{|l|c|c|c|c|c|}
\hline & $\begin{array}{c}2001 \\
(\mathrm{n}=40)\end{array}$ & $\begin{array}{c}2002 \\
(\mathrm{n}=40)\end{array}$ & $\begin{array}{c}2003 \\
(\mathrm{n}=40)\end{array}$ & $\begin{array}{c}2004 \\
(\mathrm{n}=39)\end{array}$ & $\begin{array}{c}2005 \\
(\mathrm{n}=40)\end{array}$ \\
\hline Não & 17,5 & 15 & 7,5 & 2,5 & 2,5 \\
\hline De vez em quando & 47,5 & 60 & 37,5 & 30 & 22,5 \\
\hline Freqüentemente & 35 & 25 & 55 & 67,5 & 75 \\
\hline
\end{tabular}




\section{CURSO MEDICINA E CIÊNCIAS MÉDICAS ${ }^{72}$}

(Fonte FUVEST)

Questão 1: Onde fez seus estudos de ensino fundamental?

\begin{tabular}{|l|c|c|c|c|c|}
\hline & $\begin{array}{c}2001 \\
(\mathrm{n}=477)\end{array}$ & $\begin{array}{c}2002 \\
(\mathrm{n}=373)\end{array}$ & $\begin{array}{c}2003 \\
(\mathrm{n}=373)\end{array}$ & $\begin{array}{c}2004 \\
(\mathrm{n}=373)\end{array}$ & $\begin{array}{c}2005 \\
(\mathrm{n}=374)\end{array}$ \\
\hline Só em escola pública & 8,6 & 7,2 & 8,5 & 7 & 5,9 \\
\hline Só em escola particular & 73,8 & 81 & 77,1 & 79,4 & 78,6 \\
\hline Maior parte em escola pública & 7,8 & 3,2 & 5,9 & 4,3 & 1,9 \\
\hline Maior parte em escola particular & 7,1 & 5,6 & 5,1 & 6,7 & 8,8 \\
\hline Metade em cada tipo de escola & 2,5 & 2,7 & 3,2 & 2,4 & 4,5 \\
\hline No exterior (qualquer tipo de escola) & 0,2 & 0,3 & 0,3 & 0,3 & 0,3 \\
\hline
\end{tabular}

Questão 2: Onde você realizou seus estudos de ensino médio?

\begin{tabular}{|l|c|c|c|c|c|}
\hline & $\begin{array}{c}2001 \\
(\mathrm{n}=477)\end{array}$ & $\begin{array}{c}2002 \\
(\mathrm{n}=373)\end{array}$ & $\begin{array}{c}2003 \\
(\mathrm{n}=373)\end{array}$ & $\begin{array}{c}2004 \\
(\mathrm{n}=373)\end{array}$ & $\begin{array}{c}2005 \\
(\mathrm{n}=374)\end{array}$ \\
\hline Só em escola pública & 5,1 & 4,5 & 3,5 & 3,2 & 2,9 \\
\hline Só em escola pública federal & 2,1 & 1,1 & 1,9 & 2,1 & 3,5 \\
\hline Só em escola particular & 88,4 & 91,4 & 88,8 & 91,2 & 91,7 \\
\hline Maior parte em escola pública & 0,8 & 0,8 & 1,6 & 1,1 & 1,1 \\
\hline Maior parte em escola particular & 3,4 & 1,6 & 2,9 & 2,1 & 0,8 \\
\hline Metade em cada tipo de escola & 0,2 & 0,3 & 0,3 & 0,3 & - \\
\hline Em supletivo ou madureza & - & 0,3 & - & - & - \\
\hline No exterior (qualquer tipo de escola) & - & - & 0,8 & - & - \\
\hline
\end{tabular}

Questão 3: Em que período você realizou seus estudos de ensino médio?

\begin{tabular}{|l|c|c|c|c|c|}
\hline & $\begin{array}{c}2001 \\
(\mathrm{n}= \\
477)\end{array}$ & $\begin{array}{c}2002 \\
(\mathrm{n}= \\
373)\end{array}$ & $\begin{array}{c}2003 \\
(\mathrm{n}=373)\end{array}$ & $\begin{array}{c}2004 \\
(\mathrm{n}=373)\end{array}$ & $\begin{array}{c}2005 \\
(\mathrm{n}= \\
374)\end{array}$ \\
\hline Diurno (só de manhã ou só a tarde) & 90,1 & 85,8 & 88,5 & 87,6 & 84,8 \\
\hline Diurno integral (manhã e tarde) & 4,6 & 7,2 & 6,4 & 6,5 & 9,6 \\
\hline Noturno & 0,6 & 1,6 & 1,3 & 0,5 & 0,8 \\
\hline Maior parte diurno & 4,4 & 4,5 & 3,2 & 5,1 & 4 \\
\hline Maior parte noturno & 0,2 & 0,8 & 0,5 & 0,3 & 0,3 \\
\hline Metade no diurno, metade no noturno & - & - & - & - & - \\
\hline
\end{tabular}

\footnotetext{
${ }^{72} \mathrm{~N}^{\mathrm{o}}$ de alunos engloba também o curso de Medicina da USP de São Paulo.
} 
Questão 4: Você se preparou, por quanto tempo, ou está se preparando em algum cursinho pré-vestibular?

\begin{tabular}{|l|c|c|c|c|c|}
\hline & $\begin{array}{c}2001 \\
(\mathrm{n}=477)\end{array}$ & $\begin{array}{c}2002 \\
(\mathrm{n}=373)\end{array}$ & $\begin{array}{c}2003 \\
(\mathrm{n}=373)\end{array}$ & $\begin{array}{c}2004 \\
(\mathrm{n}=373)\end{array}$ & $\begin{array}{c}2005 \\
(\mathrm{n}=374)\end{array}$ \\
\hline Não & 13,2 & 14,7 & 13,3 & 15,1 & 14,7 \\
\hline Sim, menos de um semestre & 2,5 & 3,2 & 0,8 & 1,6 & 2,1 \\
\hline Sim, um semestre completo & 2,3 & 2,4 & 3,7 & 3,5 & 2,4 \\
\hline Sim, de um semestre a um ano & 32,8 & 28,2 & 27,5 & 29,6 & 29,7 \\
\hline Sim, de um ano a um ano e meio & 11,5 & 10,7 & 7,2 & 10,8 & 10,2 \\
\hline Sim, de um ano e meio a dois & 23 & 26 & 27,7 & 21,2 & 24,1 \\
\hline Sim, mais de dois anos & 14,6 & 14,5 & 19,7 & 18,3 & 16,8 \\
\hline
\end{tabular}

Questão 5: Qual o grau de instrução mais alto que seu pai obteve?

\begin{tabular}{|l|c|c|c|c|c|}
\hline & $\begin{array}{c}2001 \\
(\mathrm{n}=477)\end{array}$ & $\begin{array}{c}2002 \\
(\mathrm{n}=373)\end{array}$ & $\begin{array}{c}2003 \\
(\mathrm{n}=373)\end{array}$ & $\begin{array}{c}2004 \\
(\mathrm{n}=373)\end{array}$ & $\begin{array}{c}2005 \\
(\mathrm{n}=374)\end{array}$ \\
\hline Não freqüentou escola & 0,2 & - & - & - & 0,3 \\
\hline $\begin{array}{l}\text { Iniciou o ensino fundamental, mas } \\
\text { abandonou entre a 1 }{ }^{\mathrm{a}} \text { e a 4 }\end{array}$ & 1,1 & 1,6 & 2,4 & 0,8 & 0,3 \\
\hline $\begin{array}{l}\text { Iniciou o ensino fundamental, mas } \\
\text { abandonou entre a 5 e a 8 }\end{array}$ & 1,9 & 1,3 & 2,9 & 1,3 & 1,6 \\
\hline Ensino fundamental completo & 2,5 & 2,7 & 1,3 & 1,1 & 0,8 \\
\hline Ensino médio incompleto & 1,1 & 1,3 & 2,1 & 1,6 & 1,6 \\
\hline Ensino médio completo & 10,5 & 9,4 & 8,8 & 9,1 & 8,3 \\
\hline Universitário incompleto & 7,1 & 3,7 & 7,8 & 7,5 & 7 \\
\hline Universitário completo & 61,6 & 66,3 & 60,3 & 61,6 & 65,1 \\
\hline Mestrado ou Doutorado & 14,1 & 13,6 & 14,2 & 16,9 & 15 \\
\hline
\end{tabular}


Questão 6: Qual o grau de instrução mais alto que sua mãe obteve?

\begin{tabular}{|l|c|c|c|c|c|}
\hline & $\begin{array}{c}2001 \\
(\mathrm{n}=477)\end{array}$ & $\begin{array}{c}2002 \\
(\mathrm{n}=373)\end{array}$ & $\begin{array}{c}2003 \\
(\mathrm{n}=373)\end{array}$ & $\begin{array}{c}2004 \\
(\mathrm{n}=373)\end{array}$ & $\begin{array}{c}2005 \\
(\mathrm{n}=374)\end{array}$ \\
\hline Não freqüentou escola & - & - & - & - & - \\
\hline $\begin{array}{l}\text { Iniciou o ensino fundamental, mas } \\
\text { abandonou entre a 1 }\end{array}$ & 1,3 & 0,3 & 0,5 & 1,3 & 1,6 \\
\hline $\begin{array}{l}\text { Iniciou o e ensino fundamental, mas } \\
\text { abandonou entre a 5a e a 8 }\end{array}$ & 1,9 & 2,1 & 2,4 & 1,9 & 1,1 \\
\hline $\begin{array}{l}\text { Ensino fundamental completo } \\
\text { Ensino médio incompleto }\end{array}$ & 1,9 & 1,9 & 3,2 & 2,7 & 1,6 \\
\hline Ensino médio completo & 2,3 & 0,5 & 3,2 & 1,6 & 2,1 \\
\hline Universitário incompleto & 17,1 & 13,7 & 15,5 & 16,1 & 13,6 \\
\hline Universitário completo & 9,3 & 11 & 8,5 & 9,7 & 8,3 \\
\hline Mestrado ou Doutorado & 58,5 & 61,7 & 57,6 & 57,1 & 63,4 \\
\hline
\end{tabular}

Questão 7: Qual a situação profissional atual de seu pai?

em \%

\begin{tabular}{|c|c|c|c|c|c|}
\hline & $\begin{array}{l}2001 \\
(\mathrm{n}= \\
477)\end{array}$ & $\begin{array}{l}2002 \\
(\mathrm{n}= \\
373)\end{array}$ & $\begin{aligned} & 2003 \\
&(\mathrm{n} \\
&=373) \\
&\end{aligned}$ & $\begin{array}{c}2004 \\
(n=373)\end{array}$ & $\begin{array}{l}2005 \\
(\mathrm{n}= \\
374)\end{array}$ \\
\hline Proprietário de empresa grande ou média & 2,5 & 2,1 & 1,9 & 2,4 & 0,8 \\
\hline Proprietário de pequena ou microempresa & 17,4 & 16,4 & 15,9 & 16,2 & 16,1 \\
\hline $\begin{array}{l}\text { Funcionário público da administração direta } \\
\text { ou autarquia }\end{array}$ & 9,3 & 11,5 & 10,5 & 8,4 & 14,2 \\
\hline $\begin{array}{l}\text { Profissional liberal, trabalhando por conta } \\
\text { própria }\end{array}$ & 33,3 & 30,3 & 33,2 & 32,1 & 31,1 \\
\hline Funcionário de empresa privada ou estatal & 21,9 & 24,7 & 19,7 & 23,7 & 24,4 \\
\hline $\begin{array}{l}\text { Capitalista (vive de rendimento de aluguéis } \\
\text { ou de investimentos financeiros) }\end{array}$ & 0,4 & - & 1,6 & 1,1 & 1,1 \\
\hline Aposentado ou pensionista & 8,5 & 7,8 & 10,2 & 8,6 & 4,6 \\
\hline $\begin{array}{l}\text { No momento, não exerce atividade } \\
\text { remunerada e nem recebe pensão ou } \\
\text { aposentadoria }\end{array}$ & 3,2 & 1,6 & 2,4 & 2,7 & 2,1 \\
\hline Outra & 3,4 & 5,6 & 4,6 & 4,9 & 5,6 \\
\hline
\end{tabular}


Questão 8: Qual a situação profissional atual de seu mãe?

em \%

\begin{tabular}{|c|c|c|c|c|c|}
\hline & $\begin{array}{l}2001 \\
(\mathrm{n}= \\
477)\end{array}$ & $\begin{array}{l}2002 \\
(\mathrm{n}= \\
373)\end{array}$ & $\begin{array}{l}2003 \\
(\mathrm{n}= \\
373)\end{array}$ & $\begin{array}{c}2004 \\
(n=373)\end{array}$ & $\begin{array}{l}2005 \\
(\mathrm{n}= \\
374)\end{array}$ \\
\hline Proprietária de empresa grande ou média & 1,1 & 0,8 & 1,1 & 0,5 & 0,3 \\
\hline Proprietária de pequena ou microempresa & 9,2 & 11,6 & 9,1 & 9,1 & 9,9 \\
\hline $\begin{array}{l}\text { Funcionária pública da administração direta } \\
\text { ou autarquia }\end{array}$ & 11,6 & 15,1 & 15,7 & 13,4 & 17,5 \\
\hline $\begin{array}{l}\text { Profissional liberal, trabalhando por conta } \\
\text { própria }\end{array}$ & 20,6 & 16,7 & 21,1 & 18 & 21 \\
\hline Funcionária de empresa privada ou estatal & 16,8 & 16,1 & 14,4 & 17,7 & 16,9 \\
\hline $\begin{array}{l}\text { Capitalista (vive de rendimento de aluguéis } \\
\text { ou de investimentos financeiros) }\end{array}$ & 0,8 & 1,3 & 0,5 & 1,1 & 1,1 \\
\hline Aposentada ou pensionista & 9,9 & 10,2 & 8,5 & 9,1 & 7 \\
\hline $\begin{array}{l}\text { No momento, não exerce atividade } \\
\text { remunerada e nem recebe pensão ou } \\
\text { aposentadoria }\end{array}$ & 23,5 & 23,1 & 24,8 & 25,8 & 22,3 \\
\hline Outra & 6,5 & 5,1 & 4,8 & 5,1 & 4 \\
\hline
\end{tabular}

Questão 9: Qual é a sua cor?

em \%

\begin{tabular}{|l|c|c|c|c|c|}
\hline & $\begin{array}{c}2001 \\
(\mathrm{n}=477)\end{array}$ & $\begin{array}{c}2002 \\
(\mathrm{n}=373)\end{array}$ & $\begin{array}{c}2003 \\
(\mathrm{n}=373)\end{array}$ & $\begin{array}{c}2004 \\
(\mathrm{n}=373)\end{array}$ & $\begin{array}{c}2005 \\
(\mathrm{n}=374)\end{array}$ \\
\hline Branca & 80,9 & 76,7 & 78,8 & 77,5 & 75,8 \\
\hline Preta & 0,4 & 0,5 & 0,5 & - & 0,3 \\
\hline Amarela & 14,7 & 14,4 & 15 & 14,7 & 14,5 \\
\hline Parda & 4 & 8 & 4,6 & 7,5 & 9,1 \\
\hline Indígena & - & 0,3 & 0,8 & - & 0,3 \\
\hline
\end{tabular}

Questão 10: Qual é a renda familiar mensal (em reais) de sua casa?

\begin{tabular}{|l|c|c|c|c|c|}
\hline & $\begin{array}{c}2001 \\
(\mathrm{n}=477)\end{array}$ & $\begin{array}{c}2002 \\
(\mathrm{n}=373)\end{array}$ & $\begin{array}{c}2003 \\
(\mathrm{n}=373)\end{array}$ & $\begin{array}{c}2004 \\
(\mathrm{n}=373)\end{array}$ & $\begin{array}{c}2005 \\
(\mathrm{n}=374)\end{array}$ \\
\hline Inferior a 500 & 1,1 & 0,5 & 1,3 & - & 0,5 \\
\hline Entre 500 e 1500 & 6,5 & 6,5 & 8 & 4,8 & 6,5 \\
\hline Entre 1500 e 3000 & 21,1 & 21,6 & 20,1 & 20,2 & 18,4 \\
\hline Entre 3000 e 5000 & 24,4 & 23,5 & 27,1 & 23,7 & 24,1 \\
\hline Entre 5000 e 7000 & 17,1 & 17,6 & 17,2 & 18,3 & 19,2 \\
\hline Entre 7000 e 10000 & 15,8 & 15,7 & 13,1 & 14,5 & 16,5 \\
\hline Superior a 10000 & 14,1 & 14,6 & 13,1 & 18,3 & 14,9 \\
\hline
\end{tabular}


Questão 11: Quantas pessoas contribuem para a obtenção dessa renda familiar?

\begin{tabular}{|l|c|c|c|c|c|}
\hline & $\begin{array}{c}2001 \\
(\mathrm{n}=477)\end{array}$ & $\begin{array}{c}2002 \\
(\mathrm{n}=373)\end{array}$ & $\begin{array}{c}2003 \\
(\mathrm{n}=373)\end{array}$ & $\begin{array}{c}2004 \\
(\mathrm{n}=373)\end{array}$ & $\begin{array}{c}2005 \\
(\mathrm{n}=374)\end{array}$ \\
\hline Uma & 35,6 & 34,9 & 36,1 & 34,6 & 32,8 \\
\hline Duas & 59,1 & 61,6 & 57 & 58,4 & 62,6 \\
\hline Três & 3,8 & 3 & 5,1 & 4,6 & 2,7 \\
\hline Quatro & 0,8 & 0,5 & 1,6 & 1,9 & 1,1 \\
\hline Cinco ou mais & 0,6 & - & - & 0,3 & 0,3 \\
\hline
\end{tabular}

Questão 12: Quantas pessoas são sustentadas com a renda familiar? em \%

\begin{tabular}{|l|c|c|c|c|c|}
\hline & $\begin{array}{c}2001 \\
(\mathrm{n}=477)\end{array}$ & $\begin{array}{c}2002 \\
(\mathrm{n}=373)\end{array}$ & $\begin{array}{c}2003 \\
(\mathrm{n}=373)\end{array}$ & $\begin{array}{c}2004 \\
(\mathrm{n}=373)\end{array}$ & $\begin{array}{c}2005 \\
(\mathrm{n}=374)\end{array}$ \\
\hline Uma & 0,2 & 0,8 & 2,1 & 0,5 & 0,5 \\
\hline Duas & 1,2 & 3 & 4,3 & 2,4 & 1,9 \\
\hline Três & 8,5 & 10,8 & 13,9 & 11,6 & 16,7 \\
\hline Quatro & 44,9 & 44,9 & 43,7 & 47,6 & 47 \\
\hline Cinco & 35,6 & 29 & 25,9 & 26,6 & 26,9 \\
\hline Seis & 7,2 & 7,3 & 5,9 & 7,8 & 5,1 \\
\hline Sete & 1,4 & 3 & 3,2 & 1,9 & 1,6 \\
\hline Oito ou mais & 0,8 & 1,3 & 0,8 & 1,3 & 0,3 \\
\hline
\end{tabular}

Questão 13: Você exerce atualmente atividade remunerada?

\begin{tabular}{|l|c|c|c|c|c|}
\hline & $\begin{array}{c}2001 \\
(\mathrm{n}= \\
477)\end{array}$ & $\begin{array}{c}2002 \\
(\mathrm{n}= \\
373)\end{array}$ & $\begin{array}{c}2003 \\
(\mathrm{n}= \\
373)\end{array}$ & $\begin{array}{c}2004 \\
(\mathrm{n}=373)\end{array}$ & $\begin{array}{c}2005 \\
(\mathrm{n}= \\
374)\end{array}$ \\
\hline Não & 95,6 & 94,4 & 93,9 & 95,2 & 94,9 \\
\hline Eventualmente & 3,1 & 4,3 & 3,5 & 3,5 & 3,8 \\
\hline Em meio-período (até 20 horas semanais) & 0,8 & 0,8 & 1,3 & 0,8 & 0,3 \\
\hline $\begin{array}{l}\text { Em período semi-integral (de 21 a 32 horas } \\
\text { semanais) }\end{array}$ & 0,2 & - & 0,5 & - & 0,3 \\
\hline $\begin{array}{l}\text { Em tempo integral (mais de 32 horas } \\
\text { semanais) }\end{array}$ & 0,2 & 0,5 & 0,5 & 0,5 & 0,8 \\
\hline
\end{tabular}


Questão 14: Como pretende se manter durante seus estudos universitários?

em \%

\begin{tabular}{|l|c|c|c|c|c|}
\hline & $\begin{array}{c}2001 \\
(\mathrm{n}= \\
477)\end{array}$ & $\begin{array}{c}2002 \\
(\mathrm{n}= \\
373)\end{array}$ & $\begin{array}{c}2003 \\
(\mathrm{n}= \\
373)\end{array}$ & $\begin{array}{c}2004 \\
(\mathrm{n}=373)\end{array}$ & $\begin{array}{c}2005 \\
(\mathrm{n}= \\
374)\end{array}$ \\
\hline Somente com recursos dos pais contando, para o & 23,6 & 19,3 & 20,5 & 20,7 & 22,6 \\
\hline $\begin{array}{l}\text { Trabalhando, mas cos } \\
\text { essencial, com os recursos da família }\end{array}$ & 1,3 & 2,4 & 0,5 & 0,5 & 1,6 \\
\hline $\begin{array}{l}\text { Trabalhando para participar do rateio das } \\
\text { despesas da família }\end{array}$ & 1,1 & 1,3 & 0,8 & 0,8 & 0,8 \\
\hline $\begin{array}{l}\text { Por minha conta, com recursos oriundos de } \\
\text { trabalho remunerado }\end{array}$ & 2,9 & 1,1 & 2,4 & 3 & 1,9 \\
\hline $\begin{array}{l}\text { Com bolsa de estudos ou crédito educativo } \\
\text { bolsa ou crédito educativo, }\end{array}$ & 5,7 & 5,6 & 6,9 & 4,8 & 5,4 \\
\hline $\begin{array}{l}\text { Com am com o apoio } \\
\text { trabalhando e contando ainda com } \\
\text { da família }\end{array}$ & 0,8 & 1,1 & 1,6 & 1,3 & 1,9 \\
\hline \begin{tabular}{l} 
Outros \\
\hline
\end{tabular}
\end{tabular}

Questão 15: Quantos carros existem em sua casa?

\begin{tabular}{|l|c|c|c|c|c|}
\hline & $\begin{array}{c}2001 \\
(\mathrm{n}=477)\end{array}$ & $\begin{array}{c}2002 \\
(\mathrm{n}=373)\end{array}$ & $\begin{array}{c}2003 \\
(\mathrm{n}=373)\end{array}$ & $\begin{array}{c}2004 \\
(\mathrm{n}=373)\end{array}$ & $\begin{array}{c}2005 \\
(\mathrm{n}=374)\end{array}$ \\
\hline Nenhum & 2,9 & 4,8 & 4,3 & 3,5 & 7,3 \\
\hline Um & 28,3 & 25,1 & 31,2 & 29,6 & 27,7 \\
\hline Dois & 43,4 & 43,3 & 44,5 & 42,2 & 44,9 \\
\hline Três & 18 & 20,3 & 13,9 & 18 & 14,5 \\
\hline Quatro & 6,5 & 5,3 & 4,3 & 3,8 & 4,6 \\
\hline Cinco ou mais & 0,8 & 0,8 & 1,9 & 3 & 1,1 \\
\hline
\end{tabular}

Questão 16: Quantos microcomputadores existem em sua casa?

\begin{tabular}{|l|c|c|c|c|c|}
\hline & $\begin{array}{c}2001 \\
(\mathrm{n}=477)\end{array}$ & $\begin{array}{c}2002 \\
(\mathrm{n}=373)\end{array}$ & $\begin{array}{c}2003 \\
(\mathrm{n}=373)\end{array}$ & $\begin{array}{c}2004 \\
(\mathrm{n}=373)\end{array}$ & $\begin{array}{c}2005 \\
(\mathrm{n}=374)\end{array}$ \\
\hline Nenhum & 9,8 & 9,9 & 7,2 & 5,9 & 4,3 \\
\hline Um & 72,4 & 64,9 & 70,7 & 63,1 & 63,2 \\
\hline Dois & 15 & 20,4 & 18,7 & 23,7 & 23,7 \\
\hline Três & 2,7 & 3,5 & 2,7 & 5,9 & 7 \\
\hline Quatro ou mais & - & 1,3 & 0,8 & 1,3 & 1,9 \\
\hline
\end{tabular}


Questão 17: Você acessa a Internet?

\begin{tabular}{|l|c|c|c|c|c|}
\hline & $\begin{array}{c}2001 \\
(\mathrm{n}=477)\end{array}$ & $\begin{array}{c}2002 \\
(\mathrm{n}=373)\end{array}$ & $\begin{array}{c}2003 \\
(\mathrm{n}=373)\end{array}$ & $\begin{array}{c}2004 \\
(\mathrm{n}=373)\end{array}$ & $\begin{array}{c}2005 \\
(\mathrm{n}=374)\end{array}$ \\
\hline Não & 10,4 & 7 & 6,1 & 1,9 & 2,7 \\
\hline De vez em quando & 41,9 & 46 & 41,1 & 42,3 & 36,2 \\
\hline Freqüentemente & 47,7 & 47 & 52,8 & 55,8 & 61,1 \\
\hline
\end{tabular}




\section{CURSO CIÊNCIAS BIOLÓGICAS}

(Fonte FUVEST)

Questão 1: Onde fez seus estudos de ensino fundamental?

\begin{tabular}{|l|c|c|c|c|c|}
\hline & $\begin{array}{c}2001 \\
(\mathrm{n}=40)\end{array}$ & $\begin{array}{c}2002 \\
(\mathrm{n}=40)\end{array}$ & $\begin{array}{c}2003 \\
(\mathrm{n}=40)\end{array}$ & $\begin{array}{c}2004 \\
(\mathrm{n}=40)\end{array}$ & $\begin{array}{c}2005 \\
(\mathrm{n}=40)\end{array}$ \\
\hline Só em escola pública & 32,5 & 25 & 27,5 & 20 & 30 \\
\hline Só em escola particular & 47,5 & 50 & 47,5 & 47,5 & 45 \\
\hline Maior parte em escola pública & 10 & 7,5 & 10 & 12,5 & 5 \\
\hline Maior parte em escola particular & 7,5 & 15 & 12,5 & 12,5 & 17,5 \\
\hline Metade em cada tipo de escola & 2,5 & 2,5 & 2,5 & 7,5 & 2,5 \\
\hline
\end{tabular}

Questão 2: Onde você realizou seus estudos de ensino médio?

\begin{tabular}{|l|c|c|c|c|c|}
\hline & $\begin{array}{c}2001 \\
(\mathrm{n}=40)\end{array}$ & $\begin{array}{c}2002 \\
(\mathrm{n}=40)\end{array}$ & $\begin{array}{c}2003 \\
(\mathrm{n}=40)\end{array}$ & $\begin{array}{c}2004 \\
(\mathrm{n}=40)\end{array}$ & $\begin{array}{c}2005 \\
(\mathrm{n}=40)\end{array}$ \\
\hline Só em escola pública & 10 & 10 & 12,5 & 7,5 & 10 \\
\hline Só em escola pública federal & - & - & - & - & - \\
\hline Só em escola particular & 82,5 & 87,5 & 82,5 & 85 & 82,5 \\
\hline Maior parte em escola pública & 5 & - & - & 2,5 & 2,5 \\
\hline Maior parte em escola particular & 2,5 & 2,5 & 5 & 5 & 5 \\
\hline Metade em cada tipo de escola & - & - & - & - & - \\
\hline No exterior (qualquer tipo de escola) & - & - & - & - & - \\
\hline
\end{tabular}

Questão 3: Em que período você realizou seus estudos de ensino médio? em \%

\begin{tabular}{|l|c|c|c|c|c|}
\hline & $\begin{array}{c}2001 \\
(\mathrm{n}=40)\end{array}$ & $\begin{array}{c}2002 \\
(\mathrm{n}=40)\end{array}$ & $\begin{array}{c}2003 \\
(\mathrm{n}=40)\end{array}$ & $\begin{array}{c}2004 \\
(\mathrm{n}=40)\end{array}$ & $\begin{array}{c}2005 \\
(\mathrm{n}=40)\end{array}$ \\
\hline Diurno (só de manhã ou só a tarde) & 87,5 & 92,5 & 82,5 & 82,5 & 90 \\
\hline Diurno integral (manhã e tarde) & 5 & 5 & 7,5 & 7,5 & 2,5 \\
\hline Noturno & 2,5 & - & 2,5 & - & - \\
\hline Maior parte diurno & 5 & 2,5 & 7,5 & 10 & 7,5 \\
\hline Maior parte noturno & - & - & - & - & - \\
\hline Metade no diurno, metade no noturno & - & - & - & - & - \\
\hline
\end{tabular}


Questão 4: Você se preparou, por quanto tempo, ou está se preparando em algum cursinho pré-vestibular?

\begin{tabular}{|l|c|c|c|c|c|}
\hline & $\begin{array}{c}2001 \\
(\mathrm{n}=40)\end{array}$ & $\begin{array}{c}2002 \\
(\mathrm{n}=40)\end{array}$ & $\begin{array}{c}2003 \\
(\mathrm{n}=40)\end{array}$ & $\begin{array}{c}2004 \\
(\mathrm{n}=40)\end{array}$ & $\begin{array}{c}2005 \\
(\mathrm{n}=40)\end{array}$ \\
\hline Não & 28,2 & 32,5 & 42,5 & 32,5 & 41 \\
\hline Sim, menos de um semestre & - & - & 2,5 & 5 & 2,6 \\
\hline Sim, um semestre completo & - & 7,5 & 2,5 & 7,5 & 2,6 \\
\hline Sim, de um semestre a um ano & 38,5 & 30 & 27,5 & 32,5 & 28,2 \\
\hline Sim, de um ano a um ano e meio & - & 15 & 10 & - & 5,1 \\
\hline Sim, de um ano e meio a dois & 20,5 & 7,5 & 12,5 & 22,5 & 10,3 \\
\hline Sim, mais de dois anos & 12,8 & 7,5 & 2,5 & - & 10,3 \\
\hline
\end{tabular}

Questão 5: Qual o grau de instrução mais alto que seu pai obteve?

\begin{tabular}{|l|c|c|c|c|c|}
\hline & $\begin{array}{c}2001 \\
(\mathrm{n}=40)\end{array}$ & $\begin{array}{c}2002 \\
(\mathrm{n}=40)\end{array}$ & $\begin{array}{c}2003 \\
(\mathrm{n}=40)\end{array}$ & $\begin{array}{c}2004 \\
(\mathrm{n}=40)\end{array}$ & $\begin{array}{c}2005 \\
(\mathrm{n}=40)\end{array}$ \\
\hline Não freqüentou escola & - & - & - & - & - \\
\hline $\begin{array}{l}\text { Iniciou o ensino fundamental, mas } \\
\text { abandonou entre a 1 }\end{array}$ & 5 & 2,5 & 7,5 & - & 2,5 \\
\hline $\begin{array}{l}\text { Iniciou o } 4^{\mathrm{a}} \text { série } \\
\text { abandonsino fundamental, mas }\end{array}$ & 7,5 & - & 5 & 5 & - \\
\hline $\begin{array}{l}\text { Ensino fundamental completo } \\
\text { Ensino médio incompleto }\end{array}$ & 5 & 5 & - & 5 & 2,5 \\
\hline Ensino médio completo & 7,5 & - & 5 & 5 & 5 \\
\hline Universitário incompleto & 12,5 & 12,5 & 20 & 12,5 & 17,5 \\
\hline Universitário completo & 10 & 15 & 5 & 12,5 & 15 \\
\hline Mestrado ou Doutorado & 45 & 52,5 & 52,5 & 40 & 50 \\
\hline
\end{tabular}


Questão 6: Qual o grau de instrução mais alto que sua mãe obteve?

\begin{tabular}{|l|c|c|c|c|c|}
\hline & $\begin{array}{c}2001 \\
(\mathrm{n}=40)\end{array}$ & $\begin{array}{c}2002 \\
(\mathrm{n}=40)\end{array}$ & $\begin{array}{c}2003 \\
(\mathrm{n}=40)\end{array}$ & $\begin{array}{c}2004 \\
(\mathrm{n}=40)\end{array}$ & $\begin{array}{c}2005 \\
(\mathrm{n}=40)\end{array}$ \\
\hline Não freqüentou escola & - & - & - & - & - \\
\hline $\begin{array}{l}\text { Iniciou o ensino fundamental, mas } \\
\text { abandonou entre a 1a e a 4 }\end{array}$ & 5 & 2,5 & 5 & 2,5 & 5 \\
\hline $\begin{array}{l}\text { Iniciou o ensino fundamental, mas } \\
\text { abandonou entre a 5a e a 8 }\end{array}$ & - & - & 7,5 & 5 & 2,5 \\
\hline Ensino fundamental completo & 7,5 & - & 2,5 & 2,5 & 2,5 \\
\hline Ensino médio incompleto & - & 2,5 & 7,5 & 5 & 2,5 \\
\hline Ensino médio completo & 35 & 20 & 17,5 & 15 & 20 \\
\hline Universitário incompleto & 5 & 15 & 7,5 & 5 & 7,5 \\
\hline Universitário completo & 37,5 & 47,5 & 45 & 57,5 & 50 \\
\hline Mestrado ou Doutorado & 10 & 12,5 & 7,5 & 7,5 & 10 \\
\hline
\end{tabular}

Questão 7: Qual a situação profissional atual de seu pai?

\begin{tabular}{|l|c|c|c|c|c|}
\hline & $\begin{array}{c}2001 \\
(\mathrm{n}= \\
40)\end{array}$ & $\begin{array}{c}2002 \\
(\mathrm{n}= \\
40)\end{array}$ & $\begin{array}{c}2003 \\
(\mathrm{n}=40)\end{array}$ & $\begin{array}{c}2004 \\
(\mathrm{n}=40)\end{array}$ & $\begin{array}{c}2005 \\
(\mathrm{n}= \\
40)\end{array}$ \\
\hline Proprietário de empresa grande ou média & - & 2,5 & 2,5 & - & - \\
\hline Proprietário de pequena ou microempresa & 15,4 & 17,5 & 15 & 5 & 7,7 \\
\hline $\begin{array}{l}\text { Funcionário público da administração direta } \\
\text { ou autarquia }\end{array}$ & 7,7 & 20 & 5 & 20 & 7,7 \\
\hline $\begin{array}{l}\text { Profissional liberal, trabalhando por conta } \\
\text { própria }\end{array}$ & 33,3 & 15 & 30 & 25 & 17,9 \\
\hline $\begin{array}{l}\text { Funcionário de empresa privada ou estatal } \\
\text { Capitalista (vive de rendimento de aluguéis } \\
\text { ou de investimentos financeiros) }\end{array}$ & - & - & - & - & - \\
\hline $\begin{array}{l}\text { Aposentado ou pensionista } \\
\text { No momento, não exerce atividade } \\
\text { remunerada e nem recebe pensão ou } \\
\text { aposentadoria }\end{array}$ & 2,6 & 5 & - & - & 2,6 \\
\hline \begin{tabular}{l} 
Outra \\
\hline
\end{tabular} & 7,7 & 2,5 & 12,5 & 2,5 & - \\
\hline
\end{tabular}


Questão 8: Qual a situação profissional atual de seu mãe?

em \%

\begin{tabular}{|l|c|c|c|c|c|}
\hline & $\begin{array}{c}2001 \\
(\mathrm{n}= \\
40)\end{array}$ & $\begin{array}{c}2002 \\
(\mathrm{n}= \\
40)\end{array}$ & $\begin{array}{c}2003 \\
(\mathrm{n}=40)\end{array}$ & $\begin{array}{c}2004 \\
(\mathrm{n}=40)\end{array}$ & $\begin{array}{c}2005 \\
(\mathrm{n}= \\
40)\end{array}$ \\
\hline Proprietária de empresa grande ou média & - & - & - & - & - \\
\hline Proprietária de pequena ou microempresa & 15 & 15 & 10 & 10 & 5 \\
\hline $\begin{array}{l}\text { Funcionária pública da administração direta } \\
\text { ou autarquia }\end{array}$ & 12,5 & 27,5 & 22,5 & 27,5 & 7,5 \\
\hline $\begin{array}{l}\text { Profissional liberal, trabalhando por conta } \\
\text { própria }\end{array}$ & 17,5 & 7,5 & 5 & 22,5 & 12,5 \\
\hline $\begin{array}{l}\text { Funcionária de empresa privada ou estatal } \\
\text { Capitalista (vive de rendimento de aluguéis }\end{array}$ & 22,5 & 17,5 & 17,5 & 17,5 & 27,5 \\
\hline ou de investimentos financeiros) & 10 & 17,5 & 10 & 5 & 15 \\
\hline $\begin{array}{l}\text { Aposentada ou pensionista } \\
\text { momento, não exerce atividade }\end{array}$ & 20 & 7,5 & 27,5 & 12,5 & 27,5 \\
\hline $\begin{array}{l}\text { Nomunerada e nem recebe pensão ou } \\
\text { aposentadoria }\end{array}$ & 2,5 & 7,5 & 7,5 & 5 & 2,5 \\
\hline \begin{tabular}{l} 
Outra \\
\hline
\end{tabular}
\end{tabular}

Questão 9: Qual é a sua cor?

em \%

\begin{tabular}{|l|c|c|c|c|c|}
\hline & $\begin{array}{c}2001 \\
(\mathrm{n}=40)\end{array}$ & $\begin{array}{c}2002 \\
(\mathrm{n}=40)\end{array}$ & $\begin{array}{c}2003 \\
(\mathrm{n}=40)\end{array}$ & $\begin{array}{c}2004 \\
(\mathrm{n}=40)\end{array}$ & $\begin{array}{c}2005 \\
(\mathrm{n}=40)\end{array}$ \\
\hline Branca & 82,5 & 92,5 & 92,5 & 75 & 82,1 \\
\hline Preta & 2,5 & 2,5 & - & - & - \\
\hline Amarela & 7,5 & 2,5 & - & 10 & 10,3 \\
\hline Parda & 7,5 & 2,5 & 7,5 & 15 & 7,7 \\
\hline Indígena & - & - & - & - & - \\
\hline
\end{tabular}

Questão 10: Qual é a renda familiar mensal (em reais) de sua casa? em \%

\begin{tabular}{|l|c|c|c|c|c|}
\hline & $\begin{array}{c}2001 \\
(\mathrm{n}=40)\end{array}$ & $\begin{array}{c}2002 \\
(\mathrm{n}=40)\end{array}$ & $\begin{array}{c}2003 \\
(\mathrm{n}=40)\end{array}$ & $\begin{array}{c}2004 \\
(\mathrm{n}=40)\end{array}$ & $\begin{array}{c}2005 \\
(\mathrm{n}=40)\end{array}$ \\
\hline Inferior a 500 & 2,6 & - & 5,1 & - & - \\
\hline Entre 500 e 1500 & 12,8 & 12,5 & 12,8 & 10 & 10 \\
\hline Entre 1500 e 3000 & 33,3 & 45 & 28,2 & 35 & 40 \\
\hline Entre 3000 e 5000 & 41 & 12,5 & 33,3 & 17,5 & 20 \\
\hline Entre 5000 e 7000 & 5,1 & 22,5 & 20,5 & 30 & 22,5 \\
\hline Entre 7000 e 10000 & 5,1 & 2,5 & - & 7,5 & 2,5 \\
\hline Superior a 10000 & - & 5 & - & - & 5 \\
\hline
\end{tabular}


Questão 11: Quantas pessoas contribuem para a obtenção dessa renda familiar?

\begin{tabular}{|l|c|c|c|c|c|}
\hline & $\begin{array}{c}2001 \\
(\mathrm{n}=40)\end{array}$ & $\begin{array}{c}2002 \\
(\mathrm{n}=40)\end{array}$ & $\begin{array}{c}2003 \\
(\mathrm{n}=40)\end{array}$ & $\begin{array}{c}2004 \\
(\mathrm{n}=40)\end{array}$ & $\begin{array}{c}2005 \\
(\mathrm{n}=40)\end{array}$ \\
\hline Uma & 30 & 22,5 & 27,5 & 17,5 & 35 \\
\hline Duas & 62,5 & 67,5 & 65 & 72,5 & 55 \\
\hline Três & 5 & 7,5 & 5 & 7,5 & 5 \\
\hline Quatro & - & - & - & 2,5 & 5 \\
\hline Cinco ou mais & 2,5 & 2,5 & 2,5 & - & - \\
\hline
\end{tabular}

Questão 12: Quantas pessoas são sustentadas com a renda familiar?

\begin{tabular}{|l|c|c|c|c|c|}
\hline & $\begin{array}{c}2001 \\
(\mathrm{n}=40)\end{array}$ & $\begin{array}{c}2002 \\
(\mathrm{n}=40)\end{array}$ & $\begin{array}{c}2003 \\
(\mathrm{n}=40)\end{array}$ & $\begin{array}{c}2004 \\
(\mathrm{n}=40)\end{array}$ & $\begin{array}{c}2005 \\
(\mathrm{n}=40)\end{array}$ \\
\hline Uma & - & - & - & - & - \\
\hline Duas & 2,5 & 2,5 & - & - & 2,5 \\
\hline Três & 12,5 & 15 & 15 & 10 & 2,5 \\
\hline Quatro & 35 & 42,5 & 47,5 & 45 & 55 \\
\hline Cinco & 40 & 30 & 25 & 42,5 & 35 \\
\hline Seis & 5 & 10 & 10 & 2,5 & 2,5 \\
\hline Sete & 5 & - & - & - & 2,5 \\
\hline Oito ou mais & - & - & 2,5 & - & - \\
\hline
\end{tabular}

Questão 13: Você exerce atualmente atividade remunerada?

\begin{tabular}{|l|c|c|c|c|c|}
\hline & $\begin{array}{c}2001 \\
(\mathrm{n}=40)\end{array}$ & $\begin{array}{c}2002 \\
(\mathrm{n}=40)\end{array}$ & $\begin{array}{c}2003 \\
(\mathrm{n}=40)\end{array}$ & $\begin{array}{c}2004 \\
(\mathrm{n}=40)\end{array}$ & $\begin{array}{c}2005 \\
(\mathrm{n}=40)\end{array}$ \\
\hline Não & 95 & 97,5 & 90 & 97,5 & 90 \\
\hline Eventualmente & 5 & 2,5 & 2,5 & 2,5 & 7,5 \\
\hline Em meio-período (até 20 horas semanais) & - & - & 5 & - & 2,5 \\
\hline $\begin{array}{l}\text { Em período semi-integral (de 21 a 32 horas } \\
\text { semanais) }\end{array}$ & - & - & - & - & - \\
\hline $\begin{array}{l}\text { Em tempo integral (mais de 32 horas } \\
\text { semanais) }\end{array}$ & - & - & 2,5 & - & - \\
\hline
\end{tabular}


Questão 14: Como pretende se manter durante seus estudos universitários?

em \%

\begin{tabular}{|l|c|c|c|c|c|}
\hline & $\begin{array}{c}2001 \\
(\mathrm{n}= \\
40)\end{array}$ & $\begin{array}{c}2002 \\
(\mathrm{n}= \\
40)\end{array}$ & $\begin{array}{c}2003 \\
(\mathrm{n}=40)\end{array}$ & $\begin{array}{c}2004 \\
(\mathrm{n}=40)\end{array}$ & $\begin{array}{c}2005 \\
(\mathrm{n}= \\
40)\end{array}$ \\
\hline Somente com recursos dos pais contando, para o & 40 & 32,5 & 32,5 & 27,5 & 37,5 \\
\hline $\begin{array}{l}\text { Trabalhando, mas con } \\
\text { essencial, com os recursos da família }\end{array}$ & 45 & 47,5 & 50 & 37,5 \\
\hline $\begin{array}{l}\text { Trabalhando para participar do rateio das } \\
\text { despesas da família }\end{array}$ & - & - & - & - & 2,5 \\
\hline $\begin{array}{l}\text { Por minha conta, com recursos oriundos de } \\
\text { trabalho remunerado }\end{array}$ & - & 2,5 & 2,5 & - & 5 \\
\hline $\begin{array}{l}\text { Com bolsa de estudos ou crédito educativo } \\
\text { bolsa ou crédito educativo, }\end{array}$ & 5 & 2,5 & 5 & 2,5 & 7,5 \\
\hline $\begin{array}{l}\text { Com am } \\
\text { trabalhando e contando ainda com o apoio } \\
\text { da família }\end{array}$ & - & - & - & 5 & - \\
\hline \begin{tabular}{l} 
Outros \\
\hline
\end{tabular} & & 17,5 & 15 & 10 \\
\hline
\end{tabular}

Questão 15: Quantos carros existem em sua casa?

\begin{tabular}{|c|c|c|c|c|c|}
\hline \multicolumn{6}{|c|}{ em \% } \\
\hline & $\begin{array}{c}2001 \\
(\mathrm{n}=40)\end{array}$ & $\begin{array}{c}2002 \\
(\mathrm{n}=40)\end{array}$ & $\begin{array}{c}2003 \\
(\mathrm{n}=40)\end{array}$ & $\begin{array}{c}2004 \\
(n=40)\end{array}$ & $\begin{array}{c}2005 \\
(\mathrm{n}=40)\end{array}$ \\
\hline Nenhum & 10 & 2,5 & 5 & 7,5 & 7,5 \\
\hline Um & 37,5 & 42,5 & 27,5 & 42,5 & 47,5 \\
\hline Dois & 50 & 47,5 & 57,5 & 45 & 37,5 \\
\hline Três & 2,5 & 2,5 & 10 & 5 & 2,5 \\
\hline Quatro & - & 5 & - & - & 2,5 \\
\hline Cinco ou mais & - & - & - & - & - \\
\hline
\end{tabular}

Questão 16: Quantos microcomputadores existem em sua casa?

\begin{tabular}{|c|c|c|c|c|c|}
\hline \multicolumn{6}{|c|}{ em \% } \\
\hline & $\begin{array}{c}2001 \\
(n=40)\end{array}$ & $\begin{array}{c}2002 \\
(n=40)\end{array}$ & $\begin{array}{c}2003 \\
(n=40)\end{array}$ & $\begin{array}{c}2004 \\
(\mathrm{n}=40)\end{array}$ & $\begin{array}{c}2005 \\
(n=40)\end{array}$ \\
\hline Nenhum & 12,5 & 7,5 & 12,5 & 10 & 7,5 \\
\hline Um & 85 & 77,5 & 77,5 & 72,5 & 67,5 \\
\hline Dois & 2,5 & 15 & 10 & 15 & 20 \\
\hline Três & - & - & - & 2,5 & 2,5 \\
\hline Quatro ou mais & - & - & - & - & 2,5 \\
\hline
\end{tabular}


Questão 17: Você acessa a Internet? em \%

\begin{tabular}{|l|c|c|c|c|c|}
\hline & $\begin{array}{c}2001 \\
(\mathrm{n}=40)\end{array}$ & $\begin{array}{c}2002 \\
(\mathrm{n}=40)\end{array}$ & $\begin{array}{c}2003 \\
(\mathrm{n}=40)\end{array}$ & $\begin{array}{c}2004 \\
(\mathrm{n}=40)\end{array}$ & $\begin{array}{c}2005 \\
(\mathrm{n}=40)\end{array}$ \\
\hline Não & 17,5 & 7,5 & 5 & 7,5 & 5 \\
\hline De vez em quando & 85 & 40 & 40 & 32,5 & 35 \\
\hline Freqüentemente & 2,5 & 52,5 & 55 & 60 & 60 \\
\hline
\end{tabular}




\section{CURSO ADMINISTRAÇÃO}

(Fonte FUVEST)

Questão 1: Onde fez seus estudos de ensino fundamental?

em \%

\begin{tabular}{|l|c|c|c|c|c|}
\hline & $\begin{array}{c}2001 \\
(\mathrm{n}=44)\end{array}$ & $\begin{array}{c}2002 \\
(\mathrm{n}=44)\end{array}$ & $\begin{array}{c}2003 \\
(\mathrm{n}=44)\end{array}$ & $\begin{array}{c}2004 \\
(\mathrm{n}=45)\end{array}$ & $\begin{array}{c}2005 \\
(\mathrm{n}=45)\end{array}$ \\
\hline Só em escola pública & 6,8 & 9,1 & 18,2 & 2,2 & 11,1 \\
\hline Só em escola particular & 72,7 & 72,7 & 56,8 & 77,8 & 62,2 \\
\hline Maior parte em escola pública & 9,1 & 6,8 & 6,8 & 6,7 & 11,1 \\
\hline Maior parte em escola particular & 6,8 & 9,1 & 9,1 & 4,4 & 11,1 \\
\hline Metade em cada tipo de escola & 4,5 & 2,3 & 6,8 & 8,9 & 4,4 \\
\hline
\end{tabular}

Questão 2: Onde você realizou seus estudos de ensino médio?

\begin{tabular}{|l|c|c|c|c|c|}
\hline & $\begin{array}{c}2001 \\
(\mathrm{n}=44)\end{array}$ & $\begin{array}{c}2002 \\
(\mathrm{n}=44)\end{array}$ & $\begin{array}{c}2003 \\
(\mathrm{n}=44)\end{array}$ & $\begin{array}{c}2004 \\
(\mathrm{n}=45)\end{array}$ & $\begin{array}{c}2005 \\
(\mathrm{n}=45)\end{array}$ \\
\hline Só em escola pública & 4,5 & 2,3 & 4,5 & - & 6,7 \\
\hline Só em escola pública federal & - & 2,3 & - & 6,7 & - \\
\hline Só em escola particular & 84,1 & 84,1 & 86,4 & 91,1 & 86,7 \\
\hline Maior parte em escola pública & - & 2,3 & 6,8 & 2,2 & 2,2 \\
\hline Maior parte em escola particular & 6,8 & 6,8 & 2,3 & - & 2,2 \\
\hline Metade em cada tipo de escola & 2,3 & - & - & - & 2,2 \\
\hline Em supletivo ou madureza & - & 2,3 & - & - & - \\
\hline No exterior (qualquer tipo de escola) & 2,3 & - & - & - & - \\
\hline
\end{tabular}

Questão 3: Em que período você realizou seus estudos de ensino médio? em \%

\begin{tabular}{|l|c|c|c|c|c|}
\hline & $\begin{array}{c}2001 \\
(\mathrm{n}=44)\end{array}$ & $\begin{array}{c}2002 \\
(\mathrm{n}=44)\end{array}$ & $\begin{array}{c}2003 \\
(\mathrm{n}=44)\end{array}$ & $\begin{array}{c}2004 \\
(\mathrm{n}=45)\end{array}$ & $\begin{array}{c}2005 \\
(\mathrm{n}=45)\end{array}$ \\
\hline Diurno (só de manhã ou só a tarde) & 84,1 & 88,6 & 95,5 & 84,4 & 91,1 \\
\hline Diurno integral (manhã e tarde) & 6,8 & 4,5 & - & 8,9 & 4,4 \\
\hline Noturno & - & - & - & - & - \\
\hline Maior parte diurno & 6,8 & 4,5 & 4,5 & 4,4 & 4,4 \\
\hline Maior parte noturno & 2,3 & - & - & - & - \\
\hline Metade no diurno, metade no noturno & - & 2,3 & - & 2,2 & - \\
\hline
\end{tabular}


Questão 4: Você se preparou, por quanto tempo, ou está se preparando em algum cursinho pré-vestibular?

\begin{tabular}{|l|c|c|c|c|c|}
\hline & $\begin{array}{c}2001 \\
(\mathrm{n}=44)\end{array}$ & $\begin{array}{c}2002 \\
(\mathrm{n}=44)\end{array}$ & $\begin{array}{c}2003 \\
(\mathrm{n}=44)\end{array}$ & $\begin{array}{c}2004 \\
(\mathrm{n}=45)\end{array}$ & $\begin{array}{c}2005 \\
(\mathrm{n}=45)\end{array}$ \\
\hline Não & 30,2 & 36,4 & 43,2 & 35,6 & 31,1 \\
\hline Sim, menos de um semestre & 4,7 & 4,5 & - & 6,7 & 2,2 \\
\hline Sim, um semestre completo & 7 & 9,1 & 4,5 & 4,4 & 2,2 \\
\hline Sim, de um semestre a um ano & 34,9 & 29,5 & 25 & 20 & 46,7 \\
\hline Sim, de um ano a um ano e meio & 4,7 & 4,5 & 6,8 & 11,1 & 4,4 \\
\hline Sim, de um ano e meio a dois & 16,3 & 13,6 & 15,9 & 15,6 & 11,1 \\
\hline Sim, mais de dois anos & 2,3 & 2,3 & 4,5 & 6,7 & 2,2 \\
\hline
\end{tabular}

Questão 5: Qual o grau de instrução mais alto que seu pai obteve?

\begin{tabular}{|l|c|c|c|c|c|}
\hline & $\begin{array}{c}2001 \\
(\mathrm{n}=44)\end{array}$ & $\begin{array}{c}2002 \\
(\mathrm{n}=44)\end{array}$ & $\begin{array}{c}2003 \\
(\mathrm{n}=44)\end{array}$ & $\begin{array}{c}2004 \\
(\mathrm{n}=45)\end{array}$ & $\begin{array}{c}2005 \\
(\mathrm{n}=45)\end{array}$ \\
\hline Não freqüentou escola & - & - & - & - & - \\
\hline $\begin{array}{l}\text { Iniciou o ensino fundamental, mas } \\
\text { abandonou entre a 1a e a 4a série }\end{array}$ & - & 4,5 & 2,3 & 2,2 & - \\
\hline $\begin{array}{l}\text { Iniciou o ensino fundamental, mas } \\
\text { abandonou entre a 5a e a 8 }\end{array}$ & - & - & - & - & - \\
\hline $\begin{array}{l}\text { Ensino fundamental completo } \\
\text { Ensino médio incompleto }\end{array}$ & - & - & 6,8 & - & 6,7 \\
\hline Ensino médio completo & 2,3 & - & 6,8 & - & 4,4 \\
\hline Universitário incompleto & 9,1 & 9,1 & 13,6 & 15,6 & 6,7 \\
\hline Universitário completo & 18,2 & 9,1 & 6,8 & 11,1 & 15,6 \\
\hline Mestrado ou Doutorado & 54,5 & 68,2 & 54,5 & 60 & 55,6 \\
\hline
\end{tabular}


Questão 6: Qual o grau de instrução mais alto que sua mãe obteve?

\begin{tabular}{|l|c|c|c|c|c|}
\hline & $\begin{array}{c}2001 \\
(\mathrm{n}=44)\end{array}$ & $\begin{array}{c}2002 \\
(\mathrm{n}=44)\end{array}$ & $\begin{array}{c}2003 \\
(\mathrm{n}=44)\end{array}$ & $\begin{array}{c}2004 \\
(\mathrm{n}=45)\end{array}$ & $\begin{array}{c}2005 \\
(\mathrm{n}=45)\end{array}$ \\
\hline Não freqüentou escola & - & - & - & - & - \\
\hline $\begin{array}{l}\text { Iniciou o ensino fundamental, mas } \\
\text { abandonou entre a 1a e a 4a série }\end{array}$ & - & - & 6,8 & - & - \\
\hline $\begin{array}{l}\text { Iniciou o ensino fundamental, mas } \\
\text { abandonou entre a 5a e a 8 }{ }^{\mathrm{a}} \text { série }\end{array}$ & 2,3 & 2,3 & 2,3 & - & 4,4 \\
\hline $\begin{array}{l}\text { Ensino fundamental completo } \\
\text { Ensino médio incompleto }\end{array}$ & - & - & - & 4,4 & - \\
\hline Ensino médio completo & 13,6 & 11,4 & 18,2 & 11,1 & 24,4 \\
\hline Universitário incompleto & 13,6 & 11,4 & 2,3 & 8,9 & 13,3 \\
\hline Universitário completo & 61,4 & 70,5 & 63,6 & 62,2 & 37,8 \\
\hline Mestrado ou Doutorado & 4,5 & 2,3 & 4,5 & 8,9 & 20 \\
\hline
\end{tabular}

Questão 7: Qual a situação profissional atual de seu pai?

em \%

\begin{tabular}{|c|c|c|c|c|c|}
\hline & $\begin{array}{l}2001 \\
(\mathrm{n}= \\
44)\end{array}$ & $\begin{array}{l}2002 \\
(n= \\
44)\end{array}$ & $\begin{array}{c}2003 \\
(n=44)\end{array}$ & $\begin{array}{c}2004 \\
(n=45)\end{array}$ & $\begin{array}{l}2005 \\
(\mathrm{n}= \\
45)\end{array}$ \\
\hline Proprietário de empresa grande ou média & 11,4 & 2,3 & 11,4 & 6,7 & 2,2 \\
\hline Proprietário de pequena ou microempresa & 13,6 & 22,7 & 15,9 & 17,8 & 31,1 \\
\hline $\begin{array}{l}\text { Funcionário público da administração direta } \\
\text { ou autarquia }\end{array}$ & 2,3 & 20,5 & 11,4 & 6,7 & 11,1 \\
\hline $\begin{array}{l}\text { Profissional liberal, trabalhando por conta } \\
\text { própria }\end{array}$ & 25 & 29,5 & 11,4 & 22,2 & 17,8 \\
\hline Funcionário de empresa privada ou estatal & 29,5 & 11,4 & 38,6 & 35,6 & 22,2 \\
\hline $\begin{array}{l}\text { Capitalista (vive de rendimento de aluguéis } \\
\text { ou de investimentos financeiros) }\end{array}$ & - & - & - & - & 2,2 \\
\hline Aposentado ou pensionista & 6,8 & 9,1 & 11,4 & 6,7 & 4,4 \\
\hline $\begin{array}{l}\text { No momento, não exerce atividade } \\
\text { remunerada e nem recebe pensão ou } \\
\text { aposentadoria }\end{array}$ & 2,3 & 2,3 & - & - & 4,4 \\
\hline Outra & 9,1 & 2,3 & - & 4,4 & 4,4 \\
\hline
\end{tabular}


Questão 8: Qual a situação profissional atual de seu mãe?

em \%

\begin{tabular}{|l|c|c|c|c|c|}
\hline & $\begin{array}{c}2001 \\
(\mathrm{n}= \\
44)\end{array}$ & $\begin{array}{c}2002 \\
(\mathrm{n}= \\
44)\end{array}$ & $\begin{array}{c}2003 \\
(\mathrm{n}=44)\end{array}$ & $\begin{array}{c}2004 \\
(\mathrm{n}=45)\end{array}$ & $\begin{array}{c}2005 \\
(\mathrm{n}= \\
45)\end{array}$ \\
\hline Proprietária de empresa grande ou média & 4,5 & - & 4,5 & 4,5 & - \\
\hline Proprietária de pequena ou microempresa & 13,6 & 18,2 & 11,4 & 9,1 & 15,6 \\
\hline $\begin{array}{l}\text { Funcionária pública da administração direta } \\
\text { ou autarquia }\end{array}$ & 6,8 & 22,7 & 20,5 & 25 & 20 \\
\hline $\begin{array}{l}\text { Profissional liberal, trabalhando por conta } \\
\text { própria }\end{array}$ & 15,9 & 22,7 & 18,2 & 25 & 11,1 \\
\hline $\begin{array}{l}\text { Funcionária de empresa privada ou estatal } \\
\text { Capitalista (vive de rendimento de aluguéis } \\
\text { ou de investimentos financeiros) }\end{array}$ & - & - & 2,3 & - & 2,2 \\
\hline $\begin{array}{l}\text { Aposentada ou pensionista } \\
\text { momento, não exerce atividade }\end{array}$ & 18,2 & 18,2 & 15,9 & 4,5 & 17,8 \\
\hline $\begin{array}{l}\text { Nemunerada e nem recebe pensão ou } \\
\text { aposentadoria }\end{array}$ & 6,8 & 2,3 & 9,1 & 6,8 & 4,4 \\
\hline \begin{tabular}{l} 
Outra \\
\hline
\end{tabular} & $6,8,4$ & 9,1 & 24,4 \\
\hline
\end{tabular}

Questão 9: Qual é a sua cor?

em \%

\begin{tabular}{|l|c|c|c|c|c|}
\hline & $\begin{array}{c}2001 \\
(\mathrm{n}=44)\end{array}$ & $\begin{array}{c}2002 \\
(\mathrm{n}=44)\end{array}$ & $\begin{array}{c}2003 \\
(\mathrm{n}=44)\end{array}$ & $\begin{array}{c}2004 \\
(\mathrm{n}=45)\end{array}$ & $\begin{array}{c}2005 \\
(\mathrm{n}=45)\end{array}$ \\
\hline Branca & 100 & 90,9 & 97,7 & 86,7 & 86,7 \\
\hline Preta & - & - & - & - & - \\
\hline Amarela & - & 2,3 & - & 4,4 & - \\
\hline Parda & - & 6,8 & 2,3 & 8,9 & 13,3 \\
\hline Indígena & - & - & - & - & - \\
\hline
\end{tabular}

Questão 10: Qual é a renda familiar mensal (em reais) de sua casa?

\begin{tabular}{|l|c|c|c|c|c|}
\hline & $\begin{array}{c}2001 \\
(\mathrm{n}=44)\end{array}$ & $\begin{array}{c}2002 \\
(\mathrm{n}=44)\end{array}$ & $\begin{array}{c}2003 \\
(\mathrm{n}=44)\end{array}$ & $\begin{array}{c}2004 \\
(\mathrm{n}=45)\end{array}$ & $\begin{array}{c}2005 \\
(\mathrm{n}=45)\end{array}$ \\
\hline Inferior a 500 & - & - & 4,5 & - & - \\
\hline Entre 500 e 1500 & 9,1 & 9,1 & 18,2 & 4,4 & 4,4 \\
\hline Entre 1500 e 3000 & 20,5 & 25 & 18,2 & 24,4 & 22,2 \\
\hline Entre 3000 e 5000 & 36,4 & 34,1 & 20,5 & 20 & 24,4 \\
\hline Entre 5000 e 7000 & 11,4 & 22,7 & 20,5 & 17,8 & 22,2 \\
\hline Entre 7000 e 10000 & 13,6 & 4,5 & 13,6 & 13,3 & 13,3 \\
\hline Superior a 10000 & 9,1 & 4,5 & 4,5 & 20 & 13,3 \\
\hline
\end{tabular}


Questão 11: Quantas pessoas contribuem para a obtenção dessa renda familiar?

\begin{tabular}{|l|c|c|c|c|c|}
\hline & $\begin{array}{c}2001 \\
(\mathrm{n}=44)\end{array}$ & $\begin{array}{c}2002 \\
(\mathrm{n}=44)\end{array}$ & $\begin{array}{c}2003 \\
(\mathrm{n}=44)\end{array}$ & $\begin{array}{c}2004 \\
(\mathrm{n}=45)\end{array}$ & $\begin{array}{c}2005 \\
(\mathrm{n}=45)\end{array}$ \\
\hline Uma & 31,8 & 29,5 & 27,3 & 22,2 & 24,4 \\
\hline Duas & & & & & \\
\hline Três & 65,9 & 65,9 & 63,6 & 68,9 & 62,2 \\
\hline Quatro & - & 4,5 & 6,8 & 4,4 & 11,1 \\
\hline Cinco ou mais & - & - & 2,3 & 2,2 & 2,2 \\
\hline
\end{tabular}

Questão 12: Quantas pessoas são sustentadas com a renda familiar?

\begin{tabular}{|l|c|c|c|c|c|}
\hline & $\begin{array}{c}2001 \\
(\mathrm{n}=44)\end{array}$ & $\begin{array}{c}2002 \\
(\mathrm{n}=44)\end{array}$ & $\begin{array}{c}2003 \\
(\mathrm{n}=44)\end{array}$ & $\begin{array}{c}2004 \\
(\mathrm{n}=45)\end{array}$ & $\begin{array}{c}2005 \\
(\mathrm{n}=45)\end{array}$ \\
\hline Uma & - & - & - & 2,2 & - \\
\hline Duas & - & 2,3 & 4,5 & - & - \\
\hline Três & 15,9 & 15,9 & 15,9 & 11,1 & 8,9 \\
\hline Quatro & 31,8 & 22,7 & 40,9 & 53,3 & 53,3 \\
\hline Cinco & 43,2 & 43,2 & 34,1 & 22,2 & 35,6 \\
\hline Seis & 6,8 & 13,6 & 2,3 & 4,4 & 2,2 \\
\hline Sete & - & - & 2,3 & 4,4 & - \\
\hline Oito ou mais & 2,3 & 2,3 & - & 2,2 & - \\
\hline
\end{tabular}

Questão 13: Você exerce atualmente atividade remunerada?

\begin{tabular}{|l|c|c|c|c|c|}
\hline & $\begin{array}{c}2001 \\
(\mathrm{n}=44)\end{array}$ & $\begin{array}{c}2002 \\
(\mathrm{n}=44)\end{array}$ & $\begin{array}{c}2003 \\
(\mathrm{n}=44)\end{array}$ & $\begin{array}{c}2004 \\
(\mathrm{n}=45)\end{array}$ & $\begin{array}{c}2005 \\
(\mathrm{n}=45)\end{array}$ \\
\hline Não & 84,1 & 90,9 & 90,9 & 93,3 & 93,3 \\
\hline Eventualmente & 6,8 & 4,5 & - & - & - \\
\hline Em meio-período (até 20 horas semanais) & 6,8 & 2,3 & - & - & 2,2 \\
\hline $\begin{array}{l}\text { Em período semi-integral (de 21 a 32 horas } \\
\text { semanais) }\end{array}$ & 2,3 & - & 4,5 & 2,2 & - \\
\hline $\begin{array}{l}\text { Em tempo integral (mais de 32 horas } \\
\text { semanais) }\end{array}$ & - & 2,3 & 4,5 & 4,4 & 4,4 \\
\hline
\end{tabular}


Questão 14: Como pretende se manter durante seus estudos universitários?

em \%

\begin{tabular}{|c|c|c|c|c|c|}
\hline & $\begin{array}{c}2001 \\
(\mathrm{n}= \\
44)\end{array}$ & $\begin{array}{l}2002 \\
(\mathrm{n}= \\
44)\end{array}$ & $\begin{array}{c}2003 \\
(n=44)\end{array}$ & $\begin{array}{c}2004 \\
(n=45)\end{array}$ & $\begin{array}{l}2005 \\
(\mathrm{n}= \\
45)\end{array}$ \\
\hline Somente com recursos dos pais & 25 & 11,4 & 22,7 & 33,3 & 17,8 \\
\hline $\begin{array}{l}\text { Trabalhando, mas contando, para } 0 \\
\text { essencial, com os recursos da família }\end{array}$ & 56,8 & 61,4 & 54,5 & 57,8 & 66,7 \\
\hline $\begin{array}{l}\text { Trabalhando para participar do rateio das } \\
\text { despesas da família }\end{array}$ & 9,1 & 13,6 & 2,3 & 4,4 & - \\
\hline $\begin{array}{l}\text { Por minha conta, com recursos oriundos de } \\
\text { trabalho remunerado }\end{array}$ & 4,5 & 2,3 & 13,6 & 2,2 & 8,9 \\
\hline Com bolsa de estudos ou crédito educativo & - & 2,3 & 2,3 & - & 2,2 \\
\hline $\begin{array}{l}\text { Com bolsa ou crédito educativo, } \\
\text { trabalhando e contando ainda com o apoio } \\
\text { da família }\end{array}$ & 4,5 & 9,1 & 2,3 & 2,2 & 2,2 \\
\hline Outros & - & - & 2,3 & - & 2,2 \\
\hline
\end{tabular}

Questão 15: Quantos carros existem em sua casa?

\begin{tabular}{|l|c|c|c|c|c|}
\hline & $\begin{array}{c}2001 \\
(\mathrm{n}=44)\end{array}$ & $\begin{array}{c}2002 \\
(\mathrm{n}=44)\end{array}$ & $\begin{array}{c}2003 \\
(\mathrm{n}=44)\end{array}$ & $\begin{array}{c}2004 \\
(\mathrm{n}=45)\end{array}$ & $\begin{array}{c}2005 \\
(\mathrm{n}=45)\end{array}$ \\
\hline Nenhum & 9,1 & 2,3 & 11,4 & 2,2 & 2,2 \\
\hline Um & 20,5 & 31,8 & 27,3 & 24,4 & 35,6 \\
\hline Dois & & & & & 53,3 \\
\hline Três & 50 & 56,8 & 29,5 & 42,2 \\
\hline Quatro & 20,5 & 6,8 & 29,5 & 15,6 & 15,6 \\
\hline Cinco ou mais & - & - & 2,3 & 4,4 & 4,4 \\
\hline
\end{tabular}

Questão 16: Quantos microcomputadores existem em sua casa?

\begin{tabular}{|l|c|c|c|c|c|}
\hline & $\begin{array}{c}2001 \\
(\mathrm{n}=44)\end{array}$ & $\begin{array}{c}2002 \\
(\mathrm{n}=44)\end{array}$ & $\begin{array}{c}2003 \\
(\mathrm{n}=44)\end{array}$ & $\begin{array}{c}2004 \\
(\mathrm{n}=45)\end{array}$ & $\begin{array}{c}2005 \\
(\mathrm{n}=45)\end{array}$ \\
\hline Nenhum & 6,8 & 9,1 & 13,6 & 11,1 & 8,9 \\
\hline Um & 70,5 & 72,7 & 65,9 & 55,6 & 75,6 \\
\hline Dois & 20,5 & 15,9 & 15,9 & 28,9 & 13,3 \\
\hline Três & 2,3 & 2,3 & 2,3 & 2,2 & 2,2 \\
\hline Quatro ou mais & - & - & 2,3 & 2,2 & - \\
\hline
\end{tabular}


Questão 17: Você acessa a Internet? em \%

\begin{tabular}{|l|c|c|c|c|c|}
\hline & $\begin{array}{c}2001 \\
(\mathrm{n}=44)\end{array}$ & $\begin{array}{c}2002 \\
(\mathrm{n}=44)\end{array}$ & $\begin{array}{c}2003 \\
(\mathrm{n}=44)\end{array}$ & $\begin{array}{c}2004 \\
(\mathrm{n}=45)\end{array}$ & $\begin{array}{c}2005 \\
(\mathrm{n}=45)\end{array}$ \\
\hline Não & 6,8 & - & 7 & 4,4 & - \\
\hline De vez em quando & 34,1 & 43,2 & 46,5 & 28,9 & 24,4 \\
\hline Freqüentemente & 59,1 & 56,8 & 46,5 & 66,7 & 73,3 \\
\hline
\end{tabular}




\section{CURSO FARMÁCIA-BIOQUÍMICA}

(Fonte FUVEST)

Questão 1: Onde fez seus estudos de ensino fundamental?

em \%

\begin{tabular}{|l|c|c|c|c|c|}
\hline & $\begin{array}{c}2001 \\
(\mathrm{n}=50)\end{array}$ & $\begin{array}{c}2002 \\
(\mathrm{n}=80)\end{array}$ & $\begin{array}{c}2003 \\
(\mathrm{n}=80)\end{array}$ & $\begin{array}{c}2004 \\
(\mathrm{n}=80)\end{array}$ & $\begin{array}{c}2005 \\
(\mathrm{n}=80)\end{array}$ \\
\hline Só em escola pública & 26 & 33,8 & 35 & 30 & 26,3 \\
\hline Só em escola particular & 50 & 46,3 & 42,5 & 47,5 & 53,8 \\
\hline Maior parte em escola pública & 12 & 8,8 & 6,3 & 7,5 & 11,3 \\
\hline Maior parte em escola particular & 8 & 6,3 & 11,3 & 15 & 6,3 \\
\hline Metade em cada tipo de escola & 4 & 5 & 5 & - & 2,5 \\
\hline No exterior (qualquer tipo de escola) & - & - & - & - & - \\
\hline
\end{tabular}

Questão 2: Onde você realizou seus estudos de ensino médio?

\begin{tabular}{|l|c|c|c|c|c|}
\hline & $\begin{array}{c}2001 \\
(\mathrm{n}=50)\end{array}$ & $\begin{array}{c}2002 \\
(\mathrm{n}=80)\end{array}$ & $\begin{array}{c}2003 \\
(\mathrm{n}=80)\end{array}$ & $\begin{array}{c}2004 \\
(\mathrm{n}=80)\end{array}$ & $\begin{array}{c}2005 \\
(\mathrm{n}=80)\end{array}$ \\
\hline Só em escola pública & 8 & 10 & 15 & 8,8 & 7,5 \\
\hline Só em escola pública federal & - & 1,3 & 1,3 & 1,3 & - \\
\hline Só em escola particular & 86 & 80 & 80 & 85 & 90 \\
\hline Maior parte em escola pública & - & 3,8 & 3,8 & 2,5 & 1,3 \\
\hline Maior parte em escola particular & 4 & 3,8 & - & 2,5 & 1,3 \\
\hline Metade em cada tipo de escola & 2 & 1,3 & - & - & - \\
\hline No exterior (qualquer tipo de escola) & - & - & - & - & - \\
\hline
\end{tabular}

Questão 3: Em que período você realizou seus estudos de ensino médio?

\begin{tabular}{|l|c|c|c|c|c|}
\hline & $\begin{array}{c}2001 \\
(\mathrm{n}=50)\end{array}$ & $\begin{array}{c}2002 \\
(\mathrm{n}= \\
80)\end{array}$ & $\begin{array}{c}2003 \\
(\mathrm{n}=80)\end{array}$ & $\begin{array}{c}2004 \\
(\mathrm{n}=80)\end{array}$ & $\begin{array}{c}2005 \\
(\mathrm{n}=80)\end{array}$ \\
\hline Diurno (só de manhã ou só a tarde) & 93,9 & 90 & 81,3 & 91,3 & 85 \\
\hline Diurno integral (manhã e tarde) & 6,1 & 6,3 & 10 & 7,5 & 8,8 \\
\hline Noturno & - & 1,3 & 2,5 & - & 2,5 \\
\hline Maior parte diurno & - & 2,5 & 6,3 & 1,3 & 2,5 \\
\hline Maior parte noturno & - & - & - & - & 1,3 \\
\hline Metade no diurno, metade no noturno & - & - & - & - & - \\
\hline
\end{tabular}


Questão 4: Você se preparou, por quanto tempo, ou está se preparando em algum cursinho pré-vestibular?

\begin{tabular}{|l|c|c|c|c|c|}
\hline & $\begin{array}{c}2001 \\
(\mathrm{n}=50)\end{array}$ & $\begin{array}{c}2002 \\
(\mathrm{n}=80)\end{array}$ & $\begin{array}{c}2003 \\
(\mathrm{n}=80)\end{array}$ & $\begin{array}{c}2004 \\
(\mathrm{n}=80)\end{array}$ & $\begin{array}{c}2005 \\
(\mathrm{n}=80)\end{array}$ \\
\hline Não & 36 & 23,8 & 23,8 & 37,5 & 27,5 \\
\hline Sim, menos de um semestre & 4 & 1,3 & 1,3 & 1,3 & 2,5 \\
\hline Sim, um semestre completo & 2 & 5 & 2,5 & 7,5 & 2,5 \\
\hline Sim, de um semestre a um ano & 26 & 42,5 & 38,8 & 28,8 & 33,8 \\
\hline Sim, de um ano a um ano e meio & 8 & 3,8 & 11,3 & 5 & 5 \\
\hline Sim, de um ano e meio a dois & 14 & 13,8 & 10 & 12,5 & 18,8 \\
\hline Sim, mais de dois anos & 10 & 10 & 12,5 & 7,5 & 10 \\
\hline
\end{tabular}

Questão 5: Qual o grau de instrução mais alto que seu pai obteve?

\begin{tabular}{|l|c|c|c|c|c|}
\hline & $\begin{array}{c}2001 \\
(\mathrm{n}=50)\end{array}$ & $\begin{array}{c}2002 \\
(\mathrm{n}=80)\end{array}$ & $\begin{array}{c}2003 \\
(\mathrm{n}=80)\end{array}$ & $\begin{array}{c}2004 \\
(\mathrm{n}=80)\end{array}$ & $\begin{array}{c}2005 \\
(\mathrm{n}=80)\end{array}$ \\
\hline Não freqüentou escola & - & - & - & - & - \\
\hline $\begin{array}{l}\text { Iniciou o ensino fundamental, mas } \\
\text { abandonou entre a 1 }\end{array}$ & 10,2 & 3,8 & 2,5 & 5 & 2,5 \\
\hline $\begin{array}{l}\text { Iniciou o e ensino fundamental, mas } \\
\text { abandonou entre a 5a e a 8 }\end{array}$ & 2 & 6,3 & 6,3 & 2,5 & 6,3 \\
\hline $\begin{array}{l}\text { Ensino fundamental completo } \\
\text { Ensino médio incompleto }\end{array}$ & 4,1 & 7,5 & 1,3 & 1,3 & 1,3 \\
\hline Ensino médio completo & - & 3,8 & 7,6 & 2,5 & 1,3 \\
\hline Universitário incompleto & 18,4 & 23,8 & 29,1 & 22,5 & 13,9 \\
\hline Universitário completo & 4,1 & 10 & 6,3 & 12,5 & 6,3 \\
\hline Mestrado ou Doutorado & 59,2 & 40 & 39,2 & 47,5 & 63,3 \\
\hline
\end{tabular}


Questão 6: Qual o grau de instrução mais alto que sua mãe obteve?

\begin{tabular}{|l|c|c|c|c|c|}
\hline & $\begin{array}{c}2001 \\
(\mathrm{n}=50)\end{array}$ & $\begin{array}{c}2002 \\
(\mathrm{n}=80)\end{array}$ & $\begin{array}{c}2003 \\
(\mathrm{n}=80)\end{array}$ & $\begin{array}{c}2004 \\
(\mathrm{n}=80)\end{array}$ & $\begin{array}{c}2005 \\
(\mathrm{n}=80)\end{array}$ \\
\hline Não freqüentou escola & - & - & - & 1,3 & - \\
\hline $\begin{array}{l}\text { Iniciou o ensino fundamental, mas } \\
\text { abandonou entre a 1a e a 4 a série }\end{array}$ & 8 & 6,3 & 2,5 & 1,3 & 5 \\
\hline $\begin{array}{l}\text { Iniciou o ensino fundamental, mas } \\
\text { abandonou entre a 5 e a 8 }\end{array}$ & 2 & 3,8 & 7,5 & 1,3 & 1,3 \\
\hline $\begin{array}{l}\text { Ensino fundamental completo } \\
\text { Ensino médio incompleto }\end{array}$ & 2 & 7,5 & 2,5 & 3,8 & 3,8 \\
\hline Ensino médio completo & 2 & 6,3 & 7,5 & 7,5 & 2,5 \\
\hline Universitário incompleto & 6 & 12,5 & 11,3 & 12,5 & 12,5 \\
\hline Universitário completo & 52 & 42,5 & 46,3 & 41,3 & 52,5 \\
\hline Mestrado ou Doutorado & 2 & 2,5 & 1,3 & 3,8 & 1,3 \\
\hline
\end{tabular}

Questão 7: Qual a situação profissional atual de seu pai?

\begin{tabular}{|c|c|c|c|c|c|}
\hline & $\begin{array}{l}2001 \\
(\mathrm{n}= \\
50)\end{array}$ & $\begin{array}{l}2002 \\
(\mathrm{n}= \\
80)\end{array}$ & $\begin{array}{c}2003 \\
(n=80)\end{array}$ & $\begin{array}{c}2004 \\
(n=80)\end{array}$ & $\begin{array}{l}2005 \\
(\mathrm{n}= \\
80)\end{array}$ \\
\hline Proprietário de empresa grande ou média & 6 & 2,5 & - & - & 2,6 \\
\hline Proprietário de pequena ou microempresa & 20 & 16,3 & 15,2 & 7,7 & 21,8 \\
\hline $\begin{array}{l}\text { Funcionário público da administração direta } \\
\text { ou autarquia }\end{array}$ & 8 & 10 & 13,9 & 10,3 & 15,4 \\
\hline $\begin{array}{l}\text { Profissional liberal, trabalhando por conta } \\
\text { própria }\end{array}$ & 22 & 23,8 & 11,4 & 23,1 & 25,6 \\
\hline Funcionário de empresa privada ou estatal & 22 & 25 & 32,9 & 37,2 & 16,7 \\
\hline $\begin{array}{l}\text { Capitalista (vive de rendimento de aluguéis } \\
\text { ou de investimentos financeiros) }\end{array}$ & - & - & 2,5 & 1,3 & 1,3 \\
\hline Aposentado ou pensionista & 18 & 12,5 & 8,9 & 10,3 & 9 \\
\hline $\begin{array}{l}\text { No momento, não exerce atividade } \\
\text { remunerada e nem recebe pensão ou } \\
\text { aposentadoria }\end{array}$ & 2 & - & 3,8 & 2,6 & 3,8 \\
\hline Outra & 2 & 10 & 11,4 & 7,7 & 3,8 \\
\hline
\end{tabular}


Questão 8: Qual a situação profissional atual de seu mãe?

em \%

\begin{tabular}{|l|c|c|c|c|c|}
\hline & $\begin{array}{c}2001 \\
(\mathrm{n}= \\
50)\end{array}$ & $\begin{array}{c}2002 \\
(\mathrm{n}= \\
80)\end{array}$ & $\begin{array}{c}2003 \\
(\mathrm{n}=80)\end{array}$ & $\begin{array}{c}2004 \\
(\mathrm{n}=80)\end{array}$ & $\begin{array}{c}2005 \\
(\mathrm{n}= \\
80)\end{array}$ \\
\hline Proprietária de empresa grande ou média & - & - & 1,3 & - & - \\
\hline Proprietária de pequena ou microempresa & 6 & 11,3 & 16,3 & 10 & 7,5 \\
\hline $\begin{array}{l}\text { Funcionária pública da administração direta } \\
\text { ou autarquia }\end{array}$ & 22 & 11,3 & 15 & 15 & 17,5 \\
\hline $\begin{array}{l}\text { Profissional liberal, trabalhando por conta } \\
\text { própria }\end{array}$ & 10 & 10 & 7,5 & 13,8 & 12,5 \\
\hline $\begin{array}{l}\text { Funcionária de empresa privada ou estatal } \\
\text { Capitalista (vive de rendimento de aluguéis } \\
\text { ou de investimentos financeiros) }\end{array}$ & - & - & 1,3 & 1,3 & - \\
\hline $\begin{array}{l}\text { Aposentada ou pensionista } \\
\text { momento, não exerce atividade }\end{array}$ & 28 & 20 & 27,5 & 27,5 & 25 \\
\hline $\begin{array}{l}\text { No pensão ou } \\
\text { remunerada e nem recebe } \\
\text { aposentadoria }\end{array}$ & 4 & 12,5 & 12,5 & 5 & 3,8 \\
\hline \begin{tabular}{l} 
Outra \\
\hline
\end{tabular} & & 16,3 & 8,8 & 13,8 & 18,8 \\
\hline
\end{tabular}

Questão 9: Qual é a sua cor?

em \%

\begin{tabular}{|l|c|c|c|c|c|}
\hline & $\begin{array}{c}2001 \\
(\mathrm{n}=50)\end{array}$ & $\begin{array}{c}2002 \\
(\mathrm{n}=80)\end{array}$ & $\begin{array}{c}2003 \\
(\mathrm{n}=80)\end{array}$ & $\begin{array}{c}2004 \\
(\mathrm{n}=80)\end{array}$ & $\begin{array}{c}2005 \\
(\mathrm{n}=80)\end{array}$ \\
\hline Branca & 96 & 87,5 & 85 & 85 & 81,3 \\
\hline Preta & - & - & - & - & 2,5 \\
\hline Amarela & 2 & 3,8 & 7,5 & 5 & 10 \\
\hline Parda & 2 & 7,5 & 7,5 & 8,8 & 6,3 \\
\hline Indígena & - & - & - & 1,3 & - \\
\hline
\end{tabular}

Questão 10: Qual é a renda familiar mensal (em reais) de sua casa? em \%

\begin{tabular}{|l|c|c|c|c|c|}
\hline & $\begin{array}{c}2001 \\
(\mathrm{n}=50)\end{array}$ & $\begin{array}{c}2002 \\
(\mathrm{n}=80)\end{array}$ & $\begin{array}{c}2003 \\
(\mathrm{n}=80)\end{array}$ & $\begin{array}{c}2004 \\
(\mathrm{n}=80)\end{array}$ & $\begin{array}{c}2005 \\
(\mathrm{n}=80)\end{array}$ \\
\hline Inferior a 500 & 2 & 1,3 & 5 & 2,5 & 1,3 \\
\hline Entre 500 e 1500 & 14 & 21,3 & 22,5 & 18,8 & 16,3 \\
\hline Entre 1500 e 3000 & 38 & 46,3 & 35 & 31,3 & 28,8 \\
\hline Entre 3000 e 5000 & 30 & 18,8 & 25 & 27,5 & 25 \\
\hline Entre 5000 e 7000 & 4 & 7,5 & 5 & 8,8 & 17,5 \\
\hline Entre 7000 e 10000 & 8 & 3,8 & 5 & 6,3 & 2,5 \\
\hline Superior a 10000 & 4 & 1,3 & 2,5 & 5 & 8,8 \\
\hline
\end{tabular}


Questão 11: Quantas pessoas contribuem para a obtenção dessa renda familiar?

\begin{tabular}{|l|c|c|c|c|c|}
\hline & $\begin{array}{c}2001 \\
(\mathrm{n}=50)\end{array}$ & $\begin{array}{c}2002 \\
(\mathrm{n}=80)\end{array}$ & $\begin{array}{c}2003 \\
(\mathrm{n}=80)\end{array}$ & $\begin{array}{c}2004 \\
(\mathrm{n}=80)\end{array}$ & $\begin{array}{c}2005 \\
(\mathrm{n}=80)\end{array}$ \\
\hline Uma & 32 & 33,8 & 46,3 & 40 & 35 \\
\hline Duas & 56 & 57,5 & 47,5 & 55 & 55 \\
\hline Três & 8 & 6,3 & 5 & 3,8 & 6,3 \\
\hline Quatro & 4 & 2,5 & 1,3 & 1,3 & 3,8 \\
\hline Cinco ou mais & - & - & - & - & - \\
\hline
\end{tabular}

Questão 12: Quantas pessoas são sustentadas com a renda familiar?

\begin{tabular}{|l|c|c|c|c|c|}
\hline & $\begin{array}{c}2001 \\
(\mathrm{n}=50)\end{array}$ & $\begin{array}{c}2002 \\
(\mathrm{n}=80)\end{array}$ & $\begin{array}{c}2003 \\
(\mathrm{n}=80)\end{array}$ & $\begin{array}{c}2004 \\
(\mathrm{n}=80)\end{array}$ & $\begin{array}{c}2005 \\
(\mathrm{n}=80)\end{array}$ \\
\hline Uma & - & 1,3 & 1,3 & - & - \\
\hline Duas & 4 & - & 3,8 & 5 & - \\
\hline Três & 10 & 13,8 & 10 & 12,5 & 16,3 \\
\hline Quatro & 40 & 52,5 & 52,5 & 42,5 & 43,8 \\
\hline Cinco & 32 & 22,5 & 30 & 30 & 27,5 \\
\hline Seis & 12 & 8,8 & 1,3 & 8,8 & 11,3 \\
\hline Sete & 2 & 1,3 & 1,3 & 1,3 & 1,3 \\
\hline Oito ou mais & - & - & - & - & - \\
\hline
\end{tabular}

Questão 13: Você exerce atualmente atividade remunerada?

\begin{tabular}{|l|c|c|c|c|c|}
\hline & $\begin{array}{c}2001 \\
(\mathrm{n}=50)\end{array}$ & $\begin{array}{c}2002 \\
(\mathrm{n}= \\
80)\end{array}$ & $\begin{array}{c}2003 \\
(\mathrm{n}= \\
80)\end{array}$ & $\begin{array}{c}2004 \\
(\mathrm{n}=80)\end{array}$ & $\begin{array}{c}2005 \\
(\mathrm{n}= \\
80)\end{array}$ \\
\hline Não & 98 & 93,8 & 93,8 & 95 & 95 \\
\hline Eventualmente & 2 & 5 & 3,8 & 2,5 & 5 \\
\hline Em meio-período (até 20 horas semanais) & - & 1,3 & 1,3 & 2,5 & - \\
\hline $\begin{array}{l}\text { Em período semi-integral (de 21 a 32 horas } \\
\text { semanais) }\end{array}$ & - & - & - & - & - \\
\hline $\begin{array}{l}\text { Em tempo integral (mais de 32 horas } \\
\text { semanais) }\end{array}$ & - & - & 1,3 & - & - \\
\hline
\end{tabular}


Questão 14: Como pretende se manter durante seus estudos universitários?

em \%

\begin{tabular}{|c|c|c|c|c|c|}
\hline & $\begin{array}{l}2001 \\
(\mathrm{n}= \\
50)\end{array}$ & $\begin{array}{l}2002 \\
(\mathrm{n}= \\
80)\end{array}$ & $\begin{array}{c}2003 \\
(\mathrm{n}=80)\end{array}$ & $\begin{array}{c}2004 \\
(n=80)\end{array}$ & $\begin{array}{l}2005 \\
(\mathrm{n}= \\
80)\end{array}$ \\
\hline Somente com recursos dos pais & 46,9 & 45 & 50 & 38,8 & 50 \\
\hline $\begin{array}{l}\text { Trabalhando, mas contando, para o } \\
\text { essencial, com os recursos da família }\end{array}$ & 36,7 & 31,3 & 31,3 & 38,8 & 30 \\
\hline $\begin{array}{l}\text { Trabalhando para participar do rateio das } \\
\text { despesas da família }\end{array}$ & - & 3,8 & 2,5 & 5 & 1,3 \\
\hline $\begin{array}{l}\text { Por minha conta, com recursos oriundos de } \\
\text { trabalho remunerado }\end{array}$ & 2 & - & - & 1,3 & 1,3 \\
\hline Com bolsa de estudos ou crédito educativo & 4,1 & 5 & 6,3 & 3,8 & 8,8 \\
\hline $\begin{array}{l}\text { Com bolsa ou crédito educativo, } \\
\text { trabalhando e contando ainda com o apoio } \\
\text { da família }\end{array}$ & 6,1 & 13,8 & 10 & 12,5 & 7,5 \\
\hline Outros & 4,1 & 1,3 & - & - & 1,3 \\
\hline
\end{tabular}

Questão 15: Quantos carros existem em sua casa?

\begin{tabular}{|l|c|c|c|c|c|}
\hline & $\begin{array}{c}2001 \\
(\mathrm{n}=50)\end{array}$ & $\begin{array}{c}2002 \\
(\mathrm{n}=80)\end{array}$ & $\begin{array}{c}2003 \\
(\mathrm{n}=80)\end{array}$ & $\begin{array}{c}2004 \\
(\mathrm{n}=80)\end{array}$ & $\begin{array}{c}2005 \\
(\mathrm{n}=80)\end{array}$ \\
\hline Nenhum & 8 & 7,5 & 8,8 & 5 & 5 \\
\hline Um & 40 & 46,3 & 52,5 & 45 & 43,8 \\
\hline Dois & 38 & 35 & 30 & 41,3 & 43,8 \\
\hline Três & 10 & 6,3 & 8,8 & 7,5 & 6,3 \\
\hline Quatro & 2 & 5 & - & 1,3 & - \\
\hline Cinco ou mais & 2 & - & - & - & 1,3 \\
\hline
\end{tabular}

Questão 16: Quantos microcomputadores existem em sua casa?

\begin{tabular}{|l|c|c|c|c|c|}
\hline & $\begin{array}{c}2001 \\
(\mathrm{n}=50)\end{array}$ & $\begin{array}{c}2002 \\
(\mathrm{n}=80)\end{array}$ & $\begin{array}{c}2003 \\
(\mathrm{n}=80)\end{array}$ & $\begin{array}{c}2004 \\
(\mathrm{n}=80)\end{array}$ & $\begin{array}{c}2005 \\
(\mathrm{n}=80)\end{array}$ \\
\hline Nenhum & 26 & 21,3 & 20 & 8,8 & 10 \\
\hline Um & 66 & 73,8 & 71,3 & 72,5 & 68,8 \\
\hline Dois & & & & & 12,5 \\
\hline Três & 8 & 5 & 7,5 & 3,8 & 2,5 \\
\hline Quatro ou mais & - & - & 1,3 & - & - \\
\hline
\end{tabular}


Questão 17: Você acessa a Internet? em \%

\begin{tabular}{|l|c|c|c|c|c|}
\hline & $\begin{array}{c}2001 \\
(\mathrm{n}=50)\end{array}$ & $\begin{array}{c}2002 \\
(\mathrm{n}=80)\end{array}$ & $\begin{array}{c}2003 \\
(\mathrm{n}=80)\end{array}$ & $\begin{array}{c}2004 \\
(\mathrm{n}=80)\end{array}$ & $\begin{array}{c}2005 \\
(\mathrm{n}=80)\end{array}$ \\
\hline Não & 16 & 16,3 & 8,8 & 11,3 & 5 \\
\hline De vez em quando & 52 & 42,5 & 51,3 & 45 & 43,8 \\
\hline Freqüentemente & 32 & 41,3 & 38,8 & 43,8 & 51,3 \\
\hline
\end{tabular}

